Universidade de São Paulo

Faculdade de Filosofia, Letras e Ciências Humanas

Departamento de Antropologia

Programa de Pós-Graduação em Antropologia Social

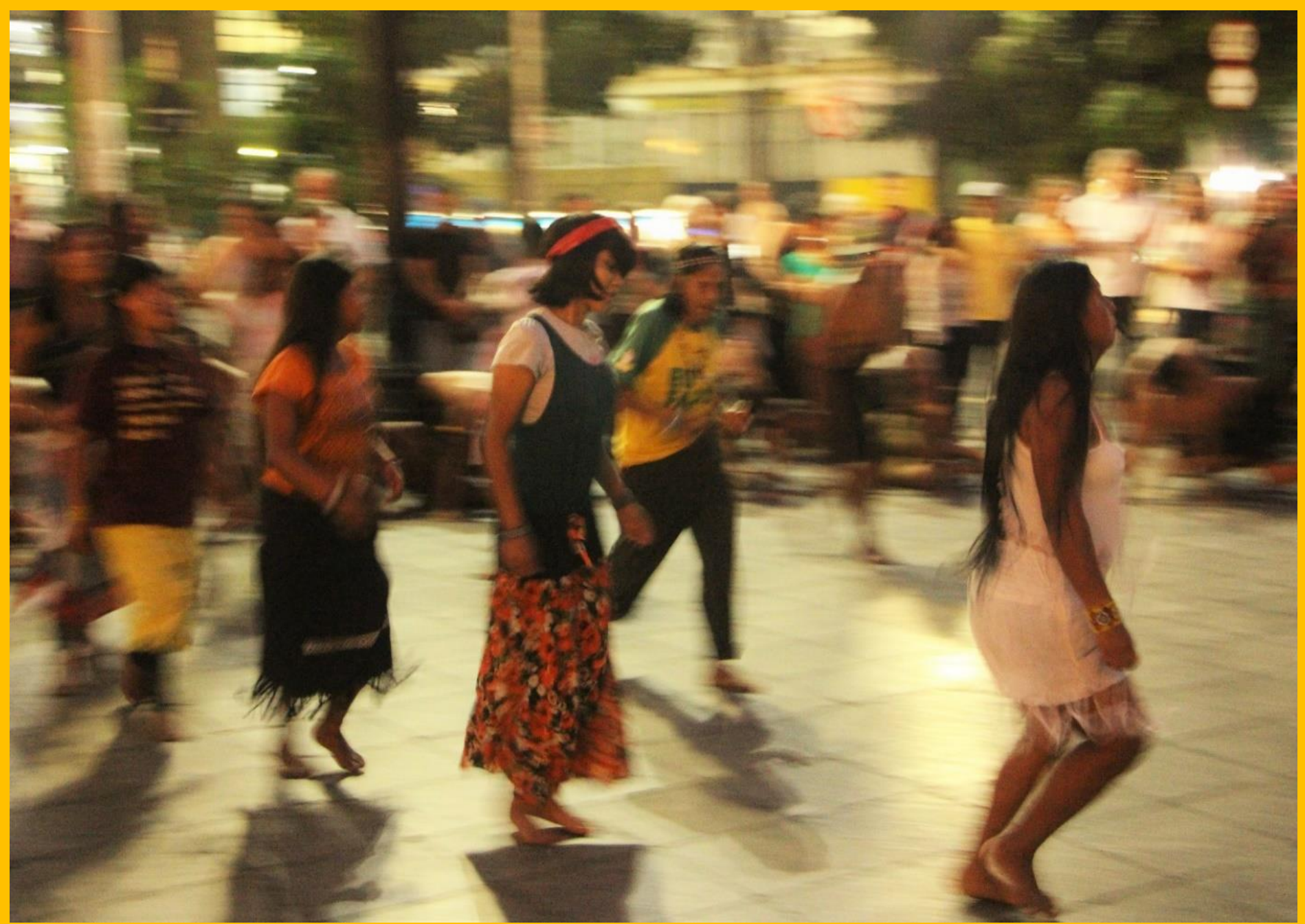

Os Guarani-Mbya ocupam o Pátio do Colégio com suas danças e cantos de força, coragem e resistência. Aline Aranha. São Paulo, 2015.

Inspirações sobre o fazer(-se) polític@ entre os Guarani-Mbya

Versão Corrigida

Aline de Oliveira Aranha 


\title{
Inspirações sobre o fazer(-se) polític@ entre os Guarani-Mbya
}

\author{
Versão Corrigida
}

Aline de Oliveira Aranha

Dissertação de Mestrado apresentada ao Programa de Pós-Graduação em Antropologia Social do Departamento de Antropologia da Faculdade de Filosofia, Letras e Ciências Humanas da Universidade de São Paulo, como parte dos requisitos para obtenção do título de Mestra em Antropologia Social.

Orientador: Prof. Dr. Renato Sztutman

São Paulo

2018 
Autorizo a reprodução e divulgação total ou parcial deste trabalho, por qualquer meio convencional ou eletrônico, para fins de estudo e pesquisa, desde que citada a fonte.

Email: oar.aline@gmail.com

Aranha, Aline de Oliveira

AA662i Inspirações sobre o fazer(-se) polític@ entre os Guarani-Mbya/ Aline de Oliveira Aranha; orientador Renato Sztutman - São Paulo, 2018. 347 f.

Dissertação (Mestrado) - Faculdade de Filosofia, Letras e Ciências Humanas da Universidade de São Paulo. Departamento de Antropologia. Área de concentração: Antropologia Social.

1. Guarani-Mbya. 2. Liderança. 3. Xamanismo. 4. Diplomacia cosmopolítica. 5. Mulheres Mbya.

I. Sztutman, Renato, orient. II. Título. 
Aranha, Aline de Oliveira. Inspirações sobre o fazer(-se) polític@entre os Guarani-Mbya. 2018. Dissertação de Mestrado. Programa de Pós-Graduação em Antropologia Social, Faculdade de Filosofia, Letras e Ciências Humanas (FFLCH), Universidade de São Paulo (USP). São Paulo, 347 páginas (Versão Corrigida).

Aprovada em 20.12.2017

\section{Banca Examinadora}

Profa. Dra. Dominique Tilkin Gallois (PPGAS - Universidade de São Paulo)

Julgamento: Assinatura:

Profa. Dra. Maria Inês Martins Ladeira (Centro de Trabalho Indigenista)

Julgamento: Assinatura:

Prof. Dr. Renato Sztutman (PPGAS - Universidade de São Paulo)

Julgamento: Assinatura:

Prof. Dra. Valéria Mendonça de Macedo (PPGCS - Universidade Federal de São Paulo) 
Aos Guarani-Mbya e sua força e coragem deveras inspiradoras, aguyjevete! 


\section{Agradecimentos}

Aos meus professores e professoras de Antropologia da USP, especialmente às queridas Beatriz Perrone-Moisés e Dominique Gallois por toda a força e inspiração nesses anos de convivência na Etnologia Indígena e pelo CEstA, e pelos belos ensinamentos desde a Graduação que foram fundamentais no percurso e amadurecimento dessa pesquisa e, em minha formação enquanto etnóloga; com todo respeito e carinho, tem muito de vocês aqui presente. À Márcio Silva pelo incentivo e disposição em me ajudar a entrar em contato com a Universitat Autònoma de Barcelona (UAB) e realizar o intercâmbio de estudos, e agradeço também por me apresentar uma grande amiga em Barcelona, a Alicinha (Alice Barbosa), que me ajudou em todos os aspectos possíveis. À Fernanda Peixoto agradeço muitíssimo por todos os ensinamentos em sala de aula e pela força e incentivo que me inspiraram muito a seguir pesquisando. Ao José Guilherme Magnani meu agradecimento especial por me incentivar a pesquisar desde a Graduação e por acreditar tanto em meu potencial.

À Renato Sztutman por ter belamente me apresentado ao casal Clastres e às etnografias sobre os Guarani, e também pela paciência e pelos anos de (des)orientação. Um agradecimento especial à querida Valéria Macedo por todos os ensinamentos e trocas, e por ter me levado pela primeira vez a uma aldeia Guarani e, por nunca ter desistido de me incentivar a continuar com a pesquisa entre os Guarani. Agradeço também, com muito carinho à Adriana Testa pelas trocas, pelo incentivo, apoio e por todas as dicas que foram fundamentais para o desenvolvimento dessa pesquisa. À querida Profa. Montserrat Ventura i Oller da UAB por todos os ensinamentos, pela generosidade e paciência inabaláveis. À todos os professores de Antropologia da UAB com os quais tive a oportunidade de trocar e aprender tanto, especialmente, Virgínia Fons, Josep Lluís Mateo e Verena Stolcke. Agradeço também, à Banca Examinadora pela leitura atenta e instigadora.

Às Kzetes que me acolherem em Araraquara e me ensinaram a viver em um coletivo de mulheres fortes e guerreiras. Agradeço especialmente às irmãs Maria, Bia Bolinha (Maria Beatriz Cardoso) e Fernandinha (Maria Fernanda Cardoso) por toda alegria, amor e carinho e por terem me ensinado tanto, à Bia Axé (Beatriz Maciel) por todos os aprendizados, as risadas e toda a ternura e cumplicidades de taurinas, à Inca (Ayni) pela força, paciência e garra que me inspiram até hoje, e à mais novinha das kzetes, que tive a oportunidade de conhecer, a Branquinha (Mariana Favorito) pela doçura e simplicidade. Agradeço também à minha amiga Denden (Denise Tiburzi) por todos os anos de amizade e pelas loucuras de sempre. À seu companheiro de anos, Fabinho (Fabiano Dalla Costa) pelas risadas verdadeiras e sem motivo e pelas caipirinhas maravilhosas. À Bá (Bárbara Fernandes) pela amizade e apoio de sempre. À Lili (Lilian Cardozo) pelos encontros e caminhadas. Ao Thi (Thiago Arellano), meu querido amigo e vizinho que me dava carona desde o colégio, cuja doçura e amor me fortalecem continuamente e me fazem desejar seguir em frente. 
Muito obrigada pelas revisões das traduções e por topar minhas loucuras, principalmente quando elas são intraduzíveis. À seu companheiro maravilhoso, Emmanuel Arellano pela generosidade e pelo acolhimento latino-mexicano.

Agradeço também à minha amigona do coração, Renata Izzo e à sua filhinha maravilhosa, Valentina, por terem me acolhido em Barcelona e se provado verdadeiras companheiras para todas as horas. À meu querido amigo Matheus de Moraes, pela grandeza do coração e pela generosidade, e por também ter me acolhido em Barcelona e por ter me ajudado tanto em tudo que eu precisava, você é demais, de verdade! Nunca vou cansar de te agradecer por ter arrumado meu computador em um momento de crise e de Relatório Final!

Aos companheiros da Revista Cadernos de Campo pelo trabalho e empenho coletivo e também pelos aprendizados. Aos queridos companheiros de Mestrado, Bruno Pereira, Renata Cortez, Carolina Mazzariello, Gabi Freire, Diogo Maciel, Rafael Hupsel, Hélio Menezes, um agradecimento especial por todas as trocas e ensinamentos, dentro e fora das aulas. À Henrique Pougy, meu muito obrigada, por ter me incentivado e acreditado tanto em mim. Ao Bulga (Lucas Bulgarelli) por todas as brisas e pela sua sensibilidade à flor da pele, você é uma grande inspiração de vida e de militância. Ao Caiporinha (Arthur Fontgaland) pelo carinho, pela delicadeza de sempre e por ser uma luzinha colorida e perfumada nesse breu que parece ser a Pós-Graduação. Ao querido Gu (Gustavo Berbel) por toda poesia e alegria de sempre, você merece alcançar o mundo (e tenho certeza que vai). À Mari-vilhosa (Mari Machini) pela força, alegria e pelos sorrisos sinceros.

Aos companheiros do CEstA, Lucas Ramiro e Frank Nabeta pelo período que fomos companheiros de trabalho, por vocês terem me ensinado tanto, por todas as cumplicidades nos inúmeros eventos que organizamos juntos e por terem me salvado nos perrengues de pesquisa tantas e tantas vezes.

Aos meus amigos Guarani e xeramoĩ e xejaryi agradeço imensamente pela alegria, pelos ensinamentos, pelas trocas, por terem me recebido tão bem, me ensinado a ouvir e a sentir com o coração e pelas tantas caminhadas que fizemos e ainda faremos juntos. Aguyjevete anhete pavẽ̃ı! Um agradecimento especial àqueles cujas palavras e ensinamentos estão presentes aqui.

Aos meus pais, pela confiança, força, incentivo e, principalmente, pelo amor e carinho incondicional que me fortalece tanto. Sem vocês nada disso seria possível. Muito obrigada por tudo! Vocês são uma grande inspiração de força e coragem para mim! Agradeço também a meus avós, por sua fé, força e garra apesar de todas as dificuldades pelos caminhos, que muito me ensinaram e inspiraram a persistir.

Agradeço também ao CNPq e à Fapesp (Processo 2015/00569-9), pela concessão da Bolsa de Mestrado que permitiu a dedicação integral à pesquisa.

Essa caminhada não foi fácil, mas agradeço por todos os aprendizados! Aguyjevete pra quem luta! 
Um índio descerá de uma estrela colorida, brilhante De uma estrela que virá numa velocidade estonteante E pousará no coração do hemisfério sul Na América, num claro instante Depois de exterminada a última nação indígena E o espírito dos pássaros das fontes de água límpida Mais avançado que a mais avançada das mais avançadas das tecnologias

Impávido que nem Muhammad Ali

Virá que eu vi Apaixonadamente como Peri

Virá que eu vi

Tranquilo e infalível como Bruce Lee

Virá que eu vi

O axé do afoxé Filhos de Gandhi

Virá

Um índio preservado em pleno corpo físico

Em todo sólido, todo gás e todo líquido

Em átomos, palavras, alma, cor

Em gesto, em cheiro, em sombra, em luz, em som magnífico

Num ponto equidistante entre o Atlântico e o Pacífico

Do objeto-sim resplandecente descerá o índio

$\mathrm{E}$ as coisas que eu sei que ele dirá, fará

Não sei dizer assim de um modo explícito

[...] E aquilo que nesse momento se revelará aos povos

Surpreenderá a todos não por ser exótico

Mas pelo fato de poder ter sempre estado oculto

Quando terá sido o óbvio

(Um Índio. Veloso, Caetano. 1977, grifos meus) 


\section{Resumo}

Aranha, Aline de Oliveira. Inspirações sobre o fazer(-se) polític@ entre os Guarani-Mbya.

A intenção aqui é pensar como as transformações nas formas e estratégias mbya de liderança e ação cosmopolítica são mobilizados e produzidos, criativamente, no confronto cada vez mais intenso com a política e modo de ser, pensar e de se comportar jurua (não-indígena), elucidando o (in)tenso trabalho de tradução implicado nessas e em outras amplas redes de relações que compõem o mundo guarani. Há aí toda uma gestão e mobilização dessas relações de aliança e parentesco, em que diferentes domínios e perspectivas demandam diferentes retóricas e ações, e identidades étnicas tornam-se armas políticas, principalmente após a Constituição de 1988, envolvendo então toda uma diplomacia cosmopolítica mbya que parte de uma ética de moderação, xamânica, com vistas à fabricação de pessoas e coletivos saudáveis e alegres nesta terra perecível (tekoaxy), e se acentua ainda mais nesse contexto de constrangimento territorial e superpovoação, que impõe diversos limites ao exercício de sua territorialidade. Estas transformações estão inseridas em contextos como os de luta pela demarcação de terras e salvaguarda de direitos indígenas constitucionais, tal como em projetos de fortalecimento cultural sob a rubrica da "cultura", nos quais o domínio da burocracia passa a corresponder a um maior domínio da arena de batalha e, com isso, afirmação e demarcação da diferença e resistência mbya contra o Estado. Retórica esta que passa então a afetar diretamente a produção de enunciados e perspectivas guarani para o futuro de suas lideranças e de sua "comunidade". Estamos também diante de um contexto cada vez maior de valorização e protagonismo público de jovens mulheres mbya (kunhãgue), assim como da abertura e conquista de espaços de fala e atuação política no âmbito da "comunidade", antes majoritariamente ocupados por figuras masculinas ou mais velhas e experientes. A partir disso, buscamos então refletir sobre a complementaridade e fortalecimento mútuo de ambos sujeitos, kunhãgue e avakue (homens mbya), e como suas diferentes capacidades-poderes (-po'aka) se relacionam aos processos mbya de construção e composição de pessoas, lideranças e chefias, coletivos, discursos e práticas. A ideia então é alargamos de fato nossas concepções de política e pensar as movimentações desempenhadas pelos diversos sujeitos correspondendo mais a disposições cosmopolíticas diferenciantes e, portanto, relacionais, do que a funções ou (o)posições propriamente ditas ou mesmo fixas, a capacidades singulares de agir, fazer agir, afetar e ser afetado, que contam com diferentes modalidades e estilos de liderança e áreas de atuação, influência e prestígio. Tais figuras políticas podem ainda ser pensadas como tradutoras de mundos ou diplomatas cosmopolíticas, transitando por diferentes códigos e agenciando diferentes mundos.

\section{Palavras-chave}

Guarani-Mbya; liderança; xamanismo; diplomacia cosmopolítica; mulheres Mbya. 


\section{Abstract}

Aranha, Aline de Oliveira. Inspirations on making (oneself) politic(al)s among the Guarani-Mbya.

The intention here is to think about how transformations in mbya manners and strategies of leadership and cosmopolitical action are, creatively, mobilized and produced in the increasingly intense confrontation with the politics and the manner of being, thinking and, the so called, behaving jurua (non-indigenous), elucidating the (in)tense work of translation implied in these and other bonds of relations that make up the Guarani world. There is a whole management and mobilization of these relations of alliance and kinship, in which different domains and perspectives demand different rhetoric and different actions, and ethnic identities become political weapons, especially after the Brazilian Constitution of 1988, involving a whole mbya cosmopolitical diplomacy that starts from an ethics of moderation, shamanic, with a view to the production of healthy and joyful people and groups in this perishable land (tekoaxy), and is even more accentuated in this context of territorial constraint and overpopulation, which imposes various limits on the exercise of its territoriality. These transformations are embedded in contexts such as the struggle for land demarcation and the safeguarding of indigenous constitutional rights, as in cultural strengthening projects under the rubric of "culture" (with commas), in which the mastery of bureaucracy implies a better domain of the battlefield and, with that, the affirmation and demarcation of the difference and resistance Mbya against the State. This rhetoric, thus, directly affects the production of Guarani statements and perspectives for the future of its leaders and its "community". We are also faced with a growing context of valorization and public protagonism of young mbya women (kunhãgue), as well as the opening and conquest of spaces of speech and political activity within the "community", previously mostly occupied by male figures or older and more experienced people. From this, we seek to reflect on the complementarity and mutual strengthening of both subjects, kunhãgue and avakue (mbya men), and how their different capacities-powers (-po'aka) relate to the mbya processes of construction and composition of people, leadership, collectives, discourses and practices. The idea then is to widen our conceptions of politics and to think the movements performed by the various subjects as corresponding more to differententiating cosmopolitical dispositions, therefore, relational, than to functions or proper (o)positions or even fixed ones, more a singular capacities-powers of act, make acting, affect and be affected, that count with different modalities and styles of leadership and areas of influence and prestige. Such political figures can still be thought as translators of worlds or cosmopolitical diplomats, transiting through different codes and agencing different worlds.

\section{Keywords}

Guarani-Mbya; leadership; shamanism; cosmopolitical diplomacy; Mbya women. 


\section{Sumário}

11

11

30

31

32

56

71

88

Abertura (ao[s] outro[s])

Inspirações sobre o fazer(-se) polític@ entre os Guarani-Mbya Nota sobre ortografia e pronúncia Mbya

\section{Capítulo I. Entre caminhos e caminhadas: movimento e ação política Guarani-Mbya}

Os Guarani e o complexo de aldeias da Serra do Mar: os caminhos e caminhadas que levam à presença Mbya em São Paulo

A criação e manutenção de yoyrupa: os percursos de yoy mbyte à yoy apy

Diferentes estratégias guarani de resistência pelos caminhos e caminhadas

A luta pelas demarcações e a Comissão Guarani Yvyrupa: as novas gerações de lideranças e suas estratégias inovadoras de mobilização

Capítulo II. Disposições cosmopolíticas Guarani: entre domínios e personagens

A atualidade do contra-Estado e para-guerra: (dis)junções entre política e xamanismo

A socialidade xamânica Mbya

Xamanismo e inspiração: a disposição em guiar um coletivo e seguir uma orientação

Tenondegua kuery: aqueles que seguem à frente, iluminando o caminho

Dinâmicas cosmopolíticas transformacionais mbya: paralelos atuais

(Des)continuidades ontológicas: de capacidades e potências de afecção cosmopolíticas diversas

Diplomatas-tradutores de mundos em perpétuo movimento e transformação

Disposições coletivas atuais: gestão de relações entre parentelas no Tekoa Tenonde Porã

A multiplicação de lideranças: divisão de responsabilidades e a construção do consenso coletivo

De inspirações e disposições cosmopolíticas na construção-proteção de um tekoa

Capítulo III. Modos de liderar e se movimentar: complementaridade e produção de diferenciações cosmopolíticas

Movimentação relacional generalizada entre mundos: parentesco e (re)produção de diferenciações nesta terra

De encontros e desencontros cosmopolíticos: o perigo-potência da transformação

Sem palavra mítica, não há movimento: a palavra-nome e a produção de boas disposições na organização coletiva

Os problemas com as mulheres indígenas na Antropologia e entre os Guarani

Dinâmicas cosmopolíticas entre convivência, cuidado e liderança mbya

A fabricação do gênero do corpo: entre o (des)controle e o desejo desmedido

Sobre a gestão de relações cotidianas-políticas, entre gêneros e a formação das novas gerações

Algumas considerações finais

Referências Bibliográficas 


\title{
Abertura (ao $[\mathrm{s}]$ outro $[\mathrm{s}])$
}

\section{Inspirações sobre o fazer(-se) polític@ entre os Guarani-Mbya}

\author{
Só a ANTROPOFAGIA nos une. Socialmente. Economicamente. Fi- \\ losoficamente. Única lei do mundo. Expressão mascarada de todos os indivi- \\ dualismos, de todos os coletivismos. De todas as religiões. De todos os trata- \\ dos de paz. Tupi, or not tupi that is the question. (Andrade, 1928) \\ As etnografias são as construções analíticas de acadêmicos; os povos \\ que eles estudam não o são. É parte do exercício antropológico reconhecer \\ quanto a criatividade desses povos é maior do que aquilo que pode ser compre- \\ endido por qualquer análise. (Strathern, 2006 [1988]: 23, grifos meus)
}

Os Guarani Mbya ${ }^{1}$, como se sabe, mantêm uma longa e conturbada história de contato com a sociedade envolvente, embora esteja entre um de seus ideais, precisamente, o viver apartado dos não-indígenas (jurua kuery)². Destacam-se suas estratégias de mobilidade para fugir e se distanciar do assédio dessa presença massiva e do avançar das cidades nas poucas porções de terra que ainda lhe restavam de seu território e, em que podiam se movimentar de acordo com os seus preceitos divinos, o que os levou, em muitos casos, a se espalharem forçadamente e desordenadamente, em busca de tornaremse invisiveis aos olhos jurua, por preferirem o não enfrentamento direto na questão da terra, essa dádiva divina que a eles caberia apenas cuidar e guardar. Essa "aversão" Guarani, "em brigar por terra”, os fez serem reconhecidos como "índios errantes ou nômades" e somado ao "estigma de 'índios aculturados' em virtude do uso de roupas e outros bens e alimentos industrializados", foram vistos aos olhos jurua também como "estrangeiros", "do Paraguai”, e via de regra, foi "distorcido de seu significado original e utilizado para reiterar a tese, difundida entre os brancos, de que os Guarani não precisavam de terra pois nem 'lutavam’ por ela”, o que favoreceu os "interesses fundiários e econômicos especulativos” jurua que, ao buscarem “descaracterizar a ocupação territorial Guarani”, acaba por negar-lhes, "sistematicamente, o direito à terra” (Ladeira, 2000: 14).

Tais situações perpassam a memória dos povos Guarani da colonização (ou “invasão" como eles mesmos dizem) aos dias atuais, e sua histórica atitude em relação ao

\footnotetext{
${ }^{1}$ Os Guarani-Mbya se auto-identificam entre si como nhandeva que traduzem como "nós" ou "aqueles que somos nós”, "nossa gente”. Estão espalhados por diversos tekoa (“aldeias”) no Brasil, Paraguai, Argentina e Uruguai. No Brasil, estão localizados no interior e no litoral das regiões Sul (Paraná, Santa Catarina, Rio Grande do Sul) e Sudeste (São Paulo, Rio de Janeiro e Espírito Santo). Para mais informações ver Mapa Guarani Digital (2017).

${ }^{2}$ Kuery corresponde em mbya a um coletivizador, portanto, ao se referirem a jurua kuery os Guarani querem dizer, "o coletivo jurua”, ou seja, os não-indígenas.
} 
Estado $^{3}$ que, por sua vez, segue respondendo a seus deslocamentos como caso de polícia ${ }^{4}$, confinando-os em pequenos aldeamentos e cerceando-lhes o direito à terra e seus recursos. Isso, por sua vez, não os impede de fazer o (im)possível para recriar as condições de um bem viver (teko porã), de acordo com seus costumes e territorialidades ancestrais que se inspiram nos comportamentos das divindades, pais e mães (Nhanderu e Nhandexy kuery) da palavra-espírito-nome (nhe'ê) guarani. Tendo em vista as perseguições culturais e físicas que seguem sofrendo ainda hoje, os Guarani-Mbya desenvolveram vários mecanismos para preservar suas tradições espirituais e estabelecer relações com a sociedade nacional, garantindo assim sua reprodução enquanto povo. Por isso, sem excluir “o convívio inevitável com o branco, com quem sempre procuraram manter um relacionamento amistoso", utilizam-se mesmo do "modelo de trajar-se copiado da população regional" o que significa, certamente "mais do que a submissão a um processo contínuo de aculturação", mas uma estratégia propriamente guarani de "auto-preservação" (Idem). Foi desta forma que, segundo Ladeira, os Guarani tentaram (e seguem tentando) "sob o traje que encobre diferenças profundas" e com muita "tolerância e intencional opacidade, resguardar-se de novas feridas" (Idem).

Nos últimos anos, particularmente a partir dos anos 1980, quando iniciativas guarani - junto a seus apoiadores e parceiros jurua - se voltaram para a articulação de suas reivindicações ${ }^{5}$ territoriais junto ao Estado brasileiro, multiplicaram-se eventos, pesquisas, projetos de manejo sustentável e de fortalecimento cultural e socioambiental, intensificando-se a presença jurua em muitas aldeias mbya, passando o Estado então a responder aos Guarani, também, através de políticas públicas. Tais inflexões são postas em cena pelo crescente e cada vez mais obrigatório manejo do código da "cultura" - signo que separa sujeitos a partir de marcadores como "índios" e "brancos", implicando uma ampla rede de traduções e transformações nessa convivência e interlocução de sistemas

\footnotetext{
${ }^{3}$ Tomo o Estado aqui, no sentido clastreano do termo, isto é, como um princípio filosófico contra o qual é possível se posicionar, o que é bem diferente de falar do Estado visto de dentro, revelando todas as suas complexidades. Com isso, quero dizer que não compreendo o Estado enquanto um monobloco que não se diferencia a partir de cada contexto dado, apenas faço uso aqui de um outro sentido analítico.

${ }^{4}$ Para saber mais sobre o contraste entre os Guarani como questão de polícia e questão de políticas, ver Macedo (2010).

${ }_{5}$ O Centro de Trabalho Indigenista (CTI) inicia no fim da década de 1970 um mapeamento das áreas ocupadas pelos Guarani no Sul e Sudeste do Brasil que, em sua maioria consistiam em "ocupações autônomas, desconhecidas do Estado brasileiro”. Com o desenvolvimentismo desenfreado expulsando os Guarani de suas áreas tradicionais, restaram apenas pequenas áreas nas quais se viram confinados. A Terra Indígena (T.I.) Tenonde Porã (Barragem/Krukutu) e a Terra Indígena Jaraguá são as únicas T.I.s no município de São Paulo. É no começo dos anos 1980 que os Guarani passam a se organizar, com o apoio de seus parceiros, pela regularização de suas terras (ver Centro de Trabalho Indigenista 2016a).
} 
de entendimento distintos que devem se fazer visiveis para serem considerados "verdadeiros" (aos olhos dos outros). Esta atitude, diante do cenário contemporâneo, contrasta diretamente com a estratégia guarani, historicamente predominante, de invisibilidade cultural na interação com os jurua kuery, em que procuravam não revelar a cultura, não "mostrar o segredo", interditando a esses seres os modos de conexão entre nhandeva'e (“aqueles que somos nós”) e Nhanderu e Nhandexy kuery (os ancestrais divinos) (Macedo 2010), para não serem assimilados pelo Estado.

Em linhas gerais, a minha trajetória de pesquisa com os Guarani-Mbya começa em 2010, com o projeto de Iniciação Científica "Lideranças político-religiosas entre os povos guarani: Revisão bibliográfica da produção recente”, no qual busquei examinar o estado atual da reflexão sobre a relação entre xamanismo e liderança política entre os Mbya que se localizam entre o litoral da região sudeste do Brasil e a Grande São Paulo, centrando-me na bibliografia produzida na última década - tendo em vista a imensa bibliografia sobre esses povos -, com foco principal na figura de grandes lideranças espirituais ou chefes-xamãs. Tratava-se então de levar adiante a reflexão de Pierre (2003 [1974]; 1990 [1974]; 2011 [1980]) e Hélène Clastres (1978 [1975]) sobre o xamanismo e o profetismo guarani, aprofundando a questão de como estes se veem inseridos no processo de constituição da chefia e da liderança política e espiritual entre os Guarani. Em 2012, ainda na Iniciação Científica, desenvolvi, em inteira ressonância com a pesquisa anterior, o projeto "As atuais formas de liderança política entre os Guarani-Mbya da Terra Indígena Tenonde Porã no embate com a política jurua (não-indígena)”, propondo realizar, a partir da aliança entre a pesquisa bibliográfica e o trabalho de campo, um mapeamento das lideranças no Tekoa Tenonde Porã (Barragem/Morro da Saudade), localizado em Parelheiros, extremo sul da cidade de São Paulo. Na pesquisa de campo tive a oportunidade de transitar, em alguma medida, entre a figura do cacique ("chefe" político - tekoaruvixa), as lideranças que o acompanhavam e o auxiliavam, e as lideranças espirituais ou chefes-xamãs, em suas redes de relações políticas que compreendem a dinâmica intra, inter e extra aldeia. Busquei ali também verificar a relação dessas lideranças com o xamanismo guarani - que cada vez mais percebia que não se reduzia somente

\footnotetext{
${ }^{6}$ Esta Iniciação Científica, que teve duração de três anos (2010-2013), contou com bolsa do CNPq-RUSP e foi orientada pelo Prof. Dr. Renato Sztutman. Para mais detalhes ver Aranha, Aline de O. 2012. Lideranças político-religiosas entre os povos guarani: Revisão bibliográfica da produção recente, Ms.; 2013. As atuais formas de liderança política entre os Guarani-Mbya da Terra Indígena Tenonde Porã no embate com a política jurua (não-indígena), Ms.

7 Tekoa remete a lugar e deve ser entendido como um emaranhado de relações em um bom lugar para se viver. A tradução por "aldeia” remete à estratégia política guarani de se fazer visível e compreensível para as políticas públicas do Estado, mas uma possível tradução para o português seria "local em que se vive". Para um desenvolvimento desta ideia, ver Capítulo II.
} 
à figura masculina do xamã e estaria mais bem relacionado à dinâmica singular do próprio princípio agentivo guarani, o $n h e^{\prime} \tilde{e}-$, para conferir em que medida este poderia levar à constituição de uma liderança política e como está estreitamente imbricado à produção de sujeitos, coletivos, discursos e práticas. A intenção foi, portanto, pensar essas formas de liderança guarani atualizadas na relação cada vez mais intensa com o mundo dos brancos, listando seus focos, motivações e planos de ação atuais, para melhor compreender seu lugar nesse confronto entre mundos, buscando sempre uma compreensão a partir da própria filosofia política guarani, para tentar conceitualizar alguns dos "mecanismos criativos" de organização e agência política destes povos, para além e aquém da esfera do Estado e da sociedade envolvente (ver Sztutman 2012b).

Aliei o trabalho de campo à pesquisa bibliográfica, para com isso, qualificar melhor em que medida a relação entre liderança e xamanismo se verificava em outros contextos contemporâneos, bem como suas transformações em relação à liderança tida como "tradicional", que converge a liderança "política" com a "espiritual” 8 . O interessante para nós era verificar a oposição entre esses dois polos, mais do que complementares, vitais um para o outro, e compreender suas diferentes disposições cosmopolíticas. Para tanto, se fez necessário compreender como se dava a criação dessas novas formas de associação e de representatividade a partir de toda uma filosofia política guarani anterior a elas, sem recair no "problema indecidível da autenticidade" (Carneiro da Cunha 2009), mas revelando toda uma criatividade política propriamente indígena, capaz de atualizar toda uma

\footnotetext{
${ }^{8}$ O termo "liderança" utilizado aqui, corresponde a uma tradução Mbya para o português, dos responsáveis pela dinâmica cosmopolítica intra, inter e externa aos tekoa. Além disso, a opção pelo uso desse termo se dá por ser esta uma palavra que não implica necessariamente uma distinção marcada de gênero. Emprego o termo liderança "política" (também uma tradução Mbya) então, para explicitar a diferença na disposição desempenhada por esse modo de liderança, que além de se ocupar do âmbito externo à aldeia, deve também, se ocupar dos problemas internos, seja dentro do universo da própria família nuclear ou, ainda entre as famílias de uma "comunidade". A chamada liderança "espiritual” (também uma tradução nativa da disposição desempenhada pel@s xamãs) cuidando mais da parte "espiritual” da aldeia, de sua saúde, e sua permanência enquanto Mbya nesta Terra, como me contaram meus interlocutores. Por isso, liderança aqui tem um significado amplo que engloba até mesmo@ cacique, assim como os chefes de família, já que tod@, chefe(a), antes de tudo, é também uma liderança local, mas o contrário não é verdadeiro. Prefiro não utilizar o termo "pajé", mesmo que, em certos contextos de interlocução, seja uma tradução nativa para o português daqueles que consideram como um xamã, pelo fato dos Mbya, na própria língua, consideraram esse termo em um sentido pejorativo: ipaje é traduzido por eles como "feitiço" e ipajeva'e se refere a "feiticeiro" ou "aquele que faz feitiço" (ver Macedo 2012a). Sobre a tarefa cada vez mais urgente da Antropologia em se atentar para o "português dos índios", ver Perrone-Moisés (2015).

9 A “tradição" como algo "original” não é um objeto acessível à análise, pois ela é sempre inventada, daí não ser possível definir a sua "autenticidade". Portanto, o que é considerado "tradicional” sempre está em relação a outra coisa e, segundo Carneiro da Cunha (2009), se refere tanto a modos de seleção, organização e ação, como a conteúdos. $\mathrm{O}$ "interesse indígena certamente é não "permanecer o mesmo" e menos ainda "voltar ao passado", mas preservar "a integralidade de suas relações 'sociais' (intra e extra-humanos), e para isso é preciso continuar se transformando (diferenciando)", em um incessante esforço para "desestabilizar o convencional" (Wagner, 2010b: 144), "não para conformar-se a ele" (Coelho de Souza, 2010: 106). O mais importante a compreender aqui, de acordo com Coelho de Souza, é que "o foco dos esforços assim como dos receios indígenas não está na oposição entre conservação e transformação, tradição e inovação:
} 
filosofia da chefia, da guerra, entre outras faces do "Contra-Um” ameríndio. Inclui-se aí, portanto, a busca dos termos e fundamentos de uma "antropologia política propriamente ameríndia” (Perrone-Moisés 2011), isto é, em termos propriamente Guarani. Foi a partir dessas referências que busquei iniciar minha investigação de campo a respeito da relação entre chefia, liderança e xamanismo na T.I. Tenonde Porã (o que não exclui suas relações com outros parentes que ocupam a costa litorânea das regiões Sul e Sudeste no Brasil), onde a chefia e liderança política das aldeias não mais correspondia, necessariamente, à sua liderança espiritual e esta também já não se remetia a uma só figura, convivendo ali diferentes xeramoĩ e xejaryi (literalmente "meu avô" e "minha avó”, em referência a sábios anciões, rezadores(as) e-ou xamãs) com estilos próprios de liderança e orientação. Estas questões foram então desenvolvidas e aprofundadas na pesquisa de Mestrado (20152017) e são, em alguma medida, produto direto de algumas reflexões que vêm sendo trabalhadas desde 2010 nos projetos de Iniciação Científica, somadas à experiência de campo entre os Mbya (2012-2013; 2015-2016).

O uso do “@” no título da Dissertação e ao longo do texto serve aqui para expressar um englobamento entre as letras “a” e "o", fazendo aparecer o duplo sentido do gênero da políti@: do fazer política ou político entre os Guarani-Mbya e do fazer-se político ou política em todos os planos, por meio da mobilização relacional que cada pessoa ${ }^{10}$ (que contêm em si muit@s) se dispõe a realizar. Essa tensão pode por vezes se separar na análise, mas ocorre inevitavelmente ao mesmo tempo, daí minha intenção em realizar uma etnografia avessa à tendência androcêntrica ${ }^{11}$ de boa parte da literatura

o risco não é transformar-se, mas transformar-se completa e definitivamente - isto é, dar fim à transformação" (Ibidem: 106-7). Ao buscar transformar-se, diferenciando-se dos outros, o mundo ameríndio revela a mútua imbricação entre aquilo que o Ocidente acredita que está estabelecido, que é da ordem do dadofeito-fabricado, e aquilo que imagina que é da ordem da construção, pois até mesmo o "dado" deve ser construído, lição que aprendemos nesses nossos (des)encontros com os outros. A antropologia reversa, por exemplo, (contra)inventada pelos melanésios no encontro colonial (culto à carga), seria uma das múltiplas maneiras nativas de conferir sentido cognitivo a uma "nova situação, usando velhas ferramentas para novos problemas" (Strathern, 2014b [1987]: 156). Outras sociedades, outros métodos de apreensão do $(s)$ outro $(s)$. Nesse sentido, a antropologia não seria (só) privilégio do Ocidente, afinal "tudo está em tudo e reciprocamente" (Donzelot, 1976: 155 apud Goldman, 1999: 76).

${ }^{10}$ Categoria de construção coletiva que organiza e dá sentido à experiência social de cada grupo. Podemos pensar a pessoa mbya então como "uma relação constituída por e constituinte de outras relações”, não como "uma essência, mas uma existência (ou melhor, um existir, enquanto ato)” (Testa, 2014: 281; 284).

${ }^{11}$ Não há muitas reflexões sobre mulheres na (cosmo)política. Por que será que elas não aparecem nas análises e se aparecem, ocupam um espaço tão reduzido, restrito e-ou secundário? Sobre o persistente androcentrismo nas descrições e análises de formas políticas nas Américas, que seguem em busca de chefes, xamãs e outras lideranças masculinas, pensando a política como acontecendo apenas entre eles, ver Perrone-Moisés (2015). As análises acabam reduzindo as mulheres a uma série de estereótipos que acaba as aprisionando à esfera da (re)produção, sedução e-ou doméstica, negando-lhes@ @olític@. Entretanto, pesquisas focadas unicamente em mulheres chefes ou xamãs, "longe de resolverem o problema, apenas o invertem”, já que "a chefia, entre os índios, é patentemente um cargo que só pode ser assumido por um casal” (Perrone-Moisés, 2015: 37). Nesse sentido, o papel das esposas de chefes e lideranças está "longe de ser coadjuvante no estabelecimento do prestígio do marido, mesmo porque não existe chefe solteiro. Em 
etnológica, fazendo, de fato, jus às relações entre os gêneros e outros seres dos cosmos, de maneira a (re)pensar a fronteira constantemente (re)estabelecida entre humanidade e não-humanidade a partir dos próprios Guarani que, como entre outros povos ameríndios, entendem que toda relação é intensamente social e deve ser manejada como tal, como num relacionalismo generalizado (ver Viveiros de Castro 2002a). Daí o interesse desse trabalho no fazer(-se) polític@, no plano mesmo das ações e disposições cosmopolíticas ${ }^{12}$ mbya e sua poética da resistência, para repensar a política ameríndia a partir dos próprios Guarani, o que caminha junto a meus interesses de formação enquanto etnóloga, que busca uma maior aproximação tanto ao que os "índios" dizem, quanto ao que eles fazem, mas também em relação ao que nós dizemos sobre eles e, a esses nossos (des)encontros, essa mútua afetação que ocorre nas e pelas relações que estabelecemos com eles (ver, nesse sentido, Favret-Saada 2005 [1990]).

A ideia aqui é colocar em questão a própria (dis)posição (des)privilegiada d@ etnólog@ na elaboração de uma análise antropológica, pois é em intensidade que é preciso compreender tudo, já nos ensinavam Deleuze e Guattari (2010 [1980]: 210). O esforço, portanto, reside em uma tentativa de pensar para além dos limites-contornos-confortos de uma certa Antropologia ${ }^{13}$, partindo da ideia de que a "filosofia da diferença é uma filosofia da relação” e que toda relação é de transformação recíproca (Viveiros de Castro,

muitos casos, os próprios termos nativos tratam de emparelhar chefes e suas mulheres, reconhecendo-as como 'chefas', ou melhor, como parte-mulher-da liderança, mesmo que as descrições insistam em tomá-las por 'mulheres de chefe'. No caso dos índios, não há 'primeiras damas' ou 'príncipes consortes' a acompanhar 'chefes' e 'chefas': são casais” (Ibidem: 37-38, grifos meus; ver também, nesse sentido, Viveiros de Castro [1986], sobre o casal-chefe arawete). A respeito do predomínio do viés masculino na análise antropológica e, por consequência, na Etnologia Indígena em geral, ver também Colpron (2005), Overing (1986), Lasmar (1996) e Strathern (2006 [1988], 2014 [1984]).

${ }^{12}$ Uma noção analítica renovada que busca unir o que não é separado nas sociedades ameríndias, a política e o cosmos, e que passa então a compreender a diplomacia cósmica, isto é, o tal relacionalismo generalizado, de negociação entre corpos-peles-roupas dos diversos seres do cosmos que cuidam de diferentes domínios e espaços, em incessante movimento. Tais sujeitos, apesar de compartilharem o ponto de vista humano, não possuem os mesmos corpos, visto que estes são fabricados localmente, a posição de humano dependendo do ponto de vista de cada ser na relação. Seria nessa diplomacia cosmopolítica que cada corpo e gênero se individua, fabricando sua "roupa" específica e atuando a partir de suas próprias disposições (ver Viveiros de Castro 2002a). Viveiros de Castro (2011a) chega a afirmar ainda que o perspectivismo ameríndio seria uma cosmologia contra o Estado. A noção de cosmopolítica empregada por Sztutman (2012a) é uma extensão do conceito proposto inicialmente por Isabelle Stengers e Bruno Latour no âmbito dos science studies. Para Sztutman não se trata de reduzir o termo cosmopolítica ao problema de uma "política dos outros", uma "etno-política", como se a verdadeira política fosse algo exclusivo ao mundo ocidental, ou ainda como se nós não fôssemos também "étnicos”, na medida em que definimos nossa política por meio de um "cosmos sempre particular" (Sztutman 2015).

${ }^{13}$ A Antropologia como estudo da(s) diferença(s) e tentativa de tradução da(s) experiência(s) de encontro com outros povos, revela-se uma espécie de ficção, uma equivocação controlada (Viveiros de Castro 2004) que faz ressoar na análise pelo menos dois pontos de vista heterogêneos. Procuro aqui privilegiar uma perspectiva antropológica que envolta em uma incessante (re)invenção de si mesma e de seus outros, que ao confrontar-se com outros mundos (estando ela mesma entre-mundos), produz tantos outros possíveis. 
2007: 99). Por isso, já não buscamos explicar ${ }^{14}$, mas compreender os funcionamentos dos pensamentos dos outros, pela (contra)síntese disjuntiva ${ }^{15}$ que aqueles estabelecem com os nossos, sem pretensão de resolver as suas contradições, nem reduzi-las (somente) à "nossa" tradução, mas entender o que se passa entre, sem reduzir essas multiplicidades a grandes partilhas dialéticas, pois aqui,como em todolugar, não existe@mocinh@e@ @ bandid@, mas sujeitos que se afetam mutuamente. Tal mudança de perspectiva deve vir acompanhada do desejo ou da aceitação de que já passou a hora de "radicalizar o processo de reconstituição da disciplina”, para que a Antropologia possa então "assumir integralmente sua verdadeira missão, a de ser a teoria-prática da descolonização permanente do pensamento" (Viveiros de Castro, 2015: 20).

Segundo Goldman, é P. Clastres e sua antropologia contra o Estado que faz "aquilo que a antropologia promete e nem sempre cumpre", que é se abrir para "a possibilidade de modificarmos nosso próprio pensamento a partir de uma relação com pensamentos outros" (Goldman, 2011 b: 583). É urgente reconhecer nossos interlocutores como sujeitos dotados de reflexividade própria, "teóricos com os quais podemos e devemos tentar dialogar e aprender" (Goldman, 2008: 7). Aprender com os "nativos" não é repetir ou reproduzir o que eles nos ensinam, mas uma abertura do nosso pensamento para a criatividade "nativa", como propunha Wagner (2010b), um modo de fazer o discurso "nativo" agir no interior do discurso d@ etnógraf@, fazendo o trabalho de "tradução cultural" aparecer como trabalho criativo de invenção em relação. $\mathrm{O}$ devir-outro sendo o devir do próprio pensamento antropológico. O meu objetivo então é colocar os pensadores "acadêmicos" e "indígenas" no mesmo pé de igualdade na produção do pensamento antropológico, ainda que os modos de apreensão e incorporação da diferença (e, portanto, do outro) permaneçam distintos. Se deixar afetar mais por modos outros de se fazer e pensar, por exemplo,@ polític@ ${ }^{16}$, pode transformar ofazer(-se) etnográfico ${ }^{17}$. Um dos métodos mobilizados aqui, nessa análise, é o uso de trechos de falas nativas mbya (inclusive

\footnotetext{
${ }^{14}$ Já não se trata (mais) de “interpretar" o(s) pensamento(s) dos outro(s) (isso é problema deles!), mas de realizar uma "experimentação com ele, e portanto com o nosso" (Viveiros de Castro, 2002: 124).

${ }^{15}$ Deleuze chama de "síntese disjuntiva ou disjunção inclusiva", esse "modo relacional que não tem a semelhança ou a identidade como causa (formal ou final), mas a divergência ou a distância; um outro nome deste modo relacional é 'devir' [...] Diferença positiva antes que opositiva, indiscernibilidade de heterogêneos antes que conciliação de contrários, a síntese disjuntiva faz da disjunção 'a natureza mesma da relação', e da relação um movimento de 'implicação recíproca assimétrica' entre os termos ou perspectivas ligados pela síntese, a qual não se resolve nem em equivalência nem em identidade superior" (Viveiros de Castro, 2007: 99-100, grifos meus).

16 "Política e pensamento selvagens têm, pois, algo a nos dizer e, reciprocamente, temos algo a aprender com eles” (Goldman, 2011 b: 589). Contra a nossa política-polícia de estabilização da diferença, a micropolítica das multiplicidades.

${ }^{17} \mathrm{O}$ que não exclui que tal disposição já não tenha sido levada a cabo em muitas das clássicas monografias que lemos. Para uma leitura sobre a história da construção da experiência e da autoridade etnográfica ver Clifford $(1998[1994])$.
} 
quando se trata de citações destas em outras bibliografias) dando presença, autoridade e poder efetivo a elas nesse fazer, que não se encerra nas páginas das etnografias.

Essa busca incessante pelos termos de uma filosofia ameríndia da cosmopolítica parte de uma leitura renovada da Etnologia Indígena, da proposição de uma Antropologia contra o Estado que permite questionar alguns (pré)conceitos, avançando ainda mais na apreensão das diferenças, fazendo-as proliferar ao invés de tentar estabilizá-las em certas caixinhas, e que prioriza a perspectiva das transformações, os dualismos em perpétuo desequilíbrio, o encontro entre-dois ${ }^{18}$, próprios do devir. Nesse processo mesmo de equivaler “conceitos” externos e, portanto, transformar(-se pelo[s]) significados outros, @ antropólog@como@ “xamã de seus significados” (Wagner, 2010b: 72),deve ser capaz de transitar e traduzir muitos mundos, viajar de corpo e alma e ainda voltar para contar a história, isto é, afetar-se pelas relações e produzir(-se) algo eficaz a partir delas. Não seriam apenas os outros canibais. Por isso, levar a sério o que indígenas dizem é perceber, por exemplo, que quando os Guarani-Mbya dizem algo em português sobre política e liderança, isto é, sobre nossos conceitos, estão traduzindo para nós, o que entendem sobre isso a partir da relação de conhecimento que estabelecem conosco, isto é, a partir de suas próprias categorias de pensamento.

É importante dizer também que esse trabalho não é uma etnografia sobre o Tekoa Tenonde Porã, mas uma caminhada junto às lideranças guarani que ali convivem e atuam. Busco, além disso, experimentar quais seriam algumas de suas relações com a questão do gênero, geração e o xamanismo mbya, na tentativa de contribuir para uma possível teoria nativa da liderança ou das disposições de gênero na cosmopolítica mbya. A ideia a partir daí é descrever as diferenças e aproximações entre a chefia ou as lideranças de uma "comunidade" e as chefias e lideranças de um coletivo de parentes, uma vez que estas não se resumem a um(a) únic@ líder, mas a todo um coletivo de pessoas que caminham sob a condução-influência de um(a) chefe(a) ou casal-chefe de tekoa e-ou de família extensa. Coletivo esse que desempenha também uma série de papéis e disposições necessárias ao grupo, na promoção-proteção de seu bem-estar físico-espiritual. Sigo então buscando pensar como as transformações nas formas e estratégias mbya de liderança e ação cosmopolítica no cenário atual são mobilizadas e produzidas, criativamente, no embate cada

\footnotetext{
${ }^{18}$ Nesse modelo problemático proposto também por de Deleuze e Guattari, as forças-potências do(s) pensamento(s) nômade(s), assim como o Estado, estão por todas as partes. E ainda que o Estado opere uma captura - sempre incompleta - da ciência nômade, ele nunca captura tudo: sempre vai existir um fora, um contra. O desafio que eles se colocam e nos inspira é: como fazer do pensamento uma máquina de guerra? E se nos inspirarmos pelos pensamentos selvagens-e-contra-Estado? É mais do que preciso então desinteriorizar continuamente a fôrma do pensamento de Estado, incorporando toda a potência da ciência nômade ou selvagem (na melhor e mais potente acepção da palavra).
} 
vez mais intenso com a política e modo de ser, pensar e de se comportar jurua, e têm seus efeitos na fabricação e proteção de corpos-espíritos, parentes, aliados e coletivos guarani. Estas transformações estão inseridas em contextos contemporâneos como os de luta pela demarcação de terras (yvy re jajoguero'a) e salvaguarda de direitos indígenas constitucionais - em face da ofensiva oficial do Estado brasileiro em aliança com interesses predominantes do agronegócio e da bancada "ruralista" -, tal como em projetos de fortalecimento cultural ou socioambiental sob a rubrica da "cultura", da "natureza" e da "tradição", palavras mágicas que funcionam enquanto dispositivos fundamentais nestas ações. Tal retórica passa então a afetar diretamente a produção de enunciados e perspectivas guarani para o futuro de suas lideranças (-uvixa kuery) e de sua "comunidade" (outra palavra mágica), que em situação de constrangimento territorial e superpovoação - com a morosidade nos processos de regularização de demarcação de T.I.s pelo Estado brasileiro - impondo limites à sua territorialidade e a seus próprios modos de organização cosmopolítica, impede violentamente sua movimentação espacial pela plataforma terrestre (yoyrupa), a sua ocupação controlada, suas práticas de relação de convivência em equilíbrio-tensão com outros seres, espaços e poderes, e a abertura de novos caminhos: bons, belos, bonitos (-porã) e verdadeiros porque eficazes na sustentação da vida nesta terra perecível (marã), imperfeita e doente (tekoaxy).

Neste cenário, o maior domínio do português, das leis e da burocracia jurua implicadas na requerida enunciação de uma identidade étnica (que se enquadre visualmente dentro dos padrões jurua do "índio verdadeiro”) pelo Estado brasileiro, principalmente após a promulgação da Constituição de 1988, passa a corresponder a um maior domínio político da arena de batalha e de visibilidade para a luta pela demarcação de suas terras e pelo reconhecimento de seus modos de ser, pensar e agir (nhandereko $\left.{ }^{19}\right)$, a afirmação mesma da diferença e resistência mbya contra o Estado, na medida em que este último se contrapõe diretamente e radicalmente ao seu. É possível perceber aí toda uma "indigenização" (Sahlins 1997) guarani dos processos burocráticos, a sua apropriação de lógicas outras dentro da sua própria, mantendo uma dinâmica de relações que oscila entre a proximidade e distância com a política dos brancos, que segue lutando por sua "dignidade" enquanto povo e contra a "humilhação" e a "desigualdade" com a qual convivem

\footnotetext{
${ }^{19}$ Nhandereko é como os Guarani-Mbya traduzem “cultura” neste contexto político de afirmação étnica, e corresponde a seu modo ideal de viver, a modos de agir e a comportamentos considerados adequados segundo as orientações dos deuses que os anciões interpretam e fazem circular entre os seus. O que não quer dizer que seja algo estável, ou mesmo fechado e fixo, mas construído e inspirado nos comportamentos das divindades, incluindo seus desvios de comportamentos quando caminhavam-criavam yzyrupa, sendo tanto modelo de reflexões, como de aprendizados, contados através de kaujos (“causos") e outros contos míticos - método de aprendizado-imitação guarani inspirado nos mitos (ver, neste sentido, Ramo 2014).
} 
diariamente, subvertendo assim a lógica mesma de assimilação e tutela praticada pelo Estado, em sua recorrente tentativa de domesticação velada. Essa ampla rede de traduções e transformações implicada na interação com o Estado e a sociedade envolvente, cria novas possibilidades de agenciamentos guarani no mundo jurua, levando a um amplo investimento das lideranças na formação de jovens guerreir@s (xondaro e xondaria kuery) para a continuidade desta luta, ou mesmo no engajamento e manejo de políticas públicas voltadas para garantia de recursos em áreas diversas e essenciais tais como educação, plantio e alimentação, saúde, saneamento, abastecimento de água, moradia, entre outros, ou mesmo com o mundo dos projetos, que circulam amplamente dentro das aldeias. Tal movimento, no contexto de interação atual, teve impactos na tendência à convergência política entre chefia e xamanismo, promovendo uma crescente "disjunção" - de disposições - entre tais esferas (ver Macedo 2010). É na tentativa atual de criação de um espírito "comunitário" em oposição aos brancos que aparecem mais fortemente essas jovens lideranças que buscam cada vez mais se especializar nessa esfera de interlocução. Elas devem investir com mais intensidade em um aprendizado de conhecimentos jurua, atuando enquanto mediadores entre a coletividade e o mundo não-indígena, devendo saber manejar bem códigos em guarani py (língua guarani) e jurua py (língua portuguesa).

Há toda uma gestão e mobilização guarani dessas relações de comunicação entre $\operatorname{corpos}^{20}$, seres e poderes, onde diferentes domínios demandam diferentes retóricas e ações, e identidades étnicas tornam-se armas políticas, principalmente pós 1988, envolvendo toda uma diplomacia cosmopolítica que parte de uma ética da moderação, xamânica, com vistas à fabricação de pessoas e coletivos saudáveis e alegres nesta terra perecível e que se acentua ainda mais nesse contex to de constrangimento territorial e superpovoação, impondo limites ao exercício de sua territorialidade. O interesse, portanto, reside na maneira como tais relações se atualizam e se produzem nos dias de hoje, com a

\footnotetext{
${ }^{20} \mathrm{O}$ que distingue e faz variar os diferentes tipos de seres (humanos e não-humanos) são seus corpos. Todos são potencialmente e perigosamente sujeitos, sendo o corpo o lócus mesmo da diferença. O corpo é visto antes pelo que ele pode fazer, como afeta e é afetado, que por suas características fisiológicas supostamente fixas (ver Lima 2002). É também a grande arena na qual as transformações são possíveis, daí a sua instabilidade e seu constante manejo e cuidado. Por isso, parto aqui da centralidade que o corpo ocupa durante toda a experiência das pessoas guarani nesta terra doente (tekoaxy), em que tudo se corrompe e perece, pensando a fabricação destes corpos como uma tarefa cotidiana que preenche toda sua existência justamente porque é através dela que se produzem pessoas e coletivos com potencialidades distintas, mas que se comunicam e se afetam entre si. O que importa aí então, é diferenciar os corpos e seus comportamentos (em relação), tentando incessantemente controlar as afecções provenientes de corpos outros, na busca da proteção dos parentes-humanos. O objetivo central do xamanismo perspectivista ameríndio é estabelecer e manter a conexão-comunicação diplomática entre seres heterogêneos, num esforço contínuo para manter a própria sociedade.
} 
proximidade intensiva e extensiva dos jurua kuery e sua incapacidade de manter moderados seus comportamentos, pensamentos e ações, considerados agressivos e perigosos do ponto de vista Guarani, produzindo em seus corpos descontentamento e insatisfação.

Partindo aqui do ponto de vista de algumas das lideranças guarani atuais que convivem entre si e atuam dentro da T.I. Tenonde Porã, especialmente aquelas que habitam o tekoa de mesmo nome, busco compreender a sua atuação ${ }^{21}$ e mobilização de relações, isto é, suas potências e capacidades de afecção nas movimentações relacionais. É importante ressaltar que busquei aqui entender em que medida as configurações atuais de liderança apresentam uma "novidade" em comparação àquelas lideranças que meus próprios interlocutores consideram como mais ou menos "tradicionais" (termo sempre relacional, não absoluto e que não necessariamente remete a um problema de ordem temporal ou às relações de interlocução com os brancos), aliando essa minha convivência, encontros e caminhadas em campo ao lado dos Guarani e meus dados etnográficos a uma ampla revisão bibliográfica da relação entre xamanismo, política, poder ${ }^{22}$, parentesco, gênero e geração presente, de maneira central ou periférica, na literatura sobre os Guarani, e que me permite uma série de indagações e inspirações, ainda mais com os cruzamentos entre esta e os estudos recentes que se inscrevem no campo da Antropologia Política e da Etnologia Indígena e percorrem temas como corporalidade, construção da pessoa e do parentesco e fabricação do corpo-humanidade entre os povos ameríndios.

Opto aqui por apresentar e descrever meus próprios interlocutores, em respeito e atendendo seus pedidos - uma vez que são eles lideranças da "linha de frente" -, somente por seu nome em guarani ou genericamente como "liderança" e, apenas em passagens e temáticas que não possam gerar qualquer desconforto ou a possbilidade de problemas internos ou externos a esse tekoa, especialmente entre as mulheres e os mais velhos, que são pessoas bem mais reservadas, sendo até mais preservadas pelo coletivo, a grande maioria preferindo então evitar a exposição desnecessária nos meios jurua. Além disso, há todo um contexto político difícil que persegue tanto antropólog@s como lideranças indígenas. Assim, por entender que a biografia ou o nome em português dessas pessoas não afeta diretamente a análise aqui proposta, prefiro nomear menos e falar da

\footnotetext{
${ }^{21}$ É importante deixar claro que as esferas ou espaços de atuação, que correspondem à trajetória de cada pessoa, sendo ela Guarani ou não, são relativizadas no tempo e no espaço. O que etnografamos são apenas fragmentos desse movimento.

${ }^{22}$ Faço aqui uso do termo "poder", tal como proposto por Testa (2014), em seu sentido mais genérico, que se aproxima da definição de "agência” ou capacidade de agir, e que não reflete, necessariamente, poder coercitivo, justamente porque este entendimento permite dialogar mais diretamente com os usos que os próprios Mbya fazem dessa palavra, em enunciados em português.
} 
cosmopolítica mbya de maneira mais geral, sem fixar as localidades e pessoas, mas fazendo referência direta a meus interlocutores de pesquisa. Durante minha experiência de campo tive que tomar muito cuidado com meus comportamentos e ações tanto dentro como fora da aldeia, pois a minha posição de amiga-parceira-jurua ${ }^{23}$-antropóloga estava sempre em movimento. Tal (dis)posição podia mudar a partir de cada contexto de relação ou convivência, refletindo no "ciúmes" ou mesmo na "desconfiança" 24 de outras famílias que eu não estava tão próxima em determinados momentos, principalmente quando envolvia disputas ou tensões entre elas, por isso, tive que ter cuidado ao circular entre elas, mas também fui inserida em suas redes de parentesco e aliança. A confiança que podem estabelecer é sempre momentânea, pois estão sempre em alerta no estabelecimento de relações, todo mundo está sempre sob intensa suspeita, o que ocorre inclusive entre si (entre parentes). Também posso contar que conviver e trabalhar com eles é entrar no tempo guarani, das perguntas e respostas que devem vir sempre quando (e se) houver inspiração ${ }^{25}$, o que muitas vezes pode não ocorrer em português. Essa temporalidade própria, é possível ser sentida e percebida mesmo nos limites da cidade grande de São Paulo, onde a velocidade dos acontecimentos pode tomar um grau maior que em outras localidades, mas onde é possível perceber que ainda assim eles seguem resistindo (e criando diferentes estratégias para isso) às inúmeras interferências e seduções de fora.

Esse trabalho parte também de uma perspectiva não androcêntrica da diplomacia cosmopolítica e do xamanismo guarani, o que possibilita a abertura a um outro olhar na

\footnotetext{
${ }^{23}$ Como sou mulher, e de fora, o termo nativo, em mbya, que utilizam para se referir a mim e a outras mulheres nas aldeias da região Sudeste do Brasil, é xaryi (ou jaryz), já no Sul do país, o termo mais utilizado para se referir às mulheres de fora, não-indígenas, é xenhora (ver, nesse sentido, Prates 2013). Como comenta Testa: “-Jaryi é um termo de parentesco usado para se referir à avó, mas também é usado para se referir a qualquer senhora idosa (que, portanto, provavelmente é avó de alguém, mesmo que não seja de quem assim se dirige a ela). O termo também é usado para se referir a mulheres não indígenas (independente da sua idade)" (Testa, 2014: 141, nota 120).

${ }^{24}$ Essa recorrente desconfiança em relação aos outros também envolve uma postura das próprias divindades em relação a seus filhos caçulas, que se não caminharem bem seguindo seus ensinamentos, deixarão de ser "olhados", cuidados por elas, ficando assim em uma posição vulnerável, sujeitos aos olhares de outros seres-poderes. O que fica claro no comentário de um interlocutor de Ramo: "se você não desconfiar aí Nhanderu também vai falar 'Poxa, ele não está se cuidando', e aí também não vai olhar, pra ajudar” (Ramo, 2014: 154; ver também Capítulo III). As mulheres mbya (kunhãgue), mas não só elas, são sempre mais desconfiadas que os homens (avakue) e como em campo, são eles que, primeiramente, recebem e fazem contato com as pessoas de fora, até eu conseguir acesso e a mínima confiança das kunhãgue, levou um certo tempo, o que também diz muito a respeito de sua força e resistência contra as interferências de fora.

${ }^{25}$ Como aprendi com os Guarani, o silêncio diz muito e é importante aprender a sentir as pessoas e as situações. Eles lidam de maneira diferente com as palavras, sendo ensinados a não falar à toa, só mesmo quando inspirados, o que envolve um intenso controle sobre a fala que também pode revelar-se um grande poder de movimentação cosmopolítica. O conhecimento ou os saberes passam diretamente pelo corpo e são revelados pelas divindades a partir de uma relação singular que se estabelece entre eles e nhe 'ẽ pelos caminhos, daí talvez venha a dificuldade em falar sobre espiritualidade (tradução nativa para "xamanismo"), pois ela tem mais a ver com sentir com o coração. Daí que o saber seja um saber do corpo também, o que para os Guarani, está diretamente relacionado ao caminhar (imitando o percurso ou os comportamentos das divindades que servem como imagem-guia para as suas ações aqui na terra), sinônimo de conhecer e aprender.
} 
descrição das diferentes disposições coletivas de produção, proteção e manutenção da vida nesta terra. Ainda que meu trabalho não esteja inteiramente focado nas questões de gênero (o que exigiria uma revisão bibliográfica mais exaustiva), ele se guia por elas e pela recusa do androcentrismo, capazes de talvez reconfigurar todo o fazer etnográfico ${ }^{26}$ contemporâneo (ver Strathern 2006 [1988], 2014a [1984]). É importante ressaltar também que essa intenção parte também do fato dos Guarani (assim como outros povos) viverem atualmente um contexto cada vez maior de valorização e protagonismo ${ }^{27}$ público de jovens mulheres mbya (kunhãgue), assim como a abertura e conquista de espaços de fala e atuação política no âmbito da "comunidade" e, em alguns casos, "para fora" dela também, que antes eram majoritariamente ocupados por figuras masculinas ou mais velhas e experientes. A partir disso, busco refletir sobre a diferença, complementaridade e fortalecimento (-mbaraete) mútuo de ambos sujeitos ${ }^{28}$, kunhãgue e avakue (homens mbya), e suas diferentes capacidades-poderes (po'aka) - adquiridas via experiências de comunicação xamânicas - na construção e composição de pessoas, lideranças e chefias, coletivos, discursos e práticas. A ideia é alargar de fato nossas concepções de política e pensar as movimentações desempenhadas pelos diversos sujeitos correspondendo mais a disposições cosmopolíticas diferenciantes e, portanto, relacionais, do que a funções ou (o)posições propriamente ditas ou mesmo fixas, a capacidades singulares de agir, fazer agir, afetar e ser afetado, que contam com diferentes modalidades e estilos de liderança e áreas de atuação, influência e prestígio (que estão sempre em movimento). Tais figuras políticas podem ser pensadas também como tradutoras de mundos ou diplomatas cosmopolíticos, transitando por diferentes códigos e agenciando diferentes mundos, onde tudo é polític@29 (relação, diálogo e negociação).

\footnotetext{
${ }^{26}$ Marilyn Strathern faz da perspectiva do gênero um demolidor da ideia de sociedade como algo estável, propondo uma profusão de múltiplas socialidades. Para tanto, ela parte da análise das socialidades políticas e domésticas entre os povos melanésios (ver Strathern 2006 [1988]).

${ }^{27}$ Que decorre também da emergência dos planos de ação dos feminismos jurua - e seus próprios entendimentos a respeito da "valorização" das mulheres -, que são cada vez mais requeridos pelas agências de financiamento das Organizações Não-Governamentais (ONGs) e que acabam afetando também a dinâmica interna das aldeias e, muitas vezes, contribuindo ou estimulando um maior empoderamento das kunhãgue e dos jovens seja concedendo-lhes espaços nos projetos, na política comunitária e no quadro de empregos internos.

${ }^{28}$ É importante dizer aqui também que não tomo os sexos ou os gêneros, os "homens" ou "mulheres" guarani enquanto categorias estanques, biologicamente dadas, mas como socialmente construídas pela diferenciação, o que implica uma certa noção de corpo e de pessoa e uma outra economia da diferença. Ambos estão socialmente engajados na proteção-produção de pessoas dentro de um coletivo, daí não ser possível fazer uma separação definitiva ou um corte profundo entre o âmbito de atuação pública-política ou privada-doméstica, ou entre masculino e feminino, pois estes se constroem em e pela relação (e os faz, ao mesmo tempo, complementares), mas não exclui que existam diferenciações de sexo ou gênero entre eles. ${ }^{29}$ Do ponto de vista da "micropolítica" de D\&G, "uma sociedade se define por suas linhas de fuga, que são moleculares" (Deleuze e Guattari, 1996 [1980]: 94). Em suma, para eles, "tudo é político, mas toda política é ao mesmo tempo macropolítica e micropolítica" (Ibidem: 90).
} 
Essas questões também são parte de uma certa inquietação minha com a literatura guaranióloga que acaba por centralizar e concentrar grande parte da administração e circulação dos saberes-poderes inspirados pelas divindades na figura dos chefes-xamãs, dispensando atenção, muitas vezes, na descrição etnográfica, para a importância, valor e centralidade das mulheres no sistema xamânico guarani e na produção, proteção e mobilização de pessoas e relações (ver Capítulo III). A partir da proposta de uma outra leitura da literatura (que serve como inspiração para situar algumas das minhas questões) e da minha experiência de campo, busco refletir então sobre o que é e o que faz uma liderança guarani, me valendo também de uma reflexão sobre como os próprios Guarani pensam a questão do gênero nas relações de diplomacia cosmopolítica, aqui compreendidas, em linhas gerais, enquanto diferentes saberes-poderes que expressam corporalidades distintas e tomam lugar na organização coletiva, isto é, disposições ou capacidades diferentes de agir sobre este mundo e sustentá-lo.

Irei agora descrever, brevemente, alguns dos caminhos que cada um dos capítulos que compõem essa Dissertação irá seguir. Ressalto também que parto primeiramente de um registro bibliográfico mais geral (sem pretensão alguma de esgotá-lo ou resolvê-lo) para introduzir e complexificar a discussão de meu registro etnográfico, por uma questão de método, por acreditar que a análise fica mais compreensível assim, (des)construindo pouco a pouco certas perspectivas e desamarrando certos esteriótipos para explicitar a diferença que pretendo enunciar na análise antropológica e, finalmente, chegar à discussão sobre a potência das mulheres guarani (o que, certamente, não impede outro método de leitura ou análise). Por isso, começo falando dos principais temas percorridos pela literatura guaranióloga para depois chegar à analise da minha experiência de campo e à questão de gênero. De todo modo, a pesquisa de campo direcionou toda a discussão bibliográfica e entra aqui como uma espécie de “controle” dessa revisão. É importante dizer também que a grande maioria das palavras utilizadas entre aspas e-ou itálicos, que fazem referência direta à dinâmica política do Tekoa Tenonde Porã são traduções nativas de como entendem a sua própria maneira de fazer(-se) polític@, entre outras coisas, em português. É importante ainda ressaltar que essas traduções dependem de cada pessoa e do contexto enunciativo em questão e, muitas vezes, tomam um sentido de um ato político. Quando não estou me referindo especificamente a essa aldeia, o uso desses recursos pode remeter mais à literatura e a conceitos ou termos já consagrados.

No primeiro capítulo ("Entre caminhos e caminhadas: movimento e ação política Guarani-Mbya") a ideia é contextualizar de maneira geral os Guarani e o complexo de 
aldeias da Serra Mar, consideradas como um local importante de transição para o movimento corporal-espacial com fins espirituais em busca de uma terra sem mal (yry marã e' $\tilde{y}$ ) - própria à humanidade Guarani -, incluindo aqueles tekoa que se situam nos limites do município de São Paulo (SP). Falo um pouco das diferentes estratégias de resistência pelos caminhos que levaram à presença Mbya em SP, e têm relação direta com o que contam as narrativas míticas que lhes servem de inspiração, onde os heróis fundadores da segunda terra (yvy pyau), Sol (Kuaray) e Lua (Jaxy), fazem a caminhada do centro da terra (yvy mbyte) até a beirada do oceano (yvy apy), criando a plataforma terrestre (yzyrupa) e as condições de vida para seus filhos caçulas (nhandera'y ijapyrepyre’i). Me centro aqui na história da fundação das aldeias da capital paulista, especialmente do Tekoa Tenonde Porã (Barragem/Morro da Saudade) e em sua importância social na promoção e manutenção das redes de relações e intercâmbios de diversas ordens entre as aldeias mbya de SP, além do seu protagonismo, no momento atual, na luta pela demarcação de terras, lançando mão de uma série de estratégias criativas e inovadoras de resistência em suas mobilizações políticas na cidade, nas redes sociais e na retomada de territórios, que auxiliam na formação das novas gerações de lideranças e que tem na Comissão Guarani Yvyrupa (CGY), o seu principal instrumento de organização política. Essas "retomadas" ocorrem como uma forma de protesto pela não regularização física da demarcação de suas terras, uma espécie de autodemarcação indígena, e se dão, principalmente, pelo fato de um grande número de famílias conviverem em um espaço de terra muito reduzido (aquele oficialmente homologado pelo Estado), que impossibilita a criação de espaços ideais para construção de casas e roças, e para a manutenção do ideal da boa distância ${ }^{30}$, que preza pela autonomia de cada chefia de família extensa e sua subsistência. Ressalto então a centralidade que a mobilidade guarani pelos espaços-tempos tem na construção de sua memória e territorialidade, suas ações, seus caminhos e pensamentos, tendo em vista a reprodução e proteção do parentesco. Entendo os Guarani-Mbya também enquanto guardiões de yzyrupa, auxiliares dos Nhanderu e Nhandexy kuery aqui na terra e, os seus tekoa como cinturões de proteção que sustentam esse mundo, pontos de passagens de fortalecimento corporal-espiritual para as caminhadas em direção à terra sem mal,

\footnotetext{
${ }^{30}$ É importante ressaltar aqui também a relação entre retomada de terra e liderança de um grupo: tradicionalmente, é sempre uma liderança espiritual que segue à frente (tenondegua), mostrando o caminho, tomando a iniciativa de abrir novas aldeias ou espaços de convivência e sobrevivência, orientando e cuidando da condução de um coletivo. Tal disposição depende, segundo Testa, "dos conhecimentos e habilidades adquiridos e do reconhecimento que outros membros do grupo atribuem às capacidades dessa liderança" que, frequentemente, é "desempenhada por um casal mais velho" (casal-xamã), ainda que possa "também ser distribuída por diferentes membros de um grupo, de acordo com as atividades em pauta” (Testa, 2014: 176; ver também Pimentel [2012: 130] e a figura do “tendotâ").
} 
onde desejam recobrar, integralmente, a divindade de seus corpos-espíritos, reproduzindo e imitando os movimentos e os comportamentos das divindades aqui na terra.

No segundo capítulo ("Disposições cosmopolíticas Guarani: entre domínios e personagens”), fruto em grande parte do desenvolvimento da minha pesquisa de Iniciação Científica, apresento de maneira geral, a relação entre liderança, política e xamanismo entre os Mbya, e as principais referências teóricas e etnográficas com a qual a pesquisa dialoga que remetem tanto à tradição, quanto às transformações no contra-Estado e paraguerra ameríndio. Sigo aí a divisão e distinção de responsabilidades coletivas atuais ou, o que vim chamando de disposições e capacidades diversas de liderança e chefia envolvidas no fazer(-se) (cosmo)polític@ ${ }^{31}$ guarani, que envolve toda uma multiplicidade de seres, saberes e poderes. Me proponho então a descrever como a socialidade xamânica guarani e seus próprios modos de conceber e produzir chefia e liderança contam com diferentes estilos ou disposições que atuam diretamente na produção incessante do espaço-vidasaúde-força-alegria-leveza dos corpos-parentes e do tekoa, e têm seus paralelos atuais, fazendo aparecer a alternante (e, portanto, complementar) dinâmica entre disjunção e conjunção na relação entre poder, parentesco, gênero, geração e xamanismo. Por isso, é importante ressaltar aqui a complementaridade (e não o antagonismo) do casal guarani, assim como de suas diferentes disposições na divisão do trabalho e produção da diferença.

A ideia, portanto, é pensar estas relações (mesmo que assimétricas e necessitando ser melhor conceitualizadas a partir de uma mudança de perspectiva etnográfica) entre os Mbya, como uma colaboração entre os gêneros, complementos diferenciais um do outro (que tem base em preceitos divinos), atuando juntos na promoção do bem viver (teko porã) entre parentes (-retarã kuery). Como uma espécie de controle dessa revisão bibliográfica, parto para a descrição da gestão das relações entre as numerosas parentelas no Tekoa Tenonde Porã, o estabelecimento de relações de aliança e parentesco que ocorrem aí na chave da afirmação de sua in(ter)dependência e evitação do conflito, na tentativa de promoção da cooperação e produção de boas disposições entre os diferentes núcleos de parentesco pelo Conselho de lideranças da aldeia e pelas suas lideranças espirituais (nhaneramoĩ e nhandejaryi kuery, literalmente, nossos avôs e avós, sábios anciões eou rezadores, xamãs) com vistas à construção do consenso coletivo e, consequentemente, da chefia do tekoa (tekoaruxiva), isto é, d@ "cacique” e da “comunidade”. Ressalto também

\footnotetext{
${ }^{31}$ Essas disposições são distintas, porém complementares, interdependentes na promoção do bem-estar coletivo. A diferenciação no manejo dos distintos domínios de comunicação com a exterioridade (planos horizontal e vertical) seria inseparável entre os Guarani, que mais bem a entendem como transversal.
} 
as dificuldades decorrentes desse difícil trabalho no atual contex to político de confinamento territorial e superpopulação, que leva à multiplicação e pluralidade de figuras de liderança, principalmente entre as novas gerações, que devem procurar se formar e se especializar no manejo dos diferentes planos de comunicação com a exterioridade, atuando enquanto auxiliares-guerreir@s (xondaro e xondaria kuery) na proteção-produção do tekoa, articulando as suas reivindicações políticas junto ao Estado brasileiro. A partir dessas figuras do movimento, busco compreender quais são os atributos complementares de chefia e liderança e seus diferentes estilos (teko), que resistem a uma centralização permanente ou mesmo estável, estando sempre e, necessariamente, em movimento. Busquei então seguir a atuação cosmopolítica das pessoas guarani - esse agregado de relações corporificadas em movimento -, enquanto caminhos iluminados (omoexakã) por Nhanderu e Nhandexy Ete, pelos quais cada um busca desenvolver e aprimorar suas capacidades-poderes (-po'aka), com vistas a alcançar o teko porãa que tem como base as práticas e condutas inspiradas pelos deuses, verdadeiramente adequadas a seus corpos-espíritos que trazem alegria e satisfação e, consequente, saúde aos parentes.

No terceiro capítulo ("Modos de liderar e se movimentar: complementaridade e produção de diferenciações cosmopolíticas”), proponho seguir expandindo a nossa compreensão do que é política e xamanismo e as múltiplas interpretações que podem decorrer daí, a partir das relações entre as gerações e os gêneros entre os Guarani-Mbya, estas últimas fundadas, necessariamente, na lógica de complementaridade do casal - enquanto seres distintos e diferenciados, com diferentes atuações na enunciação e criação (e destruição) do próprio mundo - como unidade política-doméstica, na produção do parentesco-humanidade, que busca reproduzir o fluxo de desdobramento (-mbojera) do movimento das divindades. Ressalto aqui a importância, pouco comentada na literatura guaranióloga, da atuação feminina na chefia e liderança do grupo de parentes (-retarã kuery) junto a seus companheiros, sua capacidade de agencia política no âmbito da família extensa ou mesmo nuclear e para além dela, no âmbito da comunidade (ocupando aí, inclusive o maior número dos cargos remunerados atualmente), ou para "fora" dela, quando seu prestígio ultrapassa o grupo local, seja a partir da disposição xondaria (auxiliar-guardiã-guerreira) ou mesmo enquanto xejaryi ou kunhã karai (xamã-rezadora). Eles devem atuar juntos na fabricação e fortalecimento (-mbaraete) da conexão entre os corpos (-ete) e espíritos mbya (nhe'ê), isto é, na produção de boas disposições entre parentes, controlando os sentimentos demasiadamente mundanos que deixam a pessoa vulnerável a ataques de outros seres e podem incorrer em transformação animal (-jepota), e que devem 
ser evitados por meio da replicação de uma série de comportamentos que os aproximariam das próprias divindades, mães e pais dos nhe'ẽ, e que podem levá-los à obtenção da maturação e perfeição corporal-espiritual (aguyje).

Não é nosso objetivo aqui fazer um mapeamento de todas as teorias sobre chefia indígena, nem de gênero, parentesco e xamanismo, e sim levantar questões mais que resolvê-las (embora não deixe de apontar também algumas possibilidades). Ressaltamos que a discussão sobre representação política dos Guarani realizada pela tradição etnológica, por exemplo, concentra o olhar e privilegia a interlocução com figuras de chefia e liderança masculinas - assim como a Antropologia em geral (ver Overing 1986, Strathern 2006 [1988], 2014a [1984], Lasmar 1996) -, como o xamã $\tilde{a}^{32}$ e o guerreiro na descrição etnográfica e, acaba assim colocando algumas dificuldades para que possamos contextualizar e demonstrar a centralidade do par feminino-masculino, isto é, das pessoas mbya e de seus nhe'ẽ que, como dito, devem se fortalecer juntos na produção-proteção desse mundo. Como já destacou Ciccarone, "nossas categorias e olhares não são inocentes" (2001: 15), nesse sentido, a intenção aqui então é tentar superar algumas dicotomias presentes no pensamento ocidental relacionadas às distinções e separações entre natureza e sociedade, feminino, masculino, público, privado, político e doméstico, ritual e cotidiano, ou mesmo política e gênero, sujeito e objeto, dominação, hierarquia e subordinação, que só fazem sentido separados em nossas análises, nas quais, por vezes, estabelecemos um corte profundo sem estancar sua ferida, privilegiando um lado em detrimento do outro, o que dificulta a análise antropológica da socialidade dos outros e a compreensão de sua filosofia cosmopolítica. É importante atentar para o fato que entre eles, os nossos outros, essas rupturas podem não fazer sentido e por isso, talvez elas devam ser rompidas e superadas para gerar simultaneidades (isto $e$ aquilo, ao mesmo tempo) e não separações (isto ou aquilo), o que pode auxiliar na compreensão dessas outras lógicas de pensamento e ação. Não acredito também que o domínio político ou público seja uma espécie de transformação melhorada ou mais importante (ou mesmo restrita unicamente à masculinidade) que a esfera doméstica (supostamente restrita às mulheres), pois compreendo aqui que a centralidade da ritualidade cotidiana reside justamente em sua potência em revelar a produção das relações entre gênero, parentesco e poder, envolvendo uma

\footnotetext{
32 Ainda que em alguns casos, aponte a liderança e orientação das mulheres nos movimentos migratórios e na dinâmica de produção-proteção dos tekoa. Para uma discussão a respeito da relação das mulheres e a orientação xamânica, ver Ciccarone (2001, 2004), Ladeira (2007 [1992]), Mello (2006), Prates (2013), Ramo (2014), Testa (2014).
} 
negociação entre sujeitos a todo momento e que podemos chamar, talvez de diplomacias cosmopolíticas domésticas, ressaltando a sua necessária continuidade.

Por isso, nosso propósito é conferir visibilidade - mas não só - às vozes das mulheres mbya, fazê-las aparecer na dinâmica cosmopolítica de convivência, cuidado e liderança guarani, levando a sério o que dizem e fazem. Para tanto, me inspirei principalmente nos estudos de gênero contemporâneos empreendido por antropólogas atentas à importância das mulheres indígenas e em uma perspectiva que não necessariamente visualiza as relações de gênero na chave da "dominação masculina” (Overing 1986, Strathern 2006 [1988], 2014a [1984], Franchetto 1996, Lasmar 1999, Belaunde 2006, McCallum 2013, entre tantas outras). Busco então entender em que consistiriam essas disposições diferenciantes mbya e como elas se relacionam aos processos de produção e proteção de pessoas, parentes e coletivos. Por isso, pretende-se também pensar como certas formas de relação que os Guarani desenvolvem nessa terra, por exemplo, com seres-donos-espíritos e seus domínios de cuidado e ação, estando intimamente associadas aos seus preceitos divinos orientadores e à produção de movimento e diferença podem nos auxiliar a pensar a relação que estabelecem com o mundo jurua. Comento também acerca da importância da instituição estatal Escola na formação dos jovens e de seu paralelo com a formação corporal-espiritual na opy (casa de reza-canto-dança-cura), as lideranças e professores da aldeia atuando juntos na preparação d@s nov@s guerreir@s mbya, incorporando conhecimentos outros sem deixar de cultivar os próprios modos de saber-aprender-fazer e de cuidar-caminhar adiante com seus próprios saberes-poderes. 
Página | 30

\section{Nota sobre ortografia e pronúncia Mbya}

Acerca dos padrões ortográficos utilizados nesta Dissertação, é importante ressaltar que não há uma norma ortográfica única para o idioma mbya, cada região tem a sua própria maneira de escrever, por isso faço uso aqui da grafia do contexto em que as aprendi, em São Paulo, na T.I. Indígena Tenonde Porã. As palavras guarani são em sua grande maioria oxítonas e, nesta T.I. os Guarani não fazem uso da acentuação, como outras aldeias, quando a sílaba tônica foge à essa regra, como na palavra xondaria (“tchondária”), somente em algumas palavras, geralmente, nasalizadas (como em kunhãgue). As palavras em guarani estão em itálico ou entre aspas (principalmente quando trata-se de uma tradução guarani para o português), e as grafias dessas palavras quando citadas de outros autores estarão tal qual foram gravadas em suas fontes. A respeito da pronunciação dessas palavras: o j tem som de dj; o x produz som de tch ("tchê”, "tcha”) como xeramoĩ e xejaryi ou xamoĩ e xaryi; o v, tem um som intermediário entre o v em português e w do inglês; o y (sexta vogal guarani) é uma vogal gutural, com som próximo do u francês (como jaryju “dja-uu-dju”: "nos levantamos de novo" ou genericamente "bom dia"); o k substitui o c, qu; iniciais nasalizadas iniciam com mb, nh, nd, ng, etc.; o uso do apóstrofo (') como em nhe’ẽ indica oclusão na pronúncia, entre outras tantas especificidades que não caberá aqui desenvolver. 
Capítulo I. Entre caminhos e caminhadas: movimento e ação política GuaraniMbya

AGUYJEVETE!

Reguata'i ndaje ra'e, rire'indaje reupity'i kova'e reko ra'ı̃ rupi ae ma nderatay py'i rupa'i rupi, mbory nhamandu nhemopu'ã, mbory nhamandu kuray'ã rupa re, mbory nhamandu raky kue rei e'ỹ gui rerojapyxaka rire vy mã

Nhe'é kue'iry mbopy'aguaxua kue'iry tove katu tape rupa'i tomõ pã ũ porã̃ katu he'ere ague'i mbojerovia pora'ĩ agui ndaje mĩrami nderete'i reupity pora'ĩ kova'e jery'ma va'erãko aguyjevete kova'e rema nderete'i reno' ã porã'i va'erãko ha'e opamba'e reko anhete, ko yoy rupa gui katuve'ma, yoy rupa gui anhove'yma nhanderete'i jareko porã verity va'erã rami ve'yma, nhanderu yoy rupa va'e mbyte mbyte rupi jepe ha'e ramigua etegui jepeama anhete mbory araymã guive'yma, mbory arapyau guive'yma anhete, mby'aguaxuve rekorã'i re joguerojapyxaka anhete onhembojerovia pora'̃ oikovy ae guivyma anhete nderete'i reno'ã porá ĩ va'erãko anhete kova'e rupi jery-jery'i nhanderete'i nhano'â'i raẽ'ma Aguyjevete anhete

Você fez uma caminhada pra chegar até aqui e alcançou para isso acontecer, lá no seu lar, durante vários amanheceres, vários ocasos, vários anoiteceres, você esperou, se concentrou e pediu para que os nhe'ẽ que nos guiam, protegem e fortalecem pudessem belamente iluminar o seu caminho você pediu com verdadeira confiança e, assim, isso se realizou seu corpo purificado alcança de novo o que agora acontece por tudo isso, aguyjevete

desse modo, você sentirá o bem-estar do seu corpo apesar dos males que certamente existem nesta Terra e que não são somente deste mundo persistimos no nosso belo viver persistimos no meio deste mundo verdadeiramente, apesar de tudo, assim é vários ara yma, muitos ara pyau, com o propósito de adquirir coragem e fortalecimento nhaneramõi kuery, nhandejaryi kuery se concentram verdadeiramente respeitam a sua boa forma de viver certamente, sentirás o bem-estar do seu corpo assim, novamente, nosso corpo persevera verdadeiramente Aguyjevete

(Guata Porã - Belo Caminhar, 2015: 5) 


\section{Os Guarani e o complexo de aldeias da Serra do Mar: os caminhos e caminhadas que levam à presença Mbya em São Paulo}

A identificação do subgrupo ${ }^{33}$ Guarani Mbya $^{34}$, que também se autodenomina Nhandeva, pode ser determinada através de "especificidades culturais e linguísticas bem nítidas", visto que mantêm uma "unidade religiosa e linguística" que lhes permite reconhecer seus "iguais" mesmo vivendo em aldeias separadas por grandes distâncias geográficas e distintas sociedades nacionais (Brasil, Paraguai, Argentina e Uruguai) (Ladeira, 2000: 12). Nhandeva35, na língua mbya, quer dizer “nós”, “nossa gente” ou "os que somos nós" (Ibidem: 13). Também é utilizada a autodesignação nhandeva’e ("aqueles que somos nós") ou o termo nhande’i va'e kuery, como meus interlocutores mbya dizem entre si, e que poderia ser traduzido para o português como "os que são dos nossos" (onde o uso do diminutivo ' $i$ indica conotação espiritual, destacando a sua descendência em relação aos ancestrais divinos ${ }^{36}$ ), ou fazem uso do termo nhandekuery (“nós” ou “os nossos”).

Apesar dos diversos tipos de pressões e interferências externas que os Guarani vêm sofrendo no decorrer dos séculos desde a "invasão" europeia, e da grande dispersão de suas aldeias, o que, em grande parte, decorre das más experiências vivenciadas por eles, entre “missões jesuíticas, colonização ibérica, política indigenista oficial e o contato sistemático e diversificado com a sociedade nacional" que acaba por influir duramente nos seus próprios modos de organização interna, eles nunca cansaram de empreender movimentos migratórios em direção ao litoral por motivos políticos-espirituais (Idem).

\footnotetext{
${ }^{33}$ Segundo a literatura etnográfica aponta há três subgrupos guarani que habitam o Brasil, pertencentes à família Tupi-Guarani, do tronco linguístico Tupi: Mbya, Nhandeva (Chiripa ou Xiripá) e Kaiova (ou Kaiowa). Essa classificação, utilizada no Brasil sobretudo a partir dos anos 1950, com Schaden (1974 [1954]), se baseia em diferenças dialetais, de costumes e de práticas rituais, além de poder ser observada também na "disposição dos lugares e regiões que ocupam dentro de um mesmo e amplo espaço geográfico" (Ladeira, 2000: 12). Embora genérica, é aceita atualmente mais em função das diferenças explicitadas e vivenciadas pelos próprios Guarani, do que pela identificação deles mesmos com essas denominações.

${ }^{34}$ A maioria das pessoas que formam hoje os coletivos guarani que trataremos aqui se autodenominam como grupo, em um contex to de etnificação, enquanto Mbya, ainda que existam algumas famílias da parcialidade Nhandeva vivendo nessas aldeias, e que, atualmente, se autodesignam enquanto Tupi-Guarani ou simplesmente Tupi. Os Mbya se utilizam também, em determinados contextos, simplesmente do termo geral Guarani, assim como o faremos aqui. Em outros contextos, podem usar também o termo MbyaGuarani. Ainda assim, os seus anciões recordam que, antigamente, a palavra mbya não caracterizava um etnônimo propriamente dito, mas um termo genérico para "gente" ou indivíduo.

35 Autodenominação dos subgrupos Guarani classificados pela literatura como Mbya e Nhandeva (TupiGuarani, Xiripá), em um sentido amplo, que não se confunde com a denominação antropológica do dialeto. ${ }^{36}$ No contex to das atividades xamânicas, em que é comum o uso das "belas palavras" (ayvu porã), repletas de metáforas, os homens Guarani são chamados de jeguakava'e poranguei e as mulheres de jaxukava'e poranguei. Cadogan (1959) traduz esses termos como representando "os portadores dos belos adornos originários”, onde o termo jeguaka, de acordo com a mitologia Guarani, corresponderia ao adorno de penas sobre o qual repousava Nhanderu Tenonde Papa, antes de criar o universo.
} 
Isso se insere em sua própria definição da plataforma terrestre $(\text { yvyrupa })^{37} \mathrm{e}$ à sua dinâmica social decorrente das redes de parentesco, comunicação e reciprocidade que ultrapassa todas as aldeias e é conservada através de intercâmbios constantes (desde sementes, espécies vegetais e medicinais, a artefatos de uso ritual, entre outros). Nesse sentido, seus pontos de parada e de passagem visam a manutenção, a proteção e a formação de novos espaços ou aldeias, preferencialmente em locais estratégicos, a partir dos seus próprios "referenciais simbólicos e práticos" (Ibidem: 42). É importante ressaltar ainda, segundo Ladeira, que "os Guarani incorporaram o litoral, com suas serras, a mata Atlântica e o mar, como território 'original' conforme mencionam relatos míticos da criação do Mundo”, e que desenvolveremos mais detidamente a seguir (Ibidem: 41).

Tal insistência Mbya em permanecer no litoral, perdura até hoje, mesmo que em muitos casos ocupem "locais desfavoráveis e inadequados a eles, do ponto de vista da subsistência, e sem recursos", como acontece nos casos das pequenas áreas demarcadas em que vivem confinados, que se soma aos inúmeros impedimentos que sofrem no uso dos recursos naturais das matas próximas às suas aldeias, devido à intensa fiscalização que os Parques Estaduais que atravessam essas terras impõem (Ibidem: 42). Essa atitude guarani, persiste e vai além do "motivo comum - a busca da terra sem mal (yoy marãey ${ }^{38}$ ), da terra perfeita (yoyju miri), o paraíso guarani, onde para se chegar é preciso atravessar a 'grande água”" (Idem). É, nesse sentido, que a análise de versões dos mitos de origem e construção do mundo e da humanidade (Guarani-Mbya) é fundamental para a compreensão de algumas de suas regras de ação sobre o seu "mundo", sobre a plataforma terrestre (yvyrupa), da qual, como argumentamos aqui, seriam guardiões (xondaro e xondaria kuery), pois são eles os verdadeiros filhos caçulas (nhandera’y ijapyrepyre' $i^{39}$, literalmente "nossos filhos caçulas” ou "pedaços de nós”) de Nhanderu Tenonde ("Nosso Pai Primeiro") e Nhandexy Tenonde ("Nossa Mãe Primeira"), e seus tekoa ("lugar em que se vive" e é possível exercer o teko) com suas opy (casa de reza-canto-dança-cura) "representam os suportes e estruturas desse mundo” (Ibidem: 41). Ladeira e Azanha (1988), levantam dados históricos importantes da presença Guarani no Estado de São Paulo (SP), demonstrando a "tradicionalidade" da sua ocupação. Os autores comentam que os Guarani do litoral paulista:

\footnotetext{
37 Atualmente, os Guarani-Mbya fazem uso de uma tradução política, em português, do conceito mbya de yəyrupa, que poderia ser entendida como o "[nosso $]$ mundo sem fronteiras", visto que "a terra é uma só" (ver, nesse sentido, Vera Popygua 2017).

38 Yyy marã'eỹ é traduzida, de forma consagrada pela literatura, por “terra sem mal”, e significa literalmente "terra que não perece", "terra que não se estraga”, que não se corrompe, onde nada tem fim, nada se acaba ou estraga, tudo se renova ciclicamente e continuamente.

39 Ver Ladeira (2007 [1992]: 143) e Testa (2014).
} 
que habitam hoje [1988] os aldeamentos de Itariri, Rio Branco, Bananal, Rio Silveira, Boa Vista (Promirim), e ainda os aldeamentos do Mboi-Mirim, Morro da Saudade, Crucutu e Jaraguá, no planalto paulista, compreendem na verdade dois grupos que se diferenciam quanto ao dialeto e a alguns aspectos da cultura: os Ñandeva (ou Xiripá) e os Mbyá. (Ladeira e Azanha, 1988: 13, alterações minhas)

Os Nhandeva, segundo os antropólogos, começaram a migrar para o leste "desde seu habitat original no baixo rio Iguatemi, afluente da margem direita do Paraná” no início do século XIX (Idem). Curt Nimuendaju, que conviveu com esse grupo (autodenominado Tañyguá, Oguauíva ou Apapocuva) de 1905 a 1910, em sua obra clássica (1987 [1914]) discorre sobre sua migração para o planalto e o litoral paulista, fundando aldeias por onde passavam ou por onde foram sendo obrigados a se retirar - pelo avanço descontrolado da presença e colonização jurua -, e mover-se novamente (Ladeira e Azanha, 1988: 13-14). Em 1911, o Serviço de Proteção ao Índio (SPI), "por insistência de Nimuendaju”, até então seu funcionário, cria “a Povoação Indígena de Araribá (atualmente município de Avaí-SP), que passou a abrigar os remanescentes Apapocuva que viviam na região" (Ibidem: 15). Nimuendaju, passa então os anos de 1912 e 1913 “visitando os grupos Guarani do litoral paulista, do Paraná e do Mato Grosso, no intuito de transladá-los para a nova povoação - onde [segundo ele] não teriam problemas de terra e poderiam contar com a assistência do SPI", obtendo a recusa dos "Tañyguâ" de Itariri e dos "Oguauiva" do Bananal e, mesmo aqueles grupos que seguiram junto com ele para Araribá, poucos realmente se fixaram ali, como atesta o próprio indigenista em tom pessimista:

Eles se recusaram duas vezes a aceitar as propostas de mudança para a reserva dos Gua-
rani no Araribá, que o governo lhes fez em 1912 e 1913 por meu intermédio. Revoltados,
assistiram à abertura de uma ferrovia ao longo da margem do Itariry, exatamente em
cima da extensa fileira de túmulos de seus antepassados e, amaldiçoando o perjúrio do
Governo, juraram morrer onde haviam nascido e onde jaziam os ossos dos seus antepas-
sados. Não demorará muito para que este juramento se cumpra ${ }^{40}$. (Nimuendaju, 1987
[1914]: 10)

Boa parte desses "subgrupos Nandeva vieram para o litoral, procurando se fixar ao longo da Serra do Mar, movimento este que se prolongou durante as décadas seguintes" (Ladeira e Azanha, 1988: 15). Em 1927, o SPI adquire duzentos alqueires de terras nas vizinhanças do aldeamento do Bananal, afim de assim garantir terras para os Guarani do litoral, de maneira a fixá-los em um só local, o "atual [em 1988] Posto Indígena de Peruíbe, no município do mesmo nome” (Ibidem: 14, alterações minhas). Seria então a partir das primeiras décadas do século XX, que "os núcleos Ñandeva do litoral passam a

\footnotetext{
${ }^{40}$ Ver também o depoimento do Capitão Antônio Branco para uma descrição pormenorizada, do ponto de vista de um Guarani, da epopeia de fixação dos Nhandeva em Itariri (Antonio Branco apud Ladeira e Azanha, 1988: 45-52).
} 
receber o reforço de outros grupos, também Guarani”, classificados "na literatura etnográfica como Mbyâ", grupo este que se distingue "dos moradores mais antigos - a quem chamam de Tupi-Guarani ou Xiripá - dizendo-se Guarani" e que, a partir das décadas de 1950 e 1960, passa a constituir a população dominante no litoral (Ibidem: 15). Os estudiosos, de acordo com os autores, "parecem hoje convencidos de que os Mbyá atuais descendem daqueles grupos que não se submeteram aos encomenderos espanhóis e tampouco às missões jesuíticas, refugiando-se nos montes e nas matas subtropicais da região do Guairá paraguaio e dos Sete Povos”, aparecendo na literatura, no século XIX com o nome genérico de “'Cainguá' (ou Kayguá), corruptela do nome depreciativo que lhes aplicavam os outros subgrupos Guarani: Kaaguyguá, "habitantes da mata”41 (Ibidem: 15-16).

No entanto, o "habitat original dos Mbyá - onde ainda permanece o grosso de sua população - compreende, ao norte, a porção do Paraguai Oriental entre os rios Yguazu e Monday; ao sul, o alto Paraná, ainda em território paraguaio”, e é mais “intensamente” ao largo do século XX que esse grupo avança para o leste, "penetrando em território argentino no seu extremo norte (província de Missiones) e brasileiro (estado do Rio Grande do Sul, Paraná e Santa Catarina)” (Ibidem: 16). Pelas informações de que disponham Ladeira e Azanha, seria possível traçar:

\begin{abstract}
duas rotas de penetração dos Mbyá em território brasileiro - que corresponderam a subgrupos Mbyá diversamente distribuídos em seus habitats originais: uma que, da Argentina, adentra o território brasileiro pelo Rio Grande do Sul (e que, mais tarde, deslocando-se para o norte, formará os aldeamentos de Rio Branco (SP), de Boa Esperança (ES) e Boa Vista, em Ubatuba (SP); e outra, que do Paraguai atinge o Estado do Paraná, onde formará vários aldeamentos (Palmeirinha, Rio das Cobras, etc.) e que, mais tarde, será responsável pelo grosso da população Mbyá dos aldeamentos de São Paulo e Rio de Janeiro. (Idem: 16)
\end{abstract}

A escassez de notícias ${ }^{42}$ sobre os Mbya em território brasileiro se daria, de acordo com esses autores, "em grande parte, às imprecisões daqueles que entraram em contato com os grupos Guarani no século passado, notadamente no estado do Paraná; englobando todos os grupos como 'Guarani”" que, sem especificar “diferenças dialetais, não diferenciavam os Mbyá dos outros subgrupos Guarani” (Ibidem: 16-17). Ainda assim, as migrações Mbya, de “contingentes demográficos menores que a dos Ñandeva, seguiram contudo o mesmo padrão: a procura da 'Terra sem Mal' ( (ry-Ñanimbyré para os Ñandeva;

${ }^{41}$ É interessante notar que um livro lançado em 2016 e organizado pelo Centro de Trabalho Indigenista (CTI) e o Programa Aldeias da Secretaria Municipal de Cultura da Prefeitura de São Paulo, tenha como título, ka’aguy re jaiko, que os Mbya traduziram para o português como "vivemos na mata".

42 Além disso, como bem aponta o Relatório de Identificação e Delimitação da T.I. Tenonde Porã (RCID T.I Tenonde Porã), a "pobreza das informações contidas nas fontes imperiais deriva do fato de que a política indigenista praticada na época visava tão somente a redução dos índios que mantinham sua autonomia, com o objetivo de promover um processo de assimilação forçado, conforme os princípios estabelecidos por Rondon, liberando as terras para a colonização” (RCID T.I. Tenonde Porã, 2010: 85). 
Yvỹ-Maraẽ̃ para os Mbyá)” (Ibidem: 19). À maneira daquelas migrações desempenhadas pelos Tañyguá e Apapocuva, estas se realizavam tendo à frente "chefes religiosos (ñanderu) que conduziram seus grupos por orientação e mandado dos deuses-heróis (ÑanderuMirĩ) à procura da Y vỹ-Maraeỹ, situada do outro lado do mar (pará guachu)" (Idem). O corpus de mitos e lendas recolhidos por León Cadogan (1959) faz referência aos atos de grandes líderes espirituais que encabeçaram migrações para o litoral brasileiro, "em tempos remotos”, com a finalidade de atravessar a "grande água”, onde creem os Mbya encontrar-se o paraíso. Tais líderes são tidos como “heróis divinizados”, pois "atravessaram a pé o mar e chegaram ao paraíso" (Ladeira e Azanha, 1988: 16).

Inúmeros relatos Guarani, antigos e atuais, no qual mencionam seu desejo de atravessar o mar em busca da terra sem mal foram obtidos por antropólogos, etnólogos e indigenistas, e em todos eles fica evidente a centralidade que o mar ocupa em sua tradição. Esse mar que, "no pensamento e cosmologia Guarani, ocupa um lugar ambíguo: ao mesmo tempo, obstáculo a transpor para se atingir o paraíso e ponto de chegada, pois é ali, nas suas proximidades, que o destino Guarani pode se realizar" (Ladeira, 2000: 19). H. Clastres comenta também sobre a importância do mar para o pensamento-ação Mbya:

Talvez esta tradição (dos heróis que conseguiram atingir o paraíso atravessando a pé o mar) deve ser entendida, como suspeita Cadogan, enquanto memória de migrações coletivas para o leste, outrora efetuadas pelos Mbyá. Mas, com ou sem valor histórico, ela possui um incontestável valor ético: homens e deuses não estão definitivamente separados, a grande água que figura a sua separação - o mar - não é intransponível; houve homens que puderam atravessá-lo nos tempos passados e atingir a Terra sem Mal. (Clastres, H. 1978 [1975]: 89)

Foi Nimuendaju quem primeiro discutiu qual seria o sentido e a continuidade das migrações Guarani para o leste, mesmo em casos que já não precisavam mais fugir de grupos inimigos ou dos efeitos da colonização que avançavam cada vez mais ao redor de suas ocupações (Ladeira e Azanha, 1988: 19). O autor se questionava sobre o que fariam os Guarani no litoral, se não tiravam do mar absolutamente nada de sua subsistência, permanecendo ali ao redor, vivendo apenas da agricultura e da caça:

É muito curioso que o mar represente papel tão relevante para um povo que vive nas profundezas mais remotas do continente e cujo modo de vida é integralmente interiorano. Isto fica sobretudo evidente quando os Guarani chegam de fato ao mar. A impressão do quebrar das ondas, que, como inimigo feroz, parecem estar sempre arremetendo contra a terra, é-lhes lúgubre: acreditam achar-se diante de uma permanente e ameaçadora fatalidade. Por isso, nenhum dos numerosos bandos que atingiram o litoral estabeleceu-se na beira do mar [...] Sempre recuaram até onde não pudessem ver nem ouvir o mar; às vezes internavam-se a mais de um dia de viagem do litoral. (Nimuendaju, 1987 [1914]: 99) 
Nimuendaju conclui que somente os "fatos históricos" poderiam explicar esse "desejo irrefreável” Guarani:

a marcha para leste dos Guarani não se deveu à pressão de tribos inimigas; tampouco à
esperança de encontrar melhores condições de vida do outro lado do Paraná; ou ainda ao
desejo de se unir mais intimamente à civilização - mas exclusivamente ao medo da des-
truição do mundo e à esperança de ingressar na "Terra sem Mal"4s. (Nimuendaju, 1987
[1914]: 102]

Essa "perseverança” Guarani é amplamente apontada pelo autor em seus relatos sobre as caminhadas que empreendiam em direção ao mar, e que ele mesmo presenciou no início do século XX. De acordo com Meliá, essas buscas pela "terra sem mal”:

\begin{abstract}
e de uma "terra nova" estrutura marcantemente seu pensamento e suas vivências; $a$ 'terra sem mal'e a síntese histórica e prática de uma economia vivida profeticamente e de uma profecia realista, com os pés no chão (...) é um povo em êxodo, embora não desenraizado, pois a terra que procura é a que lhe servirá de base ecológica, amanhã como em tempos passados [...] A tradição, neste caso, é profecia viva. A busca da 'terra sem mal', como estrutura do modo de pensar do Guarani, dá forma ao dinamismo econômico e à vivência religiosa, que lhe são tão próprios. (Meliá, 1989: 293 apud Ladeira, 2000: 41, grifos meus)
\end{abstract}

E, como atesta Ladeira, o "complexo Mata Atlântica, Serra do Mar e o próprio mar representam o ideal de vida como transição. A Mata Atlântica, em termos de ecologia e de economia, possui ainda os resquícios das primeiras criações (Nhanderu mymba)" (Ladeira, 2007 [1992]: 153). É nesse sentido que a Serra do Mar adquire, "uma significação toda especial para os Guarani: ela é o ‘dique do mar’ (yvỹ paiãry jocoã)”, daí que a “clara predileção dos Mbyá e Ñandeva pela Serra do Mar - ao invés da orla, como os antigos Tupi - encontre seu fundamento no mito de origem da 'terra em que vivemos' (yvý pyaú)" (Ladeira e Azanha, 1988: 21). Ladeira e Azanha recorrem então a uma versão desse mito transcrita por P. Clastres (1980: 77) que conta que esta terra:

(a "terra imperfeita”) foi criada por Tupã (ou Ñanderu Papá Mirĩ, "nosso pequeno pai primeiro") em meio ao oceano, que resultou da inundação que destruiu a "primeira terra" (yvy tenondê). Esta terra, como a primeira, está fadada à destruição: diz o mito que isso irá ocorrer quando o Criador, ateando fogo a terra (no oeste), destruirá o seu suporte (de madeira), provocando assim sua inundação. (Ladeira e Azanha, 1988: 21)

Para Nimuendaju, como vimos, seria o medo desta inundação catastrófica, o motivo das migrações Guarani para o leste. Para os Mbya, as terras que buscam ocupar no litoral já foram habitadas por seus antepassados, e os seus tekoa, o "lugar (onde é possível manifestar a nossa) (a) maneira de ser (teko)", se encontram nas proximidades do mar, nas imediações da Serra do Mar, lugar onde podem viver nos montes das matas, de onde

\footnotetext{
${ }^{43}$ Entretanto, como recorda Viveiros de Castro, "por seu poder de superação dos obstáculos que foram postos entre eles e seu teko, seu modo de ser: o mar terá sido o menor deles” (Viveiros de Castro, 1987: xxviii).
} 
podem ver o mar e encontrar e garantir os meios de sua subsistência, escondidos e longes o suficiente para se prevenir de possíveis cataclismas (Ibidem: 21; Ladeira, 1989: 61). No entanto, essa procura pela terra sem mal parece cada vez mais, nas condições de vida atuais em que se encontram os Guarani, se concentrar "na manutenção de um lugar", onde possam “'viver bem', isto é, onde possam reproduzir o ñandereko ('nosso modo de ser')” e não tanto, como antes, na busca desse espaço mítico que se valia de diversos deslocamentos migratórios pelo território ${ }^{44}$ (Ladeira e Azanha, 1988: 22, grifos meus). O litoral sul de SP já concentrava assim, desde o início do século XX, grande contingente populacional:

os Ñandeva (Oguauiva, Tañyguá) eram maioria nas aldeias de Peruíbe e de Itariri, e os Mbyá nas aldeias próximas do Rio Branco (Itanhaém) [...] região de Parelheiros - compreendendo-se aqui os atuais bairros da Barragem e Crucutu - foi sempre um ponto de parada e de passagem obrigatória dos grupos Mbyá que, partindo das aldeias do Paraná (especialmente Palmeirinha e Rio das Cobras) e do Rio Grande do Sul, se dirigiam às aldeias do litoral e viceversa. Desse modo, várias famílias permaneceram e ocuparam, por tempo indeterminado, locais estratégicos dessa região. (Ladeira e Azanha, 1988: 30, grifos meus)

Foi logo no início do século XX que alguns grupinhos mbya partiram do Rio Grande do Sul (RS), próximos à fronteira com a Argentina, em direção ao leste, alguns se fixando em aldeias no Paraná (PR) e outros em aldeias do litoral paulista, formando assim a maior parte da população de "Itariri, Aguapiú [Aguapeú], Rio Silveira, Boa Vista e Parati-Mirim” (Idem: 30). É também nessa época, que segue em direção ao Espírito Santo (ES) um grande grupo saído da região fronteiriça entre Brasil e Argentina, liderado por "Dona Maria” Tataxĩ Yva Rete, uma grande kunhã karai (liderança políticaespiritual) que, segundo Ciccarone, chega a seu destino no início da década de 1960 (Ciccarone, 2004: 86). A trajetória desse grande grupo, que passou por vários pontos do litoral do Rio Grande do Sul (RS), Santa Catarina (SC), Paraná (PR), São Paulo (SP) e Rio de Janeiro (RJ), é uma referência constante para grande parte das famílias guarani do litoral, pois muitas das localidades que "pararam" ou se assentaram em sua longa caminhada, reveladas à kunhã karai Tataxĩ por meio de sonhos, tornaram-se algumas das aldeias guarani atuais.

Essas migrações para o litoral apresentam muitas vezes motivações diversas, cujos fatores encontram-se estreitamente imbricados. Muitos desses movimentos, como testemunhado por Nimuendaju, foram liderados por profetas-xamãs ${ }^{45}$ que, inspirados

\footnotetext{
${ }^{44}$ Sobre a "terra em que nada se esgota”, “que não acaba”, em sua dissertação, Pierri (2013a) a toma antes como uma relação que se estabeleceria entre os vetores perecível e imperecível, isto é, entre o mundo terrestre e o celeste, e não apenas ou somente como um lugar específico ou localizável, mas como uma relação cuja possibilidade de alcançar decorre da transformação corporal.

${ }_{45}$ No entanto, segundo Ciccarone, e como veremos mais detidamente no Capítulo II, a importância da "união da sociedade no êxito de um levante migratório como movimento de libertação contra a ordem colonial apontado [...] não é entretanto reconhecido como fator tão essencial quanto o prestígio xamânico.
} 
por aconselhamentos divinos, aspiravam atingir, através de suas rezas e com o próprio corpo, à tão sonhada terra sem mal, sem passar pela prova da morte. Em outros casos, somada à essa motivação central que guia a concepção de mundo guarani, buscava-se mais diretamente fugir de uma situação de risco como, por exemplo, o regime de exploração do trabalho do SPI, um surto epidêmico, ou podia ocorrer simplesmente por conta do avanço da urbanização e todos os problemas decorrentes disso, ou pela pressão de outras frentes de colonização, como os ataques de bugreiros ou grileiros, aberturas de estradas, estabelecimento de fazendas, etc. Ainda assim, os Guarani mantinham ativa sua dinâmica territorial, continuando a migrar e a formar suas aldeias junto ao mar, a partir de onde procuravam, através da orientação de suas lideranças espirituais, as práticas necessárias para ascender com o corpo à terra sem mal. É importante ressaltar ainda que em qualquer desses casos, a escolha dos lugares para formação de novos assentamentos em que permaneciam ao longo de sua trajetória de vida, ou a decisão sobre se deveriam seguir (ou não) sua caminhada em busca de novos lugares, era frequentemente inspirada por sonhos xamânicos ${ }^{46}$.

Uma outra prática bastante comum entre grupos de língua tupi-guarani e motor de deslocamentos de um grupo familiar inteiro, ocorre pela morte de um importante parente (-etarã) próximo, sobretudo quando se trata de um(a) chefe(a). Tal prática, de acordo com a cosmologia guarani, se dá porque uma porção agentiva do espírito terreno de um morto se desdobra em uma "sombra" $(-\tilde{a})$ de seu corpo ${ }^{47}$ terrestre (ãgue, "aquilo

\footnotetext{
O xamã-profeta precisa da sociedade da mesma forma que esta, como 'chamado social' precisa dele/dela para enfrentar os infortúnios" (Ciccarone, 2001: 243).

${ }^{46}$ Por isso, quando uma liderança espiritual recebe a revelação por sonho de que há um lugar mais adequado para seguir com seu grupo e constituir um tekoa que tenha as condições necessárias e adequadas para se viver bem (teko porã), ele(a) "passará o tempo em que se estabelece na localidade inicialmente reconhecida como correspondente ao sonho questionando-se, com base na avaliação a respeito da qualidade de vida que obtiver para si e seu grupo" naquele lugar, "se realmente encontrou o lugar exato que lhe foi indicado. Caso morra alguma criança, por exemplo, ou a lavoura do milho não vingue, ou ocorra algo de ruim, provavelmente chegará à conclusão de que aquele lugar não era efetivamente o local revelado, ou que ele não soube a maneira certa de agir. Mas dificilmente imaginará que não deve fiar-se no sonho" (Pierri, 2013b: 180-81).

${ }^{47} \mathrm{O}$ que os ameríndios consideram por corpo não remeteria a uma fisiologia distintiva visto que reconhecem "uma uniformidade básica dos corpos", mas a um "conjunto de maneiras ou modos de ser que constituem um habitus", onde o corpo aparece entre "a subjetividade formal das almas e a materialidade substancial dos organismos" (Viveiros de Castro, 2002a: 380). Esse corpo remete então a afetos e pode ser entendido como um "feixe de afecções e capacidades" (tanto de afetar como de ser afetado), a "origem das perspectivas", às quais se associam comportamentos, hábitos, habilidades e desejos que singularizam cada espécie humana: "o que ele come, como se move, como se comunica, onde vive, se é gregário ou solitário... A morfologia corporal é um signo poderoso dessas diferenças de afecção, embora possa ser enganadora, pois uma figura de humano, por exemplo, pode estar ocultando uma afecção-jaguar” (Idem). Daí também que se possa pensar o conceito ameríndio de alma, inversamente à noção corrente ocidental, como sendo inscrito "no próprio corpo como perspectiva" (Idem).
} 
que já teve sombra, já teve corpo", ou simplesmente o "espírito dos mortos”, que permanece na terra após a morte física e tem forte potencial patogênico, podendo trazer e gerar enfermidades, principalmente para aqueles parentes mais próximos [Macedo, 2010: 241]). Por isso, há uma postura específica e ideal em relação aos mortos, um necessário esforço necessário no processo de esquecimento daqueles que se foram, para não atrair o seu espectro terrestre e gerar mais doenças e mortes entre parentes. O abandono da localidade onde morreram pessoas especialmente importantes para a memória de um grupo busca então facilitar o seu esquecimento e distanciar-se espacialmente de ãgue. Esse motivo apresenta-se estreitamente imbricado com outros fatores de ordem mais prática, e-ou bastante críticas e urgentes - mesmo que não sejam muito descritos nas etnografias clássicas - como a fuga dos postos do SPI, as epidemias que assolavam as localidades, a produtividade do solo, as condições ecológicas, ou mesmo as pressões externas diversas derivadas do processo de colonização jurua, e que, via de regra, eram também interpretados a partir da chave xamânica, idioma amplamente mobilizado por suas lideranças espirituais.

Ainda que nem sempre a saída de um grupo familiar de um lugar tenha "uma causa exclusiva e relacionada a razões puramente transcendentais", os "motivos da escolha para o estabelecimento temporário ou 'permanente' dos grupos familiares estão sempre subordinados a manifestações de ordem divina”, dessa maneira, somente "uma manifestação dessa esfera poderá alterar o que foi estabelecido” (Ladeira e Azanha, 1988: 29). Somente por motivos de tal ordem, revelados geralmente através de sonhos que, algumas vezes abandonam suas roças em época de colheita, ou os gêneros alimentícios já colhidos, o que, por sua vez, também explicaria o "por que os Guarani que são levados à força de seus tekoa, por fazendeiros e grileiros, persistem num retorno, sempre pacífico, mas inevitável, pois a ordem que os afastou de seu lugar não partiu da mesma esfera divina que lhes indicou o caminho” (Idem, grifos meus). É possível perceber que a determinação cosmológica de seguir o caminho do Sol, ao leste, direção da morada de Nhanderu e Nhandexy Tenonde, também poderia partir de outras motivações, igualmente urgentes. Ciccarone, por exemplo, baseia sua análise em como os "momentos de crise", lidos na chave dos mitos de criação do mundo reorganizam e dão sentido e corpo às migrações:

Os Mbya - parcialidade do povo Guarani - representam a vida terrena como uma sucessão de eventos dramáticos que impelem a sociedade a produzir constantes reorganizações de sentido e estratégias caracterizadas pela mobilidade, como condição ontológica do seu modo de ser. O drama, que emerge no nível dos mitos de criação de mundos concebidos como instáveis e sujeitos à destruição, eclode no plano da história das relações de contato como redução progressiva dos espaços apropriados para a manutenção do seu sistema de vida, colocando em perigo a existência da sociedade. Nas tentativas de 
reparação e compensação dos dramas sociais, os Mbya recorrem aos mitos como instrumentos para a reflexividade do grupo, recriando-os numa memória do futuro que dá sentido às crises e às formas de mobilização acionadas para enfrentar as desordens. Neste contexto, a migração representa a modalidade mítico-histórico do movimento de conquista de novos espaços como processo de refundação do mundo e da sociedade, conduzido por grupos familiares articulados entre si por laços de parentesco e sob o guia da liderança xamânica. (Ciccarone, 2001: 5)

Foram alguns desses motivos, relacionados a situações de crise que impulsionaram grupos mbya falantes a realizarem seus deslocamentos para o litoral, estabelecendose também em SP desde pelo menos o início do século XX - segundo consta na literatura $^{48}$-, engrossando assim a demografia guarani no Estado, comprometida por séculos de intensa e violenta colonização. É desde Nimuendaju (1987 [1914]) então que se sabe que a esses grupos forçosamente sedentarizados nos aldeamentos do SPI, e a outros dispersos nas matas ainda não colonizadas pelo Estado, vieram se somar grupos migratórios de inspiração profética. Schaden registra pelo menos três levas de grupos mbya que teriam chegado ao litoral de SP em 1924, 1934 e 1946, respectivamente, deixando claro que fala apenas das migrações das quais teve notícia, e que devemos entender que tais datações são aproximadas e que os registros de que dispomos pouco ou nada conseguem abranger a totalidade e dinâmica dos movimentos percorridos pelos Guarani (Schaden, 1974 [1954]: 5).

Ladeira e Azanha (1988) buscaram realizar, no âmbito dos estudos que subsidiaram o convênio Funai-Sudelpa (Fundação Nacional do Índio e Superintendência do Desenvolvimento do Litoral Paulista) - que resulta nas demarcações de terras guarani na década de 1980 em SP -, um mapa atualizado dessas migrações a partir do relato de pessoas-chave que lideraram ou integraram grupos locais dominantes, somando aos registros de Nimuendaju e Schaden os movimentos mais recentes, reconstituídos a partir da "memória" desses interlocutores, parte importante do movimento de ocupação guarani junto à Serra do Mar no século XX ${ }^{49}$. Aqui, nessa Dissertação, o importante a reter dessa história da grande resistência guarani na Serra do Mar, diz respeito, sobretudo, à constituição da T.I. Tenonde Porã, local onde estabelecemos interlocução de pesquisa com as lideranças atuais e de onde partem, em sua grande maioria, os eventos etnográficos que analisaremos mais adiante, que contam um pouco do histórico de luta atual pela

\footnotetext{
${ }^{48}$ A documentação quinhentista e seiscentista também registra movimentos proféticos semelhantes, inicialmente compilados por Métraux (1931) e posteriormente discutidos por H. Clastres (1975 [1978]).

${ }^{49}$ Deve-se ter em mente que não raro esses percursos são traçados em linha contínua, pelos pesquisadores, mas são caminhos cheios de idas e vindas, uma vez que os grupos podiam parar e se estabelecer durante muitos anos ou mesmo décadas em um local e serem depois motivados por algum acontecimento crítico a se mudar, iniciando uma nova migração. Outros grupos muitas vezes poderiam utilizar também percursos semelhantes, parando nos mesmos lugares ou em locais bem próximos entre si.
} 
demarcação de terras (yoy re jajoguero' ${ }^{50}{ }^{50}$ em SP. Por isso, nos concentraremos no que de central dessa história diz respeito aos caminhos que levaram à formação e ocupação desta T.I. em SP.

Nos relatos dos mais velhos, essa história começa primeiramente com Seu Joaquim, primo de Xapé, e Dona Jandira, sua esposa (fundadores também da T.I. Jaraguá), que foram viver em 1950 em Itaquaquecetuba e logo em seguida na aldeia da Barragem (Tekoa Tenonde Porã) com a família de Xapé (que chega aí no final dos anos 1940 e continua até o final da década de 1950, indo depois para o Rio Branco, ainda que, seus descendentes voltem a viver na aldeia Barragem depois e sigam lá até hoje, ocupando papel central na articulação política entre as famílias) e de Ramiro (primo de Jandira e irmão mais velho do xeramoĩ José Fernandes que, na época da publicação do livro [1988] e demarcação da T.I Barragem [1987] ainda era o seu cacique e liderança espiritual principal) (Ladeira e Azanha, 1988: 30-31). Na época, a área hoje reconhecida como formando parte da T.I. Tenonde Porã era uma propriedade grilada por um japonês para o qual os Guarani trabalhavam e que lhes oferecia proteção do assédio de outros posseiros e grileiros, em troca de mantimentos ${ }^{51}$. Por volta de 1960, o grupo familiar liderado pela kunhã karai, Dona Vitalina ${ }^{52}$ (falecida em 1979), originário da aldeia de Palmeirinha (PR), chega a SP fugido, por recusar continuar se submetendo às normas de trabalho forçado do Posto Indígena do SPI. Por isso, decidem então partir em direção ao litoral paulista, com esperança de encontrar um novo lugar para se estabelecer e viver bem (Ibidem: 31 32). Esse grupo ficou durante três meses em Itariri e curtas temporadas nas aldeias de Rio Branco, Silveira e Serrinha (Juqueí), decidindo retornar à sua antiga aldeia em Palmeirinha e depois resolvendo voltar de maneira definitiva para o litoral paulista. Na volta à SP, foram abrigados por Seu Joaquim que até então já morava na Cidade Dutra.

O xeramoĩ Nivaldo ${ }^{53}$, neto da xejaryi Dona Vitalina, antigo cacique da Barragem e que também foi cacique do Krukutu (T.I. Tenonde Porã), enfatiza as torturas e o regime de trabalho imposto pelo SPI, e continuado pela Funai, na aldeia de Palmeirinha (atual

\footnotetext{
${ }^{50}$ É a maneira como os Mbya me traduziram em guarani "luta pela terra”. O radical -ero'a vem de "arremeter-se contra, agarrar e derrubar: xivi oguero’a guaxu a onça agarrou o veado”, já -jero'a é traduzido como “dobrar-se”, -joguero’a como “arremeter(em)-se um contra o outro” e jajoguero'a como "brigamos uns com os outros ou com alguém; vamos brigar” (Dooley, 2006: 39, 70).

${ }_{51}$ Muitos pretensos proprietários de terras incidentes em áreas tradicionalmente ocupadas pelos Guarani convidavam grupos indígenas a se fixarem na pretensa propriedade a título de caseiros ou protetores com o objetivo de garantir sua posse (Macedo, 2010; RCID Tenonde Porã, 2010).

${ }^{52}$ Ladeira comenta que Nivaldo, antigo cacique da Barragem "relata as dificuldades de seu grupo, liderado então por sua avó Vitalina, parando e vivendo em várias aldeias do litoral de São Paulo, em busca de um lugar para formarem uma aldeia própria, no início dos anos 60" (Ladeira, 2000: 44, grifos meus).

${ }^{53}$ Ver Depoimento de Nivaldo (Nivaldo apud Ladeira, 1984: 134-141).
} 
T.I. Mangueirinha) como o principal motivo da vinda de sua família, à SP, em meados da década de 1950. Em seu depoimento, ele conta que depois de muito andar por aí, eles resolveram acampar embaixo da Ponte do Socorro e um japonês chamado Kugo lhes indicou o local onde ficava a aldeia da Barragem (onde viveram Xapé, Ramiro e Seu Joaquim, contratados anteriormente por ele para trabalhos de lavoura), chamando-os para trabalhar com ele e viverem no local. Depois da desconfiança inicial em relação a esse jurua e suas intenções, resolveram conhecer o local que ele havia indicado e por ali decidiram se estabelecer. É a partir de 1965 que inúmeros outros grupos familiares, oriundos principalmente de Palmeirinha (PR), Rio das Cobras (PR) e do Rio Branco (SP), além de outras famílias dispersas nas regiões da Serra do Mar vieram juntar-se à ocupação Guarani da Barragem, transformando essa aldeia - que até 1981 era chamada de Vila Guarani, e na época da publicação (1988) do livro, já era conhecida como Morro da Saudade - na mais populosa aldeia Guarani do Estado de São Paulo.

Nivaldo passa a chefiar a aldeia da Barragem em 1975, sucedendo o seu pai, Eduardo, filho mais velho de Dona Vitalina. O grande aumento demográfico ocorrido a partir da década de 1980 com a agregação de várias famílias vindas do PR, dificultou definitivamente a atuação de Nivaldo, de acordo com Ladeira e Azanha (1988), que não conseguiu mediar os interesses de seu grupo familiar, nem dos demais núcleos familiares da aldeia, acarretando conflitos internos que motivaram os grupos a buscar novos espaços para se fixar. O grupo familiar liderado por sua avó - formado por seus filhos, seus cônjuges e descendentes - constituiu até os anos 1980, o grupo dominante da aldeia. No entanto, a partir de 1980, a chefia política e espiritual ficou a cargo do grande xeramoĩ José Fernandes, irmão de Ramiro, antigo morador e membro de outro grupo familiar. Foi a família desse xeramoĩ que atuou então como agente mediador entre o grupo até então dominante dos descendentes de Dona Vitalina e as demais famílias que se fixaram posteriormente nesta mesma aldeia (Ibidem: 32). Nivaldo, a partir de 1984, viveu nas aldeias do Silveira, Patrimônio e Krukutu, tendo elegido esta última, contígua à aldeia da Barragem/Morro da Saudade, para viver junto à sua família extensa e a outras famílias que o acompanhavam em suas andanças e decidiram permanecer seguindo-o, exercendo nesse local a sua liderança (Ibidem: 32-33).

É possível notar na grande maioria dos casos relatados e registrados por Ladeira e Azanha (1988) que a motivação imediata para fugir para o litoral envolvia também uma reação guarani a toda uma sorte de violências praticadas pelos próprios órgãos indigenistas oficiais, que se usavam da pressão e exploração de seu trabalho como forma de 
estabelecer controle sobre a população indígena, uma política deliberada à época, sofrendo inclusive tortura física e aprisionamento se não se submetessem aos desígnios dos capitães, cargos geralmente ocupados por indígenas que eram controlados pelo SPI, fato também atestado por Macedo (2010) e pelo RCID T.I Tenonde Porã (2010) (ver também Capítulo II). Schaden realiza também algumas observações sobre os Guarani com quem teve contato nos antigos aldeamentos controlados pelo SPI, nos alertando para a recusa ativa guarani em se submeter aos desígnios do órgão indigenista federal:

Os funcionários do S.P.I. são unânimes nas queixas com relação à dificuldade de submeter os Guaraní às normas do Serviço. Sem que sejam violentos, - ao contrário, são chorões -, esses indios sempre acham um jeito de fugir aos regulamentos. No Araribá, como vimos, houve a tentativa de enquadrar os Guarani no sistema econômico-administrativo do posto, dando-se-lhes cafezais já formados. Dentro de poucos anos estava tudo arruinado. (Schaden, 1974 [1954]: 65 , grifos meus)

Uma série de abusos contra os direitos humanos que inclui tortura, trabalho escravo, cerceamento do direito de ir e vir entre tantas outras violências praticadas e operadas pelo SPI e depois pela Funai nos Postos Indígenas, são extremamente recorrentes nos relatos dos anciãos guarani que nasceram ou tiveram que viver nos aldeamentos dos Estados do Sul ${ }^{54}$ do Brasil em algum momento de sua trajetória, e podem ser considerados como um dos principais desencadeadores de deslocamentos de famílias inteiras para o litoral de SP. Contudo, na maioria desses casos, como já comentado, a opção de fugir dessas situações é interpretada sob a chave de inspiração xamânica, que acabava motivando movimentos de caráter profético-espiritual. O importante a se entender aqui é que a trajetória desses grupos migratórios, que se deslocavam por motivações distintas, se cruzava e frequentemente resultava em alianças, trocas e casamentos e na decisão, por algumas partes, de ficar ou de partir.

Ladeira e Azanha (1988), em sua análise, listam o que consideram ser os principais fatores que justificariam a posição de liderança política que a aldeia Barragem/Morro da Saudade ${ }^{55}$ exercia sobre as demais aldeias do Estado de SP tais como, a liderança do chefe político-espiritual José Fernandes na aldeia que, devido ao seu prestígio

\footnotetext{
${ }^{54}$ Além desse fator principal, o fato de duas T.I.s., Rio das Cobras e Mangueirinha, ambas localizadas no Estado do PR, também serem habitadas por indígenas da etnia Kaingang é entendido pelos Guarani como motivos de problemas, pois a convivência entre diferentes etnias em uma mesma área gera inúmeras tensões entre os modos de organização próprios a cada uma delas e que, no caso Guarani, se relacionam diretamente ao seu ideal de viver e de casar entre si, isto é, não se miscigenar. Muitas vezes nessas T.I.s, de acordo com os relatos de seus ancióes, os Guarani foram presos pelos próprios Kaingang, cooptados a serviço do SPI. Nessas áreas mencionadas o trabalho compulsório e o uso de indígenas como "capatazes" era uma realidade até hoje relembrada com muito pesar pelos anciões guarani que ali viveram.

${ }^{55}$ Este tekoa foi também sede da Aguaí (Ação Guarani Indígena) e é a sede da Comissão Guarani Yvyrupa (CGY) desde a sua fundação (2006) até os dias atuais; as duas são organizações políticas supralocais guarani, mas a primeira foi extinta na década de 1990, quando por dificuldades financeiras, encerrou suas atividades, dando lugar à segunda, de âmbito nacional.
} 
(conduzia as cerimônias de nhemongarai, de atribuição de nomes às crianças guarani, em praticamente todas as aldeias da época, sendo também chamado a atuar em casos mais delicados de saúde e feitiçaria e nos aconselhamentos a respeito das questões políticas eou sociais internas) estende sua influência às demais aldeias guarani; a localização geográfica estratégica dessa aldeia, ponto de passagem obrigatório dos Guarani em marcha de outras aldeias da periferia de SP (Krukutu, Mboi-Mirim e Jaraguá) e do Sul do país, que se dirigiam ao litoral e, mesmo daqueles que dali seguiam caminho reverso:

o trajeto histórico dos Guarani rumo ao litoral é feito pela estrada da Barragem até a
localidade de Engenheiro Ferraz, seguindo-se pela trilha indígena até a aldeia de Itariri
e Bananal. De Engenheiro Ferraz também podem atingir as aldeias do litoral norte, se-
guindo até Santos e Bertioga e daí, pela "estrada velha”, chegar até as aldeias do Silveira,
em Barra do Una e Boa Vista, em Ubatuba. (Ladeira e Azanha, 1988: 33)

Os autores relacionam também que a proximidade desta aldeia em relação à Serra do Mar (cinco a seis horas de caminhada) e ao centro urbano de São Paulo (cerca de 50 $\mathrm{km}$ ), possibilita aos seus moradores acesso fácil às matérias-primas para a confecção de artesanato e à sua comercialização no centro da capital. Dessa maneira, grande parte dos Mbya de outras aldeias do litoral ou daquelas do PR, SC e RS que passam algumas temporadas nessa aldeia, marcham diariamente para o centro de SP para vender sua produção artesanal, o que possibilita a aquisição de alguns bens industrializados hoje considerados “indispensáveis” tais como “roupas, tecidos, panelas, sabão, querosene, etc.” (Idem). Além disso, outro fator considerado importante pelos autores é "o tradicionalismo do grupo familiar dominante e da chefia, [que] concorre para a eficiência das práticas religiosas e/ou rituais que vigoram no cotidiano, com a participação intensa da grande população infantil, promovendo uma forte coesão social - o que possibilita o controle de eventuais cisões” (Idem, alterações minhas). A soma de todos esses fatores promoveria a tal "estabilidade" dessa aldeia, apesar de todas suas condições físicas precárias em termos de território demarcado, uma vez que conta com muito "pouco espaço para a prática da agricultura (que, não obstante é exercida com todo rigor religioso exigido pela tradição Guarani)", não disponha de "nascentes ou de matas naturais" e seja constantemente visitada "por diversas instituições assistenciais" (Ibidem: 34).

Já a aldeia do Krukutu, apesar de estar situada a cerca de cinco quilômetros de distância da aldeia da Barragem/Morro da Saudade, também às margens da represa Billings, poderia ser considerada como um prolongamento desta (compondo inclusive, atualmente, uma única e mesma T.I.), pois, nessa época, "além dos vínculos familiares, da organização conjunta para o plantio do milho e do feijão", encontravam-se "sob a orientação espiritual de José” Fernandes (Idem). No entanto, o processo de cisão e dispersão, 
típico da socialidade guarani, acaba aparecendo aí para marcar a diferença de atuação e autonomia política de cada tekoa que, mesmo atualmente sendo configurada como uma mesma e única T.I. (declarada em 2016) possui seus próprios caciques, conselhos de lideranças, chefias de família e modos de liderar. Depois da saída do xeramoĩ José Fernandes para o Jaraguá (onde atualmente é cacique e líder espiritual no Tekoa Pyau, T.I. Jaraguá), o processo de cisão, elemento central do fazer(-se) polític@mbya, fez mais pessoas se mobilizarem e acomodarem seus fogos (tatapy) e cantos-rezas (tarova'i) em novos espaços, onde poderiam exercer de maneira renovada e "verdadeira" seu teko (modo de serpensar-agir), que parte, geralmente, da interpretação do casal-liderança de cada grupo familiar, das normas inspiradas nos comportamentos e ações dos parentes divinos.

Até a década de 1940, o território ocupado pelos Guarani na região da Barragem e do Krukutu era considerado por eles, segundo Ladeira e Azanha (1988), como uma continuação da aldeia do Rio Branco que, "pela extensão de seu território e por sua proximidade, garante a base econômica das aldeias do planalto", e porque eles "continuam utilizando o mesmo caminho e trilhas para se deslocar entre essas aldeias” (Ibidem: 37). De acordo com o RCID da T.I Tenonde Porã (2010), que integra em uma única T.I as aldeias Barragem e Krukutu, essa T.I. forma parte de um complexo de aldeias da região da planície litorânea da Serra do Mar, junto às atuais T.I.s Rio Branco, Aguapeu e Itaoca, onde ao menos até a década de 1950, cada família extensa e seus aliados habitavam seus próprios tekoa, sob a guia de uma liderança político-xamânica própria. Nesse sentido, embora localizadas na zona sul do município de SP, em Parelheiros ${ }^{56}$, no bairro Barragem, às margens da represa Billings, estas aldeias constituem um importante "ponto de passagem” para as famílias guarani que se dirigiam às aldeias do litoral, sabe lá a quanto tempo, em suas caminhadas rumo ao mar. Então, se essas aldeias guarani, situadas na capital paulista foram também formadas por grupos familiares cuja perspectiva era "o acesso à Serra do Mar”, elas podem ser “consideradas do ponto de vista territorial enquanto aldeias do litoral', pois compartilham um mesmo território-universo mítico-xamânico, compondo juntas um mesmo complexo de caminhos que mantém entre si relações de aliança e parentesco (Ladeira, 2000: 44, grifos meus).

A importância política e social da aldeia da Barragem/Morro da Saudade (chamada atualmente também de Tekoa Tenonde Porã) por sua "localização estratégica" que

\footnotetext{
${ }^{56}$ Segundo Ladeira (2000), o distrito de Parelheiros limita-se ao Sul do município de SP com o distrito de Marsilac, ao Norte e a Leste com o de Grajaú e a Oeste com os de Cidade Dutra e Jardim Ângela. Em média, do centro de SP (por exemplo, da Catedral da Praça da Sé), até o bairro a distância é de cerca de 50 $\mathrm{km}$, sendo esta aldeia mais próxima do litoral do que do centro da cidade.
} 
"favorece a recepção, a permanência temporária, e cada vez mais definitiva, de grupos familiares vindos do interior" e como "local de encontro e troca de informações já é notada no início da década de 80, assim como a interdependência entre as aldeias do litoral57" (Idem, grifos meus). Como atesta Benedito Calixto (1905 [1903]), nascido na própria Vila de Itanhaém, ao registrar uma série de caminhos e regiões de ocupação autônoma dos Guarani já no século XIX, o curso do rio Branco é utilizado como rota para seus deslocamentos da Serra do Mar em direção a região de Parelheiros e Santo Amaro:

Todo esse sertão, quase inculto e deshabitado, que se extende desde o immenso Valle da Ribeira de Iguape e grande parte do município de Itanhaém, até as margens do Rio Verde e Itararé, abrangendo os municípios de Faxina, Apiahy, Piedade, Uma, Itapecirica, etc., é ainda hoje constantemente percorrido por essa tribu de Guainá [sic: Guarani] nas suas idas e vindas para o littoral. Esta zona pouco povoada do nosso prospero Estado, incontestavelmente uma das mais incultas, foi sempre a preferida pelos indios. Ahi se encontram ainda verdadeiros sertões, nos quais o elemento civilizador é por enquanto muito escasso. [...] Ahi estão elles verdadeiramente "em sua casa”; toda essa região é inteiramente despovoada, ninguém os encommoda, a não ser algum caçador que uma ou outra vez penetra nessas florestas. Dahi também lhes são fáceis as suas viagens para os centros povoados, pois estão apenas a três e quatro dias de Santos e São Paulo, e a dia e meio de Itanhaem, aonde vem vender o producto de suas industrias e fazer seus pequenos provimentos [...] ou seguem pelo rio Branco de Itanhaem, subindo a serra de Santa Cruz dos Parelheiros e dahi a Santo Amaro, onde tomam a estrada geral até Sorocaba e Faxina; ou descendo pelo rio Juquiá, seguindo até Xiririca e dalli a Itapeva da Faxina, que dista apenas doze léguas de S. João Baptista e do Rio Verde. São estes, pois, os pontos por elles preferidos para os seus trajectos, entre esses dois núcleos, um no litoral, e outro no interior, ambos isolados dos centros populosos. É necessário que nos esforcemos por conserval-os nessa posição, tão vantajosa para elles, protegendo-os e procurando de alguma forma pol-os a coberto da ganância e do ódio dos mestiços e demais invejosos que os aborrecem por índole e que vão a pouco e pouco expulsando do aldeamento do Itariry e do Rio Verde. (Calixto, 1905 [1903]: 501-502, grifos meus)

Assim, com a intensificação do processo de colonização da Serra do Mar, uma série de pontos de ocupação guarani tiveram que ser progressivamente abandonados, especialmente pelo aumento da pressão e assédio de posseiros e grileiros. Ademais, a implementação gradativa das Unidades de Conservação (UC) a partir da década de 1960, que, a partir da década de 1970 culmina na criação do Parque Estadual da Serra do Mar, contribuiu também para a contínua expulsão dos Guarani de seus locais de moradia, pois muitos desses locais passaram a ser considerados como pertencentes aos limites do Parque, o que acaba resultando na consequente concentração e confinamento guarani nas pequenas áreas homologadas na década de 1980, pelo convênio Funai-Sudelpa. Ainda assim, eles continuaram a tentar utilizar as localidades que foram expulsos como pontos

\footnotetext{
${ }_{57}$ É importante ressaltar então que, na concepção guarani do espaço e da plataforma terrestre (yvyrupa), todas as aldeias que eles ocupam fazem parte de um mesmo território, que lhes é comum (mesmo que atualmente ele não seja contíguo), revelando assim a sua interdependência. As grandes redes de alianças estabelecidas pelas famílias extensas e, consequentemente entre os diversos tekoa, sustentam e dão garantia à mobilidade e dispersão necessária à sua reprodução física e cultural, característica da sua organização político-social, alterando constantemente a composição e densidade populacional de cada aldeia (Ladeira e Azanha, 1988: 53).
} 
de caça e coleta, mas diante da intensa fiscalização e repressão dos órgãos ambientais e dos demais ocupantes jurua da região foram restringindo cada vez mais suas atividades produtivas aos espaços das áreas demarcadas. A T.I. Barragem dá origem ao Tekoa Tenonde Porã (que, como vimos, na década de 1970, era conhecido como "Vila Guarani”, e no início dos anos 1980 como "Morro da Saudade"), que passa a ser assim reconhecida desde o período dos estudos para a revisão da demarcação, pós 1988, até os dias de hoje. Monteiro, sobre a ocupação guarani na capital comenta:

\begin{abstract}
[...] a história das migrações - voluntárias ou involuntárias - não terminou no século XIX. Longe dos salões do Instituto Histórico e Geográfico, do Museu Paulista e da Academia Paulista de Letras, um outro movimento bem mais discreto trazia uma nova leva de migrantes - ou seriam imigrantes? - guaranis para a Capital. Complementando uma longa tradição de movimentos de populações guaranis para esta região, pequenos grupos se estabeleceram em três comunidades: Morro da Saudade, Krukutu (ambos no extremo sul do município) e Jaraguá. [...] O processo contínuo de ajuste aos tempos também se revela na transformação do nome da aldeia situada em Parelheiros. Segundo Maria Inês Ladeira, na década de 1970 a placa Vila Guarani anunciava a entrada da aldeia; na década de 1980, já com alguma assistência indigenista, os índios decidiram mudar o nome para Morro da Saudade; e recentemente, seguindo a tendência dos tempos, elegeu-se um nome em guarani: Tekoa Tenonde Porã. (Monteiro, 2004: 66-67, grifos meus)
\end{abstract}

Foi a "comunidade" que habita este tekoa quem escolheu o seu nome em guarani que, segundo relatos, se originou do grupo de canto e dança das crianças da aldeia, e significa, segundo seu idealizador, o xeramoĩ Valdelino, "luz e esperança" ou "aliança para o futuro" (Ladeira, 2000: 17). De acordo com Ramo e que vai de encontro com o que me ensinaram meus interlocutores, Tenonde é o primeiro de uma fila ou @ filh@mais velh@, sendo utilizado também em referência aos primeiros pais e mães dos nhe'ẽ (nomes-espíritos), Nhanderu e Nhandexy Tenonde, ou mesmo ao se referirem ao karai è̀ kunhã karai, lideranças espirituais que dirigem os cantos-reza e curas na opy (casa de reza-cantodança-cura) (Ramo, 2014: 160-61). Tenonde Porã revela então o sentido coletivo e espiritual do nome da aldeia, que seguindo a luz, inspirada por Nhanderu e Nhandexy Tenonde encontra esperança para um futuro melhor para suas crianças e jovens, que serão os próximos a caminhar nesse duro embate com o mundo jurua, nessa luta diária por uma vida mais digna e menos sofrida nessa terra tekoaxy, que segue exigindo o respeito dos jurua por seus costumes e tradições, como veremos a seguir, com as novas gerações de lideranças (-uvixa kuery) assumindo um espaço que antes era protagonizado pelos seus anciões, suas lideranças espirituais, na luta pela proteção da plataforma terrestre (yryrupa) e que, progressivamente, se desdobra em uma luta pela demarcação de terras (yoy re jajo- 
guero’a) na conjuntura atual. Essa nova geração continua caminhando adiante com a sabedoria e força espiritual dessas lideranças espirituais, com fé (-jerovia $)^{58}$ e esperança em dias melhores, formando assim uma grande aliança para um futuro bom-belo-bonito-correto-verdadeiro (porã), fortalecendo (-mbaraete) ainda mais o nhandereko.

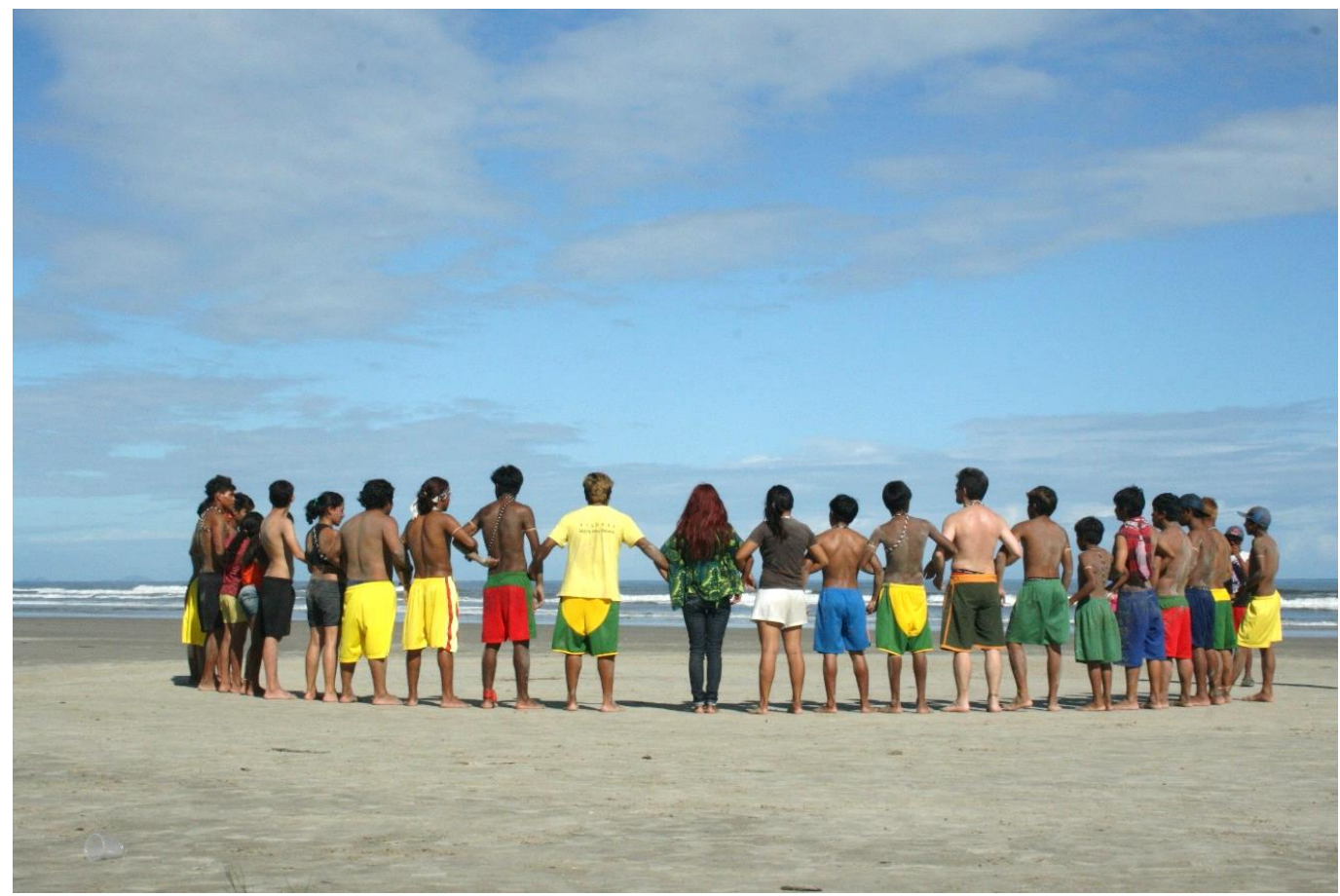

Xondaro ha’egui xondaria kuery. Aline Aranha. Bertioga, 2012.

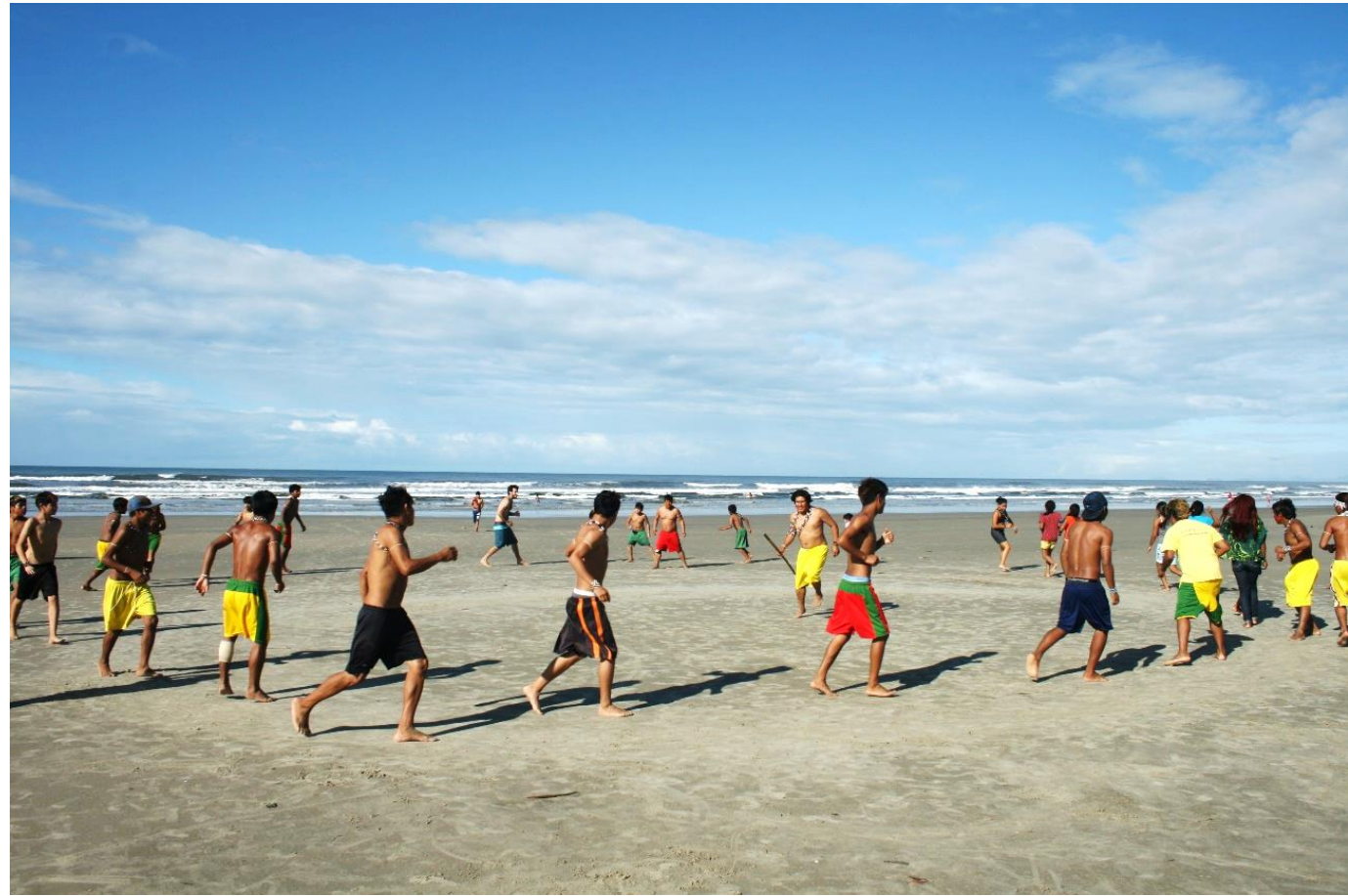

Xondaro jeroky de frente para o mar. Aline Aranha. Bertioga, 2012.

58 -Jerovia pode ser traduzido com o ato de "exercer fé ou confiança (em alguém): ojerovia ete Nhanderuete re (ele) exerce fé em Deus" (Dooley, 2006: 67). Esse termo deriva de -erovia, "acreditar" (Ibidem: 38). 
O Tekoa Tenonde Porã, como comentado, integra a T.I. Barragem (26,30 hectares [ha] de área demarcada, homologada em 14 de abril de 1987) que é contígua à T.I. Krukutu, (26 ha de área demarcada, homologada em 14 de abril de 1987), ambas localizadas nos limites do extremo sul do município de SP, formando parte de um mesmo complexo geográfico, territorial e xamânico que envolve estas áreas demarcadas e os caminhos de ligação às outras aldeias no litoral paulista. Juntas, estas T.I.s compõem uma área demarcada de cerca de 52 ha, resultantes do convênio Sudelpa-Funai, que regularizou parte de seu território em um contexto em que era negado todo e qualquer direito aos Guarani (e não só a eles) especialmente, em relação à sua ocupação na Serra do Mar, até mesmo o seu reconhecimento por parte da Funai. A demarcação se dá então, nesse contexto, de acordo com as limitações políticas e disputas judiciais impostas pela época, a sua delimitação tendo como base principal o perímetro da alegada propriedade daquele japonês que conferia proteção aos Guarani, utilizando-se de sua mão de obra para seus próprios fins de grilagem, e que lhes "doou" a terra por meio de um "papel” (ver Ladeira e Azanha 1988). Isto é, a sua delimitação se deu com base na área de abrangência das ações judiciais movidas pela comunidade contra aqueles que se diziam proprietários das terras e em resposta às ações de reintegração de posse. O critério principal adotado pelo Estado foi, portanto, o da posse alegada por esses pretensos proprietários e não o da extensão efetiva da tradicional ocupação guarani na região, que viria a ser caracterizada antropológica e ambientalmente por estudo técnico específico, a partir dos novos critérios constitucionais de $1988^{59}$. Assim, sendo os estudos referentes à demarcação das referidas T.I.s anteriores à Constituição atual, que assegura os direitos territoriais indígenas, imprescindíveis à sua reprodução física e cultural, as lideranças guarani voltam a se mobilizar e buscar a garantia desses direitos, decidindo no âmbito dos estudos de identificação e delimitação para a demarcação de suas terras, se unificar em uma única T.I. - a T.I. Tenonde Porã -, uma vez que toda a área de ocupação tradicional reivindicada, seria compartilhada pelos habitantes dessas aldeias homologadas no final dos anos 1980. No entanto, apesar da mobilização guarani, o processo de "revisão" dos limites territoriais tem início apenas em 2002, cujo Relatório de Identificação e Delimitação para "correção" da área demarcada foi publicado e aprovado apenas em 19 de abril de 2012 pela FUNAI, no Diário Oficial da União (Portaria FUNAI/PRES n ${ }^{123}$ ).

\footnotetext{
${ }^{59}$ Segundo o site Povos Indígenas no Brasil do Instituto Socioambiental (ISA), todas as Constituições anteriores à atual, reconheceram aos povos indígenas os direitos sobre os territórios por eles habitados. Para mais informações, ver: https://pib.socioambiental.org/pt/Constituição. Acesso em 20 out 2017.
} 
A tradicionalidade da ocupação guarani na área que abrange toda a T.I. Tenonde Porã foi caracterizada em novembro de 2000, no Relatório de interferências da linha de transmissão de 750 kv Itaberá - Tijuco Preto III, que resulta em um Termo de Ajustamento de Conduta (TAC) entre as instituições Furnas e Funai, no qual ambas reconhecem os impactos do empreendimento jurua sobre a área e entram em acordo que uma das principais medidas de compensação seria, o custeio, por parte de Furnas, dos gastos operacionais com os estudos de identificação e delimitação da T.I., já que a Funai alegava não dispor de recursos orçamentários para tanto (ainda que a regularização fundiária das T.I.s no país seja um de seus deveres constitucionais). Alguns dos antigos pontos-paradas tradicionais, levantados nesses estudos, se converteram nas atuais "retomadas" de terra, dada à não regularização efetiva da demarcação (física) da T.I., que ainda segue em curso, apesar desta ter sido finalmente declarada como de posse permanente Guarani pelo Ministro da Justiça no Diário Oficial da União (Portaria ${ }^{\circ}{ }^{548}$ ) em 5 de maio de 2016 e, portanto, reconhecida oficialmente como de ocupação tradicional Guarani pelo Estado brasileiro, após anos de intensa mobilização das lideranças e das comunidades que, diante do descaso do Governo com suas reivindicações de terra, resolveram sair de suas aldeias com seus cantos-reza e danças de força e coragem exigindo a regularização de suas terras, como logo veremos.

Ainda que tenham conquistado mais esta vitória, com a declaração da T.I., eles sabem que a batalha não acabou ${ }^{60}$, e que devem seguir lutando para exigir que se cumpra, de fato, o rito da demarcação, que depois de passar pela demarcação física, deve seguir para a sanção presidencial para sua efetiva homologação. Junto às "retomadas" de terra, a T.I. Tenonde Porã corresponde a um conjunto de seis aldeias, até o momento (e que segue se multiplicando): Tekoa Tenonde Porã (Barragem/Morro da Saudade), Tekoa Krukutu, Tekoa Kalipety, Tekoa Yyrexakã, Tekoa Guyrapaju e Tekoa Kuaray Rexakã (os 4 últimos tekoa, fruto de retomadas de terra). A T.I., localiza-se, portanto, entre os limites dos municípios de São Paulo (as 4 primeiras aldeias), São Bernardo do Campo, São Vicente e Mongaguá (as 2 últimas aldeias) e corresponde a um território de 15.969 ha. Além disso, a T.I. Tenonde Porã pertence também a um conjunto de aldeias Guarani localizadas no município de SP, sendo três delas oficialmente homologadas pelo Estado brasileiro: Tekoa Tenonde Porã (T.I Barragem), Tekoa Krukutu (T.I. Krukutu), localizados na região

\footnotetext{
60 Além da pauta das demarcações, os Guarani se posicionam, junto ao movimento indígena nacional, contra a Proposta de Emenda à Constituição (PEC) 215, projeto da "bancada ruralista" no Congresso Nacional que pretende retirar do Poder Executivo e passar para o Legislativo a responsabilidade final sobre os processos de demarcação de Terras Indígenas.
} 
de Parelheiros - extremo sul -, e a T.I. Jaraguá61 (1,87 hec, homologada em 1987) extremo noroeste -, que conta atualmente com três tekoa, o Tekoa Ytu, Tekoa Pyau e uma retomada de terra, Tekoa Itakupe. Essas T.I.s de SP compõem, junto às do Aguapeú, a do Rio Branco (Itanhaém) e de Itaoca, um mesmo complexo de aldeias que configura entre si um espaço contínuo de interação, formando parte de um mesmo território de ocupação tradicional junto às outras aldeias do litoral e do interior de SP, RJ, ES, PR, SC e RS do Brasil (ver Mapa Guarani Digital 2017 e Centro de Trabalho Indigenista 2015a).

A grande densidade populacional ${ }^{62}$ do Tekoa Tenonde Porã é emblemática, considerando-se o tamanho médio de outros coletivos Mbya no Brasil. O que corresponde, sobretudo, ao processo de concentração e sedentarização em pequenos aldeamentos a que foram submetidos pelos órgãos estatais, que tinham como objetivo direto se apropriar de seu território de circulação para colonização, dificultando a abertura de novos tekoa. A convivência de distintos grupos familiares em uma mesma área, somada a alguns fatores conjunturais, como a maior facilidade de acesso a serviços e benefícios públicos, conquistados em sua maioria pelas reivindicações das lideranças junto aos órgãos estatais competentes, também acaba atraindo mais famílias que, cada vez mais tornam-se dependentes desses benefícios governamentais na falta de terras devidamente regularizadas para caça, coleta e plantio tradicionais, o que acaba levando-as a se concentrar onde enxergam maiores possibilidades de obtenção desses auxílios e-ou doações ${ }^{63}$ como meio $^{\circ}$ de sustentar a própria família. Atualmente, este tekoa conta com mais de cento e cinquenta famílias, distribuídas em grandes núcleos de parentesco com relações de aliança e parentesco entre si, número este que pode variar de acordo com os deslocamentos físicos de grupos e indivíduos entre aldeias. Este grande número de famílias vive e compartilha entre si um mesmo e restrito espaço, que não dá muita liberdade para se movimentar em busca de espaços autônomos e adequados para roçar e plantar suas sementes e

\footnotetext{
${ }^{61}$ Para uma discussão sobre a T.I. Jaraguá e as lideranças, ver Nogueira da Silva (2015).

${ }^{62}$ Esta densidade populacional é excepcional em relação ao padrão tradicional de organização social guarani, uma vez que cada aldeia é comumente formada apenas por algumas famílias extensas, e há algumas décadas não excederia uma centena de pessoas, sendo até hoje raramente superior a duas centenas.

${ }^{63}$ Além disso, as recentes transformações no âmbito doméstico e familiar, com seus membros inseridos numa série de papéis e funções integrais relacionada a empregos assalariados proporcionados pelo Estado brasileiro (Escolas, Unidade Básica de Saúde [UBS], projetos culturais) no âmbito da comunidade, que os distanciam das atividades tradicionais de subsistência, além do recebimento de renda por meio de aposentadorias, programas de transferência de renda (Bolsa Família) do Governo Federal e Estadual (Renda Mínima), não foram muito avaliadas no sentido de causar maior dependência dos Guarani de um modelo econômico exterior. Como uma interlocutora mbya me contou: "as matas, foram as nossas margens, a gente tem outra forma de saber viver, por exemplo, não podemos mais sobreviver de caça e pesca [...] de qualquer forma a gente sabe agora viver de outra forma, mesmo vendendo artesanato ou plantando as coisas, tem outras formas" (Para Yxapy do Tekoa Koenju [RS], Local: São Paulo, 2016). Ainda assim, eles continuam entendendo a mata "como a nossa cidade, nosso teatro, nosso supermercado, nosso tudo, a mata, é dela que vivemos, então é coisa que faz muita falta” (Karai Poty, Tekoa Tenonde Porã 2016).
} 
desenvolverem suas atividades de sustento, mas que seguem lutando pela regularização física de suas áreas de uso, passagem e ocupação tradicional para assim obterem a segurança e com isso a autonomia no uso dos recursos naturais que se localizam dentro da própria T.I. ou em áreas próximas, e permitem sua subsistência. No entanto, até os dias atuais eles sofrem com grandes impedimentos e dificuldades no uso desses recursos devido, principalmente, ao bloqueio e fiscalização estatal no Parque que atravessa a T.I., que busca restringir e criminalizar as suas atividades de caça, pesca e coleta de materiais para utensílios domésticos, artesanato, fabricação de remédios do mato (moã) e construção de casas, entre outras atividades.

O Tekoa Tenonde Porã é, portanto, uma das aldeias guarani mais populosas de SP, residem aí distintos grupos de parentesco de procedências diversas, o que aumenta as possibilidades de casamento, pois há maior possibilidade de os jovens encontrarem cônjuges possíveis dentro da própria aldeia sem ferir diretamente as regras sociais e de consanguinidade, e contribui para gerar um constante aumento populacional. Isso dificilmente acontece em aldeias menores ${ }^{64}$, que contam com poucas famílias e já possuem algum vínculo de parentesco entre si. Aí os jovens têm que se deslocar por outros tekoa em busca de esposas (e cada vez mais é possível observar as mulheres circulando também), onde também podem passar a viver, ainda que temporariamente - pelo menos até nascer o primeiro filho e receberem o auxílio e conselhos dos sogros em seu fortalecimento físico-espiritual -, compondo regra de residência matrilocal e que, geralmente, pode não ocorrer no caso dos filhos de lideranças espirituais ou muito prestigiosas, que acabam voltando para viver junto aos pais, em suas aldeias de origem, levando a esposa junto.

A ocupação guarani da Serra do Mar forma, portanto, uma rede de aldeias, um "local estratégico e de proteção, apesar da proximidade do mar, e significa, ainda, a possibilidade da realização do destino ou da concretização do projeto", de transpor o mar para atingir o paraíso (Ladeira, 2007 [1992]: 153, grifos meus). É, portanto, “o lugar ideal para a espera ou para o desenvolvimento das ações que auxiliam esse empreendimento” (Idem, grifos meus). A localização da T.I. Tenonde Porã é, nesse sentido, estratégica para os Mbya, pois além de fazer parte de um complexo de caminhos-aldeias, é um importante espaço de transição para se viver bem (teko porã) de acordo com código ético-xamânico guarani (nhandereko),

\footnotetext{
${ }^{64}$ Essa, portanto, seria uma das particularidades das aldeias guarani localizadas em SP, como a T.I Tenonde Porã e a T.I Jaraguá, já que, em geral, o costume seria de o “jovem procurar esposa em outras aldeias, onde provavelmente passa a viver integrando-se ao núcleo residencial do sogro” (Ladeira, 2000: 21). O “controle’ populacional das aldeias Guarani Mbya” é então "aliado às dinâmicas definidas pelos casamentos e pela reciprocidade entre afins" (Idem).
} 
com autonomia de movimento - em seu ideal de convivência, não desejam ser incomodados pelas autoridades estatais, a não ser para exigir que estas cumpram com seus deveres, garantindo autonomia política e subsistência digna, dentro de seus tekoa -, que pode levá-los a se fortalecer e atingir aguyje (maturação corporal-espiritual). Objetivo este que corresponde diretamente à persistente ocupação Guarani na região, que podem ser entendidos então como "guardiões" não só da Serra do Mar, mas de yvyrupa, assim como os seus espíritos protetores, os nhe'ẽ kuery enviados pelos Nhanderu e Nhandexy kuery, e os seus tekoa, como um cinturão de proteção da região, mesmo quando as áreas demarcadas são mínimas e completamente desgastadas pelo (ab)uso jurua contínuo do solo, da fauna e da flora. É importante nos atentarmos às estratégias de resistência e de luta guarani pela demarcação das aldeias de SP, mas antes é importante ressaltar também o que eles compreendem por território e como desenvolvem a sua territorialidade através do movimento, construindo e protegendo o seu próprio mundo, seguindo a orientação dos parentes divinos.

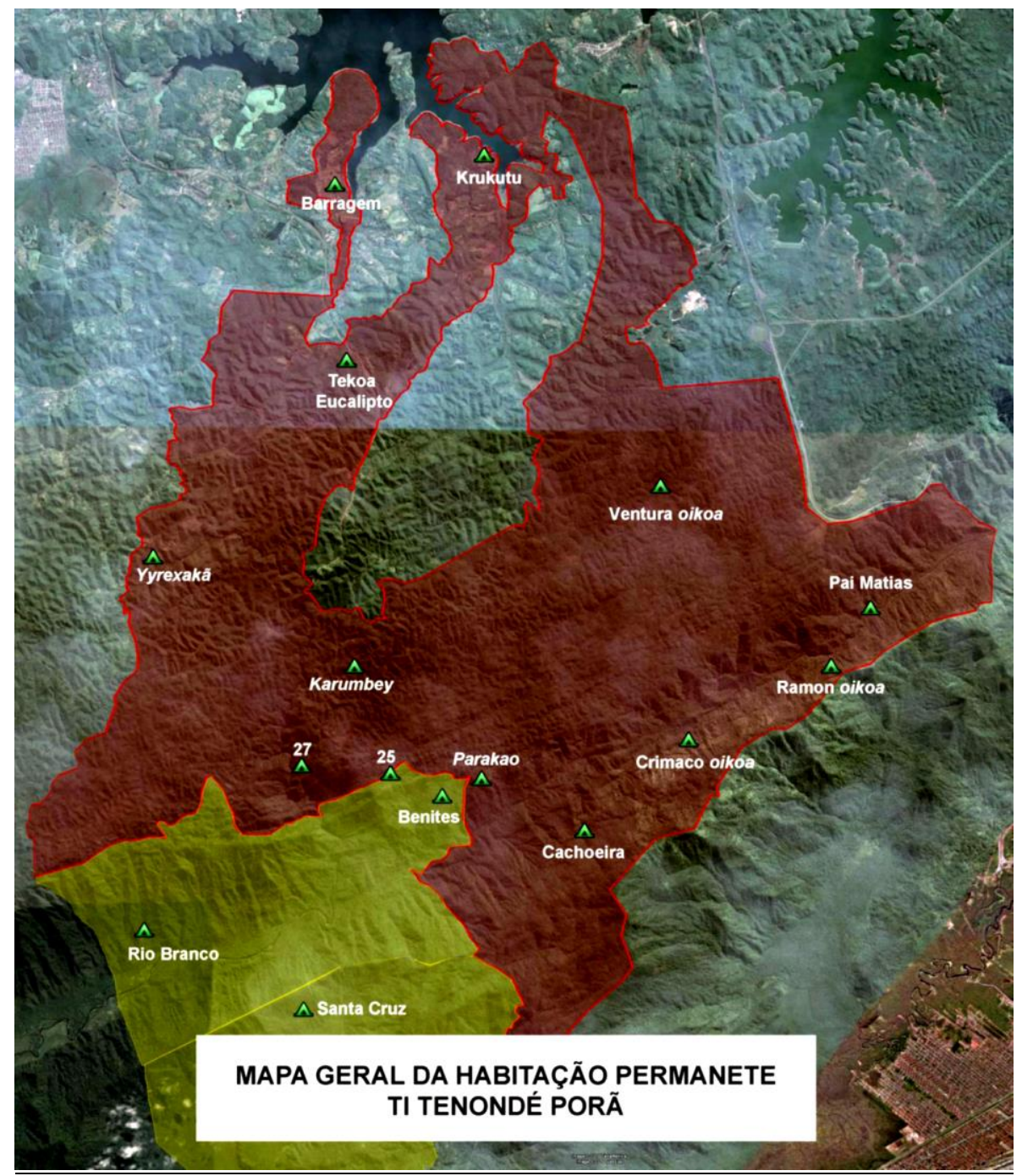

Mapa geral da T.I. Tenonde Porã. In: RCID T.I. Tenonde Porã (2010). 


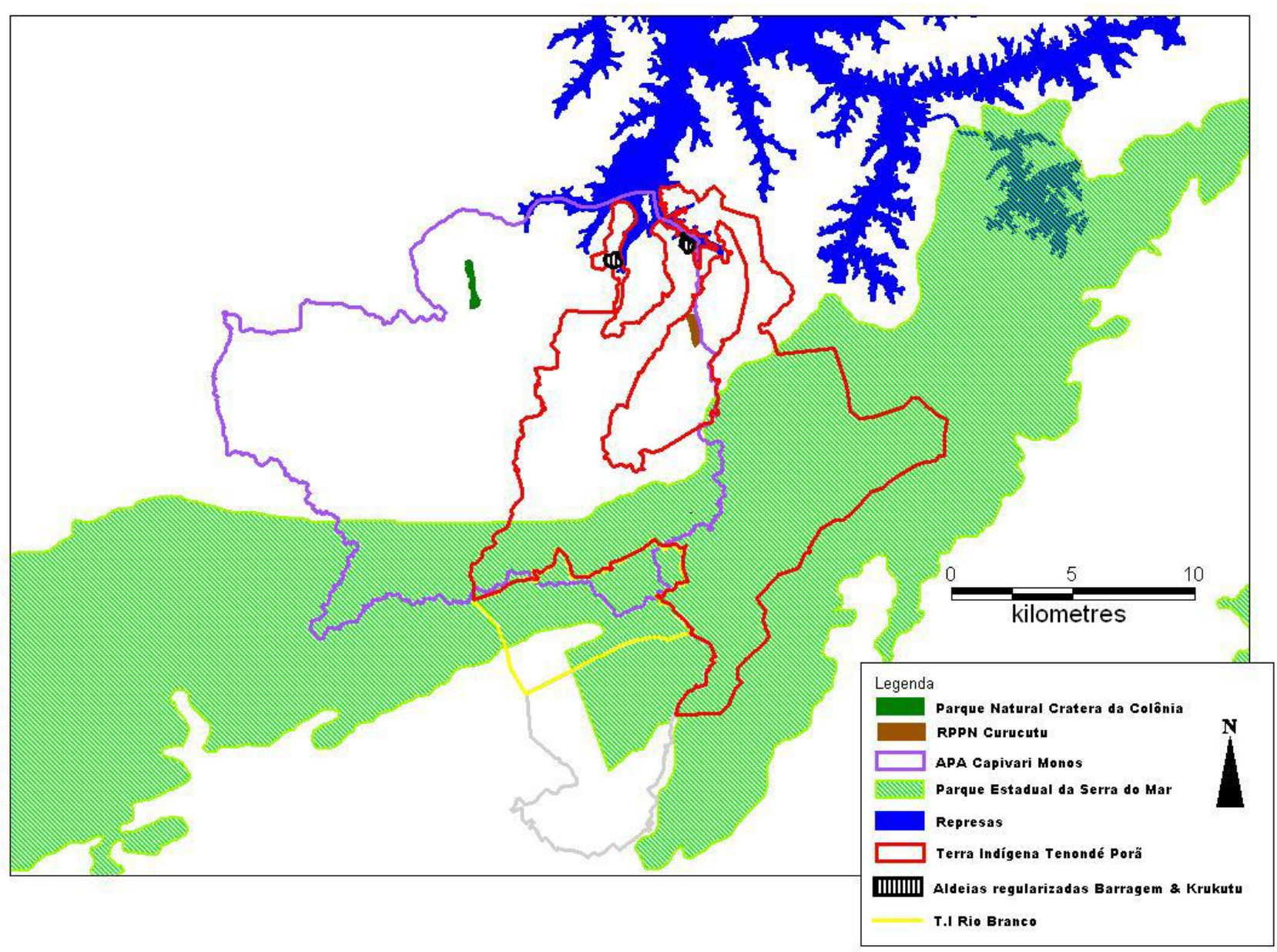

Mapa da T.I. Tenonde Porã e Unidades de Conservação. In: RCID T.I. Tenonde Porã (2010).

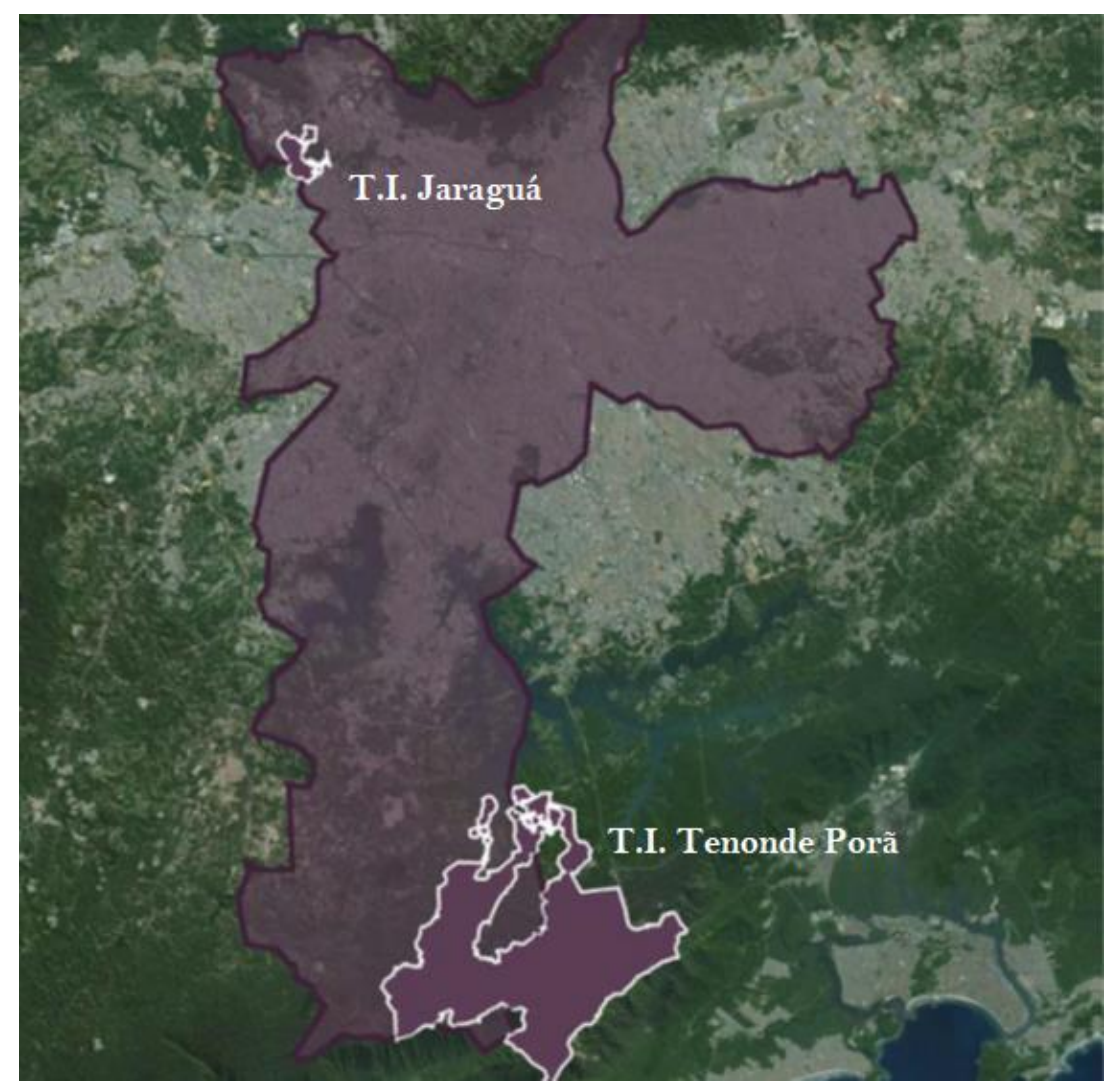

Terras Indígenas Guarani no município de São Paulo. In: Centro de Trabalho Indigenista (2016c). 


\section{A criação e manutenção de yvyrupa: os percursos de yvy mbyte à yvy apy $y^{65}$}

Aqui, nos concentramos em algumas das principais características da ocupação territorial guarani ou, em outras palavras, em suas práticas de territorialidade, isto é, as lógicas que os coletivos guarani imprimem no espaço onde vivem e conceitualizam o seu mundo terreno, e que passa pela análise dos locais onde insistem em preservar suas aldeias e assentamentos, como viemos mostrando. O conceito de territorialidade é explorado em Gallois (2004) de uma maneira comparativa em relação ao conceito de terra e território e suas supostas equivalências. Segundo a antropóloga, todos os povos inscrevem uma lógica própria no espaço que ocupam e concebem como seu, o que pode ser descrito pela Antropologia em termos de múltiplas e diferenciadas territorialidades, já que nem sempre tais lógicas derivam ou se relacionam necessariamente às noções nativas de território ou mesmo de terra, tal qual a noção jurídico-ocidental a concebe ${ }^{66}$ :

A noção de “Terra Indígena” diz respeito ao processo político-jurídico conduzido sob a égide do Estado, enquanto a de "território" remete à construção e à vivência, culturalmente variável, da relação entre uma sociedade específica e sua base territorial [...] Na transformação de um território em terra, passa-se das relações de apropriação (que prescindem de dimensão material) à nova concepção, de posse ou propriedade. [...] o contato coloca um grupo indígena diante de lógicas espaciais diferentes da sua e que passam a ser expressas também em termos territoriais. Como já se viu, o contato é um contexto de confronto entre lógicas espaciais. Por este motivo, as diversas formas de regulamentar a questão territorial indígena implementadas pelos Estados Nacionais não podem ser vistas apenas do ângulo do reconhecimento do direito à "terra", mas como tentativa de solução desse confronto. (Gallois, 2004: 39, 41, grifos meus)

O conceito mbya que mais se aproxima daquilo que os jurua kuery concebem por "território" seria yəyrupa [yvy significa terra e rupa suporte, leito, base, esteio], termo este que poderia ser traduzido literalmente como o próprio "suporte" ou "plataforma terrestre”, e abrangeria toda a extensão do território onde os Guarani se estabelecem ou consideram possível e ideal estabelecer suas aldeias e assentamentos. Ainda que tal conceito não coincida de maneira exata com a noção ocidental de território, uma vez que designa a amplitude total que os Guarani consideram ser a plataforma terrestre, espaço

\footnotetext{
${ }^{65}$ Segundo Ladeira: "O começo do mundo ou início do mundo ou princípio do mundo ou Yry Apy implica em tempo (origem) e, sobretudo, lugar (origem). É o lugar, por excelência, onde existem as boas coisas dos tempos primordiais, onde Nhanderu iniciou a construção do mundo. Apy significa extremidade, ponta. Yry apy é a extremidade do mundo, que se encontra na beirada do oceano (Ladeira, 2007 [1992]: 85). 66 Como aponta Gallois (2004), e é muito bem resumido por Macedo (2010), @ antropólog@ e a população indígena que estão "implicados na definição dos limites de uma terra estão diante da difícil tarefa de traduzir territorialidades [que remetem a concepções cosmológicas] em Terras Indígenas”, este dispositivo estatal, que muitas vezes se restringe ao que se compreende, na sociedade envolvente, aos códigos da etnicidade e da "posse" (Macedo, 2010: 63, alterações minhas). No entanto, como constata Gallois (2004), a apropriação indígena dos limites territoriais e étnicos ocidentais, está sempre sujeita aos seus modos próprios de pensar e agir nesse mundo.
} 
que é compartilhado com outros seres e coletivos - e, nesse sentido, se aproxime mais da ideia jurua de planeta Terra -, ele orienta de maneira ativa a territorialidade desse grupo ao longo de toda a sua extensão, especialmente nos lugares onde assentam seus tekoa, apesar da grande dispersão e mesmo de sua fragmentação atual. Os critérios de dispersão dos assentamentos guarani ao longo do seu território são diversos e, na maioria das vezes, confundem-se entre si, correspondendo tanto a fatores de ordem cosmológica, às dinâmicas políticas entre as redes de parentesco, inimizade e aliança e às dinâmicas históricas presentes no contato com a sociedade envolvente, como bem aponta a literatura.

A configuração que esse território apresenta atualmente no Brasil, pela atual distribuição de seus tekoa corresponde a cerca de 153 T.I.s ocupadas pelos Guarani desde o litoral do ES e RJ, passando pelo litoral e interior dos Estados de SP, PR, SC e RS. Seu contingente populacional seria composto por grupos familiares que, historicamente, procuram formar seus assentamentos junto às regiões montanhosas da Mata Atlântica, como a Serra do Mar, a Serra da Bocaina, a Serra do Tabuleiro, dando continuidade aos seus processos de migração em direção à costa Atlântica (Ladeira, 2000: 14). Junto a essas T.I.s, devem ser também contabilizadas as cerca de 105 áreas correspondentes a outras localidades, apontadas pelos Guarani como tendo sido desocupadas recentemente por força da pressão fundiária e demais circunstâncias relacionadas, uma vez que estas compõem o seu horizonte de concepção territorial. Portanto, de acordo com o mapeamento das terras tradicionalmente ocupadas pelos Guarani no Sul e Sudeste do Brasil realizado pelo Centro de Trabalho Indigenista (CTI), com referências que se acumulam desde o final da década de 1970 até os dias atuais e, recentemente publicado no Atlas das Terras Guarani no Sul e Sudeste do Brasil ${ }^{67}$, foram levantadas 258 aldeias (CTI 2015a, 2015b). No Paraguai, as aldeias Mbya encontram-se dispersas preponderantemente na região oriental do país, na Argentina concentram-se na província de Misiones e, até recentemente, havia também a ocupação Mbya no Uruguai, em localidades ao norte de Montevidéu, de onde também foram expulsos (RCID Tenonde Porã, 2010: 32-33).

Segundo o levantamento contido no Atlas, das 153 terras ocupadas atualmente, apenas 17 estão plenamente regularizadas como sendo de posse permanente e uso exclusivo dos Guarani. Em conjunto elas somam uma superfície que não totaliza nem 30 mil hectares em todo o país, para uma população de mais de 13 mil guaranis, o que traz prejuízos incomensuráveis para exercerem seu modo de vida, de acordo com seus costumes

\footnotetext{
${ }^{67}$ Além de oferecer a localização exata das aldeias, o Atlas faz um levantamento de todas as T.I., os grupos étnicos presentes em cada uma delas, a sua superfície de cobertura e a situação jurídica e administrativa em relação aos processos de demarcação em tramitação.
} 
e tradições. E, foi apenas no final da década de 1980 que algumas dessas terras, especialmente em SP e no RS, começaram a ser regularizadas a partir das reivindicações dos próprios Guarani, com a assessoria do CTI. Dessas 153 T.I.s ocupadas e mais 105 áreas guarani hoje desocupadas, apenas 99 (28 em SP, 2 em ES, 6 no RJ, 16 no PR, 20 em SC, 27 no RS) são contabilizadas pelo sistema online da Funai como áreas Guarani - mesmo que compartilhem algumas delas com outros povos, principalmente nos Estados do Sul -, pois foi iniciada alguma providência administrativa para a sua regularização ${ }^{68}$ (ver Fundação Nacional do Índio 2017).

A grande morosidade dos processos administrativos de regularização das T.I.s, somada à enorme incidência de conflitos judiciais que envolvem esses processos no Sul e Sudeste "contribuem para aumentar a insegurança da população guarani no âmbito de seu território e acaba por se traduzir na deterioração da qualidade ambiental das áreas [...] resultante do processo de colonização" (RCID Tenonde Porã, 2010: 35). Assim, ao analisar a situação das ocupações tradicionais guarani no Sul e Sudeste do Brasil devese atentar de que o território que está sendo reconhecido pelas autoridades competentes do Estado, se dá de maneira descontínua, uma vez que cada uma das T.I.s Guarani localizadas nestas regiões corresponde apenas a uma parcela do seu amplo território. No entanto, mesmo com todas as dificuldades referentes aos processos de regularização das T.I.s, a plataforma terrestre (yzyrupa) continua sendo percebida, concebida e vivenciada pelos Guarani como um espaço único no qual buscam estabelecer suas aldeias e espaços de convivência, mesmo que ele seja também compartilhado com outros povos e pessoas de fora e que, cada vez mais se veja atravessado por inúmeras cidades, estradas, fazendas, empreendimentos de grande impacto e por tantas fronteiras, estatais e nacionais.

Diante de todo um processo histórico de muita resistência, marcado também por muita violência, séculos de opressão, preconceitos, omissão e injustiças que perduram até hoje, está claro que não será possível obter o reconhecimento de todo o seu "território", e nem é essa a pretensão dos Guarani, que estão cientes de que este espaço coincide em grande parte com a parcela mais urbanizada e as cidades mais importantes em termos econômicos do território nacional, assim como não têm interesse em viver longe das matas e nascentes. É, portanto, imprescindível, que os Guarani tenham suas reivindicações de terras tradicionalmente ocupadas reconhecidas de fato pelo Estado brasileiro para que, ao menos nesses espaços possam deter o usufruto exclusivo e ter condições

\footnotetext{
${ }^{68}$ A legislação específica que rege atualmente os trabalhos de Identificação e Delimitação de T.I.s é composta do Artigo 231 da Constituição Federal (1988), do Decreto no 1775 (de 8 de janeiro de 1996), da Portaria no 14 (9 de janeiro de 1996), e pela Lei $n^{\circ} 6001$ (1973) que dispõe sobre o Estatuto do Índio.
} 
necessárias para reproduzir seus costumes e tradições, garantindo a sua reprodução física e cultural, conforme determina o texto magno do país. No entanto, a Constituição segue ainda hoje não sendo de todo cumprida na prática e, cada vez mais, impugnada pelas recorrentes tentativas das bancadas ruralistas que ocupam o Congresso Nacional em decidir o destino das populações indígenas e tradicionais.

Conforme já foi bastante explorado na literatura antropológica, os GuaraniMbya não concebem fronteiras rígidas na sua concepção de espaço, circulando constantemente entre as aldeias, preservando assim grandes redes de troca, seja de bens - materiais e imateriais -, por meio de intercâmbios diversos - de sementes para uso alimentar, ritual e para fins comerciais, mas também de remédios, cerimônias rituais e saberes -, promovendo também alianças e parcerias na troca de pessoas, que casam entre si ao largo de toda a yzyrupa, intensificando as redes de relações que acabam por ultrapassar as fronteiras estatais e nacionais criadas pelos jurua kuery69. Essas redes passam constantemente por reconfigurações diversas:

Suas aldeias não se situam em áreas contínuas, e cada qual por sua vez também passa a ser considerada oficialmente como uma unidade administrativa reconhecida a partir da categoria “Terra Indígena”, cada qual com uma escola, um posto de saúde, um programa de assistência, uma associação indígena, enfim uma comunidade jurídica específica sobre a qual também se soma uma série de conflitos e ações judiciais. Tal situação acaba influindo nas relações políticas entre aldeias ou projetando novas alianças, rivalidades e formas de circulação de pessoas. Para os Guarani, apesar de não contíguo nem exclusivo, seu território multifacetado pressupõe uma continuidade concreta uma vez que a dinâmica de sua ocupação num vasto espaço geográfico acontece e é observada nas sucessivas composições formadas a partir de elos de afinidade e consanguinidade que levam à reprodução e a novas produções de conhecimentos e experiências, assim como a um constante reordenamento espacial, com a recuperação de antigos locais e a formação de novas aldeias. Os movimentos e as articulações impulsionadas pelas diversas parentelas implicam comunicação constante, renovação de experiências e de lembranças e promovem um contínuo fluxo de saberes, de práticas rituais, de cultivos e de espécies naturais. Supondo que os Guarani apreendam seu mundo em sua totalidade, onde todos os níveis de sua existência estão associados (incluindo as contradições e as transgressões), é o seu território, aparentemente descontínuo e indefinido, compartilhado e fragmentado, a base que sustenta seu modo de vida e dinamiza as relações dentro e fora de sua sociedade. (Ladeira, 2011: 717-720)

\footnotetext{
69 As possibilidades de casamento de um Guarani se estendem então ao longo de todo esse território, no entanto ela ocorre preferencialmente entre aqueles que falam o mesmo idioma, configurando uma espécie de endogamia linguística, mas ainda que também possam ocorrer casamentos entre os subgrupos guarani, mais frequentes em determinadas regiões que outras, prevalece sempre o horizonte de poder se comunicar na mesma língua e compartilhar um espírito proveniente de Nhanderu e Nhandexy retã ("morada" dos pais e mães dos nhe'ê), o casamento com não-indígenas ou mesmo com outras etnias é muito raro, mas também acontece. Parte (minoritária) da população da T.I. Tenonde Porã foi formada a partir de casamentos de grupos nhandeva (com os quais Nimuendaju esteve em contato) com indígenas moradores dos aldeamentos do litoral. São essas as famílias que atualmente se auto-identificam como Tupi-Guarani. A maior parte da população atual da T.I., no entanto, é formada por grupos classificados como Mbya falantes, que engrossaram a demografia indígena da região depois de outras levas migratórias advindas do RS, no início do século XX, conforme relatos de alguns de seus mais antigos moradores. É importante ressaltar também que os que se auto-identificam como Tupi e ali vivem adotaram o dialeto mbya, dominante dentro das aldeias e nas relações interpessoais.
} 
A importância do conceito de yoyrupa aparece mais claramente nas migrações de inspiração mítica retratadas na literatura especializada desde Métraux, passando por Nimuendaju, Cadogan e H. Clastres, que tinham à frente profetas xamânicos que anunciavam a possibilidade de ascensão com o corpo $(-e t e)^{70}$ terreno à já consagrada "terra sem mal”. Os percursos migratórios que servem de inspiração e referência aos Mbya desde tempos imemoriais têm sua origem no mais importante percurso mítico desempenhado, que marca e dá início à formação da plataforma terrestre: a história dos primeiros ancestrais míticos, Nhanderu Tenonde, Nhandexy Tenonde e os irmãos ${ }^{71}$ Kuaray (Sol) e Jaxy (Lua), responsáveis pela própria consolidação de yəyrupa. Em uma versão coletada pelo Grupo Técnico (GT) responsável pelo Relatório de Identificação e Delimitação da Terra Indígena Tenondé Porã, o então cacique do Tekoa Tenonde Porã à época narra de forma "marcante" esse percurso realizado pelos heróis míticos pelo território guarani:

O cacique inicia dizendo que sempre existiu o caminho entre Yvy Mbyte, que é o ponto central da terra para os Guarani e compreende a região da tríplice fronteira Brasil, Paraguai e Argentina, e Yvy Apy, que é a borda da terra, dada pelo limite do mar. Segundo o próprio [cacique] Timóteo, a região da Serra do Mar onde se localizam as aldeias do litoral (incluindo a TI Tenondé Porã) é também chamada de Yy rembere, ou borda do mar. Ele enfatiza que o primeiro a percorrer esse caminho foi Nhanderu Tenonde Papa, o criador do mundo e o principal ancestral divino dos Guarani. Como relata o mito, depois do desentendimento entre o Nhanderu Tenonde e sua esposa [Nhandexy], ele sai em direção ao leste deixando-a e indo se estabelecer na sua morada. Ele alega que se o seu filho Kuaray, que estava no ventre da mãe, quisesse segui-lo, ela deve levá-lo [...] Conta-se que no princípio do mundo, existia apenas a noite primordial (Pytũ Ymã) e Nhanderu Tenonde Papa, repousava sobre seu Jeguaka, o adorno de penas, do néctar do qual se alimentava o Maino'i primordial (beija-flor). $A$ única luz que existia era a do calor do próprio coração de Nhanderu Tenonde Papa. É apenas no momento em que Nhanderu Tenonde cria a primeira terra (Yvy Tenonde) que aparece a luz solar. Kuaray, seu filho, nas narrativas de origem Mbya, é criado para iluminar a primeira terra a partir do reflexo da iluminação do coração de Nhanderu Tenonde ou do reflexo de sua sabedoria divina. O Sol (Kuaray) é, portanto, a imagem da sabedoria de Nhanderu Tenonde, ou seja, um reflexo dele, donde a suposta confusão entre os dois personagens míticos. Toda a trajetória do mito dos irmãos Sol e Lua, vai de Yvy Mbyte (centro da terra) até o Yy rembere (a borda do mar). Esse foi o mesmo caminho seguido pelo primeiro ancestral divino, Nhanderu Tenonde, antes de se estabelecer em sua morada, que se situa além do mar. (RCID Tenonde Porã, 2010: 47-49, grifos e alterações minhas)

Essa trajetória também é recorrente em outros relatos Guarani, e pode ser entendida como um desafio posto por Nhanderu Tenonde para que seus filhos caçulas se coloquem em movimento para chegar à beira do mar e tentar alcançar a terra sem males:

Nós sabemos que eles, os xeramõi mais antigos, sempre falam que nós viemos do $\Upsilon_{\gamma y}$ Mbyte, que é o centro do mundo, é isso que eles explicam. Ele nos colocou justamente no centro do mundo para ficarmos afastados da beira do mar, como um desafio, para ficarmos longe e termos que caminhar para chegar à beira-mar. É isso que tentamos explicar para os jurua (não indígenas, brancos) e para os órgãos governamentais, quando nos reunimos com

\footnotetext{
70 O sufixo -ete pode ser entendido como o “corpo físico de pessoa” (Dooley, 2006: 40).

${ }^{71}$ Como já foi notado pela etnologia guarani, a versão mbya desse mito - que teria incidência pan-americana de acordo com Lévi-Strauss (1993 [1991]) - não aponta os irmãos Sol (Kuaray) e Lua (Jaxy) como gêmeos, mas Lua como uma criação do próprio Kuaray (ver Cadogan 1959).
} 
eles. E nós contamos aquilo que sabemos pelos nhaneramõi, que são os mais velhos, os que têm sabedoria. [...] Os jurua, na visão deles, nos misturaram muito com outros povos, mas, ao mesmo tempo, eles nos dividiram. Com a divisão do território eles nos dividiram, daí eles falam que viemos de outro país. Por isso, há hoje uma grande confusão, separaram todos nós, mas havia vários grandes xeramõi que realmente faziam caminhadas sagradas e vieram parar para o lado de cá. Nós já viemos com essa função de caminhar para tentarmos alcançar Terra sem Males, além da beira-mar. (Adriano Morinico - Karai Jekupe, Tekoa Yrya Yvate, SC, In: Guata Porã - Belo Caminhar, 2015: 19, grifos meus)

Seria, portanto, impensável, aos Guarani que eles tenham alguma vez abandonado o percurso de ligação entre o centro da terra (yzy mbyte) e a borda do mar (yzy apy), cujo percurso inicialmente é traçado pelos primeiros ancestrais míticos. O grande desafio de estabelecer-se junto ao litoral fica claro na fala do xeramoĩ João Silva: “Agora, nós estamos na beira de Nhanderu retã (a cidade de Nhanderu), pertinho da capital de nosso deus" (Xeramoĩ João Silva - Vera Mirim, Tekoa Xapukai/Brakui, RJ, In: Guata Porã - Belo Caminhar, 2015: 32). É importante ressaltar também que a espacialização da vida ritual guarani é pautada pela referência da localização do Sol nascente (Nhamandu, Kuaray), direção da morada de Nhanderu e Nhandexy Tenonde, ficando todos os amba ${ }^{72}$ das opy voltados para a direção leste, nhanderenondere (literalmente, “à nossa frente”). Em relação à "missão" de criação da terra pelos irmãos míticos, e como esta migração torna-se o modelo de migração mbya, Ciccarone comenta:

A terra destinada à humanidade aparece nas suas criações à medida que o herói civilizador, do corpo resplandescente, o Sol, Kwaray, junto ao irmão trapaceiro, a Lua, Jacy, caminha e nomeia os elementos. Coloca-se aqui a importância da aliança entre "irmãos" necessária para o sucesso do empreendimento civilizatório. Completada a missão, eles voltam à morada do Pai. Institui-se no mito o modelo da migração, da caminhada da sociedade, que unida pela solidariedade e as alianças familiares, institui o mundo mbya, nomeando-o, e segue para o seu destino eterno. $\mathrm{O}$-guata, a caminhada, é a representação do percurso de reatualização do mito da fundação do mundo guarani e de seus heróis fundadores. O caminhar é a figura do movimento que simboliza a trajetória da existência individual e coletiva. (Ciccarone, 2001: 50, grifos meus)

A imagem da ilha é também uma importante matriz cosmológica, pois é através dela que os Guarani percebem e pensam a configuração da plataforma terrestre, uma vez que em mais um episódio mítico, o da recriação de yryrupa após o dilúvio que destruiu a primeira terra (yvy tenonde), Nhanderu Tenonde:

desceu à terra num raio de luz e chegou em um lugar que era composto apenas por águas. Chegou na região de yoy mbyte e criou o mundo apenas com a ponta de sua varinha (yvyra'i). Inicialmente fez apenas uma pequena ilha, onde cabia apenas a planta de seus pés e depois foi aumentando e aumentando ela. (RCID Tenonde Porã, 2010: 50, grifos meus)

Sobre o surgimento de Nhanderu e da primeira terra, um xeramoĩ comenta:

\footnotetext{
${ }^{72}$ Espécie de “altar” que se localiza na direção do sol nascente, onde estão dispostos os mba'epu ete’’, os instrumentos musicais sagrados utilizados nos cantos-reza, curas e danças coletivas na opy'i.
} 
Tudo começou no meio das trevas, havia apenas escuridão e mar, sem sequer existir um único ser vivo. Veio um vento do norte e um vento do sul que, se encontrando, fizeram surgir um pequeno redemoinho e Nhanderu Tenonde, (nosso primeiro pai) se concretizou ali, em cima do mar, flutuando e segurando apenas o seu popygua (cajado). Nhanderu não teve pai nem mãe; nasceu por ele mesmo. Ainda sendo deus, ao existir ali, passou por dificuldades, pois não havia algo concreto onde pisar. Por isso, ele teve a necessidade de criar o mundo que hoje chamamos Yryrupa, o Planeta Terra. Tudo era escuro e, no meio do escuro, Nhanderu desce e paira por cima do mar. Ele pensa o que é que vai fazer, por que é que ele veio. E, então, ele sabe através do coração: "vou fazer a Terra”. Nasceu junto com ele aquilo que seria o gérmen da pindo marã e'y, a palmeira sagrada. Ele a plantou em cima do oceano. Suas raízes foram se expandindo e, no contato com a água, se transformando em terra. Por ser uma planta muito sagrada, é invisível a nós, simples seres humanos. Assim que plantou o pindo marãe'y, ele gerou o tatu ratã' $i$ (tatu). Foi esse tatu que o ajudou a espalhar a terra assim gerada. Até agora, aquele pindo ainda está lá em Yry Mbyte, o centro do mundo, o lugar que, hoje, os não indígenas chamam Paraguai. Só que ninguém vai ver, porque foi Nhanderu quem plantou. Essa planta dele, que ninguém tira, vai durar muito tempo e vai segurar a Terra. Mas se tirarem aquela plantinha que ele plantou, aí a Terra vai cair, porque é ela que segura. É assim que nós sabemos. A partir unicamente desse pedacinho de terra, é que fizeram tudo o que existe no mundo. (Xeramoĩ Timoteo Oliveira - Karai Tataendy, Tekoa Itanhaen, SC, In: Guata Porã - Belo caminhar, 2015: 9, grifos nossos)

Nesse relato do xeramoĩ é possível perceber que Nhanderu Tenonde também passou por dificuldades, assim como seus filhos caçulas ainda passam vivendo nessa terra imperfeita que ele mesmo criou para eles, e que sabia das coisas através do seu coração, py'a, que acrescido do intensificador guaxu pode ser traduzido como "coração forte" ou "coragem"73 para enfrentar as adversidades e seguir com fé (-jerovia) na caminhada. Através dessas águas cristalinas, as lideranças espirituais podiam saber para onde ir:

Quando Nhanderu se gerou, ele fez um tipo de bengala (vara, cajado, popygua'i) e, dessa bengala, ele fez a Terra; e é nessa primeira Terra que ele criou o lago. Ali é o centro da terra, Try Mbyte, como se fosse o cérebro da Terra, que, recentemente, os não indígenas descobriram como "Aquífero Guarani”. [...] A água que está debaixo da Terra serve como se fosse um espelho, mas isso somente para aqueles que são os líderes espirituais. Através disso, eles sabem onde podemos ir, onde existem outros parentes e assim por diante. (Timóteo da Silva - Verá Popygua, Tekoa Takuari, SP, In: Guata Porã - Belo caminhar, 2015: 9, grifos nossos)

Ladeira também explorou essa importância cosmológica das ilhas e aldeias do litoral como matriz de constituição e configuração atual de yoyrupa, que fica evidente em um dos depoimentos de um interlocutor, em que ele narra a origem do mundo e a imbricação entre os primeiros percursos de yəy mbyte à yvy apy, como pontos privilegiados de acesso à yoy marã’eñ:

\footnotetext{
${ }^{73}$ Interessante notar que a tradução guarani para “coragem” é a mesma para “coração forte”. Isso também pode ter relação com o centro das emoções, o fígado, que é uma outra tradução para py'a ou mby'a, além de coração. Então, ao tentar controlar de modo eficaz as emoções, pode se obter coragem e coração forte para suportar a vida sofrida (tekoaxy) nesta terra e passar pelas provações pelo caminho. O radical -py'a guaxu, de acordo com Dooley, pode ser traduzido como "ter coragem, ser corajoso: pendepy'a guaxu ke, xeretarã kuery fiquem com coragem, meus parentes”, enquanto -mbopy'a guaxu seria o ato de "encorajar alguém: huvixa nhombopy'a guaxua rupi ijayvu o chefe falou dando coragem aos outros" e -nhembopy'a guaxu, "ficar corajoso: onhembopy'a guaxu joe opu'ã aguã ficou corajoso para lutar” (Dooley, 2006: 160). Já mby'a guaxu seria a forma não-relacional de py'a guaxu e pode também ser traduzida como "coragem” (Idem). Para mais informações a respeito das relações entre corpo e emoções entre os Guarani, ver Chamorro (2009).
} 
Então, do começo do mundo (yvy apy), vieram andando, procurando seus lugares, seus verdadeiros lugares. Vieram do começo do mundo e andaram pela beirada do oceano (yy eẽ remberupi meme), para encontrar o fim do mundo (yzy apy). Eles andaram sobre as águas e ficaram no meio das águas (yy paũ rupi), nas ilhas (paracupe). Eles andaram para o bem. E se separaram, cada um com suas companheiras, cada um com suas famílias. Eles andaram e atravessaram as águas, parando sempre no meio do oceano. Então, deixaram as ilhas para nós, filhos caçulas (ay apyre), para vivermos nesses lugares. Quando eles vieram, eles passaram onde hoje se chama Argentina, Uruguai e Paraguai. Depois vieram para este mundo (Brasil). Então vieram para este meio do mundo (yzymbytere). Então começou a caminhada para a beira do oceano. E foram fundando vários lugares para depois "serem cidades” (tetã). Passaram em Kuriyty (Curitiba) e pararam algum tempo. Ali se separaram. Alguns desceram pelo mato, em direção ao mar, à procura de seu lugar. E encontraram Opavãpy ou Iparavãpy (Paranaguá). E, de novo, se separaram naquele lugar. E de lá foram para as ilhas (yva paũ = espaço no céu, ou yy paũ = espaço entre as águas), no meio do oceano. (Karai Rataendy apud Ladeira, 2007 [1992]: 143-144, grifos meus)

Pode-se entender então que o percurso realizado pelos Guarani entre yry mbyte e o yoy apy imita ${ }^{74}$ o percurso primeiro (tenonde) da criação e constituição de yəyrupa pelos heróis míticos, Nhanderu e Nhandexy Tenonde e seus filhos Kuaray e Jaxy, atualizando-o. O estabelecimento e manutenção das aldeias do litoral (yy rembere) e da conexão e circulação entre elas e as aldeias da região fronteiriça (yzy mbyte) seria, portanto, imprescindível, do seu próprio ponto de vista para a própria preservação da configuração original, ainda que transformada, de yzyrupa. Deve ser por isso que eles insistem tanto em protegê-las e guardá-las até hoje, lutando pela manutenção dos seus fogos (tataypy), suas aldeias, e principalmente, de suas opy e seus amba, que consideram ser um dos fatores de sustentação desse mundo. Em suas profecias, as lideranças espirituais frequentemente alertam que caso não existam mais opy ao longo desse território, Nhanderu Tenonde enviará o fogo que está destinado a destruir essa segunda terra. Segundo Davi Kopenawa, se não houver mais xamãs, aqueles que, na cosmologia Yanomami, sustentam esse mundo (humano e não-humano), graças as desventuras agressoras daqueles que ele chama de "povo da mercadoria" (os "brancos"), o céu vai cair, desabando sobre todos, dando fim a este mundo e à humanidade:

Quando todos nós tivermos desaparecido, quando todos nós, xamãs, tivermos morrido, acho que o céu vai cair. É o que dizem nossos grandes xamãs. A floresta será destruída e o tempo ficará escuro. Se não houver mais xamãs para segurar o céu, ele não ficará no lugar. Os brancos são apenas engenhosos, eles ignoram o xamanismo, não são eles que poderão segurar o céu $[\ldots .$.$] Não são só os Yanomami que morrerão, mas todos os brancos também. Nin-$ guém escapará à queda do céu. Se morrerem os xamãs que o mantêm no lugar, ele cairá mesmo. É o que dizem nossos anciãos. (Kopenawa apud Albert, 2000: 255, grifos meus)

A opuraheiva (rezadora-xamã) Estela Vera, do povo Ava-Guarani também comenta sobre isso e alerta:

\footnotetext{
${ }^{74}$ Sobre a imitação dos comportamentos divinos pelos Guarani, ver também Capítulo III.
} 
Se não tiver mais reza e rezador, o mundo vai acabar. Tudo vai acabar, os sinais de que o mundo está acabando já estão aparecendo. Hoje temos menos rezadores (opuraheiva), chuvas sem limite. Está tudo fora do tempo [...] Se hoje o mundo ainda não acabou é pela vida destes inocentes, pois, do mesmo jeito que o Kuarahy (Sol) ilumina a gente, ele pode sumir e acabar com tudo. Isso vai acontecer quando acabarem os opuraheiva. Kuarahy pode fazer uma troca e nos devolver o que fizemos contra terra, para então, renovar e começar tudo de novo. (Vera, 2016, grifos meus)

Sobre o fim dessa terra, uma outra kunhã karai, Mbya, chamada Doralice comenta:

Agora nhe'e kuery, os espíritos que moram com Nhanderu, estão falando para os pajés que a terra vai acabar outra vez. Antigamente já houve a escuridão. Não amanhecia mais, assim mesmo veio a água. Nessa terra onde nós estamos agora, mais tarde ou mais cedo isso também vai acontecer. Se isso não acontecer, a gente não vai aguentar mais o calor aumentando, e vai vir chuva, e vai vir yapó ha'puá tatareve'gua, barro com fogo do céu. Nhanderu acha que o mundo já está muito velho e quer limpar a terra. Depois vem a água e limpa tudo. Aí pode começar de novo. (Fernandes (Kunhã Tatá), 2011: 29)

Os Mbya do litoral comprovam, através de sua versão dos mitos sobre a construção do mundo e dos cataclismas que o abalaram, que a sua ocupação "à beira do oceano" ocorre desde a criação do primeiro mundo e que, nos dias atuais, "a crença de que um novo evento que destruirá o mundo está prestes a se suceder, tem-se acentuado":

A justificativa desta crença é a falta de condições atuais para que os Mbyá possam viver em conformidade com os ensinamentos tradicionais, o que os leva a se submeterem a inúmeras transgressões, tais como o consumo de alimentos e de outros produtos dos brancos. É justamente essa ameaça que faz com que o complexo Serra do Mar/Mata Atlântica se configure como estratégico pois, segundo a tradição, é sobre o mar, e atravessando-o, que aqueles que atingirem a "plenitude" alcançarão yvy marãey, a “Terra sem Mal” e, portanto, a salvação. (Ladeira, 1996: 776, grifos meus)

Ladeira ressalta que as ilhas do PR e do litoral de SP por apresentarem áreas de mata preservada possibilitaria aos Mbya a sua sobrevivência, pelo uso dos recursos naturais que ali se encontram e que também compõem o seu acervo cultural, levando a um "não distanciamento total" das suas "normas" de vida. Viver nessas ilhas, tem um significado de cunho extremamente espiritual que dificilmente é explicitado por eles, que "ao longo dos séculos, têm procurado manter em sigilo vários aspectos do seu comportamento e universo filosófico, incompatíveis com a visão de mundo da sociedade envolvente" (Ibidem: 777). Isso se torna manifesto na fala da xejaryi, Dona Ilza, entrevistada por sua filha e por membros do GT para o RCID da T.I. Tenonde Porã, uma das mais antigas moradoras do Tekoa Tenonde Porã, filha de Xapé, que é apontado por sua família extensa que ainda hoje ali vive, como o responsável pela fixação dos Guarani nessa aldeia:

Diz que eles não estavam andando por nada (oguata rę), era por que estavam se preparando para o aguyje (elevação espiritual), foi por isso que vieram andando para cá de longe. Então chegaram nesse lugar, eram muito religiosos, por isso vieram para atravessar o mar através da iluminação de Nhanderu [...] Como vamos falar disso com os jurua, pois não vão entender? (RCID Tenonde Porã, 2010: 65, grifos meus) 
Esse tema foi bastante explorado na literatura guaranióloga, que parte dessa articulação entre as movimentações territoriais e o xamanismo guarani, e ora os associa diretamente ao profetismo, com a busca da terra sem mal, ora à abordagem contemporânea da busca de teko, o modo de ser ou o próprio "sistema" guarani, que passa também pela centralidade da orientação xamânica, e foi amplamente discutido, entre muitos outros estudiosos $^{75}$, por Ladeira (2007 [1992]; 2008 [2001]) e mais recentemente por Pissolato (2007), que realiza um apanhado geral da bibliografia clássica e recente acerca da temática a partir de uma releitura proposta pelos estudos amazônicos contemporâneos. Ao comentar sobre a produção etnológica recente, na qual tekoa aparece com uma forte conotação espacial associada à noção de tradicionalidade, comumente relacionada à definição de teko, Pissolato ressalta:

[...] em geral o que parece orientar os autores é a noção de que há um "sistema” (uma outra tradução possível para teko) englobando uma ética religiosa, uma forma econômica, um código de solidariedade, enfim, uma orientação para o estar-no-mundo deixada pelos antepassados. Estando o teko dado, é como se os Guarani buscassem maneiras de lhe dar continuidade nos diferentes contextos que se apresentam. Particularmente, os grupos guaranis buscariam modos de atualizá-lo a despeito das inúmeras advertências históricas, dificuldades com que se deparam efetivamente para pôr em prática aquele "sistema", no que se ressalta muito frequentemente a importância da garantia de terras que lhe sejam compatíveis, entre outras coisas. Na experiência das populações guaranis contemporâneas, em que problemas como o da terra tornam-se prementes, envolvendo negociações constantes com instâncias diversas de representação "do jurua", o teko, ou, como se ouve muitas vezes, o nhandereko (literalmente "nosso [inclusivo] 'modo de ser") tende a oporse ao "sistema do jurua", e o tekoa torna-se um modo usual de referência à "aldeia”, isto é, determinada área de ocupação entendida como dotada de condições fundamentais à reprodução da vida. A afirmação de uma "cultura guarani” pelo enfoque da mobilidade mbya aparece como um marco na bibliografia das últimas décadas. $\mathrm{O}$ ethos religioso-migrante, nestes trabalhos, tende a receber um tratamento ampliado. Não é mais ou apenas o mito da terra sem mal que possibilita que se caminhe, como já foi observado, mas um ethos caminhante que estaria dado desde o início pelos criadores dos humanos (Guarani) na Terra, que os orientaria a caminhar e reproduzir um "verdadeiro" modo de vida. Este compreenderia a prática de cultivar e "espalhar" sementes, um modo apropriado de convivência e uma "espiritualidade guarani”. (Pissolato, 2007: 108-109, grifos meus)

O modo de ser guarani compreende além de uma orientação para as relações de troca entre famílias, as práticas de subsistência (cultivo, caça, coleta, artesanato), atividades rituais, e o relacionamento dos humanos com o ambiente, tem no movimento, no “mover, cuidar do território", seu elemento central (Ladeira, 2008 [2001]: 223, grifos meus). A mobilidade aparece então como uma estratégia central que fundamenta a ocupação territorial guarani, que cria e dá sentido à sua concepção de cosmos relacional. Ela é o motor central da socialidade xamânica, que opera de acordo com o próprio sistema (teko), sempre passível de transformação, e possibilita a prática do parentesco em aberto (Pissolato, 2007: 214), que diz respeito ao movimento das pessoas e de coletivos mbya pela

\footnotetext{
${ }^{75}$ Nimuendaju (1987 [1914]), Cadogan (1959), Clastres, P. (1990 [1974]), Clastres, H. 1978 [1975], etc.
} 
terra. Seria através da movimentação por yəyrupa que outra estratégia fundamental se faz também visível: a multilocalidade. Pissolato, por exemplo, chama atenção não só para o aspecto coletivo da mobilidade, amplamente discutido pela literatura, mas também para o lugar central da autonomia pessoal e da dimensão multilocal que caracterizaria o socius mbya, definindo um universo vasto de sociabilidade potencial (Ibidem: 176). Ela define multilocalidade por meio da compreensão do ponto de articulação entre as perspectivas local e supralocal, localizando nesse ínterim a consciência do parentesco guarani que compreende simultaneamente "um foco local, da consciência orientada pelos ideais de partilha, proteção e troca pacífica, e a perspectiva multilocal, pela qual o contex to atual é sempre interpretado como uma possibilidade, entre outras, de vivência do parentesco" (Ibidem: 212). Nesse universo multilocal de parentes espalhados, busca-se sempre atualizar as oportunidades de deslocamento para estender relações, o que configura também um dos aspectos da instabilidade dos grupos locais mbya (Ibidem: 172). Assim, se "o ideal de sociabilidade é a vida entre parentes, que só se conhece na produção diária das relações”, configurando o foco local, "os parentes são muitos e estão em muitos lugares, e sempre é possível buscá-los (dimensão multilocal)” (Ibidem: 193). A forma multilocal da socialidade xamânica mbya amplia significativamente as oportunidades de convivência que uma pessoa ou uma família pode experimentar ao longo de sua trajetória, uma vez que podem aí ser resgatados vínculos para a busca de novas condições de vida em outro lugar, e também acaba promovendo uma grande circulação de pessoas pelo cosmos. Casamentos e rompimentos constituiriam a engrenagem fundamental nessa ampla dispersão de parentes por diversas localidades do território terrestre. A respeito da diferença entre os movimentos migratórios e a mobilidade entre aldeias, alerta Ladeira:

muito embora os movimentos migratórios também possam estar relacionados a fatores de parentesco, não devem ser confundidos, entretanto, com a mobilidade entre aldeias, relacionadas à dinâmica social - casamentos, visitas de parentes, intercâmbios, etc. (Ladeira, 2000: 41, grifos meus)

Por conta das migrações e da mobilidade entre as aldeias, os Mbya vivem, tanto quanto possível, "em contínuo processo de reorganização social [...] sob o determinador da busca de localização num espaço que facilite o acesso à yəyju miri, ('a terra sem mal')", que dá "forma e estrutura à sua movimentação" (Ibidem: 15, grifos meus):

A migração é um processo de expansão territorial [...] A memória da migração é uma memória mítico-histórica de multilocalidade que remete à experiência do sujeito e é permeada pela dramaticidade da desordem identificada com a invasão das terras, exploração, perseguição e epidemias desencadeadas pelas frentes colonizadoras que tornam sempre mais precária e inviável a perpetuação do modo de vida buscado e representado nos cenários narrativos da vida na "ilha", símbolo da existência da sociedade isolada do mundo dos 
brancos. A migração configura-se como um processo de desterritorialização. Multilocalidade equivale não somente a pluralizar as experiências, mas também a construir a rede de comunicação permitida pela mobilidade (bens, palavras e cônjuges) entre os lugares percorridos, o que torna difícil isolar um único movimento migratório como se fosse um fenômeno separado de um fluxo de movimentações desencadeadas pela desordem e que apresentam entre si uma articulação interna estruturada pelos laços de parentesco. (Ciccarone, 2001: 241, grifos meus)

A escolha dos lugares (tekoa) onde possam viver conforme os seus próprios costumes (nhandereko), formando seus assentamentos familiares, parece constituir-se na motivação básica das "andanças” (oguata) mbya (Ladeira e Azanha, 1988: 23). O tekoa seria:

o lugar onde existem as condições de se exercer o "modo de ser" Guarani [...] o lugar que reúne condições físicas (geográficas e ecológicas) e estratégicas que permitem compor, a partir de uma família extensa com chefia espiritual e política própria, um espaço político-social fundamentado na religião e na agricultura de subsistência. (Ladeira, 2000: 15)

Seriam suas lideranças espirituais que determinariam a "escolha" desse "lugar" ouvindo "as belas palavras" e agindo por inspiração divina, como comenta a xejaryi Dona Aurora do Tekoa Boa Esperança (ES): "Bom, nós vamos ver, nós vamos ficar lá outra vez; se não dá, nós procuramos mais, depois que Deus falar pra mim, nós procura outro lugar...”76 (Carvalho apud Ladeira e Azanha, 1988: 23, grifos meus). A expressão tekoa porã estaria assim associada à noção guarani de "vida livre", ao "viver que pode ser exercido em conformidade com os mandamentos divinos, sem interferência e sem conflito com os juruâ", sendo, por isso então, que quando os Mbya definem a Serra do Mar como "terra boa”, querem dizer"que ali ainda é possível reproduzir as normas tradicionais em termos do uso da terra e da relação com os parentes" (Ibidem: 23-24). Não seria, portanto, "qualquer" lugar visado pelos Mbya:

tem que ter mato (quer dizer, deve ter caça elou pesca), que se possa plantar (nem que seja o mínimo) e que se possa manter uma distância (não necessariamente física) dos juruá. E, ainda que seja alto, que tenha água (rio) e pedras, são as "belas palavras", as palavras divinas ouvidas pelo ñanderu que vão conduzir a fixação em um determinado lugar. (Ibidem: 2425, grifos meus)

O percurso dos grupos mbya que chegaram mais recentemente à Serra do Mar, entre a década de 1930 e 1940, povoando os aldeamentos do litoral de SP e RJ, não é, nesse sentido, "aleatório", pois "vários pontos do litoral são tidos como território onde viveram seus antepassados, e a perambulação e a procura de fixação sempre ocorrem nesses mesmos locais” (Ladeira, 1984: 132). A “escolha” desses lugares não seria, por-

\footnotetext{
${ }^{76}$ É interessante notar que mesmo sabendo que mulheres também possam ouvir as belas palavras e guiar migrações, a literatura clássica continue falando majoritariamente dos líderes masculinos como aqueles capazes de escutar os conselhos divinos e guiar seu grupo até yəyju porã.
} 
tanto, "gratuita: ela segue a tradição, seja ela histórica e/ou cosmológica (Ladeira e Azanha, 1988: 25). O conjunto das "belas palavras" (nhe'ẽ porã ou ayvu porãa ${ }^{77}$ ), seria assim o que define "as normas do seu agir", expressas nos cantos-reza, repetidos de geração a geração:

Quando amadurecer os frutos de suas roças, darão de comer aos de tua tribo, sem exceção alguma. Para que se fartem todos é que os frutos chegam a amadurecer, e não para que sejam objetos de avareza. Dando de comer a teu próximo, virão os de cima que ama aos do assento de teus fogões (tekoa/tataypy-rupã) e eles adicionarão dias à tua vida para que repetidas vezes possas voltar a semear. Este preceito sagrado transmitido textualmente de geração a geração é cumprido religiosamente... (Cadogan, 1948: 139 apud Ladeira e Azanha, 1988: 23)

Além dos tekoa, os lugares em que assentam os seus fogos, tataypy rupa ${ }^{78}$, ao redor dos quais reúnem-se as famílias, é também uma das maneiras como os Guarani designam as suas próprias aldeias, como explicita Cadogan ao traduzir o termo como "asiento de fogones, población” (Cadogan, 1959: 105). Isso também fica claro no trecho abaixo:

Nosso pai primeiro diz: 'Meus filhos, vocês têm que passar por todas as provas. Onde, onde meus filhos tiverem assento junto aos seus fogos (tatáypyre), seus pensamentos devem estar voltados uns aos outros, em todos os lugares (Mbyarekoa). (Karai Rataendy apud Ladeira, 2007 [1992]: 85)

De um modo geral, os Mbya se organizam em "pequenos grupos familiares, $d e-$ signados pelo nome do local onde viviam, ou pelo de seu líder político" (Ladeira, 2000: 13, grifos meus). O contingente populacional variaria "de um modo geral, de 20 a 300 pessoas, compondo unidades familiares integradas pelas chefias espiritual e política que podem coincidir”, e a organização espacial interna seria determinada pelas relações de afinidade e consanguinidade:

Segundo os padrões tradicionais Guarani, a família extensa é composta, em princípio, pelo casal, filhas, genros e netos, constituindo-se numa unidade de produção e consumo. Atualmente, a família extensa, ainda que tenha algumas variantes na sua composição, é a unidade de produção. Porém, a "propriedade" das roças e o consumo dos produtos é da família elementar, depois do nascimento dos filhos do casal. Isto não exclui os serviços nas roças do sogro e a realização de mutirões entre as famílias. (Ibidem: 15, grifos meus)

\footnotetext{
${ }^{77}$ É importante salientar que as ayvu porã “não devem ser entendidas como um código fixo de regras de conduta, mas como formas usadas pelos Mbya para comunicar modos específicos de agir e viver que considerem 'porã (bons, tanto em termos éticos, como estéticos). Inclusive, as ayvu porã, compartilhadas em situações coletivas ou em sessões individuais de aconselhamento (-mongeta), expressam também os modos como aquele que as enuncia entende que as pessoas devem agir" (Testa, 2014: 183).

${ }^{78}$ De acordo com Timóteo, em seu livro "Yvyrupa. A terra Uma Só”, tataypy rupa seriam "as aldeias, onde se acende o fogo; lugares remanescentes em Yvyrupa; a ocupação Guarani” e “tekoa = tapyi: lugares onde acontece nosso próprio modo de vida” (Vera Popygua, 2017: 76).
} 
A "família-grande” seria então a "unidade social e econômica básica da sociedade Guarani”, dispondo de “autonomia política e, em geral, de território próprio”, e na "dependência do prestígio do líder religioso" em um mesmo "tekoa (aldeia - grupo local)" podem "estar vinculadas outras 'família-grande”, sendo "dominante (e a parentela a ela ligada) [...] aquela que 'primeiro chegou' ao local", e "a escolha do local" realizada "através do contato do ñanderu com os deuses", sendo "este último que vem a ser o líder político-religioso do tekoa" (Ladeira e Azanha, 1988: 25). Sobre a relação entre o movimento da migração e formação de um novo tekoa, os antropólogos observam:

Se um líder religioso (isto é, aquele que adquiriu prestígio suficiente no domínio e conhecimento das normas e conceitos sintetizados na expressão ñandereko) consegue reter junto a si seus genros e sobretudo seus filhos, pode então constituir uma "família grande" e procurar, conforme os desígnios dos deuses, o "lugar" (tekoa) onde poderão viver em conformidade com o ñandereko. (Ibidem: 25-26)

Os mitos de origem orientam, inclusive, a "separação" da sociedade Mbya em pequenos grupos familiares, com chefia própria, a fim de se "espalharem” pelo mundo, caminhando para o bem (oguata porã) junto a suas companheiras e famílias:

Quando Nhanderu Tenonde (nosso Pai primeiro) construiu esse mundo (depois do terremoto), ele disse: Esse mundo não durará muito tempo. Meus filhos que vão estar no mundo vão ter que se separar. O mundo é muito grande. Por isso, vão se separar em, mais ou menos, três famílias, e deverão caminhar (oguata) [...] Eles andaram para o bem. E se separaram, cada um com suas companheiras, cada um com suas famílias. (Karai Rataendy apud Ladeira, 2007 [1992]: 142-3, grifos meus)

Até mesmo os Nhanderu e Nhandexy kuery possuem cada qual o seu amba, sua "morada”, espaço onde vivem e guardam os espíritos-palavras de seus filhos caçulas, os nhe'ẽ que enviam à yryrupa) ou mesmo suas próprias cidades (tetã):

Marangatu pra nós é Kuaray. Nós chamamos de Nhamandu. Ele mora aqui no céu. $A$ capital é aqui no céu. Não é do outro lado do mar, não é do outro lado de Tupã. É do céu. Lá tem duas cidades. Nhamandu tem uma cidade, que ele divide com Jakaira. Jakaira é do outro lado da rua. (Xeramoĩ Timoteo Oliveira - Karai Tataendy, Tekoa Itanhaen, SC, In: Guata Porã - Belo Caminhar, 2015: 14, grifos meus)

Esse preceito de separação em pequenos grupos está profundamente conectado a todas as instâncias e estratégias de subsistência da sociedade guarani, uma vez que garante a manutenção das "relações de reciprocidade social e política; o 'controle', a conservação e a configuração de seu amplo território tradicional, o não-comprometimento dos recursos naturais das matas" (Ladeira, 1996: 777). No entanto, deria devido à essa “extraordinária mobilidade espacial dos Guarani”, que os tekoa apresentam uma "extrema instabilidade em sua composição” (Schaden, 1974 [1954]: 12). Os Mbya seriam aqueles que mais "abusam" dessas caminhadas, a composição das aldeias podendo variar de duas 
a trinta famílias elementares, estando a tradicionalidade dessa variação e o processo de cisão inscrito na estrutura mesma de sua organização social, que tanto motiva sua movimentação e seus deslocamentos pela plataforma terrestre, além das "acusações de feitiçaria, mortes súbitas, casamentos, conflitos com brancos invasores, etc" (Ladeira e Azanha, 1988: 26). A partir disso tudo, podemos afirmar que as estratégias guarani de movimentação por esse cosmos relacional envolvem uma intensa reflexão em torno do tema do caminhar (-guata). Se como notou inicialmente Ladeira (2007 [1992]: 143), todos os seres têm seus lugares (tekoa) próprios para estabelecerem seu próprio modo de ser (teko), podemos dizer também que todos os seres têm seus próprios caminhos. Nesse sentido, cada parentela teria seu próprio lugar e caminhos específicos através dos quais buscam realizar e fortalecer a própria existência, seu próprio teko. Seria por isso também, conforme observou Pissolato (2007), que cada indivíduo reflete sobre sua própria existência a partir dos caminhos percorridos ao longo da própria trajetória de vida. Os próprios Guarani diferenciam o bom-belo caminhar ou caminhar para o bem ${ }^{79}$ (oguata porã) do caminhar sem rumo, à toa, sem motivo (oguata rive), quando se referem a alguém que anda entre as aldeias sem estabelecer relações, geralmente antes da estabilização de um casamento ou decorrente de sua crise ou finalização, ou por conta de alguma experiência traumática. Diferenciam disso a mudança para um lugar para contrair casamento ou para acompanhar uma liderança política e-ou espiritual, isto é, deslocamentos que teriam alguma relevância importante na (inconstante) experiência de vida da pessoa. Caminha-se para encontrar e visitar parentes e para criar novos e estabelecer alianças. A caminhada é como uma fórmula, central na manutenção e criação de novos vínculos, tanto no espaço, quanto entre parentes, configurando assim sua ampla rede de coletivos, daí sua importância:

O guata, a caminhada, é a representação do percurso de reatualização do mito original da fundação do mundo mbya e de seus heróis fundadores: a existência do mundo terreno se faz e é feita pelo movimento, nomeando o espaço, recompondo o território, redescobrindo e reconquistando o mundo. A migração é a celebração e a lamentação dos Mbya sobre o mundo natural e humano. Um rito de identificação de um povo que não para, um povo que caminha no espaço vivenciado como um campo de constante travessia, movimento e reciprocidade, uma comunicação de palavras, bens, mulheres e homens que circulam ininterruptamente. (Ciccarone, 2001: 13-14)

Nas palavras belas de uma xejaryi, quem segue a palavra divina, caminha bem:

Yry Mbytere, no centro do mundo, os Mbya cantam para Nhanderu. Quem acredita mesmo em Nhanderu ouve a voz dele e, se ele disser: "é esse o caminho que vocês vão seguir", eles precisam seguir o caminho. Assim, eles continuam a caminhada, assim os nossos avós vieram pra cá. Quem ouve a voz de Nhanderu e segue o que ele diz, isso que é guata porã, o belo caminhar. Nhanderu guiava eles para eles fazerem a caminhada e mostrava o caminho, e por onde deviam seguir.

${ }^{79}$ Caminhar para o bem é a tradução para oguata porã, sugerida por Karai Rataendy, interlocutor principal de Ladeira no livro Caminhar sob a luz (2007 [1992]), fruto de sua pesquisa de Mestrado. 
Assim, eles vieram de Santa Maria e de outros lugares e seguiram juntos. Eles caminhavam a pé. Tinha muita gente a quem Nhanderu ia mostrando o caminho para chegar no litoral [...] Eles ficaram em São Paulo, formaram uma aldeia, ficaram um mês, dois meses. Assim eles caminhavam, faziam aldeias pelo caminho, porque Nhanderu não os queria no mesmo lugar. (Xejaryi Tereza Djatxuka, Tekoa Mboapy Pindo, ES, In: Guata Porã - Belo Caminhar, 2015: 47, grifos meus)

A mobilidade guarani é, portanto, um tema central pelo lugar que ocupa na trajetória de vida de cada pessoa ou grupo. O não se deter que, marca de modo forte a trajetória das pessoas mbya, englobaria tanto a dimensão do parentesco quanto aquilo que traduzem por termos como "alegria”, "saúde”, devendo ser sempre, segundo Pissolato (2007), considerado do ponto de vista de cada indivíduo em seu próprio entendimento do seu modo de ser (teko) e em suas experiências singulares. A prática da mobilidade está aqui fundada numa percepção da existência humana como experiência de busca incessante por melhores condições de vida, traduzindo antes um modo de pensar, sentir, querer e fazer que os efeitos propriamente práticos que produz, de deslocamentos de indivíduos ou de famílias por diferentes locais ao longo da plataforma terrestre. Assim sendo, a mobilidade, enquanto prática e pensamento, corresponderia a um aspecto fundamental na percepção da vida mbya: sua multiplicidade de caminhos ou possibilidades constantes de alteração e transformação das condições ideais de vida (dentro das possibilidades ainda possíveis ainda, limitadas pelo avanço e aproximação constante do modo de ser e de se comportar jurua - jurua reko), reflexo do ethos buscador guarani, que se orienta pela ética do caminhar (-guata) ou “não se deter”, em busca de um “verdadeiro” modo de vida, de modos de fortalecimento da existência nesta terra imperfeita e corrupta, em que "verdadeiramente bom” não há, de modo a tornar a vida mais durável. Diante do que foi exposto até agora, cabe então ressaltar que a mobilidade, que se reflete no modelo da caminhada, faz parte da própria resistência guarani, é o elemento fundante de sua própria existência pois faz aparecer a relação de trocas, materiais e imateriais que os Guarani mantêm entre si, com as aldeias presentes em seu território e com outros seres do cosmos, e os faz seguir (re)existindo, protegendo, guardando e recriando esse mundo terreno, sempre sob inspiração dos pais e mães dos nhe'ê, seguindo a imagem-guia de seus ancentrais divinos apesar de todas as dificuldades pelo caminho.

\section{Diferentes estratégias guarani de resistência pelos caminhos e caminhadas}

O Serviço de Proteção aos Índios (SPI), criado em 1910, era o órgão federal responsável pela política indigenista do Estado até 1967, quando foi extinto em razão de denúncias de corrupção. A Funai é então criada para substituir o SPI, mantendo "boa 
parte de sua estrutura e funcionários, bem como a missão institucional de tutelar os índios - desprovidos de plena capacidade civil - e promover sua integração à 'comunhão nacional', o que foi devidamente formulado no Estatuto do Índio, criado em 1973" (Macedo, 2010: 33). Os representantes do órgão indigenista, em sua posição de "tutores", "acenavam para a inferioridade e a provisoriedade da condição indígena, tentando adequar os Guarani aos padrões de trabalho, moradia e outros costumes que poderiam integrá-los à 'comunhão nacional”' (Idem). Em referência à atuação do SPI e da Funai no contexto do litoral paulista, Macedo aponta que:

a orientação do SPI e posteriormente da Funai consistia em procurar concentrar a população nos postos indígenas (evitando suas “perambulações” pelas cidades), controlar sua configuração política (evitando desentendimentos, que entre os Guarani costumam incorrer em deslocamentos) e manejar conflitos fundiários, bem como promover modelos de trabalho e produtividade. (Idem: 33)

Schaden também menciona as queixas recorrentes dos servidores do SPI, motivadas pelos constantes "fracassos" diante das iniciativas do órgão em: "impor aos silvícolas, no interesse destes, umas tantas 'matrizes econômicas', sem que eles estejam em condições de integrá-las satisfatoriamente em seu sistema de padrões de comportamento" (Schaden, 1974 [1954]: 56). Nesse sentido, em seu grande empenho de "diminuir a perambulação" e impor modelos de trabalho da sociedade envolvente aos "incultos" indígenas, o SPI e posteriormente a própria Funai, "acabavam sendo também motor de deslocamentos, inclusive de migrações do Sul para o Sudeste” (Macedo, 2010: 34), como já viemos mostrando. O xeramoĩ Nivaldo, neto da kunhã karai Dona Vitalina, viveu até os vinte anos na aldeia Palmeirinha (PR), e conta como as imposições violentas do chefe de posto do SPI motivou a fuga de seu grupo familiar e de outros parentes guarani, que viajaram a pé, durante três meses, até chegar ao litoral de SP:

Às vezes trabalhávamos vinte dias. Até que o chefe mudou e o trabalho ficou o mesmo: faz isso, faz isso, faz isso. Obrigado fazer. Então, se não fazia por preguiça já vinha a polícia em cima da gente. Então tinha que ficar amarrado e depois levavam e ficava na cadeia dois, três dias. Depois tinha que tocar o serviço [...] Fugimos por causa do chefe. Uma turma. Cinco, seis famílias, todos parentes. (Nivaldo apud Ladeira, 1984: 136)

De acordo com o RCID da T.I. Tenonde Porã, o Serviço de Proteção aos Índios e Localização dos Trabalhadores Nacionais (SPILTN, que a partir de 1918 torna-se apenas SPI) foi criado, através do Decreto nº 8.072 de 1910:

com o fito de prestar assistência à população indígena do país, ressalvando se que para isso devia-se "fazer respeitar a organização interna das diversas tribos, sua independência, seus hábitos e instituições, não intervindo para alterá-los, senão com brandura e consultando sempre a vontade dos respectivos chefes" (Art $2^{\circ}$. grifos nossos), [no entanto, na prática] a atuação do Serviço no Estado de São Paulo foi sempre marcada pelo intuito de subordiná-los, concentrá-los em terras de extensão arbitrárias, liberando suas terras tradicionais 
para a colonização e buscando a assimilação dos índios à população nacional. (RCID T.I. Tenonde Porã, 2010: 93, grifos e alterações minhas)

Um exemplo dessa política se dá com a implementação do Posto Indígena de Araribá, que ao "desativar todos os antigos aldeamentos do Estado", busca concentrar ali “todos os Guarani dispersos por outros aldeamentos e demais localidades autônomas, liberando as terras para colonização”, apesar da grande relutância Guarani em aceitar se submeter a isso, ainda mais quando o órgão indigenista tinha como objetivo concentrálos em um único e mesmo espaço, que seria compartilhado com outros povos indígenas (Ibidem: 94). Esse mesmo relatório também cita um trecho do relatório de Horta Barbosa, responsável pela $5^{\text {a }}$ Inspetoria do SPI, em que fica evidente esse tipo política promovida e aplicada pelo órgão, que buscava insistentemente "integrar” os Guarani à população nacional, transformando-os em trabalhadores rurais:

no Decreto da reserva não há a declaração de que as terras eram só e exclusivamente para moradia de índios; nem o Serviço tomou nenhum compromisso com o Estado de seguir esta ou aquella directriz no desempenho da sua missão junto aos índios, missão que é complexa, pois que partindo inicialmente da protecção pura e simples, e sempre dominada pelo sentimento e pela intenção de pratica-la, encaminha-se ciente e intencionalmente para o entrelaçamento do dois ramos da população brasileira [trabalhadores nacionais e índios], aspirando alcançar a fusão de ambas num tipo único. (Horta Barbosa, 1928a, ft 955-956 apud RCID T.I Tenonde Porã, 2010: 94)

Em outro trecho, Horta Barbosa comenta como os Guarani nunca aceitaram as tentativas do SPI de concentrá-los em Araribá:

Mas baldados foram os esforços da Inspectoria no sentido de concentrar na Povoação Indígena do Araribá, os guaranys, tanto do interior como do litoral. Estes últimos resistiram a todos os meios de que se utilizou a Repartição para indusil-os a installarem as suas residências naquelle estabelecimento, e acabaram obtendo do Snr. General Rondon a promessa da Inspectoria dar-lhes assistencia no próprio lugar donde elles não queriam sahir, e onde afinal, a tiveram effectivamente, pela creação do Posto do Bananal. (Horta Barbosa, 1928a, Ft 950-951, apud RCID T.I Tenonde Porã, 2010: 95, grifos meus)

Podemos entrever através da escassa documentação disponível acerca das práticas do SPI, uma cronologia de sua atuação no Estado de SP que, segundo o RCID da T.I. Tenonde Porã, "resume-se pelo fracasso progressivo de sua missão diante da resistência dos índios contra o principal eixo dessa política que era o projeto de concentração":

Inicialmente, o Serviço admitia apenas Araribá como espaço de ocupação para os Guarani, buscando atrair todos os outros grupos para lá (como também é relatado nas obras de Nimuendaju), liberando o litoral para a colonização. O fracasso dessa primeira estratégia relatado acima, quando Rondon promete aos índios a criação do Posto de Peruíbe, reconhecendo o direito de permanência no litoral, foi apenas o primeiro de uma série. (RCID T.I Tenonde Porã, 2010: 95)

O SPI, traçando uma segunda estratégia de concentração passa então a atuar com os Guarani em duas frentes: "inicialmente tentava-se convencer os Guarani dispersos 
ainda em vários pontos do Estado a deslocarem-se ao Araribá" e para os que "teimavam" em permanecer em localidades no complexo de aldeias e ocupações do litoral, "tentavam convencê-los a concentrarem-se todos em torno do recém-criado Posto do Bananal":

Estes [Guaranis do litoral] deviam estar concentrados na aldeia do Bananal, cujas terras a Inspectoria de São Paulo conseguiu do Governo do Estado, que fossem declaradas reservadas para tal fim. De facto, elles lá possuem plantações de bananeiras e a Inspetoria alcançou que plantassem algum café e fizessem roças de arroz, milho, etc. No entanto, nem se conseguiu de todas as famílias do litoral que prometessem ir morar em terras da aldeia, nem também se conseguiu estabilizar nellas as que lá se consideram moradoras. (Horta Barbosa, 1928a, ft 971, apud RCID T.I Tenonde Porã, 2010: 96)

É apenas a partir da década de 1950, quando se cria o Posto Indígena do Rio Branco em Itanhaém e se institui o Posto Indígena de Itariri (batizado de Carvalho Pinto) que o órgão indigenista oficial finalmente reconhece:

esse último aldeamento constituído oficialmente desde 1837, mas tendo permanecido esquecido pelo SPI desde a criação do órgão, a despeito do fato de que os índios guarani nunca abandonaram o local, indo contra todas as tentativas, documentadas, de expropriação das suas terras. Em 1949, o delegado do SPI em São Paulo recomenda a criação do Posto de Itanhaém, para atender a população do Rio Branco e a população dispersa na região da TI Tenondé Porã [...] Ao citar o trajeto utilizado pelos índios para a chegar à capital, onde vendiam artesanato, e supostamente mendigavam, o funcionário supunha que a criação do Posto do Rio Branco resultaria na concentração dos grupos dispersos e interromperia as expedições para a capital [...] Mais uma vez, os intentos do SPI foram por terra. Nem se conseguiu que os Guarani se concentrassem nos postos então existentes (Bananal e Rio Branco), nem tampouco que abandonassem seus assentamentos e seus percursos tradicionais na Serra de Paranapiacaba (TI Tenondé Porã), por onde mantinham a ligação com as aldeias da TI Tenondé Porã e rumavam quando necessário para a capital, sobretudo para a venda de artesanato. (RCID T.I Tenonde Porã, 2010: 96-97, grifos meus)

Essa "convicção ingênua dos funcionários do SPI de que o estabelecimento de um simples posto [...] garantiria a sedentarização dos Guarani e o abandono de seus percursos tradicionais" foi reproduzida até o período de atuação da Funai (Ibidem: 97-98). No início da década de 1980, uma socióloga servidora da Funai, designada pelo então Presidente do órgão, emite a Portaria nº 1486 (4 de março de 1983) para a realização de estudos visando a identificação e delimitação das terras ocupadas pelos guarani no litoral paulista ("Rio Branco, Serra do Itatins, Peruíbe, Represa Billings, Rio Silveira, Boa Vista do Sertão do Prumari e Bracuí”), que segue até então as diretrizes “integracionistas” do já extinto SPI, sugerindo que a demarcação dessas aldeias resultaria no "abandono das aldeias da beira do planalto, região abrangida pela TI Tenondé Porã, querendo crer que o critério de escolha dos Guarani para a eleição dos seus assentamentos era um mero capricho" (Ibidem: 8; 98). Uma vez que as aldeias do litoral eram tratadas até meados da década de 1980 como "não assistidas pela FUNAI", o estudo realizado pela socióloga vem esclarecer no período anterior à vigência do convênio Sudelpa-Funai (conquista da 
ampla mobilização das lideranças guarani do Estado de SP), que do ponto de vista "antropológico” (como ela mesma afirma), as áreas Guarani localizadas na capital paulista eram importantes "pontos de parada" para aqueles que transitavam para visitar seus parentes, entre o interior (RS e PR, sobretudo) e o litoral (Rio Branco, Rio Silveira etc.), sugerindo, no entanto, que sejam regularizadas apenas as áreas do litoral, mediante a promoção de "políticas de atração" para que os então residentes nas áreas da T.I.s Barragem e Krukutu desocupassem suas terras e se estabelecessem naquelas:

Diante dessa situação sugerimos: $1^{\circ}$ - que a FUNAI regularize a situação fundiária das
áreas Guarani do litoral; $\mathcal{2}^{\circ}-$ que sejam criados núcleos de assistência […] que forneçam
aos Guarani um tipo de assistência/orientação, que promova socialmente o grupo, e
atraia os índios acima referidos [Barragem, Krukutu, Mboi Mirim e Jaraguá]; $3^{\circ}-$ seja
realizado um trabalho de base junto aos índios de S.P. conscientizando-os das vantagens da
transferência para o litoral; $4^{\circ}-$ a área da Barragem, tendo em vista o direito adquirido
após tantos anos de posse, poderia ser mantida para o grupo, não como moradia mas
como ponto de passagem, uma espécie de pousada temporária para os índios Guarani em
trânsito. (Fonseca, 1983, parte VII. Conclusão apud RCID T.I Tenonde Porã, 2010: 8-9)

Antônio Branco, célebre cacique do Itariri, relata em depoimento registrado durante os estudos da Sudelpa, como os Guarani permaneceram em suas aldeias apesar das inúmeras tentativas de convencimento do SPI (inicialmente na figura de Nimuendaju) de concentrá-los em Araribá, de onde eles recebiam notícias do massacre pelo qual estavam passando seus parentes e das epidemias que assolavam a região:

Eu nasci em 1909. Meu pai morava aqui. O Curt Nimuendaju, esse eu conheci. Esse foi o primeiro homem que aqui no Itaporanga, em uma área de terra dos índios, também tinha lá, meu povo tinha lá também que aqui, a gente tava sabendo, quando começou a Sociedade de Proteção aos Índios, ele recolheu o povo pra Araribá e coitado dos índios, morreu tudo. Foi o tal do Curt. Cheguei a conhecer ele. Ele queria levar um pessoal daqui também, então... Então, a gente sabia da notícia, como é que tava o Araribá e o meu velho falou: digo não, eu não vou pra lá. Se eu for pra lá, que nem o meu povo que saiu lá de Itaporanga, vão morrer tudo, como de fato que havia muita doença lá. Então meu pai quis ficar aqui. (Antônio Branco apud Ladeira e Azanha, 1988: 50, grifos meus)

Nada justificava legalmente esse tipo de política de atração promovida pelo SPI:

nem para a legislação do período e muito menos para a atual, que o SPI se reservasse o direito de escolher arbitrariamente o Araribá como única povoação do Estado, com o intuito expresso de "alterá-los", "fundindo-os" aos trabalhadores nacionais, sem nem ao menos garantir usufruto exclusivo dos índios nessa povoação, uma vez que lá habitavam também trabalhadores nacionais [...] Nada justifica posteriormente também que o governo tenha até a década de 1950 reconhecido com muito custo apenas o Bananal como terra legítima dos Guarani no litoral. Se todos os aldeamentos ocupados deveriam ser convertidos em povoações, isso valia para Itariri, São João Batista do Rio Verde, Piraju, Faxina, Bananal, entre outros. (RCID T.I. Tenonde Porã, 2010: 101-102)

No RCID da T.I. Tenonde Porã é levantada a grave omissão do SPI no que diz respeito ao não cumprimento da determinação geral de seu decreto de criação, em relação 
às terras ocupadas pelos índios, como demonstra o Capítulo II, em que fica claro as providências que deveriam ter sido tomadas pelo órgão para as aldeias e assentamentos guarani do litoral, uma vez que havia a clara disposição dos Guarani em sua manutenção, e se reflete em sua insistência em nelas permanecerem até hoje, a despeito de todo esbulho praticado pelas frentes de colonização da região:

CAPÍTUlO II - Das Terras Ocupadas Por Índios. Art. $3^{\circ}$ : O Governo Federal, por intermédio do Ministério da Agricultura, Industria e Comércio, e sempre que for necessário, entrará em acordo com os governos dos Estados ou dos municípios; a) para que se legalizem convenientemente as posses das terras atualmente ocupadas pelos índios. (Decreto $\mathrm{n}^{\circ}$ 8072/1910 apud RCID T.I. Tenonde Porã, 2010: 102, grifos meus)

O SPI, no entanto, se viu obrigado pela persistência Guarani em permanecer no litoral, a reconhecer os assentamentos do Bananal, Rio Branco e do Itariri, admitindo "o fracasso de sua empresa de concentração dos índios e liberação das terras”, que nessa sua "omissão" deu espaço "para o avanço dos fazendeiros até mesmo sobre as poucas terras" que "arbitrariamente decidia como legítimas para os índios" (RCID T.I. Tenonde Porã, 2010: 104). E, mesmo durante o período de atuação da Funai, a política de atração empreendida pelo SPI, de inspiração claramente integracionista, visava que as demarcações das T.I.s Guarani do litoral, "resultassem no deslocamento dos índios das aldeias da capital então ocupadas (Barragem, Krukutu, Mboi Mirim e Jaraguá) para esses pontos no litoral, que no momento a Funai aceitava reconhecer", proposta que também fracassou (Ibidem: 105). É possível entrever então que, desde os tempos do SPI os processos de regularização fundiária das T.I.s Guarani não partiam do reconhecimento da própria extensão de sua ocupação para qualificar a sua delimitação, mas tão só e "unicamente de critérios políticos advindos do processo de colonização” (Ibidem: 10). Em Aldeias livres no Estado de São Paulo, Ladeira destaca a existência autônoma e independente da assistência da Funai de seis aldeias e dois núcleos familiares guarani no litoral de SP nos anos 1980 (Ladeira, 1984: 123). Como podemos notar, ao longo de todos esses exemplos mencionados da atuação dos órgãos federais indigenistas, a única coisa que se mantém constante diante de todos os insucessos em concentrar os Guarani arbitrariamente em um único espaço, foi a sua resistência em não aceitar se submeter a essa dinâmica integracionista estatal, criando uma série de estratégias para manter suas dinâmicas próprias de mobilidade e seus espaços de convivência. Até o fim da década de 1960 então, de acordo com Ladeira e Azanha, os Guarani não encontravam grandes dificuldades em estabelecer suas aldeias junto à Serra do Mar:

Chegando em pequenas levas, os “discretos” e "pacíficos” Guarani-Mbyá aparentemente não constituíam ameaça à especulação imobiliária e à grilagem de terras junto ao litoral. 
Ao invés de se indisporem com os índios, os especuladores passariam, nas décadas de 40 e 50, a propor-lhes aliança e proteção em troca de serem reconhecidos como senhores das terras ocupadas por eles. Durante muitos anos esse acordo perdurou: aos Guarani o título de propriedade nada significava, uma vez que, a seu modo, usufruíam com exclusividade as matas da Serra do Mar - até então ricas em fauna e flora. Para os pretensos proprietários, cujo interesse maior era a obtenção de títulos de domínio para posterior especulação, a situação parecia mais vantajosa ainda, pois os índios exerceriam, para esses "proprietários", a posse dessas terras. (Ladeira e Azanha, 1988: 7)

A necessidade de regularização das ocupações guarani no litoral de SP e RJ "se dá em razão da rápida transformação desse litoral a partir da década de 70, com a construção de estradas e rodovias (principalmente a Rio-Santos), da crescente e desordenada ocupação e especulação imobiliária, da intensificação do turismo e da consequente invasão dos espaços Guarani” (Ladeira, 2000: 66). Esses fatores, especialmente a especulação imobiliária, "responsável pelo verdadeiro loteamento do próprio Parque Estadual da Serra do Mar” acabaram com a relativa "paz” dos Guarani, pois com a "valorização crescente provocada pelos especuladores, começa a crescer também o número de disputas judiciais sobre terras do litoral norte, inseridas ou não na Serra do Mar”, passando então os próprios Guarani a serem "envolvidos, a princípio como meros figurantes em litígios judiciais patrocinados por terceiros sobre as áreas que ocupavam e sobre as quais têm direito, possessório e constitucional” (Ladeira e Azanha, 1988: 7-8). Nos anos 1970, praticamente todas as áreas Guarani passaram "a ser alvo de cobiça e de sucessivas invasões" 80 (Ibidem: 8). A forte especulação imobiliária os forçam a defender as poucas terras que ainda lhes restavam, "em vista da total indisponibilidade de outras terras junto à Serra do Mar", rompendo assim a sua histórica estratégia de "fugir do confronto", que era "pregada pelos seus líderes religiosos", e que "só pôde ser ultrapassada por se tratar de um confronto na justiça, isto é, pacifico" (Idem: 8, grifos meus). É nesse novo quadro, que passa por uma série de ações e processos de reintegração de posse e usucapião contra as áreas que ocupam na Serra do Mar que os Guarani se veem inseridos, e contra os quais, junto a parceiros jurua constroem novas estratégias de ação e resistência política, para proteger e garantir a manutenção de seus espaços de (con)vivência. Nessas inúmeras disputas judiciais, os Guarani contaram com o apoio de organizações indigenistas nãogovernamentais (ONGs) e sua assessoria jurídica, conseguindo garantir o reconhecimento de algumas das áreas que ocupavam dentro desse complexo de aldeias do litoral

\footnotetext{
${ }^{80}$ Nivaldo conta à Ladeira as dificuldades enfrentadas por seu grupo familiar, liderado por sua avó, a kunhã karai "Dona Vitalina”, no início dos anos 1960: "Conta do tempo em que se instalaram na Barragem e do documento (um comprovante de pagamento de imposto emitido pelo Incra) no qual um particular doava, por escrito, a terra aos índios e de como, através deste documento, se protegiam de outros pretensos proprietários do terreno" (Ladeira, 2000: 44, ver também Depoimento do Nivaldo apud Ladeira 1984).
} 
na década de 1980, quando se dá início aos procedimentos formais para regularização fundiária das T.I.s.

No entanto, em razão do modo dinâmico de organização da sociedade Guarani, determinado pela ampla dispersão geográfica de suas aldeias, por sua história secular de contato e por seu comportamento ético-xamânico em relação a terra que ocupam e buscam, foram de um modo geral, considerados "nômades e aculturados", o que comprometeu durante algum tempo o acesso a seus direitos constitucionais enquanto indígenas (Ladeira, 2000: 65-66). Mesmo que, em um primeiro momento, eles não pedissem a "demarcação" de suas terras, seu desejo era o de viver em paz em seus espaços de convivência junto às matas, sem nenhuma forma de controle por parte do Estado brasileiro (Ibidem: 66). Para os Guarani, “a demarcação significa a deformação de seu território e o seu próprio confinamento, porém estão conscientes de que, no mundo atual, esta é a única alternativa” (Ibidem: 68). Nos anos 1980, portanto, o CTI passa a atuar junto aos Guarani da Serra do Mar, "oferecendo suporte institucional e recursos para questões fundiárias e demandas cotidianas", ainda que sua "missão institucional era justamente inverter os vetores que orientavam a atuação do órgão [indigenista] oficial”:

Em vez de “integração à comunhão nacional”, o CTI se propunha proteger e fortalecer dinâmicas culturais daquelas populações. E assim vinha chegando à Serra do Mar um novo idioma relacional entre índios e brancos, em que a cultura passa a atuar como principal moeda de troca nas relações com o Estado e a sociedade civil organizada. Para tanto, era preciso estabelecer um outro modelo de indigenismo, contrastando com a atuação da Funai. E o gesto fundador desse contraste foi uma proposta feita pelo CTI às lideranças Guarani para que lutassem pela posse das terras na Justiça representados por seus advogados, em vez de serem representados pela Funai, a despeito de sua condição de tutelados ao órgão. (Macedo, 2010: 47, alterações minhas)

A atuação do CTI é central para a garantia das terras Guarani em SP e RJ nesse contexto e se dá, a partir de dois planos de ação, que parte primeiramente da ideia de:

dar condições de fato para fixação e estabilização dessas aldeias, principalmente através de apoio às roças e reforçando a comunicação entre elas, propiciando o deslocamento dos Guarani entre as aldeias; e, simultaneamente, participando do processo de reconhecimento legal dessas terras através de ações na justiça. (Ladeira e Azanha, 1988: 8)

O segundo aspecto desse plano resultou do entendimento que, apesar de até aquele momento ser de compreensão geral das entidades de apoio aos povos indígenas que somente a Funai poderia representar os interesses destes na Justiça, o CTI, sendo de fora do Governo, poderia questionar o “'monopólio’ pretendido pela Funai nas questões que envolviam direitos dos índios e de suas comunidades”, pedindo apoio ao Prof. Dalmo Dallari acerca das "alternativas jurídicas" a que poderiam recorrer para que "os próprios índios pudessem figurar como autores em ações possessórias” (Idem: 8). Foi 
assim, que discutiram também com outros advogados "as medidas jurídicas necessárias para salvaguardar os direitos territoriais dos Guarani, sem que tais medidas tivessem que ser tomadas por iniciativas da Funai”, posto que as aldeias guarani do litoral, com exceção do Posto de Peruíbe, não eram reconhecidas pelo órgão federal até o início dos anos 1980, que se referia aos Guarani “como sendo do Paraná”, desconsiderando o seu movimento histórico para o litoral e sempre buscando novos meios para "atraí-los para os postos do sul do país ou para o posto de Peruíbe, onde, segundo ela [Funai], concentrava-se a população indígena do litoral” (Ibidem: 9, alterações minhas). Assim, o plano de ação do CTI era "entrar com ações possessórias na justiça comum tentando obter o título dominial das áreas ocupadas pelos Guarani”, já que a atuação da Funai ignorava e pouco fazia em relação à ocupação guarani na Serra do Mar. Apesar da assessoria prestada pelos juristas consultados, os membros do CTI consideraram a necessidade de "um advogado com disponibilidade integral para prestar uma assistência direta às comunidades (propor e acompanhar ações)", contratando, no final de 1981, os advogados:

Carla Antunha e Marco A. Barbosa para que, com exclusividade, se dedicassem às questões pertinentes aos projetos do CTI, desenvolvendo nossa proposta de ação. Em 1982, no mês de setembro, seguindo a orientação do professor Dallari, a Comunidade Guarani, representada por três líderes, outorgou procuração pública aos advogados do CTI, ao professor Dallari e Antônio Carlos Sedeh para defenderem seus direitos em juízo. (Idem)

Segundo Ladeira e Azanha, os juízes acataram todas as ações propostas pela Comunidade Guarani na década de 1980, e em "todos esses processos, a Funai foi intimada a figurar nos autos como assistente legal da comunidade indígena” (Ibidem: 9-10). Os advogados do CTI foram também responsáveis pela publicação em português da obra clássica de Nimuendaju (1987 [1914), destacando na abertura do livro, como esta tradução era uma das estratégias de conferir maior visibilidade cultural aos Guarani e à situação de suas terras, comentando aí também sobre a sua atuação junto a eles:

em 1981, passamos a trabalhar como advogados dos índios Guarani de São Paulo na defesa de suas terras. Dentre vários outros problemas que tivemos que enfrentar, a falta de documentos e de conhecimento por parte da população paulista sobre estes índios eram significativos. As terras não estavam demarcadas, a Funai não reconhecia a maior parte destas aldeias, os governos municipais e estaduais não tinham qualquer política em relação a elas. A especulação imobiliária desenfreada e selvagem ameaçava açambarcar praticamente todas as áreas restantes sob domínio Guarani. Foi em caráter de urgência que começamos a atuar na defesa dessas terras [...] vários segmentos da população paulista tomaram conhecimento, pela primeira vez, desses índios, que viviam até então como que escondidos ou fugitivos em pontos da Serra do Mar. Juntamente, então, com o andamento dos processos, foram os Guarani buscando meios de se fazer mais visiveis aos olhos da população envolvente. (Antunha Barbosa e Barbosa 1987: X, grifos meus) 
Nessas ações movidas pelos advogados, a cultura era o mote central tanto na argumentação da defesa quanto da acusação. Assim, "a posse da terra pelos Guarani implicava a posse de uma 'cultura" (Macedo, 2010: 49). Por isso, "para além dos autos dos processos, o CTI, a CPI [Comissão Pró-Índio] e outras entidades e pessoas nesse período passam a investir na maior veiculação da cultura Guarani, estabelecendo alianças com políticos e órgãos da imprensa” (Idem), o que contrasta diretamente com a estratégia guarani de invisibilizar a própria cultura na relação com jurua kuery, inaugurando assim uma nova postura, em que os Guarani passam a incorporar novas formas de articulação orquestradas pelos parceiros jurua que encontravam pelos caminhos, mesmo que sempre imprimindo nelas os seus próprios modos de organização na defesa de suas terras. Essas alterações inovadoras nos modos Guarani de se organizar para defender suas terras implicava então o estabelecimento de alianças com uma gama diversificada de não-indígenas, que não acontecia até então. A própria aceitação da ideia de “demarcação", percebida por eles como uma deformação de seu mundo, conta com a aversão de seus anciões pela imposição de limites arbitrários às suas aldeias pelo Estado, órgão estrangeiro, de fora, pois a entendiam como uma coerção à sua liberdade de movimento (Ladeira, 2000: 68). Esses limites eram comparados às cercas jurua, as quais associavam aos animais de criação dos brancos, que vivem cercados, como em uma prisão. Essa fixação de localidades e "comunidades" configurava para os Guarani, "que não condicionam sua existência nas diminutas áreas demarcadas, a desfiguração do mundo e retaliação de seu território" (Ibidem: 8, grifos meus), restringindo a sua movimentação em busca de novos lugares e também de relações, bem como as suas dinâmicas próprias de diferenciação entre os grupos familiares, cada qual com suas próprias lideranças políticas e-ou espirituais, que parte de seu próprio “sistema” de pensamento-ação (teko), que dá sentido e ânimo à vida nesta terra. Como conta uma jovem liderança Mbya:

\footnotetext{
Antes, nós não nos preocupávamos com a destruição. Porque antes nós não tínhamos divisa e toda a região era Mbya, e não havia destruição. E agora, com a chegada do progresso, nós estamos preocupados com a destruição e fomos obrigados a ter divisas". (Trecho de carta ao Governador de São Paulo, 1997 apud Ladeira, 2000: 8)
}

Aqui percebemos a ironia guarani a respeito da noção de progresso dos brancos. Outra importante e reconhecida liderança mbya comenta como o desenvolvimento jurua traz destruição às matas e aos serem que ali vivem e circundam suas aldeias, e que a relação que os Guarani estabelecem com a "natureza” parte, ao contrário, de um envolvimento:

Muitas vezes o branco fala que tem que preservar a natureza, mas muitas vezes só fala e não faz. O Guarani ama a natureza em silêncio, através do conhecimento milenar. Aquele que fica distante da natureza se torna uma coisa dura, com coração de pedra. Porque a 
cidade muitas vezes traz bastante recursos, então diz que o progresso traz desenvolvimento, mas também traz destruição. Nosso futuro, nosso desenvolvimento, para os Guarani significa nosso conhecimento. Respeitar a natureza significa desenvolvimento. É diferente do branco. Eu já fico com receio quando fala desenvolvimento sustentável, desenvolvimento não sei o quê... Eu falaria na minha língua envolvimento. (Vera Popygua, Timoteo, 2006: 32, grifos meus)

O que, segundo Ladeira, não quer dizer que:

\begin{abstract}
as suas estratégias para conviver com essa realidade não se atualizem. Nos últimos 20 anos, as recorrentes disputas sobre as áreas que ocupam, vêm forçando os Guarani a um confronto que, todavia, preferem delegar à terceiros (seus aliados - ONGS, FUNAI, MPF). Além da briga pela terra ferir os princípios éticos de como viver e conviver no mundo, não querem se responsabilizar pela aceitação (que, de fato, quando ocorre é sempre parcial) dos termos de acordos que formalmente acontecem no âmbito das regras, das instâncias de poderes e da lógica do dominador. De todo modo, observa-se que alguns conceitos, divulgados no âmbito do discurso interno, vêm se integrando ou se adaptando ao conjunto das normas de relacionamento com os brancos. (Ladeira, 2000: 9, grifos meus)
\end{abstract}

No entanto, em relação à sua postura em relação aos brancos, em que as tensões, aliadas às "pressões diversificadas exercidas pelos 'donos' dos terrenos”” não raro se desdobravam em deslocamentos, atitude comum à sua histórica estratégia de evitação do conflito, Ladeira descreve como eles se mostram "esquivos com relação à regularização fundiária da área que ocupam e prontos a partir, a qualquer momento, em busca de outro lugar" (Ladeira, 2007 [1992]: 45). Essa atitude guarani em relação à deformação de seu mundo deve ser entendida, portanto, como uma marca da sua resistência na luta pela preservação de sua territorialidade (ver Gallois 2004), e não confundida como uma suposta aversão à demarcação de terras em si (ver Ladeira e Pierri 2015). O CTI por sua vez, mesmo sabendo que não podia prescindir da Funai na regularização institucional das terras guarani, decide então participar ativamente do processo e em 1983, no governo do Estado sob gestão de Franco Montoro (Partido do Movimento Democrático Brasileiro - PMDB), apresenta à Secretaria do Interior do Governo de SP um programa para regularização fundiária das áreas Guarani no Estado, que consistia no levantamento fundiário, demarcação física e assistência jurídica. Como resultado desse encaminhamento, em 1984 os advogados do CTI foram contratados pela Equipe de Resoluções de Conflitos de Terra da Sudelpa para acompanhar a implantação desse programa, por meio de um convênio firmado com a Funai. O Governo do Estado de SP patrocinou esses estudos, demarcou fisicamente as áreas Guarani em território paulista e a Funai as homologou, reconhecendo-as oficialmente como T.I.s, com exceção da aldeia de Mboi-Mirim, hoje completamente tomada pela urbanização jurua (Ladeira e Azanha, 1988: 10).

Esses estudos fornecem dados importantes, como já levantamos aqui, a respeito da história e de como se deu a ocupação guarani na Serra do Mar, pressionando a Funai, 
através da Sudelpa, a cumprir com seu dever constitucional de demarcação de áreas indígenas no país, uma vez essa iniciativa não partia do órgão federal. Como explicita bem o RCID da T.I. Tenonde Porã, o convênio estabelecido entre a Funai e a Sudelpa, "é explícito em indicar que a iniciativa da regularização das TIs de São Paulo partia do Governo do Estado, limitando-se a Funai à corroborar os estudos”, o que é apontado na Cláusula VI do convênio: "reconhecerá os trabalhos produzidos pela SUDELPA, homologando as demarcações e promovendo as suas inscrições junto ao Serviço do Patrimônio Imobiliário da União, nos termos do artigo no 198 da Constituição” (RCID T.I. Tenonde Porã, 2010: 11, grifos meus). A Funai teve, portanto, um papel secundário nesse processo, apenas respaldando as propostas do Governo do Estado que, "embora ousadas para a época, não se baseavam nos critérios que a legislação constitucional atual [1988] demanda" (Ibidem: 15, alterações minhas). O antropólogo Plínio dos Santos que coordenou o primeiro GT de identificação dos novos limites das aldeias Barragem e Krukutu (T.I. Tenonde Porã) em 2002 (é nomeado um novo GT em 2010 para a realização de estudos complementares, requisitados pela Funai), realiza um histórico das disputas pelas terras Guarani na região e os impactos de grandes obras que atravessaram seus caminhos:

O histórico dos Guarani na região de Tenondé Porã foi marcado por disputas de grileiros e chacareiros pela posse da terra. Por ser uma região de Mata Atlântica densa, foi durante décadas inóspita a aventureiros, período no qual os Guarani não tinham muitos problemas com os juruá ("brancos”), porém alguns fatores modificaram o habitat dos Guarani: a construção da ferrovia de Jundiaí a Santos, a grande explosão demográfica ocorrida na região de Santo André (Parelheiros e a Cratera), a atuação das empresas exploradoras de areia, a grande especulação imobiliária que tem ocorrido na região, a tentativa de construção de barragens pela Companhia de Saneamento Básico do Estado de São Paulo (Sabesp) e, por fim, a criação de Unidades de Conservação [...] Ocorre também na área da TI a implementação de alguns empreendimentos, como o da empresa Furnas Centrais Elétricas, controlada pela Eletrobrás. Devido ao traçado da Linha de Transmissão de $750 \mathrm{kv}$ Itaberá-Tijuco Preto III atingir diretamente a TI em questão, o Ministério Público Federal solicitou a Furnas que realizasse um estudo dos impactos causados pela construção da obra, pois o local que a Linha irá passar terá restrições de uso do solo. Assim sendo, entre os meses de setembro e outubro de 2000, a antropóloga Maria Inês Ladeira realizou os estudos que serviram de base para a elaboração do Termo de Ajustamento de Conduta (TAC Funai-Furnas). Atendendo à solicitação das comunidades indígenas, no estudo foi priorizada a regularização fundiária das Terras Indígenas acima referidas e como o empreendimento afetará o ambiente utilizado pelos índios. Dentre as medidas compensatórias inseridas no TAC está a regularização fundiária desta $T I$ [...] $\mathrm{O}$ segundo empreendimento é a construção, pelo governo do estado de São Paulo, do "Rodoanel Mário Covas”, auto-estrada que irá circundar a cidade de São Paulo e atingirá indiretamente Tenondé Porã. O relatório, elaborado pela antropóloga Bernadete C. Oliveira, apresenta diagnóstico e análise da área demonstrando dados que irão fornecer subsídios ao Estudo de Impacto Ambiental (EIA-Rima) do empreendimento no que diz respeito ao processo de licenciamento ambiental. Neste relatório, os índios também indicam projetos como medida mitigadora. A Sabesp, no começo da década de 1990, tentou implantar o Projeto Barragens no rio Capivari e no Mono. Tal projeto previa a construção de três barragens denominadas Médio Capivari, Embura e Alto Capivari. A construção inundaria 1.424 ha, sendo 1.183 ha de vegetação, o que equivale a $11 \%$ da vegetação natural da bacia hidrográfica, atingindo áreas imprescindíveis para a sobrevivência dos índios Gua- 
rani das Terras Indígenas Rio Branco de Itanhaém e Tenondé Porã ${ }^{81}$. O Ministério Público Federal, por meio de Ação Civil Pública, impediu a continuação deste projeto que se encontra suspenso. Hoje a Sabesp tem a intenção de implementar um projeto de meio ambiente numa área denominada Fazenda Capivari, de propriedade do próprio órgão, inserida nos perímetros da TI. (Plínio dos Santos, 2004: 283-284)

Como podemos perceber, através dos fragmentos aqui apresentados, os Guarani, assessorados por seus parceiros e advogados jurua, buscavam sempre como medida indenizatória a regularização de suas terras, que consideram ser o seu bem maior, pois são elas que lhes possibilitam adquirir suficiente autonomia em relação ao Estado para seguir adiante com o nhandereko, seu sistema de pensamento e ação, sem grandes interferências de fora dentro de suas aldeias. A "cultura” passa então a ser o mote central na disputa por terras no âmbito jurídico, é então usada como uma estratégia guarani para se fazer visível para o Estado e para a sociedade envolvente e, com isso, apressar a demarcação das terras diante do avanço da ocupação jurua ao redor do seu território tradicional. Isso contrasta diretamente com a estratégia, historicamente predominante, de invisibilidade cultural na interação com os jurua, em que os Guarani procuravam não revelar a "cultura" para não serem assimilados pelo Estado. Desse modo, ainda que tenham que se apropriar do discurso do Direito, criado pelos jurua, para conseguir a demarcação e alguns serviços públicos básicos dentro das aldeias, esta estratégia é parte da própria resistência políticoxamânica guarani, do seu devir contra o Estado, que segue não aceitando se submeter plenamente ao controle e aos modos de organização estatais, próprios aos jurua kuery. Essa apropriação funciona mais como uma potência de recusa, sendo a luta pela terra e por melhores condições de vida aí fundamental, pois é a partir dela que eles adquirem efetivamente essa potência. O processo de luta para assegurar esses direitos fundamentais é, nesse sentido, um ato de resistência em si mesmo, a demarcação funcionando como a

\footnotetext{
${ }^{81}$ O CTI encaminhou ao Ministério Público Federal (MPF) em São Paulo, um relatório a respeito do projeto da Sabesp, que contrapõe os impactos no meio ambiente, segundo os princípios éticos e de subsistência Guarani, à forte pressão exercida pela empresa que chegou a elaborar e divulgar um vídeo acusando os Guarani pela falta de abastecimento de água para a população local, caso o projeto não fosse aprovado (ver Ladeira e Vera 1993 e Instituto Socioambiental 1996). O MPF, no entanto, interviu reconhecendo que as áreas impactadas eram de ocupação tradicional guarani e o projeto da Sabesp foi arquivado. Esse relatório do CTI, em colaboração com os Guarani, demonstra a sua preocupação em relação aos programas de preservação jurua dos ecossistemas, especialmente da fauna e flora da Mata Atlântica que circundam suas áreas de ocupação. Como complementa Ladeira: "Por trás desses temores existe ainda a questão que envolve a ética religiosa no que diz respeito à criação do mundo. Para os Guarani Mbya, os empreendimentos realizados pelos não índios significam a deformação dos elementos do mundo original. Nhanderu (nosso pai) criou esse mundo (que compreende o complexo territorial em questão) para os Guarani viverem'. Modificar o percurso ou a vazão de um rio, interferir no lugar ( $a m b a)$ das criações de Deus (Nhanderu mymba) são artifícios com os quais os Guarani Mbya, pelos princípios religiosos e morais que fundamentam a sua prática, não podem ser coniventes” (Ladeira e Vera 1993). Esse foi um passo importante na mobilização Guarani para que essas áreas, "necessárias à sua reprodução física e cultural”, como garante à Constituiçao de 1988, fossem reconhecidas pelo Estado brasileiro. O relatório patrocinado pela empresa Furnas (Ladeira 2000) reiterou esses direitos e levou ao TAC, que marca os novos procedimentos demarcatórios de "revisão" executados pela Funai e que ainda se encontram em processo.
} 
possibilidade nos dias atuais, de garantia e continuidade do seu modo de ser-pensar-agirviver (nhandereko), sem entrar em um confronto violento direto com os jurua, sem ferir seus preceitos ancestrais de diplomacia cosmopolítica. Os jovens Guarani estão cada vez mais se colocando à frente nessa luta, participando ativamente de manifestações e de movimentos nacionais protagonizados pelos diversos povos indígenas que habitam o Brasil e se organizando politicamente nos moldes "burocráticos" jurua, mas tentando manter sempre seus próprios modos de pensar e agir, apesar de todas as dificuldades que a interlocução direta com o mundo jurua impõe.

Ainda assim, em um primeiro momento as demarcações das T.I.s foram entendidas por seus sábios anciões como um espaço fixado, limitado, controlado e designado pelo Estado (que é quem terá a decisão final de delimitá-la e homologá-la), submetendo a "comunidade" a uma série de normas e constrangimentos, fragmentando assim seu amplo território, dádiva divina, de cuidado, proteção e circulação coletiva, enclausurando-os em uma lógica de sedentarização ${ }^{82}$, restringindo na prática sua movimentação espacial. Por outro lado, a produção dessas T.I.s é marcada pelos próprios modos guarani de ação, ocupação e uso das terras, além de ser produto direto das redes de relações que se constroem nos espaços de convivência, pelas trocas e alianças estabelecidas com outras aldeias e seres-poderes. Portanto, ainda que seu território tenha sido fragmentado pela lógica de pensamento-ação jurua, sua concepção de yoyrupa não passa a refletir o significado jurídico de T.I. (ver Gallois 2004). E já que a autonomia política, ao menos dentro das T.I.s deve ser aceita e respeitada pelo Estado, como garante a Constituição Federal, foi mais fácil aceitar essa que seria a opção mais razoável diante do avanço descontrolado da ocupação jurua, pois ao menos ali, naquelas áreas demarcadas eles poderiam tentar viver bem e fortalecer seu próprio sistema de pensamento-ação (nhandereko), resistindo assim, na prática, ao jurua reko.

Nessa conjuntura política de novos direitos garantidos na Constituição e de novas estratégias no embate com a política jurua, os Guarani tiveram então que estabelecer alianças e parcerias com advogados, intelectuais e organizações indigenistas jurua que os auxiliaram nessa luta pelo reconhecimento e regularização de suas aldeias e assentamentos. Esse processo, abre a necessidade de uma nova postura guarani diante desse novo cenário, cada vez mais burocrático, exigindo um entendimento maior, ainda que

\footnotetext{
82 Os Guarani fazem corpo às socialidades ameríndias que visavam um pequeno impacto na terra, lançando mão de modos diversos de dispersão, pois não tinham ainda limites. Eles seguiam avançando, caminhando, protegendo, conservando, domesticando e agredindo-predando ao mesmo tempo, a partir de territorialidades que lhes são próprias (ver, nesse sentido, Gallois 2004).
} 
mínimo dos direitos escritos pelos jurua, e que os xeramoĩ-cacique que acompanharam e se mobilizaram para conseguir as demarcações das terras do litoral de SP em um primeiro momento, preferiam não mais se envolver, visto que se fazia necessária uma interlocução cada vez mais direta e complexa com os jurua kuery. Isso faz aparecer uma nova geração de jovens, lideranças, que busca se especializar nesse tipo de interlocução, deixando os xeramoĩ-cacique e as xejaryi concentrados na diplomacia cosmopolítica interna de cada tekoa e, em sua conexão com outras aldeias, atuando assim, cada qual a partir de suas próprias disposições, juntos na proteção e manutenção de yvyrupa. O xeramoĩ Nivaldo comenta como o processo de luta pelos direitos foi um processo difícil e demorado, e como as lideranças de sua geração tinham pouca desenvoltura nesse âmbito jurídico da demarcação, contando para tanto com o apoio de um advogado jurua:

\begin{abstract}
Não sei como estava o pensamento, não sabem ler, não sabem nada de nada... pensamos a demarcação da área ali. Aí lutamos, aí a gente era só gente grande mesmo, naquele tempo não tem liderança nenhuma pra apoiar o nosso trabalho de demarcação. Só que nós estávamos com um advogado, bom mesmo, até do coração mesmo tem amizade de ajudar, por isso que essa partezinha demarcou ali [refere-se às aldeias do litoral e capital de São Paulo] [...] E assim mesmo foram oito anos de luta, com dez alqueires aí pra demarcar, e a Barragem a mesma coisa, dez alqueires pra demarcar. E nós fizemos associação, mesmo sem saber o que era isso naquele tempo. Aí falamos com o José Fernandes e o Samuel: "Como é que a gente vai fazer?”. Aí pensaram, né, aí colocaram... Aguaí. Tinha escritório lá em Santo Amaro. Estudamos, pensamos, aí chamaram Aguaí. Então andamos por aí. Direto Brasília, direto Brasília, direto Brasília [...] Então lutamos oito anos pra demarcar esse pedacinho aí. E agora, por que vai acontecer isso aí? Só querendo fazer estudo do índio, como é que está a história, como é que é o pensamento, o que que está pensando, essa coisa toda aí vai demorar muito também, né [refere-se aos estudos para identificação e delimitação da T.I. Tenonde Porã e à demora no processo de regularização das T.I.s Guarani pelo Estado brasileiro]. (Nivaldo apud RCID T.I. Tenonde Porã, 2010: 130, grifos e alterações minhas)
\end{abstract}

Com auxílio de Irmã Luizinha (religiosa da Congregação São Vicente de Paula, que apoiava os Guarani do Tekoa do Rio Silveira na questão das terras e demandas cotidianas da época), e em conjunto com outras lideranças de várias aldeias, o xeramoĩ Samuel (mais conhecido como Jejoko) idealizou a Ação Guarani Indígena (Aguaí) em 1983, segundo Macedo (2010), assumindo o posto de presidente da organização. Essa seria "uma associação voltada para reivindicações fundiárias, no âmbito da qual fizeram viagens a Brasília e encontros entre lideranças guarani”, conseguindo chamar a atenção do Governo para as demarcações do complexo de aldeias do litoral paulista (Macedo, 2010: 56). Manoel Lima, antigo cacique do Tekoa Tenonde Porã, em depoimento para a produção do RCID da T.I. de mesmo nome, comenta como foi que se deu o início desse trabalho entre as lideranças:

Eu ajudei no andamento do processo de demarcação dessa área na década de 1980. Foi incorporado um trabalho como vocês estão fazendo hoje. Foi oficializado, homologado pela FUNAI em 1987, junho de 1987. Me lembro que demorou para acontecer a demarcação 
das áreas. Nós não tínhamos informação de como nós deveríamos agir para chegar mais perto desse processo de demarcação. Eu me lembro que na época nós fomos pra Brasília, o Zé Fernandes, o Nivaldo, o capitão Branco, lá de Itariri, um Guarani lá do Rio Branco, não me lembro o nome dele em português. Quando chegamos em Brasília, eu vi os caciques e as lideranças experientes, falando sobre demarcação. Aquelas exigências... Perguntaram de onde viemos, qual município, quantas famílias existiam. Nós não tínhamos ideia de como chegava no presidente, delimitar isso, (como era). Nós fomos aos lugares e voltamos aqui para aldeia. Nos informamos, juntamos todas as famílias, município por município. Voltamos pra lá e cada um pediu uma área pra si. Queriam que nós nos integrássemos noutra entidade, secretaria de município, do estado, ong - qualquer coisa assim. Para não ficar cada um pra si. (Manoel Lima apud Nogueira da Silva, 2015: 128-129, grifos meus)

A Aguaí foi então uma associação de articulação política dos Guarani do Sudeste, criada para atuar como uma unidade no contexto de demarcação de terras na década de 1980, e de certo modo, constitui uma das experiências de articulação inter-aldeias que antecederam e formaram a base da Comissão Guarani Yvyrupa (CGY), organização Guarani de escopo nacional voltada também para a unificação das lutas pelo reconhecimento e garantia do território guarani. O xeramoĩ José Fernandes, outra grande liderança que participou ativamente desse processo, ressalta as inúmeras dificuldades enfrentadas, "como fome, frio e noites dormidas ao relento, esperando ser atendidos por autoridades em Brasília” durante as viagens que fazia junto a outras lideranças para cobrar do Governo as demarcações de terra (Nogueira da Silva, 2015: 128):

É - diz o cacique - sofremos bastante os caciques. Nós fomos a pé, passava fome, tem algum lugar que só dá por a pé. Não tinha condição. Já hoje não, que para ir já é mais fácil, a turma só no avião, vai no ônibus. Mas primeiro não. Eu, Jijocó, Altino, Nivaldo, Capitão Branco, nós sofremos bastante. (José Fernandes apud Nogueira da Silva, 2008: $55)$

Timoteo Popygua também comenta sobre a articulação da Aguaí e sua principal “missão”, que era a demarcação de terras guarani, anunciando também como a nova geração de lideranças vai se formando ao acompanhar os xeramoĩ-cacique nessa luta:

Na época era o José Fernandes o cacique. Depois de dois anos comecei a acompanhar o Zé
Fernandes nas reuniões da Aguaí - Ação Guarani Indígena, uma associação das aldeias do
litoral sul, litoral norte e da capital, em que só os caciques e pajés participavam. A luta da
Aguaí era para demarcação de terra indígena. Conseguiram demarcar a Rio Branco, conse-
guiram demarcar a Itariri, Tenondé Porã, Krukutu, aldeia do Silveira e Ubatuba, e con-
seguiram também no Rio de Janeiro, em Angra dos Reis e Sapukaia. Não é que eles não
tinham dificuldades, mas eles são fortes na parte espiritual, então conseguiram. Depois de dois
anos já conhecia todas as aldeias de São Paulo, porque eu participava com o Zé Fernandes.
Ele falava assim: “um dia que eu parar alguém tem que seguir". Eu me lembro que partici-
pavam uns trinta jovens, de quatorze anos até vinte, aqui na aldeia. Só que depois de
dois, três anos, quatro anos, todo mundo foi pra vários lugares, e eu fiquei só aqui. (Vera
Popygua, 2006: 31, grifos meus)

Na fala acima, vemos que Timoteo comenta como o xeramoĩ, quando fosse parar de se envolver diretamente nesse enfrentamento com os jurua, para viver e fortalecer o nhandereko mais internamente, lhe alerta que alguém tem que seguir com a luta. Essa luta, 
que se desenrola no âmbito da diplomacia cosmopolítica guarani com os jurua kuery conta com as novas gerações de lideranças tomando cada vez mais a frente nesse embate (ainda que as lideranças mais velhas continuem sustentando e protegendo os parentes e a própria yzyrupa no plano mais "espiritual”). As jovens lideranças, seguindo com a luta dos seus avós (nhaneramoĩ e nhandejaryi kuery), atuariam mais diretamente no âmbito jurídico jurua, além também de auxiliá-los na articulação interna às aldeias. Nesse sentido, as diferentes gerações trabalham juntas, cada qual a seu modo, como guardiãs (xondaro e xondaria kuery) de yzyrupa. As novas gerações devem aprender, além do nhandereko, levando adiante a sabedoria de seus anciões, a articular a esfera dos direitos constitucionais com suas reivindicações, continuando assim com a luta e resistência iniciada por eles. Marcos Tupã, Coordenador Tenonde da CGY comenta a respeito desse aprendizado da luta, da qual ele também faz parte, e que passa, em grande parte, por "acompanhar" os seus pais e avós:

\begin{abstract}
Nós acompanhamos as reuniões, as lutas dos nossos pais, o que eles passaram, as viagens, quantas viagens que eles fizeram na época para ir para Brasília de trem. Ficaram na porta da Funai por quinze dias sem o presidente da Funai atender, noites mal dormidas. Não se reconhecia, nem mesmo a Funai reconhecia os Guarani. Então, nós que estamos atuando hoje, eu, Timóteo, o Adolfo Timóteo, somos lideranças que acompanharam os xeramoĩ mais velhos na luta deles. E hoje estamos continuando com a luta, com a história. Cada tempo se constrói uma história. Então, o que nós conseguirmos hoje, e depois de nós os mais novos que estão se formando, o que forem conseguir vai dar continuidade a nossa história, do povo Mbya Guarani e das lutas, dificuldades, desafios. Porque antigamente a luta, a tentativa de extermínio dos povos indígenas era com arma de fogo, era com perseguição, era escravização, evangelização, e hoje o que manda no pensamento do jurua é essa ganância. A ganância fala mais alto e o pensamento de se enriquecer e a tinta da caneta que vai mudando, vai afirmando o que de fato eles desejam. É triste, mas é a realidade que vamos cada vez mais enfrentar durante nossa luta [...] Se eu não tenho conhecimento eu não vou dar valor, se eu tenho conhecimento de como foi a história de luta, com certeza eu vou dar meu valor. Mesmo esse processo de formação de liderança, de participação na discussão política essas coisas, nós nos interessamos, nós lutamos, nós vamos continuar, porque nós sabemos o que é que os xeramoĩ passaram para demarcar essas terras hoje. (Marcos Tupã apud Nogueira da Silva, 2015: 129-130, grifos meus)
\end{abstract}

É nesse mesmo processo, com a associação de grandes xeramoĩ e xejaryi na luta pela demarcação de terras via Aguaí, em que se buscava ampliar a articulação política entre as lideranças das demais aldeias guarani dos outros Estados que se encontravam na mesma situação, sem garantia e reconhecimento por parte dos jurua de suas ocupações e assentamentos, vivendo toda uma sorte de situações complicadas, que ocorre o surgimento da CGY. A CGY possibilita então essa articulação entre os diferentes Estados de ocupação guarani no Brasil. Com ela, e seu envolvimento com outras organizações indígenas, a luta guarani pela demarcação ganha maior visibilidade e, uma nova postura se desenrola, levando os Guarani a se envolver cada vez mais com outros movimentos so- 
ciais apoiadores de suas reivindicações territoriais, e também a se mobilizar politicamente por meio de campanhas de luta e pedidos de apoio online, além das manifestações na cidade. Como essa luta se dá de uma maneira pacífica, pelo não enfrentamento direto na questão da terra, ocorrendo, na maioria dos casos, dentro da esfera jurídica, no mundo dos papéis jurua, é uma estratégia aprovada pelas lideranças mais velhas.

Já a estratégia jurua de colocar os Guarani em pequenas áreas, onde não pudessem desenvolver plenamente seu próprio sistema de pensamento e ação, de acordo com a orientação dos parentes divinos, buscando transformá-los em trabalhadores nacionais, acabou colocando-os em uma situação precária em que sua relativa autonomia em relação ao Estado foi drasticamente ameaçada. Isso os levou a aceitar e mesmo cobrar o auxílio do Estado e dos jurua dentro das aldeias hoje demarcadas, o que, por sua vez, tornandoos dependentes de doações e de programas estatais de transferência de renda, entre outras políticas públicas de assistência, para sobreviver ${ }^{83}$ em meio à falta de regularização de terras, forçando ainda mais a sua integração à sociedade envolvente. É por isso que a regularização de suas terras é central para retomada de parte de sua autonomia política e econômica em relação ao Estado, com suas roças e espaços de coleta e caça garantidos, garantindo a sua subsistência e se fortalecer mais, internamente.

\section{A luta pelas demarcações e a Comissão Guarani Yvyrupa: as novas gerações de lideranças e suas estratégias inovadoras de mobilização}

O CTI, como vimos, desde a sua fundação na década de 1980, atua junto ao povo Guarani, tendo como um de seus principais eixos "o reconhecimento de seus direitos territoriais e humanos, o fortalecimento de suas formas de organização e mobilização e a valorização das práticas e conhecimentos tradicionais das comunidades guarani”, que desenvolve através do Programa Guarani (Centro de Trabalho Indigenista, 2017a). O Programa Guarani apoia a CGY desde a sua fundação (2006). A CGY é uma organização fundada e gerida por lideranças guarani do Sul e Sudeste do Brasil, que articula nacionalmente "a luta desse povo pela recuperação de seu território tradicional, usurpado paulatinamente desde a Invasão Europeia” (Idem). Nessa organização representativa do povo Guarani se colocam em pauta interesses comuns para além das fronteiras nacionais e dos

\footnotetext{
${ }^{83}$ É interessante notar também que enquanto não obtêm a regularização das terras que tradicionalmente ocupam, os Guarani fazem uso da máquina do Estado de diversas maneiras, seja por meio dos cargos públicos que ocupam dentro das aldeias, seja através dos múltiplos projetos de fortalecimento cultural e socioambiental financiados pelo Governo Estadual, Municipal e Federal, além de alguns receberem aposentadorias e auxílios de programas de transferência de renda do Estado, como já comentado.
} 
circuitos de produção local de cada tekoa. Esse território que é entendido como constituindo a base de sustentação de suas aldeias, que são ao mesmo tempo consideradas os "suportes" do mundo terrestre:

\footnotetext{
Yvyrupa é a expressão utilizada em guarani para designar a estrutura que sustenta o mundo terrestre, e para nós seu significado evoca o modo como sempre ocupamos o nosso território de maneira livre antes da chegada dos brancos, quando não existiam as fronteiras (municipais, estaduais e federais) que hoje separam nosso povo. (Comissão Guarani Yvyrupa, 2017a, grifos meus)
}

Foi em uma "grande assembleia", que reuniu "mais de 300 lideranças políticas e espirituais, realizada em novembro de 2006 na Terra Indígena Peguaoty, no município de Sete Barras/SP”, que a “Comissão Nacional de Terras Guarani Yvyrupa”, posteriormente nomeada apenas de "Comissão Guarani Yvyrupa”, é fundada (Idem). A partir daí a CGY veio a se consolidar cada vez mais "como importante protagonista político do movimento indígena nacional, realizando suas assembleias anuais, e garantindo, pouco a pouco, vitórias importantes na longa luta pelo reconhecimento dos direitos territoriais de nosso povo" (Idem). Seu "escritório móvel” é localizado no Tekoa Tenonde Porã (Comissão Guarani Yvyrupa, 2017b). E a composição da CGY conta além da Coordenação Tenonde, com a Coordenação Nacional, a Coordenação Regional, o Conselho dos nhaneramoĩ e nhandejaryi kuery e a Comissão Mirim, composta por jovens lideranças em formação, que se ocupam da comunicação nas redes sociais e da produção e divulgação de vídeos e manifestos de luta. Em referência a seus modos próprios de organização política, e quais seus objetivos com a criação da página web, afirmam:

A forma de articulação interna da CGY apoia-se nos modos próprios de organização política
guarani, não buscando sobrepujar a autoridade dos caciques e lideranças espirituais e sim forta-
lecê-los, e por isso não buscamos replicar a lógica do sistema representativo característico da po-
lítica dos brancos. Nossa legitimidade advém do fato de que as comunidades guarani encon-
tram nas lideranças que compõem a coordenação da organização importantes mediadores, tra-
dutores e assessores dos caciques e lideranças locais frente aos conflituosos e burocráticos processos
de identificação e delimitação das terras indígenas guarani [...] Criamos essa página para di-
vulgar em primeira mão os problemas do nosso povo, que sofre cada vez mais com a falta de terra,
vivendo em acampamentos em beira de estrada, em áreas minúsculas devastadas pela ganância
dos jurua (brancos) e para buscar apoio daqueles que ainda se preocupam com o futuro da huma-
nidade, que nossos anciãos sabem que chegará ao fim se as coisas continuarem como estão. Os
ataques dos ruralistas no Congresso e a omissão do governo deixam nossa situação cada vez mais
difícil e por isso precisamos apelar para um grito de apoio. (Comissão Guarani Yvyrupa,
2017a)

Em março de 2007, a 6 a Câmara de Coordenação e Revisão do Ministério Público Federal (MPF), atendendo à solicitação das lideranças da CGY, sediou evento em Brasília formalizando o início das atividades da organização perante as instituições governamentais e da sociedade civil. Foi também nessa ocasião que foi divulgada oficialmente 
a "Carta Política" de criação da Comissão, datada de novembro de 2006, na qual contextualizam a sua fundação, sua forma de organização e seus principais objetivos:

Resgatando os movimentos de luta dos seus antepassados pelo direito a terra, baseando nos ensinamentos de suas lideranças espirituais e dos nhanderamói, respondendo aos anseios de suas comunidades por uma vida digna e de conformidade com o nhandereko foi criada a Comissão Nacional de Terra Guarani “ $Y$ vy Rupa”. A Comissão Nacional de Terra Guarani " $Y$ vy Rupa" é uma organização política que se sustenta no próprio modo de articulação e representação Guarani, diferenciando-se do modelo de organização imposto pela sociedade ocidental - formalista e burocrático [...] é a legitima representação do Povo Guarani, na sua longa caminhada por uma verdadeira autonomia política, e tem como principal objetivo fortalecer as comunidades Guarani na sua luta pela defesa das Terras e de seu Território Tradicional. (Centro de Trabalho Indigenista, 2017a)

Desde então, a CGY atuou sistematicamente cobrando a Funai de seu dever constitucional de garantir os direitos territoriais dos povos indígenas, obtendo algumas conquistas e avanços nos processos de demarcação. A trajetória da organização também pode ser observada a partir de depoimentos de alguns de seus coordenadores ${ }^{84}$, como Maurício Gonçalves, que comenta a importância do processo de luta pela terra como meio de sobrevivência nesse embate com as leis jurua, ressaltando a força de seus anciões:

A luta Guarani não é de agora, ela sempre foi anunciada, desde "o descobrimento" do Brasil, e a partir daí, iniciou-se a luta do povo indígena e do povo Guarani. Na medida em que foram avançando as grandes cidades e o povo não indígena foi aumentando, nós começamos a luta de manter nossa cultura, nossa língua e nosso jeito de ser. Tínhamos tudo que precisávamos da natureza, ela oferecia a mata, os rios, as caças, a pesca, tudo isso nós tínhamos, e quando começou a formar o grande povo dos brancos, eles não olharam o grande povo que já vivia aqui, que é daqui mesmo. E nós estamos aqui nestes muitos estados, do RS ao ES, um povo que resistiu a tudo isso, ao massacre, ao extermínio, foram acontecendo várias coisas e nosso povo foi perdendo seu espaço, mas mantemos nosso próprio jeito de viver e de ser Guarani. Nossos velhos, nossos grandes xeramoĩ, nossos antepassados tiveram uma grande sabedoria e só eles sabem como conseguimos manter toda essa cultura até hoje [...] Antigamente, antes dos jurua virem, nós não tínhamos lei, não havia lei que dizia que esta terra era Guarani, esta terra era de outro índio, essa terra não pode ser do índio... Na nossa terra não havia limite, nós vivíamos livremente, tínhamos liberdade para viajar, para procurar outras matas, de ponta a ponta tínhamos liberdade e hoje nós vivemos em uma terra onde os limites são colocados, os jurua se apossaram de tudo. Para enfrentar essa limitação nós precisamos nos organizar, para lutar e defender nossos direitos. Existem leis no Brasil que reconhecem os direitos dos povos indígenas, que reconhecem o jeito de nós nos organizarmos dentro das nossas comunidades. Nós vemos que há muito tempo essas leis existem, mas elas não são colocadas na prática [...] Então devido à apropriação dos brancos nós vivemos muitas vezes em acampamentos de beira de estrada, debaixo de lonas, passando dificuldades, muitas vezes correndo risco de vida. E tudo isso porque não é dado na prática o direito que existe no papel. E por isso naturalmente fomos vendo que nós, enquanto povo Guarani, precisávamos nos organizar e entender um pouco mais como funciona a sociedade do branco, como está organizada a sociedade do branco, como ela é feita. Hoje nós somos formados enquanto lideranças indígenas que defendem o direito do nosso povo. Nós temos nossa organização própria dentro das nossas comunidades, nós temos nossos xeramoĩ, nossas xejaryi, nossas lideranças jovens, mulheres, nossas crianças, e isto faz com que tenhamos força para que continuemos sendo o povo Guarani. Os jurua avançaram tanto que hoje as nossas terras estão praticamente todas nas mãos dos jurua. Para nossa sobrevivência nós

${ }^{84}$ Edição realizada por Maria Inês Ladeira e Eliza de Castilla (CTI) de pronunciamentos dos coordenadores da CGY durante assembleias realizadas nas aldeias Peguaoty (SP), Araçai (PR), Pindoty (SP) e em reuniões em aldeias no RS, SC, PR, SP, RJ e ES, entre 2006 e 2010 (ver Povos Indígenas no Brasil [PIB] 2006/2010, 2011, Instituto Socioambiental [ISA]). 
precisamos das terras, elas têm que ser demarcadas pelo governo [...] Dentro da cidade não tem como mantermos todo o nosso sistema, não existe mata, não existe rio. E para nós mantermos nossa cultura toda a noite temos nosso jeroky na Opy'i, isso fortalece nossa luta e fortalece a união do povo guarani. Nós sabemos e dizemos que a terra é Guarani, mas infelizmente precisamos do Kuatia, o papel de um jurua dizendo que aquela área é do Guarani. Nossa luta política é de enfrentamento, com o governo, com a Funai, com o MPF, levando as nossas reivindicações. É importante os mais jovens escutarem o que eles [nhaneramoĩ e nhandejaryi kuery] falam e ajudá-los, porque são eles que pedem força para Nhanderu para poder cuidar de nós. É por isso que nós temos essa força, essa garra, essa vontade de continuarmos lutando pelos nossos direitos. Eles pedem pela demarcação para que possam ter sua casinha e suas plantações. É muito importante mesmo ouvirmos a fala deles e seus conselhos. É com a força deles e de Nhanderu que nós temos esta reunião. (Gonçalves, 2011: 718, grifos e alterações minhas)

Timoteo Popygua também comenta sobre a criação da CGY, suas formas de organização na luta pela demarcação e suas maiores preocupações:

Por que nasceu a Comissão Terra Guarani Yryrupa? Porque na ideia jurua ele divide a terra por exemplo em estado, município, mas não tem divisão federativa para o povo Guarani. Então, começou a nascer essa organização que é própria do povo Guarani [...] O intuito é de lutar por aquilo que nós acreditamos que é o significado também da terra. Yryrupa significa que a terra é uma só, não tem divisão. Várias cidades foram instaladas em cima das terras do povo Guarani, e a gente está lutando para garantir o espaço onde nós permanecemos hoje, no Sul, Sudeste, restituir o que já foi nosso, e também garantir a manutenção do nosso próprio modo de ser Guarani. Um grande desafio nosso agora é de que as terras sejam homologadas, demarcadas fisicamente. Nossa luta pela demarcação envolve política, planejamento, gestão territorial, gestão ambiental, educação e saúde dentro das comunidades, e nós temos que acompanhar sempre. Eu acho que a importância maior da Comissão é o Conselho, principalmente os pajés, caciques, conselheiros que são os mais velhos. E a instância maior da nossa organização é a assembleia, onde todos participam, e nós coordenadores, mas quem fortalece mesmo a Comissão é a própria base, principalmente os tekoas [aldeias] [...] nós, coordenadores, apenas coordenamos os encontros, as datas, encaminhamos documentos, e fazemos as petições. Agora, quem decide é a própria aldeia, próprio cacique, próprio xeramõi, é assim que é a composição da Comissão Tryrupa. Na verdade Yvyrupa tem um grande significado para o povo Guarani, porque quando Nhanderu criou a terra, criou bem perfeito e nós chamamos de Yryrupa. E Yryrupa não é só onde tem aldeia, mas se a gente vai falar do mundo é Yryrupa. Quando Nhanderu fez o mundo, ele fez com carinho, criou essa beleza natural, a natureza, que brota da terra. Nosso grande inimigo são as pessoas que destroem a natureza, por exemplo o agronegócio [...] Nós acreditamos que tem que mudar pra melhor. E pensando no futuro governo, a gente tem que procurar sempre dialogar, porque se for esperar com os braços cruzados com certeza não vai acontecer. É claro que somos diferentes, tem que ser respeitada a diferença, nossa cultura, nossa realidade, mas nós fazemos parte dessa nação, então temos que ser respeitados pelo governo. $A$ maior preocupação nossa realmente é a terra, porque sem terra não há vida, sem terra não há nhandereko, não há nosso modo de ser guarani. (Vera Popygua, 2011: 718, grifos meus)

Renato da Silva, também resume bem qual o significado de yryrupa para os Gua-

rani, as dificuldades em fazer os jurua entenderem essa concepção, e como se dá a forma-

ção e o reconhecimento das aldeias pelos xamãs-rezadores:

Yvyrupa é ter um território único, onde a gente transita livremente. Por exemplo, eu até hoje eu não conheço Argentina, Paraguai, mas os mais velhos contam que toda ocupação que nós temos hoje, esse é Tryrupa. Quando a gente forma aldeia, a gente nunca abandona, porque essa terra já é reconhecida através da reza, porque através do Nhanderu foi revelado esse lugar, então esse espaço é Yryrupa. Essa região do Vale os mais velhos já falavam que já foi habitada, onde tiveram o rezador forte, então, até hoje, é isso que dá proteção, que protege do mal, da maldade... esse é o nosso território, onde os jovens vão se visitar, as famílias vão visitar os parentes, esse é o território que a gente tem. Yvyrupa, traduzindo, é o lugar onde podemos pisar, caminhar sem preocupação, é o território que já foi reconhecido por rezador [...] A comissão é composta por lideranças que já têm algum conhecimento, o domínio da organização 
do jurua, dos governos, dos estados, do governo federal. E a luta pela terra é assim, a gente tem o direito nosso, que não se combina com o direito escrito, porque pelo nosso entendimento Nhanderu deixou essa terra para nós. Então muitas vezes a gente tem essa dificuldade de explicar [...] Porque a terra, no nosso conhecimento é única, não tem divisão, então, nessa parte é um pouco complicado, mas a gente tem um papel muito importante de informar as comunidades. (Da Silva, 2011: 718, grifos meus)

A $6^{\mathrm{a}}$ Assembleia Geral da CGY, ocorrida em Abril de 2013 na aldeia Ko'ẽju (em São Miguel das Missões, RS), reuniu caciques, mulheres, crianças, lideranças políticas e espirituais de mais de 50 tekoa guarani do Sul e do Sudeste do Brasil, e também da região de Misiones (Argentina), para uma série de atividades e discussões acerca da situação fundiária das aldeias localizadas no Brasil, sobre as difíceis condições de vida enfrentadas por todo o povo Guarani e os rumos da política indigenista no Brasil. Na assembleia, elaboram documentos para pressionar a Funai e os poderes públicos responsáveis a cumprir com seus deveres constitucionais e acelerar o ritmo dos processos de demarcação, além de cobrar também providências imediatas em regiões que nem tiveram os GTs de identificação e delimitação iniciados, assim como a urgência na análise daqueles processos já iniciados, exigindo também a defesa de seus direitos em referência aos diversos empreendimentos de grande impacto que ameaçam a segurança e integridade de suas terras e de seus parentes (Centro de Trabalho Indigenista, 2013). Em anúncio público sobre esta Assembleia, endereçado aos povos indígenas, às associações e entidades indígenas, aos órgãos públicos responsáveis pela questão indígena no Brasil, e às organizações não-governamentais indigenistas e outras entidades comprometidas com o bemestar dos povos indígenas, a CGY relata que foi nessa grande reunião, que aprovaram o Estatuto Social da Comissão e iniciaram o processo para registro da organização no Cadastro Nacional de Pessoas Jurídicas (CNPJ):

Constituída em 2006 - na Terra Indígena Peguaoty, no município de Sete Barras (SP) -, por nossas lideranças políticas e espirituais preocupadas em dar continuidade à luta dos mais velhos pelo reconhecimento de nossos direitos territoriais e em assegurar as condições de vida necessárias para o desenvolvimento pleno do nhandereko - constantemente desrespeitado e ameaçado por aquilo que a sociedade dos jurua (não-indígenas) insiste em chamar de "progresso" a CGY promoveu nos últimos anos um amplo movimento de articulação das tekoa guarani. Por essa carta pública, queremos anunciar que demos um importante passo no último dia 12 de abril: por consenso das mais de 300 pessoas presentes aprovamos o estatuto social da nossa Comissão Guarani Yryrupa para registramos em cartório e oficializarmos junto à sociedade e ao poder público brasileiro nossa organização. Esse ato foi simbolicamente realizado em São Miguel das Missões, palco de tristes e sangrentos episódios de nossa história, ainda hoje marcada pelo empenho dos jurua em nos reduzir e diminuir e contra o qual continuamos a resistir! [...] Dentro de um contexto político e econômico bastante adverso ao bem-estar dos povos indígenas do Brasil, a Comissão Guarani Yvyrupa é uma resposta aos setores da política brasileira empenhados na anulação dos direitos indígenas bravamente conquistados e garantidos pela Constituição Federal do Brasil 1988 [...] Basta de desrespeito e preconceito contra nosso povo, habitantes originários dessas terras! (Idem) 
São nessas assembleias gerais que ocorrem a cada três anos que caciques, lideranças e anciões se reúnem para avaliar o momento político que estão passando e realizar um balanço geral e coletivo da atuação desempenhada pela organização e por suas lideranças nos diferentes Estados do país, além de ser também um importante espaço para renovação e fortalecimento de suas diretrizes de ação, e o momento que são realizadas as eleições dos novos coordenadores, a nível regional e nacional, responsáveis (durante esse período de três anos) por articular as pautas e reivindicações locais com as do movimento indígena de todo o país frente ao Estado brasileiro, e realizar ações e reuniões políticas ao longo do ano. As assembleias gerais são o seu maior e principal fórum de debate, compartilhamento coletivo dos problemas enfrentados por cada localidade e de articulação das estratégias a serem encaminhadas amplamente como ações prioritárias em cada região, uma vez que estão ali reunidas lideranças de todas as regiões do Brasil. Nesse momento são levantadas as principais demandas relativas à saúde e educação apresentadas pelas comunidades e levadas adiante pelos seus "representantes". Além disso, aí também são encaminhados documentos reivindicatórios exigindo o reconhecimento dos direitos constitucionais de cada região ou localidade aos órgãos competentes do Estado brasileiro. Também são convidados na assembleia, representantes centrais de órgãos municipais, estaduais e federais para debates, nos quais as lideranças da CGY pedem esclarecimentos e fazem suas reivindicações. No último dia da assembleia, são encaminhados para votação o texto final dos documentos produzidos ao longo da semana. Essas assembleias também representam um importante espaço de formação política para as novas gerações, sendo ali realizadas também oficinas de comunicação, de direitos territoriais e ambientais, entre outras atividades, importantes para garantir o reconhecimento e preservação de suas terras tradicionais, nas quais os mais jovens aprendem acompanhando as lideranças mais experientes, e se obtêm destaque em seu desejo de seguir nessa frente de luta, podem vir a compor também a Comissão Mirim da CGY, que se encarrega da comunicação da organização nas redes sociais.

No entanto, ainda que tenham obtido vitórias importantes nos últimos anos no reconhecimento de seus direitos territoriais, muitas terras reivindicadas ainda não estão em posse dos Guarani, o que representa mais desafios pela frente e motiva a continuidade e o fortalecimento da luta. Entre 2013 e 2017, as comunidades guarani de SP se organizaram e foram às ruas inúmeras vezes em uma série de atos públicos para reivindicar a demarcação de suas terras e pedir o apoio da sociedade civil nessa luta. Isso se dá logo pós-junho de 2013, palco de grandes manifestações no país que teve como estopim o 
aumento das tarifas de transporte público e os grandes atos encabeçados pelo MPL (Movimento Passe Livre) duramente reprimidos pelo Poder Executivo (Municipal, Estadual e Federal) em todo o país, que indignou centenas de brasileiros e acabou inspirando também grandes mobilizações Guarani na cidade. A partir daí, os Guarani ocuparam as ruas e as redes sociais para protestar e exigir o cumprimento de seus direitos constitucionais, contando também com o apoio e a parceria de alguns movimentos sociais mais experientes em organizar manifestações na cidade.

Em SP, estas ações acabaram se multiplicando em muitos atos pela cidade e divulgação de vídeos, manifestos e cartas públicas, diante do contexto de ações judiciais que as aldeias Guarani estavam sendo submetidss pelo Estado brasileiro, especialmente em relação a reintegração de posse movida contra o Tekoa Pyau e Tekoa Itakupe da T.I. Jaraguá, e a longa demora no processo de regularização das T.I.s Jaraguá e Tenonde Porã, ademais das recorrentes tentativas da bancada ruralista em aprovar a PEC do fim do mundo (PEC 215), que ameaça diretamente os direitos indígenas duramente conquistados e garantidos pela Constituição de 1988. Respondendo então à essas ameaças recorrentes movidas pela bancada ruralista no Congresso Nacional e dando início a uma série de mensagens guarani divulgadas por vídeos-manifestos nas redes sociais em busca de apoio na luta por seus direitos, o xeramoĩ Karai Mirĩ envia uma "Mensagem à bancada ruralista”, na própria língua, em mbya, com legendas em português, em que inicia sua fala se preparando, se concentrando-meditando fumando seu petỹgua (cachimbo sagrado de comunicação intermundos):

\footnotetext{
[...] Eu falo para que vocês deputados que são donos de terra, que não mudem a Constituição, que não inventem mais leis para nos atrapalhar [...] Então, eu falo para que vocês deputados que estão aí... que me vejam, que me escutem enquanto eu falo. Foram vocês que criaram essa terra para si mesmos? Eu não fiz a terra onde vivo e nem vocês fizeram. Vocês também não pagaram nada para Nhanderu (Nosso Pai). Mesmo assim, vocês querem levar toda a terra para vocês como se vocês a tivessem criado. É só para ter essas coisas no coração que vocês se tornam deputados. Só para a cada quatro anos se preocuparem com a eleição. E por isso vocês querem destruir as leis que nos protegem. Acham que se nos exterminarem ficará melhor para vocês. Acham que Nhanderu vai cuidar melhor de vocês assim [...] É para termos onde dormir, para termos onde criar nossos filhos. Para isso que queremos terra. Mas como não vendemos terra, vocês não querem devolvê-la para nós. Parece até que vocês que fizeram essa terra, que vocês que fizeram as matas, que vocês que criaram a água. Nas cidades de vocês se quisermos água, nós temos que comprá-la. Temos que pagar para tomar água. Mas vocês não pagam para Nhanderu. Só querem tudo para vocês. É só para ficar rico que vocês querem ser deputados, o pensamento de vocês está tomado por uma ganância descontrolada [...] Essa terra não é minha e não é de vocês. Não foram vocês que fizeram e não fui eu. A terra que está aí é de Nhanderu! As matas e os pássaros que nela vivem. Mas não há mais árvores frutíferas para os pássaros se alimentarem. Vocês destruíram os animais de caça. Vocês destruíram tudo. Vamos viver numa terra deserta, devastada? Sem nada do que antes havia sobre ela, sem ter o que comer? E por isso estou bravo com vocês brancos, com os deputados. Por que vocês só querem maltratar aqueles que sofrem? Colocar mais leis que dificultam a nossa vida? Como vamos ficar agora? Vamos todos nos destruir? Vocês querem enganar todos os indios. Querem me enganar. Se quiserem me matar podem matar. Mas o meu espírito vocês não podem matar. Ele vai voltar
} 
para a morada do meu pai celestial. Ele vai buscar meu espírito. O meu corpo vocês podem matar, hoje, amanhã, no dia que quiserem. (Karai Mirĩ apud Comissão Guarani Yvyrupa, 2013, grifos meus)

As mobilizações guarani na cidade têm início em setembro de 2013, com o fechamento pacífico de uma das pistas da Rodovia Bandeirantes (no sentido da capital), que atravessa a T.I. Jaraguá (zona noroeste de SP), por cerca de 200 xondaros e xondarias, para chamar a atenção da sociedade envolvente para a luta Guarani pela demarcação (que, como veremos, só veio ser garantida com a publicação da portaria declaratória das T.I.s, em 2015, para a T.I. Jaraguá, e em 2016, para a T.I. Tenonde Porã). Além disso, nesse ato reivindicavam também o arquivamento da já citada PEC 215 e das ações judiciais movidos pelo Governo do Estado de SP contra as T.I.s Guarani cujos territórios se sobrepõem aos limites dos Parques Estaduais. Junto a esse grande ato que trouxe muita visibilidade à sua luta pela terra (yvy re jajoguero’a), os Guarani divulgaram o vídeo-manifesto "Por que fechamos a Bandeirantes" em todas suas redes sociais, em que partem de um discurso altamente politizado, na própria língua, traduzido com legendas para o português, explicando os motivos desse simbólico protesto:

Hoje nós indígenas Guarani de todas as aldeias de São Paulo fechamos pacificamente a rodovia dos bandeirantes que passa sobre uma de nossas aldeias. Fizemos isso para vocês brancos saberem que nós existimos e que estamos lutando por nossas terras. Porque precisamos de terra para ter onde dormir e criar nossas crianças. Esse nome, "bandeirantes", para nós significa a morte dos nossos antepassados. Mas muitos de vocês brancos que estão aí tem muito orgulho deles e dos seus massacres contra nosso povo. Em homenagem a eles vocês batizaram o palácio do governador e levantaram estátuas por toda parte. Há muitos que querem repetir o que fizeram os bandeirantes no passado, nos exterminando e roubando nossas terras para enriquecer. Os políticos ruralistas, aliados do Governo, querem aprovar a PEC 215, para suspender todas as demarcações que ainda faltam, e ainda roubar terras que já estão demarcadas. Nossos guerreiros vão continuar resistindo, e faremos o que for necessário para ter uma parte das nossas terras de volta. Nós somos os primeiros habitantes desse território. Será que há muita terra pra pouco índio? Não é essa a nossa realidade. Vivemos no pouco que sobrou da Mata Atlântica, nossas terras são minúsculas e somos muitos. Enquanto alguns poucos políticos e empresários tem muita terra e ainda querem mais. Com esse ato pacífico que fazemos agora exigimos: - Que os deputados arquivem a PEC 215, e parem de tentar destruir nossos direitos. - Que o Ministro da Justiça publique as portarias declaratórias das Terras Indígenas Jaraguá e Tenondé Porã. - Que o Governador do Estado retire as ações judiciais contra nossos parentes que têm áreas em sobreposição com Parques Estaduais [...] Vamos às ruas nesse dia para mostrar que nesse país deve ter espaço para todos! (Comissão Guarani Yvyrupa, 2013b)

Marcos Tupã, resume bem a razão que leva os Guarani a mudar de postura e ir às ruas lutar mais diretamente pela demarcação de terras:

Se não tem PEC, dialogamos com o governo. Com a ameaça da PEC, não tem outro jeito: temos de lutar [...] A PEC 215 acaba com qualquer garantia de demarcação de novas terras indígenas no país [...] Por isso, estamos mobilizados nacionalmente. Queremos que a proposta seja arquivada: sua aprovação levará a mais confrontos e mais genocídio, porque os povos indígenas não ficarão de braços cruzados. (Tupã, 2013a) 
Página | 96

Ele também comenta que junto à publicação das portarias declaratórias, reivindicam “a correção dos limites dessas duas terras indígenas”, pois em SP (mas não só):

vivemos em áreas muito pequenas. As famílias cresceram bastante, e o espaço não permite que vivamos à nossa maneira. O que temos são apenas fragmentos de terra. Não dá para desenvolver nossos saberes e práticas, nem transmiti-los às crianças. A correção dos limites permitirá que tenhamos mais mata e espaço para nossas roças e atividades tradicionais. (Idem, grifos meus)

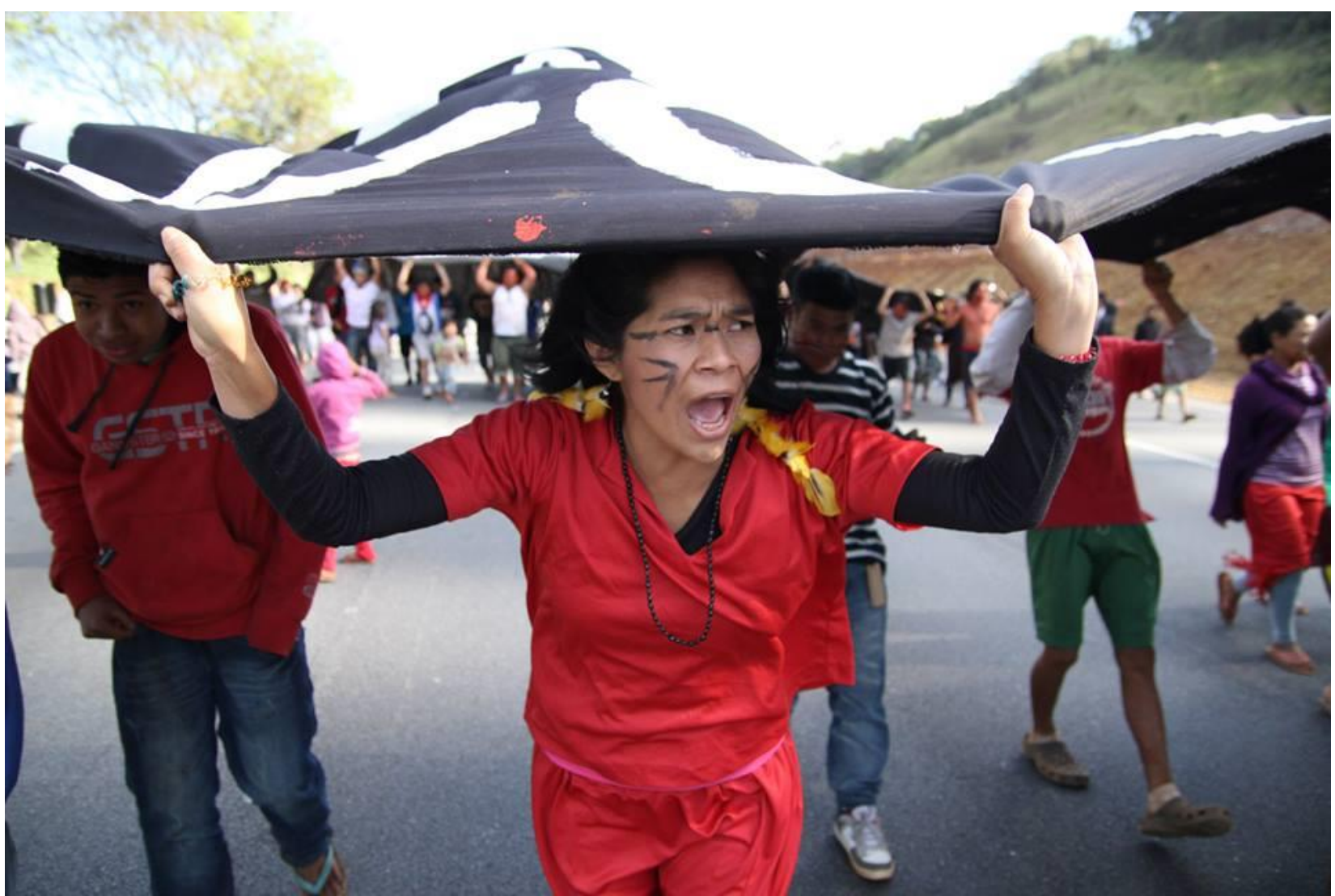

Xondaria e xondaro kuery ocupando a Bandeirantes. Arquivo CGY. São Paulo, 2013.

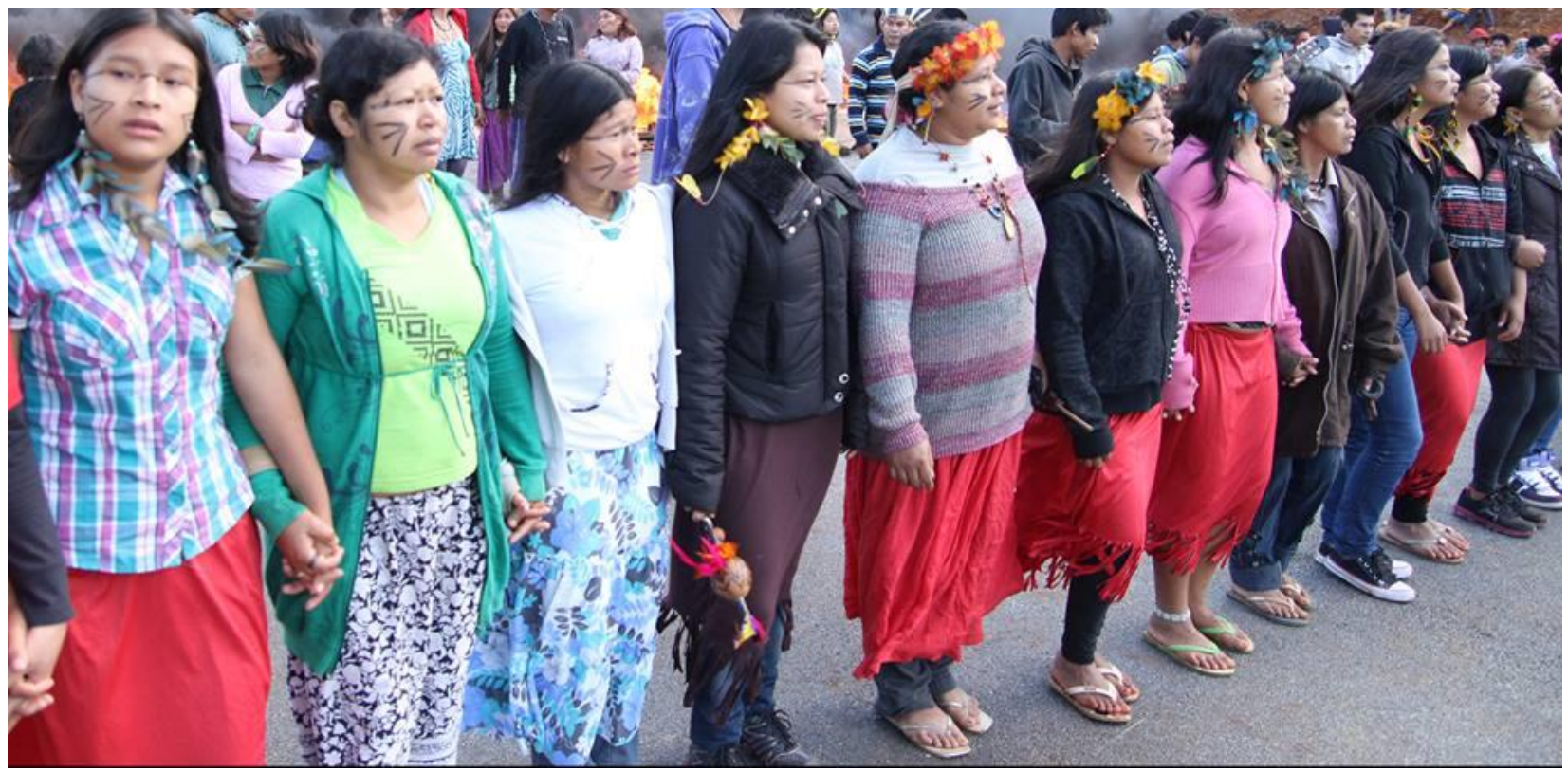

Xondaria kuery cantando-rezando e dançando na Bandeirantes. Arquivo CGY. São Paulo, 2013. 


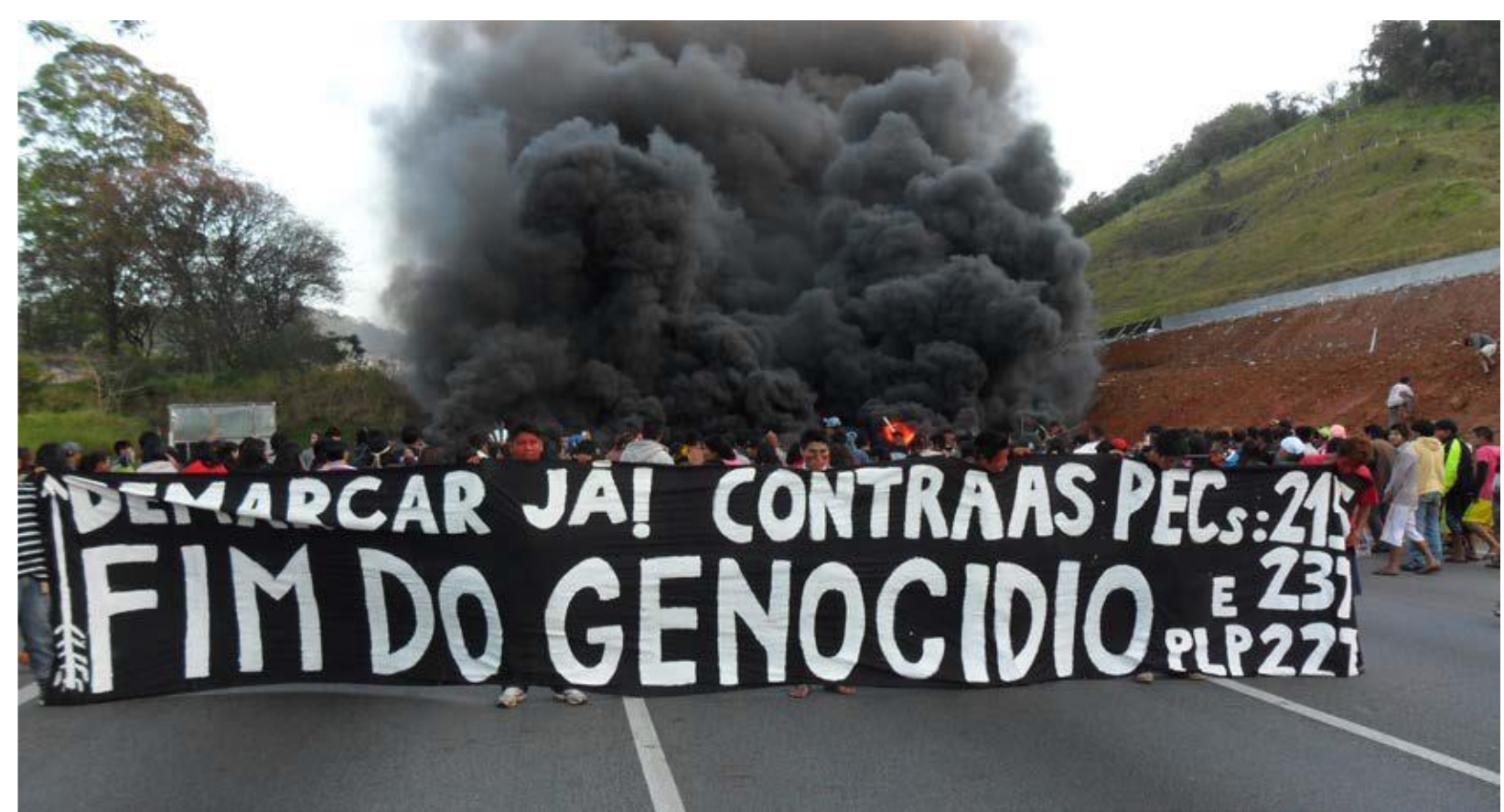

Ato Guarani na Rodovia Bandeirantes. Arquivo CGY, São Paulo, 2013.

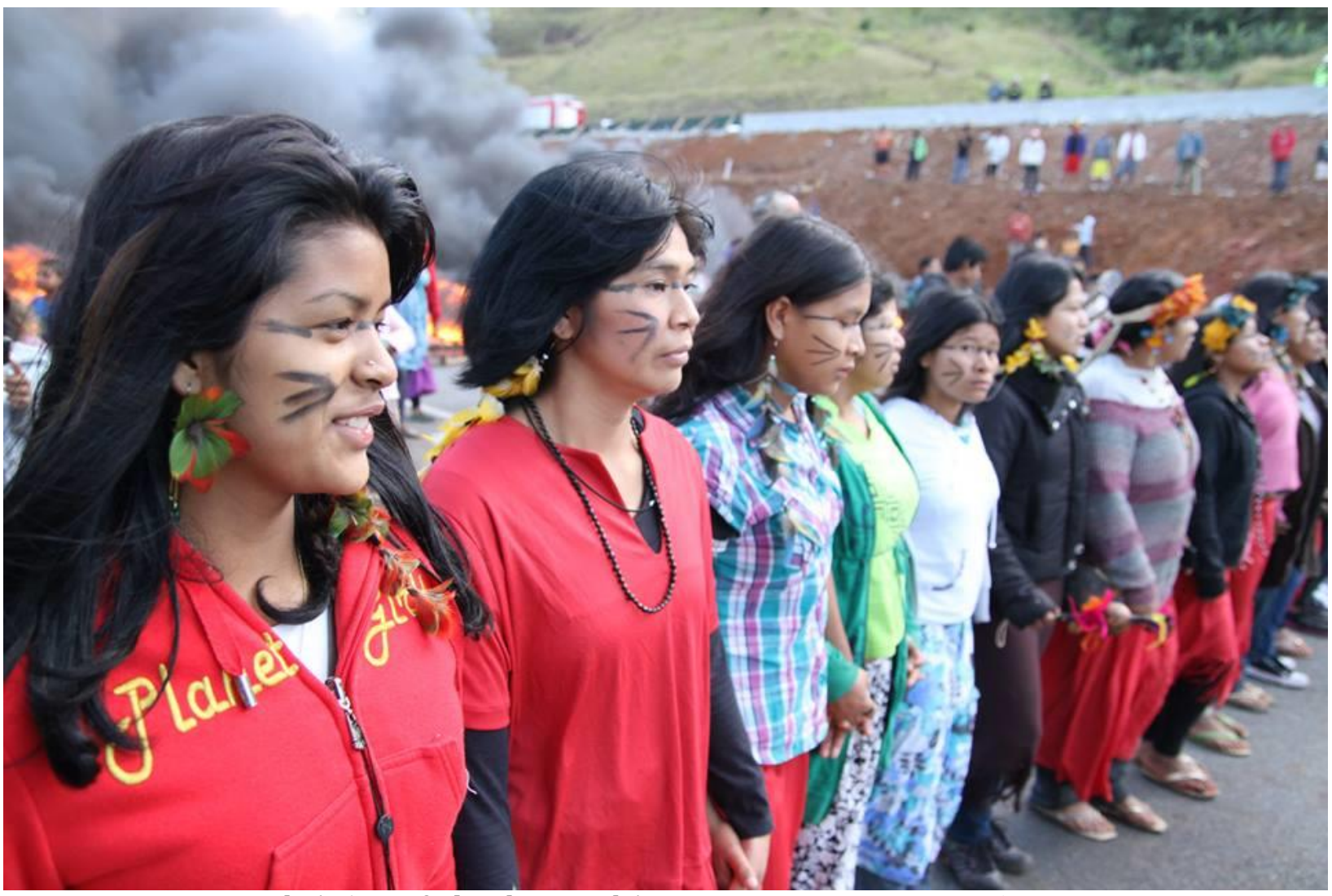

Xondaria kuery fechando a Bandeirantes. Lucas Keese. São Paulo, 2013.

O coordenador Tenonde da CGY também comenta sobre os processos judiciais movidos pelo Governo contra as T.I.s que se sobrepõem aos Parques Estaduais, e que no caso da capital, a T.I. Jaraguá conta com cerca de 300 hectares sobrepostos ao Parque 
Estadual do Jaraguá, e a T.I. Tenondé Porã com 45\% de sua superfície no interior do Parque Estadual da Serra do Mar:

\begin{abstract}
Como indígenas, não pensamos em desmatar. Temos uma forma de viver tradicionalmente, junto à natureza [...] Acreditamos que estar perto do mar, dentro da Mata Atlântica, nos dá fortaleza espiritual para buscar a "terra sem mal" que estabelecem nossas crenças. A maioria dessas áreas, hoje, está dentro de parques estaduais. E somos acusados de invasores de parques [...] Queremos que o governo retire essas ações judiciais, reconhecendo a permanência dos indígenas nas terras que estão em sobreposição, e que possa haver uma gestão compartilhada entre governo do estado, povos indígenas e Funai. (Idem, grifos meus)
\end{abstract}

Esse primeiro ato de ocupar a Bandeirantes, deu o start para uma série de estratégias inovadoras dos Guarani na luta pela demarcação, e fortaleceu muito, principalmente as novas gerações de xondaro e xondaria, que não fraquejaram até conseguir imprimir suas reivindicações na agenda do Governo, através da visibilidade adquirida pela continuidade que suas mobilizações na cidade e na imprensa trouxeram. Foi nesse mesmo vídeo-protesto e com o chamamento público via mídias sociais que os Guarani convocaram todos os apoiadores para um grande ato em outubro de 2013, na Avenida Paulista, intitulado “Ato em Defesa dos Direitos Indígenas e da Constituição Federal”, que também comemoravava os 25 anos de intensa mobilização indígena desde apromulgação da Constituição em 1988. O grande ato, levou a causa Guarani para as ruas da capital e para o mundo da internet, além de protestarem também contra a ameaça iminente de aprovação da PEC 215 e do Projeto de Lei Complementar (PLP) 227, que atacam diretamente seus direitos territoriais, denunciando ali também o genocídio da população menos favorecida promovido pelo Estado, contando com o apoio de quilombolas e indígenas de outros povos e de diversos movimentos sociais jurua (ver Instituto Sociambiental 2013b). O ato também fazia parte da agenda de Mobilização Nacional Indígena, apoiada por organizações indígenas e indigenistas como o Instituto Socioambiental (ISA), o Conselho Indigenista Missionário (Cimi), o CTI e a CPI-SP, além de movimentos sociais como o Greenpeace, a Coordenação Nacional de Comunidades Quilombolas (Conaq), o MPL, entre outros. A Mídia Ninja transmitiu o ato em tempo real pela Internet, atuando também na divulgação de muitos outros atos dos Guarani na capital (ver Instituto Sociambiental 2013a). Ali também as lideranças guarani formaram uma assessoria de imprensa, para falar com as mídias e redes de TV, além de se prepararem para a saída da mobilização por meio de uma reunião interna no Vão Livre do Masp, que ao final contava sempre com uma concentração-meditação que se inspirava na força dos cantos-reza de suas xondaria e na dança-luta dos xondaro, antes de saírem para os atoscaminhadas. Esse primeiro grande ato na cidade marchou da Avenida Paulista até o Mo- 
numento às Bandeiras, localizado ao lado do Parque do Ibirapuera, que presta homenagem aos bandeirantes, responsáveis pelo assassinato de indígenas desde a chegada dos “invasores” jurua. Os Guarani hastearam um pano vermelho nesse Monumento que simbolizava o sangue derramado de seus antepassados, e que também foi pintado de vermelho por apoiadores jurua. Marcos Tupã, em carta batizada de "Monumento à resistência do povo guarani", comenta a respeito desse ato guarani que "homenageia aqueles que nos massacraram”, respondendo às críticas jurua sobre a intervenção:

Para nós, povos indígenas, a pintura não é uma agressão ao corpo, mas uma forma de transformá-lo. Nós, da Comissão Guarani Yvyrupa, organização política autônoma que articula o povo guarani no sul e sudeste do país, realizamos no último dia o2 de outubro, na Av. Paulista, a maior manifestação indígena que já ocorreu em São Paulo desde a Confederação dos Tamoios. Mais de quatro mil pessoas ocuparam a Av. Paulista, sendo cerca de quinhentas delas dos nossos parentes, outros duzentos de comunidades quilombolas e mais de três mil apoiadores não-indígenas, que viram a força e a beleza do nosso movimento. Muitos meios de comunicação, porém, preferiram noticiar nossa manifestação como se tivesse sido uma depredação de algo que os brancos consideram ser uma obra de arte e um patrimônio público. Saindo da Av. Paulista, marchamos em direção a essa estátua de pedra, chamada de Monumento às Bandeiras, que homenageia aqueles que nos massacraram no passado. Lá subimos com nossas faixas, e hasteamos um pano vermelho que representa o sangue dos nossos antepassados, que foi derramado pelos bandeirantes, dos quais os brancos parecem ter tanto orgulho. Alguns apoiadores não-indígenas entenderam a força do nosso ato simbólico, e pintaram com tinta vermelha o monumento. Apesar da crítica de alguns, as imagens publicadas nos jornais falam por si só: com esse gesto, eles nos ajudaram a transformar o corpo dessa obra ao menos por um dia. Ela deixou de ser pedra e sangrou. Deixou de ser um monumento em homenagem aos genocidas que dizimaram nosso povo e transformou-se em um monumento à nossa resistência. Ocupado por nossos guerreiros xondaro, por nossas mulheres e crianças, esse novo monumento tornou viva a bonita e sofrida história de nosso povo, dando um grito a todos que queiram ouvir: que cesse de uma vez por todas o derramamento de sangue indígena no país! Foi apenas nesse momento que esta estátua tornou-se um verdadeiro patrimônio público, pois deixou de servir apenas ao simbolismo colonizador das elites para dar voz a nós indígenas, que somos a parcela originária da sociedade brasileira. A tinta vermelha que para alguns de vocês é depredação já foi limpa e o monumento já voltou a pintar como heróis, os genocidas do nosso povo. Infelizmente, porém, sabemos que os massacres que ocorreram no passado contra nosso povo e que continuam a ocorrer no presente não terminaram com esse ato simbólico e não irão cessar tão logo. Nossos parentes continuam esquecidos na beira das estradas no Rio Grande do Sul. No Mato Grosso do Sul e no Oeste do Paraná continuam sendo cotidianamente ameaçados e assassinados a mando de políticos ruralistas que, com a conivência silenciosa do Estado, roubam as terras e a dignidade dos que sobreviveram aos ataques dos bandeirantes. Também em São Paulo esse massacre continua, e perto de vocês, vivemos confinados em terras minúsculas, sem condições mínimas de sobrevivência. Isso sim é vandalismo. [...] Que tipo de sociedade realiza tributos a genocidas diante de seus sobreviventes? Apenas aquelas que continuam a praticá-lo no presente. Esse monumento para nós representa a morte. E para nós, arte é a outra coisa. Ela não serve para contemplar pedras, mas para transformar corpos e espíritos. Para nós, arte é o corpo transformado em vida e liberdade e foi isso que se realizou nessa intervenção. Aguyjevete pra todos que lutam! (Tupã, 2013b, grifos meus)

Em abril de 2014, os Guarani da capital lançaram também a campanha "Resistência Guarani SP”, com o mesmo objetivo de conferir maior visibilidade e reconhecimento público à necessidade de rapidez e continuidade no processo demarcatório de suas terras, que até aquele momento dependia apenas da assinatura das portarias declaratórias pelo Ministério da Justiça $(\mathrm{MJ})$ para serem reconhecidas oficialmente pelo Estado 
brasileiro como de posse permanente Guarani, já que os estudos de identificação e delimitação das T.I.s em SP já haviam sido publicados e aprovados pela Funai entre 2012 e 2013, após mais de 10 anos do início dos estudos dos GTs designados para essa função (ver Campanha Guarani 2014 e Comissão Guarani Yvyrupa 2014a, 2015a). O lançamento da campanha ocorre com a ocupação simbólica, por parte dos Guarani, durante 24 horas do Museu do Anchieta, localizado no Pátio do Colégio, no centro da cidade, mais um local simbólico da empresa colonial, que celebra o local de fundação da cidade de SP. Esse local simboliza, para os Guarani, um dos marcos das violências sofridas pelos seus antepassados no período colonial pela missão jesuíta que tentava catequizá-los a qualquer custo. A ocupação guarani foi então mais uma estratégia para chamar a atenção e cobrar atitudes em relação às demarcaçoes do MJ e protestar novamente contra a decisão judicial que determinava a reintegração de posse e, consequentemente, o despejo de mais de 700 Guarani do Tekoa Pyau e Tekoa Itakupe da T.I. Jaraguá. A ação foi divulgada na Internet novamente em formato de vídeo-manifesto, falado na língua guarani e legendado em português, no qual os Guarani afirmam o porquê ocuparam o Pátio do Colégio:

Hoje nós indígenas guarani das aldeias de São Paulo ocupamos pacificamente o Pátio do Colégio. Foi aqui que os brancos fundaram essa cidade e começaram a tomar as nossas terras que eram do nosso povo. Fizemos isso pensando que em poucos dias, chega a data que vocês chamam de "Dia do Índio". Nesse dia, porém, nos acostumamos a ser enganados. Cada 19 de abril, os governos promovem festas para os índios, e tentam fazer a gente comemorar, quando não há motivo pra isso. Mas cansamos de ser enganados. Pra nós, "Dia do Índio" será o dia que o Ministro José Eduardo Cardozo assinar a demarcação das nossas terras tradicionais. Ocupando esse lugar simbólico, o Pátio do Colégio, não estamos nos vingando, nem enganando vocês, como já nos fizeram. Queremos apenas surpreendê-los para dizer que precisamos da demarcação das nossas terras. Nossas terras não são mais aqui no centro da cidade, não são no Pátio do Colégio. Esse lugar já foi tomado de nós há muito tempo, e não vamos pedir de volta. Nossas aldeias estão nas margens da cidade, onde sobrou um pouco das matas em que sempre vivemos. Uma de nossas terras perto do Pico do Jaraguá e a outra, no Extremo Sul da cidade. Há muito tempo é lá que estamos para tentar viver em paz a nossa cultura. E muitos de vocês não sabem disso, mesmo estando tão perto de nós. Amanhã, estaremos aqui na frente do Pátio do Colégio ${ }^{85}$, onde convidamos o Ministro Cardozo, para mostrar a ele e a todos vocês, a força de nossas danças e de nossos cantos, e explicar porque estamos lutando pela demarcação de nossas terras. Não vamos nos cansar até atingir nosso objetivo. Não temos outra escolha. (Comissão Guarani Yvyrupa, 2014b, grifos meus)

Essa campanha chamada também de “Assina logo, Cardozo!” incluía uma petição pública online que exigia do Ministro da Justiça a assinatura das portarias declaratórias, e pedia assinaturas de apoio nessa luta. No texto da petição, ressaltaram:

Nós, indígenas guarani da Grande São Paulo, lançamos essa petição para pedir assinaturas daqueles que querem nos apoiar na luta pelos nossos direitos. Nossa esperança é que o apoio de vocês ajude a fazer funcionar a caneta da única pessoa que possui agora o poder de

\footnotetext{
${ }^{85}$ Aqui fica claro o intenso planejamento guarani dos atos a serem realizados na cidade, território já to-
} mado pelos jurua. 
trazer a garantia de nossas terras tradicionais, para termos onde criar nossas crianças, e praticar nossa cultura [...] Somos mais de dois mil indígenas, que continuamos resistindo para manter nosso modo de vida, falando nossa língua e realizando nossos rituais, mas hoje só temos garantido uns pequenos pedaços de terra, onde vivemos apertados e com muita dificuldade. A terra foi feita pelas divindades para todos os povos. Não é nossa, e não é dos brancos. Mas a verdade é que os brancos hoje se dizem donos de todos os lugares onde vivíamos no passado, e para nós não sobrou quase nada, e por isso hoje sofremos. Já faz muito tempo que aguardamos por essa assinatura, mas sabemos que também faz tempo que o Ministro Cardozo não usa a sua caneta para ajudar nenhum povo indígena. Por isso que enviamos para ele de presente uma belíssima caneta decorada com o trançado tradicional guarani, que costumamos usar nos nossos artesanatos tradicionais. Mandamos esses e outros presentes para lembra-lo de sua obrigação, e gravamos um vídeo que vocês podem ver no site da nossa campanha. Mas como pensamos que talvez uma caneta não será suficiente para ele, mesmo que seja tão bonita, anunciamos que nessa campanha lançada agora, para cada assinatura de um apoiador que conseguirmos, compraremos mais uma caneta, que também será enviada para o gabinete do Sr. Ministro. Esperamos o apoio de vocês para que o Ministério da Justiça fique cheio de canetas, presenteadas com a intenção de trazer de volta os direitos que perdemos. (Comissão Guarani Yvyrupa, 2014a, grifos meus)

A caneta utilizada no vídeo, decorada com trançado tradicional guarani, é também benzida com a fumaça (-ataxĩ) do petỹgua. Eles ressaltam ainda que a cada assinatura de apoio ao abaixo-assinado, outra caneta seria enviada para o Ministro, e foi assim que centenas de canetas foram enviadas a seu Gabinete. Em suas mobilizações na cidade, os Guarani levavam faixas de protesto com os dizeres Peme'ẽ jery ore'yry ("Devolvam a nossa terra”) e “Assina logo, Cardozo", cantando-rezando e dançando xondaro ao fazerem a sua caminhada pela cidade, exigindo que seus direitos fossem, de fato, respeitados e cumpridos na prática. Muitas canetas também foram arrecadas nesses atos que aconteciam, principalmente na Avenida Paulista, com concentração no Museu de Arte de São Paulo Assis Chateaubriand (MASP), palco de saída de inúmeras mobilizações sociais em SP. A estratégia guarani através dessas mobilizações nas ruas da cidade de buscar dialogar com a sociedade em busca de apoio às suas reivindicações, se dava paralelamente também ao uso em escala mais intensiva que as novas gerações de lideranças guarani faziam de intervenções políticas via redes sociais e outras ferramentas de Internet como as petições públicas, nas quais expunham o porquê de suas ações por meio de vídeos e manifestos, explicitando assim as intenções do seu movimento político, e se fazendo cada vez mais visíveis para àqueles que não os viam e, com isso, mais barulho, não só em SP, mas também junto a outras mobilizações do movimento indígena nacional.

Em junho de 2014 o ato guarani, que contou com o apoio de outros movimentos sociais, protestou novamente contra a PEC 215 em frente à Assembleia Legislativa do Estado de SP (Alesp) onde ocorria, ao mesmo tempo, uma audiência pública acerca da PEC organizada por integrantes da bancada ruralista. Dali eles partiram caminhando novamente até o Monumento às Bandeiras, onde mais uma vez realizaram uma intervenção em que afixaram uma faixa com os dizeres "Bandeirantes de ontem, ruralistas de 
Página 102

hoje”, fazendo frente aos recorrentes ataques jurua à demarcação de terras indígenas no país. Essa manifestação foi chamada por um manifesto público divulgado pela CGY, o "Manifesto Antirruralista", que convocava os movimentos sociais do campo e da cidade para se unirem a eles na formação de uma "Frente Antirruralista", como forma de reagir contra os ataques aos seus direitos promovidos por políticos ligados ao agronegócio, que também visam a criminalização e enfraquecimento da luta pela reforma agrária e moradias populares:

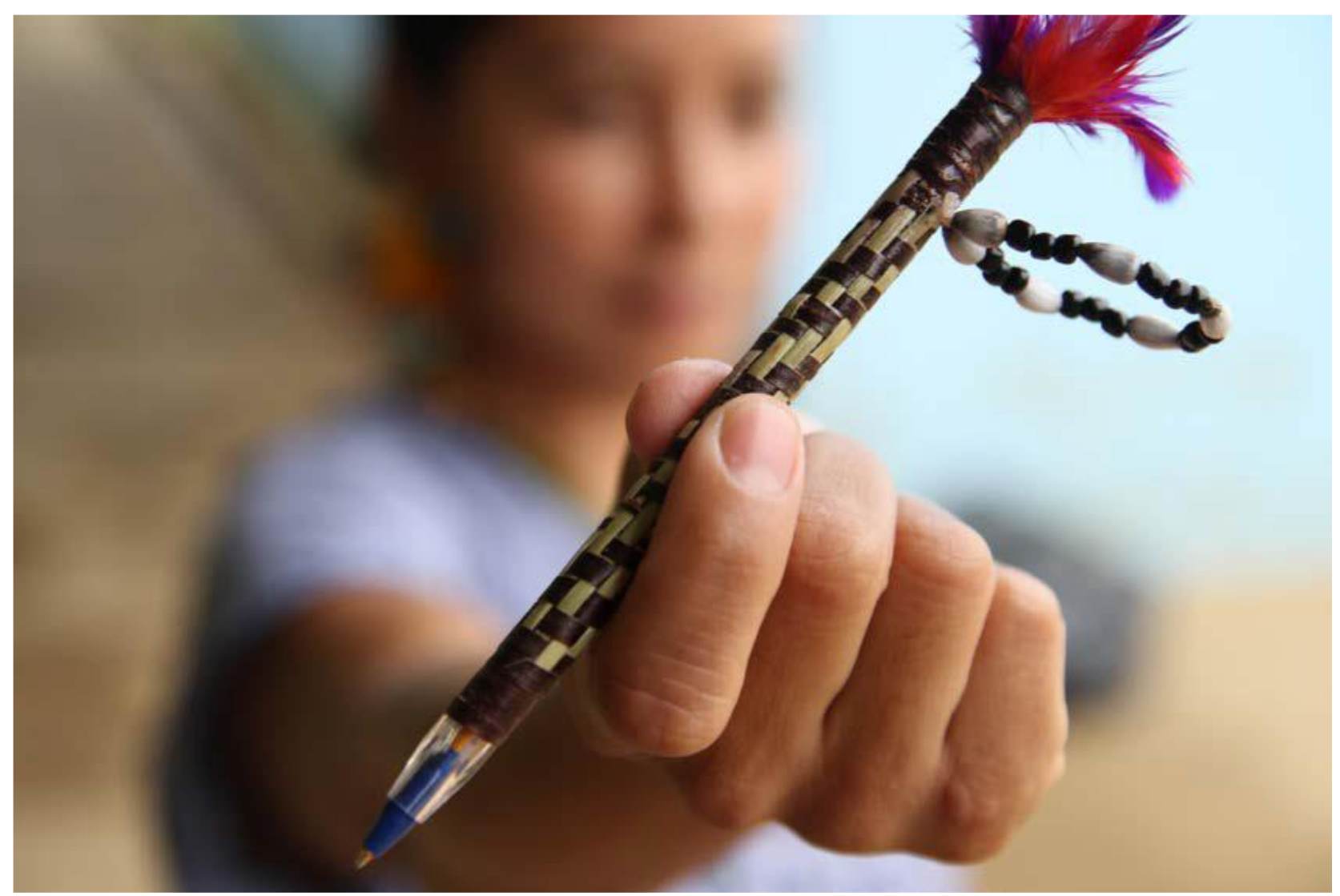

Assina logo, Cardozo. Lucas Keese. Tekoa Tenonde Porã, 2014.

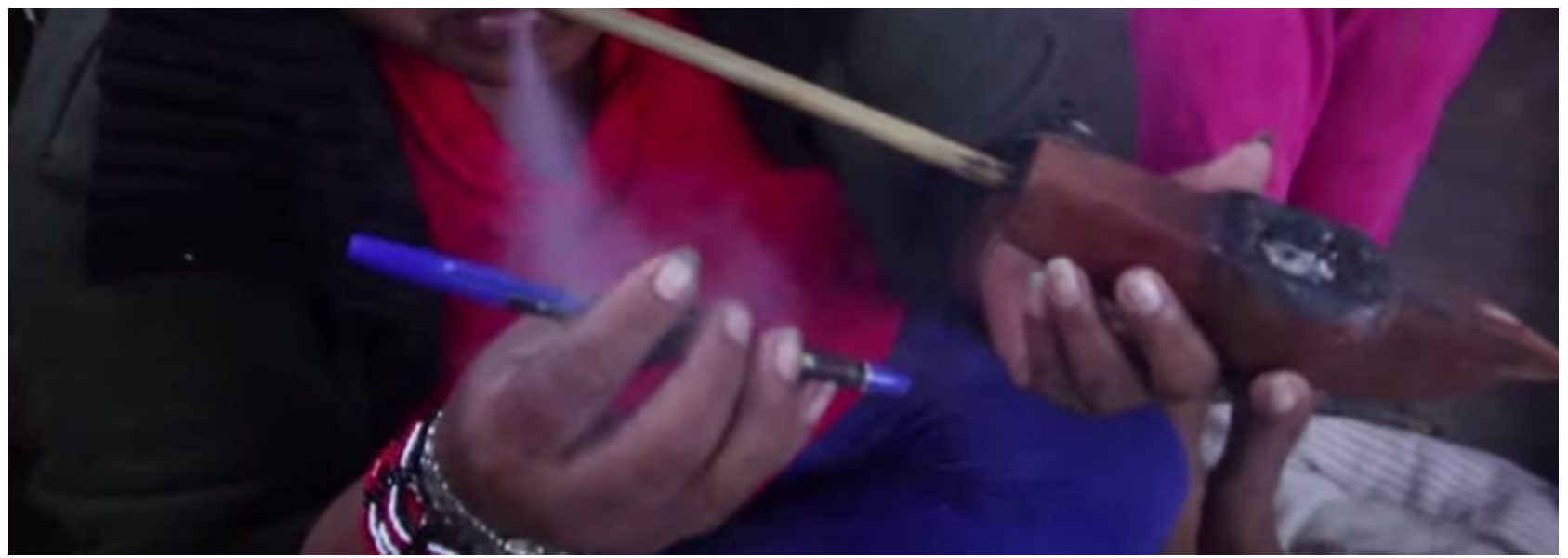

Enfumaçando (omoataxĩ) a caneta dos jurua com o petỹgua. Arquivo CGY. São Paulo, 2014. 
[...] Os ruralistas de hoje são os bandeirantes de ontem, e por meio da caneta querem nos matar como nos mataram no passado com suas armas de fogo. Têm o espírito dos bandeirantes aqueles que usam de seu poder para enriquecer e concentrar terras, enquanto nós povos originários continuamos nas beiras de estrada, espoliados de nossos tekoa, e grandes massas de excluídos seguem sem ter onde dormir, sem ter onde morar, sem ter onde plantar. Enquanto os brancos homenageiam em estátuas, ruas e rodovias aqueles que nos mataram, seus governantes continuam encarnando o espírito dos bandeirantes. Pedro Alvares Cabral foi o primeiro ruralista. Muitos o sucederam [...] Estamos felizes hoje de contar com o apoio de outros movimentos sociais que defendem os excluídos, pois isso nos permite saber que não são todos os brancos que carregam o espírito dos bandeirantes. São muitos os que percebem que só quando esse espírito ruim for derrotado, teremos a vitória dos de baixo, dos povos humildes. Aguyjevete ao Movimento Passe Livre, que desde o ano passado tem nos lembrado que “os barões do campo, são os mesmos barões das catracas”, e mais uma vez se somam conosco. Aguyjevete ao Movimento dos Trabalhadores Rurais Sem Terra de São Paulo, que vem agora se somar, pois os mesmos latifundiários que nos massacram nas florestas e no Congresso, são os que os massacram cotidianamente no campo. Aguyjevete ao Comitê Popular da Copa de São Paulo, que vem junto pra escancarar a todos que essa é a Copa dos Ruralistas, aliados de primeira hora das empreiteiras e mineradoras que enriquecem junto com a Fifa. Com esse ato, chamamos a todos os de baixo, do campo ou da cidade, a todos os excluídos, para se juntarem em torno de uma Frente Antirruralista na luta para expurgar dessas terras o espírito dos bandeirantes, que comanda essa ilha desde a invasão de Cabral. Vamos mostrar que terra é pra todos que vivem dela! (Comissão Guarani Yvyrupa, 2014c, grifos meus)

Os Guarani saíram às ruas novamente, em julho de 2014, caminhando do Masp até o Tribunal Regional Federal da $3^{\text {a }}$ Região, em SP, onde protocolaram um documento exigindo, mais uma vez, a assinatura imediata das portarias declaratórias das T.I.s e a suspensão da reintegração de posse do Tekoa Pyau na T.I. Jaraguá. Esse ato soma-se à retomada do Tekoa Itakupe no mesmo mês, que se encontrava sob ameaça de reintegração. Houve ainda mais um protesto em 2014, durante a cerimônia de abertura da Copa do Mundo FIFA de futebol, em junho, na Arena Corinthians (SP). Quando os olhos de todo o mundo estavam voltados para o grande campeonato mundial, os Guarani souberam se aproveitar dessa oportunidade para dar mais visibilidade à luta pela demarcação. Foi então que um jovem xondaro guarani, previamente selecionado pelas lideranças guarani e convidado pela organização do evento para participar de um ato solene antes da primeira partida do torneio representando a população indígena no país, acompanhado de dois outros jovens, um branco e uma negra, caminhou junto a eles pelo gramado do Estádio, onde soltaram pombas brancas, celebrando a paz entre as nações. Depois disso, o jovem xondaro corajosamente, diante de centenas de seguranças e câmeras das redes de televisão, rádio e órgãos de impressa, estendeu para o alto para todos verem uma faixa em que estava escrito "Demarcação Já”, que havia escondido antes da entrada no campo, na própria cueca (Comissão Guarani Yvyrupa 2014d; ver também Locatelli 2014). 


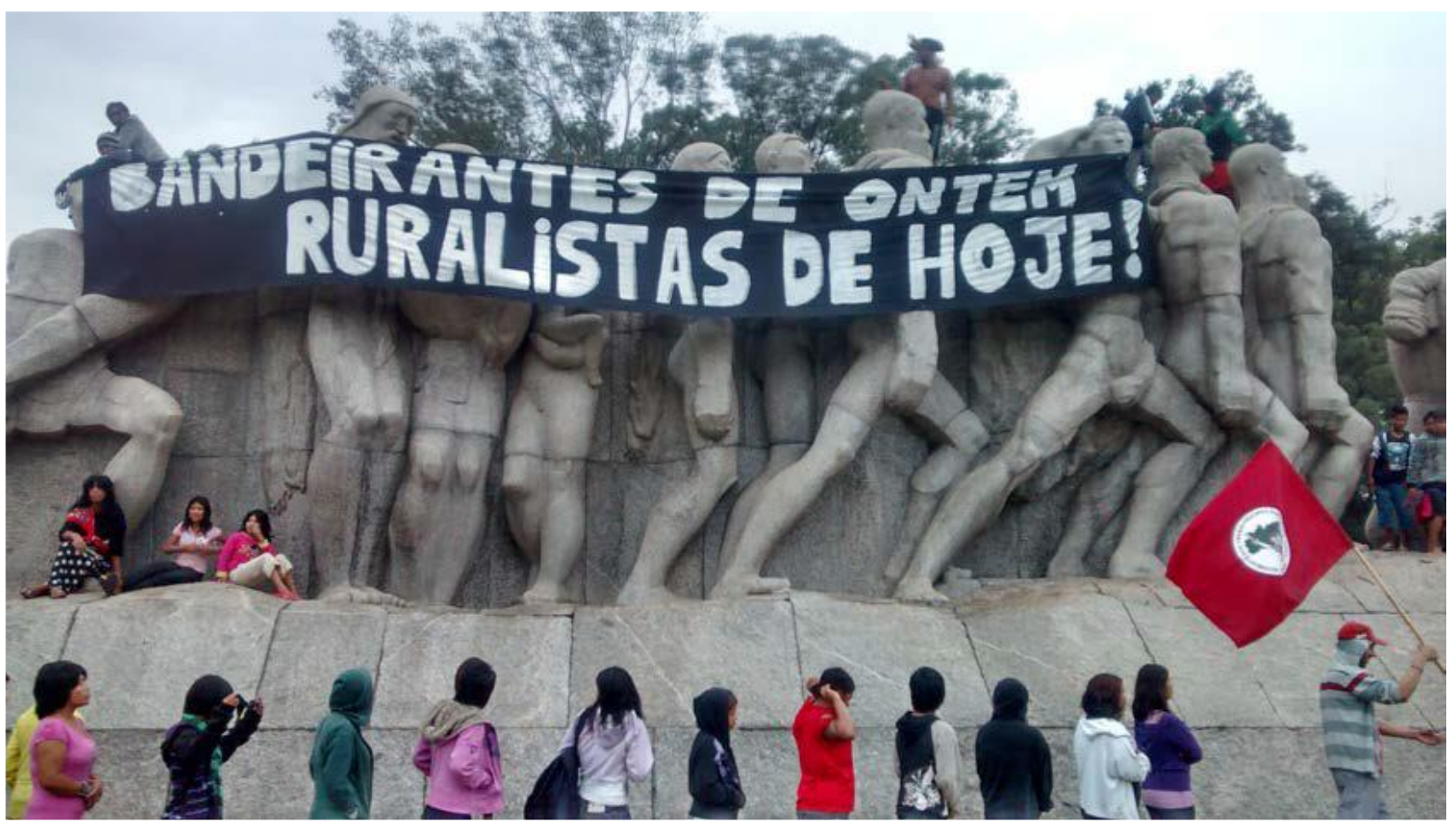

Ato guarani “Anti-Ruralista”. Rafael Nakamura. São Paulo, 2014.

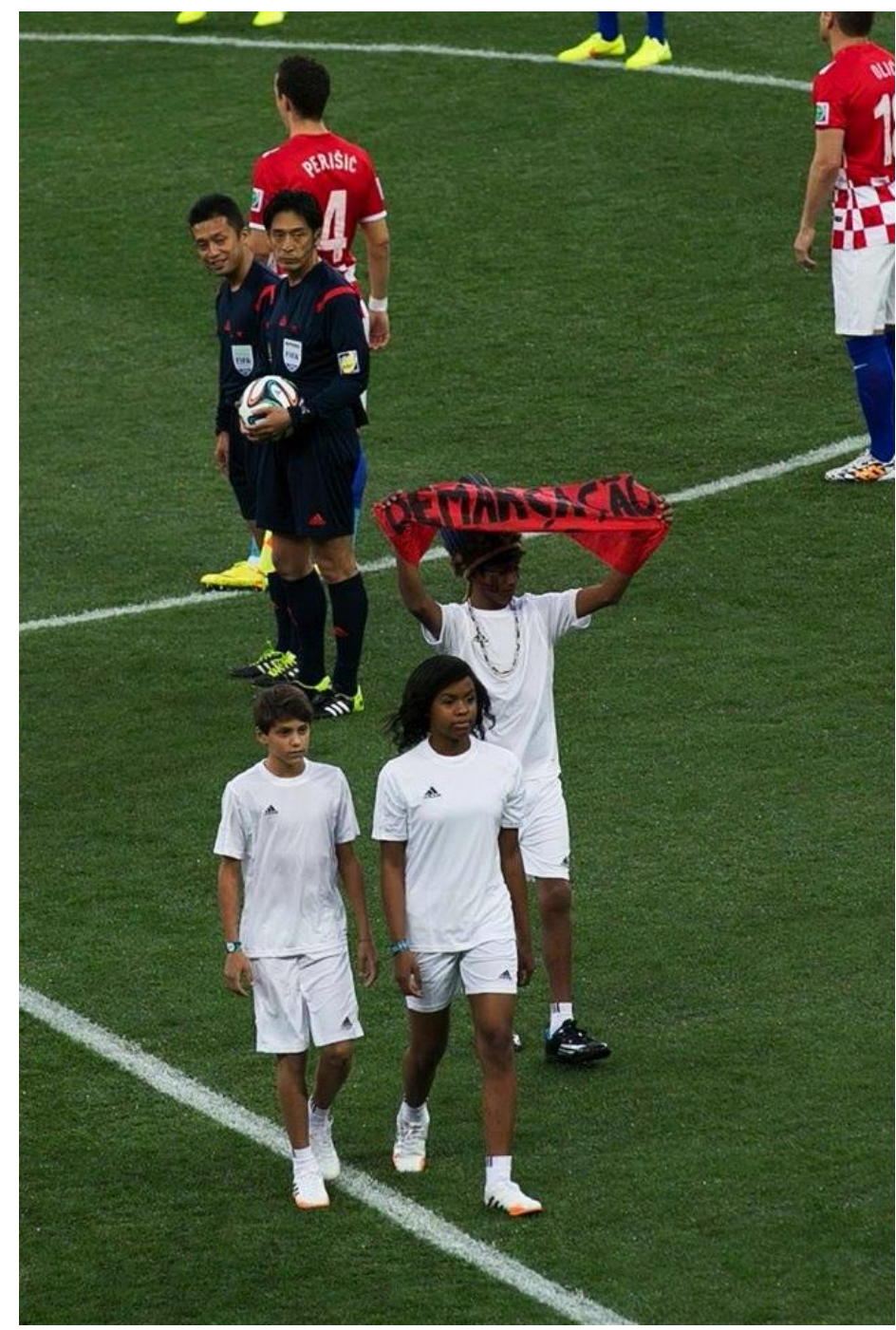

Xondaro protesta na Abertura da Copa do Mundo. Arquivo CGY. São Paulo, 2014. 
O protesto, como era de se esperar, foi censurado pela Federação Internacional de Futebol (Fifa), e as redes de TV nacionais também tentaram omitir essa imagem, mas ela foi amplamente noticiada pela imprensa online, principalmente nas redes sociais internacionais, gerando muita visibilidade à luta. Em agosto de 2014, diante, mais uma vez, da ameaça iminente de despejo judicial, as comunidades guarani organizaram novamente outro ato de protesto contra a reintegração de posse do Tekoa Pyau, dessa vez na retomada do Tekoa Itakupe (T.I. Jaraguá) (ver Instituto Socioambiental 2014). O protesto ocorreu na data limite estipulada pela Justiça para que a Funai realizasse a desapropriação da área, onde centenas de guarani vivem sob condições muito precárias, à margem da Rodovia dos Bandeirantes. Em abril de 2015, a campanha "Assina logo, Cardozo" continua e o Tekoa Itakupe, ainda sob risco de reintegração de posse, leva a uma nova onda de mobilizações das comunidades guarani na cidade, organizadas pela CGY.

Ao mesmo tempo que os Guarani ganhavam cada vez mais apoiadores na luta, acabavam também incomodando cada vez mais os que se dizem "donos" das terras que ocupam. No Tekoa Itakupe, o pedido de reintegração de posse movido por Antônio Tito Costa quase chegou a ser cumprido pela Polícia Militar em 2014, mas as comunidades mesmo diante dessa incerteza, com fé em sua caminhada rumo a garantia de suas terras, se mantiveram firmes e finalmente conquistaram a assinatura da Portaria Declaratória da T.I. Jaraguá em maio de 2015 , portaria esta que rompe um longo período sem atitudes tomadas pelo Governo Federal a respeito das demarcações de T.I.s no Brasil (ver Instituto Socioambiental 2015a). A partir dessa vitória do movimento, o mote das manifestações se torna “O Jaraguá é Guarani! Agora é Tenonde”, para reivindicar mais uma vez a imediata assinatura da portaria declaratória da T.I. Tenonde Porã pelo Ministro da Justiça e a suspensão da ameaça, ainda vigente, de reintegração de posse no Tekoa Itakupe. Por isso, em junho de 2015, os Guarani outra vez se concentraram no Vão Livre do Masp em um grande ato onde caminharam cantando-rezando suas "músicas tradicionais", dançando sua “dança de guerra” (xondaro), "e principalmente rezando para que Nhanderu ilumine o coração endurecido das autoridades dos Juruá", até a Justiça Federal (Fórum Pedro Lessa), onde ocorria uma audiência de conciliação a respeito da reintegração (Comissão Guarani Yvyrupa 2015b). É também nesse mesmo período que é lançado o rap guarani "A todo povo de luta”, feito por jovens guarani da T.I. Tenonde Porã, como música de protesto que fala sobre a luta pela demarcação: 
a todo povo guarani eu saúdo:

Mbya, Guarani, Kaiowa, Nhandeva

Antes do jurua subir a serra

eu mando um abraço para todo irmão negro

hoje já corre no sangue, bate forte no peito

carrego o dom de ritmo e poesia

eu e todo povo da periferia

pra chegar e somar

canta rap sempre quis

mesmo sofrendo a gente sabe ser feliz

medo de prova, o dia a dia é nosso teste

A todo povo de luta: Aguyjevete!

Demarcação já - é a terra protegida

Demarcação já - é a mata preservada

nossa maior luta é por autonomia

xondaros e xondarias todo dia. (Comissão Guarani Yvyrupa, 2015c)

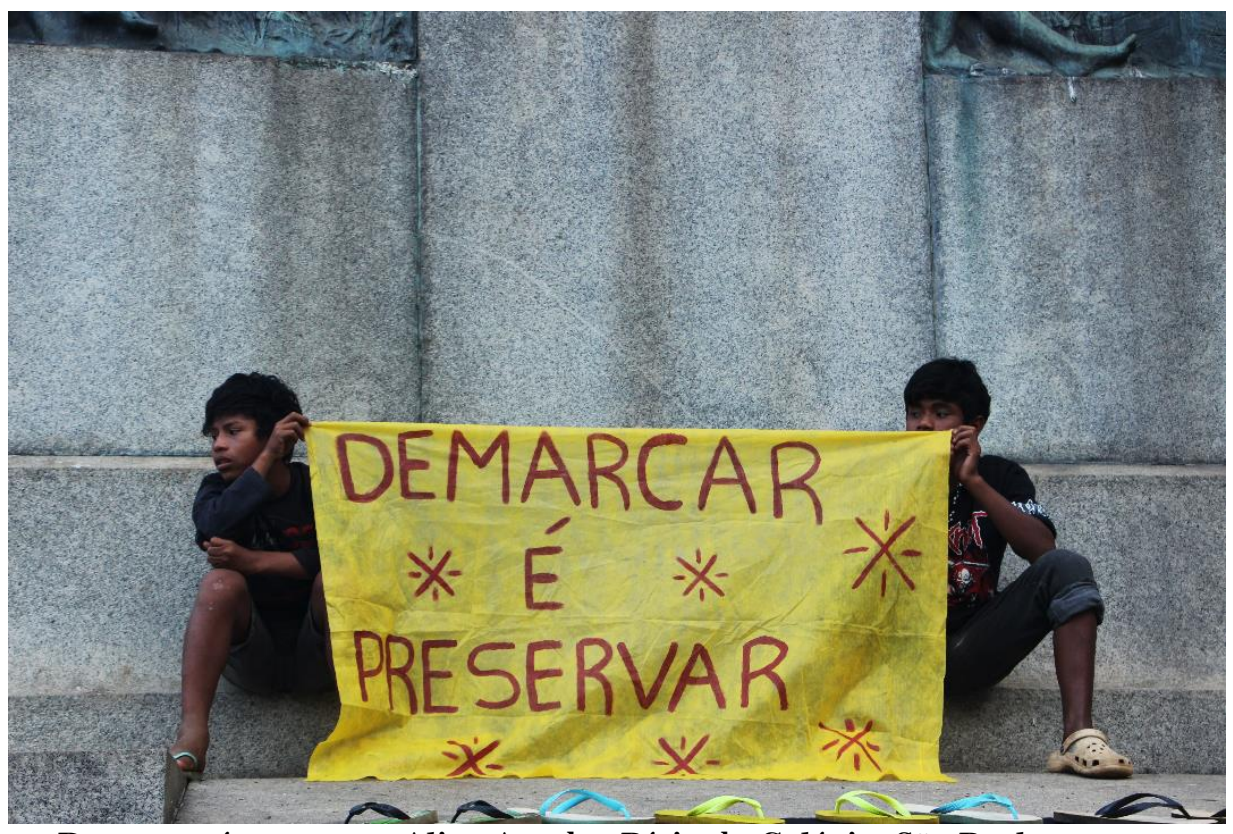

Demarcar é preservar. Aline Aranha. Pátio do Colégio, São Paulo, 2015.

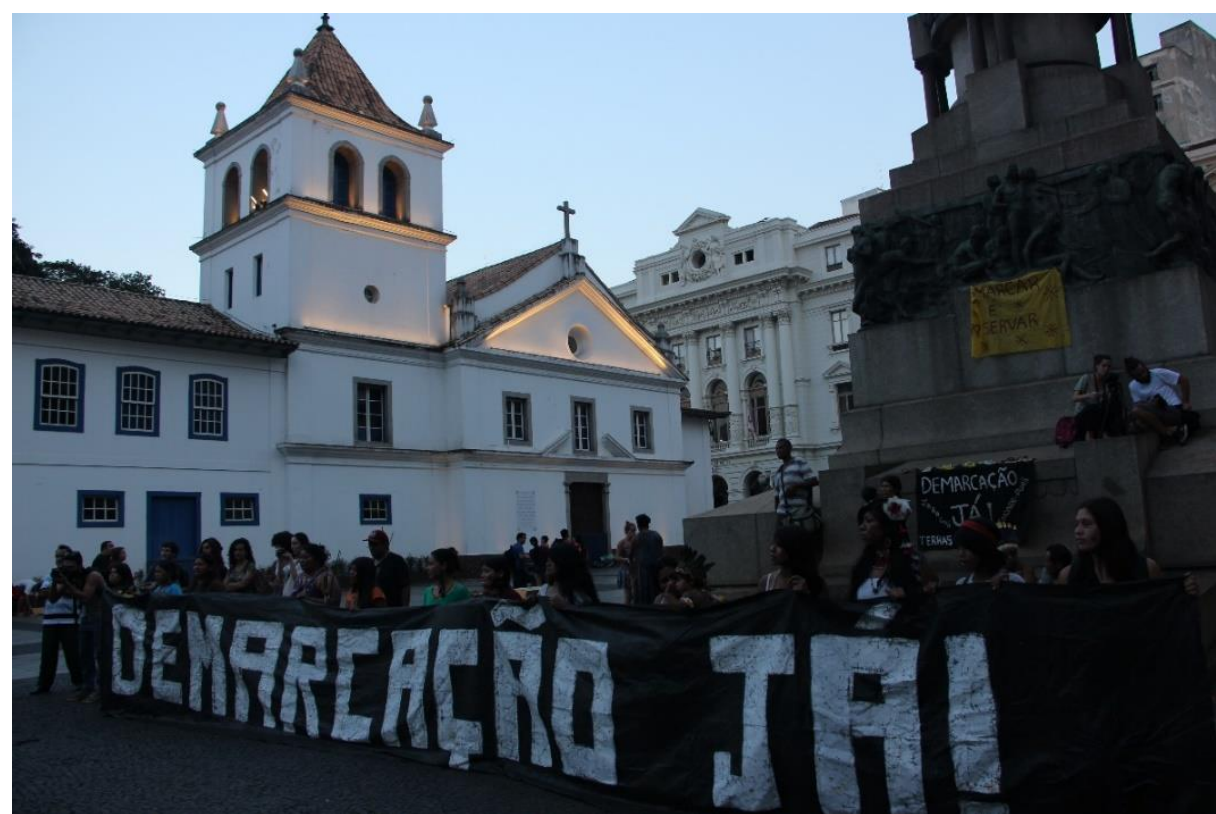

Demarcação já! Aline Aranha. Pátio do Colégio, São Paulo, 2015. 


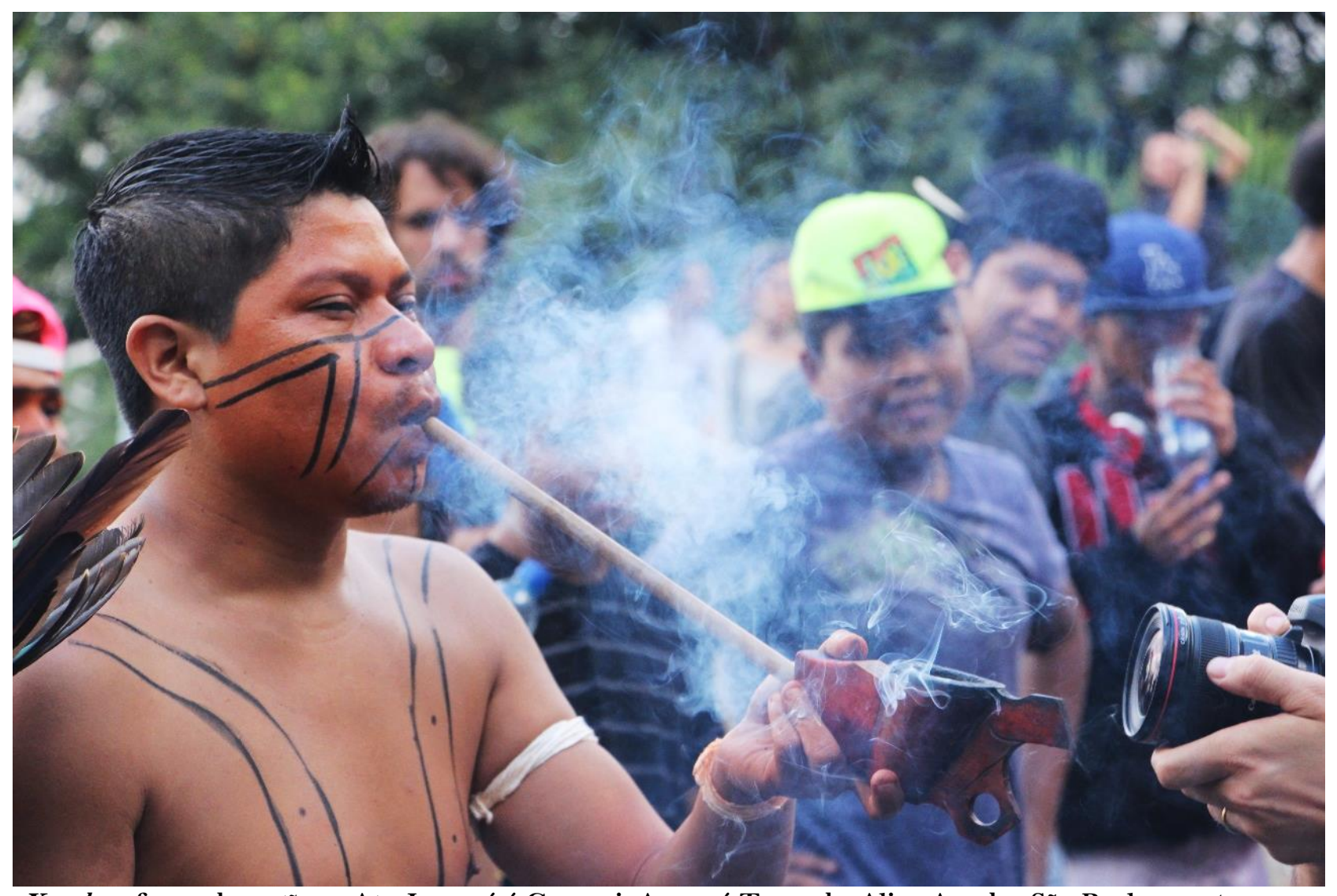

Xondaro fumando petỹgua. Ato Jaraguá é Guarani, Agora é Tenonde. Aline Aranha. São Paulo, 2015.
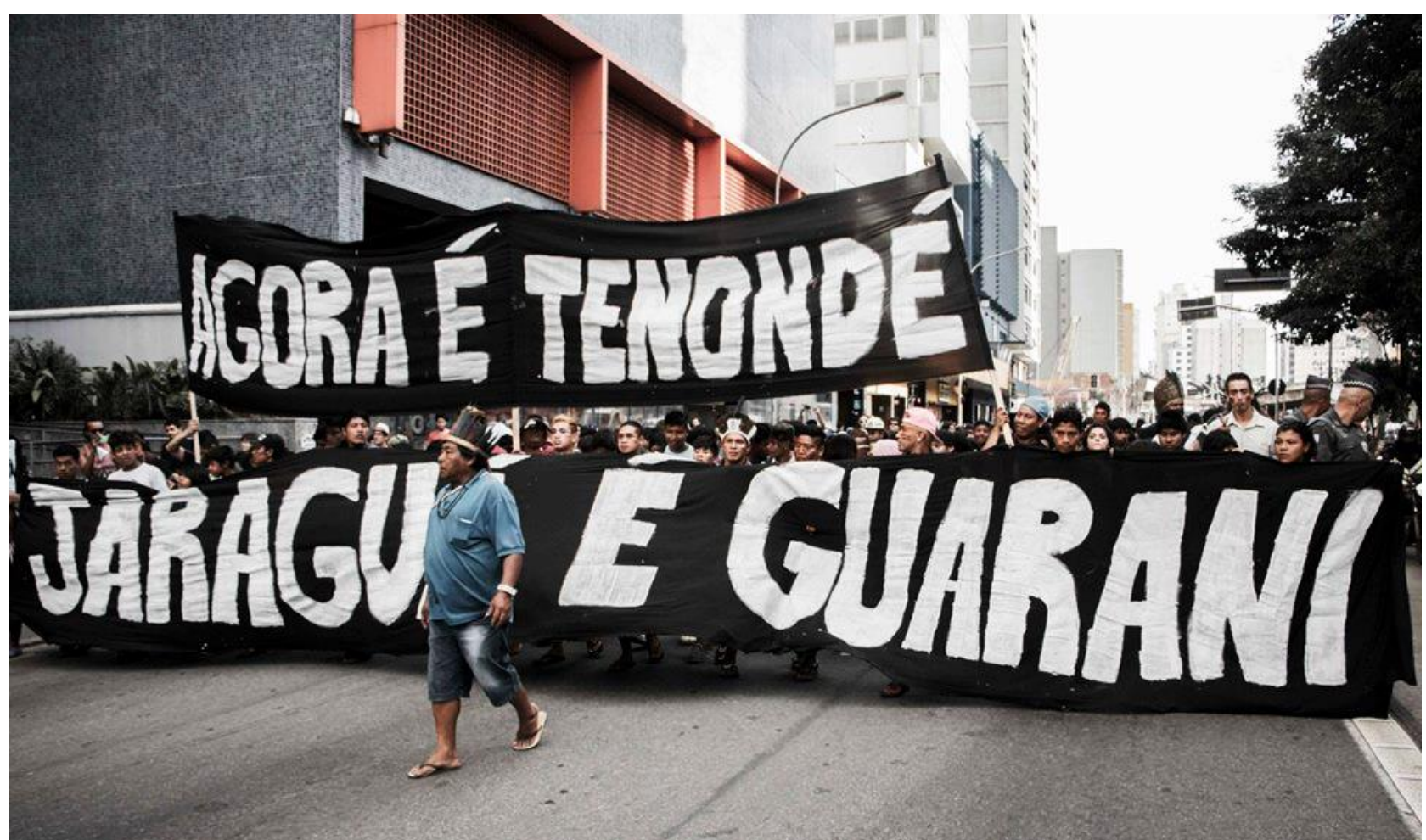


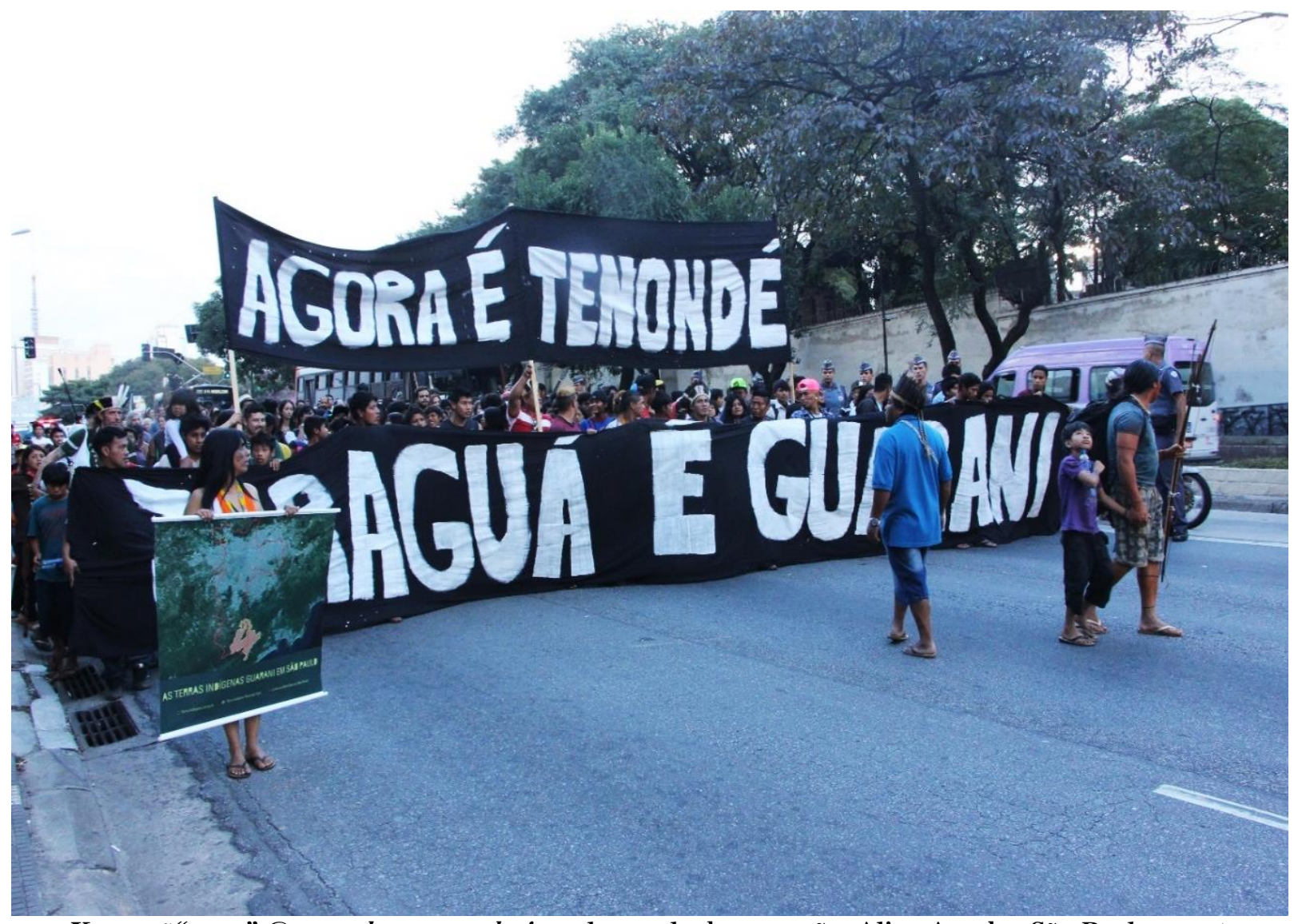

Xeramoĩ “puxa” @s xondaro e xondaria na luta pela demarcação. Aline Aranha. São Paulo, 2015.

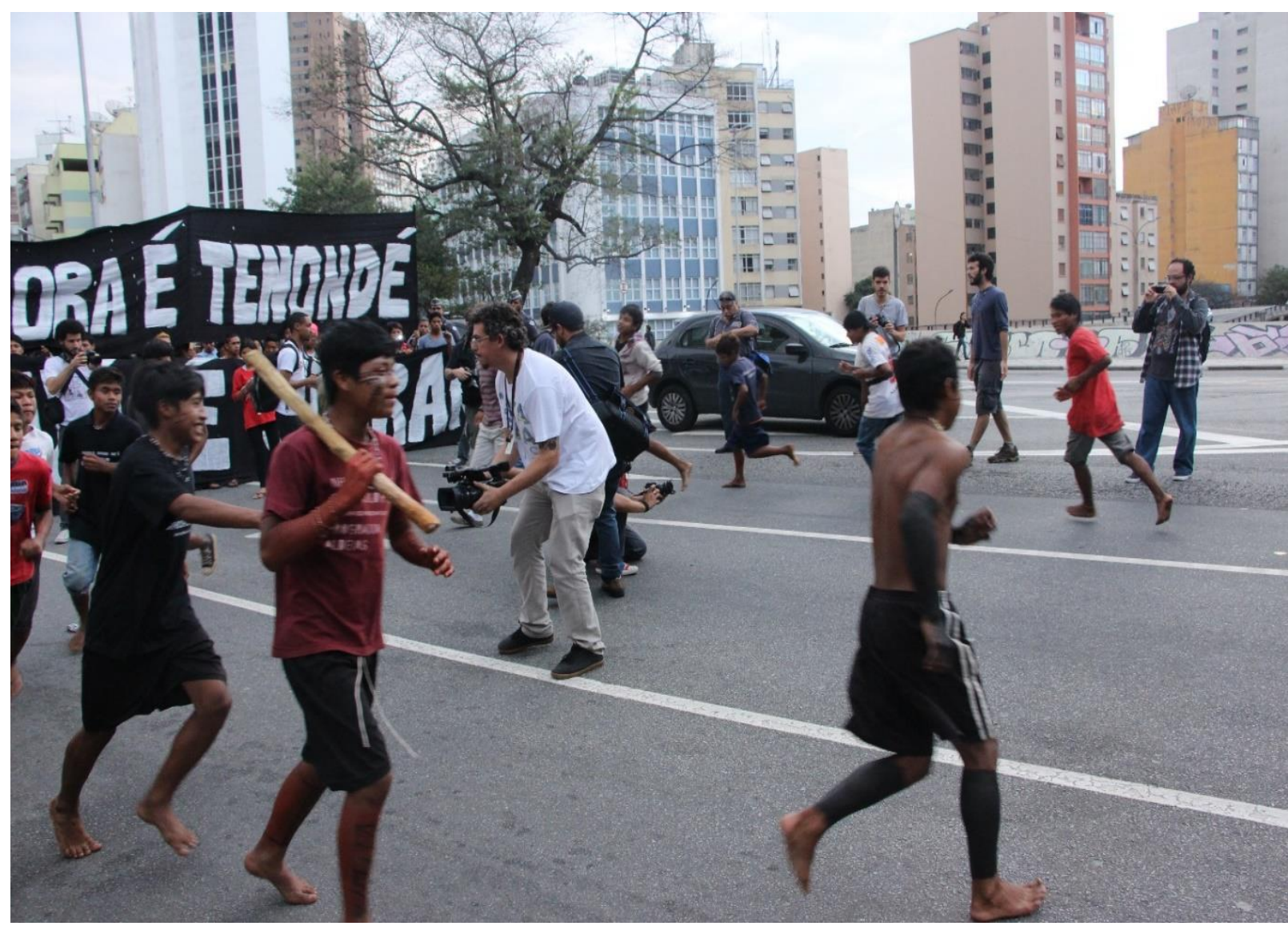

Força, leveza, coragem e alegria na luta pela demarcação. Aline Aranha. São Paulo, 2015. 


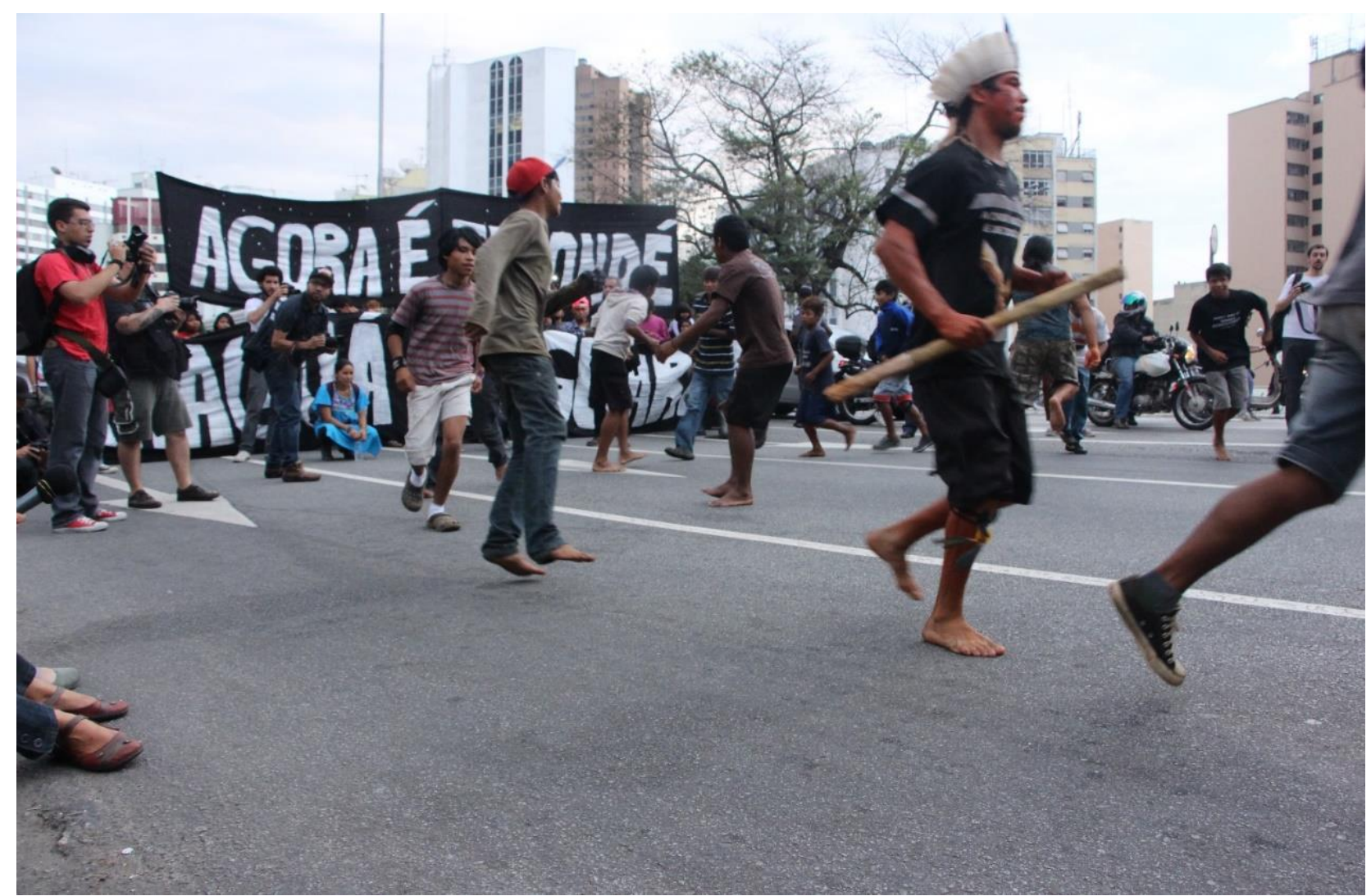

Dançando na cidade, na luta pela demarcação. Aline Aranha. São Paulo, 2015.

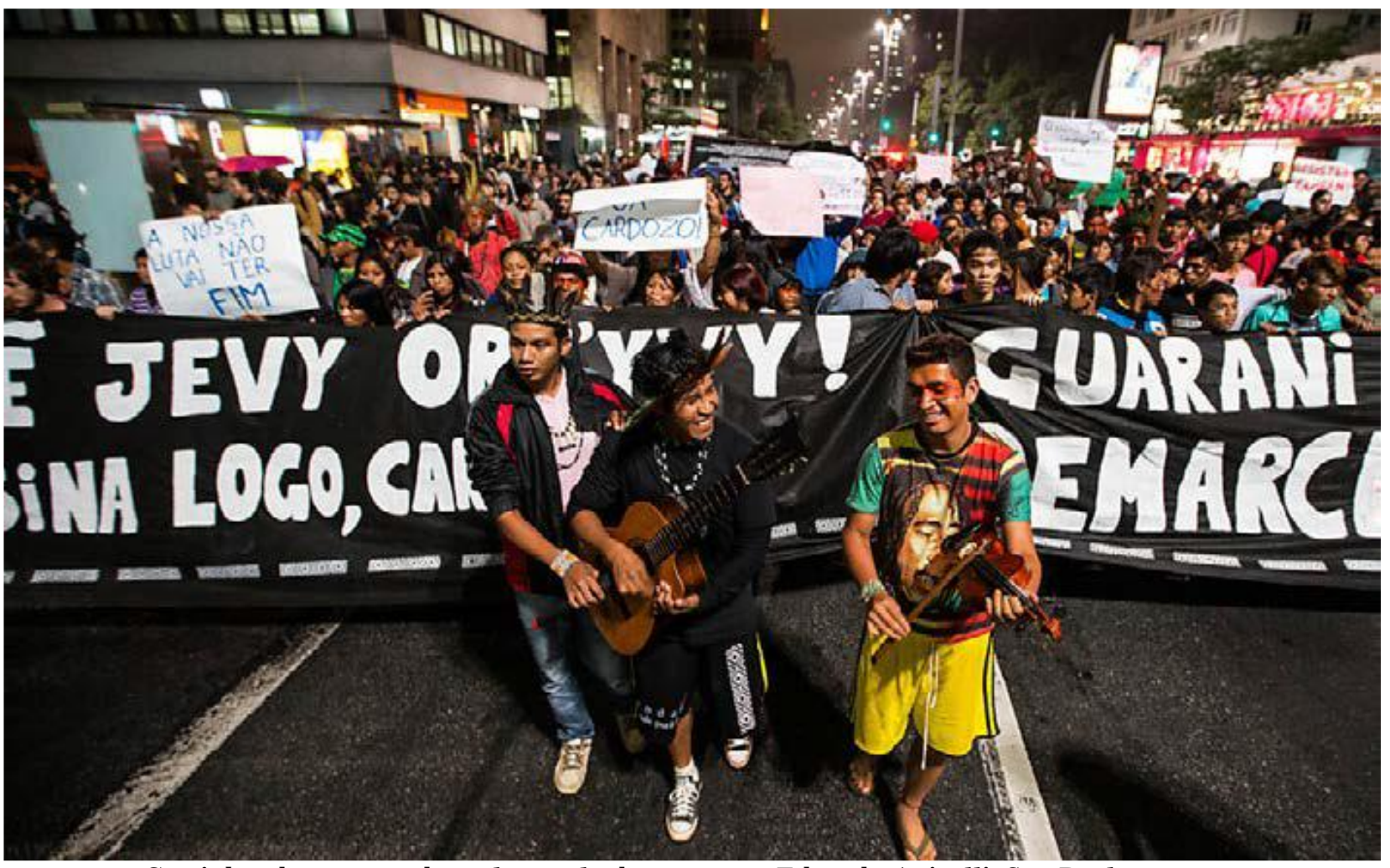

Caminhando e cantando na luta pela demarcação. Eduardo Anizelli. São Paulo, 2014.

No mês seguinte, agosto de 2015, mais um ato na Paulista é convocado, dessa vez pela Articulação dos Povos Indígenas do Brasil (Apib), Articulação dos Povos Indígenas 
da Região Sudeste (Arpin-sudeste) em parceira com a CGY (ver Instituto Socioambiental 2015b). Nesse ato, os Guarani receberam o apoio de lideranças indígenas de todo o país, que marcharam em manifestação ao Dia Internacional dos Povos Indígenas, instituído pela ONU há cerca de vinte anos, comemorado em 9 de agosto. Mas, diante da crise que toma conta de toda a agenda política do país, a incerteza da manutenção dos direitos conquistados na Constituição de 1988 torna-se uma ameaça real e as comunidades guarani de SP resolveram então intensificar suas ações na cidade, decidindo não mais esperar a atitude do Estado brasileiro em cumprir com seu dever constitucional no processo de demarcação de T.I.s. Motivados pela publicação de portarias declaratórias de outras T.I.s pelo MJ que aconteciam já nos últimos respiros do Governo Dilma (Partido dos Trabalhadores - PT), os Guarani resolveram adotar uma nova estratégia, afirmando em carta divulgada pelo site do ISA: "Muito tempo já passou e não existe mais nenhum motivo para seguirmos esperando confinados enquanto vemos a cidade crescer e nossos problemas aumentarem. ANTES QUE SEJA TARDE! ANTES QUE SEJA TEMER! DEMARCAÇÃO JÁ!” (Instituto Socioambiental 2016a). Para tanto, se prepararam fisicamente, se fortaleceram espiritualmente para não mais aceitar serem iludidos, iniciando uma outra série de ações que culminaram no atendimento de suas expectativas depois de anos de mobilizações.

Reconhecida pela Funai em 2012 com 15.969 hectares de extensão, a T.I. Tenonde Porã teve seu processo de demarcação iniciado oficialmente em 2002 pela reivindicação e sob intensa vigilância e mobilização das próprias lideranças guarani e abriga hoje uma população de mais de 1400 pessoas, em um total de seis aldeias espalhadas ao longo da T.I., algumas dessas, fruto de retomadas. Foram mais dez anos até que o órgão indigenista aprovasse e publicasse o Relatório Circunstanciado de Identificação e Delimitação (RCID) em 2012 e, desde então, os Guarani aguardavam a assinatura da portaria declaratória pelo MJ, sem contar com nenhum impedimento legal ${ }^{86}$ para tanto, vivendo confinados a uma área de apenas 52 ha (correspondente às T.I.s oficialmente homologadas na década de 1980, a T.I. Barragem e a T.I. Krukutu, cada qual com cerca de 26 ha), fator que ocasiona uma série de desequilíbrios sociais e culturais.

\footnotetext{
${ }^{86}$ De acordo com o Decreto Presidencial n 1775 , que regulamenta o processo de demarcação de T.I.s no país, abre-se, a partir da publicação desses estudos, o período de 90 dias para que os interessados apresentem contestações administrativas. Após esse período, no caso das T.I.s. localizadas na capital de SP, já encerrado, cabe ao Ministro da Justiça publicar uma portaria declaratória que permite iniciar o processo de indenização dos ocupantes não-indígenas para devolver as áreas ao usufruto exclusivo das comunidades indígenas.
} 
Diante das expectativas crescentes da publicação da portaria da T.I. Tenonde Porã, em razão da publicação de outras portarias no país, frustradas pelo Governo, as comunidades guarani de SP decidiram reivindicar diretamente, através da CGY, o compromisso pela demarcação da T.I. do prefeito Luiz Marinho (PT-SP) da cidade de São Bernardo do Campo, no ABC paulista (ver Instituto Socioambiental 2016b). Xondaros ocuparam o saguão de entrada da Prefeitura por cerca de duas horas, saindo de lá com uma declaração oficial assinada pelo próprio prefeito em apoio à demarcação da T.I. que possui parte de seus limites dentro desse município. No dia seguinte, 4 de maio de 2016, foi a vez do saguão do escritório da Presidência da República, na Avenida Paulista, ser ocupado por mais de 200 xondaros e xondarias para pressionar e exigir que uma comissão de representantes de suas comunidades fosse recebida pelo Ministro da Justiça em Brasília para efetivar a assinatura e publicação da portaria declaratória da T.I. (pendente desde 2012) garantindo assim a posse permanente da área, antes que o Governo Dilma sofresse o impeachment no Senado Federal, em vias de ocorrer. As comunidades pressionavam o Governo em release divulgado pelo site do ISA chamado "AVISO DE PAUTA: O dia D de Demarcação da Terra Indígena Tenonde Porã”:

\begin{abstract}
[...] O ministro da justiça já mudou de nome, até a presidente pode mudar e seguem adiando nosso direito de viver em nosso território tradicional. Estamos cansados de esperar e por isso resolvemos dizer: BASTA! Exigimos Demarcação Já! A prefeitura da cidade de São Paulo já manifestou publicamente seu apoio à demarcação de nossas terras no município. A inclusão das TIs Jaraguá e Tenondé Porã no Plano Diretor da cidade como Zona Especial de Proteção Ambiental (ZEPAM) foi um passo importante nesse sentido. Na terçafeira (03/05) nossas lideranças estiveram na prefeitura de São Bernardo e conseguiram mais um apoio, a assinatura de um documento em que o prefeito de São Bernardo, Luiz Marinho, se manifesta a favor da demarcação da TI Tenondé Porã. Agora é a vez do Ministro da Justiça, Eugênio Aragão e da Presidente Dilma Rousseff se mostrarem do lado da demarcação de nossa terra. Se a presidência e os dois prefeitos envolvidos na questão são todos do Partido dos Trabalhadores, não acreditaremos nas supostas boas intenções do PT com o povo Guarani se a portaria declaratória da TI Tenonde não sair enquanto o partido segue no Governo Federal. O Partido dos Trabalhadores, que hoje está sendo atacado por setores conservadores da sociedade, será responsável caso não ocorra essa demarcação e fiquemos sem garantias de viver em nosso território tradicional, podendo ser expulsos de várias aldeias! Agora não há mais desculpas, se não houver assinatura da portaria declaratória nos próximos dias, o PT será favorável a que fiquemos sem terras para viver, será favorável ao nosso genocídio! (Instituto Socioambiental, 2016a)
\end{abstract}

A ocupação do saguão durou cerca de 8 horas e também ocorreu de maneira pacífica, mesmo munidos de seus arcos-flechas, da fumaça dos petỹgua assim como dos cantos-reza de força, coragem e resistência das xondarias e dos xondaros que não cessarem até o final, além de contarem com a presença e a força política-espiritual de alguns dos seus sábios conselheiros e anciões da comunidade ali presentes. O Ministro da Justiça Eugênio Aragão, que cedeu pela pressão da ocupação em SP, respondeu amigavelmente 
ao protesto e se comprometeu a vir no dia seguinte à capital, junto à comissão de lideranças que viajou à Brasília, para a tão esperada assinatura da Portaria Declaratória $\left(\mathrm{n}^{\circ}\right.$ 548) da T.I., publicada naquele mesmo dia, 5 de maio de 2016 no Diário Oficial da União, reconhecendo oficialmente a T.I. Tenonde Porã como sendo de posse permanente dos Guarani-Mbya, dando continuidade enfim ao processo demarcatório iniciado no início dos anos 2000. A portaria é assinada em cerimônia realizada no mesmo escritório da Presidência da República em SP, com a presença de lideranças e famílias das comunidades guarani que habitam a T.I., acompanhadas da presença e apoio do então prefeito da cidade, Fernando Haddad (PT) (ver Centro de Trabalho Indigenista 2016a e Instituto Socioambiental 2016d). Essa conquista, como viemos mostrando, é fruto de anos de muita mobilização dos Guarani, que saíram de suas aldeias com seus cantos-reza e danças de guerra lutando pela regularização jurídica de suas terras de ocupação tradicional. Ainda que tenham conquistado mais esta vitória, com a declaração das T.I.s em SP, eles sabem que devem seguir alertas, lutando para conseguir a sanção presidencial para a sua efetiva homologação, e estão conscientes de que o processo de demarcação pode demorar e se estender pelos próximos anos, ainda mais sob a ameaça do teor das medidas a serem tomadas pelo atual governo (Pós-Impeachment), aliado declarado de setores conservadores ligados ao agronegócio que têm interesse direto em impugnar as demarcações de T.I.s.

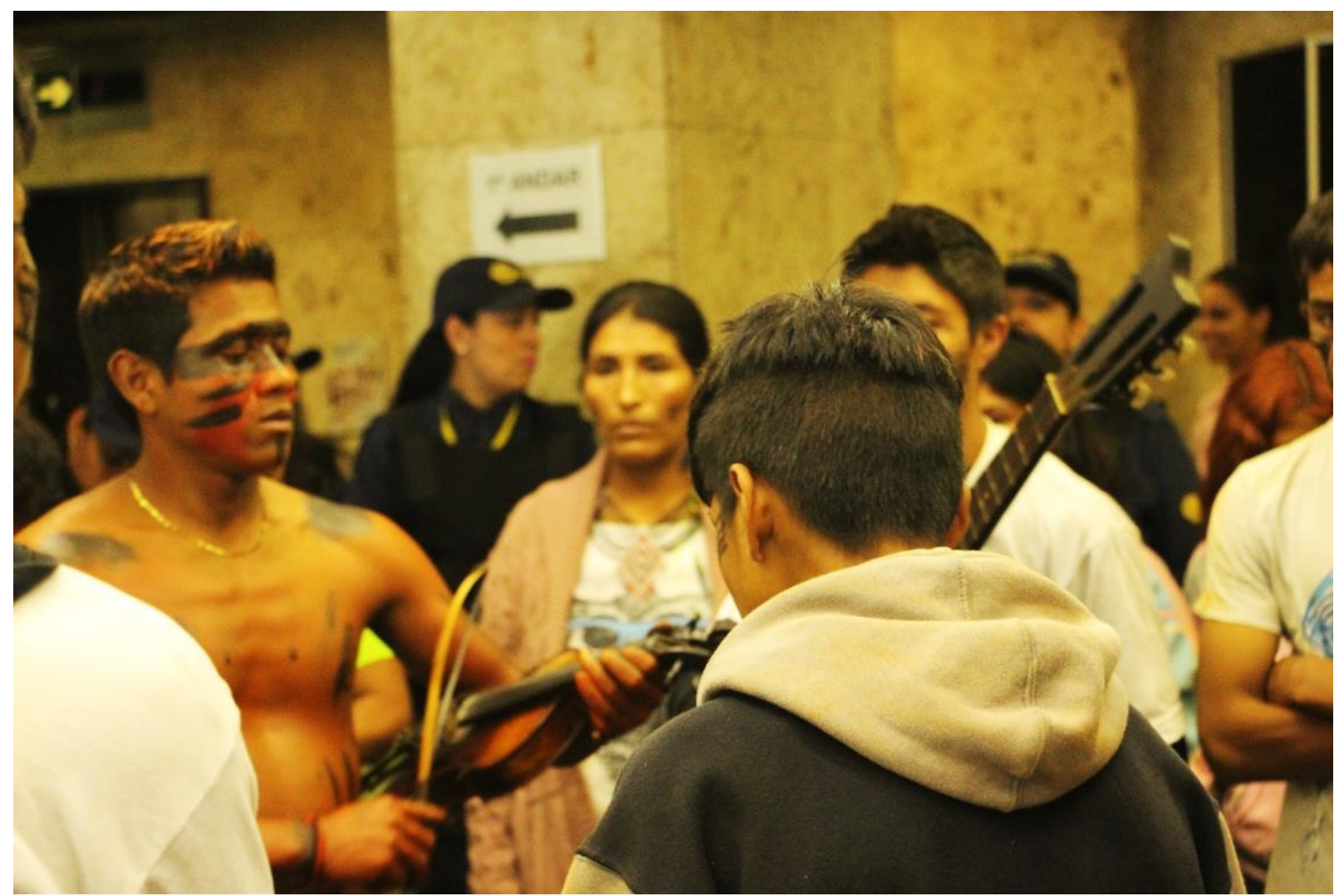

Canto-reza na Ocupação do Escritório da Presidência da República. Aline Aranha. São Paulo, 2016. 


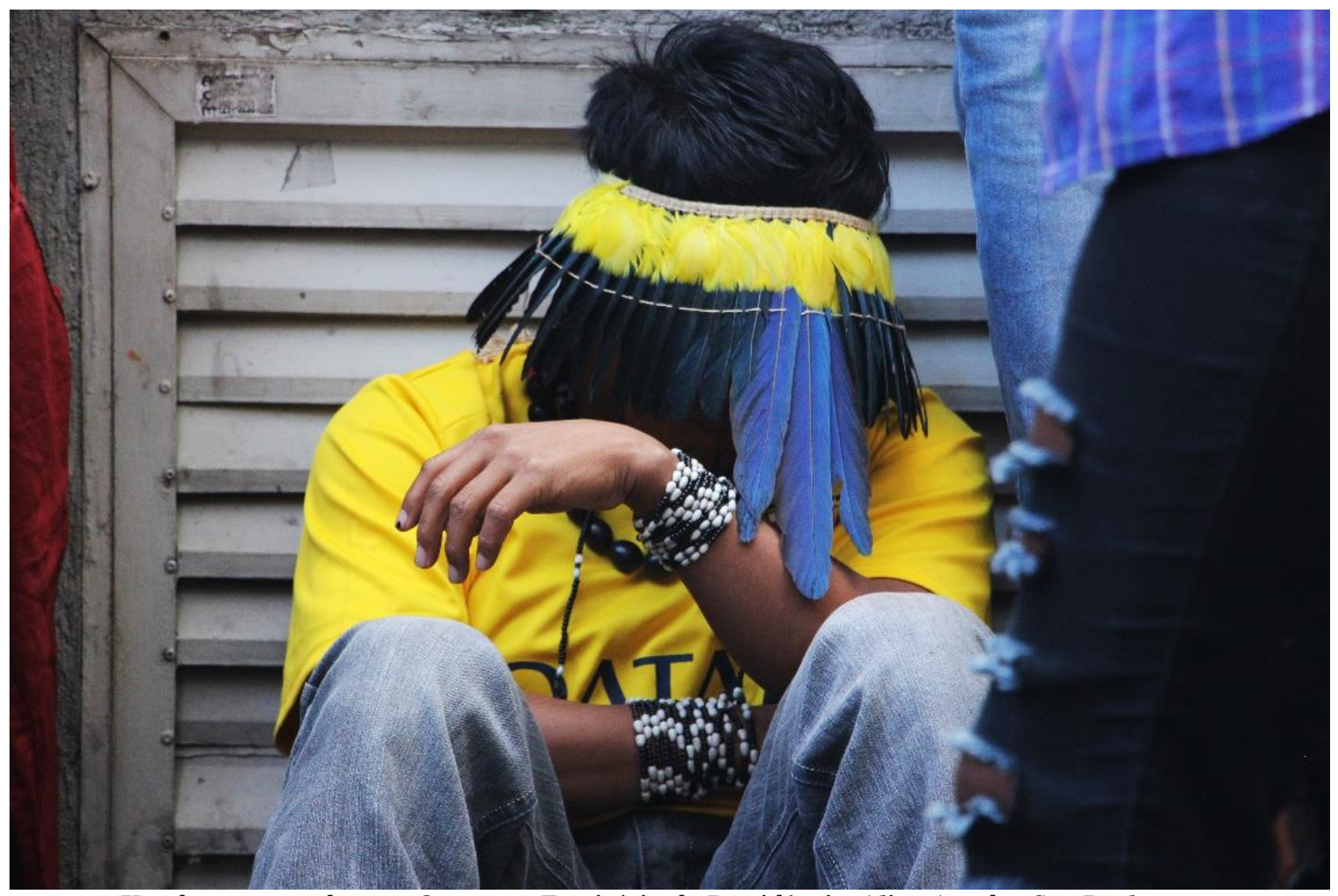

Xondaro e seus adornos. Ocupação Escritório da Presidência. Aline Aranha. São Paulo, 2016.

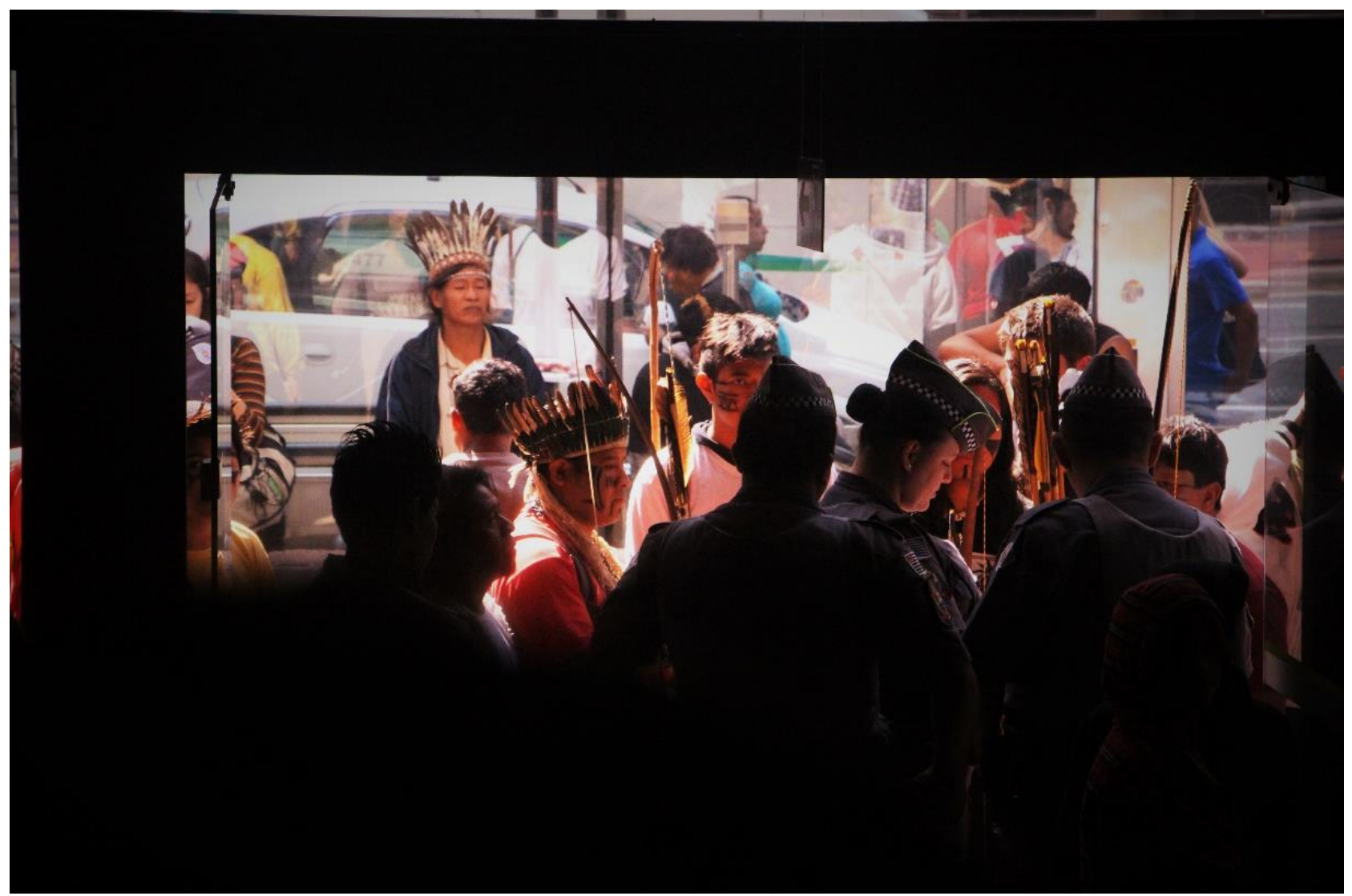

Xondaros e xondarias ocupam o escritório da Presidência da República. Aline Aranha. São Paulo, 2016. 
Por isso, em resposta às ações políticas do Presidente da República em exercício (PMDB), os Guarani ocuparam ${ }^{87}$, novamente, por cerca de 24 horas o escritório da Presidência da República em SP, da manhã do dia 30 para o dia 31 de agosto de 2017, onde entoaram seus cantos-reza e dançaram ininterruptamente, como na ocupação anterior. O motivo da ocupação foi a anulação da Portaria Declaratória da T.I. Jaraguá 88 ( ${ }^{\circ} 581$, 2015 que reconhecia 532 ha de ocupação tradicional guarani), pelo Ministro da Justiça, Torquato Jardim sob o argumento de que o Estado de SP não teria sido consultado no processo de demarcação e de que a T.I. incide sobre área pública estadual (ainda que a tradicionalidade da ocupação da área tenha sido atestada por laudos antropológicos, aprovados pela Funai). Com a anulação, o processo de demarcação da T.I. Jaraguá é interrompido e cerca de 700 Guarani voltam a ser confinados na menor T.I. demarcada no Brasil, com apenas 1,7 ha. Os Guarani exigiam então, nessa ocupação, a revogação da Portaria 683/17 do MJ, por esta ferir gravemente o direito, garantido na Constituição, sobre suas terras no Jaraguá e ainda abrir precedente para que a mesma medida seja tomada em relação a outras T.I.s no Brasil que estão em processo de demarcação e mesmo aquelas que ainda permanecem sem nenhuma providência. Primeiramente, foi chamado um ato ${ }^{89}$ contra essa anulação no dia 30 de agosto, que contou também com o apoio de milhares de jurua e de indígenas de outras etnias, em que, ao mesmo tempo que uma parte dos Guarani ocupava o saguão do escritório, outra parte ocupava o vão livre do Masp, onde fizeram falas públicas, cantaram-rezaram, dançaram, e depois caminharam pela Av. Paulista gritando "O Jaraguá é Guarani” e "Fora Temer". Nesse meio tempo, uma comissão de lideranças Guarani da T.I. Jaraguá montou barracas e estendeu faixas em frente ao MJ em Brasília, reivindicando as mesmas pautas. A comissão conseguiu, enfim, uma reunião com o então Ministro em Brasília, na qual o mesmo afirmou sofrer pressão de setores contrários à demarcação de T.I.s no Brasil, reafirmando a sua decisão em suspender a declaração da T.I. Jaraguá. Diante dessa situação, na madrugada de 13 de setembro os Guarani do Jaraguá ocuparam o Parque Estadual do Jaraguá90, ação que deu continuidade às mobilizações contra a Portaria 683/17 e a tese do marco

\footnotetext{
87 “O povo Guarani ocupou hoje a casa da Presidência em São Paulo, porque o Governo Temer invadiu no último dia 21/8 a nossa casa, a Terra Indígena Jaraguá. Temer também invadiu a nossa casa em Brasília que é a Funai, colocando ruralistas lá dentro. Não sairemos daqui até que seja revogada a Portaria 683 do Ministério da Justiça, que rouba nossos direitos sobre nossas terras tradicionais no Jaraguá [...] Fora Temer, da nossa casa! Saímos da sua casa quando vocês saírem da nossa. Aguyjevete pra quem luta!" (Carta do Povo Guarani. In: Comissão Guarani Yvyrupa 2017d). Ver também, Instituto Socioambiental (2017b). ${ }^{88}$ Ver, nesse sentido, Centro de Trabalho Indigenista (2017c) e Instituto Socioambiental (2017a).

${ }^{89}$ Ver Comissão Guarani Yvyrupa (2017c).

90 Para mais informações ver Instituto Socioambiental (2017c) e Rede Brasil Atual (2017).
} 
temporal que o parecer 001/17 da Advocacia Geral da União (AGU) quer tornar regra para todos os processos de demarcação no país.

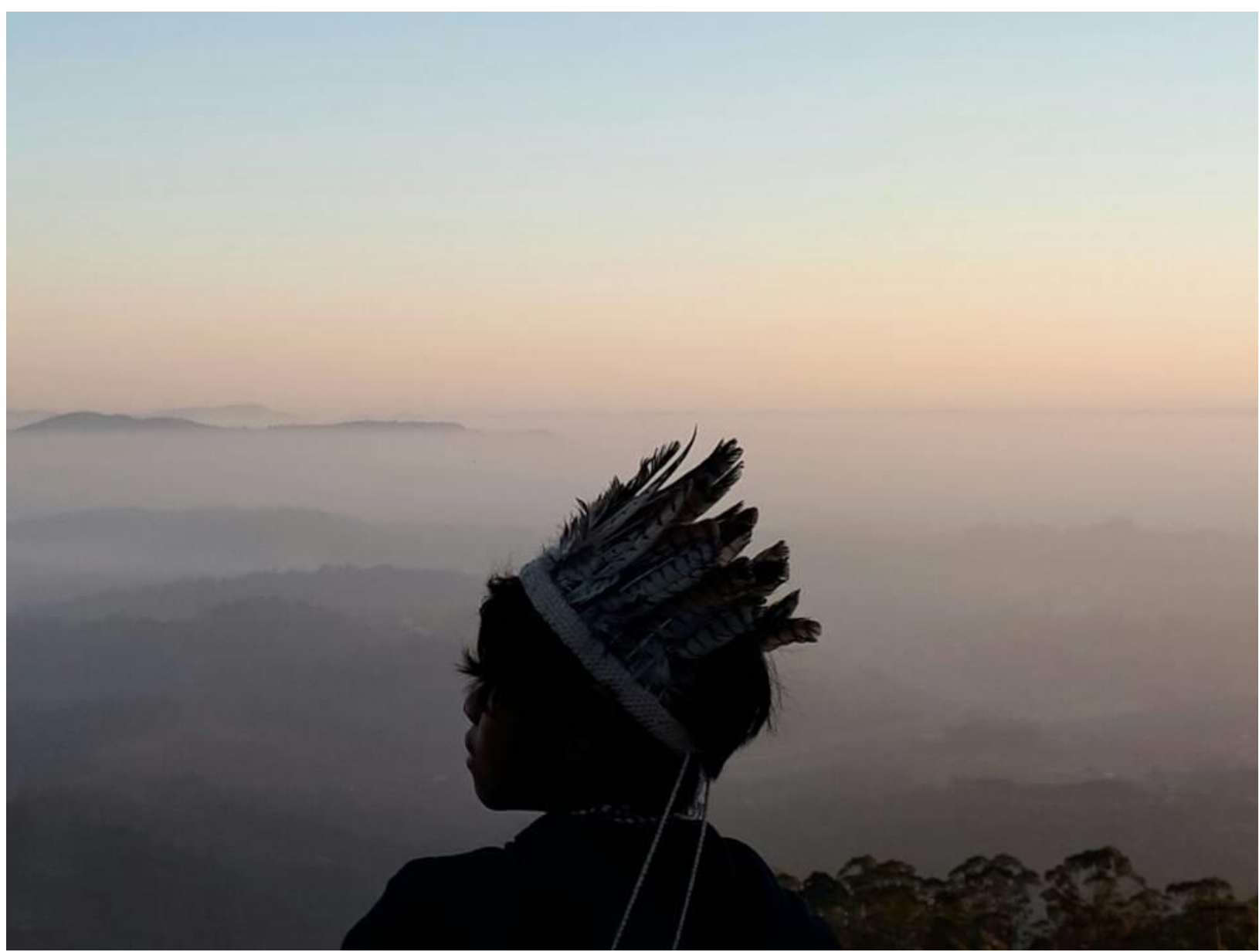

Xondaroßi meditando no Pico do Jaraguá. Arquivo CGY, 2017.

É, portanto, por meio dessa ampla mobilização Guarani em SP, que as novas gerações de lideranças constroem um novo momento político de luta pela demarcação. As transformações nas estratégias de ação ganham assim novos conteúdos e contornos, mas seguem tendo como objetivo primeiro a busca da autonomia de poder exercer plenamente o seu modo próprio de ser-pensar-agir-viver (nhandereko), mesmo que para tanto tenham tido que investir na expansão de suas parcerias com os movimentos sociais jurua e setores da sociedade civil. No entanto, podemos perceber que mesmo com as novas ações de mobilização e ocupação das ruas na cidade, os Guarani não deixaram de caminhar e seguir em frente lutando, por meio de suas rezas-canto e de suas danças-luta, por mais dignidade e autonomia em relação ao Estado. Pois, mesmo se utilizando de algumas estratégias de mobilização de movimentos sociais jurua, assim como o próprio movimento indígena nacional, buscaram imprimir sempre os seus próprios modos de se organizar e se manifestar em seus atos-caminhadas na cidade, bem como nas maneiras de 
se expressar politicamente diante da sociedade envolvente nas redes sociais. A língua guarani sempre presente nos vídeos-manifestos e nos cantos-reza, saiu das aldeias e foi levada para as ruas da cidade e para o mundo das redes sociais. Essa foi uma bela estratégia de demonstração da resistência político-xamânica guarani, dando ainda mais visibilidade à sua longa caminhada pela proteção de suas terras tradicionais (que já vem há mais de cinco séculos). As manifestações na cidade podem ser entendidas então como caminhadas guarani rumo à garantia de autonomia e resistência xamânica do nhandereko e, a atuação das novas gerações junto às lideranças mais velhas, funcionando como um dualismo cosmopolítico em perpétua transformação, posto que interdependentes, pois fazem-se coletivamente, ao mesmo tempo, e transformam-se mutuamente, como desenvolveremos no Capítulo II.

Nessas novas estratégias de ação política guarani também estão incluídas as “ $r e$ tomadas" (como eles próprios as chamam) de terra, que ocorrem dentro do próprio território das T.I.s identificadas e delimitadas pela Funai, e que cada vez mais são "puxadas" pelas lideranças mais jovens que cada vez mais ocupam a frente nessa luta pela demarcação, especialmente no pós-1988. As retomadas acontecem como uma forma de seguir buscando viver e caminhar, na prática, com o nhandereko e de se fortalecer corporalmente-espiritualmente por meio da autodemarcação do território e retomada dos plantios e práticas agrícolas, de caça e pesca ancentrais que muitos jovens já não podiam aprender na prática pela escassez de território garantido. Além disso, é também uma forma de protesto à não regularização da demarcação pelo MJ que até então sequer se dava o trabalho de assinar as portarias declaratórias das T.I.s. No entanto, mesmo com a assinatura das portarias, nenhuma providência por parte do Governo Federal foi tomada para efetivação da garantia da posse indígena desses territórios, o que significa, na prática, que o processo de demarcação está, mais uma vez,paralisado (se é que alguma vez não esteve), aumentando ainda mais s angústia guarani pela garantia de sua própria segurança, principalmente nas áreas de retomada.

Uma jovem liderança da T.I. Tenonde Porã, a respeito das retomadas do Kalipety $^{91}$ e Yyrexakã, comenta sobre como as reivindicações guarani não eram ouvidas enquanto "povo tradicional que precisava de terra para plantar, para fortalecer sua cultura, preservar a sua maneira de ser, nhandereko", e que já não tinham mais “casa, pesca, não tinha rio, não tinha espaço para plantar as sementes tradicionais", e que o espaço que tinham "demarcado, o tamanho [extremente reduzido] da terra estava matando a nossa

${ }^{91}$ O Tekoa Kalipety é uma espécie de extensão do Tekoa Tenonde Porã, como eles mesmos afirmam, local onde já conseguiram recuperar diversas tipos de batata-doce tradicionais e variedades de milho guarani. 
cultura guarani” (Poty, 2016, alterações minhas). A falta de terra, na visão guarani estava "matando" a sua "cultura". Essa liderança entende então as retomadas, como uma "luta legitima” e que "não é a caneta do Ministro de Justiça que irá dar o caminho" de continuarem buscando se instalar em suas terras, pois há aí o entendimento de que "a terra é nossa e que ali a gente vai cultivar, que ali a gente vai viver e que ali a gente vai ensinar nossas crianças, que ali a gente vai fortalecer novamente a nossa cultura" (Idem, grifos meus). Essa ação de fazer retomadas, segundo essa liderança, está vinculada com um "grande movimento também dos xondaros e das xondarias, que são os guardiões, as guardiãs, pra gente continuar a nossa luta" (Idem, grifos meus).

A ampla mobilização guarani pela efetiva demarcação das T.I.s em SP ainda continua e para conseguir realizar a $7^{\mathrm{a}}$ Assembleia Geral da CGY, em setembro de $2016 \mathrm{em}$ sua sede, no Tekoa Tenonde Porã em SP sem comprometer o orçamento da organização utilizado para outras atividades (como as reuniões de formação e articulação política e para as manifestações ao longo do ano), os Guarani lançaram uma campanha de financiamento coletivo $^{92}$ para conseguir ajuda com as despesas de deslocamento, os gastos com a alimentação e a infra-estrutura para hospedar mais de 200 parentes das regiões Sul e Sudeste do Brasil e, inclusive, da Argentina (ver Comissão Guarani Yvyrupa 2016a). Todos os apoiadores receberiam "prêmios" como colares, camisetas da CGY, ou o mapa das terras guarani, além de fotos da assembleia em troca (a depender da quantia investida na causa). O objetivo mínimo estipulado de $\mathrm{R} \$ 15.000$ para a realização da assembleia foi alcançado, e entre os dias 12 e 16 de Setembro foi realizada a Assembleia, na qual também celebravavam os dez anos de resistência da CGY, reforçando assim seu compromisso na luta pelas suas demandas históricas de reconhecimento territorial, além de realizarem, como de praxe nessas reuniões gerais, um balanço dos principais problemas que afetam as aldeias e as demandas mais urgentes, produzindo uma série de documentos destinados aos órgãos e organizações competentes (ver Centro de Trabalho Indigenista 2016b). Além disso, foram discutidas ali as estratégias de fortalecimento da luta diante de um contexto cada vez mais complicado de retrocesso político e de ataques diretos aos direitos constitucionais indígenas. Por isso, receberam também, em uma mesa de análise de conjuntura política sobre esses ataques e a criminalização do movimento indígena nacional e de seus apoiadores, a colaboração de representantes do Programa Guarani do CTI, da Apib e da Procuradora Regional da República da $3^{\text {a }}$ Região, Maria Luiza Grabner. A

\footnotetext{
${ }^{92}$ Ver campanha em: (https://benfeitoria.com/assembleiacgy). Acesso em 20 out 2017.
} 
assembleia também contou com a presença de Walter Coutinho, diretor do Departamento de Proteção Territorial (DPT) da Funai, responsável por analisar e encaminhar os estudos de identificação e delimitação de T.I.s no país para aprovação da presidência do órgão, momento no qual lideranças de todas as regiões de atuação da CGY cobraram duramente atitudes e urgência no encaminhamento desses processos, ativando um forte e enérgico discurso guerreiro ao relatarem as dificuldades sofridas em suas localidades e a longa demora ou mesma a ausência de tomada de providências por parte do Governo.

A Assembleia também é considerada um importante espaço de formação para os jovens, que podem acompanhar as lideranças nas reuniões políticas dentro e fora de suas aldeias de origem. Esses jovens se fazem então cada vez mais presentes na Assembleia, atuando como assessores de imprensa, documentando a assembleia, e postando conteúdos nas redes sociais da CGY. Ali também foram eleit@s jovens lideranças para cargos da Coordenação Mirim, e pela primeira vez, jovens mulheres para cargos de Coordenação Regional da Comissão, reconhecendo a sua força, o seu protagonismo e o seu poder de articulação política dentro das próprias comunidades guarani e, a partir daí, para além delas também. Esta foi uma experiência especial para mim e também para muitos outros jovens, por conta da quantidade de lideranças presentes e por poder ver o modo como se organizam em uma instância decisória geral e coletiva, onde conseguem chegar a consensos sem grandes desgastes emocionais, apesar da quantidade de pessoas ali presentes, atuando sempre (ou tentando agir) com calma e serenidade, o que nem sempre ocorre no dia-a-dia das comunidades. No Manifesto, redigido durante a Assembleia, eles se posicionaram contra a ameaça de retrocessos representada pelo Governo Temer (PMDB) e sua base aliada:

Nós, de todo o povo Guarani das regiões Sul e Sudeste do Brasil, nos reunimos na $7^{\text {a }}$ Assembleia da Comissão Guarani Yvyrupa para nos fortalecer na resistência contra os constantes ataques aos nossos direitos [...] nos reunimos na $o p y$, nossa casa de reza, para que Nhanderu nos dê força e coragem para seguir na nossa luta [...] Desde que nossas terras foram invadidas pelo jurua, os não-indígenas, nossa vida esteve sempre ameaçada. Passamos a viver cercados por conflitos, buscando dentro de nosso território aqueles tekoas, aquelas aldeias mais afastadas, onde pudéssemos viver em paz. Mas hoje depois de tanta destruição causada pelos jurua kuery, temos que nos organizar para lutar com todas as nossas forças e garantir as poucas terras que nos restam. Nossa luta nunca foi fácil, mas hoje a situação é ainda mais preocupante. Os jurua poderosos e seus governos que estiveram sempre contra nossos direitos, estão se fortalecendo cada vez mais, aumentando os ataques contra nossos tekoas em nome de sua ganância, que vê na terra apenas o dinheiro [...] que desenvolvimento é esse que só beneficia os poderosos? Que cria um mundo em que não tem espaço para os povos indígenas e para a preservação do meio ambiente? E agora com o novo Governo, escolhido diretamente pelos ruralistas e grandes empresários que dominam o Congresso Nacional, nossos direitos estão ainda mais ameaçados [...] Nos últimos anos, o orçamento da Funai tem sido cada vez mais redu- 
zido, impossibilitando os trabalhos de demarcação de nossas terras [ ...] Exigiremos sempre o fortalecimento da Funai $^{93}$ para garantia dos nossos direitos fundamentais. Não bastasse o corte orçamentário, os ruralistas do Congresso continuam a destruir nossos direitos através da Comissão Parlamentar de Inquérito da Funai/Incra, que foi aberta novamente mesmo tendo seu prazo expirado. Por meio da CPI nossas lideranças e apoiadores do movimento indígena são investigados como se fossem criminosos, enquanto nenhuma justiça é feita sobre o sangue derramado de nossos parentes pelos fazendeiros e pelo Estado [...] Mas nossa luta não começou hoje e nunca vai parar. Quando Nhanderu criou o mundo ele deu o papel para o jurua, enquanto deu pra nós o petỹgua, o cachimbo. Por causa da ganância o jurua não soube usar o papel, e com ele tem tentado acabar com as nossas terras, destruir nossas matas e acabar com nosso povo. Mas nós temos o petỹ gua: nossa reza, nossa união e nosso nhandereko, nosso modo de vida. E com ele continuaremos resistindo nas nossas terras tradicionais, nas nossas retomadas, plantando o alimento verdadeiro, cuidando das matas e da água fresca que Nhanderu deixou para nós. Aguyjevete pra quem luta! (Comissão Guarani Yvyrupa, 2016b)

Os discursos guarani para fora de suas aldeias são como um alerta geral de que se os jurua kuery não mudarem a sua perspectiva e modos de se relacionar com a terra e os seres que a habitam, o mundo que hoje existe, tal como o conhecemos, irá acabar. Estamos diante de uma escala fractal de relações, que começa com os pais e mães divinos, passa pelos espíritos protetores ${ }^{94}$ (nhe'ẽ kuery) que as divindades enviam à terra para inspirar seus filhos caçulas a se animarem a cuidar e guardar essa terra tekoaxy. Esses espíritos protetores, guardados pelos Nhanderu e Nhandexy kuery são como os guardiões divinos dos Guarani aqui na plataforma terrestre. É através deles que as divindades se comunicam com os Guarani aqui na terra, iluminando seus caminhos e impondo também algumas "barreiras" para que eles possam, de fato, aprender a cuidar de yvyrupa, tornando-se também os seus guardiões, para que assim possam voltar às suas moradas celestes $(a m b a)$ com o próprio corpo, além do nome-espírito, que tem a possibilidade de tornar-se incorruptível ao imitar corretamente a imagem deixada pelos comportamentos divinos aqui na terra, seguindo seu belo caminhar (-guata porã).

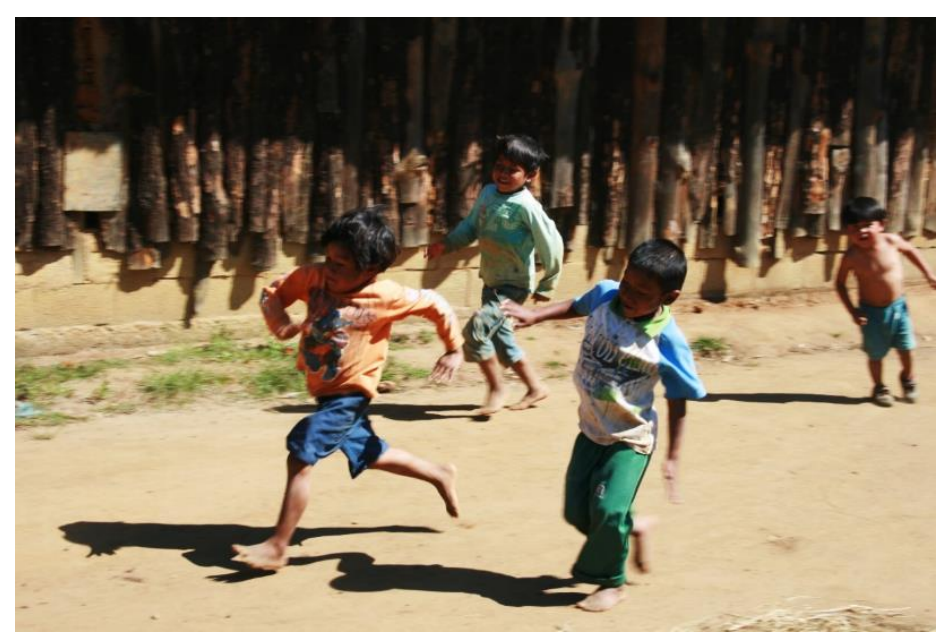

Kyrizgue brincando ao redor da opy. Aline Aranha. T.I. Tenonde Porã, 2012.

${ }^{93}$ É interessante notar essa mudança de posicionamento guarani em relação à Funai. Antes da Constituição de 1988, "fugiam" do órgão indigenista federal e agora o discurso é pelo seu fortalecimento.

${ }^{94}$ Ver o subitem Nhe'ẽ Kuery, Espíritos Protetores em Guata Porã - Belo Caminhar (2015: 20-23). 


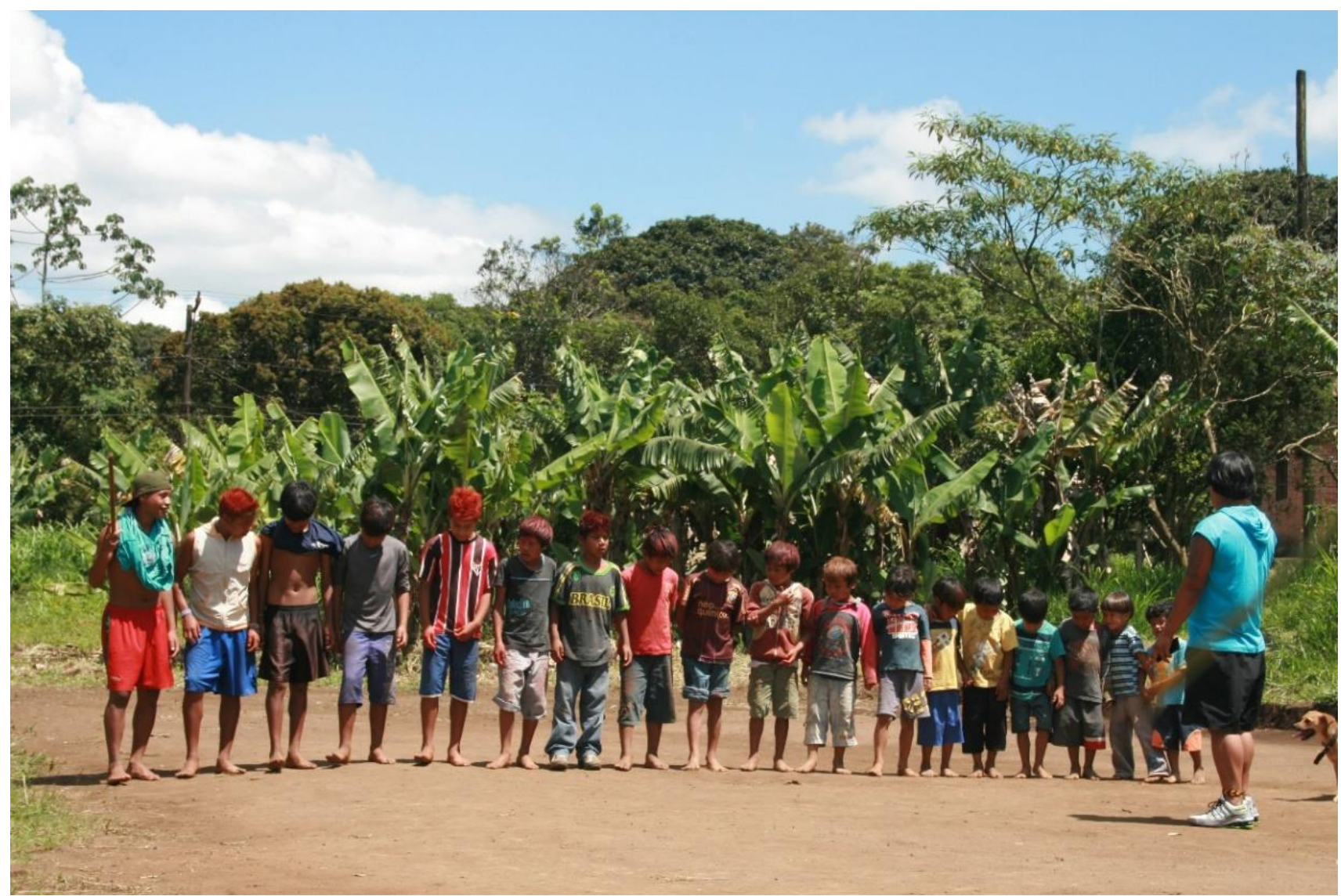

Xondaro kuery se concentrando para começar a dança. Aline Aranha. T.I. Tenonde Porã, 2012.

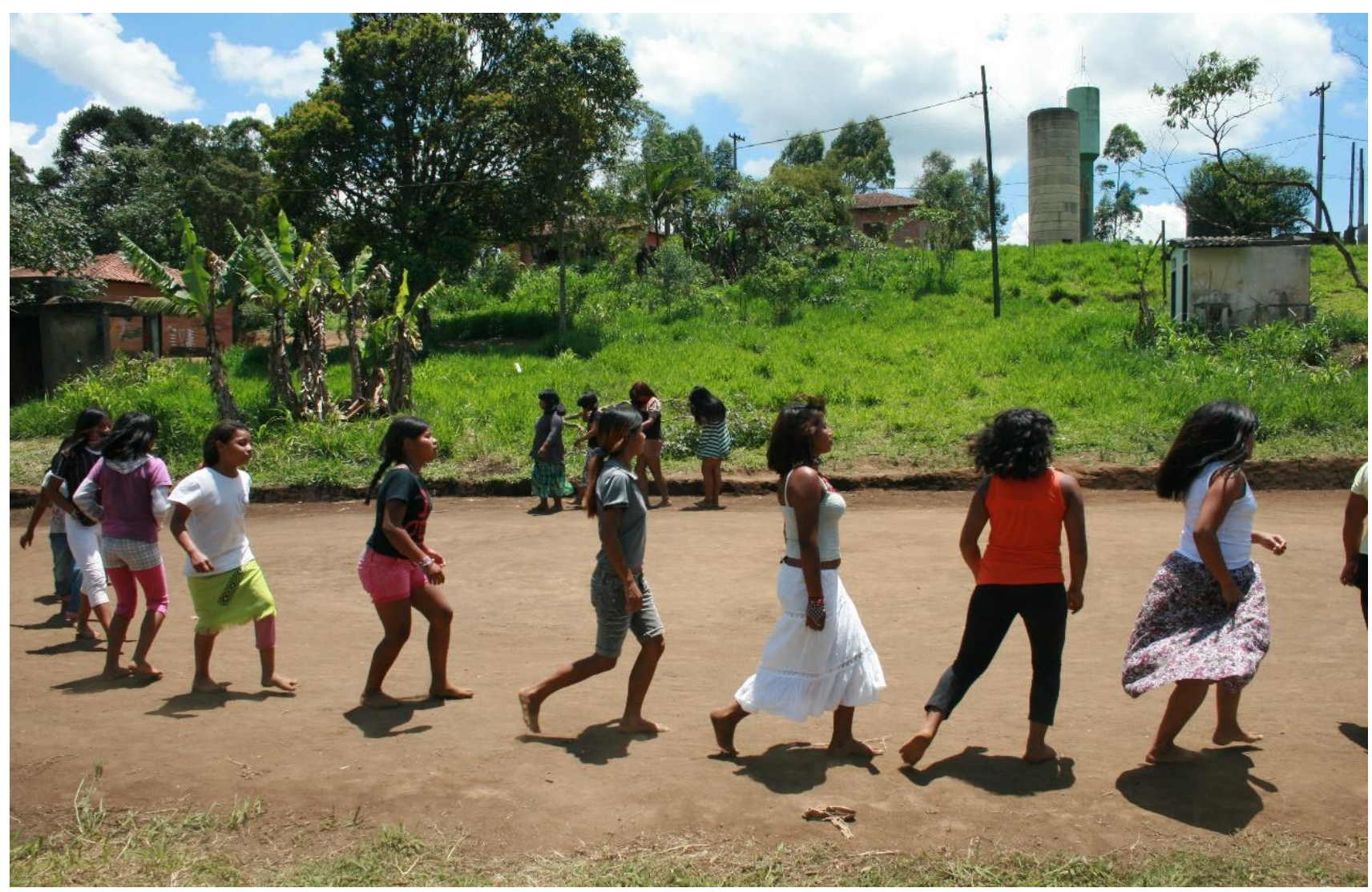

Xondaria jeroky. Aline Aranha. T.I. Tenonde Porã, 2012. 


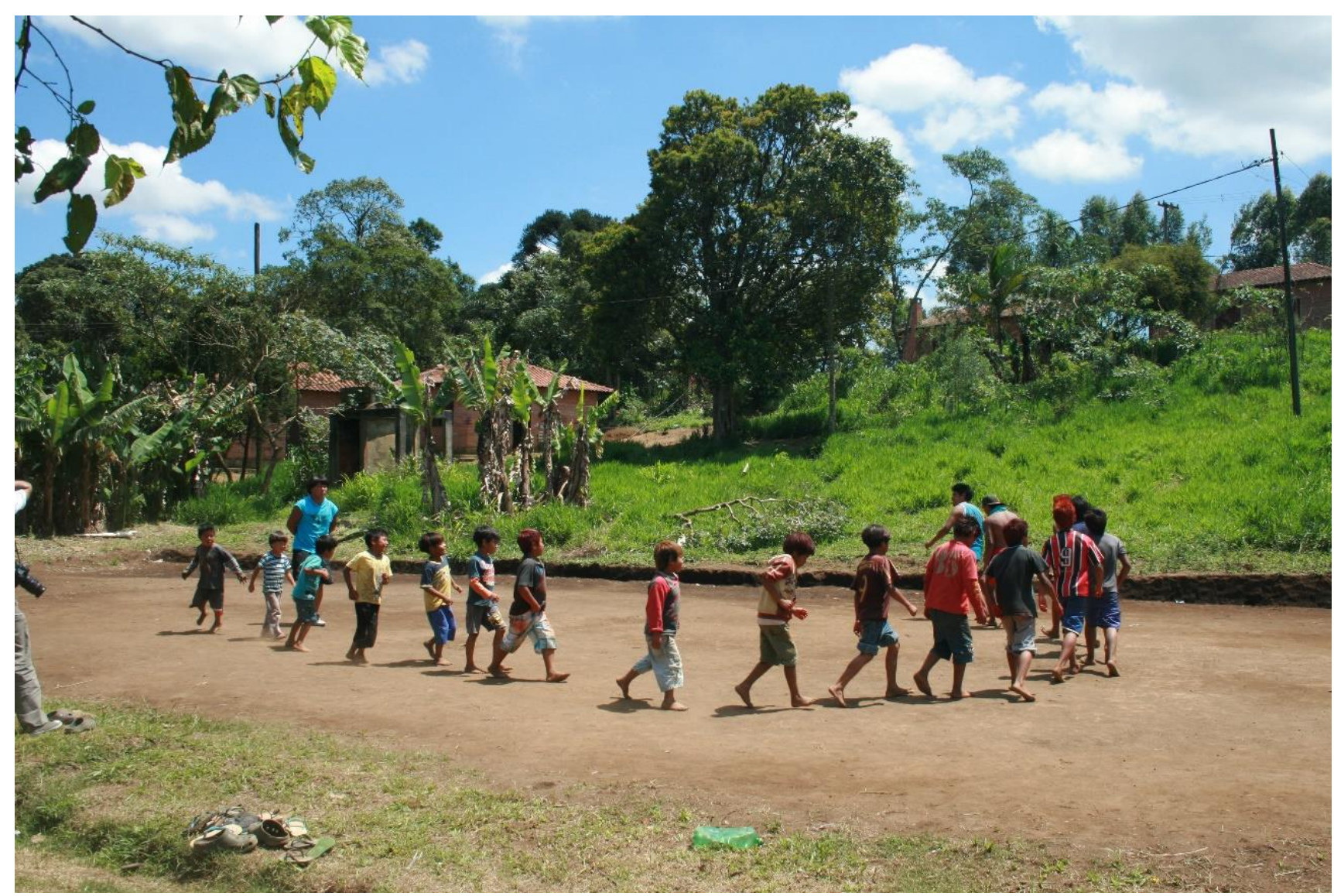

Xondaro’i jeroky. Aline Aranha. T.I. Tenonde Porã, 2012.

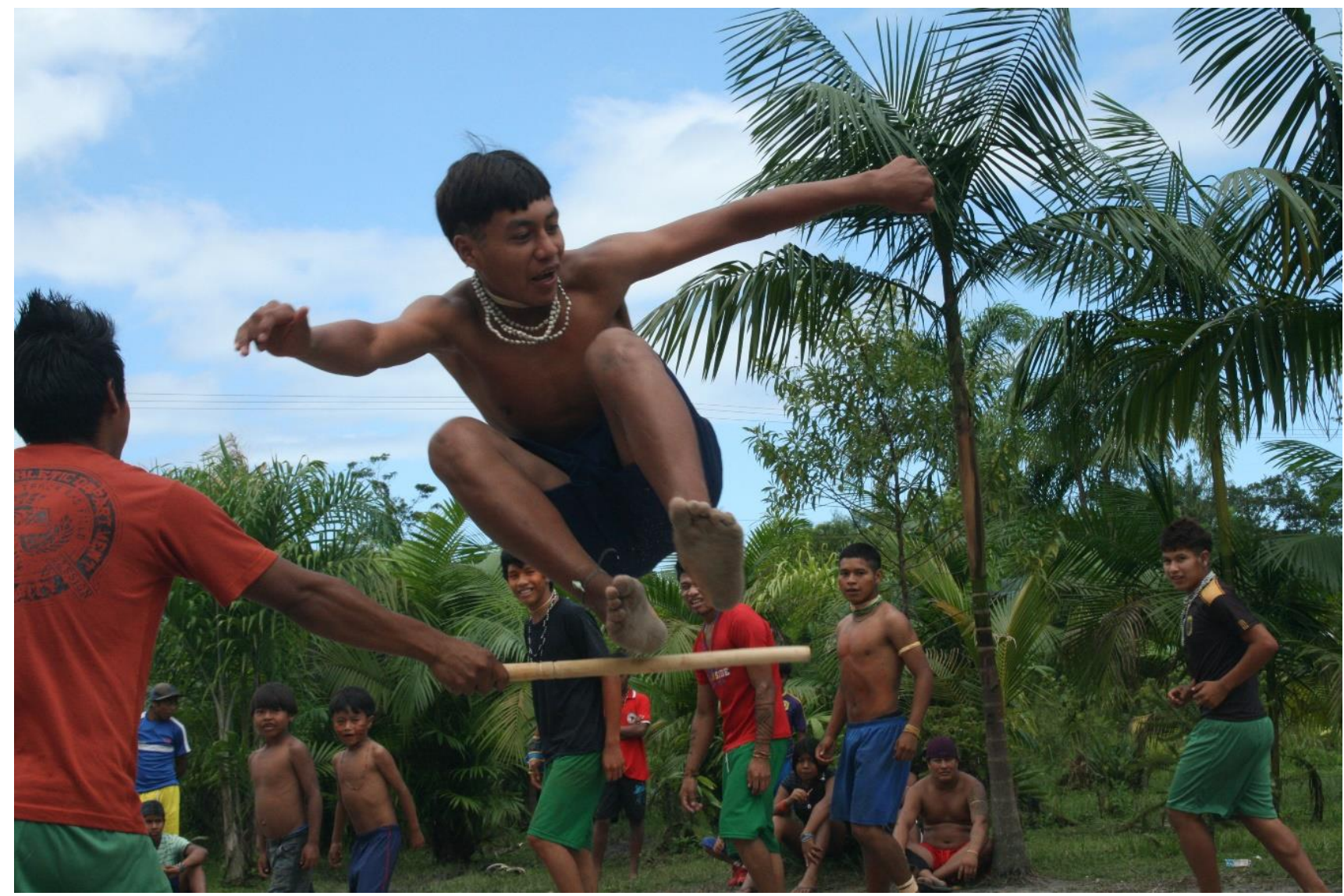

Desafio do xondaro. Aline Aranha. T.I. Rio Silveira, 2012. 


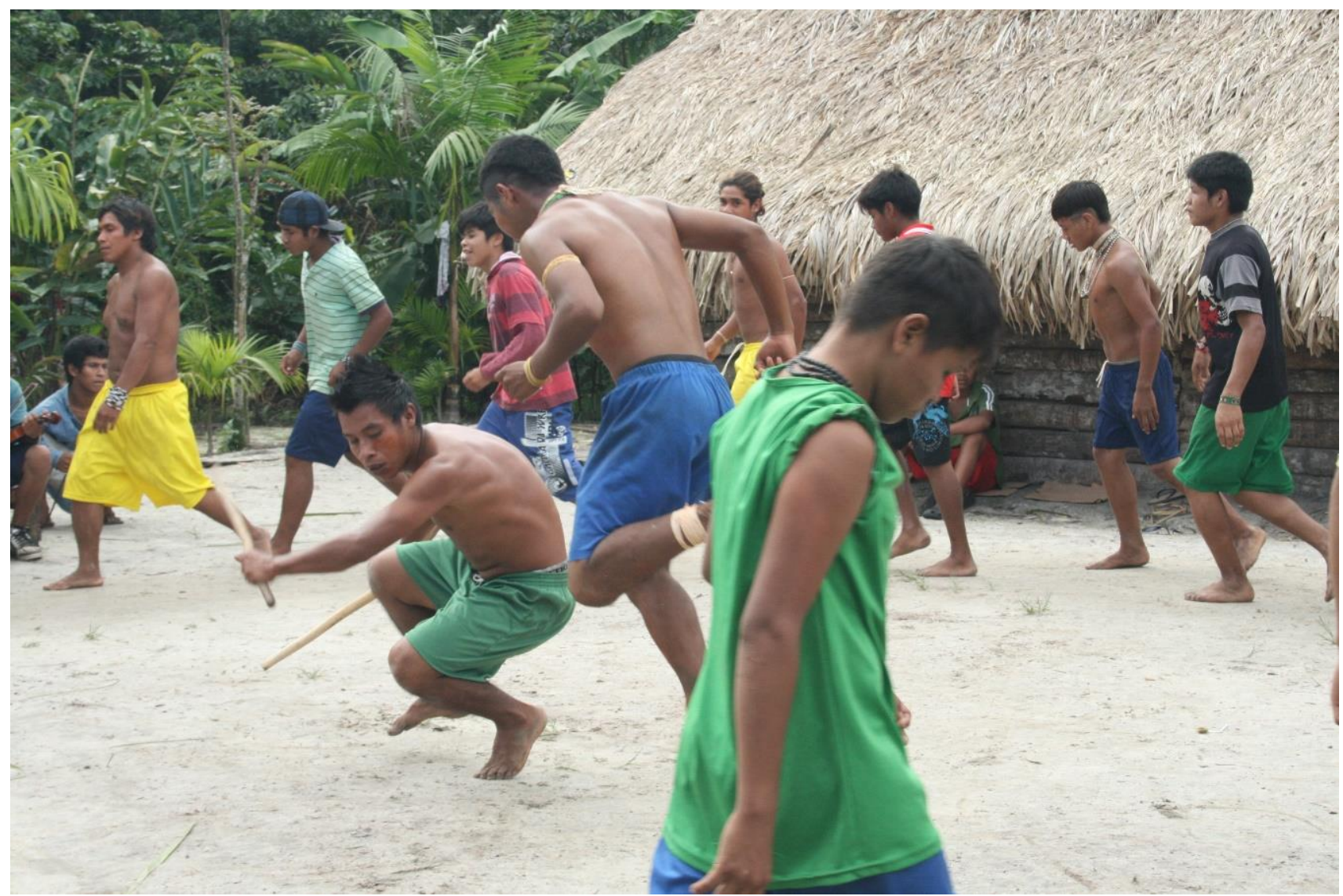

Xondaro ruvixa “testa” adversário. Aline Aranha. T.I. Ribeirão Silveira, 2012.

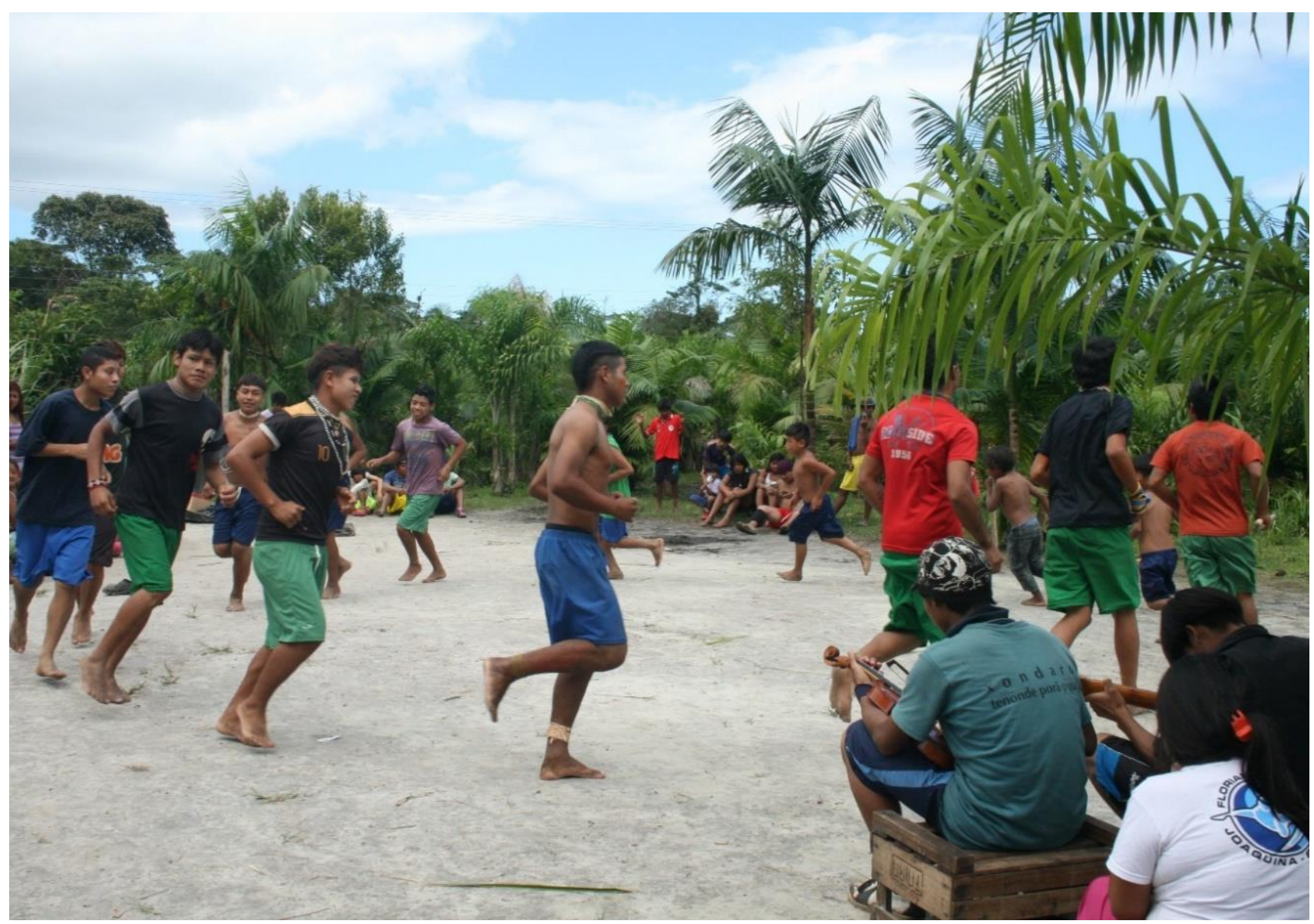

Roda de xondaro. Aline Aranha. T.I. Rio Silveira, 2012. 


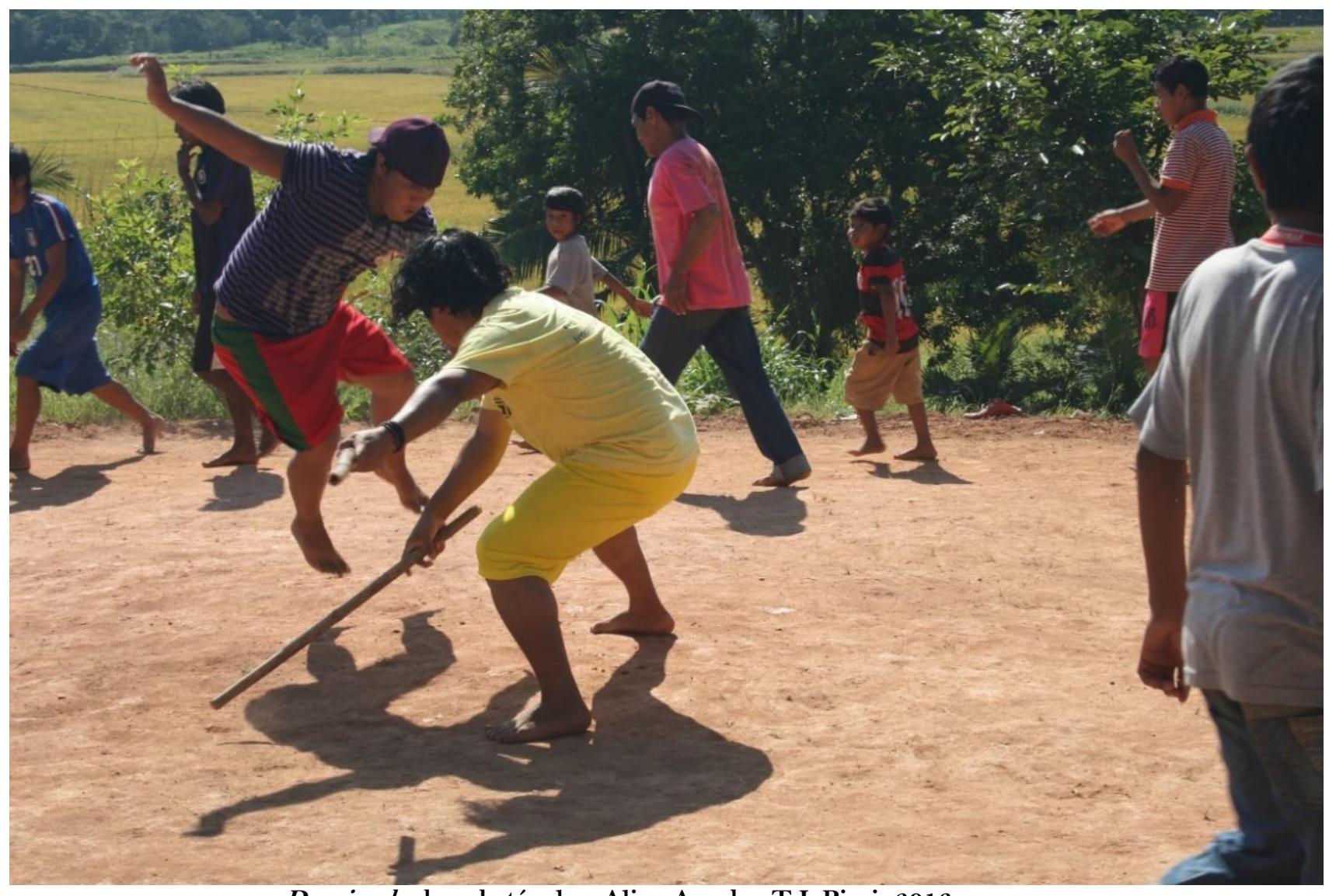

Desviando dos obstáculos. Aline Aranha. T.I. Pirai, 2013.

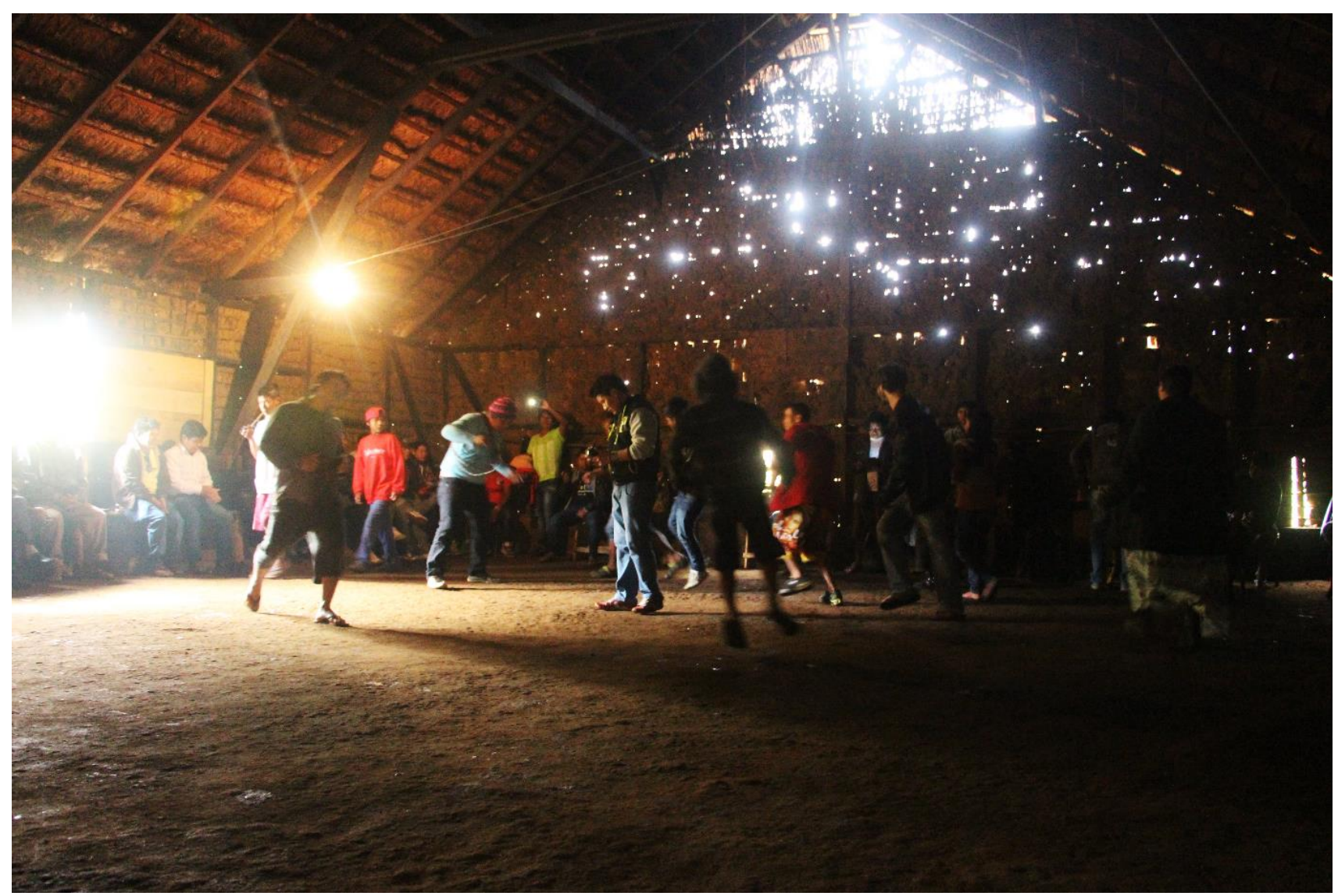


Página | 124

\section{Capítulo II. Disposições cosmopolíticas Guarani: entre domínios e personagens}

Karaí (ou o humano nu): poema baseado no livro Terra sem mal de Hélène Clastres

$\mathrm{nu}(\mathrm{a})$ entre folhas

escuta o doce canto

cortante como flecha luminosa das

palavras-alma

o movimento contorcido

repetido

exauri à dança o corpo coletivo

e deslocamos:

o nu e o nós

pela floresta simbólica eletrizada

ecoa

seu discurso ressonante

(matinalmente-maquinalmente)

repleto de promessa da terra sem mal

onde o humano está entre os Deuses

quando humanos-deuses festejam a

anomia

[separad@] de sua aldeia

nada ao redor

proferindo palavras doces

sintetizadas

na fragmentação do seu plano sociológico

mesmo

pres@na solidão de um pensamento exasperado:

canta um devir imaginado

(Berbel, Gustavo)

\section{A atualidade do contra-Estado e para-guerra: (dis)junções entre política e xamanismo}

Pierre Clastres, voltado contra a razão etnocêntrica ocidental que toma as populações indígenas como estagnadas em um estágio primeiro de evolução das formas de governo, ou incapazes de estabelecer uma forma, as toma como sociedades contra o Estado ${ }^{95}$, uma vez que sua política estaria baseada na impossibilidade do poder coercitivo para subjugar indivíduos, instrumento visivelmente presente em sociedades com Estado. Nessa recusa ativa do poder centralizado, ou coercitivo da "forma-Estado", são consideradas também pelo autor como sociedades para a guerra, essa máquina de dispersão centrífuga que permite que permaneçam demográfica e territorialmente restritas, condição

\footnotetext{
${ }_{95} \mathrm{Ou}$ ainda uma socialidade contra o Estado, pensando sobre o próprio fazer-se do social, no qual mecanis-
} mos coletivos agem contra a transcendência de um poder político separado do grupo (ver Barbosa 2004). 
básica para sua indivisibilidade, que acaba localizando aí também o "Contra-Um"96 ameríndio. Trata-se aqui efetivamente de escolha e não de uma suposta carência ou incapacidade. É nesse sentido que seria possível descentralizar o nosso olhar e compreender o Estado não como a única finalidade das formas de organização políticas de todas as sociedades, mas como uma forma particular, e que outras sociedades podem responder de maneira diferente a um aparelho de coerção separado dela ou a um poder político centralizado, com uma "recusa" 97 ativa, por exemplo. O que faria da "forma-Estado" apenas uma fatalidade, não uma finalidade ou privilégio de certas sociedades, mas um acidente, que poderia ser prefigurado e, portanto, conjurado. P. Clastres positiva a ausência (de poder coercitivo) e onde não vê coerção, contempla uma outra política, em que um poder sem coerção é pensável. O ponto defendido por ele em Copérnico e os selvagens (2003 [1969]) é que precisamos "alargar" as nossas noções de "política” e de "poder político", já que estes conceitos não dão conta da realidade indígena ${ }^{98}$, empreendendo um movimento análogo ao que Lévi-Strauss desenvolveu no "alargamento da Razão” e na proposição de um "pensamento selvagem”99. Se os indígenas são tão racionais quanto nós mesmos, eles são também tão políticos quanto nós mesmos. E eles sabem exatamente o que poderia vir a ser um grande xamã ou um chefe desmesurado, e têm, inclusive, uma infinidade de mitos a este respeito, que atentam ao perigo ${ }^{100}$ dessas figuras usurpadoras do poder (que é distribuído coletivamente entre eles), ridicularizando-as ou ainda as parodiando (ver neste sentido, Perrone-Moisés 2011). É o grupo aí que exerce o seu poder coletivo sobre@ chefe, que desponta então como “prisioneiro” daquele. O contra o Estado aparece aqui então no sentido de um mecanismo contra a concentração do poder político na figura do "Um”, isto é, contra alguém ou um aparelho que ganhe grande autonomia em relação à sociedade. Mas ainda que não detenha “o” poder, @ chefe possui prestígio, sendo necessárias qualidades que lhes sejam reconhecidas para ocupar tal (dis)posição.

\footnotetext{
${ }^{96}$ Ideia desenvolvida por P. Clastres no ensaio Do Um sem o múltiplo (2003 [1972]) no qual discorre sobre a fala de um xamã mbya de uma aldeia paraguaia que teria confessado a ele a aversão filosófica de seu povo a tudo aquilo que se assemelhe ao Um: “As coisas em sua totalidade são uma: e para nós que não desejamos isso, elas são más” (Clastres, P. 2003 [1972]: 188). Nessa “equação metafísica” própria ao profetismo guarani "que iguala o Mal ao Um" se esconde uma outra equação de ordem política que se dá "como recusa radical do Um como essência universal do Estado" (Ibidem: 233).

${ }^{97} \mathrm{O}$ poder coercitivo, particularidade de qualquer Estado, pode ser reconhecido e localizado também na sociedade indígena, mas cabe a essa mesma sociedade proteger-se contra ele e conjurá-lo, daí o reconhecimento de P. Clastres dessa sociedade como sendo "contra o Estado" e não "sem Estado".

98 A Revolução Copernicana empreendida por P. Clastres positiva a recusa do Estado, levando a sério a política e o problema do poder nas sociedades indígenas, reconhece sua positividade, sua organização: "algo deve existir na ausência".

${ }^{99}$ Que não é necessariamente o mesmo que o pensamento "dos selvagens".

${ }_{100}$ A chamada cautela diante da figura de lideranças dotados de "poder", e de movimentos de concentração desse poder, seja ele propriamente político (constituição de coletivos), ou de outra natureza.
} 
Segundo Sztutman (2013), mecanismos criativos de organização e ação políticas ameríndias, não deixariam de envolver uma filosofia da chefia indígena e a "multiplicação do múltiplo" da guerra ${ }^{101}$, que não se reduzem à política dos humanos, revelando toda uma cosmopolítica (que também é contra o Estado), na qual o xamanismo constituiria peça crucial. P. Clastres sugere que a filosofia política ocidental pode ser transformada pela filosofia política indígena. A Antropologia, ao estudar a "ciência dos selvagens"102, põe em xeque as premissas etnocêntricas da nossa própria ciência, passando então de um “discurso sobre os outros" para um diálogo com os "outros". Partimos aqui da ideia, lançada inicialmente por Sztutman, de que esta tese da sociedade contra o Estado ${ }^{103}$, pode ser desdobrada para além da dimensão especificamente explorada por P. Clastres, não sendo necessário tomá-la em sentido literal, como um protótipo. Ao invés disso, podemos fazer render essa concepção, usando sua atualidade a nosso favor, pensando a política em outros termos, enfrentando suas contradições e extraindo delas interrogações (Sztutman 2013).

Tendo visitado os Guarani algumas vezes, nas décadas de 1960 e 1970, P. Clastres produziu artigos sobre eles - publicados, em conjunto, em A sociedade contra o Estado (2003 [1974]), e também um livro que agrupa mitos, exegeses e cantos xamânicos, intitulado A fala sagrada ${ }^{104}$ (1990 [1974]). Escreveu também sobre o karai guarani, descrito agora não apenas como "pajé” (xamã, rezador-curador), mas sobretudo como um sábio, aquele que se apropria de narrativas mitológicas para produzir uma reflexão sobre a existência e uma ação sobre o mundo. O autor compara aí os karai da atualidade com os chamados caraíbas dos antigos Tupi da costa, que os cronistas dos séculos XVI e XVII identificavam como profetas. O tema do profetismo guarani foi, entre outros, estudado por Hélène Clastres em A terra sem mal ${ }^{105}$ (1978 [1975]). A antropóloga buscou demonstrar a continuidade entre o profetismo do passado e o do presente, visto que ambos seriam motivados pela busca de uma "terra sem mal”. H. Clastres escreveu sobre a figura

\footnotetext{
${ }^{101}$ Para P. Clastres, as sociedades indígenas recusariam a unificação política em nome da manutenção de comunidades pequenas e autônomas do ponto de vista político e econômico, vivendo num estado de guerra permanente que, por sua vez, levaria a um um processo contínuo de fragmentação social, que "multiplica o múltiplo", numa dinâmica propriamente ameríndia de fazer e desfazer pessoas e coletivos. Assim, o motor mesmo da produção de diferentes modos de oposição política, de sua parte, incitaria às alianças e trocas entre os coletivos. A guerra seria também, nesse sentido, motor do mecanismo contra o Estado, e as sociedades ameríndias feitas "para-a-guerra".

102 Ver Prefácio de Tânia Stolze Lima e Márcio Goldman para A sociedade contra o Estado (2003).

${ }^{103}$ Ver também o verbete do conceito "sociedade contra o Estado" em Aranha e Freire (2016).

${ }^{104} \mathrm{Em}$ A fala sagrada, o autor reflete sobre o corpus mitológico guarani, identificando ali o desenvolvimento de um pensamento propriamente reflexivo; vê-se aqui, de acordo com Sztutman (2009a) uma análise da mitologia como um comentário sobre a natureza do poder.

105 A terra sem mal é "uma análise aprofundada de como uma religião pode se converter num mecanismo de resistência ao mesmo tempo ontológica e política, e desse modo, combater um ideal de transcendência aderindo a um projeto de imanência” (Sztutman, 2009b: 2).
} 
dos grandes chefes proféticos entre os antigos Guarani, mas não entrou em muitos detalhes sobre a figura dos líderes de migração dos povos atuais. Seu interesse recaiu menos no domínio da chefia do que no aspecto "religioso", isto é, no conjunto de ideias que diziam respeito à essa busca da tão aspirada "terra sem mal”, bem como nos rituais que permitiam a comunicação entre deuses e humanos.

A convergência entre liderança política e xamânica entre os Guarani, segundo as análises empreendidas por Pierre (2003 [1974]) e Hélène Clastres (1978 [1975]), seria posterior a uma disjunção histórica entre chefes de guerra (mboruvixa) e profetas (karaı). Com a crescente centralização do poder por parte de chefias de guerra também multiplicavam-se os movimentos proféticos, que já ocorriam mesmo antes da invasão europeia e que a partir daí acabam se intensificando ainda mais -, quando muitas vezes, populações inteiras, abandonavam suas aldeias e seguiam@skarai na busca da Terra sem Mal. Segundo H. Clastres, o movimento profético guarani correspondia à uma espécie de recusa deste mundo, tendo como horizonte uma terra da abundância e da imortalidade que lhes era destinada, sem regras ou restrições sociais que corromperiam sua natureza divina, e em que a abundância faria prescindir a necessidade de trabalho e enseja festas sem fim. O casal Clastres atribuiu, em grande parte, o "fracasso" de muitos empreendimentos proféticos à terra prometida, à conversão d@s karai em lideranças políticas, que acabou levando entre os Guarani, segundo H. Clastres, à uma interiorização ascética do tema da terra sem mal e a um individualismo religioso radical a partir do século XX. O que, por sua vez, implicaria uma série de cerimoniais, além do seguimento de regras morais rígidas, fortemente assentadas sobre valores como autocontrole e comportamentos baseados na moderação marcados por prescrições individuais que incluíam proibições alimentares, uma série de abstinências e uma intensa atividade de canto-reza-dança que teria como base um certo ideal de maturação ou completude corporal-espiritual (aguyje) que remeteria e se assemelharia aos comportamentos divinos e, portanto, era tido como um meio de devir-divino. Tal passagem, marcada grandemente por referências às práticas xamânicas relacionadas às migrações proféticas foi compreendida pela literatura especializada, que comparava os Guarani atuais aos Tupi da costa e aos Guarani históricos, como correspondendo a uma passagem de uma ética canibal a uma ética ascética fundamentada em um devir-deus (Clastres, H. 1978 [1975], Viveiros de Castro 1986) ou ainda a um processo crescente de "desjaguarização", passando de uma lógica baseada na predação à uma gramática do "amor", da reciprocidade ou convivialidade (mborayu) (Fausto 2005). Nesse sentido, a imbricação acentuada entre xamanismo e guerra, observada por Sztutman $(2005,2012 \mathrm{a})$ a partir de exemplos tupi e guarani históricos e amazônicos, acaba 
deixando de se fazer tão aparente, fazendo aparecer outros arranjos, que lançam uma ênfase maior na noção de divindade. Assim, Sztutman observa entre os Guarani atuais, “todos eles um pouco profetas", os grandes xamãs, esses dirigentes espirituais, "personagens ascetas e sábios" que remeteriam a "uma figura 'indecisa' entre a fixidez-o trabalho, a vida comunitária - e a evasão - a migração, o deslocamento no espaço" (Sztutman, 2012a: 450, grifos meus). Ele vê também na figura dos pa'i Mbya e Nhandeva, grandes sábios e xamãs - tal qual os Clastres a descreveram - algo mais próximo dos karai do que dos pajés (são "mais profetas do que pajés"), visto que cultivam:

um conhecimento preciso extraído de um corpus mitológico, desenvolvem uma palavra eloquente manifestada sobretudo por meio de cantos e, ainda, mostram-se aptos não apenas em conduzir migrações, mas também em cuidar da coletividade. Nesse sentido, eles esbarram numa função política, são espécies de líderes político-religiosos. (Sztutman, 2009a: 154, grifos meus)

Tais lideranças político-espirituais imprimiriam ao "corpus mitológico uma reflexão mais pessoal, tomando como foco a condição humana e a possibilidade de sua superação" (Idem, grifos meus). É assim que elas interpretariam a "crise”, muitas vezes provocada pelo contato com o mundo dos brancos, sob o signo do cataclismo, e formulariam alternativas sob o signo da evasão, do deslocamento contínuo, vertical e horizontal (Ibidem: 155). Seria, portanto, na afirmação de um ascetismo que@ profeta conduziria os seus à terra da abundância. De acordo com Sztutman, H. Clastres ao tomar o profetismo pelo seu caráter de negação da vida social (do universo das regras) e da própria condição humana, fazendo coincidir a negação do poder político como coerção com a negação das próprias relações mundanas, acaba por negligenciar as faculdades positivas e mesmo afirmativas dessa "religião" que reside na possibilidade de construir a vida nessa terra: “evadir, mas também de parar, reterritorializar sob certo sentido" (Sztutman, 2012a: 484). Nesse sentido, ao enfatizar a contradição entre o "político" e o "religioso", H. Clastres acaba deixando de lado a comunicação efetiva entre esses dois domínios que, de acordo com Sztutman (2012a), tendem a se retroalimentar. Entre os antigos Tupi, por exemplo, todo profeta seria também um guerreiro e toda recusa da ordem, empreendida por tal figura era também uma maneira de refundar a ordem. Por isso, se as migrações:

essa manifestação da religião profética, desfazem coletivos - promovem fissões, evasões, fragmentações, estão a serviço da lógica faccionalista -, isso é porque elas também os fazem, porém em um outro plano [...] são, nesse sentido, criadores de formas, tanto cerimoniais como sociopolíticas. (Idem: 484)

E o sentido dessas transformações não poderia ser compreendido como dissociado das formas que as antecedem. Pensar o profetismo como um elemento importante 
dessa ação política é, portanto, estar atento para o processo de produção de novas formas a partir de formas já existentes (Sztutman, 2009b: 38-9). Para H. Clastres, no entanto, seriam as práticas ascéticas dos caraíbas que se combinavam com a poliginia e a riqueza, próprias aos chefes, os assimilando a estes, que fariam explodir essa suposta contradição, pois, ainda que raros, alguns caraíbas foram, efetivamente, chefes de província. E, para a antropóloga, o estatuto de chefe seria incompatível com o de “caraî", ainda que:

Sua força devia provavelmente aumentar, ao reunirem os dois poderes, mas estes não podiam mais permanecer no mesmo plano: o poder religioso acabava necessariamente subordinado ao político. Tornar-se chefe implicava deixar de ser completamente profeta: mais exatamente, conservando-se seu prestigio e força, perdia-se contudo seu estatuto. Um chefe não tem, nem pode ter, o privilégio de "livre-trânsito" em meio a províncias inimigas, pois é ele quem decide sobre as expedições guerreiras, é através dele que as comunidades se definem como aliadas ou inimigas. Com toda a evidência, ele não poderia ser exterior às alianças políticas, já que é precisamente ele quem as encarna. Da mesma forma, não pode ser exterior à comunidade cujos afazeres ele rege, nem à rede de parentesco. Um chefe sempre ocupa uma posição localizável no tempo e no espaço, pois ser chefe é, antes de mais nada, pertencer a uma linhagem privilegiada (a chefia é hereditária), é governar uma aldeia e residir nela. Por conseguinte, a ambiguidade coextensiva à personagem dos caraís, enquanto homens-deuses, era levada ao extremo, isto é, até à contradição, quando estes ascendiam à chefia [...] a contradição que representa em si mesmo o profeta-chefe poderia ser o signo e, já ao mesmo tempo, a solução de uma contradição mais profunda da sociedade guarani - entre o político e o religioso. Sabe-se que existiam, com certeza, no plano político, fortes tendências centrípetas nas sociedades tupis-guaranis: elas são atestadas em especial pelo aparecimento de grandes chefes cuja autoridade era reconhecida nas escalas da província (havia vários na época da descoberta. Como por exemplo o célebre Cunhambebe retratado por Thevet) e por tentativas (episódicas e muitas vezes fracassadas, é verdade) de confederação. Inversamente, a religião exprime sobretudo forças centrífugas, negadoras do social, como vamos ver: pois é este, interpretado no plano sociológico, o significado da Terra sem Mal. (Clastres, H. 1978 [1975]: 45, grifos meus)

A imagem oferecida pela autora é a da separação entre dois poderes de tendências diversas e incompatíveis: o "político" e o "religioso", de tendências opostas, centrípetas e centrífugas. E essa separação atuaria como uma solução para inibir:

a emergência de um poder efetivo e separado, o poder político propriamente dito, poder
de coerção, de mando e obediência. Nesse sentido, ela não se distancia de Pierre Clastres,
no que toca ao projeto dele de antropologia política: os indígenas conhecem os perigos
do Estado, por isso mesmo cuidam evitar o seu aparecimento. E eles o fazem, garante
ela, ao não permitir a condensação de papéis, como os de chefe (“tradicional” ou "de
guerra”) e os de profeta (grande xamã, líder das migrações). Quando a palavra vazia do
chefe, que jamais constitui um poder político substantivo, adquire um conteúdo que im-
pele à ação é preciso impor um freio. (Sztutman, 2012a: 57-58)

Entretanto, se para Pierre e Hélène Clastres, a figura do chefe-xamã ou do chefeprofeta aparece como uma contradição, para Sztutman, o que as fontes históricas tornam visível são as metamorfoses de uma forma na outra. A partir de uma releitura "algo heterodoxa" do casal Clastres, o antropólogo afirma que o profetismo tupi seria "a radicalização da guerra, e o profeta, a radicalização do guerreiro, visto que se torna capaz de 
converter a violência em palavra potente” (Sztutman, 2009a: 156). Nesse sentido, a despeito do que imaginaram os autores franceses, não haveria uma:

contradição entre o religioso e o guerreiro, mas sim co-extensão, entrelaçamento entre ambos. Tampouco haveria contradição entre o religioso e o político, já que o último se faz, nessas paisagens, a partir dessa exterioridade que fundamenta tanto o religioso como o guerreiro. Os profetas e os guerreiros selvagens, figuras do exterior e do movimento, ao assumirem funções políticas, fazem-se figuras-limite da "sociedade primitiva". (Idem: 156, grifos meus)

Sztutman recorda ainda o que é importante não esquecer jamais: "a diplomacia não é senão parte integrante da guerra” (Sztutman, 2009b: 38). A figura do grande xamã e do grande guerreiro seriam, nessa economia do prestígio característica das socialidades ameríndias, sujeitos magnificados a partir de um movimento de intensificação de relações, que corresponde a uma amplificação da pessoa, e que não deixa de ser também um modo de concentração:

\begin{abstract}
O guerreiro extrai a sua magnitude do campo da guerra e da inimizade - ele mata inimigos e, assim, ganha nomes e marcas. Mas, lembremos, ele também tem de deter alguma capacidade xamânica; por exemplo, sonhar. O grande xamã - que é também um guerreiro, pois foi “iniciado" para se tornar gente de verdade - extrai a sua magnitude do campo sobrenatural, da comunicação com os espíritos e divindades. Se o grande guerreiro é um inimigo potencial, o grande xamã é um demiurgo potencial, detêm as capacidades de transformação, pode dar a vida e causar a morte. Ambos concentram relações com subjetividades alheias, ambos traduzem e transitam por mundos diferentes sob o risco de não pertencer a mundo algum, sob o risco de ameaçar o próprio grupo de onde vêm. $\mathrm{O}$ profeta-andarilho, que recusa os laços de parentesco e conclama a todos para segui-lo em seu caminho à terra sem mal, sem no entanto abalar os valores guerreiros, e o chefexamã, que canaliza todo esse movimento para a constituição de uma nova forma de domínio político podem ser pensados como derivas diversas - ou mesmo fases diversas - de um mesmo fundo xamânico. Eles constituem formas diversas ou fases diversas da magnificação do xamanismo. (Sztutman, 2009b: 35, grifos meus)
\end{abstract}

Temos aqui, no caso dos chefes guerreiros ${ }^{106}$ e d@s profetas-xamãs, uma intensificação de relações de prestígio, mas também de pessoas - não necessariamente humanas -, de seguidores. Mas há uma diferença, segundo Sztutman: "os chefes de guerra acabam por formar blocos unissexuados, blocos de homens, ao passo que os profetas constituíam coletivos propriamente heterogêneos, unindo homens, mulheres e deuses" (Ibidem: 25). Tais sujeitos magnificados seriam capazes de maximizar suas propriedades de agir sobre outrem, ou seja, suas relações com a alteridade. Pensar a ação política ameríndia implicaria então pensar certos processos de personificação, intensificação e magnificação ${ }^{107}$ de relações, segundo Sztutman (2009b). Na esteira das análises de Strathern,

\footnotetext{
${ }^{106}$ A pesquisa em relação à presença de mulheres entre os chefes guerreiros, ocupando posições de chefia ou liderança na guerra entre os Guarani nos tempos antigos, ficará para um próximo momento. ${ }_{107} \mathrm{O}$ conceito de magnificação foi primeiramente desenvolvido por Roy Wagner (2011 [1991]) ao discorrer sobre a "pessoa fractal" entre os melanésios - a partir de uma reflexão anterior (2010a [1974]) sobre a constituição de coletivos nessas paisagens que não se reduziriam simplesmente a grupos sociais -, e também por Strathern (2006 [1988]), ao pensar sobre as formas de "personificação do poder", e remeteria
} 
o antropólogo confirma que há de se compreender que a gênese dessas pessoas não pode ser dissociada da gênese de coletivos. Através da revisão do material tupi antigo, Sztutman percebe então que a liderança - que não seria um fenômeno, em princípio, sociopolítico -, pode ganhar estatuto sociopolítico, fazendo aparecer coletivos. Ele sugere assim a passagem do plano da ação - correspondente ao da liderança - ao da representação - plano da chefia: "Um líder atua na composição de um coletivo, e se torna um chefe, um líder político propriamente dito, quando se faz capaz de representar esse coletivo diante de outros coletivos, quando passa da ação para a representação" (Sztutman, 2009b: 32, grifos meus).

Por isso, "o problema da chefia, este fazer aparecer um coletivo, não pode ser dissociado do problema da liderança, ou seja, da ação e persuasão sobre outrem" (Sztutman, 2012a: 316, grifos meus). Nesse sentido, um líder por ser "aquele que inicia e coordena uma ação, é aquele que captura a ação (ou quiçá a imaginação) de outrem, reunindo heterogeneidades na construção de coletivos que podem parecer homogêneos", o que, por sua vez, demanda "em algum nível se não representação política propriamente dita ao menos alguma representatividade” (Idem). Para o autor, trata-se então de pensar não apenas o que é um chefe diante do grupo ou o que ele faz pelo seu grupo, mas como se fazem chefes $e$ grupos e também como certas pessoas se tornam chefes, líderes políticos e o que isso significa. Tema este que reenvia, necessariamente, aos processos de diferenciação interna, individuação, individualização, etc., entre as pessoas ${ }^{108}$ :

Por que, por exemplo, certos personagens singulares adquirem uma capacidade de influência maior que a dos demais? O que faz com que alguns ocupem uma posição política diferenciada (o que não significa necessariamente, lembremos, deter um poder de coer(̧ão)? (Sztutman, 2012a: 75, grifos meus).

Ao avançarmos na consideração sobre o que os povos indígenas pensam (e, sobretudo, o que fazem), seja em relação às suas formas sociopolíticas, seja sobre a possibilidade de algo como um poder coercitivo, de acordo com Sztutman (2012b), poderemos prosseguir na compreensão de como os índios tangenciam experiências que tendemos a identificar com as nossas concepções de Estado e de poder político ${ }^{109}$. Seria necessário então um pessimismo menos sentimental ${ }^{110}$, capaz de lançar luz sobre a originalidade das

à capacidade maximizada de um sujeito conter outros em si e causar ações. A pessoa fractal, de acordo com Sztutman, seria composta por diversas camadas pelas relações que acumula em si, se apresenta em diferentes escalas, variando conforme seu nível de magnitude (Sztutman, 2009b: 18). A noção de magnificação foi amplamente desenvolvida por Sztutman no âmbito das cosmopolíticas ameríndias em que grupos e chefes se fazem mutuamente (ver, neste sentido, Sztutman 2005, 2012a, 2009b).

${ }^{108}$ Szutman afirma que uma "sociedade contra a divisão" não seria, nesse sentido, o mesmo que uma sociedade sem diferenciação - ponto em que, segundo o antropólogo, o etnólogo P. Clastres parece ter se equivocado (Sztutman, 2009b: 20).

109 Para um desenvolvimento melhor desses argumentos ver Sztutman, 2012b e Viveiros de Castro, 2011.

${ }^{110}$ Em referência à argumentação desenvolvida por Sahlins (1997). 
estratégias indígenas de resistência. Assim sendo, a relação entre povos indígenas e o Estado seria pensada "menos como uma contradição sem qualquer chance de resolução", do que uma "tensão inelutável" que faria brotar outras formas de resistência, outros "contras". Nesse sentido, vetores ${ }^{111}$ flexíveis e fugidios das políticas indígenas podem conviver e mesmo combinar-se com os vetores rígidos de uma política de Estado e, mesmo assim, produzir resistência e autodeterminação, "num movimento de recusa da unificação, essa flexibilidade que pulveriza os focos de poder, impedindo concentrações e permitindo a 'multiplicação do múltiplo', mobilizando toda uma política selvagem”112 (Idem, grifos meus). Com isso em vista, tentaremos entender um pouco mais como esta socialidade xamânica contra o Estado age efetivamente no caso mbya atual, buscando assim compreender alguns de seus mecanismos de pensamento e ação cosmopolítica e nos inspirar.

\section{A socialidade xamânica Mbya}

$\mathrm{O}$ xamanismo ${ }^{113}$ enquanto um modo de mediação das relações com a exterioridade, entre humanos e não-humanos, se caracteriza pelo investimento na comunicação entre mundos, através da qual é possível se apropriar de outras agências necessárias para a produção e proteção de pessoas e coletivos. @s xamãs aí emergem como mediadores por excelência, como aqueles que dispõem de certas capacidades de ação e transformação pelas relações que estabelecem com outras agências do cosmos. Chaumeil (1998 [1983]) pensa o xamanismo "como um sistema em perpétua adaptação à realidade vivida e às situações particulares de cada grupo, que incluem profundas transformações e fortes pressões sociais" (apud Ciccarone, 2001: 18). Como instituição central e modelo de pes-

\footnotetext{
${ }^{111}$ Em uma crítica-homenagem à tese de P. Clastres, Deleuze e Guattari (1997 [1980]) entendem que só é possível ser contra algo que de algum modo está presente, admitindo com isso que há certos mecanismos do Estado presentes no interior mesmo nas sociedades ditas "primitivas", contra o Estado, superando assim o "resíduo cientificista e etnocêntrico" que ainda restava na tese clastreana. A "sociedade contra o Estado" segundo Deleuze e Guattari, seria melhor vista então como um "vetor inerente à toda sociedade": os indígenas apenas o fariam funcionar de maneira mais eficaz, uma vez que o vetor estatal, sempre presente, seria rebatido com maior ênfase, conjurado a todo momento. D\&G ressaltam então que o contraEstado funciona também entre nós, em certas de formas de ação e proposição política(s), mas também de pensamento, sendo virtuais-reais entre todas as sociedades e coletivos. As sociedades ditas primitivas, seriam apenas aquelas em que o vetor contra-Estado prevalece sobre o vetor a favor do Estado: "A lei do Estado não é a do Tudo ou Nada (sociedades com Estado ou sociedades contra o Estado), mas a do interior e do exterior [...] de coexistência e de concorrência, num campo perpétuo de interação, que é preciso pensar a exterioridade e a interioridade, as máquinas de guerra de metamorfose e os aparelhos identitários de Estado" (Deleuze e Guattari, 1997 [1980]: 23-4, grifos meus).

112 Políticas [indígenas] selvagens porque não unificadoras (Sztutman, 2012b: 8).

${ }^{113}$ Ver, neste sentido, Gallois (1996) sobre o xamanismo waiãpi e Langdon (1996) a respeito das novas e velhas perspectivas analíticas em relação ao xamanismo.
} 
soa, o xamanismo, de acordo com Ciccarone, constitui um repertório de saberes e práticas acionado para enfrentar a desordem, sendo@ xamã "a autoridade legitimada nos tempos de sofrimento, das dramaticidades e das reorganizações” (Idem: 18). Chaumeil (2015 [2003]) faz uso também do termo "geometria variável" para se referir as diversas transformações do xamanismo na América do Sul. Nesse sentido, se o xamanismo é antes de tudo uma qualidade como aponta Gallois (1988), os xamãs nada mais seriam do que sujeitos mais familiarizados com essas capacidades que advém, tanto do mundo animal, como do mundo dos deuses ou heróis culturais, se apropriando, cada qual a seu modo, dessas qualidades, e controlando-as de maneira mais eficaz em seu corpo, o que os capacita, inclusive, a transmiti-las a outros, se julgarem assim necessário. Sztutman ressalta ainda que o que muitos autores denominam de "poder xamânico", ou "saber-poder xamânico", ele prefere simplesmente denominar de "agência, capacidade de agir e produzir efeitos sobre o mundo e sobre outrem, capacidade de intensificar relações, dispor de outros agentes" (Sztutman, 2012a: 454).

O xamanismo atuaria, entre os Mbya, como "paradigma da fabricação da pessoa, representando o eixo de articulação simbólica das dimensões extraordinária e ordinária da existência", daí seu papel absolutamente "determinante tanto na condução dos processos migratórios quanto na orientação da vida social” (Ciccarone, 2001: 7). Mesmo assim, o xamanismo mbya foi pensado a partir de um discurso centrado nos critérios dominantes da masculinidade, desconhecendo ou mesmo subordinando a estes critérios, o universo feminino, no qual aparece a subjetividade e o espaço da sociedade gerido pelas mulheres. Tal viés masculino fez desaparecer do discurso da tradição, a importância central das mulheres no xamanismo e na construção da pessoa guarani, criando assim "um hiato entre os discursos como textos e a textura da vida social” (Ibidem: 19). Ciccarone, ao analisar em sua tese um recente movimento migratório conduzido pela figura central da xamã (kunhã karaı) Tatatĩ introduz um distúrbio na ordem tradicional etnológica, uma vez que busca aí articular e:

restabelecer, na construção da etnografia, as pontes (interrompidas na tradição dos estudos etnológicos sobre os Mbya) entre as grandes mobilizações, as manifestações rituais e as relações da sociabilidade da vida cotidiana desta sociedade xamânica, em que emergem as expressões da subjetividade e o protagonismo das mulheres como produtoras e reprodutoras da instável ordem social. (Ibidem: 7 grifos meus).

A literatura sobre os Guarani-Mbya, de modo geral, segundo a antropóloga:

Fundamenta-se na dimensão religiosa e num olhar dividido, que opera segundo categorias hierarquizadas e opostas (sagrado/profano, vida extraordinária/vida ordinária, mente/corpo, espírito/matéria), que mesmo questionadas podem continuar agindo de forma 
implícita, veiculando interesses de pesquisa, estabelecendo padrões de gosto, valores e sentimentos, direcionando os estudos. (Ibidem: 13, grifos meus)

Nesse sentido, podemos entender o xamanismo guarani (mas não só), em que o feminino é complementar ao masculino, configurando-se como um processo contínuo de aprendizado e aperfeiçoamento do ver, ouvir e sentir. O ver seria algo com um dom, uma vocação, que implicaria um processo ativo de conquista da "visão verdadeira" através dos sonhos, repertório imagético por excelência de onde provém as experiências subjetivas que conferem saber e poder (Ibidem: 18). O saber-poder da líder xamânica Tatatĩ que leva os seus seguidores caminhando até o Espírito Santo por orientação divina, legitimava-se, nas narrativas Mbya, principalmente a partir de suas visões e revelações proféticas. Por isso, a partir daí, Ciccarone entende a adivinhação como uma "arte da persuasão para fins políticos: prever o futuro imediato e distante garante o controle do grupo” (Ibidem: 19). Já o ouvir, revela-se na importância da sonoridade no mundo mbya, que se dá a partir dos dons dos cantos e das belas palavras inspiradas pelos deuses e que "vêm do coração", do "sentir as emoções sublimes, o amor recíproco, cósmico" (Ibidem: 18-19). Diante disso, pode-se dizer que o xamanismo guarani também se baseia naquele "ver, saber, poder" a que Chaumeil (1998 [1983]) faz referência quando aponta as características que definem o xamanismo yagua. Mas, como vimos, é importante enfatizar aí também o “ouvir’, já que a audição seria um dos sentidos mais valorizados entre os Guarani como via de acesso aos saberes divinos e ao estado de máxima atenção ou concentração (-japyxaka $^{144}$ ) propício a essa interlocução, que parte de uma capacidade ainda mais fundamental que é o falar, que se desenrola também junto ao cantar e rezar belamente, e diz respeito, sobretudo, à proveniência divina do próprio espírito-nome-palavra, nhe'ẽ.

Baseada em sua etnografia sobre grupos Nhandeva e Kaiowá do Mato Grosso do Sul (MS), Montardo observa que os Guarani dizem que fazem o ritual para ouvir os deuses e viver conforme o que ouvem, para não esquecer deles, por isso, cantam para lembrar (Montardo, 2002: 237). O sentir aí seria consequência imediata do escutar, que também se realiza com o corpo, pois os afetos da raiva e do amor são trabalhados durante o canto e a dança atuando diretamente sobre ele, aperfeiçoando-os, embelezando-os, restaurando seus corpos-espíritos e os dotando de leveza, força e alegria, combatendo a tristeza.

114 - Apyxa pode ser traduzido como “ouvido" (Dooley, 2006: 17). Já o termo -japyxaka é traduzido por Dooley como "escutar (a algo): pejapyxaka xeayvu re escutem o que eu digo" e -erojapyxaka "fazer (alguém) escutar" ou "implorar a Deus" (Ibidem: 62). Pissolato traduz -japyxaka como "pôr-se em escuta atenta" (Pissolato, 2007: 162). Meus interlocutores mbya de SP sempre me traduziram -japyxaka como a busca contínua por atingir um estado de total concentração na opy ou mesmo na vida, já os meus interlocutores do Sul do país, geralmente, traduzem o termo por "meditar", em referência ao estado de meditação. 
Transformando-os enfim a exemplo dos ancestrais divinos que vivem em festa e alegria em suas moradas e, que por agradá-los, os Guarani acabam garantindo a continuidade e manutenção das condições de vida nesta terra: "O corpo que escuta, dança; o corpo que dança se torna leve, o leve é alegre e o alegre é saudável” (Ibidem: 243). Saber vencer a tristeza é o que caracteriza então o poder $\mathrm{d} @$ xamã, que para realizar tal tarefa necessita da ajuda dos "yvyra'ija kuéra" (auxiliares-guerreiros dos Nhanderu e Nhandexy no plano terrestre e no plano celeste) (Ibidem: 241).

O estado de leveza (-vevui) que os Mbya tanto perseguem e denominam aguyje, seria como um estado que lhes permite ir até a morada dos deuses e se relaciona ao estado do sonho (Ibidem: 243). O jeroky, ritual xamânico de dança guarani que tem na música um lugar central dando ritmo e movimento aos cantos-rezas, seria como um caminho a ser percorrido ao encontro das divindades, cujas aldeias "estão no mesmo nível, mas o caminho para ir até elas é constituído de uma subida e uma descida" (Ibidem: 167). Caminho este que não está isento de perigos e obstáculos a serem enfrentados, pois há sempre "onças" à espreita e, por isso mesmo, aqueles que dançam devem estar preparados, isto é, muito atentos e ágeis para defender-se, esquivar-se $e^{115}$ dos ataques, pois se não estiverem suficientemente concentrados correm o risco de perder-se no caminho e ficarem suscetíveis a contrair doenças. Isso transparece nas coreografias das danças-lutas xondaro ${ }^{16}$, nas quais se realizam movimentos de ataque e defesa, em que há sempre uma ênfase em aprender a "desviar" 117 com o corpo - aprender a não se contrapor diretamente, comportamento característico Guarani que não configura uma "não-resistência”, mas uma espécie de estratégia desenvolvida diante dos desafios que enfrentam há séculos em que a música e a dança ocupam papel central (Ibidem: 36) -, algo como um combate em que são "extraídas as armas atiradas em feitiços" (Ibidem: 209).Em tal percurso@ @ xamã ouve os deuses e canta o que eles cantam, narrando o caminho e assim incitando os participantes a acompanhá-1@ com o corpo-espírito. Nesse sentido, os rituais cotidianos

\footnotetext{
${ }^{115}$ Dooley traduz -jeary uka por “esquivar-se [lit., 'fazer com que errasse’]” (Dooley, 2006: 23). Ele também usa outro termo que tem o mesmo significado, -mbogua (Ibidem: 108). Para uma análise do movimento de esquiva (-jeavy uka) enquanto um "fazer errar", "fazer com que se engane”, próprio à ação política guarani, ver Keese dos Santos (2017).

${ }^{116}$ Expressão derivada da palavra em português “soldado" (Dooley 2006): os xondaro eram responsáveis pela caça, por aplicar sanções violentas, por proteger o agrupamento contra ataques jurua, outros indígenas ou animais selvagens nas aldeias ou nos caminhos, atuando enquanto auxiliares, guerreiros, guardiões ou mensageiros dos nhaneramoĩ e nhandejaryi kuery ("nossos avós"). Ver, neste sentido, Montardo (2002), Pissolato (2007), Macedo (2010, 2012a), Nogueira da Silva (2008, 2015), Eckart (2014), e de modo mais focalizado nessa figura e suas ações, Keese dos Santos (2017).

${ }^{117}$ Cadogan usa o termo ojaryuka para explicitar essa ideia, que traduz como um "hace desviar" (Cadogan, 1959: 46). Segundo o autor, a palavra "pecado" não existe em mbya, "empleándose la palabra jeavy = desviarse, equivocarse" (Idem).
} 
seriam uma "espécie de treinamento e preparação para a vida, o que garante a sobrevivência do grupo e a manutenção da própria Terra, numa ação análoga à desenvolvida pelos deuses" (Ibidem: 12-13). O ethos guerreiro guarani está presente então tanto nos caminhos percorridos no canto-reza-dança, como nos caminhos que se apresentam na luta diária e levam à cidade mais próxima, pois os “yvyra'ija kuéra” são "como soldados, guardiões que estão limpando caminho, protegendo de feitiçarias, raios, etc.” (Ibidem: 259). Assim, se toda pessoa mbya é um pouco xamã como estamos desenvolvendo, ela também tem uma função de guerreiro latente (ver Cretton Pereira, 2014: 16).

Com isso, o xamanismo seria "vivido não como uma fuga da realidade difícil, mas como uma luta para não sucumbir a ela" e, ao fazer o jeroky estariam "interferindo na composição do mundo e atuando na manutenção da Terra”, e se não o fizerem, o seu silêncio "fará com que o Pa'i Kuara aqueça sobremaneira a Terra, inviabilizando nela a vida", além de enviar "ventos fortes de todos os lados [qu ]e acabarão com tudo" (Ibidem: 217, alterações minhas). Por isso, de acordo com Montardo, o "xamanismo talvez trate da Terra e seus habitantes como um 'doente' em contínuo tratamento, em contínua luta pela sobrevivência física e espiritual” (Ibidem: 31). Nesse sentido, podemos entender o xamanismo aqui como uma estratégia mbya de manutenção e transformação criativa e contínua do mundo terrestre. Montardo alerta também a respeito da sua própria experiência de campo que foi marcada por mulheres xamãs ${ }^{118}$, que eram também chefes de grupo familiar, ou ajudantes de um casal-xamã:

Quando se fala em xamanismo, a primeira imagem que vem a mente é a de um homem realizando uma cura. Quero ressaltar que esta imagem não corresponde à ênfase do $x a$ manismo guarani, que recai no ritual coletivo, cotidiano de caráter mais profilático ou de uma cura ampla, que abrange a própria Terra. (Ibidem: 30, grifos meus)

Como Schaden também observou, cura e reza não seriam necessariamente habilidades reunidas em uma única pessoa, por isso, há especialistas que curam mas não são rezadores, e rezadores que não operam diretamente curas (Schaden, 1974 [1954]: 9596). Além disso, como aponta Pissolato, tais especialidades nas práticas terapêuticas não seriam exclusividaded@s xamãs, uma vez que algumas dessas aptidões se distribuem de maneira geral e variada entre os Mbya, existindo tanto habilidades específicas, próprias aos especialistas, quanto diferentes graus de envolvimento e liderança no canto, reza e

118 Principalmente pela xamã-rezadora, Odulia Mendes, sua principal interlocutora (Montardo 2002). Além dela, há pouquíssimas referências às mulheres xamã guarani, entre elas estão a kunhã karai Tatatĩ do Tekoa Boa Esperança (ES), a xejaryi Aurora e a sua atual seguidora, Joana (ver Ciccarone 2001, 2004). "Takuá Verá", heroína divinizada que alcança a plenitude da terra sem mal junto ao filho reencarnado (Cadogan 1959) é uma das raras figuras femininas citadas na literatura etnológica clássica. 
na dança, uma vez que estas seriam práticas mais estendidas, não sendo só @s xamãs que a elas se dedicam (Pissolato, 2007: 350). Nimuendaju (1987 [1914]), como outros autores, observa entre os Apapocuva a predominância masculina no xamanismo e na liderança política, considerando que apenas pajés homens poderiam atingir a perfeição divina, apesar de também reconhecer a existência de mulheres "pajés" e de práticas xamânicas comuns entre todos os humanos. Em relação aos cantos de pajelança, Nimuendaju destaca “classes” distintas de pessoas, já que:

\begin{abstract}
Não se pode conceber os pajés dos Apapocúva como uma casta fechada ou hereditária. Com relação ao canto de pajelança, os Apapocúva se dividem em quatro classes. À primeira pertencem originalmente todos os seres humanos, pois inclui todos aqueles que não foram tocados por nenhuma inspiração. A segunda classe engloba aqueles que já receberam um ou alguns cantos, que usam em seus assuntos privados; a ela pertencem a maioria dos adultos de idade madura, de ambos os sexos, embora o sexo masculino seja sempre mais representado. Quando alguém desta classe, durante a dança ritual, começa a se adiantar à fileira e a dirigir a dança dos demais, isto é sinal de que ele já se aproxima da terceira classe. Esta congrega os pajés (homens e mulheres) propriamente ditos, distinguidos com o título de Ñanderú e Nandecy. Eles usam seus poderes mágicos não só para fins pessoais, como também os põem a serviço da comunidade: a procura do nome (batismo), cura de doenças, profecias, etc. Apenas pajés homens, no entanto, atingiram o mais alto grau de perfeição, que os capacita a dirigir a festa Nemongaraí, e que termina por levá-los a assumir progressivamente a liderança social do bando; tornam-se pajés principais. Antigamente os Guarani não reconheciam outro líder que o pajé-principal. (Nimuendaju, 1987 [1914]: 74-75, grifos meus)
\end{abstract}

Entre os Mbya, as práticas que constituem o seu xamanismo como rezar (nhembo'e), dançar (-jeroky), cantar (-poraeı) e fumar tabaco (-pita), utilizadas para alcançar sabedoria e poderes de cura, entre outras boas disposições das divindades, são acessíveis a toda pessoa que se disponha a dedicar-se a uma ou várias delas, sendo resultado, portanto, tanto do investimento pessoal quanto das capacidades enviadas, pela comunicaçãorelação estabelecida com os deuses. Estas práticas são sempre produtoras de benefícios para aqueles que a elas se dedicam e a quem são disponibilizadas, sendo a reza, de acordo com Pissolato (2007), a maior produtora dessa disponibilização, uma vez que alcança a coletividade de humanos reunidos aqui na terra. Podemos, assim, a partir de tudo isso que foi aqui mobilizado afirmar que, o xamanismo guarani não se reduz à figura $\mathrm{d} @$, xamã e estaria mais bem distribuído entre toda a coletividade. A socialidade mbya é por assim dizer xamânica: as práticas e saberes xamânicos se estendem, em maior ou menor grau, a todo o coletivo. Nesse sentido, o xamanismo mbya estaria mais bem relacionado à dinâmica singular do próprio princípio agentivo guarani, o nhe’e ("linguagem-afeto"119),

\footnotetext{
${ }^{119}$ A singularidade de nhandeva'e ("aqueles que somos nós", os Guarani) está na proveniência divina de seu nhe'ẽ, codificada pelo compartilhamento de uma língua e modulada pelos nomes-espíritos advindos de diferentes domínios celestes (Macedo 2010). Macedo escolheu traduzir nhe'ẽ como "linguagem-afeto" ou "afeto linguagem", apesar da clássica tradução de Cadogan (1959) por "alma-palavra" (Macedo e Sztutman, 2014). Uma outra tradução do termo é proposta por P. Clastres (1990 [1974]): "palavra-habitante".
} 
capacidade mais fundamental de sua humanidade-divindade (Pissolato, 2007: 317). Este princípio agentivo é a potência primeira de comunicação com a esfera divina, produtora de consciência e fonte primordial de saberes-poderes e capacidades de entendimento e ação, inspirados pela relação singular que se estabelece e se mobiliza com as divindades, e que se desdobram em diferentes afecções (capacidades de afetar e ser afetado em e pela relação) ao longo da experiência e da trajetória de cada pessoa e de suas relações (que são mobilizadas por cada um[a]), e se fundamenta na busca de proteção à saúde e promoção de alegria e de bons ânimos aos parentes, consanguíneos ou não, neste e noutro mundo.

\section{Xamanismo e inspiração: a disposição em guiar um coletivo e seguir uma orientação}

A literatura sobre os Guarani, de modo geral apontou o lugar central da figura masculina do xamã, especialista na cura, dirigente de cantos-rezas (mbora'i ou mboraei, poraei e tarova' $\left.{ }^{120}\right)$ e danças (jeroky), responsável pela nominação de crianças e chefe orientador de um grupo de parentes (-retarã kuery), afirmando assim sua posição central na constituição e reprodução do social ${ }^{121}$. Nessa leitura, o xamã representa uma posição que aglutina os interesses diversos no interior de um grupo, mantendo sua unidade, sendo o principal responsável pela continuidade de um "modo tradicional de vida" e o intermediário, por excelência, entre a coletividade e o "mundo sobrenatural", tradutor direto da sabedoria divina que transmitiria aos demais. Há aqui uma compreensão do lugar absolutamente central da relação com os deuses e do controle do fluxo de capacidades existenciais que dela se origina para a constituição e reprodução social. A sua vinculação direta à posição do xamã deve-se à associação de sua figura a um modo de vida dito dos “antigos", sendo ele o representante descrito pela literatura etnográfica como o padrão de liderança entre os Guarani antigos. Seriam eles, ao mesmo tempo, figuras do movimento e coordenadores de ações coletivas, despontando como aqueles que possuem o “conhecimento" e dizem pela sabedoria (arandu) - originados pela sua experiência de vida e trabalho e pela sua relação generosa com as pessoas -, ou ainda "aqueles que seguem à

\footnotetext{
120 Os cantos vocais, mais "rezados” (tarova' $)$ que propriamente falados ou letrados, são diferentes dos mbora' $i$ que possuem uma letra específica que os xondaro e xondaria kuery seguem.

$121 @$ xamã, identificad@ como a liderança espiritual que orienta o grupo de parentes seria o modelo de pessoa exemplar guarani. No entanto, de acordo com Ciccarone, "à medida que se desvincula o xamã do resto da sociedade, isolando-o como protagonista e responsável único e absoluto pelos levantes migratórios, opera-se uma espécie de estatização do xamanismo, criando a 'teocracia' dentro de uma sociedade organizada politicamente 'contra o Estado'. Apesar de serem considerados eleitos pelos deuses, como os portadores do verdadeiro saber-poder, os indígenas não reservam aos seus xamãs uma dogmática credibilidade, sendo esta submetida à prova da experiência. São hommes (e femmes)-dieux, para parafrasear $A$. Metraux, não somente divinos, mas também e ainda humanos" (Ciccarone, 2001: 243, grifos meus).
} 
frente" mostrando o caminho - pelas qualidades que reúnem e fazem aparecer em suas ações -, atuando como mediadores privilegiados - pela sua capacidade de comunicação acentuada -, na relação que estabelecem com as divindades e outros seres - visando obter, por meio de alianças, benefícios para a subsistência do grupo de parentes -, na manutenção da tradição e na continuidade da existência - a duração da pessoa -, figuras centrais tanto nos deslocamentos físicos como nos relacionais, liderando grupos em caminhadas e formação de aldeias e nos cantos-rezas e danças aos Nhanderu e Nhandexy kuery.

Tal leitura, acaba por centralizar e concentrar grande parte da administração e circulação dos saberes-poderes inspirados pelos deuses na figura paterna e na posição ritual dos chefes-xamãs, privilegiando a interlocução com tais figuras - talvez por serem eles, as figuras que recebem os estrangeiros, ou que se fazem mais visíveis, e iniciam a relação, treinados que são para lidar com o exterior -, muitas vezes, dispensando atenção, na descrição etnográfica, para a importância, valor e centralidade das mulheres no sistema xamânico guarani - seja nestas tarefas-ações e-ou em outras também tão ou mais centrais para a manutenção desse mundo -, especialmente à singularidade das esposas destes chefes-xamãs ${ }^{122}$ na produção, proteção e mobilização de pessoas, coletivos, relações e na organização, reprodução e manutenção das atividades cotidianas e rituais entre parentes, figuras estas que cumprem papel central também na produção e circulação de alimentos, substâncias, experiências, saberes-poderes, cuidados-carinhos, memórias e na transmissão dos bons-belos e eficazes ensinamentos-conselhos divinos (ver o desenvolvimento dessa argumentação no Capítulo III).

No entanto, esse discurso que afirma o xamã como guardião do nhandereko, o "bom" modo coletivo de viver, identificado ao modo de vida dos "antigos", só se constrói como uma perspectiva que estaria sempre em negociação com a realidade mais abrangente, capaz de originar muitos pontos de vista que não aquele. O conhecimento xamânico é algo percebido pelos Mbya numa abrangência muito maior que o da atuação propriamente dita da figura d@xamã que pode, em determinados contextos, nem mesmo existir, mas é pouco provável encontrarmos aldeias sem opy (casa de reza-canto-dança-cura), segundo Pissolato (2007). A opy está ligada a uma função de proteção divina coletiva,

\footnotetext{
122 Ainda que se reconheça a importância da figura do casal-xamã que ocupa um lugar de destaque na liderança entre outros grupos Tupi-Guarani, como aponta, por exemplo, Gallois (1996) para os Waiãpi (cf. Pissolato, 2007: 157, nota 35, 176, nota 7). Nesse sentido, Pissolato reconhece que: "Apesar da literatura sobre os Guarani ter ressaltado a liderança como posição masculina, trabalhos recentes têm demonstrado que, em diversos casos, são mulheres que apresentam esta capacidade de aglutinar parentes ou de constituir um 'grupo' cujos participantes tendem a permanecer reunidos, em geral, por capacidades xamânicas que se lhes reconhece" (Pissolato, 2007: 157, nota 35).
} 
sendo um espaço de reunião na terra dos espíritos-palavras (nhe'ẽ) enviadas por Nhanderu e Nhandexy kuery, podendo estar associada à figura $\mathrm{d} @$ dirigente de reza-canto-cura, ou não. É como se a opy cumprisse a função de reunir o que na terra vive de modo disperso, concentrando nesse espaço os cuidados necessários e difundindo amplamente as capacidades adquiridas na relação com os ancestrais divinos.

Prates (2013) afirma não haver um script a ser seguido pel@s xamãs, que só seriam reconhecidos conforme a eficácia de seus poderes em certas situações (do que depende, efetivamente, o seu prestígio). No entanto, haveriam ocasiões que demandam muita atenção e um alto grau de investimento em cuidados, que costumam ser partilhados entre dois (ou duas) ou mais xamãs. Quanto aos demais participantes das solenidades rituais, conforme queiram participar, seja cantando ou dançando, o espaço lhes é oferecido, "como se todos pudessem ter essa interação direta com os deuses" (Prates, 2013: 230). Nesse sentido, @ xamã faria às vezes da intermediação, ou mesmo um certo direcionamento das atividades desenvolvidas no espaço ritual, "mas todos os presentes são potencialmente xamãs" (Idem, grifos meus). A afirmação dos estilos pessoais d@s rezadores(as) liga-se a um outro aspecto importante: a prática xamânica é compreendida aqui como prática pessoal, sendo o ritual mbya o contexto privilegiado para a afirmação desta disposição xamânica, sendo os mais prestigiosos na prática aqueles que dirigem cantos-rezas-danças e fazem curas no meio da opy. Mesmo assim, o xamanismo, de acordo com Ciccarone (2001), raramente é analisado em termos de uma arte oral e teatral, ainda que sejam essenciais aí as qualidades pessoais de cada xamã, que seria reconhecid@ pelo seu estilo próprio e pelos poderes que adquire a partir de sua relação acentuada com a esfera divina. Ela pensa@ @amã então como um(a) artista, que "improvisa diante de situações novas, anima a vida social, organiza os rituais” (Ciccarone, 2001: 19).

Contudo, a direção xamânica nunca seria capaz de se sobrepor à lógica do xamanismo como produção de saberes-poderes em um sentido mais abrangente, daí a questão do acreditar-confiar (-jerovia) ou não em seus saberes-poderes, comentário que geralmente acompanha a avaliação individual sobre a atividade d@s xamãs. Assim, o modo de constituição da (dis)posição xamânica centrada na questão da confiança na prática pessoal, em grande medida é sustentada pelo parentesco, mas a função xamânica não se submete a ele. Há aqui sempre o desejo de pôr-se sob a proteção de um(a) xamã e um lugar de possível desconfiança de sua capacidade, segundo Pissolato (2007), uma forte tendência a não se submeter plenamente à sua posição. Por isso, de acordo com Testa, é importante entender que os critérios mbya de atribuição de autoridade envolvidos na questão do 
"acreditar-confiar" contribuiriam muitas vezes, "não para a formação de grandes consensos, mas para a constituição e a multiplicação de diferentes coletivos que se vinculam às orientações específicas de seus próprios líderes (tenondegua-aquele(a) que vai na frente)” (Testa, 2014: 176). Nesse sentido, embora a liderança possa ser:

\begin{abstract}
imbuída de autoridade, não é um cargo, mas antes a posição de quem se coloca à frente, tomando a iniciativa de começar determinadas atividades e cuidando da orientação e da condução de um coletivo ao longo de uma trajetória, que pode se encerrar com a realização de uma atividade ou se estender para englobar grande parte das experiências desenvolvidas num tekoa. Assumir essa posição depende dos conhecimentos e habilidades adquiridos e do reconhecimento que outros membros do grupo atribuem às capacidades dessa liderança. (Idem, grifos meus)
\end{abstract}

Dessa maneira, vemos que a tendência a não fixar de maneira absoluta posições de orientação (fundadas possivelmente naquela recusa ativa de que nos falava P. Clastres), podendo haver múltiplas perspectivas em jogo, deve-se ao fato de que os saberes-poderes que estão em questão são sempre compreendidos nos termos do que transmitem os deuses aos humanos, ou seja, adquirir conhecimento para a vida, em qualquer âmbito, envolve a percepção do que contam os deuses, com quem os humanos devem inicialmente se aconselhar, e que ocorre já nos termos da aquisição de saberes, através do próprio espírito-nome ou alma-palavra (nhe'ẽ). Temos aqui a noção de que se passa sempre algum saber pela fala, pelo contar, que é também a forma típica de transmissão de saberes e poderes pelas divindades. O que é chamado de nhe'ẽ porã ("palavras bonitas", segundo Pissolato, 2007) são palavras simultaneamente enviadas pelos deuses e pronunciadas pelos rezadores(as), que as fariam circular pela terra. Está em jogo aqui, de acordo com Pissolato (2007), uma ciência mbya - uma ciência xamânica que articula pessoa e parentesco, autonomia e autoridade, capacitando os humanos para a vida nesta terra - na qual o processo de produzir entendimentos (saberes-poderes) seria a atividade mais fundamental dos humanos em geral e onde residiria a função principal do xamanismo entre os Mbya: proteção à saúde e constante atenção à condição de satisfação e alegria da pessoa neste mundo. Aqui, o trabalho do parentesco é obter constantemente forças disponibilizadas pelos deuses para o fortalecimento das pessoas relacionadas, ou seja, de não deixar parar o fluxo dos saberes-poderes produtores de saúde e alegria (Pissolato, 2007: 337).

A “ciência” dos Mbya compreendendo assim, sempre o que se escuta por si dos deuses e o que aconselham entre si os humanos, consistindo na boa conduta entre eles, daí o valor muito geral e que definiria o parentesco, da extensão de saberes-poderes a 
outros humanos, processo que tem na fala seu instrumento-chave. Nhanhemongueta ${ }^{123}$ ("nós nos aconselhamos") seria a maneira correta de transmissãode conhecimentos, que faz referência direta ao aprender conversando, ficando junto (Ibidem: 336). A conversa que aconselha, que produz bem-estar, tem aqui lugar privilegiado no tratamento entre pessoas, não havendo propriamente um limite preciso, na convivência entre parentes, da conversa e a transmissão de conhecimentos. Nesse sentido, o processo de conhecimento é entendido aqui como o próprio processo da existência humana, num saber agir primeiramente instruído pelas divindades - que no final das contas é sempre matéria de interpretação pessoal - a partir do qual se busca proteção, e com base também na própria experiência que tem na mobilidade ${ }^{124}$ seu maior instrumento e corresponde a um aspecto fundamental na percepção da vida: sua multiplicidade de caminhos ou possibilidades (ver Capítulo I). O que se reproduz na tendência constante em mudar a própria condição de vida, em busca de algo melhor, a tradição estando na procura em si ${ }^{125}$.

Persiste aqui, então, a ética do "caminhar" (-guata) ou "não parar", o "não se deter", em qualquer âmbito da vida humana. Cada um tem consciência de sua própria disposição e a boa consciência para fazê-lo, na medida em que Nhanderu ${ }^{126}$ o favoreça, isto é, lhe ponha algo no caminho. Daí a dinâmica própria ao parentesco Guarani, na qual a conexão vertical com os deuses e horizontal com os parentes (parentesco em aberto) traz essa abertura de caminhos que se pode experimentar continuamente e fazer a vida durar, que é caracterizada pelo movimento de indivíduos e grupos no plano local e no supralocal - uma possibilidade entre outras de vivência do parentesco seja pelos rompimentos, seja

\footnotetext{
123 Segundo uma interlocutora mbya, professora e importante liderança, nhemongueta é quando "todo mundo se reúne para pensar algo, para decidir algo, para discutir algo", uma espécie de "reunião" para "pensar junto" e "conversar" (Kerexu Yxapyry da T.I. Morro dos Cavalos [SC], Local: Tekoa Tenonde Porã, 2015).

${ }^{124}$ A mobilidade é um tema chave na análise de Pissolato (2007), pelo lugar central que ocupa na história de vida dos indivíduos e famílias com quem conviveu. A antropóloga classifica tal prática como o movimento da produção de humanidade. A ênfase mbya recai, portanto, na continuidade da pessoa, que deve se animar e encorajar nesta existência. Se a vida humana não dura, a transitoriedade ocupa um lugar de valor especial para fazê-la, justamente, durar mais, por isso a consideração do caráter transitório da condição humanasocial dá um valor altamente positivo à mobilidade como prática e pensamento.

${ }^{125}$ No entanto, essa busca não se desvincula de um pensamento que concebe a Terra como condição precária à existência humana, e ao mesmo tempo não deixa de valorizá-la como meio possível de realização desta mesma existência. Estaríamos diante do que Pissolato denomina de "ethos buscador guarani", dado desde o início pelos heróis divinos e que orientaria os Mbya a caminhar e reproduzir um "verdadeiro" modo de vida, no qual a busca contínua por lugares ou contextos melhores de vida é central. Essa busca seria nada mais que a busca em si de um modo mais apropriado de viver numa terra em que "verdadeiramente bom" não há, isto é, não deixando de visualizar também o seu limite, que é a consciência da corruptibilidade característica dessa terra imperfeita (Pissolato, 2007: 160).

${ }^{126}$ Apesar de reconhecerem uma variedade de divindades que são invocadas nas rezas e estão associados a direções distintas do espaço, em referência à relação com o domínio divino é comum também falar em Nhanderu (“Nosso Pai”) de modo unificado, especialmente quando o discurso se direciona aos jurua kuery.
} 
pela sua simples "possibilidade"127. O desafio da pessoa nesse mundo seria fazer com que o nhe'ẽ se acostume no corpo, através da busca constante de modos de fortalecimento da existência da pessoa nesse mundo, e se dá pela constante alteração de suas formas de vida (Ibidem: 43). Teko seria então essa busca em si mesma, e para vivê-la é necessário adquirir saberes-poderes nessa busca, isto é, contar com capacidades adquiridas tanto daquilo que "contam os antigos", quanto pelo que se é capaz de ver e conhecer a partir da própria experiência de vida (xereko, "meu ser”, "minha vida”) (Ibidem: 120).

Entre os Mbya se percebe então que cada um tem o seu "costume" (teko), suas tendências próprias, seja no trato com os parentes, na maneira particular de comer, ou alguma habilidade específica em determinando afazer, por isso, cada um tem seus próprios atributos, ou suas preferências, ou como dizem os Mbya, "cada um tem a sua 'sabedoria'. Note-se: 'sabedoria' ou conhecimento para viver o (próprio) teko, o 'estado de vida', que é a sua "condição" (Idem). Acima de tudo, "sabe-se"128 pela experiência, e esta só existe para cada pessoa, que tem como desafio optar pelas boas escolhas, considerando sempre, em primeiro lugar, a própria condição de satisfação, bem-estar e saúde no decorrer da vida. No entanto, Pissolato ressalta ainda que esta dimensão não exclui aquela outra tão importante de seguir uma determinada orientação, ou estar atento ao que contam os "antigos", justamente para "permanecer" ou durar nessa vida.

Nesse sentido, a questão de pôr-se sob a proteção d@ chefe(a) de parentesco local (que pode ser, simultaneamente, uma liderança, quando adquire prestígio a partir de certas capacidades como a produção de uma boa fala para os demais ou tem o poder reconhecido pela capacidade xamânica de cura), ou então abrir mão desta proteção, na busca de uma vida com mais autonomia, são perspectivas que sempre se colocam ao longo da trajetória dos Mbya que, geralmente se caracterizam por serem agrupamentos instáveis $^{129}$ (Ibidem: 70). A fala, que permite a comunicação entre parentes é então o centro da vida social mbya, pois é aí que reside a sua principal capacidade relacional e as possibilidades de acúmulo de relações, saberes-poderes e de prestígio, isto é, a sua magnificação. A capacidade de comando que se adquire a partir de habilidades como a fala e a

\footnotetext{
${ }^{127}$ E quanto mais magnificado se torna @ chefe, menor é essa possibilidade de mobilidade, dispersão, o que constitui um investimento ou uma "mudança de perspectiva" dele(a) nessa prática.

${ }^{128}$ Para Pissolato (2007), não há qualidade que melhor defina a maturidade entre seus interlocutores que a capacidade de agência: ser capaz de decidir e agir conforme a própria consciência é uma atitude que se sobrepõe a todas circunstancias que se defrontam os Mbya.

${ }^{129}$ A eventual cisão no interior de um grupo é característica da organização social mbya, assim como de outros agrupamentos tupi. Até mesmo os parentes divinos teriam suas próprias cidades-tekoa (ver, neste sentido, Guata Porã - Belo Caminhar 2015).
} 
cura ${ }^{130}$ seria então resultado direto das práticas d@ xamã, e ao mesmo tempo algo que nunca é plenamente estabelecido. Além da prática d@ especialista curador(a)-rezador(a) fundar-se na relação sem mediação com as divindades (@xamã, é @ própri@mediador(a) por excelência), a disposição de xamã implica certo investimento tanto da parte dele(a) próprio(a), como dos que se juntam a ele(a) e apostam em suas capacidades portanto, o grau de prestígio e o tipo de vínculo que os liga são elementos importantes. Assim, a liderança sobre um grupo pode então construir-se de modo mais ou menos abrangente e efetivo na prática, uma vez que@ xamã nem sempre se torna efetivamente um(a) líder de um grupo de parentes, ainda que sua função principal seja protegê-los. Desse modo, todo homem, mulher ou casal mais velho com capacidades xamânicas mais desenvolvidas que encabeça um grupo de parentes (-retarã kuery), vivendo com este e sendo considerado xamã ou não, tem potencialmente uma capacidade de liderança que poderá, conforme suas habilidades e intenções, buscar desenvolver. A (dis)posição de xamã a todo o momento é colocada à prova, pois ainda que o xamanismo permita organizar coletivos e garantir, de certo modo, a produção e proteção de parentes, sempre sob a relação de mediação com os deuses, ele não exclui do horizonte a produção de conflitos, feitiçaria e a possibilidade de uma metamorfose animal (-jepota) no confronto entre seres e mundos. Os esforços de devir-divino que se dão através da ética xamânica mbya não excluiriam os perigos de devir-animal, apenas atenuam-nos por meio de práticas de proteção e diplomacia entre mundos, próprias ao xamanismo.

Assim, o campo do xamanismo originaria simultaneamente a figura, de certa maneira, “autorizada” d@ xamã e as múltiplas perspectivas - saberes-capacidades-poderes também "inspirados" pelos deuses - que podem discordar da primeira. A hipótese de Pissolato (2007) é, então, que a função xamânica entre os Mbya é algo maior do que o trabalhod@xamã, e que o trabalhodos parentes põe no centro, justamente, o conhecimento xamânico. Daí não ser por acaso o fato do casal-xamã serem idealmente os chefes de uma família extensa, em sua função de proteção do parentesco. Um(a) bom(a) xamã seria aquele(a) que mais se aproximaria do estado de amadurecimento corporal-espiritual (aguyje), próprio aos deuses. Cretton Pereira observa que uma leitura semelhante pode

\footnotetext{
${ }^{130}$ Aparece ainda ocupando um lugar bem importante na autoconstrução do prestígio pessoal d@ chefe(a) a reza-cura, que além de ser capaz de reunir entre si o grupo familiar, pode vir a conquistar outros adeptos que venham a acreditar em suas capacidades ou poderes, e que costuma assumir a forma da afirmação do próprio estilo de reza-cura como o mais apropriado, ou como aquele que corresponde melhor ao modo como faziam "os antigos" (Pissolato, 2007: 90). Tal discurso que contrapõe a própria maneira de rezar a outros modos de reza e-ou cura é utilizado frequentemente para crítica a outras localidades, visto que a reza seria um dos lugares-chave de marcação de especificidades locais entre os especialistas e de uma identidade “autenticamente” guarani (Idem).
} 
ser feita sobre uma dita função guerreira entre os Guarani: "ela é mais do que o trabalho dos xondaro" [e das xondaria] (Cretton Pereira, 2014: 80). Neste sentido, o que parece haver é uma função de guerreir@ latente em cada pessoa mbya, "que se atualiza a cada vez que se volta a atenção para o desejo, evitando excessos, de si ou dos outros (principalmente daqueles a quem se deve educar)" (Idem). Estamos diante então de diferentes disposições xamânicas e guerreiras latentes na produção e proteção de pessoas nesse mundo.

\section{Tenondegua kuery: aqueles que seguem à frente, iluminando o caminho}

Em relação à liderança espiritual do grupo o termo mbya mais utilizado, segundo Ladeira - entre as aldeias da região Sudeste e Sul do litoral visitadas por ela - seria mbaekuaa'vae: "aquele que possui a sabedoria e diz pela iluminação (omoixakã)" (Ladeira, 2008 [2001]: 32). E seriam estas lideranças, mbaekuaa'vae kuery ("aqueles que sabem”) que, no mundo atual, conduziriam o próprio grupo na procura de lugares para viverem, seguindo a orientação divina "do criador de todas as coisas, Nhanderu tenonde gua (Nosso pai, o primeiro), aquele que possui a 'sabedoria e o poder criador ( kua ra ra $)^{131}$ ” (Idem). Desse saber advém "a capacidade de sonhar (exarau), de simbolicamente prever os acontecimentos (exaã) e de olhar no interior das coisas (seres e fatos)” (Idem). É através desse mesmo termo que os Guarani se referem também aos "irmãos mais velhos”, aqueles que primeiro desceram ao mundo para povoá-lo e "encontraram seus verdadeiros lugares" (Idem). Segundo Testa, a palavra tenonde também é utilizada para expressar a expectativa que se tem de que as divindades se coloquem à frente dos humanos, guiando-os ao longo de suas caminhadas pela terra, que saudam a elas nas rezas: "Porã ete, aguyjevete, Nhanderu ete, Nhandexy ete, tenondegua" (Testa, 2014: 176). Ao questionar-se o por quê aqueles que possuem a sabedoria e seguem a orientação das divindades sabem, Ladeira revela:

\footnotetext{
Porque, seguindo os princípios definidos no lugar de origem de sua alma, conservam na terra a comunicação com os "verdadeiros pais das almas" (nhee ru ete). Para manterem o dom ou tornarem-se capazes de receber a sabedoria reveladora, é preciso estar em sintonia entre os dois mundos e, para tanto, manter o corpo e a alma íntegros, livres das imperfeiçoes e tentações do mundo terreno. E, sobretudo, não perder as referências e a consciência do que são as normas, do que são as transgressões e do que são as variantes decorrentes das circunstâncias do momento. (Ladeira, 2008 [2001]: 32, grifos meus)
}

Para alguns grupos familiares, de acordo com Ladeira, mbaekuaa'vae seria o termo com que se referem aos "feiticeiros", que consideram o termo ava arand $u^{i s 2}$ mais adequado

\footnotetext{
${ }^{131}$ Cadogan traduz arakuaá por "entendimiento": ara = universo e kuaá = saber (Cadogan, 1959: 46). 132 Arandu, de acordo com Cadogan, vem de "endu, andu = oír, percibir" e "traduce nuestro concepto de ciencia, pudiendo esta ser mala: vai, o buena: porã̋ (Idem: 46).
} 
àqueles que possuiriam o "dom da sabedoria", isto é, os "tamói (avô genérico), tuvixa, yzyraija, oporaive (dirigentes espirituais)" (Idem). Já as mulheres que detêm o mesmo potencial e função xamânica seriam chamadas de "Kunhã Karai” (Idem). Outras designações para os dirigentes espirituais, líderes ou guias, como yvyraija ("o dono da pequena vara insígnia”), oporaive ("aqueles que cantam"), Nhanderu corresponderiam àqueles que "comanda $[\mathrm{m}]$ seu grupo por meio da orientação de Nhanderu” (ver Ladeira, 2007 [1992]: 86, nota 3, alterações minhas). Já expressões como mbaekuaa ("sabedoria divina revelada”) e mbaraete ("força verdadeira”), associadas às expressões py’a guaxu ("coração grande”, “coragem para enfrentar”) e py'a porã (“compreensão”, "paciência”), envolveriam o conjunto de qualidades desejadas que devem possuir@s dirigentes espirituais, que têm a responsabilidade da orientação espiritual e ética da comunidade e de indicar os "lugares autênticos" onde devem viver, atuando assim como@ @orientador[a]” das relações internas da sociedade Guarani (Ladeira, 2008 [2001]: 32-34, alterações minhas). São aqueles que vão na frente (tenondegua kuery), como expresso no canto mbya registrado por Testa (2014: 177):

$\begin{array}{ll}\text { Xondaro'i, xondaria'i, } & \text { Moços e moças que auxiliam nas atividades rituais, } \\ \text { jaa katy nhanderopy'i } & \text { vamos para nossa casa de rezas } \\ \text { Mbaraka mirĩ, } & \text { Chocalho usado pelos homens, } \\ \text { Takuapu mir̃ } & \text { Bastão de ritmo usado pelas mulheres } \\ \text { Yvyra'i ja tenondegua'i } i & \text { A liderança religiosa masculina vai na frente } \\ \text { Kunhã Karai tenondegua'i } i & \text { A liderança religiosa feminina vai na frente } \\ \text { Nhamombaraete nhaneramoĩ'i } & \text { Vamos fortalecer nosso avô/rezador } \\ \text { Nhamombaraete nhandejaryi'i } i & \text { Vamos fortalecer nossa avó/rezadora }\end{array}$

Tal liderança, portanto, pode ser exercida tanto "por um homem ou uma mulher, mas frequentemente é desempenhada por um casal mais velho", além de poder ser também "ser distribuída por diferentes membros de um grupo, de acordo com as atividades em pauta” (Testa, 2014: 176). Ladeira ressalta que nem todos seriam mbaekuaa'vae, e mesmo entre eles há diferentes níveis e papéis, mas acredita que "são também esses desníveis que propiciam, entre eles e com eles, discussões sobre o que é 'ser humanos na terra' (Ladeira, 2008 [2001]: 35). O ato desses "dirigentes espirituais" proferirem as mensagens e os ensinamentos recebidos seria associado ao ato de "ensinar" (traduzido por seus interlocutores como nhemongueta ${ }^{133}$ ) e seria dessa maneira que as:

\footnotetext{
"verdadeiras palavras", ayvu porã etei, e a autenticidade que as torna eternas, quando transmitidas (ayvu monhendu) e atualizadas através das gerações e, nos diversos lugares vividos, vão compondo o sistema da tradição (transmissão oral de conhecimentos e valores) Guarani. Desse modo, a não interrupção da sequência nhemboe (aprender, estudar,
}

\footnotetext{
133 -Mongeta é traduzido por Dooley como “admoestar, aconselhar", -nhemongeta como "salmodiar, cantar
} monotonamente" e nhomongeta como "aconselharem-se uns aos outros" (Dooley, 2006: 116). 
refletir) e nhemongueta (ensinar, aconselhar) é fundamental para a manutenção desse sistema. Embora o ayvu porã seja uma forma particular de falar e faça menção a conceitos especiais contidos nas mensagens divinas reveladas, às quais nem todos têm acesso, ela é interpretada na linguagem corrente ( $a y v u$ ) para que todos possam compreendê-la. Por outro lado, os Guarani têm a consciência de que aprender é um ato espontâneo e de que não se pode obrigar ninguém a receber os ensinamentos divinos. A disposição e o empenho já são característicos de cada portador de uma alma. (Ibidem: 33, grifos meus)

É, portanto, a sua própria disposição e sua vontade pessoal de refletir sobre as coisas do mundo que tornam @s dirigentes espirituais aptos a receber os ensinamentos revelados pelos pais e mães celestes e transmiti-los em "belas palavras", constituindo um elo entre o saber e o fazer, entre a orientação e a confiança estabelecidas no "mundo do criador" que, atuariam juntos na promoção do bem-estar no tekoa ${ }^{134}$ (Ibidem: 33-4). Trata-se aí, portanto, de um papel social fundamental necessário em todas as comunidades (Ibidem: 34). O potencial de curar, de tirar “o mal” da família, é a qualidade que parece ser a mais valorizada entre os Mbya em relação ao seu yryraija, de acordo com a antropóloga. Seria este o principal fator que o distingue da coletividade, uma vez que as revelações e as premonições seriam atribuições mais generalizadas (Ladeira, 2007 [1992]: 151). No entanto talvez o maior desafio para os mbaekuaa'vae seria o de:

conciliar a tolerância em relação aos anseios da comunidade, mostrando-se solidário a ela em suas demandas de absorver bens e serviços do universo dos brancos, com a orientação e os conselhos para seguirem o sistema Guarani, contrário a muitas dessas expectativas e intervenções do mundo exterior. (Ladeira, 2008 [2001]: 35)

Entre os Guarani das regiões Sul e Sudeste do Brasil atuais, a designação mais recorrente para xamã ou "pajé" é xamoĩ (ou tamoĩ) e xaryi (ou taryz), que no domínio do parentesco significa, respectivamente, “avô", “avó”, que no plural inclusivo, nhaneramoĩ kuery ("nossos avôs”) e nhandejaryi kuery ("nossas avós”) designa a posição dos "mais velhos”, sábios anciões, de modo geral. Essas expressões também podem designar@s rezadores(as), tradução em português alternativa à "pajé”. Já os termos nhanderu ("nosso pai”) e nhandexy (“nossa mãe”), além do uso no domínio do parentesco, são utilizadas

\footnotetext{
134. Tekoa vem da palavra teko, acrescida pelo sufixo - a que indica lugar e deve ser entendido no sentido de um emaranhado de relações em um bom lugar para se viver, no qual se convive e se cuida uns dos outros, isto é, se constrói um coletivo. Nesse sentido, o tekoa é algo que está sempre em construção, em um processo (in)constante de fazer crescer pessoas e relações. Então, se teko significa "modo de ser" ou "sistema”, tekoa significa "lugar onde é possível realizar um modo de ser". Se flexionamos o termo teko para a primeira pessoa do plural inclusivo temos nhandereko, que é comumente traduzido para o português como o "nosso modo de ser, Guarani”, sendo o tekoa esse lugar onde podem viver de acordo com o nhandereko. Como uma interlocutora me explicou: "teko é tipo como se fosse o sistema de cada um né [...] vai acontecer conforme é aquele sistema, da família ou o sistema da comunidade, por isso que tekoa se chama assim, teko quer dizer sistema né, esse sistema que tá girando dentro das comunidades e "a" é a base desse sistema, então cada tekoa é a base de um sistema, cada um é diferente do outro [...] tem a sua própria autonomia” (Kerexu Yxapyry da T.I. Morro dos Cavalos [SC], Local: Tekoa Tenonde Porã, 2015).
} 
também para os pais e mães divinos dos $n h e$ 'e, assim como para aqueles que são considerados pelo coletivo como xamãs. No caso feminino, a expressão kunhã karai também configura a disposição de liderança espiritual, no caso masculino, a expressão yryraija ("dono da vara-bastão”, ver Cadogan 1959) também pode designar essa disposição, ou ainda os seus auxiliares na opy, assim como os seus espíritos auxiliares (nhe'ẽ kuery) que são enviados das moradas celestes ( $a m b a)$ para participarem dos cantos-rezas-danças e curas aqui na terra.@s xamãs também podem ser chamados karai ${ }^{135}$ kuery-particularmente àqueles com discursos eloquentes e poder de visão do que está longe ou por vir.

Àqueles que realizam trabalhos de cura com sopros de tabaco por meio do petỹgua (“cachimbo sagrado") também podem ser chamados opita'i va'e "aquele(a) que fuma belamente”. São chamados oporaiva, “aquele(a) que canta”, aos que lideram o canto-reza coletivo na opy. Segundo Macedo (2010, 2012a), nem todos aqueles reconhecidos como "pajés" reúnem todas essas capacidades xamânicas, assim como nem todos que possuam algum reconhecimento nessas capacidades são considerados pajés. Assim, um(a) oporaiva pode não ser opita'i va'e, já que jovens ou adultos que receberam em sonho ou estado de vigília seu mbora'i ("canto”) dos parentes divinos, não necessariamente realizam curas com petỹgua. De todo modo, como ressalta Macedo, "mesmo que não estejam convergidos em uma pessoa, 'aquele que fala' (karai), 'aquele que fuma' (opita'iva'e) e 'aquele que canta' (oporaiva) operam modalidades de sopro, associadas à leveza, à respiração, ao que é divino e imperecível” (Macedo, 2012a: 5-6).

Além disso, expressões como "uvixá, nhanderuvixá ou oreruvixá" que, segundo os interlocutores de Nogueira da Silva podem ser traduzidas como "nosso líder", podem ser também usadas, de acordo com o autor, como sinônimos de xeramoĩ quando o uso tem conotação de o "mais respeitável”, "venerável”, mas também, em muitos casos, há evocação do termo quando há a necessidade de se referirem a qualidades de "liderança", "chefia" ou "mando" (Nogueira da Silva, 2008: 142). A liderança (uvixa) exercida por tal figura seria, nesse sentido, idealmente baseada no respeito, fruto do reconhecimento pelo grupo de que ela é detentora de conhecimento e sabedoria - dádivas divinas que devem ser postas em circulação -, por sua experiência de vida, assim como da capacidade de transmiti-los, ser generos@e de estabelecer uma comunicação eficiente com as divindades, além de ser capaz de liderar as pessoas pelo convencimento, evitando e superando conflitos com ou entre elas (Ibidem: 148). Essa liderança atua então na defesa ou proteção da comunidade,

${ }^{135}$ Karai é a forma masculina e singular do termo, que pode ser usada também para referir-se genericamente a uma mulher, apesar de nesse caso, ser mais comum empregar-se o termo kunhã karai (Mello 2006). Aos karai kuery competem a função de opygua (rezador[a]). 
os saberes-poderes aí mobilizados agindo sobre todo o grupo, reforçando seus vínculos de parentesco e garantindo a continuidade de sua existência, presente e futura. Um[a] uvixa, de acordo com o antropólogo, não desempenha uma função única, dentre as possibilidades de atuação estão: o que conduz os xondaro (auxiliares, guerreiros, guardiões ou mensageiros); @ cacique que administra problemas internos à aldeia (podendo estender sua influência a outras aldeias) ou trata de questões ligadas aos jurua ${ }^{136}$; pode designar também@xamã, enquanto liderança espiritual. Segundo seus interlocutores, um xeramoĩ seria sempre um uvixa, mas o contrário não é verdadeiro (Ibidem: 148). Nesse sentido, o termo genérico "liderança" que designa os que desempenham papéis de "autoridade" é composto pelos mesmos elementos que compõem designações mais específicas, variando em grau e em qualidade, revelando toda uma pluralidade de disposições e movimentos possíveis, compostos mais pelas relações que engendram que pelas (dis)posições que ocupam, que se revelam todas complementares, ainda que diferentes. No caso de um xeramoĩ, essas qualidades seriam multiplicadas justamente por esta figura relacioná-las e entrecruzá-las mais intensamente. Em toda essa pluralidade de grupos e disposições sociais, o único padrão se estabelece na esfera dos comportamentos gerais esperados, dentro do conjunto de normas que compõe o modo de ser e viver guarani (teko) que, de acordo com Nogueira da Silva, que a partir de uma revisão da literatura guaraniológa, descreve que dentre seus principais elementos estão incluídos: a reciprocidade (em oposição ao individualismo e à avareza), a língua guarani e a língua sagrada dos rituais, os casamentos endogâmicos (entre Mbya), a evitação da violência, os rituais cotidianos em que se busca a comunicação com as divindades, as preocupações ecológicas e escatológicas (o fim do mundo e a terra sem mal), o distanciamento dos brancos, os cuidados alimentares e a não ingestão de bebidas alcoólicas (Ibidem: 160).

@ xamã, por sua vez, teria conhecimento e sabedoria (mba'e kuaa) originados pela sua experiência de vida e trabalho, pela sua relação generosa com as pessoas e, principalmente, pela sua capacidade de comunicação privilegiada (porque acentuada) com as divindades e com os seres sobrenaturais em geral, relação esta que muitas vezes se origina da necessidade de obter benefícios para o grupo (seja através do eixo vertical ou horizontal da existência, como a relação estabelecida com os deuses e os "donos" de animais, plantas, pedras, rios, etc.) como a cura de doenças espirituais ou mesmo as doações de

\footnotetext{
${ }^{136}$ A tradução em guarani mais recorrente em referência aos não-indígenas é jurua, que literalmente significa, de acordo com Macedo (2010), "com cabelo na boca” ou "com barba”, denotando um marcador de diferença que incide diretamente no corpo. Por serem numerosos, outro nome de referência aos brancos, principalmente na opy, é heta va'e kuery, "aqueles que são muitos".
} 
cesta básicas pelos jurua, fazendo com que o grupo reconheça no xeramoĩ [e na xejaryı] qualidades importantes para sua existência, que indicam que ele[s] reúne[m] condições de ser aquele [casal] que "segue à frente", mostrando o caminho. Outro importante fator que faz um grupo se formar em torno de um casal-xamã, é sua capacidade no estabelecimento de alianças com outros grupos - famílias extensas, aldeias, jurua kuery. O xeramoĩ [e a xejaryl] seria [m], portanto, portador[es] de saberes ligados à administração da vida coletiva e cotidiana, o que implica oferecer alternativas a questões como a obtenção de alimentos ou a resolução de conflitos sendo assim, considerado[s] o[s] seu[s] maior[es] líder[es] (Ibidem: 147).

Ainda assim, um[a] uvixa que lidera ou acompanha projetos em uma aldeia pode ter força suficiente para manter uma família relativamente coesa em um núcleo de residências, baseando-se no fato de ser provedor [a] de recursos e benefícios através do trabalho que desenvolve dentro e fora da aldeia, podendo até mesmo ser escolhid@ como cacique. No entanto, segundo Nogueira da Silva, seu conhecimento sempre será considerado limitado se comparado a um xeramoĩ [e a uma xejaryı], a quem pode ter que eventualmente recorrer para aconselhamento. Nesse sentido, segundo o antropólogo, as lideranças políticas mais fortes seriam aquelas que estão mais envolvidas com a espiritualidade do grupo, portanto, os xeramoĩ [e as xejaryz]. No Tekoa Pyau localizado na T.I. Jaraguá (SP), contexto etnografado por Nogueira da Silva, o cacique é também um prestigiado xamã - ou espera-se que seja -, isto é, tem-se aí a tradicional convergência da liderança política com a espiritual, ou do xeramoĩ [e xejaryı] e o [casal-]chefe de tekoa. Já em Macedo (2010), verificamos uma recente transição entre a liderança política e a xamânica na T.I. Ribeirão Silveira (SP), promovendo uma diferenciação nas funções desempenhadas pelas diversas lideranças de famílias extensas em um mesmo tekoa, ainda que as posições ocupadas por tais figuras sejam complementares entre si, como verificamos em sua etnografia.

É importante notar que, no Tekoa Araponga (RJ), contexto etnografado por Pissolato (2007), a liderança política da comunidade era ocupada pela liderança espiritual de um casal-xamã, chefe de família extensa. Ela também comenta do estilo que prevalece nessa aldeia, que é diretamente ligado à maneira de seu chefe, cuja autoridade combina duas facetas principais: a fala forte e a capacidade xamânica. Em outros contextos, dizem que a um[a] opita'i va'e não caberia a fala impositiva, e sim aquela que orienta branda e repetidamente os que@ escutam. Assim, temos essas duas maneiras de fala que são reconhecidas como modalidades de um saber falar, e se encontram intimamente ligadas à passagem à maturidade e possivelmente à conquista de autoridade (Ibidem: 88). Ainda 
nesta deixa, temos que a autoridade ${ }^{137}$ aparece aqui como resultado de conquista pessoal, compreendendo, "um grau de liberação do controle pelo mais velho, no caso o pai e chefe da família, e, de outro, certo controle sobre membros do grupo familiar, em geral mulheres e crianças, mas possivelmente, também, outros homens" (Ibidem: 89). E se a fala branda e não excessiva, que aconselha, é reconhecida como o modo de fala que dá o tom do bom convívio nas aldeias, há um certo reconhecimento, mesmo que não seja explícito, da fala forte ou impositiva como instrumento legítimo de certa autoridade. Pode-se dizer também que há um valor positivo conferido a seu uso no trato com os brancos, mas segundo Pissolato, é possível que ultrapasse este contexto. Em nota, a antropóloga diz que quanto à relação com os brancos, ou com os que prestam serviços na área, a disposição oscila entre os dois polos, o da camaradagem e o da fala forte, sendo a última usada sempre para "cobrar" o atendimento que os brancos teriam prometido. Pissolato observa também que posições de liderança, em sua maioria masculinas, tendem a se distribuir entre familiares mais próximos ao cacique ou homens adultos que mesmo sendo menos próximos do ponto de vista do parentesco, se afirmam por sua capacidade de fala, como observado no contexto etnografado por ela em Parati Mirim. Nesse sentido, ela nota que o termo designado normalmente no plural, "lideranças", apontaria para um conjunto sem contornos muito precisos:

Tais "lideranças" manifestam-se ora como falas que querem afirmar-se perante outras na aldeia, ora como representantes do cacique, que convoca indivíduos que representariam a "comunidade" em contextos de participação extra-aldeã, geralmente envolvendo negociações com outras localidades mbya ou com brancos. (Ibidem: 77)

Haveria também uma certa relação entre a disposição em manter um casamento estável, o início de um novo grupo de parentesco e a possibilidade de constituição da posição de chefia e liderança de um coletivo:

opção pelo não-abandono e atenção à família pode representar, em certa medida, um investimento na constituição de uma posição de chefia que, de todo modo, só se sustentará em determinado grau de aceitação por parte dos assim relacionados. Para haver uma reunião de parentes é preciso, primeiro, que haja um certo estado de ânimo tanto da parte dos que encabeçam um grupo de parentesco quanto daqueles que resolvem permanecer junto dos primeiros: trata-se da própria disposição para continuar junto. Não sendo este o caso, não há terra ou população que garanta uma localidade (aldeia). As configurações que podemos perceber no espaço e no tempo são, portanto, resultados, nunca definitivos, de um conjunto de disposições que se põem em relação umas com as outras. $\mathrm{Na}$ constituição de um grupo estão implicadas, de um lado, certa atitude daquele que "vai na frente", isto é, aquele

${ }^{137}$ Um lugar especial é conferido aos modos peculiares de agir, ao maior ou menor poder de persuasão ou de autoridade sobre os parentes, de acordo com Pissolato (2007), que depende sempre destas capacidades individuais ou das disposições momentâneas dos envolvidos. Há certo consenso quanto à impropriedade de uma atitude de submissão da própria vontade, por isso, o caráter igualitário das relações de um modo geral, havendo sempre a possibilidade de decisão pessoal garantida a todos (Pissolato, 2007: 190-191). 
que entre os seus é capaz de ter prestígio suficiente para que, atrás de si, venham os outros; e a disposição para fazê-lo destes últimos" (Ibidem: 156, grifos meus)

Por isso, todos aqueles que "seguem um tamoi ('avô')" [e-ou uma avó] também estariam fazendo, o seu próprio caminho, e este pode apontar, em algum momento ${ }^{138}$, "uma direção outra que não a de continuar seguindo aquele parente” (Ibidem: 157).

\section{Dinâmicas cosmopolíticas transformacionais mbya: paralelos atuais}

A ampliação e acirramento das interações políticas com instituições do Estado brasileiro $^{139}$ e da sociedade civil, fonte de recursos e diferenciações internas e externas ${ }^{140}$, a partir da década de 1980, principalmente após a Constituição de $1988^{141}$ (quando são reconhecidos como sujeitos de direitos), influiu diretamente na conformação das posições de chefia e liderança e nos atributos e capacidades demandadas pelos coletivos mbya, fazendo aparecer "novas fontes de prestígio e formas de autoridade" e com elas novas figuras como os professores e agentes de saúde ${ }^{142}$, geralmente, jovens adultos que são

\footnotetext{
${ }^{138}$ Segundo Pissolato: "Do ponto de vista das trajetórias individuais, a história de vida de um(a) líder de grupo de parentesco pode ser lida como uma mudança de perspectiva: de indivíduo que conquista certa autonomia em relação a seu grupo familiar de origem, pondo em prática a sua própria disposição e vontade, adquire, neste processo, uma nova capacidade: a de manter junto de si os membros da família que origina, então, e os que se agregam a ela. Conforme as habilidades que lhe sejam reconhecidas nesta condição de quem aglutina parentes, poderá ser tido como um "orientador" ou "guia”, alguém que se transporta da perspectiva de quem busca a própria sorte, pode-se dizer, para guiar os parentes” (Pissolato, 2007: 157). ${ }^{139}$ Como a FUNAI (Fundação Nacional do Índio), a Escola do Governo do Estado de São Paulo, o CECI (Centro de Educação e Cultura Indígena) do Governo da Prefeitura Municipal de São Paulo, a Unidade Básica de Saúde (UBS) coordenada pela SESAI (Secretaria Especial de Saúde Indígena), entre outros atores relacionados ao Estado brasileiro. Além disso, os Guarani contam com o apoio de ONGs e apoiadores e parceiros jurua, que os auxiliam em sua luta pelo reconhecimento de suas terras e por melhorias coletivas dentro dos tekoa, assim como nos projetos de fortalecimento cultural e socioambiental.

140 Como cargos públicos internos e externos, de representação para fora das aldeias, seja no âmbito do governo, seja no âmbito do movimento político guarani ou do movimento indígena nacional. Nessa economia de prestígio própria às socialidades ameríndias é preciso saber usar sua influência na captação de recursos, de modo a convertê-los em generosidade na relação com os parentes, adquirindo assim prestígio. ${ }^{141}$ Nos anos 1980, o decréscimo populacional e o processo de homogeneização antes amplamente implementado pela política governamental indigenista de Estado foram revertidos e os indígenas passam a desenvolver movimentos em que reivindicam direitos territoriais, transformando identidades em armas políticas. Isto é, "a luta contra a absorção pelo Estado se daria, assim, por meio da apropriação das próprias armas do Estado” (Sztutman, 2012b). Duas seriam as inovações importantes promovidas pela Constituição de 1988: a inclusão de maneira positiva da diferença cultural, e o reconhecimento da diversidade cultural linguística, abandonando uma perspectiva assimilacionista, na qual o índio deixa de ser categoria transitória, fadada ao desaparecimento, e tem agora direito à diferença; os direitos sobre a terra, agora entendidos como direitos originários e, portanto, anteriores ao estabelecimento do Estado brasileiro.

${ }^{142}$ De acordo com Pimentel, no caso Kaiowa e Guarani, agentes de saúde, professores e outros profissionais, indígenas ou não, assumiram tarefas que antes se concentravam em torno d@ rezador(a), pulverizando esse prestígio que antes se concentrava nessa figura. Por isso, ainda que, em muitos casos, tais profissionais sejam aliados desses rezadores seja por meio de laços familiares ou por aliança, as novas práticas de medicina e de educação contribuem grandemente para colocar em descrédito a sua autoridade (Pimentel, 2012: 194).
} 
considerados também "lideranças" (-uvixa kuery) em oposição aos velhos "chefes sem poder" (ver Clastres, P. 2003 [1974] e Perrone-Moisés 2011). No Tekoa Tenonde Porã, nosso contex to de interlocução, essas jovens lideranças auxiliam @ cacique (posto instituído pelos não-indígenas a partir de tentativas bem sucedidas de confinamento territorial promovido pelo Estado brasileiro) em reuniões políticas internas e na cidade (tetã) e que, cada vez mais devem saber manejar o idioma da etnicidade em suas falas e discursos para fora, especialmente aqueles de reivindicação de reconhecimento territorial, além de estarem também na linha de frente do "mundo dos projetos" (ver Macedo 2010).

Essas jovens lideranças acabam, portanto, auxiliando no planejamento, escrita, implementação e execução dos projetos, e na busca de melhorias para os principais pontos da comunidade, assumindo (dis)posições e posturas que não raro contrastam com o domínio político "tradicional”, fundado na centralidade da orientação do casal-chefexamã (geralmente avós, sábios anciões, rezadores e-ou chefes de parentela) na composição, administração e dinâmica dos coletivos, mas que ainda segue sendo a principal fonte de autoridade, respeito e prestígio em qualquer grupo local independente de quem seja @ cacique (tekoaruvixa). Estes sábios anciões seriam tidos então como os principais orientadores e promotores de bem-estar e de boas disposições no coletivo de parentes e, por vezes, de uma comunidade inteira.

A emergência dessas estratégias renovadas de ação e liderança cosmopolítica, isto é, de modos atualizados de se fazer, pensar e lidar com a política no confronto-interação com os jurua kuery, revela a tensão produtiva entre os atuais (re)arranjos relacionais e as configurações tradicionais mbya, que leva à produção de uma geração de lideranças e de chefes(as) que não necessariamente são reconhecidas primeiramente como lideranças espirituais como as gerações anteriores, visto que as primeiras seriam cada vez mais jovens e formadas também na Escola (que toma grande parte de seu tempo), em contraste com as últimas, formadas somente na opy e em contato mais próximo com a mata (ka'aguy), o que as novas gerações, no contexto atual de confinamento, vêm perdendo ou se afastando cada vez mais, motivo de constantes queixas de seus anciões.

De acordo com Prates há aqui um certo “dissenso intra-geracional”, pois os anciões mbya continuam relativamente refratários à presença massiva jurua nas aldeias e tampouco parecem concordar com a maneira pela qual muitas dessas jovens lideranças agem em relação à reivindicação pelos seus direitos constitucionais, a partir de um parâmetro mais "politizado", apoiados por ONGs, que, por sua vez, "assumem um protagonismo na fabricação de 'lideranças”” (Prates, 2013: 117). Para a antropóloga, todo "ho- 
mem guarani é potencialmente liderança quando tem como interlocutor um Juruá, sobretudo em contextos de reuniões públicas, mas não será necessariamente um mburuvichá/chefe político para um coletivo em específico” (Ibidem: 119). São aquelas lideranças que são mais "famosas" no mundo jurua que reconhecidas como atuantes de fato no âmbito de articulação política interna, seja por saber falar bem ou ter relações influentes com o mundo jurua. Por isso, haveria o que ela qualifica de duas camadas de interlocução que têm efeitos na esfera supralocal de articulação de demandas:

uma realizada por mburuvichá, que tem por função gerir e expressar os desejos de seu coletivo, e outro que estabelece uma representatividade desenraizada, próxima de ONG's e flutuante em nível de uma política indigenista, estabelecida fora das fronteiras de uma orquestração do coletivo mbyá. (Ibidem: 119-120)

Sztutman ao comentar sobre os modos indígenas de falar com os brancos e a transformação de uma mesma lógica de ação política entre lideranças mais jovens e mais velhas, observa que, de modo geral:

\begin{abstract}
se os jovens deixam-se seduzir mais facilmente pela lógica da representação, os velhos (e a "gerontocracia" no sentido atribuído por Léry e Florestan Fernandes) são muitas vezes responsáveis pela imposição de freios. De um lado, emerge no cenário indígena a figura de representantes políticos capazes de fazer a mediação entre seu grupo e diferentes setores da sociedade nacional, bem como entidades políticas como comunidades, conselhos e associações, todos eles voltados para preocupações ligadas à propriedade da terra e a direitos diferenciados. Do outro lado, persiste o motor da fragmentação, revelado por um faccionalismo intenso, pelo movimento de fissão e dispersão, pelas redes de agressão e feitiçaria, enfim, por múltiplas traições que deslindam um contexto altamente movente. (Sztuman, 2012a: 380, grifos meus)
\end{abstract}

Entre meus interlocutores mbya, por exemplo, temos a produção da ideia de que as lideranças atuais também podem atuar enquanto um coletivo, visando o bem-estar da comunidade como um todo e não só o do grupo familiar, o que acaba por não expressar diretamente a lógica faccionalista característica da socialidade guarani - ainda que cada um mantenha preservada a sua autonomia, o que, por sua vez, pode entrar em choque com a aparência de unidade que um coletivo ou uma "comunidade" deve apresentar-aparentar aos olhos jurua, como veremos. Tais lideranças tomam cada vez mais a frente na luta pela demarcação de terras, traduzindo diferentes linguagens e mundos através do aprendizado do manejo entre a descontinuidade e proximidade do modo de agir e de se comportar jurua (jurua reko). Desse modo, a condição de nhaneramoĩ e nhandejaryi, tradicionalmente, chefes de família e lideranças político-espirituais do grupo de parentes, vem sendo cada vez mais potencialmente (mas não necessariamente) desassociada da (dis)posição de cacique e de liderança política em contextos de "muito núcleo pra pouca terra", como meus interlocutores me ensinaram, dada a necessidade daquelas habilidades "burocráticas" que muitas vezes não dominam, ainda que, os mais jovens reconheçam que foram 
seus avós, os principais articuladores guarani no processo de demarcação de terras no Estado de SP em um primeiro momento (década de 1980) (ver Macedo 2010).

Os impactos destas transformações em contextos de confinamento territorial e populacional, afetam diretamente a fabricação de corpos e de coletivos mbya, e com isso, suas dinâmicas cosmopolíticas de produção de parentesco e liderança, que buscam maior autonomia de movimento e de pensamento, dado o seu ideal de "boa distância" 143, principalmente espacial entre as famílias extensas, que se choca diretamente com a política estatal de constrangimento territorial, fazendo aparecer estratégias políticas criativas em busca da promoção do bem viver (teko porã) em comunidade e de um futuro melhor para seus parentes. O que passa a incluir, cada vez mais parcerias com o Governo Estadual e, principalmente, com o Municipal por meio de projetos de apoio ao fortalecimento cultural e socioambiental ${ }^{144}$ interno e de um movimento que busca a retomada de maior autonomia econômica dentro das aldeias e em relação ao Estado, além de uma relação de proximidade cada vez maior com ONGs, como o seu principal parceiro, o CTI, que os auxiliam na luta pela demarcação de suas terras e também nesse mundo dos projetos.

Nesse sentido, a disposição de liderança política demandaria d@ cacique e outras lideranças (uvixa kuery) da “comunidade” que@ auxiliam, grande capacidade de conciliar e articular as demandas e interesses de diversas famílias e de suas respectivas chefias de parentela locais, demandando grande "jogo de cintura” para conseguir agradar a maioria das famílias e ter sua atuação então reconhecida, visto que esta é, idealmente, controlada pelo conjunto de parentelas que convivem juntas em uma mesma terra demarcada, o que, por sua vez, pode ocasionar muitos problemas, seja de ordem político-espiritual ou

\footnotetext{
143 A ética da "boa distância" é um tema amplamente desenvolvido por Lévi-Strauss nas Mitológicas (2006 [1968]). De acordo com Sztutman: "se a passagem do contínuo ao discreto diz respeito ao modo de operação dos mitos em qualquer tempo ou espaço, em $A$ origem dos modos à mesa essa boa distância é associada a uma moral imanente própria aos povos ameríndios, a uma ética do decoro e moderação que salta dos mitos para ganhar a experiência, como podemos atestar nas referências aos rituais de puberdade das moças, às práticas culinárias cotidianas e à própria organização social” (Sztutman, 2009c: 299).

144. Tem destaque aí o Programa Aldeias, implantado em 2014 pela parceria estabelecida entre as lideranças guarani e a Secretaria Municipal de Cultura do município de São Paulo, com o objetivo de fortalecer e promover as expressões culturais tradicionais guarani nas aldeias presentes no município. Há também um Projeto de lei (No 01-00181/2016), denominado "Teko Porã: Política Municipal de Fortalecimento Ambiental, Cultural e Social de Terras Indígenas", lançado em 19 de abril de 2016 por iniciativa do Vereador Nabil Bonduki (PT-SP) na Câmara Municipal de SP, em parceria com a CGY e o CTI, principal apoiador das iniciativas guarani, sendo também quem está à frente, junto aos Guarani, da gestão do Programa Aldeias. Esse projeto de lei (PL Teko Porã) visa implementar nas T.I.s de SP uma gestão ambiental integrada, incluindo outros órgãos gestores do munícipio também na iniciativa, além de pretender consolidar o Programa Aldeias, que por ser apenas um "programa” não teria garantias de continuidade em outras gestões. O PL Teko Porã reconhece ainda a importância da economia solidária para garantir maior autonomia das comunidades guarani, levando em consideração a Política Nacional de Gestão Territorial e Ambiental de Terras Indígenas (PNGATI).
} 
mesmo de ordem político-econômica. Os conhecimentos dessas lideranças "políticas" podem ser considerados limitados se comparados aos de um casal-chefe-xamã - que detém sabedoria pela sua experiência de vida e da sua relação privilegiada (porque mais desenvolvida) com as divindades -, sendo, portanto, improvável que@s atuais caciques e lideranças que não acumulem a disposição xamânica, contrariem ou desconsiderem orientações, conselhos, ressalvas ou presságios dos nhaneramoĩ e nhandejaryi em suas ações e decisões, no âmbito de atuação interno ou mesmo externo, ainda que, na prática, possam deter maior poder de decisão ou ação imediata em casos cotidianos e-ou extremos, relacionados à gestão do tekoa, da relação entre as famílias e à interlocução com os brancos.

A maioria dessas lideranças que auxiliam @ cacique, geralmente "mais jovens”, além da vivência da $o p y$, também tiveram alguma experiência escolar, o que ampliou suas possibilidades e capacidades de agenciamentos no mundo jurua, assim como nas relações entre parentelas, atuando diretamente através do engajamento e manejo de políticas públicas voltadas para obtenção de recursos em áreas diversas como educação, plantio e alimentação, saúde, saneamento, abastecimento de água, moradia, entre outros, ou mesmo com o mundo dos projetos de fortalecimento cultural e socioambiental, que circulam cada vez mais dentro das aldeias e são considerados, na maior parte das vezes, como positivos. Tal movimento, no contexto de interação atual, teve impactos na recorrente convergência política-espiritual entre chefia e xamanismo, promovendo uma crescente "disjunção" entre tais esferas. Tal disjunção, no entanto, não expressaria uma separação estrita entre essas esferas, que se retroalimentam e se produzem entre si, o que nos faz entendê-las como maneiras dinâmicas de aproximação e afastamento na interação com a alteridade, isto é, entre estratégias ou disposições diferentes de ação cosmopolítica mbya. Como por exemplo,@s xamãs com suas rezas-canto (tarova’i) direcionados às divindades que inspiram força e coragem e curam como remédios, os xondaro com suas danças-lutas que visam a proteção coletiva, as xondaria com a sua força nos cantos-reza (mbora'i e tarova'i) e nos cuidados com as crianças e com a alimentação e saúde de toda a família ou coletivo, @ cacique e o coletivo de lideranças da comunidade na interação com os agentes de Estado, município, federação, com o movimento indígena, ONGs e outros parceiros jurua e também na relação interna aos tekoa, atuando na resolução de problemas entre famílias, casamentos, brigas, rixas, de distribuição de recursos, entre outros. Os 
Mbya buscam então, cada vez mais, através de sua própria organização política o "protagonismo" na luta na política externa, o que se dá paralelamente ao fortalecimento do nhandereko ${ }^{145}$ junto aos xeramoĩ e às xejaryi, no âmbito da própria aldeia ${ }^{146}$.

\section{(Des)continuidades ontológicas: de capacidades e potências de afecção cosmopo-}

\section{líticas diversas}

Macedo (2010) reconhece um contraste entre o sopro (fumaça-fala-sonho-canto) que conecta nhandeva'e kuery entre si e estes com Nhanderu [e Nhandexy] kuery, e o kuaxia (papel e seus derivados, como livro, caderno, documento etc.) como um dispositivo de conexão de sujeitos no mundo jurua. Com a ampliação do mundo dos projetos e relatórios, veio se tornando cada vez mais incisiva entre os Guarani a percepção da burocracia como uma gramática que pauta esse campo relacional e que evidencia singularidades ontológicas dos jurua. Segundo a antropóloga, em muitas ocasiões, o kuaxia foi mencionado entre seus interlocutores como expressão do pensamento e dos agenciamentos $j u$ rua, sobretudo no que diz respeito ao caráter confinado e confinante de jurua reko. Ela destaca enunciados guarani que remetem à essa ideia de que as coisas só existem para o jurua se estão no papel:

Para ser gente precisa de carteira de identidade, para ser índio precisa de carteira da Funai, para viver na terra tem que ter título, para ter título tem que ter laudo, para ter laudo tem que ter documento antigo. Para ter memória tem que ter fotografia. Para ter coisa precisa ter dinheiro. Para ter reunião precisa ter ata. Para ter recurso precisa ter projeto, planilha, relatório. Para ter conhecimento precisa ter livro, para a escola precisa caderno, para ter deus precisa de bíblia. (Macedo, 2010: 273)

Já os “Guarani não precisa $[\mathrm{m}]$ do livro, porque nhanderu fala no ouvido da pessoa” (Armindo apud Macedo, 2010: 292, alterações minhas). A antropóloga destaca também que outras falas e gestos acenam para o desejo e o empenho guarani de se apropriar de capacidades subjetivas jurua, para tornar-se capaz de agenciar os jurua e, a partir daí as relações internas, estabelecendo algumas alianças com o pessoal de fora que podem, a seu turno, gerar diferenciações internas. Isso ocorre pois a cada vez mais requerida desenvoltura com a burocracia e demais procedimentos envolvidos na elaboração de pro-

\footnotetext{
${ }^{145}$ Um sábio ancião que vive atualmente no Tekoa Tenonde Porã e é uma grande liderança, traduziu para mim: "nhandereko é nosso costume, mas se caso disser nhanderekoa, é a nossa aldeia, nosso estar, nosso ambiente né” (Karai Poty, Tekoa Tenonde Porã 2016).

${ }^{146} \mathrm{O}$ que se daria através do fortalecimento dos saberes relacionados às ervas medicinais, ao cultivo de alimentos, à caça, pesca e coleta, assim como dos cantos, rezas, das danças dos xondaro e xondaria, da história dos mais velhos entre tantos outros elementos da "tradição".
} 
jetos, relatórios, associações, comissões etc., acaba se constituindo em mais uma exigência para ocupar posições de liderança dentro das aldeias e em articulações interaldeias. O kuaxia podendo ser pensado, nessa chave, como uma objetificação ${ }^{147}$ guarani dessa singularidade plural jurua, e, em outra escala, assim pode ser também pensado o Estado brasileiro e as instituições civis que dele se desdobram. As relações com o Estado, com os representantes de governo, delegados, soldados, missionários etc. são bastante antigas, como recorda Macedo, mas foi com os processos de demarcação de T.I.s iniciados nos anos 1980 e, ainda mais, no período pós-Constituinte, que as relações institucionalizadas com os brancos passaram a ter presença mais incisiva no cotidiano das aldeias. Ainda assim, haveria aqui uma certa insubordinação guarani às lógicas e logísticas dos projetos: "o livro, o relatório, o dinheiro, o documento e outros papéis na escola, na igreja e nas instituições de modo geral operam como instrumento de afecção dos brancos, do qual é preciso se apropriar, e, o qual é preciso desprezar" (Ibidem: 295).

Nesse sentido, como alerta Macedo (2010), estar humano e experimentar um devir divino é aprender a manejar intercâmbios com os brancos, os animais e demais seres nesta terra imperfeita onde tudo perece (tekoaxy), sem abrir mão da perspectiva conferida pelo nhe'ẽ, espírito-nome enviado de por Nhanderu e Nhandexy kuery amba ("a morada dos Nhanderue das Nhandexy"). No que diz respeito aos jurua kuery, tais intercâmbios incluem "apropriar-se de suas coisas-subjetividades sem que tal incorporação implique indiferenciação”, já que na perspectiva Guarani sua singularidade em relação aos brancos não seria de ordem histórica e sim ontológica (Ibidem: 309, grifos meus). O nhe'ẽ dos jurua tem outra origem e outro destino, sendo inviável ou mesmo difícil compartilhar conhecimentos com eles que implicam conexão espiritual com Nhanderu e Nhandexy kuery. Assim, a proximidade física e os inúmeros intercâmbios com os jurua se articulam ao exercício guarani constante em estabelecer descontinuidades em relação a eles.

No que diz respeito a esses intercâmbios, o artesanato é comercializado há muito aos brancos, mas sempre prevaleceu entre os Guarani o ideal de manter os jurua afastados do cotidiano das aldeias e sobretudo da vida na $o p y$, sendo até hoje proibida a sua entrada na opy de algumas aldeias (especialmente no Sul do país), que costumavam ser escondidas de sua presença. Mas na conjuntura recente vem aumentando cada vez mais

\footnotetext{
${ }^{147}$ A noção de objetificação, segundo Macedo, seria um dos eixos centrais da obra de Marilyn Strathern, "em que a efetividade das relações depende da forma como são cifradas, ou seja, como certos objetos aparecem e circulam [...] Objetificar é então fazer as relações visíveis, na forma de coisas ou pessoas, por meio de ferramentas simbólicas que a autora define como reificação (pessoas como coisas) e personificação (coisas como pessoas). O próprio conceito de cultura ou sociedade corresponde a uma objetificação, na medida em que condensa em imagens concretas um espectro de relações” (Macedo, 2010: 7).
} 
a demanda por parte de políticas e projetos de valorização cultural de que as singularidades sejam enunciadas, tornadas visíveis, os cantos de corais infantis tomando o lugar de carro chefe desse processo. Também tem crescido a demanda por parte dos jurua de participarem de rituais na opy, o que antes lhes era totalmente negado ou mesmo escondido, uma vez que a conexão com essa esfera relacional, tida em muitos casos como sendo confinada a esta terra, pode trazer afecções perigososa que devem ser muito bem cuidadas pelos Guarani, pois podem desenrolar-se em implicações em seus próprios corposespíritos, afetando assim sua relação com os parentes divinos. Entretanto, segundo a antropóloga, seus interlocutores Guarani dizem que os brancos não podem e nem conseguem entender o mundo da opy, os jurua mantendo assim uma "relação de opacidade" ao nhandereko guarani. Apresentações de cantos, danças, e outros produtos culturais guarani voltados aos jurua kuery, operariam uma tradução do nhandereko à estética da requerida visibilidade da "cultura" 148 nesse contexto interétnico, mas os modos de conexão entre nhandeva'e e Nhanderu e Nhandexy kuery que faz com que tais "produtos" adquiram sua força e beleza verdadeiras, permanecem invisíveis ao olhar jurua (ver Macedo 2012b).

Por isso, ainda que haja um grande esforço das lideranças em controlar a entrada e a presença jurua nas aldeias, não é possível impedi-la completamente ou interromper totalmente esse fluxo, ainda mais com o crescente acesso às políticas públicas que são cada vez mais demandados pelos coletivos guarani, principalmente nas áreas de saúde, educação, moradia e saneamento básico, levando às aldeias a presença cada vez mais marcante de instituições estatais como a UBS e a Escola e, também de profissionais jurua, causando grande impacto nas relações entre as gerações. Portanto, parcerias com os jurua e a produção de enunciados guarani para fora seriam fonte tanto de recursos diferenciantes que implicam prestígio e algum grau de poder dentro das aldeias, como também

\footnotetext{
148 Para Carneiro da Cunha (2009), “cultura” vem com aspas, por se tratar do manejo de um código por parte de sujeitos que não compartilham as mesmas premissas ao atribuir-lhe sentido, isto é, pelo teor autoreflexivo desse metaconceito, produzido na interlocução interétnica. "Cultura" tem a propriedade de uma metalinguagem: é uma noção reflexiva que de certo modo fala de si mesma” (Carneiro da Cunha, 2009: 356). A fabricação da diferença "étnica”, ou mesmo de "contraste cultural”, pelos indígenas na arena interétnica, corresponderia à sua objetivação da "cultura”. As dificuldades de tradução entre os diferentes registros implicam reflexividade ou objetivação da cultura. O interessante é entender a lógica por trás desses esquemas culturais que nada mais são que maneiras próprias de construir relações. Nesse sentido, é importante ressaltar que, a "cultura" com aspas não é um fake, mas reflete a produção de enunciados nativos sobre a cultura, nos quais existe todo um processo de seleção para fazer ver aos brancos o que eles imaginam (ou desejam) que seja um "índio", produzindo, para além disso, grandes efeitos sobre o seu modo de viver e entrando em choque mesmo com as suas noções de "propriedade" de saberes, podendo gerar toda uma sorte de conflitos geracionais. De certa maneira, eles são forçados a começar a pensar sobre quais ações irão efetivamente produzir efeitos em sua performance na garantia de políticas públicas ou mesmo para chamar atenção para a sua própria luta pela sobrevivência. Os enfeites belamente fabricados por eles nessas performances têm agência, e há um certo entendimento, entre os povos indígenas (mas não só entre eles), de que a beleza produz muito, faz agir e tem poder (ver também Coelho de Souza 2010).
} 
de perigos transformacionais, o idioma da "cultura" podendo ser visto então como um “jogo de efeitos para agenciar os brancos, um nhandereko ranga ${ }^{149}$, mas também como um modo de ser agenciado por eles”, resultando numa implicação de-e-entre agências (Macedo, 2010: 317). A pessoa humana, além do nhe'ẽ (ou ao menos o nhe'ẽ porã) que a anima, é também "habitada ou visitada por outro(s), inscrito(s) na sua carne e sangue - enquanto o nhe'e porã está nos ossos, na respiração e no nome -, que são também fonte(s) de desejos, gozos e adversidades da vida na terra” (Ibidem: 310). Esses anjos ou pássaros, como traduzem alguns Guarani, corresponderiam a "um [espírito] bom (nhe’e porã, ou a sombra mais clarinha) e um ou uns maus (nhe'e vai, ou sombras mais escuras), que podem estar ou se afastar de modo temporário ou definitivo do corpo" (Idem, alterações minhas). Macedo nos lembra ainda que a vida humana entre os Guarani envolve um:

\begin{abstract}
empenho continuado para que o nhe'e porã (aquele que corresponde ao nome) goste desta terra e não se aborreça; assim como um cuidado constante para que nhe'e vai (o "ruim" e que vai ficar nesta terra) ou outros espíritos desta terra não promovam a fuga, expulsão, enfraquecimento ou captura do nhe'e porã. (Ibidem: 310-11)
\end{abstract}

E se a ida com o corpo para a terra sem mal já não é tão viável assim, ela continua sendo expressa como um ideal que deve ser recorrentemente buscado, assim como a busca de leveza, o desafio aqui na terra dos humanos (Mbya) é controlar os desejos-afetos que habitam seus corpos sem perder o nome, impedindo que nhe'ẽ porã vá embora sem o corpo ou que seja capturado por agências outras do cosmos, ocasionando a sua morte física-espiritual ou a metamorfose corporal, o que implica um constante "estar e gozar neste mundo a exemplo de nhe'e vai, o devir animal/terreno) sem pertencer a ele (a exemplo de nhe'e porã, o devir-divino/celeste). A vida na terra como uma viagem de xamã' (Ibidem: 312, grifos meus).

\title{
Diplomatas-tradutores de mundos em perpétuo movimento e transformação
}

É com a criação do SPI, na primeira metade do século XX, que surge, segundo meus interlocutores mbya, "essa configuração de cacique, vice-cacique, cabo, capitão", cargos que eram designados pelo próprio órgão indigenista estatal para trabalhar em nome de seus interesses - isto é, do Estado brasileiro - junto às comunidades e que:

que tinham uma intenção na verdade muito ruim, e que eles começaram a criar um grupo dos Guarani que então, eles mesmos, jurua, os espanhóis, os bandeirantes e... os patrões, como falam né, nas tentativas de escravização, depois na tentativa de catequização em massa, dos Guarani, incorporar eles na sociedade civilizada. (Tekoa Tenonde Porã, 2012)

${ }^{149}$ O classificador -anga, segundo Macedo (2010), remete ao que imita ou substitui algo, como uma cópia. 
Esses jurua escolhiam então geralmente alguém com maior domínio da língua portuguesa, que "facilitavam essa manipulação política, opressora e tal, em cima de seu [próprio] povo”, a mando do órgão federal:

eles começaram a chamar algumas pessoas guarani que se deixavam, se deixavam influenciar, por uma pressão muito forte, que era pra não apanhar mais, que era pra não morrer mais de fome, que não era pra ser mais morto pelos cachorros... pra não mais ficar trabalhando dias inteiros, e receber só água e farinha pra comer, esses se bandeavam pro lado dos jurua, quer dizer, a gente fala, por exemplo, do SPI, e se tornavam então os cacique, os cabos e o capitão, aí esses iam e facilitavam a manipulação do seu povo pros jurua, pra que a partir daí eles trabalhassem pros jurua sem muita... sem reagir sabe, contra isso, porque eram seus próprios, algumas pessoas do seu próprio povo tinha essa figura de ser, do capitão, do cabo e tal que, juntava a galera e fazia ele então essa manipulação política. (Tekoa Tenonde Porã, 2012, alterações minhas)

O capitão era então um chefe reconhecido pelo Estado e sua posição era oficializada pela Diretoria da Inspetoria Regional do SPI, responsável pela administração dos postos indígenas. O órgão indigenista, como vimos no Capítulo I, concentrava indígenas, por vezes de diferentes etnias, em reservas arbitrariamente elegidas pelo órgão a partir dos próprios interesses do Estado, liberando suas terras de ocupação tradicional para a colonização e, com isso, concentrando pessoas e famílias em uma mesma e única área, dificultando assim a manutenção de sua autonomia política e econômica em relação ao Estado que, junto ao regime de trabalho forçado e as torturas decorrentes disso motivou diversas fugas e migrações guarani para o litoral paulista. Por isso, ao estudarmos a cosmopolítica guarani, devemos estar atentos às funções exercidas pela chefia ou liderança de um tomando sempre cuidado em não tomar o uso de novos termos por tipos ou formas completamente novas de chefia ou liderança, mas sempre enquanto transformações que se desenrolam ao longo da história e do contexto vivenciado por cada coletivo. É, portanto, nesse sentido que as figuras do capitão e do cacique serão melhor compreendidas aqui, a partir das próprias categorias guarani e das funções que os próprios coletivos atribuíam ou relacionavam a cada uma dessas (dis)posições.

De acordo com Schaden, o capitão, instituição que "não se originou no seio da cultura Guaraní; foi-lhe imposta de fora”, ainda que lhe coubesse importantes funções na vida do grupo como representar oficialmente os interesses da aldeia perante os não-indígenas e ser ao mesmo tempo, o "chefe de polícia” no interior do grupo, tinha como "sua tarefa restabelecer a ordem e castigar os culposos, sempre que a desorganização social e o abuso do álcool façam surgir brigas e rixas no seio da comunidade" (Schaden, 1974 [1954]: 97-98). Essa figura seria então responsável por aplicar punições àqueles que apresentavam comportamentos considerados socialmente inadequados também do 
ponto de vista do interior do grupo, podendo se exceder um pouco em suas próprias interpretações - ou não como também atesta Schaden -, ou mesmo a partir daquelas do encarregado da administração do posto indígena. Segundo o antropólogo, não raro, esses capitães se convertiam em “chefes de polícia’ um tanto despóticos, na maioria dos casos, porém, sem muito êxito", o que certamente decorre, ele ressalta, da insubordinação guarani às regras que o SPI tentava lhes impor e, por reconhecerem autoridade apenas em seu "chefe religioso - ñanderü" (Ibidem: 65-66). Dessa maneira, temos que além dessa mediação entre o grupo e o Estado, o cargo de capitão esteve relacionado a maneiras de exercer a autoridade e o poder que podiam incorrer em sanções violentas, o que, por sua vez, não partia da atuação das lideranças espirituais:

Em geral o capitão ocupa o cargo enquanto não seja demitido pelo funcionário encarregado da administração do posto. Ao passo que ele precisa de apoiar-se nos podres do funcionário, o ñanderú ou paí pode exercer a sua autoridade até contra o encarregado do posto. Apesar da coexistência pacífica dos dois poderes, o temporal e o espiritual, esse estado de coisas tende, assim, a gerar um clima de permanente tensão social, que se manifesta através das relaçães entre o grupo e o funcionário do Serviço de Proteção aos Índios. Para o ñanderú convergem as manifestações de crítica e descontentamento relativas ao encarregado, que, por sua vez, encara o ñanderú como principal obstáculo ao bom desempenho de sua missão. De outro lado, o capitão é a mão direita do encarregado e representa, por assim dizer, o ponto de vista "oficial". (Ibidem: 98, grifos meus)

Então, se o capitão era alguém escolhido pelo encarregado da administração do posto indígena do SPI, dificilmente esse alguém que ia ocupar o cargo era o nhanderu, uma vez que frequentemente era visto como um obstáculo às ações do órgão indigenista. Por isso, o capitão escolhido pelo órgão nem sempre detinha prestígio entre os seus, como as lideranças espirituais. No entanto, como caberia ao capitão "representar e defender os interesses materiais do grupo" perante o órgão e a sociedade envolvente, o grupo já não poderia prescindir de seus serviços, mesmoque tal instituição entre em choque direto com outro tipo de autoridade no interior do grupo, muito mais efetiva visto que se assenta no respeito, no prestígio e na orientação espiritual e não na força:

Na medida em que lhe cabe representar e defender os interesses materiais do grupo, sempre ameaçados pelo homem branco, e servir de ponte de ligação entre os índios e o encarregado, o grupo já não pode dispensar a sua cooperação. Surge daí aquele estado de tensão que revela nitidamente não estar ainda integrada na cultura Guaraní a instituição do capitão ou chefe civil. Na realidade, há duas noções de chefia em luta virtual: a religiosa, de fundo essencialmente carismático, autoridade que pode estender-se à aldeia toda, se para tanto for suficiente o prestígio do indivíduo, mas também limitar-se ao grupo familial (havendo sempre a possibilidade de se entenderem, como vimos, em reuniões consultivas de discussão informal, os chefes de família, quando esteja em jogo interesses gerais de grupo local), e a civil, nas mãos do capitão, chefete mais ou menos despótico de toda a aldeia, tentando influir em tudo, menos no que é realmente essencial para o Guaraní, isto é, na orientação religiosa da comunidade. Embora em conflito latente, as duas chefias podem, por isso, na realidade coexistir pacificamente. O capitão não se considera competente em assuntos de natureza religiosa e o ñanderú, por seu turno, apesar de sua 
autoridade indiscutivelmente maior, não costuma imiscuir-se em questões de política interna ou externa do grupo, contanto que não atinjam, de modo ou mais ou menos direto, os interesses vitais da aldeia. E se nestes casos o ñanderú entra em ação, é porque para os problemas de real importância não concebe senão soluções de cunho religioso. (Ibidem: 98-99)

Em relação aos termos em guarani que designavam tanto o "capitão" como o "chefe religioso", estariam “mburuvtixá (ou ñanderúvitxá, como também dizem os Mbüá” (Ibidem: 99). Estas expressões em guarani querem dizer, literalmente, "nosso chefe" ou "nosso líder", segundo o autor. O radical -uvixa, em sua forma impessoal tuvixa é traduzido pelos meus interlocutores Mbya como "chefe(a)", "líder" ou "liderança" ou ainda como "grande", a depender de cada contexto. No que diz respeito ao domínio de ação dessas figuras, Schaden afirma:

A chefia política é, como vimos, de base estritamente local, jurisdição que abrange todos os indivíduos da aldeia, ao passo que a religiosa é ao mesmo tempo familial, de vez que os asseclas do ñanderú são formados de uma, duas ou mais famílias constituindo um grupo de vizinhança e não necessariamente a aldeia toda. (Ibidem: 99-100)

O antropólogo observa então que se a chefia política de uma aldeia, personificada pela figura do capitão se estenderia a todos os habitantes de uma aldeia, a chefia "religiosa" do nhanderu seria mais restrita, seu número de "seguidores" correspondendo a poucas famílias que não, necessariamente, corresponde a toda uma comunidade. A criação e nomeação de capitães pelo SPI, instituiu então, na primeira metade do século XX, um posto de mediação entre interesses do órgão e os xamoĩ presentes em cada área, mas não logrou exercer, senão muito precariamente, alguma liderança política, dada a centralidade desses mesmos xamoĩ, o que, por sua vez, não excluiu a predominância do uso da força na maneira com que esse órgão manejava sua relação com os Guarani. Assim, os Mbya, não ligavam "necessariamente a determinada pessoa o exercício das diferentes funções do governo civil, mas, de acordo com a mentalidade tribal” própria, as distribuindo pelos "pelos vários chefes de família, segundo as necessidades do momento e a competência de cada um" (Ibidem: 100). Além disso, entre eles, tendem:

\footnotetext{
a coincidir aí a chefia religiosa e a política com a direção do grupo familial [...] prova de que, como já dissemos, o cargo de capitão não se integrou ainda como instituição na cultura da tribo. A instituição, para manter-se, precisa do apoio direto e constante do funcionário do Serviço de Proteção aos Índios. (Idem: 100)
}

Temos aqui que os Guarani não têm a mesma compreensão que o Governo sobre o que é, ou o que deveria ser um capitão, associando tal figura aos seus próprios conceitos de chefia e liderança. O antropólogo reconhece ainda que nos postos, o capitão se aconselhava com o nhanderu antes de tomar decisões importantes: 
se observa que o capitão não se considera autoridade suprema. Muitas vezes se aconselha com o ñanderú para melhor definir as suas atitudes e saber as medidas que deve tomar. De qualquer forma, falta à sua autoridade a base carismática, que para o Guaraní é essencial. Quando visitei os Mbüá do Xapecó, estes tinham como capitão um moço de seus vinte e poucos anos de idade. Mas a sua autoridade parecia ser apenas nominal. "Para ser cacique", disseram-me, "é preciso saber rezar" e ser tuvitxá ou pelo menos yryráidjá (auxiliar de culto). O jovem capitão e seus companheiros obedeciam ao Paí Dionísio, ancião que tinha o plano de migrar com o seu grupo para o litoral, a fim de apressar a partida para a Terra sem Males. (Ibidem: 100-101)

Schaden também relata que entre os Mbya do Rio Branco (que não possuíam posto indígena na época), em suas viagens à cidade, cada chefe de família ou de "trinca", como eles próprios chamavam, poderia "segundo as circunstâncias, assumir as responsabilidades de mburuvitxâ", sendo também este chefe que em viagem seria o “capitão” do grupo que o acompanha” (Idem). Nesta aldeia, ele observou uma espécie de divisão do trabalho entre esses chefes, no tocando às funções de "capitão", ainda que o rezador fosse considerado seu verdadeiro chefe:

Para efeito externo, havendo necessidade de contato com representes do Governo, para defesa dos direitos ou interesses da coletividade, o capitão é Francisco, que fala bastante bem o português. Alcides, que há anos parece ter sido nomeado para o cargo, exerce a jurisdição de preferência no interior do grupo; é ele, por exemplo, quem realiza os casamentos da aldeia. Marcelino, irmão mais velho de Alcides, e por certo o principal rezador e diretor de festas religiosas, é tido como o verdadeiro chefe do Rio Branco; em sua casa é que se hospedam os visitantes. (Ibidem: 100)

Então, mesmo o órgão indigenista oficial buscando controlar os coletivos guarani com a instituição de cargos de chefia que, de certa maneira, lhes eram impostos, mais ou menos incisivamente a depender do contexto de atuação do órgão em cada comunidade, os próprios Guarani buscavam reverter esta situação imprimindo aos cargos de capitão formas políticas que lhes são próprias. No entanto, há também disputas internas para ocupar o cargo de capitão pelas vantagens que disponibilizava:

Em algumas aldeias há rivalidades e mesmo intrigas para a ocupação do cargo de capitão, isto, quando não se pode adotar a solução dos Mbüá do Rio Branco, que admitem vários capitães lado a lado. As vantagens econômicas do cargo parecem ser o motivo principal da competição. $\mathrm{O}$ chefe civil da aldeia tem maior facilidade em obter presentes do encarregado do posto e de pessoas estranhas e às vezes explora os companheiros da aldeia, obrigando-os a trabalhar em sua roça, a título de castigo, quando se tenham embriagado ou feito alguma desordem. (Ibidem: 101)

Nimuendaju, ao comentar sobre a liderança dos "pajés-principais", relata como membros do próprio Estado brasileiro nomeavam e destituíam "principais" que, por vezes também recebiam patentes e uniformes de capitão, além de presentes do Governo:

Antigamente os Guarani não reconheciam outro líder que o pajé-principal. Mas, quando passaram a se relacionar com as autoridades brasileiras, estas - que jamais haviam levado em consideração os costumes e necessidades "destes bugres" - nomearam principais todos aqueles que prometiam usar essa autoridade da melhor forma possível em favor dos que os nomearam. Qualquer delegadozinho das localidades vizinhas julgava-se no direito 
de influir de maneira civilizada sobre os "bugres", nomeando ou destituindo chefes. As coisas pioravam, no entanto, quando alguns do bando conseguiam fazer uma viagem até o presidente do estado ou mesmo da federação. Os que a empreendiam geralmente os maiores vagabundos, fofoqueiros e intrigantes da horda, enquanto os melhores elementos permaneciam tranquilamente em casa. Àqueles pretendentes, contudo, o Governo conferia uniforme e patente de capitão, presenteando-os generosamente; tampouco faltavam recomendações de manter a autoridade conferida perante os companheiros da tribo. (Nimuendaju, 1987 [1914]: 75-6)

É possível aqui relacionar então tais posições políticas de chefia demandadas, impostas e legitimadas pelo Estado ${ }^{150}$, ainda que não detendo muita autoridade no interior dos coletivos, em muitos casos, ao acesso a bens, recursos e serviços não-indígenas acionadas, quando oportuno, em benefício próprio ou do próprio grupo familiar, muito embora os próprios Guarani as apontem como criações dos não-indígenas. Por isso mesmo, de acordo com Nimuendaju, no que diz respeito à autoridade imposta desses personagens denominados pelo SPI de capitães, ela pouco se efetivava na prática, visto que:

A subordinação espontânea (voluntária) à teocracia de seu pajé-principal era a única organização profundamente alicerçada no caráter e nas concepções destas hordas, não substituível por nenhuma outra. Por isso, todas as tentativas de reunir os Guarani em colônias, "aldeamentos”, fracassaram. Os índios opunham resistência passiva à nova administração; os ressentimentos mútuos cresciam, e um belo dia, por um motivo insignificante, todo o grupo se dispersava, e cada indivíduo podia julgar-se feliz quando conseguia se incorporar a um bando vizinho mais solidamente organizado. Por isto também, o convite da instância burocrática brasileira competente, feito em 1912 aos diversos bandos Guarani, para que se reunissem na reserva Araribá, suscitou a maior desconfiança por parte dos índios. Finalmente se reagruparam na mencionada reserva em torno de seus pajés, dos quais os mais proeminentes eram Ñeẽngueí e Joguyroquý, entre os Apopocúva, Avajupiá e Oqué, entre os Oguauíva, e Ñeẽngarendý entre os Kayguá. Contudo, aquela fundação só foi possível na medida em que se deu inteira liberdade a cada grupo. (Ibidem: 76, grifos meus)

Assim, depois de muitos desacordos e tensões, e de muito embate travado entre os Guarani e os agentes federais do SPI, e com o aprendizado cada vez maior da língua portuguesa, os próprios xamoĩ da Serra do Mar conquistaram a possibilidade de serem nomeados capitães, tornando-se os principais articuladores guarani no histórico processo de demarcação de terras no Estado de SP, devido justamente a seu prestígio e liderança política-espiritual dentro das aldeias: “A agência, ou mesmo a 'força' desses tamõ $i$ caciques estava vinculada tanto à capacidade de constituição de alianças com os brancos como com nhanderu kuery (os ancestrais divinos)" (Macedo, 2010: 125). Desse modo, com

\footnotetext{
${ }^{150}$ Pimentel ressalta que atualmente, as possibilidades de adquirir proeminência para fora das aldeias continuam aumentando: "hoje, é possível eleger-se vereador, conselheiro (em várias instâncias, como os conselhos tutelares municipais, entre outros), tornar-se 'acadêmico indígena' etc." (Pimentel, 2012: 150). Ainda assim, tais "figuras sustentadas pelo indigenismo oficial ou pela democracia liberal, sejam capitães, vereadores, conselheiros" devem ser indigenizadas, no sentido proposto por Sahlins (1997) quando fala em indigenização da modernidade, uma vez que entre os Kaiowá e Guarani, tais novas figuras "para terem sucesso em suas empreitadas políticas, continuam, de qualquer forma, tendo que se mirar nos critérios em relação aos quais é avaliado, positiva ou negativamente, um mburuvicha ou tendotá. É nesse sentido que continua válida, pensamos, esta elaboração de uma teoria etnográfica da política entre eles" (Pimentel, 2012: 150, grifos meus).
} 
a criação do posto de cacique também pelo órgão indigenista federal a partir do final da década de 1970, este também, via de regra, era ocupado pelos xamoĩ, e não se resumia somente no papel de mediação e interlocução com os brancos, mas também, na liderança política-espiritual interna. Nessa época, por causa da regularização da demarcação de terras indígenas guarani e a impossibilidade de dispersão espacial devido ao avanço da ocupação jurua em seus nos espaços de parada tradicionais, força-se a coexistência de diferentes grupos locais - além de casos que convivem com outras etnias (PR, SC, RS) em uma única T.I. que, embora parentes, possuíam sua própria autonomia de movimento e seu próprio estilo de liderança, o que passa a demandar do cacique da T.I. a articulação com esses diferentes grupos de parentesco e organização política, para ser então reconhecido por eles e poder liderá-los também, e assim tomar a frente na luta política pela garantia da terra, especialmente na interlocução e atuação junto aos jurua kuery.

Assim como a distinção apontada por Schaden (1974 [1954]) entre o nhanderu e o capitão, Macedo destaca uma diferença importante entre o xamoĩ e o cacique: "se a liderança dos tamõ $i$ diz respeito sobretudo a um coletivo, independente do suporte físico no qual se assenta no momento, a liderança do cacique remete a uma aldeia, a despeito de sua fluidez populacional" (Macedo, 2010: 125). Nesse sentido, tanto a figura do capitão quanto a do cacique remeteriam a uma liderança política que estava necessariamente relacionada a um território delimitado e reconhecido pelo Estado, o próprio Posto, Reserva Indígena ou a T.I. Os cargos de cacique, cabo, capitão que são oficializados então com a criação do SPI se fortalecem ainda mais na organização que veio substituí-lo, a FUNAI, ainda que atualmente o cargo que prevalece em todas as aldeias mbya seja apenas o cargo de cacique. No entanto, de acordo com Pimentel (2012), a figura do capitão entre os Kaiowá e Guarani do MS, em muitos casos, ainda permanece como sinônimo de chefe ou principal. O que leva o antropólogo chegar a afirmar que talvez sejam os capitães, "afinal, 'mais kaiowá'151 do que tem suposto nossa vã antropologia" (Pimentel, 2012: 162):

\footnotetext{
Note-se que, quando falamos desses capitães, muitas vezes, trata-se, sim, de um tendotá/mburuvicha, alguém que, num contexto em que não houvesse a situação de confinamento, assumiria esse papel de puxar a fila, ou que, na situação de acomodação de um grupo, poderia se consolidar como principal. (Ibidem: 159)
}

\footnotetext{
${ }^{151}$ Nesse sentido, de acordo com Pimentel (2012), a posição de capitão se relacionaria aos códigos empregados pelos kaiowa e se atualizaria a partir de suas próprias disposições: "o que procuro demonstrar é que, de alguma forma, a ação dos capitães e policiais indígenas dialoga com outros códigos kaiowá (objetos, atitudes, obrigações), indo bem além da mera imposição colonial. Complementarmente, acrescento: as associações evocadas pelo yzyrapara demonstram, mais uma vez, que os grupos de língua guarani não estão tão 'desjaguarificados' como se possa imaginar" (Ibidem: 184). Yvyrapara seria uma "vara enfeitada, desenhada ou listrada. Misto de insígnia de poder e arma de defesa pessoal, é mais um daqueles objetos realizados por indígenas que desafiam as classificações modernas: sim, é um porrete, me dizem; ao mesmo tempo, sim, é benzido pelo rezador, muitas vezes" (Ibidem: 182).
} 
Nos anos 1980, de acordo com Macedo (2010), são também os xamoĩ os principais articuladores guarani no processo de demarcação de terras no Estado de SP, como vimos no Capítulo I, via a organização Aguaí e parcerias com o CTI. Nesse mesmo processo, alguns kunumĩgue, jovens tembiguai-xondaro que já acompanhavam os "mais velhos", importantes lideranças espirituais e caciques do complexo de aldeias da Serra do Mar e da capital, em reuniões e articulações políticas, aprendendo junto a eles sobre o difícil processo de regularização das terras guarani, converteram-se mais tarde, em jovens lideranças centrais na elaboração e veiculação de discursos ${ }^{152}$ propriamente guarani sobre a própria cultura e sobre a necessidade das terras para a sua existência, no âmbito das demandas fundiárias e das políticas públicas junto às instâncias jurua. Muitos desses jovens ocuparam ou ocupam a posição de cacique das aldeias em que hoje vivem, pois além de acompanharem os cacique-xamoĩ nas reuniões e articulações políticas, tiveram, em sua maioria, alguma experiência escolar, o que acabou ampliando suas possibilidades de agenciamentos no mundo jurua (ver Macedo 2010, 2012b).

Gallois (2000) comenta também sobre o contraste nos modos que os mais velhos e os mais jovens waiãpi formulam as suas "falas para brancos", acerca de seus "discursosação" no âmbito da cena interétnica atual e do contato-confronto mais intenso com os brancos, construídos a partir de uma retórica da autonomia ou de uma perspectiva que visa mais diretamente a negociação. Os mais velhos têm também aí prioridade e seus discursos se desenvolvem a partir de um estilo mais profético muito marcado, no qual responsabilizam os brancos pela situação trágica em que se encontram, caracterizando assim as suas "falas duras" em oposição aos brancos, um modo propriamente waiãpi de confrontá-los e ameaçá-los através de sua palavra potente e valente. Tais discursos se construiriam com os "mesmos recursos retóricos que usam quando falam diretamente com seus destinatários” waiãpi (Gallois, 2000: 217). Aos jovens que se destacam pelo domínio do português e são considerados como "mensageiros das aspirações de suas comunidades", caberia traduzir a fala desses chefes mais velhos, "introduzir as reivindicações e estabelecer as condições para a negociação com palavras amenas" (Ibidem: 223, grifos meus). Entre os Guarani, as lideranças mais jovens também fazem um grande esforço para tentar traduzir (de maneira eficaz) para o português as belas, ainda que duras palavras dos seus sábios anciões nas negociações e reivindicações junto aos jurua kuery.

\footnotetext{
${ }^{152}$ É possível localizar aqui a dimensão política da terra sem mal, na produção de discursos cosmopolíticos - ao mesmo tempo proféticos e políticos - sobre as terras a serem recuperadas para continuidade do nhandereko, o que, por sua vez, não implica a sua estabilização.
} 
É, portanto, com a atual Constituição (1988), que "o índio tem direito a voz […] não precisa mais de FUNAI, do advogado, de pessoal falar pelos indígenas, todos os indígenas podem falar por eles", como comentou comigo um interlocutor mbya (Tekoa Tenonde Porã 2012), levando à cena política, de acordo com Macedo (2010), a produção de enunciados guarani que passam a figurar na mídia ou nos autos dos processos judiciais demarcatórios, com intenção mesma de dar visibilidade à "cultura”, e assim garantir a demarcação das terras, o que contrasta com o período imediatamente anterior à década de 1980, no qual figuravam na mídia, sobretudo, enunciados sobre os Guarani produzidos por seus parceiros jurua, geralmente advogados, antropólogos ou indigenistas, e uma estratégia guarani de "invisibilidade cultural" ${ }^{153}$ no trato com os brancos. Sua interlocução até então estava voltada para membros do CTI, CPI, e outros apoiadores jurua que eram os porta-vozes de seus interesses e discursos reivindicatórios, cabendo a eles então enunciar a "cultura guarani", idioma requerido pelo Estado para reconhecer e legitimar sua existência e que passa, como vimos no Capítulo I, a ser estratégia predominante na reivindicação das terras, e no acesso a bens e serviços públicos jurua.

Após a aprovação da atual Constituição que regularizou e ampliou os direitos indígenas, as comunidades passaram a ter, de fato, o poder garantido em suas mãos, sem grandes interferências estatais, de escolher, na prática, seus próprios caciques, os projetos culturais e socioambientais a serem realizados internamente como modo alternativo de geração de renda e afirmação econômica, ainda que, no que diz respeito aos projetos ambientais jurua que, muitas vezes, envolvem jurisdição própria ao Governo do município ou do Estado a que estão vinculados ou mesmo outros empreendimentos jurua de grande impacto que podem ocorrer nas áreas próximas às T.I.s, a consulta a que têm direito $^{154}$ não se cumpra efetivamente, o que demanda constante atenção das lideranças e seus parceiros jurua nos projetos externos que possam causar algum impacto dentro das aldeias e que, em geral, envolvem compensação socioambiental - algumas dessas "compensações" levaram à implementação de GTs de Identificação e Delimitação das T.I.s Guarani em SP, por exemplo (ver, neste sentido, Ladeira [1996; 2001; 2006], a respeito dos impactos de grandes empreendimentos estatais nas T.I.s Guarani e sobre a privatização dos Parques Estaduais que se encontram dentro delas).

\footnotetext{
${ }^{153}$ Estratégia descrita também por Ladeira (2007 [1992]: 25).

${ }^{154}$ Obrigação disposta na lei que ratifica a Convenção 169 da Organização Internacional do Trabalho (C169 - OIT), reafirmada na Declaração da Organização das Nações Unidas (ONU) sobre Direitos dos Povos Indígenas (DNUDPI).
} 
Tradicionalmente, como me contaram meus interlocutores guarani, era o casalchefe de família extensa que, geralmente acumulava também a chefia e a liderança espiritual de seu grupo de parentes, que conduzia e orientava seu grupo, curando-protegendo sua família ou mesmo pessoas vindas de outros núcleos ${ }^{155}$ de parentesco e-ou aldeias, quando seu prestígio ultrapassava o próprio grupo local, convergindo então a atuação xamânica com a liderança e chefia local de um tekoa. No entanto, como vimos, com a demanda do manejo do código da "cultura", ou da representação étnica, cada vez mais demandada d@ chefe(a)na interlocução com os brancos, de um modo geral, a condição de xamoĩ (e-ou de xaryı) vem sendo cada vem mais potencialmente, mas não necessariamente, desvinculada da posição de cacique, promovendo segundo Macedo (2010), uma disjunção crescente entre chefia e xamanismo, e que nos remete também àquela disjunção histórica entre chefes de guerra e xamãs-profetas. Ainda assim, é importante frisar que teríamos aqui, antes uma disjunção de disposições do que de seres ou posições, já que, mesmo que não convirjam necessariamente na mesma pessoa, chefia e xamanismo seguem estreitamente imbricados (Macedo, 2010: 145). Tais oposições reiteram o investimento pela não indiferenciação de forças, que se atualizariam em diferentes domínios relacionais, incluindo pessoas singulares e coletivos (Macedo 2012a). Nosso interesse aqui é mostrar que não se trata apenas de conjunção de disposições como situação tradicional ou disjunção como situação moderna, mas que a cosmopolítica guarani se movimenta entre essas alternativas-tensões, que se complementam e cuja ligação é o tempo toda atualizada, podendo até mesmo ser pensadas como "dualismos em perpétuo desequilíbrio" (Lévi-Strauss, 1993 [1991]: 316), ou ainda, um "dualismo em perpétuo movimento", num movimento de disjunção que nunca se efetiva de fato já que são interdependentes, e que foi denominado por Perrone-Moisés de "movimentos entre-dois ${ }^{156}$ ", visto que "em seus mundos tudo é dois, porque tudo é relação e dois é condição, necessária e suficiente, de relação (Perrone-Moisés, 201 1: 877, 872, grifos meus). O que importa aqui são os modos guarani de conceber e de relacionar esses pares de opostos, uma vez que a diferença entre eles é o que permite a relação e a produção do que quer que seja a partir daí.

Assim, de um lado, mas na mesma linha, estariam os xamãs - que têm acesso maximizado à linguagem divina e sua agentividade; de outro lado, estariam também @s

\footnotetext{
${ }^{155}$ É assim que meus interlocutores guarani se referem às famílias extensas e seus agregados.

${ }^{156}$ Em sua tese de livre docência, Perrone-Moisés (2015) afirma que esse movimento se dá, primordialmente, entre os polos festa-e-guerra.
} 
caciques e outras lideranças "políticas", que não necessariamente dominam profundamente as "belas palavras" (ayvu porã) ${ }^{157}$ divinas, se especializando mais na discursividade institucional - a língua portuguesa, bem como a retórica da "cultura"158 e da "natureza", palavras mágicas pelos agenciamentos que promovem através do mundo dos projetos e na relação com jurua kuery (Macedo 2010). Contudo, lembra Macedo, o que está em jogo aí é a produção da diferença, que deve ser visível e inteligível aos jurua, "dado que esta passou a ser motor de direitos e recursos" (Macedo, 2010: 316). Um dos interlocutores com quem a antropóloga esteve em campo reforça ainda que muitos xamoĩ já não são chamados a assumir a posição de cacique, pois hoje em dia "é preciso saber fazer projeto, falar bem o português, saber mexer com dinheiro, documentos, associação, enfim, com kuaxia ('papel')” e antigamente isso não era tão necessário, já que a FUNAI ou as igrejas os auxiliavam com comida, roupas e remédios ${ }^{159}$ (Ibidem: 126). Dessa maneira, tanto@s xamãs quanto@s caciques e as demais lideranças que@s acompanham atuariam como tradutores de mundos ${ }^{160}$ (em maior ou menor grau), que tornam relações visíveis nos eixos horizontal e vertical da existência, transpondo códigos ou corpos diferentes e, com isso traduzindo e agenciando relações.@s primeir@s se concentrando mais na conexão dos parentes com os deuses para produção de boas ações e disposições, e @s últim@s, na

${ }^{157}$ As belas palavras (nhe'ẽ porã ou ayvu porã - repertório específico dos deuses e dos antigos) é o modo de fala e de transmissão de saberes-poderes pela esfera divina. Elas são simultaneamente enviadas pelos deuses e pronunciadas pelos rezadores e rezadoras, que têm acesso maximizado a estas "belas palavras" divinas e as fariam circular pela Terra.

${ }^{158}$ Retórica esta que consiste na enunciação da diferença étnica em um contex to de luta pela afirmação dos direitos indígenas diante da sociedade envolvente, e que não manifesta, necessariamente, a perspectiva indígena, mas a perspectiva jurua. Além de ser fonte de diferenciações internas, entre outras coisas, tal retórica visa a captação de diversos recursos para a comunidade, tendo em vista a sobrevivência e bemestar do coletivo (ver Macedo 2010).

159 Além disso, a condição de xamoĩ impõe restrições e uma interlocução regrada com os brancos, cuja posição, em alguns enunciados entre os Mbya, guardaria alguma homologia com animais, os donos-espirituais dos múltiplos domínios terrestres (-ja kuery) e os espíritos dos mortos (ãgue), sendo todos estes seres habitantes desta terra e nela confinados, o que possui uma série de implicações agentivas das quais é preciso se proteger (ver, nesse sentido, Macedo 2012a). Por isso não ser por acaso, segundo Macedo (2010), que uma das designações alternativas para os jurua seja yəypo ou yoypore que, literalmente significa "habitantes da terra" ou "gente da terra", "gente que veio da terra", traduzido por ela também como "aqueles que foram feitos e pertencem à terra” (Macedo 2012a). Ladeira (2007 [1992]) comenta que os antigos se referiam aos não-Mbya como "yzyipokuére e etavakuére. O primeiro corresponde a todos aqueles que foram gerados nesse mundo’ e, portanto, não têm uma alma proveniente da morada de Nhanderu Tenonde (Nosso Pai Primeiro), nem podem transitar nessa morada. O segundo termo designa 'todos aqueles que são maioria, que são muitos no mundo’ e, por isso, podem ser uma ameaça” (Ladeira, 2007 [1992]: 40). O nhe'ẽ dos jurua os faz, portanto, "confinados e confinantes” (Macedo, 2012a: 24). Dooley também traduz vypóry e yəy póry como "não-índio [lit., 'habitante do mundo’”” (Dooley, 2006: 150).

$160 \mathrm{O}$ desenvolvimento desse argumento pode ser encontrado no artigo "Xamanismo e tradução: pontos de vista sobre a Floresta Amazônica” de Carneiro da Cunha (2009). 
interlocução com o mundo jurua e dos parentes (-retarã kuery), sendo de preferência, oradores(as) de belas palavras ${ }^{161}$, tanto em nhande py ("nossa língua”, mbya) nas articulações intra e inter-aldeias, quanto em jurua py (língua jurua, português) nas demandas e interações com essa esfera, ambas disposições equacionando interesses e mundos em um exercício retórico constante como já nos dizia Macedo (2010), atuando conjuntamente e ao mesmo tempo sob a iluminação dos parentes divinos que disponibilizam aos seus filhos caçulas capacidades-poderes (po’aka) ${ }^{162}$ de ação neste mundo. Daí a importância, também das jovens lideranças (mas não só elas) guarani desenvolverem uma relação também eficiente com esta esfera de comunicação, para adquirirem capacidades-poderes de cativar por meio da fala tanto seus inimigos como seus parentes, acumulando relações e prestígio entre os seus e além, através de suas boas-ações, se magnificando.

Temos aqui, de acordo com Macedo (2010, 2012a), uma relação ao mesmo tempo de assimetria e complementaridade entre os polos ou vetores xamoĩ e xondaro, que implica e demanda uma multiplicidade e diversificação de figuras nas ações coletivas mbya. Ao discorrer sobre as articulações na conjuntura contemporânea entre chefia e xamanismo a partir da cosmopolítica guarani, em que as relações institucionalizadas com o Estado e as agências não-indígenas se acentuaram, multiplicando projetos, políticas e eventos, dissociando a figura central d@xamã no domínio político tradicional do cargo de chefia pelo protagonismo crescente d@s caciques e novas lideranças, Macedo (2010, 2012a) pensa as posições de xamoĩ e xondaro como oposições complementares e diferenciantes. Associadas, ambas disposições remeteriam a vetores ou princípios agentivos cor-

161 E mesmo que, tais "belas palavras" não correspondam ao mesmo gênero narrativo d@s karai ("aquele[a] que fala belamente") e demandem diferentes retóricas em contextos específicos, isso não diminui sua importância vital na organização da comunidade (Macedo 2012a). Há todo um regime estético guarani atuando aí também pois embora, em alguns momentos, tais lideranças devam produzir falas duras aos jurua, essas palavras devem soar tão poéticas e serem ditas de uma maneira bonita-verdadeira (porã) como deve ser o uso de sua própria língua, tanto entre si como na comunicação com as divindades, para que sejam de fato eficazes, ganhem agência, também entre os brancos (ver, nesse sentido, Gallois 2000).

${ }_{162}$ É interessante notar que o verbo -eropo'aka, frequentemente traduzido pelos Mbya como "aguentar", deriva de po'aka que significa poder, capacidade e autoridade. De acordo com Testa, o verbo -eropo'aka também pode ser traduzido como “desenvolver uma capacidade', uma vez que -ero = desenvolver uma ação em que o sujeito também é participante e -po'aka = capacidade-poder. Também usam o termo 'aguentar' para se referirem à -erombaraete, que eu traduziria como 'desenvolver sua força”' (Testa, 2014: 159160). Dooley traduz po'a como "sorte pessoal” e comenta que "na cultura antiga, a sorte era vista como sendo dom de Deus para certo indivíduo. Daí, ele poderia achar caça facilmente, acertar a caça com flecha quase sem mirar, persuadir outros com palavras aptas, etc.)" (Dooley, 2006: 152). Já po'aka enquanto uma derivação de po'a é traduzido por ele como "autoridade, poder: nhanderuvixa ipo'akave nosso líder tem mais autoridade; xepo'aka ha'e kuery re tenho autoridade sobre eles" e também como "capacidade" ou "prevalecer, predominar sobre: ngovaigua re ipo'aka prevaleceu (venceu, ganhou) sobre seu inimigo", enquanto o verbo -mbopo'aka significaria algo como "dar autoridade a, investir com autoridade" e -eropo'aka "suportar (pessoas), aguentar, aturar (Idem). 
respondentes aos eixos vertical e horizontal da existência, no manejo da alteridade, planos distintos e complementares, classificados pela antropóloga como vai ("feio", "ruim", associado à predação e à perecibilidade) e porã ("belo", "bom”, associado ao que é incorruptível e imperecível), princípios que toda pessoa guarani seria habitada (nhe ẽ porã, de origem e destino celeste e nhe'ẽ vai de itinerário terrestre, que é convertido em ãgue após a morte) e atuantes em diferentes escalas da socialidade guarani, perpassando toda sua cosmologia e a construção de seus coletivos.

Atualmente, a oposição complementar-diferencial xamoĩ-xondaro se atualizaria exatamente nestas relações institucionalizadas com os jurua, que devem ser, idealmente, evitadas ou minimizadas pela condição de xamoĩ que se caracteriza por sua interlocução maximizada com Nhanderu e Nhandexy kuery e que devem ser, portanto, protagonizadas ou mediadaspel@s caciques e lideranças auxiliares que@s assessoram,os xondaro, treinados para administrar as relações com as alteridades do eixo horizontal da existência, habitantes desta terra e nela confinados, como as potências animais e seus espíritos-donos (-ja kuery), os espíritos dos mortos (ãgue) e os jurua, que implicam uma série de afecções perigosas (Macedo 2012a). Nesse sentido, Macedo pensa a posição d@ cacique, na conjuntura atual, que implica cada vez mais destreza na relação com os brancos e suas instituições, levando ao deslocamento da chefia do vetor-xamoĩ para o vetor-xondaro ou do vetor porã para o vetor vai, "sem estancar a conectividade inerente a ambos os domínios” (Macedo, 2012a: 17). Tais disposições remetem então a distintas ênfases e corporalidades ${ }^{163}$ específicas na gestão cosmopolítica mbya, promovendo aí uma certa divisão de responsabilidades. A complementaridade e assimetria entre tais vetores também são reconhecidas no comentário de um dos interlocutores de Macedo quando ele comenta "que o pajé é considerado o 'maior líder na aldeia', enquanto o cacique 'é só uma parté (como os xondaro)" (Idem, grifos meus). Na T.I. Ribeirão Silveira (SP), quando um xeramoĩ ainda era cacique, as "lideranças políticas" de cada um dos núcleos de parentesco da T.I., além de serem chamadas "xondaro" eram também consideradas como "os xondaro do xeramõ (Macedo, 2010: 124).

E como hoje em dia uma aldeia raramente corresponde a apenas uma família extensa, desentendimentos podem surgir, daí a ênfase em "aconselhar” (“ñemoñe’’”, na língua kaiowa), postura que@ mburuvicha deve ter, de acordo com Pimentel: “Uma fala

\footnotetext{
${ }^{163}$ Apesar do idioma da corporalidade ser comum às socialidades ameríndias, estas só podem ser comparadas por meio de suas diferenças, que se manifestam em suas formas de organização social, relação com o meio e cosmologia, e que operam, em seus próprios termos, uma espécie de "sócio-fisio-lógica" que, por sua vez, se apoiaria em uma “fisio-lógica” própria (Seeger, Da Matta e Viveiros de Castro, 1979: 12-3).
} 
ríspida pode gerar um desentendimento, uma agressão. É preciso ter firmeza e tato” (Pimentel, 2012: 137). Macedo lembra ainda que, "diferentemente dos xondaro de outrora, o cacique não deve ser violento, e sim conciliador na orquestração das relações internas à aldeia" (Macedo, 2010: 128). Nesse sentido, exercer a liderança implica "fala comedida, autoridade e, nos dias de hoje, capacidade de atrair recursos dos brancos” (Idem). E nesse contexto de atuação de relações intensificadas com as instituições jurua, a “'linha de frente’ constituída pelas chamadas lideranças [...] fazem a mediação entre os recursos dos brancos e os moradores", seja por meio de cargos ou projetos (Ibidem: 139, grifos meus). No entanto, como comenta com um interlocutor de Macedo, nas aldeias guarani, "o ruvixavepe, 'líder maior', era com frequência um tamõi, a quem estava submetido o xondaro ruvixa, "líder dos xondaro" que o auxiliava no manejo da cosmopolítica guarani (Macedo, 2012a: 14). Assim, sob o comando dos xamoĩ [e das xaryl], líder[es] de parentela e agregados, estariam os xondaro, "idealmente caçadores-guerreiros-mensageiros-guardiães responsáveis por conseguir recursos e combater animais, brancos e outros inimigos" (Macedo, 2010: 121). E já que para os Guarani, o consumo excessivo de carne, sal, óleo, açúcar, entre outras comidas jurua, torna o corpo pesado, impedindo diretamente a transfiguração corporal-divina (aguyje), e "a grande leveza do corpo", como o sopro, seria um ideal tanto do xamoĩ [e da xaryl] como do xondaro [e da xondaria], assim como de toda pessoa guarani, a disjunção entre tais (dis)posições não espelharia uma "dicotomização absoluta" ou mesmo fixa, pois cabe também aos xondaro [e as xondaria] "se despojarem do peso da carne" e aos xamoĩ [e as xaryl] enfrentarem "nos corpos das pessoas aquilo que os xondaro enfrentavam na mata: espíritos desta terra (dos mortos, dos animais e outros donos espirituais)" (Macedo, 2010: 123). Macedo faz uso de uma fala de uma liderança mbya de Morro dos Cavalos (Palhoça/SC), que compara a divisão de poderes entre os Guarani e os jurua para pensar a complementaridade que remete à oposição entre xamoĩ e xondaro:

Podemos considerar que quem funciona como o Poder Judiciário nas aldeias é o pajé. Às vezes, o cacique e a comunidade se perguntam: “O que vamos fazer?”. E, quando as coisas não vão muito bem, alguém diz: "Vamos perguntar para o pajé". Quando perguntam para o pajé o que ele acha, ele vai explicar como a comunidade tem que fazer para dar tudo certo. É como se estivéssemos consultando nosso Poder Judiciário. É assim que fazemos para não errarmos o caminho e fazermos as coisas certas. Na aldeia, é como se o cacique fosse nosso Poder Executivo e as lideranças fossem nosso Poder Legislativo, já que são elas que fazem as leis. (Macedo, 2012a: 17, grifos meus) 


\section{Disposições coletivas atuais: gestão de relações entre parentelas no Tekoa Tenonde Porã}

O Tekoa Tenonde Porã já possuiu tanto caciques que eram também xamoĩ - que iniciaram a permanência efetiva no local, garantindo sua posse, como também atraindo uma grande massa de seguidores -, como de jovens líderes, que acompanhavam essas lideranças espirituais e tiveram alguma experiência escolar, mas não eram considerados xamãs. Todas essas lideranças atuaram juntas, dentro de suas próprias capacidades e a partir de suas próprias gestões, tanto na construção deste tekoa, como em sua manutenção e obtenção de prestígio entre os jurua e outros tekoa, que se converteram em bens e serviços internos e no seu protagonismo na luta política pela demarcação de terras em SP. No entanto, de acordo com meus interlocutores, "liderança, cacique, tudo isso é coisa de jurua" uma vez que os territórios guarani eram "formados por núcleos", e cada um desses núcleos de parentesco ${ }^{164}$ possuía sempre "pessoas espiritualizadas como os xeramoĩ, os yvyraija, o que faz as pessoas cantar, dançar, eram esses que lideravam os grupos, então não tinha o cacique de todo mundo", esses:

líderes espirituais se fortaleciam, se somavam, nos encontros das consagrações, das festas tradicionais onde ocorriam os casamentos e de forma rotativa ia cada um para um lado e depois voltava conforme ia tendo mais filhos e hoje tem essa mudança. (Jera Poty, Tekoa Kalipety 2015)

E mesmo antes dessa situação intensificada de contato com jurua kuery e da proximidade forçada entre as famílias devido ao confinamento em pequenos territórios promovido pelo Estado brasileiro, antigamente era o:

xeramoĩ, o líder espiritual, é que guiava as pessoas, do seu núcleo né, que sabia a hora certa de sair, dessa área, sabia o outro lugar pra onde tinha que ir, todas essas situações. Além de cuidar de todo o bem-estar do seu núcleo, do bem-estar físico, do bem-estar espiritual, da alimentação, do bom-comportamento, de seguimento das regras na concepção guarani e tal. (Jera Poty, Tekoa Tenonde Porã 2012, grifos meus)

Por isso, "antigamente não era assim, não precisava dessa coisa de decidir junto... era o líder espiritual que guiava o grupo", já nos dias atuais os xeramoĩ ficaram mais com:

\footnotetext{
${ }^{164}$ A palavra "núcleo", para os meus interlocutores mbya, possui ao menos dois sentidos: o de um mesmo grupo familiar (joegua meme) convivendo junto e vivendo perto um do outro; e também o sentido de dimensão espacial, isto é, pessoas que moram muito perto em um mesmo espaço, não necessariamente sendo de uma mesma família, mas configurando-se enquanto "núcleo familiar" ou mesmo um núcleo de residências, como por exemplo: Pedro regua kuery (“as pessoas que estão com o Pedro”). Geralmente utilizam o nome do chefe ou da chefa da família que simboliza e representa o grupo internamente e diante de outros grupos. Quem mora perto, sendo ou não da mesma “família”, é por se "relacionar bem” com as outras famílias, por isso, geralmente acontece de pessoas mais "próximas" - tanto em amizade, alianças, quanto por parentesco - morarem perto uma das outras, especialmente nesse contexto de confinamento, que promove uma grande proximidade espacial, e que também não exclui a dimensão do conflito (sempre) presente no cotidiano de uma comunidade.
} 
essa parte de cuidar da parte espiritual, das doenças das pessoas, a parte de se formar, aprender cada vez mais sobre as ervas medicinais que curam as doenças e de aconselhar, de mostrar caminhos, para as pessoas se tornarem boas pessoas, para as pessoas respeitarem as regras do ciclo da vida e tal, das nossas e da natureza também. (Idem, grifos meus)

Tradicionalmente então, de acordo com Timóteo Vera Popygua165: "não tinha representante externo, não tinha cacique", era o xeramoĩ ou yryraïa que "conduzia e orientava famílias através de sua sabedoria de ver e saber o que ia acontecer", através de sua "antevisão", sendo eles até hoje os seus "chefes":

quem domina como o cacique, como o chefe das pessoas, até hoje aqui na nossa aldeia [...] o que a gente busca, como deve ser feito, como que vai ser encaminhamento, como que vai ser desdobramento do seu trabalho são os pajés (nhanderu'i, “pequeno deus”). (Timoteo Vera Popygua, Tekoa Tenonde Porã 2012)

Os seus avós, com sua sabedoria de vida, sua "vivência", teriam mais conhecimento para passar, segundo Popygua, liderança atual do Tekoa Krukutu, "pra nós é um livro vivo”, por isso que os respeitam tanto, pois são eles os verdadeiros "orientadores das relações internas da comunidade" (Popygua, Tekoa Tenonde Porã 2012). Já ouvi também meus interlocutores se referirem a um falecido e importante xeramoĩ como um "pendrive cheio de sabedoria” e um outro xeramoĩ comparando as lideranças espirituais a um "dicionário" e a um “computador". É por isso, de fato, que até hoje:

quem são os nossos chefes de verdade são os nossos xeramoĩ [...] eles que são a força assim da aldeia, eles que mantêm a nossa cultura forte, eles que continuam caminhando com as nossas sabedorias adiante [...] eles só não estão nesse cargo que também hoje é extremamente importante porque a maioria então se remete a estudo, a concentração, a formação pro lado mais espiritual, então ele não tem tempo de ir pra escola, não tem tempo de estudar a cultura dos jurua, de participar das reuniões [...] então naturalmente se dividiu nesse sistema. (Jera Poty, Tekoa Tenonde Porã 2012, grifos meus)

A posição de cacique ou de "liderança local' ou "chefe do tekoa" (tekoa ruvixa) do Tekoa Tenonde Porã recentemente voltou a ser ocupada por um xamoĩ - até o final de 2016 -, que era então auxiliado por outras lideranças mais jovens, reconhecidas também pela comunidade, que entendem um pouco mais a língua portuguesa e das questões relacionadas aos direitos constitucionais indígenas e ao mundo dos projetos, compondo junto a outras lideranças mais velhas e, idealmente, de distintos núcleos familiares (joegua meme $)^{166}$, o Conselho de lideranças da comunidade - e que, atualmente é quem está à

\footnotetext{
${ }^{165}$ Liderança reconhecida nacionalmente na luta política pelas demarcações das terras Guarani-Mbya via CGY, onde ocupa cargo de coordenação regional, e também em outras organizações do movimento indígena nacional, já foi cacique dessa mesma aldeia, e atualmente é cacique no Tekoa Takuari (Eldorado-SP). ${ }_{166}$ De acordo com Dooley, o uso do intensificador geral meme pode ser traduzido como "igualmente, cada um(a): joegua meme nhandekuai somos igualmente irmãos; peteĩ rami meme oikuaa entendiam (o assunto) de modo igual” (Dooley, 2006: 113). Já o termo joegua pode significar também “pessoas da mesma etnia” ou "irmãos um do outro" (Ibidem: 30).
} 
frente do tekoa ${ }^{167}$, na ausência de um(a)nov@ cacique indicad@ pela comunidade (para facilitar a compreensão e o limite de nossa análise etnográfica, nos utilizaremos aqui desse último período em que o cacique era também xamoĩ). A chefia e liderança política deste tekoa pode, portanto, em alguns contextos, não mais corresponder, necessariamente, à sua liderança espiritual e, esta última também não corresponde a uma só figura, convivendo diferentes xeramoĩ e xejaryi na mesma aldeia e dentro da mesma T.I.

E, mesmo com o deslocamento da disposição de liderança espiritual da posição de chefia e liderança política institucional que corresponde, atualmente, à posição de cacique, entendemos aqui que chefia e liderança embora, por vezes, pertencentes a planos distintos e assimétricos - cada qual correspondendo a seus devidos papéis na gestão e proteção de relações de um coletivo ou comunidade -, na prática, tais domínios são plenamente conectados, sempre se complementando, se cruzando, não se separando propriamente (uma vez que, obviamente, tudo que se opõe necessita desse seu outro-oposto para existir). As próprias lideranças "linha de frente" na atual gestão da aldeia enfatizam o lugar central ocupado pelas lideranças espirituais na manutenção e continuidade da existência, presente e futura, por isso, ainda que não ocupem cargos oficiais, aqueles $x e$ ramoĩ e xejaryi que se dispõem a atuar no âmbito da comunidade, acabam exercendo influência, tanto nos comportamentos, como nas orientações das decisões políticas do tekoa.

O xamoĩ-cacique ficaria mais ligado, dessa maneira, à questão da “saúde” e ao aconselhamento coletivo, inclusive das próprias lideranças que atuam dentro da aldeia, e que tomam a frente, sob seu comando, nas questões mais relacionadas com a cidade (tetã) e os jurua, ficando o xamoĩ-cacique com aquelas relativas à dinâmica interna, contando também com apoio dessas lideranças nessas atividades. Ele atuaria, portanto, como seu líder espiritual, como "aquele que cuida" da continuidade e permanência desta "comunidade" (coletivo de parentelas em um mesmo tekoa). O que, no entanto, não postula algo muito rígido, podendo o xamoĩ-cacique participar também de atividades fora da aldeia, ainda que geralmente isso seja mais difícil de acontecer, visto que por ser também chefe de família extensa e renomado xamã, trabalha mais internamente, sendo poupado, muitas vezes, deste trânsito aldeia-cidade pelas lideranças que o auxiliam.

\footnotetext{
${ }^{167}$ No inicio de 2017, após o então cacique deixar o cargo, o Conselho de lideranças dessa aldeia, ficou a cargo da sua gestão política, abolindo, de certa forma, a figura d@ cacique ali. Segundo seus membros, seria um modo de dividir os trabalhos e responsabilidades entre as lideranças e mais uma tentativa de evitar a concentração das decisões nas mãos de uma única pessoa ou grupo.
} 
É preciso frisar que@ cacique, ainda mais quando é xeramoĩ ou xejaryi ${ }^{168}$, não lida sozinh@na interlocução com os “brancos”, ou mesmo com os assuntos e problemas que vem de "fora", podendo ser mais ou menos ativos nessa interlocução e tendo outras lideranças auxiliares que acabam os assessorando ou tomando a frente nesse trabalho e se responsabilizando por, eventualmente, aplicar sanções punitivas. Esses auxiliares podem ser da família mesmo (esposas, irmãos, irmãs, cunhados, genros, filhos, filhas, netos e netas) ou, no caso da aldeia em questão, de outras famílias influentes politicamente (ver também neste sentido, Pissolato, Macedo, Nogueira da Silva). Em todo caso, mesmo tendo essa assessoria de outras lideranças "linha de frente", o cacique-xamoĩ deste tekoa em questão era bem ativo na interlocução com os brancos, principalmente com parceiros de projetos e ação indigenista, ainda que permanecesse mais atuante nas articulações internas ou inter-aldeias, com as lideranças mais jovens atuando mais à frente na interlocução externa à comunidade.

Em todas as conversas que tive com meus interlocutores em campo - geralmente jovens lideranças -, foi possível notar que consideram os xeramoĩ da comunidade, como o seu "maior líder" ou a "liderança mais forte", já que seriam eles os responsáveis pelo cuidado com a "parte espiritual" junto às xejaryi, tratando da "saúde espiritual e física" de seus parentes através da promoção diária de rituais de reza, cura, dança e canto, zelando pela continuidade tanto de seus parentes, como da aldeia enquanto grupo, atuando assim como orientadores e aconselhadores (nhemongueta va'e) das relações entre parentes, por meio da enunci(ação) de ensinamentos sobre o bom comportamento dos "antigos" - e que todos idealmente deveriam ter - e do modo de vida deixado pelas divindades (teko pora ${ }^{169}$ ), discursando sobre o nhandereko (como foi, como está sendo e como vai ficar dependendo das ações atuais), e fazendo a mediação e tradução entre esse mundo terreno e o mundo dos deuses - pela “iluminação" inspirada pelas belas palavras divinas que recebem

\footnotetext{
${ }_{168} \mathrm{O}$ fato da (dis)posição de cacique ser ou não ocupada por um(a) xamã é mais uma questão de contexto histórico e tem a ver também com as circunstâncias políticas de cada coletivo. Em relação à figura das "cacicas" mbya atuais, que podem, mas não necessariamente, serem também lideranças espirituais, ver Rebelo (2015).

169 São enfatizados aí os preceitos relacionados ao teko porã, que implicam comedimento nos comportamentos entre parentes, no bom uso da palavra, um saber falar e "fazer o que fala" (senão a palavra é vazia, sem sentido, à toa), gerando a generosidade-reciprocidade (mborayvu) entre parentes, além da importância dos cantos-rezas (mbora'i e tarova), das dancas (jeroky), o respeito às regras matrimoniais (-mendakuaa) e o uso dos alimentos verdadeiros (tembi'u ete'i) que, segundo meus interlocutores seriam as comidas do "mato", como palmito, frutas nativas, o mel, carne de caça, peixe do rio, etc. É reprovada a falta de boas disposições de reciprocidade-generosidade entre os parentes, assim como o modo de vida parecido aos dos jurua kuery (jurua reko), considerados, primeiramente, como seus inimigos. Nesse sentido, a comida que eles "caçam" e "pescam" no mercado, como eles mesmos dizem, é considerada uma comida "morta”, porque contém "veneno" (agrotóxicos), sendo associada a doenças (de ordem físico-espiritual), enquanto a comida "verdadeira”, propriamente guarani que vem da mata (ka'aguy), da roça é associada a saúde (física-espiritual).
} 
através de sua relação acentuada com essa esfera e devem fazer circular - de maneira eficiente e, por isso, controlada - entre os seus aqui na terra.

Os nhaneramoĩ e as nhandejaryi são então considerados a "força" da aldeia, uma vez que seriam os portadores dos saberes a serem aprendidos, traduzidos e levados adiante pelos "mais jovens" e pelo coletivo de lideranças (-uvixa kuery) da comunidade, sendo, portanto, personagens centrais inclusive no mundo dos projetos e na formação dessas jovens lideranças, principalmente em seu treinamento para a luta pela terra, com a opy (espaço de ensinamento-conselho cuidado pelos avós), que vinha perdendo espaço para a lógica estatal-burocrática da Escola jurua, retomando cada vez mais seu espaço central nessa instrução das novas gerações. Sua fala, direcionada a seus netos (nhaneramyminõ kuery) ou aos Nhanderu e Nhandexy kuery, enquanto "puro valor", como nos dizia P. Clastres (2003 [1974]) seria para produzir resultados, falar bonito é falar com eficácia, através de um discurso que diz o "bem” da sociedade (Sztutman 2013), daí a potência dessa fala, uma fala que deve produzir efeitos no interior dos coletivos e também para fora deles. Testa enfatiza também essa mesma importância:

Seu falar (-ayvu) exprime também a capacidade de fazer, meio pelo qual o coletivo consegue colocar à prova a eficácia desse falar e dos saberes que ele enuncia. Nisso, uma liderança, seja cacique ou rezador, ocupa e mantém essa posição à medida que suas palavras são capazes de se traduzirem em ações. (Testa, 2014: 208)

É interessante notar que os Mbya pensam e expressam grande parte das relaçõesalianças cosmopolíticas que fazem um coletivo e um(a) chefe(a) por meio do idioma estruturante do parentesco, ainda que, na prática, nem sempre um tekoa seja constituído por uma mesma parentela, podendo adquirir, por exemplo, na forma de tratamento, uma relação entre um casal de avós e seus netos, assinalando assim uma assimetria geracional (que pode ocultar outras relações de consanguinidade ou aliança). Os xeramoĩ e xejaryi se referem àqueles que protegem e orientam como xeramyminõ kuery, literalmente, "meus netos”, que além de expressar uma relação de consanguinidade, também remete às relações de confiança-aliança estabelecidas entre a liderança e um coletivo, isto é, entre aqueles(as) que orientam e aqueles(as) que seguem suas palavras ou seus passos, o que não necessariamente remete a seus descendentes consanguíneos ${ }^{170}$, mas muitas vezes, a aliados e agregados. Os "netos” se referem assim também se referem a seus "avós”, muitas

\footnotetext{
${ }^{170}$ A respeito do processo contínuo de fazer parentes, da produção das relações de consanguinidade a partir de um "fundo virtual de afinidade" que se desenvolvem entre os povos amazônicos, Viveiros de Castro comenta: "Se chamarmos 'liberdade' à finalidade mesma da vida social, então, no caso amazônico, os meios para tal fim não são a igualdade e a fraternidade, mas a diferença e a afinidade - liberté, différence, affinité. Enfim: a Relação como semelhança ou a Relação como diferença. Mas onde entra, nisso tudo, a consanguinidade? Ela precisa, justamente, entrar, pois não está lá como fato. Uma vez que a afinidade é o estado
} 
vezes por terem sido eles aqueles que o nomearam, que revelaram o seu nome-espírito (nhe'ẽ), o que configura uma conexão muito forte entre eles, mesmo que não sejam parentes consanguíneos, por isso, quando esses avós que os nominaram partem para a morada celeste, é possível que tenham, inclusive, que trocar de nome. Além disso, também podem ser chamados xamoĩ àqueles que ainda não são avôs, mas tenham a capacidade xamânica de fala, canto-reza e cura maximizada, sendo reconhecida por um coletivo (ver, nesse sentido, Macedo 2010). Também são chamados xeramoĩ ou nhaneramoĩ e xejaryi ou nhandejaryi kuery, "nossos avós”, aos mais velhos de modo geral, mesmo os que não sejam considerados xamãs, mas por serem considerados sábios anciãos, reconhecidos por sua capacidade de fazer circular conhecimentos e orientações através de conselhos (mongueta). Igualmente polissêmica é a expressão nhanderu, "nosso pai" e nhandexy, "nossa mãe" que, além de seu uso no domínio do parentesco, é utilizada para os pais e mães imortais dos nhe'ẽ kuery, e também é uma designação alternativa para @s xamãs. Eckart (2014) ressalta também que a relação modelar constitutiva de um coletivo mbya e, portanto, da sua chefia, seria esta relação xamoĩ[-xaryi-]tamyminõ (avô[ó $]$-neto[a])171.

Tem-se aqui a figura do casal-xamã despontando como construção dessa possibilidade de existência nesse mundo tekoaxy. Daí, sua preocupação central com a manutenção da "tradição" - o que na prática, pela intepretação individual que cada liderança realiza do teko, pode corresponder também a um discurso de legitimação dessa posição de liderança do grupo - podendo entrar, por vezes, em embate com as transformações nas estratégias políticas utilizadas pelas lideranças mais jovens que, cada vez mais próximos dos jurua, se apropriam de seus conhecimentos - ainda que os guaranizando e os utilizando a seu favor ${ }^{172}$-, o que deve se dar com certo controle, moderação e cuidado

fundamental do campo relacional, algo deve ser feito [...] A consanguinidade deve ser deliberadamente fabricada; é preciso extraí-la do fundo virtual de afinidade, mediante uma diferenciação intencional e construída da diferença universalmente dada. Mas então, ela só pode ser o resultado de um processo, necessariamente interminável, de despotencialização da afinidade: sua redução pelo (e ao) casamento. Este, em suma, é o sentido do conceito de afinidade potencial: a afinidade como dado genérico, fundo virtual contra o qual é preciso fazer aparecer uma figura particular de socialidade consanguínea. O parentesco é construído, sem dúvida; ele não é dado. Pois o que é dado é a afinidade potencial" (Viveiros de Castro, 2002a: 423). ${ }^{171}$ No entanto, como estamos mostrando, a liderança entre os Mbya não pode ser resumida apenas a essa relação presente no domínio do parentesco, ainda mais quando se trata do contexto atual, onde as coisas se complexificam um pouco mais, com as jovens lideranças se colocando cada vez mais à frente na gestão da comunidade, compondo uma série de outras relações (com jurua kuery, por exemplo) tão fundamentais quanto essa, assim como aos xeramoĩ e xejaryi caberia outras tantas importantes alianças com os seresdonos-espíritos dessa terra na produção-proteção dos parentes, trazendo o alimento e-ou a cura.

${ }^{172}$ De acordo com Prates, estamos diante de uma "micropolítica que se move contra o Estado utilizandose dele próprio” (Prates, 2013: 38). O perigo da captura, reside quando o desejo em ocupar espaços políticos de interlocução com jurua, permeados por uma facilidade de acesso a recursos sedutores que vem de fora, passa a fazer mais sentido do que a própria vida entre parentes. No entanto, Prates afirma que ainda que intensa, a relação vivida por alguns jovens mbya com o mundo encantado de bens materiais jurua não marcha de forma linear, sendo mais de "um ir e vir, um se aproximar e se distanciar" e que "essa força da 
para que não implique em indiferenciação. Há aqui também a compreensão que somente através da observação do teko (modo de ser-agir-pensar) é que seria possível transcender e transformar-se na pessoa $i d e a l$, que é a própria divindade e, quem representaria essa possibilidade seriam justamente os "mais velhos", figuras com potencial xamânico maximizado, não apenas por serem considerados "guardiões" dos bons-belos-bonitos costumes ${ }^{173}$, mas também porque são neles que se veem aquelas qualidades de modo mais acentuado e, também porque são eles que buscam desenvolvê-las melhor, tendo passado pelo duro aprendizado do ver-ouvir-falar.

Tradicionalmente, como viemos mostrando, eram então os xeramoĩ e as xejaryi que enquanto um casal com capacidades xamânicas mais desenvolvidas, cuidava do coletivo de parentes. Uma jovem liderança desta aldeia, faz uma bela analogia dessa imagem com os "bichinhos": "era como os bichinhos assim, no meio do mato, cada um cuidando do seu núcleo, da sua manada" (Jera Poty, Tekoa Kalipety 2013). Jera Poty comenta ainda que os territórios eram grandes e cada família para visitar a outra andava muito, só se encontrando nos rituais ou casando os filhos entre si, não tendo esse "contato direto" e "constante" como acontece hoje em dia. Assim, nessa época, “um xeramoĩ sô”, geralmente chefe de família extensa junto à sua esposa, “já bastava, dando conta de seu próprio núcleo, sem grandes problemas" (Idem). É comum, portanto, as próprias lideranças da comunidade enfatizarem o lugar central ocupado pelas lideranças espirituais ${ }^{174}$, de cada família extensa, na manutenção e continuidade da existência, presente e futura do coletivo de parentes e do tekoa, orientando e conduzindo o seu grupo ou além dele através de seus conhecimentos e sabedoria, fazendo circular entre os seus o modo de ser, estar, viver dos "antigos" por sua atuação enquanto mediadores privilegiados na relação com as divindades e outros seres-poderes do cosmos. Esse espaço, como vimos, atualmente é cada vez mais complementado pela atuação de jovens lideranças no Conselho da "comunidade", que também cuidam do coletivo e de sua permanência em um determinado espaço, orientando e conduzindo junto aos seus sábios anciões, todo o grupo que vive neste tekoa, ainda que se

relação com os Juruá tende mais a ser capturada e revertida em potência mbyá do que em um desejo de devir juruá ou de proximidade com seu mundo" (Ibidem: 44).

${ }^{173}$ Se por um lado, comportamentos ascéticos, considerados incorruptíveis, seriam necessários para atingir esse objetivo, estes não implicariam em negação dos valores sociais, tal como adverte H. Clastres, pois são esses mesmos valores, que se inspiram nos comportamentos dos ancestrais divinos, que constroem o lugar dessa pessoa ideal.

${ }^{174}$ É interessante lembrar uma imagem que Perrone-Moisés, inspirada na etnografia de Pedro Cesarino, evoca ao falar dos chefes-xamãs marubo, ali onde toda pessoa é também considerada uma casa: o xamã enquanto variante de anfitrião porque muito visitado, como um "salão de festas, frequentado por convidados que vêm dançar, e por duplos, que saem para participar de outras festas, noutras pessoas-malocas" (Perrone-Moisés, 2015: 65). 
especializando mais na mediação entre a coletividade e o mundo jurua, devendo, portanto, saber manejar bem tanto os códigos importantes em guarani py como em jurua py.

Isso se dá, em grande parte, por este tekoa contar com muitas famílias nucleares e muitos núcleos de parentesco (grupos familiares extensos), cada qual com seus adensamentos relacionais e seus respectivos chefes de família - geralmente um casal-xamã (que é, ao mesmo tempo, pai, mãe, avô, avó, sogro, sogra) que tenta manter junto de si seus filhos e filhas, genros e noras, netos e netas -, que podem também ser as suas lideranças espirituais ${ }^{175}$. Tais parentelas compartilham entre si um pequeno e mesmo território (26 ha homologados oficialmente, como vimos no Capítulo I) o que, por sua vez, dificulta o distanciamento espacial entre elas, que é quase nulo (mesmo agora com a assinatura da Portaria Declatória da T.I.), mas não implica, necessariamente, uma perda de autonomia ou subordinação de umas às outras, ocorrendo apenas algumas assimetrias de poder político entre elas dentro do tekoa (que correspondem também às disposições e movimentaçõess em jogo em dado contexto), que são constitutivas da própria socialidade políticoxamânica guarani, como veremos.

E com muitos sábios-anciões-rezadores atuando numa mesma área é evidente que podem ocorrer "rixas" entre eles, já que como comentam meus interlocutores, diferentemente dos seres divinos, estes também são acometidos por "fraquezas humanas" tais como “inveja", "ciúme”, pelo desejo de possuir mais recursos - além daqueles denominados “imateriais”, que não são tão intangíveis assim (ver, nesse sentido, Coelho de Souza 2010) - para distribuir entre os seus e, assim, obter mais prestígio entre eles. O prestígio que adquirem através de suas práticas de reza, cura e canto para além do próprio grupo de parentes (-retarã kuery) seria, no entanto, “oscilante", pelo fato mesmo de serem "muitos" e, com isso, "de tempos em tempos", cada qual "dentro de algum problema, acaba se destacando". Como alerta Pimentel, a manutenção da credibilidade da liderança de um[a] xamã e de quem se associa com ele[a] se deve, sobretudo, ao diagnóstico coletivo sobre “as condições de sanidade/prosperidade do local” (Pimentel, 2012: 147).

\footnotetext{
${ }^{175}$ Isso pode mudar a qualquer momento, pela constante movimentação, característica da socialidade guarani, assim como a disposição e prestígio dos atuais xeramoĩ, os chamados "pajés", em português, já que estes são legitimados pela eficácia de suas curas e ensinamentos, bem como de suas práticas de acordo com o teko ("modo de ser" e viver dos antigos) do que também dependeriam para obter "iluminação" divina. Aqui, como vimos, há o discurso que afirma ser preciso acreditar no que contam os xamãs em geral, mas na prática se procura ou se deve procurar sempre um xamã em quem se acredita, e desse modo, dependendo do interlocutor, o número e nomes de xamãs atuantes considerados e disponibilizados será diferente. É interessante notar também que o prestígio das xejaryi, geralmente, não oscila tanto, pois as mulheres são consideradas como sendo mais "espiritualizadas" que os próprios homens, incluindo os anciões (ver, neste sentido, Capítulo III).
} 
Alguns desses xeramoĩ e xejaryi têm suas respectivas opy'i ("casinha de reza”, espaço sagrado de conexão com Nhanderu e Nhandexy kuery), mas também podem operar juntos na opy guaxu (“casa de reza grande”) em alguns contextos bem determinados como quando esta abriga cerimônias coletivas gerais ou mesmo reuniões políticas, tanto internas, como com jurua kuery e suas instituições. A opy guaxu é considerada como a opy de toda a comunidade, não pertencendo a nenhum núcleo de parentesco específico e, portanto, não possuindo alguém que possua a responsabilidade direta de cuidar dela efetivamente. Quem acaba tendo que assumir esse papel é o cacique e as lideranças que o auxiliam, pois estas, ainda que pertençam a famílias influentes politicamente, tentam se colocar numa posição "neutra” dentro da comunidade, afirmando que não possuem "núcleo" e que, por isso, não frequentam uma opy’i específica, somente a opy guaxu que é de todos os núcleos da aldeia. Tal situação se complexificou com a entrada de um xamoĩ, que possuía a própria opy`i, como cacique, passando muitas das reuniões que diziam respeito tanto aos projetos coletivos, como ao Conselho da aldeia em específico, serem realizadas ali, ficando a opy guaxu mais para as reuniões gerais e com as instâncias jurua.

Essa atuação de lideranças em conjunto em uma opy por assim dizer "comunitária”, contrasta em parte com a literatura disponível sobre esse povo que, geralmente aponta o lugar ocupado por um homem ou um casal mais velho, assumindo uma posição que combina a chefia sobre um coletivo de parentes e sua orientação xamânica, com um tekoa que também lhe é próprio e que, por vezes, possui também uma opy própria, dirigindo a reza-canto entre os seus e disponibilizando seus conhecimentos para a cura de doenças e infortúnios terrestres aos que demandam sua ajuda. Ladeira, por exemplo, comenta que a permanência de dois yzyraija (lideranças político-espirituais) em um mesmo tekoa que abriga muitas famílias contradiz um preceito divino contido nos mitos, que “implica controle territorial e demográfico, na organização social e nas regras de reciprocidade, em equilíbrio dos recursos naturais em termos de sua utilização para subsistência" e "funda-se no critério de que um yryraija e uma kunhã karai como complemento, ou vice-versa, é capaz de guiar seu grupo até yoy apy”, onde é possível alcançar yoy marã'eỹ, dentro de um modelo que consideram como ideal e buscam desenvolver em seu próprio tekoa que, lembremos, é o local onde é possível viver esse modo ideal de ser (teko) guarani (Ladeira, 2007 [1992]: 93, grifos meus). 


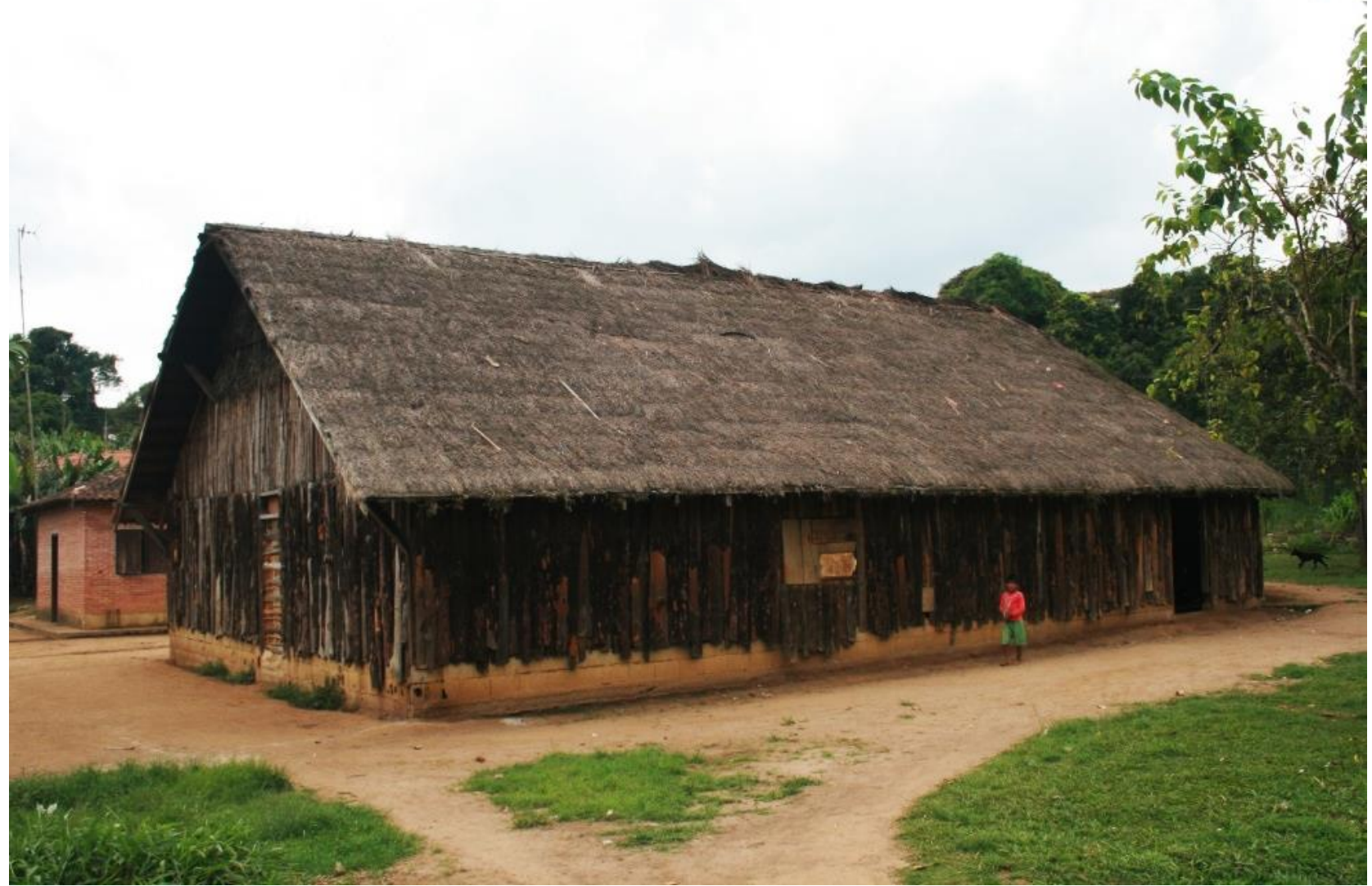

Opy guaxu. Aline Aranha. T.I. Tenonde Porã, 2012.

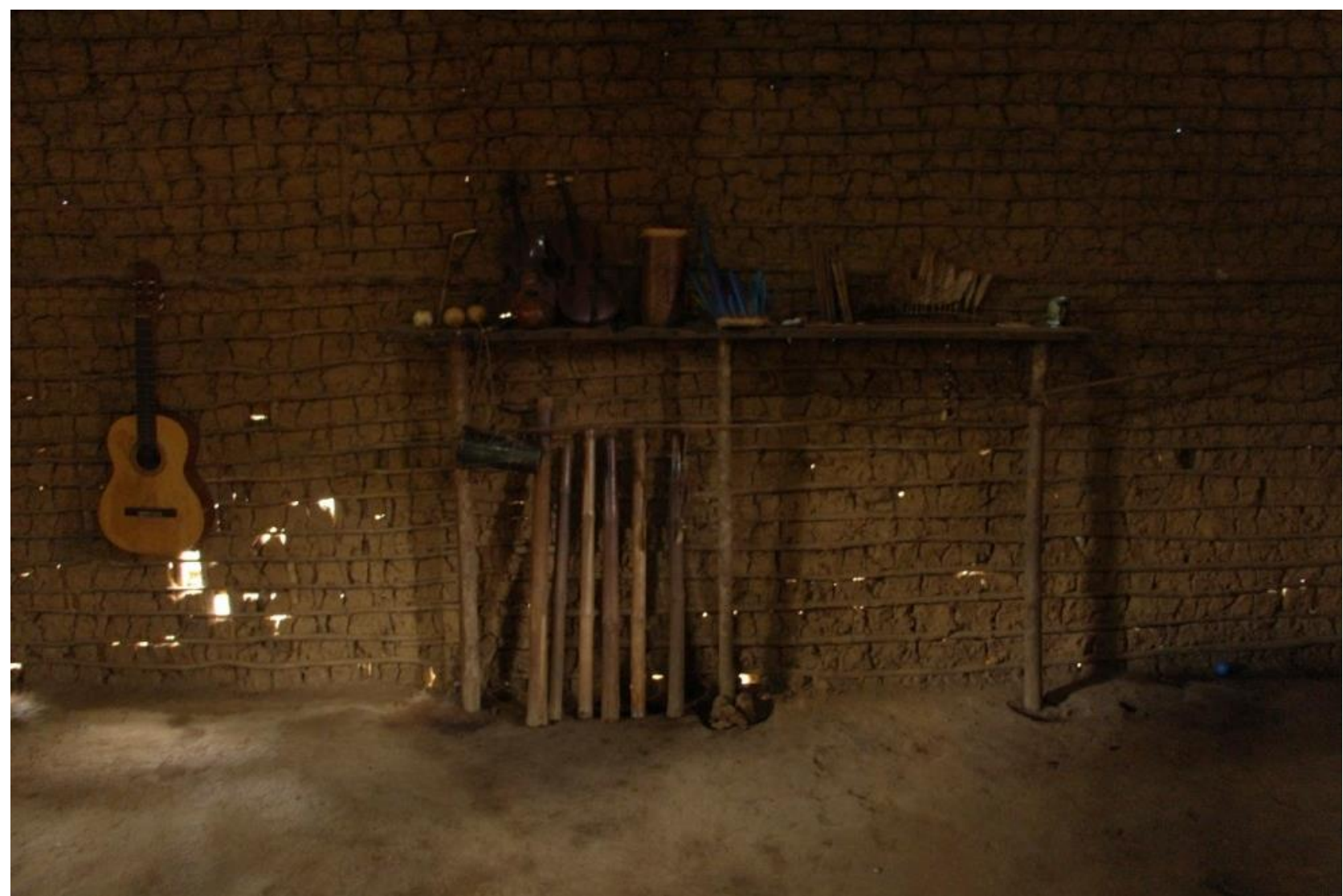

Opy’̈ e instrumentos sagrados. Aline Aranha. T.I. Tenonde Porã, 2016. 
Assim, tal como ensina o preceito divino, ainda que ocorra esse movimento de concentração de parentelas em um mesmo tekoa promovido pelo contexto atual de confinamento, há aqui também presente um movimento de dispersão-cisão-diferenciação, que já não se realiza com tanta intensidade quanto desejada no espaço-tempo, mas na tendência cada vez maior ao distanciamento e à diferenciação entre as parentelas ${ }^{176}$ :

Incluem-se nestes contextos de relações [ [...] a criação de caminhos e roças específicas, a construção de casas de rezas próprias e o uso separado que se faz dos diferentes espaços de uma mesma Terra Guarani, como o campo de futebol, rios e áreas de mata. Evidentemente, há muitos saberes, experiências e espaços que são comuns e compartilhados, inclusive, entre moradores de diferentes lugares. Neste sentido, as experiências de separar, diferenciar, aproximar e compartilhar estão relacionadas à ideia de que cada grupo (humano ou não) tem seu próprio modo e lugar de viver, ideia também expressa na noção de $\operatorname{teko}(a)$. (Testa, 2014: 54)

É no contex to da demarcação das terras, do desenvolvimento de projetos, da criação de conselhos, instituições, corais etc., que devem partir de vetores coletivizantes que aparece a “enunciação de unidades étnicas ou sociais, do tipo 'comunidade' - e diferenciantes - promovendo deslocamentos físicos e relacionais” (Macedo, 2010: 317). Nesse sentido, a mobilização do conceito de "comunidade" pelos Guarani dessa aldeia pode ser vista também como uma apropriação recente para o discurso político interétnico ${ }^{177}$, em interlocução com instâncias jurua para a garantia e obtenção de recursos via políticas públicas, que exigem a delimitação de uma coletividade circunscrita a um espaço restrito. Essa coletividade, expressa no conceito "comunidade", que necessita pensar e decidir em conjunto pela multiplicidade de núcleos, anciões e lideranças que abriga, também acaba por expressar um pouco do sentimento envolvido na questão de estarem convivendo juntos, num mesmo espaço e pertencerem a um mesmo povo sendo, no limite, todos parentes e que, por isso, devem estabelecer alguns acordos e alianças de colaboração entre si. Assim, internamente, o conceito se refere ao conjunto total de grupos de famílias extensas habitando um espaço único, isto é, "pessoas enraizadas" naquele local que, muitas vezes nasceram e ainda vivem ali, podendo ser traduzido para o guarani, segundo meus interlocutores, como nhandekuery ("nós”, "os nossos"), o que, por sua vez, implica também que

\footnotetext{
${ }^{176}$ Eckart (2014), em etnografia realizada neste mesmo tekoa, também observa essa diferenciação em relação à multiplicação das opy na mesma T.I. Para Eckart, as relações assimétricas entre as parentelas se expressariam nessa diferenciação entre a opy guaxu e as múltiplas opy'i. Ele chega a relacionar a distinção elaborada pelos Guarani entre estas opy àquela diferenciação descrita por Macedo (2010; 2012a) entre os eixos de comunicação vertical e horizontal, que remetem aos polos xamoĩ e xondaro (Eckart, 2014: 84-87). 177 A respeito do tema da mobilização de uma autorepresentação étnica coletiva, Gallois comenta: "Se a terra é para os Wajãpi de hoje um suporte de sua etnicidade, o que parece óbvio resultou, na verdade, de um longo processo de aprendizado de gestão do coletivo. Processo que só se cristalizou com a apropriação de uma territorialidade limitada, pois sem limites, nada precisava ser coletivo" (Gallois, 2004: 40, grifos meus).
} 
todos os núcleos familiares estejam "alinhados", caminhando juntos em "um só pensamento" (peteĩ ramijaguata) nas decisões a serem tomadas coletivamente, pela "comunidade".

Entretanto, esse conceito de uma comunidade una, fechada sobre si mesma, requerido pelo Estado, ONGs, e outras instâncias jurua entra em choque com a própria lógica faccional da socialidade xamânica guarani, onde o parentesco constitui peça central, uma vez que é em sua constante produção-proteção que reside a autonomia de conduçãoorientação desempenhada pela liderança, geralmente de um casal-xamã, que toma a frente de um coletivo de parentes visando protegê-los diante de outros coletivos, tanto humanos - Guarani -, como não-humanos - seres confinados a esta terra. Ainda que, para tanto, essa liderança também exija o estabelecimento de alianças com outros coletivos, e a promoção de laços de solidariedade e cooperação entre outras famílias agregadas que seguem sob sua orientação. Nessa lógica, portanto, o fluxo de generosidade (mborayvu) e solidariedade ${ }^{178}$ se concentra, primordialmente, entre os parentes diretos (e alguns agregados), por isso, cada chefia de família deve assegurar e disponibilizar benefícios, materiais e imateriais para seu próprio coletivo (kuery), mantendo-os juntos, alegres e saudáveis. Nesse sentido, a ideia de uma única chefia que represente um coletivo como uma aldeia, ainda mais quando esta conta com inúmeras famílias extensas e suas respectivas lideranças, diria mais das "organizações não governamentais e agências estatais envolvidas do que da lógica mbyá de relação com o Estado brasileiro" (Prates, 2013: 38). Prates comenta que a construção das lideranças atuais se dá dentro desse mesmo quadro posto pelas agências estatais ou não governamentais: "não necessariamente representativas do coletivo, mas representativas da necessidade de representação criada por essas agências" (Ibidem: 44).

As lideranças da comunidade, ao tentarem fazer essa mediação entre parentelas devem então tentar também deixar a posição parcial de seu próprio grupo de parentes, que age primeiramente em benefício dos seus - a partir da lógica da fissão -, de maneira a expandir a sua generosidade e solidariedade para além dele e assim obter a confiança de outros grupos, promovendo a boa convivência entre eles para não sofrerem acusações e retaliações. Que, por sua vez, podem ocorrer em via de mão dupla: tanto dos próprios parentes e aliados, quanto dos que se situam mais distantes. Essas agências jurua acabam interferindo assim na lógica mesma do parentesco mbya que busca privilegiar a proteção-produção do próprio grupo local e que contrasta, portanto, com a noção de unidade

${ }^{178}$ Nessas socialidades da dádiva-dívida, as relações são preciosas e, por isso devem ser cultivadas cuidadosamente através de trocas recíprocas constantes. A generosidade torna a pessoa bonita-boa (porã), sendo equivalente a uma qualidade moral suprema, enquanto a avareza torna a pessoa feia-ruim (vai). 
que os jurua kuery requerem para a disponibilização de benefícios a uma T.I. - espaço delimitado tal qual eles (esses outros) também definiram nas leis que escreveram -, ainda que, como descrito, não exclua também a cooperação entre os diferentes grupos e suas respectivas lideranças que convivem de um mesmo coletivo ${ }^{179}$. Por isso, nestes processos de diferenciação e união entre parentelas, os grupos familiares presentes em uma mesma área devem buscar entrar em acordo entre si e, de alguma maneira, aceitar essa aparente condição de comunidade unificada, embora na prática, essa tal unidade só ocorra em certas situações que exigem a confluência entre objetivos e interesses comuns como, por exemplo, na luta pela demarcação efetiva da T.I. ou na mobilização dos direitos sociais ali solicitados, pois na questão da distribuição do espaço e de acesso a esses bens, serviços e recursos não-indígenas há sempre muitos desentendimentos.

Portanto, nos dias atuais, temos que as relações de consanguinidade e as alianças cosmopolíticas - entre humanos e não-humanos, do ponto de vista Guarani - daqueles que coabitam o mesmo espaço devem atuar juntas na produção de uma "comunidade" unidade que "mascara" uma multiplicidade, as diferenças de atuação e representação das famílias extensas, seus estilos de liderança-, devido a essa necessidade de apresentação e representação requerida pela lógica jurua. Este movimento de concentração de multiplicidades em uma representação de unidade requerido pelo Estado, contrasta com a tradicional ética guarani da "boa distância" 180 entre os múltiplos núcleos de parentesco, que contam cada qual com sua liderança interna, dado que a proximidade excessiva ocasionaria conflitos entre os diferentes estilos de pensar e de se movimentar de cada família extensa, pois, como vimos, cada pessoa, assim como cada família e, portanto, cada coletivo tem um teko (modo de ser-agir-pensar) ${ }^{181}$. O que corresponde às distintas maneiras que cada grupo local procura se diferenciar de outros coletivos ou parentelas, seguindo a interpretação que a sua liderança ou chefe(a) de parentela faz do conjunto de valores e

\footnotetext{
${ }_{179}$ As "possibilidades" que surgem das relações com os brancos, em diversos segmentos, de acordo com Pissolato (2007), entram no jogo político como uma oposição entre um princípio de autoridade (que tende a manter junto de si os parentes) e de autonomia, por exemplo, com a tendência à autonomização econômica das famílias nucleares, e que se atualiza nas diferenciações internas ao grupo, assim como na aldeia tomado em seu conjunto.

180 Montardo comenta que um xamã ao explicar a necessidade de retomar sua terra, abriu os braços em forma de cruz para exemplificar que "precisam de terra para abrir os braços e não bater nos outros" (Montardo, 2002: 246).

${ }^{181}$ Há a ideia, entre os Guarani, de que as pessoas são como passarinhos, segundo Montardo (2002). Para exemplificar essa ideia ela faz uso de uma fala mbya, que comenta sobre o absurdo que é os brancos desejarem que os Mbya troquem seu sistema de vida: "Alguém já viu o passarinho trocar o sistema dele? Para mim, cada tipo de passarinho que vive no mundo, segue o seu sistema. Eu nunca vi o beija-flor trocar a sua comida; o alimento dele sempre buscou na flor, nunca vi ele interessado em comer carne podre. Por isso, cada um tem o direito de viver de acordo com o seu sistema. Todo mundo tem que ser respeitado" (Garlet, 1997 apud Montardo, 2002: 252).
} 
normas compartilhados pela socialidade guarani $(t e k o)$ - que pela sua lógica faccional dá espaço para a criatividade e performance individual tanto política como ritual -, criando um estilo próprio de orientação e liderança de um coletivo, sem implicar em desigualdade ou subordinação, mas em algumas assimetrias (sempre em movimento) que são constitutivas de cada coletivo, a partir das configurações relacionais em jogo em dado contexto e em um dado local. Daí o ideal da boa distância entre os diversos grupos locais, que buscam viver cada qual em seu próprio espaço que, idealmente seria um tekoa próprio, lugar onde podem exercer e garantir o exercício de seu próprio modo de ser-viver-agirpensar e que cada liderança considera o próprio como o mais verdadeiro (ou mais próximo ao teko ensinado pelos ancestrais divinos).

O êxito obtido a partir de um determinado estilo de liderança ou modo de serviver-orientar (teko) dá contorno e extensão à essa liderança, que pode ser mais ou menos ampliada, atraindo (ou não) seguidores realmente dispostos a seguir tal orientação, seja porque nela confiam ou porque apostam em suas capacidades, promovendo assim a sua magnificação (o que corresponde, ao mesmo tempo, à constituição de um coletivo). Apesar de todas as dificuldades e restrições que o viver "amontoado" ou "encurralado" traz, como comentado, os diferentes núcleos familiares mbya procuram criar espaços e práticas que os permitam desenvolver orientações e experiências distintas em relação às outras parentelas, desafiando essas "noções totalizantes que costumamos expressar, mesmo que implicitamente, quando nos referimos aos Guarani como uma unidade” (Testa, 2014: 53).

Em relação à questão do "poder" ou "influência" dentro das políticas internas, os núcleos (ou grupos familiares) mais antigos, que vivem há mais tempo na aldeia ou os que são mais numerosos, costumam ser os que teriam maior "força política", conseguindo se fazer "ouvir" e tendo maior liberdade de se "movimentar", isto é, de agir politicamente por uma causa. Essa força política também pode se manifestar pelo fato do grupo familiar ter mais pessoas que se dispõem a ser lideranças em seu interior, por deter o "poder da fala" - argumentar, questionar através da palavra mobilizando ações -, característica amplamente apreciada e necessária no saber-fazer(-se) polític@ mbya. Ter lideranças atuando na política da aldeia significaria, então, ter "representação política" dentro desta, de acordo com meus interlocutores. Conseguir se "movimentar" ou "fazer um movimento", como me explicaram, dependeria do poder de ação dos "chefes de família" ou mesmo alguém que obtenha destaque através da "fala", de articular uma ideia dentro de seu pró- 
prio grupo familiar, convencê-lo e levar sua questão para a mobilização dos outros núcleos e, juntos fazer "acontecer"182 - aparecendo aí seu "poder" de articulação e mobilização. Ainda assim essa questão de se movimentar é muito relativa, já que muitas vezes, a “comunidade em massa" pode "se unir" por uma "causa" ou questão. Entre os Kaiowa, segundo Pimentel (2012), mongu'e, "movimentar-se" é também uma das traduções para "política”.

A “influência” dessas famílias mais antigas e, na maioria dos casos, numericamente maiores, segundo me contaram, se daria pelo fato de viverem a muito tempo na ald eia, terem vivenciado muitos momentos e fatos importantes dentro da luta pela sua garantia e, atualmente, pela demarcação e, também por terem presenciado inúmeros problemas tanto internos, como externos. Tendo participado de sua história passada, adquiriram então o "poder de conhecimento" e, portanto, de ação e decisão sobre o tekoa. Essas famílias normalmente são as que estão mais à frente na liderança da comunidade, principalmente as novas gerações que, pelo prestígio que podem adquirir na interlocução com o mundo jurua, principalmente no que diz respeito a projetos que trazem recursos ou, mesmo dentro do quadro de empregos institucionais (Escola, CECI, UBS) dentro da aldeia, possuiriam maior poder de movimentação, podendo influenciar diretamente - muitas vezes, por meio de alianças com outras famílias que consideram mais próximas a seu próprio estilo -, na escolha, decisão e controle de quem ou qual núcleo irá ocupar certos cargos assalariados ali dentro, assim como acontecerá o repasse de recursos ${ }^{183}$ de projetos, obtendo ainda mais prestígio na gestão da comunidade se os distribui de acordo com as expectativas e poderes aí em jogo.

Como visto no Capítulo I, a família-grande dominante em um tekoa seria "aquela que 'primeiro chegou' ao local”, ainda que possa ter outras famílias extensas vinculadas (Ladeira e Azanha, 1988: 25). Nesses casos, o estilo (teko) de liderança ou orientação predominante no grupo familiar dominante tende a se sobrepor a outros estilos na gestão de um tekoa. É nesse sentido que pessoas ou grupos familiares com maior tempo na aldeia reclamam possuir mais direitos sobre o espaço ou recursos aí presentes do que, por exemplo, uma família ou outros núcleos de parentesco mais recentes, podendo incorrer em

\footnotetext{
182 Como, por exemplo, no caso de "expulsar" uma família ou mesmo um indivíduo que pertence a uma, por algum tipo de desentendimento interno que tenha ocorrido, como em casos de "rixas", "brigas" que geram discussões e conflitos entre famílias.

${ }^{183}$ E se, no âmbito da aldeia, de acordo com Pissolato (2007), o dinheiro seria pensado efetivamente como um meio de satisfação de vontades, uma transação ou alguma troca, não gerando propriamente uma lógica do lucro, ele também não deixa de ter importantes implicações na política local. Em campo, ela observou que as funções remuneradas são alvo do interesse de várias pessoas, assim como o acesso privilegiado à comida que, no entanto, tende a concentrar-se nas mãos dos parentes mais próximos do cacique, sendo alvo de críticas por parte dos outros indivíduos em uma mesma aldeia (Pissolato, 2007: 69).
} 
conflitos. Nessa aldeia em especial, que possui "muito núcleo pra pouca terra" seria ainda mais complicada a convivência entre as famílias, visto que tradicionalmente os núcleos não eram "grudados" um nos outros, demorando, segundo me contaram, até duas horas para se chegar a um outro grupo familiar, o que acabava dando-lhes maior liberdade de organização, o que, hoje em dia, não acontece devido ao território (oficialmente demarcado) extremamente reduzido. Por isso, pode acontecer d@própri@ chefe de família ou alguém que se destaca dentro do próprio grupo, ter "voz ativa” ali dentro - sem, necessariamente, ter para fora dali -, e acabar por iniciar ações sem a devida consulta ou discussão com as lideranças "oficiais” da comunidade, começando, por exemplo, um projeto em parceria com algum(a) jurua que traria benefícios apenas para a própria família ${ }^{184}$, que pode se desenrolar em intrigas internas, entre as parentelas e, por vezes, chegar a problemas jurídicos que podem afetar a todos os habitantes daquele espaço, obrigando o cacique e as lideranças do Conselho a tomarem providências a respeito, exercendo assim um controle mais centralizado sobre os recursos e projetos.

Os desentendimentos e conflitos entre as pessoas e as famílias que vivem em um mesmo espaço de terra podem gerar tristeza, e apesar de motivarem o impulso para vários movimentos coletivos, em busca de mais autonomia e liberdade, estes acabam, muitas vezes, não podendo se efetivar de fato, pois entram em um ciclo do qual têm muita dificuldades de conseguir sair: a falta de terras efetivamente demarcadas pelo Estado brasileiro acabou criando entre eles a dependência dos serviços estatais (UBS, Escola, CECI que oferecem empregos, remédios e alimentos) presentes na aldeia para a sobrevivência do grupo, e mesmo o cadastro em benefícios sociais governamentais (Bolsa Família, Renda Mínima) que estão diretamente relacionados à sua permanência na T.I, além das inúmeras e recorrentes doações ${ }^{185}$ que recebem dos jurua, e ao mesmo tempo a proximidade da cidade (tetã) e a relativa acessibilidade ao transporte urbano, que facilita o

\footnotetext{
${ }^{184}$ Este ponto, embora fundamental para a organização social e política Mbya, raramente é levado em conta no âmbito das políticas públicas ou dos programas desenvolvidos por entidades privadas que seguem a lógica da equação Terra Indígena $=1$ comunidade, como bem aponta Testa (2014). Um exemplo claro disso é o comentário de uma liderança mbya: "Se [esse projeto] for por família eu acho melhor e vou participar. Se for comunitário, eu sei que vai dar problema. Algumas pessoas não vão se sentir dono daquilo e não vão querer participar" (Testa 2014: 121, grifos meus).

${ }^{185}$ Motivo de grande preocupação de algumas lideranças, pela grande dependência que causa entre as famílias, principalmente em relação às crianças, que recorrentemente recebem doces, bolo e guaraná, brinquedos e roupas usadas doados pelos jurua, gerando também um grande acúmulo de lixo na aldeia, que leva à mobilização das lideranças, principalmente das mulheres em limpar os papéis e plásticos nos eventos organizados por entidades beneficentes. As doações também podem ocasionar desentendimentos entre as famílias quando estas se sentem prejudicadas na "distribuição" que, geralmente é coordenada pelas lideranças do Conselho, e é um dos motivos de algumas delas desejarem proibir essas práticas dentro das aldeias, que consideram acentuar a dependência guarani em relação aos jurua kuery.
} 
saque desses benefícios, além do acesso aos materiais para a fabricação de artesanato ${ }^{186}$ e a sua comercialização, influenciando ou mesmo impedindo, na prática, essa movimentação espacial ${ }^{187}$. Em relação à geração de renda neste tekoa, além dos recursos provenientes dos cada vez mais recorrentes projetos de fortalecimento cultural e socioambiental - que dizem respeito ao coletivo que vive ali, isto é, aos Tenonde Porã pygua kuery, "aqueles que habitam Tenonde Porã - há a venda de artesanato em feiras na cidade - cuja renda corresponde, geralmente, a uma família nuclear ou extensa -, as visitas de escolas ou de outras organizações jurua dentro da aldeia, as apresentações culturais de corais de crianças e jovens - a escolha de qual "grupinho”, que pertence a uma família ou núcleo determinado, irá se apresentar também pode gerar desentendimentos entre as parentelas - e de danças xondaro na cidade, onde, geralmente, também levam artefatos para vender.

Pudemos perceber nessa aldeia que existem tanto famílias mais influentes, que participam mais ativamente da política interna e teriam mais "representantes" atuando, formalmente ou informalmente, como casos em que apenas uma pessoa da família toda atua "sozinha" e, mesmo assim obtém grande êxito, por possuir, como eles mesmos dizem, a "força da fala", a "sabedoria" e "coragem" para questionar e enfrentar as questões em pauta. Além disso, há casos em que a família é muito numerosa e não possui ninguém atuando diretamente ou efetivamente no âmbito da comunidade, por não desenvolverem - ou por se recusarem também a sair para fora do próprio grupo - essa "força da fala", na visão de alguns interlocutores. Tais grupos, considerados sem “representantes" (para fora do próprio núcleo familiar), acabam tornando-se praticamente “invisíveis”na esfera d@ polític@, segundo meus interlocutores.

\footnotetext{
186 Apesar de muitos materiais necessários à sua fabricação já não serem encontrados na mata perto da aldeia, necessitando que outros parentes tragam em suas visitas materiais para fazer artesanato (madeiras para esculpir petz̃gua e bichinhos de madeira, cera de abelha, cipó, palha para ajaka, etc.), fazendo-os cada vez dependentes de materiais industrializados da cidade para sua confecção.

${ }^{187}$ Ainda que, desde 2013 se inicie uma série de retomadas de terra, pelas quais algumas famílias nucleares e-ou extensas aproveitaram para se dispersar. No entanto, o Tekoa Tenonde Porã segue sendo um centro importante na mobilização de relações, também por ali se concentrar os serviços públicos estatais e as principais doações, além de abrigar a maioria das reuniões políticas com as instâncias jurua, levando muitas famílias a escolherem permanecer ali. Há um certo debate aí sobre qual seria a distância ideal entre a cidade (tetã) e o tekoa: algumas famílias preferem morar mais próximas à cidade enquanto outras preferem morar mais afastadas, e isso se reflete na própria disposição espacial das casas neste tekoa, com umas famílias morando mais próximas ao centro da aldeia, onde ficam localizadas a Escola, a UBS, o CECI e a opy guaxu, e as habitações das principais lideranças que tomam a frente na comunidade, assim como outras famílias, que escolheram viver mais afastadas dali. Ainda assim, há um certo entendimento de que algum trânsito deva acontecer entre a cidade e o tekoa, pois já não podem mais sobreviver sem os bens e serviços jurua, mas a questão principal gira em torno de qual deva ser a medida correta desse trânsito, tanto dos Guarani à cidade como dos jurua kuery ao tekoa, que gera um debate eterno.
} 
O coletivo de lideranças do Conselho da aldeia, junto ao cacique, tenta distribuir então os recursos ${ }^{188}$ dos projetos entre as famílias que mais precisam de apoio financeiro, principalmente àquelas que não possuem aposentadorias ou auxílios governamentais e cargos assalariados. Geralmente, essa distribuição toma a forma de doações de alimentos e também de fumo de corda (petỹ) e erva-mate $\left(k a^{\prime} a\right)$, comprada nos mercados jurua, entre aqueles que possuem e-ou cuidam das opy'i. Os projetos também podem gerar alguma renda ou alguma forma de pagamento para aqueles que estão envolvidos nas atividades (como, por exemplo, as cozinheiras) e organização de eventos, viagens, intercâmbios, incluindo aí também os anciões que, em alguns casos, podem atuar como "professores" dos ensinamentos relacionados ao nhandereko. Além disso, a merenda escolar é distribuída a todas as famílias da aldeia que tenham seus filhos-netos ali matriculados, assim como as doações que recebem dos jurua de cestas básicas. No caso dos cargos assalariados, como me explicaram e pude observar em campo, estes demandam um certo investimento da própria pessoa em obter destaque, primeiramente no interior de seu próprio núcleo e a partir disso, tendo suas habilidades reconhecidas, conseguir uma oportunidade, oferecida (ou reivindicada pela família, dependendo do ponto de vista) pelas lideranças da comunidade para ajudar a própria família. Nesse sentido, ela deve saber aproveitá-la uma vez que qualquer deslize ${ }^{189}$ nas regras internas do tekoa seria um motivo a ser levantado por qualquer pessoa (geralmente de outro núcleo, ou mesmo pelas próprias lideranças do Conselho), para que se afaste do cargo e seja substituído por alguém que considerem precisar mais e-ou que possa valorizar mais essa "oportunidade", e que a pessoa afastada, "desperdiçou".

\footnotetext{
${ }^{188}$ Há um constante esforço das lideranças da comunidade no controle e na circulação equitativa de bens e serviços, justamente para não aparentar desigualdade, privilegiando a lógica da generosidade (ainda que muitas vezes possam privilegiar os próprios parentes, fazendo aparecer a lógica faccional guarani), se magnificando através do prestígio adquirido na distribuição eficaz de recursos entre as famílias. O dinheiro tem aí além de um valor simbólico, uma dimensão prática que facilita a obtenção de alimentos industrializados (tais como óleo, açúcar, sal, enlatados, refrigerantes, café, medicamentos industrializados, materiais artesanato, etc.).

${ }^{189} \mathrm{Na}$ filosofia moral guarani, a pessoa deve ter comportamentos e atitudes exemplares, não podendo beber em demasiado e perder o "controle", nem sair muito para "festa", devendo ser generosa, calma, proativa, etc., e se "sair da linha", se envolvendo em "briga" ou alguma "confusão", pode perder até mesmo algum emprego remunerado ou ser "expulso" da aldeia. Há um forte controle do coletivo de lideranças sobre o quadro de empregos da aldeia, tentando distribuir os recursos de maneira equilibrada entre os diferentes núcleos, fazendo circular os cargos para outras pessoas ou famílias se considerarem necessário. Comportamentos que não são bem vistos (trair, beber, brigar, violência doméstica e sexual...) são motivos suficientes para mandar alguém embora (parte do trabalho do coletivo de lideranças), seja da aldeia, do trabalho, do núcleo de parentesco ou residência, etc., mas depende também do poder da família a que tal pessoa pertence e das relações e o prestígio que detém dentro da aldeia.
} 
As jovens "lideranças"190 que atuam no âmbito da comunidade, ao expandirem os recursos captados dos jurua para fora do próprio núcleo conquistam, maior legitimidade, isto é, poder de ação e decisão na esfera política comunitária, tanto interna como externamente, por serem reconhecidas pelo coletivo como aptas a atuar entre esses mundos de uma maneira eficaz, capazes tanto de circular e cativar os jurua na captação de recursos para a comunidade, garantindo assim a sua sobrevivência, como tomando a frente também na luta pela demarcação e garantia de suas terras e dos serviços estatais a que têm direito. Por isso, atuam idealmente como "representantes" de todas as famílias circunscritas nesse espaço restrito, por sua atuação eficaz no meio delas. Isso depende enormemente do contexto e momento que estão vivendo, e não impede "falatórios" (ayvuxe $r e \imath)^{191}$ a respeito de sua atuação, no interior de cada núcleo. A confiança (-jerovia) que a comunidade pode conferir a essas lideranças oscila, portanto, consideravelmente e, por vezes, acaba impedindo reconfigurações políticas radicais pelo simples fato de não reconhecerem tais capacidades em outras pessoas tão facilmente ou mesmo por não se disporem a atuar no âmbito coletivo da aldeia. Daí a importância da discussão coletiva, que deve sempre buscar o "consenso" (joo rami) 192, o que viria, por exemplo, com a "representação de todos os núcleos" 193 num problema interno, principalmente quando a decisão a ser tomada afeta diretamente a todos, como no caso dos projetos a serem implementados internamente, dos empreendimentos jurua de grande impacto que afetam a T.I. ou áreas circundantes e, questões relacionadas às suas demandas em relação ao Estado - Governo Federal, do Estado ou do município de $\mathrm{SP}$-, que só podem (idealmente) se concretizar com “a voz" de todos os núcleos.

Nesses casos, segundo me disseram as lideranças, quando qualquer um dos núcleos não concordar com a ideia apresentada, o projeto ou ideia proposta é abortado. Essa

\footnotetext{
190 De acordo com meus interlocutores, alguns podem falar que são lideranças para as pessoas de fora, seja para "parentes" ou para jurua kuery, e não serem de fato legitimadas e reconhecidas pelo coletivo de parentes ou mesmo pela comunidade.

${ }^{191}$ De acordo com Dooley, ayuxe e ayvu reko podem ser traduzidos como "fofoca: xeayvuxe rei vy e'y xeayvu não estou falando fofoca" (Dooley, 2006: 26). No entanto, ao buscarmos o sentido de ayvu reko, observamos

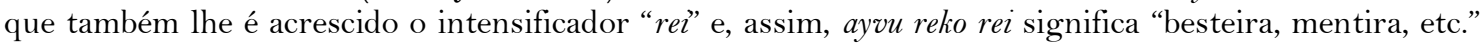
(Ibidem: 25-6). Já rei, em sua função adverbial pode significar "de maneira errada, má" e como intensificador, "muito, uniformemente, sem exceção" (Ibidem: 167). Nesse sentido, optamos por traduzir "fofoca” por "ayvuxe rę", apesar do termo também poder ser traduzido apenas como ayvuxe, ainda que nesse último caso signifique também a simples vontade de querer falar, como por exemplo, xeayzyxe ("eu quero falar") (Ibidem: $172-3)$. Dooley também traduz ayvukue por "conversa fiada, fofoca” (Ibidem: 25).

192 Como me traduziram meus interlocutores, joo rami, seria a palavra em guarani para "consenso", ou seja, quando todo mundo se sente representado através de um processo progressivo de "pensar junto", de construção de uma só ideia, boa ou ideal para todos. Dooley traduz joo rami por "semelhantes um(uns) ao(s) outro(s)" (Dooley, 2006: 73) que também pode ser dito joo-joo rami e tem o mesmo sentido: "joo-joo rami ijayvu va'e aendu ouvi os que falavam de forma igual” (Ibidem: 164). De acordo com Perrone-Moisés: "Os mecanismos do consenso supõem [...] um sem número de conversas ao pé do fogo, visitas, apresentações de pontos de vista e debates que não ocorrem no 'espaço público'. E aí, mais uma vez, embaralham-se
} 
dinâmica não aconteceria com todos os projetos, só com os “maiores", aqueles que irão afetar a comunidade em geral, já os projetos “menores" seriam aprovados só com o aval das pessoas presentes na reunião e das lideranças do Conselho, isto é, por “maioria simples", como explicaram. Porque com todos decidindo ou concordando com o que será feito, a responsabilidade se algo não correr bem ou não dar certo não cairia só em cima do coletivo de lideranças ou do cacique, e sim nas "mãos" de todos. Idealmente todos que vivem na comunidade teriam responsabilidade pelas suas decisões, por isso devem buscar produzir o consenso através da discussão coletiva, o que, na prática, pode não acontecer dessa maneira, uma vez que o fazer político e as relações que se desenrolam no cotidiano de uma comunidade são bem mais complexos, instáveis e inconstantes, que essa Dissertação tem a capacidade de ilustrar por completo. Entretanto, as decisões por consenso dependeriam também da própria "colocação da comunidade", que às vezes aparece mais, às vezes menos, o que pode ocorrer, segundo me contaram as lideranças, em casos em que as parentelas preferem não se envolver por não entenderem do assunto, ou mesmo por não se interessarem, deixando as decisões nas mãos do Conselho de lideranças que, seriam aqueles que entenderiam melhor o funcionamento de determinadas questões e teriam mais "paciência" e disposição no trato destas, principalmente em relação àquelas que envolvem negociação, interlocução ou dizem respeito à burocracia jurua ou mesmo, no aspecto interno, os problemas relacionados à violência e uso de bebida alcoólica e desavenças entre famílias.

Com isso, apesar de reconhecerem que com a construção dessa nova configuração de lideranças dentro das aldeias "aconteceram muitas coisas ruins quando tudo isso se construiu" - no que diz respeito ao confinamento em reservas e as fugas decorrentes daí e do regime forçado de exploração e violência empregado pelo SPI, além da imposição

nossos 'público' e 'privado'. Pois nos custa, aparentemente, entender que a 'política', como processo de debate e decisão da 'coisa pública', não ocorre no que nos parecem ser as ágoras ameríndias - onde são feitas declarações públicas. O debate ocorre em contextos que classificamos como domésticos, familiares, privados e informais. E nesse debate as mulheres, que a nós parecem eclipsadas ou simplesmente alijadas da 'política', sempre têm um papel central. Não é nas reuniões masculinas, nas pequenas e grandes assembleias de chefes ou anciãos, que ocorre o 'debate político'. Nesses contextos, trata-se de propor ou de anunciar, nunca de debater ou decidir. Daí não haver bate-boca nas 'ágoras' ameríndias. Faz parte da etiqueta 'política'. Daí um grupo de lideranças guarani ter-se retirado recentemente de uma assembleia quando instalou-se entre oradores uma discussão acalorada. E daí a justeza de utilizarem o termo 'política', sempre em português, como sinônimo de discussão e dissenso, ligado a uma etiqueta (ou falta de - e não seria a primeira vez que os índios nos acham maleducados) de oposição e imposição pública. A nossa política é mesmo fundada numa concepção exclusivamente guerreira (hobbesiana) e sua oratória certamente se parece mais com uma fala de guerra do que com uma fala de congregação" (Perrone-Moisés, 2015: 93, grifos meus).

${ }^{193}$ Com "representação", meus interlocutores guarani querem fazer referência às chefias de família atuando na política ou decisões coletivas da aldeia, representando o próprio núcleo, mas não necessariamente "todo mundo”. Para uma discussão sobre consenso entre os Kaiowa e Guarani do MS, ver também Pimentel (2012). 
de cargos políticos dentro das aldeias, como comentamos -, e se deve, principalmente, ao grande número de famílias ${ }^{194}$ confinadas numa área muito pequena (ainda que, agora, em processo de demarcação), multiplicando os problemas sociais decorrentes dessa situação, eles consideram que "nos dias de hoje, a configuração de lideranças na aldeia é extremamente fundamental", já que "quem decide, quem faz as coisas acontecer[em] ou não, na verdade é a comunidade em massa", daí "a importância das lideranças serem conhecidas internamente e fora da aldeia” (Jera Poty, Tekoa Tenonde Porã, 2012, grifos e alterações minhas). Essa liderança frisa que nos dias de hoje, a aldeia tem que atender a "política da cidade" também, "com governo, com Estado, com ONGs, com Prefeitura”, o que faz necessário "ter representante na comunidade para responder pelas coisas que vem de fora ou que vem de fora pra dentro da aldeia" (Idem).

Atualmente então, quem lida mais com a questão "política", seja internamente ou externamente, não seriam mais diretamente os xeramoĩ e as xejaryi e-ou chefes de parentelas, mas@ cacique - que pode, em alguns casos, ser também um xeramoĩ ou mesmo uma xejaryi ${ }^{195}$ - e o coletivo de lideranças do Conselho que @ auxilia na gestão das relações dentro do tekoa. No entanto, é @ cacique, na maioria dos contextos quem detém "autoridade" em certas questões que envolvem a "comunidade" e a "cidade", seja quando tem que decidir o que será feito em algum caso de "desentendimento" interno, seja quando é requerido pelos jurua para "falar e representar sua aldeia", na luta pela demarcação da terra e "busca de melhorias" para o que são consideradas as principais demandas coletivas (alimentação, saúde, saneamento básico, moradia e educação). Ainda que, neste último caso, seria o coletivo de lideranças, geralmente as mais jovens, que atuariam mais fortemente como uma espécie de "porta-voz" ou "representantes" da comunidade no âmbito externo, lidando mais diretamente com "o desenvolvimento e a filtragem do que vem de fora para dentro" da comunidade e, muitas vezes, com a "parte burocrática" que decorre daí, contando também com o auxílio de parceiros jurua. Devem tratar também de diversas questões internas problemáticas, dada a "desordem” social decorrente do grande número de famílias confinadas em um espaço muito restrito, que restringe (mas já não impede, especialmente com as retomadas) as possibilidades de dispersão espacial. É especialmente diante dessa situação que se fez necessária a mobilização de um coletivo de lideranças para "controlar" e proteger a comunidade que "vive dentro de uma panela de pressão

\footnotetext{
${ }^{194}$ Situação que consideram diferente da grande maioria das aldeias no Estado de SP que, segundo alguns interlocutores, o "máximo de número de pessoas é de cento e poucos" - com exceção da T.I. Jaraguá e do Rio Silveira.

${ }_{195}$ Como a cacica Dona Jandira, fundadora junto ao seu marido Joaquim, da T.I. Jaraguá (ver Capítulo I e Nogueira da Silva 2008, 2015). E também o caso atual da xejayi Dona Arminda de SC (ver Rebelo 2015).
} 
prestes a explodir", como resume bem uma importante liderança desta aldeia, que também já é avó e trabalha como cozinheira na Escola (Kerexu, Tekoa Tenonde Porã 2015). O uso do termo "autoridade" pelos meus interlocutores guarani pode, por vezes, carregar também o sentido jurua de poder "decidir sozinho o que tem que ser feito". O que só ocorre, segundo eles, em casos considerados emergenciais, geralmente relacionados a questões que envolvem violência ${ }^{196}$ @ cacique detém essa autoridade, ainda que ela seja considerada justificável (dentro desses termos) e controlada horizontalmente pelo coletivo, o conselho-coletivo de lideranças também a detém, assim como cada chefia de parentela também a detém, principalmente em questões relacionadas ao bom-belo modo de ser e viver e de se comportar (teko porã), a justificativa dada nesse caso é que são essas lideranças mais velhas as verdadeiras portadoras de "sabedoria" e "autoridade" nos assuntos da tradição. A questão da autoridade, em grande medida teria a ver então com a questão do saber-poder, e corresponde mais a maneiras diferentes de influenciar e convencer através do manejo da fala - que deve se converter em ações para não ser considerada “vazia”, à toa -, que propriamente a relações de mando e obediência. É, portanto, relacional, e dependente daqueles que se disponham a confiar em sua palavra e segui-la.

O coletivo de lideranças acaba atuando assim, junto ao cacique na resolução de "brigas" ou "rixas" entre famílias, por recursos ou doações que podem não chegar a todas elas, ou em problemas matrimoniais e relativos ao uso de bebidas alcoólicas ${ }^{197}$ dentro da aldeia, que podem, por vezes, desenrolar também para violência contra a mulher e-ou contra crianças ${ }^{198}$. Nos casos em que há violência física, os xondaro kuery (coletivo de auxiliares-guardiões-guerreiros) são instruídos a amarrar os sujeitos até que se acalmem,

\footnotetext{
196 A violência é entendida pelos Guarani como sendo uma (re)ação dos donos dos "sentimentos" que percebendo a vulnerabilidade da pessoa se apossa dela e a faz agir de acordo com sua intenção, o que pode levar a comportamentos anti-sociais, violentos e agressivos, a doenças e a vinganças, mesmo entre parentes. Nesse sentido, tais comportamentos são considerados uma espécie de "doença espiritual", que se acentua ainda mais nesse contexto de confinamento territorial levando a uma série de desequilíbrios físicoespirituais.

${ }^{197}$ As bebidas alcoólicas são associadas à predação, inclusive do próprio grupo de parentes: podem levar a fazer coisas muito perigosas que podem se desenrolar para a morte, como brigas entre casais (violência doméstica e-ou sexual), entre genros e sogros, entre noras e sogras, entre irmãos, entre irmãs, etc. É como se a bebida potencializasse ações perigosas e-ou violentas, pois colocam a pessoa (e consequentemente seus parentes) em um estado de vulnerabilidade que permite a ação de outros seres, como os espíritos dos mortos ou de outros espíritos-donos terrestres. Por isso, a raiva e o ciúme são intensamente reprimidos, pois são mecanismos avessos à proteção do parentesco, fazem querer matar e-ou morrer, são sentimentos que se desdobram sobre si mesmos, voltando-se contra quem tem-faz ou os cultiva.

${ }^{198}$ É possível perceber uma grande dificuldade de se falar sobre temas relacionados à violência, principalmente a sexual, tanto por parte dos homens quanto das mulheres, por se tratar de um tema delicado e ser entendido, pelos meus interlocutores, como algo "proibido", como um "pecado", algo que não seria admitido pelas lideranças e nem pelas regras de conduta moral mbya.
} 
para que depois possam ouvir um "aconselhamento"199 (omongueta). Dependendo da gravidade da situação, chegam a ser "expulsos" da própria aldeia, e enviados para uma outra que os aceitem - geralmente aquelas onde possua relações de parentesco.

Em grande parte desses casos, e quando visualizam a relativa facilidade na resolução dos problemas, principalmente no que diz respeito à esfera de relação com jurua kuery, o coletivo de lideranças da aldeia prefere não "incomodar" tanto, como eles mesmos dizem, o xamoĩ-cacique e mesmo os outros anciões que fazem parte do coletivo, deixandoos mais "concentrados" espiritualmente em Nhanderu e Nhandexy kuery. Além de que, segundo me explicaram meus interlocutores, são essas lideranças-auxiliares que devem se preparar para saber lidar com os problemas atuais, decorrentes da situação de confinamento e presença-proximidade intensiva de jurua kuery e seus comportamentos, por isso devem ser treinados para tomar atitudes e adotar posturas mais severas relacionadas a esta esfera relacional, enquanto os xeramoĩ e as xejaryi, geralmente não, ou mesmo prefere-se, como me disseram, "preservá-los", uma vez que estão atuando em outras esferas de proteção na relação de diplomacia com a alteridade, cuidando da força espiritualdo grupo. Temos aqui então, uma divisão de responsabilidades nessa gestão compartilhada de proteção da comunidade, movimento fundamental em sua manutenção e continuidade.

Esse novo cenário cria então as oportunidades para a formação de uma nova gramática da representação (assentada na transformação de modos anteriores): @ cacique de um tekoa que, junto a um coletivo de lideranças sob sua orientação, depende do estabelecimento de alianças com os grupos familiares e com os jurua, e da garantia do território para poder ter seu lugar e, nesse sentido, precisa agenciar tanto os jurua como ser legitimad@pelos “seus” e por esses “outros”, seja através da obtenção de prestígio pela visibilidade que adquirem as ações coletivizantes que desenvolvem e os permitem permanecer no "cargo" ou tomar à frente na liderança da comunidade, seja na capacidade que desenvolvem de resolução dos conflitos internos entre casais, famílias, ou entre núcleos de parentesco. Temos aqui então, um investimento tanto destas figuras de liderança, em suas atividades que buscam prestígio através do grupo, como do grupo que decide confiar (-jerovia) em suas capacidades, se reunir em torno delas, dotando-as de autoridade-respeito - sempre temporária ou no mínimo, revogável pelo coletivo. @ cacique e as lideranças da comunidade sendo, ao mesmo tempo, constituídos pelas referências coletivas formadoras tanto do campo do parentesco, em sua disposição ou dom de conciliar, assim como

199 O aconselhamento pode, em muitos casos, atuar como "punição” moral pela quebra de regras de comportamento mbya. As boas-belas palavras, usadas corretamente, também curam como os remédios do mato (mõ̃ ka'aguy). 
da espiritualidade, através da sua relação sempre complementar com os xeramoĩ e as $x \boldsymbol{e}$ jaryi, a quem competiria mais a disposição ou dom de aconselhar, atuando juntos tanto nas questões internas dos núcleos e que dizem respeito à aldeia como na orientação das relações que lhe são externas, todos envoltos em uma mesma trama cosmopolítica. O que remete mais a disposições coletivas diferenciantes, construídas em relação do que a funções ou posições propriamente ditas ou mesmo fixas ${ }^{200}$.

Nesse contínuo fazer e desfazer coletivos próprio aos ameríndios, a imagem do pêndulo ilustra bem essa recusa em se fixar num dos polos, daí a incessante e inescapável transformação das suas maneiras de fazer(-se) polític@, o que não implica necessariamente que tais regimes de inovação sejam irreversíveis - o que é irreversível é sim a sua contínua transformação. Nesse sentido, chefia e xamanismo enquanto instâncias mediadoras entre pessoas e mundos, implicam uma necessária interpenetração entre tais domínios, revelando toda uma ação política particular, isto é, uma cosmopolítica. O exercício da liderança na atualidade requer, portanto, destreza retórica para os de dentro e os de fora, manejando tanto códigos das redes de parentesco e xamanismo como os da retórica da "cultura". Daí a amarração direta entre a luta pela terra, xamanismo e política, entendida no sentido empregado por Pimentel (2012) como "movimentos que compõem coletivos". A convocação das lideranças, políticas e espirituais, ao nhandereko, "nosso modo" ou “jeito de ser" evoca assim as tais palavras mágicas, "natureza”, "cultura”, "comunidade” para a recuperação dos seus espaços tradicionais, onde poderão desenvolver verdadeiramente seus próprios hábitos, inspirados nas práticas e nos saberes dos “antigos” (ymagua kuery).

\section{A multiplicação de lideranças: divisão de responsabilidades e a construção do consenso coletivo}

Segundo Sztutman, o chefe e o grupo fazem-se mutuamente, pois é este quem faz aquele aparecer, conferindo-lhe uma forma objetiva (Sztutman, 2012a: 311). Enquanto lugar aparente do poder, "destituído de poder político como mando e coerção”, essa figura do chefe representaria o grupo na medida em que o faz aparecer - diante de outros grupos -, possuindo um papel fundamental:

\footnotetext{
${ }^{200}$ Como viemos mostrando, se nos dias atuais, o xamoĩ ou a xaryi já não ocupa a posição de cacique, isso ocorre, em grande parte devido à atual configuração territorial de confinamento, demandado d@ chefe de tekoa grande capacidade no manejo das interações entre todos os grupos familiares ali presentes. Tal configuração se distancia do modelo "tradicional” de chefia de parentela, geralmente, um casal-xamã-rezador, que cuidava de seu próprio grupo e de quem mais decidisse se juntar a ele. Quem não concordasse com sua atuação, poderia simplesmente formar um novo tekoa, o que hoje em dia é praticamente inviável, dada a escassez de garantia de terras efetivamente demarcadas pelo Estado.
} 
criar uma aparência de unidade - identidade - capaz, de sua parte, de eclipsar a multiplicidade de pontos de vista divergentes que poderiam irromper a todo momento. Nota-se que eclipsar não significa anular, tampouco aniquilar, pelo contrário. Não se trata de dissolver a heterogeneidade que compõe o social, mas dar a ela um ar de homogeneidade. A maneira como esse grupo ou sociedade vai aparecer pertence à contingência, não obedecendo a uma geometria rígida. (Sztuman, 2005: 255, grifos meus)

No entanto, essa representação, parece se colocar sempre de maneira esboçada, de modo que tal unidade personificada pel@ chefe[a] “não é senão uma pausa no movimento incessante de constituição de unidades por definição inconstantes, ou seja, é dotado de baixo 'coeficiente de cristalização', não existe para durar” (Sztutman, 2012a: 321). @ cacique, ainda que refletindo apenas um modo particular de exercer a liderança entre os Mbya, em geral, é a figura que mais se aproxima dessa instância representacional formalizada na projeção de unidade que o mundo jurua requer e busca dentro de um coletivo indígena, na garantia de acordos. É nessa figura que os jurua projetam o reflexo de sua fôrma-Estado. A articulação das lideranças (uvixa kuery), encabeçada pel@ chefe(a) local de um tekoa (tekoaruvixa) ocorre, em grande medida, em reuniões políticas (nhemboaty) ${ }^{201}$. Neste mesmo tekoa (Tenonde Porã) no qual convivem diversos e numerosos núcleos de parentesco, cada qual com suas respectivas chefias de parentela exige, então, da disposição de cacique grande e constante esforço em conciliar toda uma multiplicidade de interesses em jogo, seja nas relações internas e externas à aldeia, seja nas disputas por igualdade na distribuição dos recursos e alianças, devendo estar atento aos princípios que orientam o parentesco e a subsistência guarani, mas que nem sempre é capaz de fazer dialogar, gerando toda uma sorte de insatisfações e, em alguns casos, reconfigurações políticas. Ele é então, auxiliado por um coletivo de lideranças que fazem parte do que traduzem como "Conselho Guarani"202 em português (uvixa kuery nhemboaty).

Com o cacique já não dando conta de tantos trabalhos, projetos e viagens e, visando a melhor divisão das disposições coletivas internas e externas e o não acúmulo de trabalho e a concentração das decisões nas "mãos de uma só pessoa”, foi levada adiante a ideia de criar o "Conselho" da aldeia Tenonde Porã. O objetivo deste Conselho é “dividir

\footnotetext{
201 De acordo com Pimentel, um dos elementos necessários “à compreensão de uma teoria kaiowá da ação coletiva é a aty - reunião, ajuntamento" (Pimentel, 2012: 235). No entanto, como ele mesmo aponta, a forma-reunião, enquanto uma figura política ameríndia, tem sido menos objeto de reflexão antropológica do que as figuras do chefe e do xamã - que configuram a tradição nos estudos -, embora esta não seja menos importante. Para um melhor desenvolvimento desse argumento e do que caracteriza a reunião kaiowá, ver Pimentel (2012).

${ }^{202}$ É possível realizar um paralelo com o Conselho de Anciãos dos antigos Tupi da Costa, aldeia populosa e que também possuía um Conselho constituído por diversos líderes familiares já "iniciados” na arte da guerra e que dominavam a oratória, e teriam como propósito produzir "consensos por meio da palavra", sendo a autoridade de tais chefes realizada como "influência e não como mando" (ver Sztutman 2012a: "Uma Ágora Tupi”, grifos meus).
} 
melhor o trabalho" de modo a "atender melhor a comunidade", produzindo um caráter mais "coletivo" de decisões, através da promoção do "pensar junto", e da produção do "consenso". Esse coletivo de lideranças comunitárias em forma de Conselho, atua então enquanto instância decisória no encaminhamento das movimentações coletivas, por meio do trabalho colaborativo entre mulheres e homens "mais jovens" e "mais velhos", facilitando assim a divisão de responsabilidades comunitárias entre os seus integrantes, não sobrecarregando somente a figura do cacique, ou mesmo d@s xamãs.

Quem “idealizou” a "criação do Conselho Guaran”" nesta aldeia foi uma jovem liderança, também professora, em 2008. Segundo essa liderança, “apenas duas ou três pessoas na liderança da comunidade não estavam dando conta de tudo o que tinham para fazer, para pensar ou para cuidar". A "ideia desde o início era aumentar o número tanto de mulheres na liderança, como de homens" e por isso, “em uma Reunião Geral as lideranças abriram para quem estivesse interessado em se candidatar e fazer parte do grupo de Conselho", que foi então se consolidando na esfera comunitária. Segundo as lideranças do Conselho, em todas as reuniões que fazem, sempre abrem o espaço para "pessoas interessadas a contribuir" e "participar do movimento", ainda que quem acabe tomando a frente nesse espaço sejam lideranças de famílias "antigas”, mais influentes politicamente, e seus aliados, como destacamos anteriormente. Com o Conselho instituído, quando ocorrem desentendimentos ou problemas internos relacionados, por exemplo, ao uso de bebidas alcoólicas que incorrem em brigas, desavenças familiares ou conflitos matrimoniais, o cacique não precisa mais decidir o que será feito sozinho (a depender da gravidade), tendo a possibilidade de debater com esse coletivo de modo a encontrarem juntos uma melhor solução para os problemas que surgem no âmbito comunitário. O que vale também para as questões que vem de "fora", da "cidade", não mais competindo só à figura do cacique a tomada de decisões, que antes do surgimento do Conselho dependiam só dele, segundo me contaram, adquirindo um caráter de decisão mais "coletivo". Além disso, é o Conselho que auxilia a comunidade na ausência do cacique e, nesse sentido, possui também a prerrogativa de decisão emergencial em alguns casos mais sérios e urgentes. É por isso que este coletivo deve aprender a "cuidar da comunidade" em sua ausência, e ser respeitado pelo conjunto de famílias que aí vivem, uma vez que, idealmente, todas as famílias estariam ali “representadas”. Temos aqui, a construção de uma visão entre meus interlocutores de que "as lideranças da comunidade podem ser um coletivo", o que, por sua vez, transmitiria a ideia de que sendo um coletivo traz a "representação de que a coisa é de todos", e de que "a comunidade é sempre a que decide tudo" - o que, na prática, só 
ocorre em relação às questões que afetam diretamente a todos. E que, por sua vez, contrasta em parte com a configuração política “tradicional”, quando eram as lideranças espirituais quem guiavam os grupos de parentes, tomando a frente tanto nas orientações, como nas decisões que dizem respeito ao coletivo, e hoje, nesse contexto de confinamento territorial, a "comunidade", a partir dos seus próprios representantes - que podem ser essas mesmas lideranças espirituais, ou ainda influenciados por elas -, seria quem "decide" e toma a frente. Ao traduzir o que seria este coletivo de lideranças da comunidade, Jera Poty nos inspira com suas belas palavras: "são pessoas que ficam cuidando um do outro, pensando junto, decidindo junto", iluminando assim a construção de uma "comunidade" a partir dos próprios parâmetros guarani (Tekoa Kalipety 2015, grifos meus).

Busca-se aí produzir um caráter decisório mais coletivo, justamente, por conta do grande número de núcleos de parentesco convivendo entre si nessa aldeia. Existe uma "constante consulta” aos núcleos, justamente para "não se indispor com ninguém”, o que é central no apaziguamento dos conflitos e disputas internas, e na promoção da harmonia entre eles. Mais uma vez, vemos aparecer a construção de uma unidade, assentada numa multiplicidade constitutiva e fundamental, nessa produção e manutenção das relações sociais de uma comunidade. Segundo meus interlocutores, uma das particularidades dessa aldeia em questão seria que, por ser muito populosa, na maioria das vezes, o cacique procuraria ouvir ao menos a opinião dos membros do Conselho e só poucas vezes (casos extremos-emergenciais) decidiria "sozinho". Em aldeias "menores" - com menos grupos familiares extensos e menos populosas, característica de grande parte dos agrupamentos guarani -, pode acontecer d@ cacique acabar “decidindo sozinho[a]”, concentrando mais o poder, uma vez que não existiria um "Conselho" ali constituído e nem uma "consulta" efetiva à “comunidade”, nos mais diversos assuntos. Nesse sentido, @ cacique de uma T.I ou de um tekoa populoso deve ter muito "jogo de cintura” para conseguir agradar a maioria, e mesmo assim, segundo meus interlocutores mbya, "sempre acaba desagradando alguém”. É certo também que aqueles que aconselham (nhemongueta va'e), geralmente anciões, têm a função de falar sobre as ações que observam, que consideram certas ou erradas, dentro de um grupo de parentes - e para além dele, em certos casos - mas, segundo meus interlocutores, eles não se colocam numa "relação de poder" como as lideranças da comunidade, capaz de "determinar" situações, ou o que vai acontecer a partir da ação de alguém que fez algo considerado "ruim" ou "errado", dentro das regras de convivência em um tekoa. No entanto, o Conselho de lideranças da aldeia deve agir como os mais velhos que aconselham, por isso, conversam com a pessoa que descumpriu as regras, apontando o que ela fez de errado e quais as consequências de seu erro para além do seu 
núcleo familiar. A diferença entre o Conselho da comunidade e essas lideranças dos núcleos familiares, segundo meus interlocutores, é que estas últimas seriam mais “independentes", atuando dentro do próprio grupo e de seus interesses - ainda que devam também prestar esclarecimentos ao cacique e seus auxiliares acerca de suas atividades - e a formaConselho instituída estaria mais ligada à figura $\mathrm{d} @$ cacique e possuiria maior "liberdade de ação" na esfera da comunidade que aquelas lideranças dos núcleos, o que não exclui também que estas também possam obtê-la, em certas ocasiões, principalmente quando diz respeito a seus próprios parentes. As lideranças que compõem o Conselho seriam como assessores, auxiliares do cacique na gestão da aldeia, ajudando a discutir e a resolver questões internas e externas que dizem respeito ao conjunto de parentelas.

Caberia assim ao cacique delegar a essas lideranças, funções que o representem em sua ausência ou distribuir responsabilidades e tarefas tais como levar mensagens, dar informes, explicar as questões políticas para a comunidade, chamá-la para participar das reuniões gerais, organizar as reuniões, eventos, rodas de conversa, convidar outras aldeias para participar ou mesmo para visitar, entre outras tantas atividades coletivas. $\mathrm{O}$ trabalho dessas lideranças consistiria em resolver e organizar em grande parte as demandas internas, acompanhar discussões sobre projetos que possam gerar renda, a sua implementação e execução, organizar mutirões, além de ter que "responder" pelas coisas que vem de "fora”, isto é, da "cidade", para "dentro" da aldeia, participando tanto de "reuniões" internas, coletivas, como de reuniões na "cidade", com jurua kuery. Nestas reuniões do Conselho são discutidas questões sobre os trabalhos a serem realizados por cada um, e também sobre os projetos e problemas internos, e só quando consideram necessário geralmente, casos em que as decisões afetam todo o tekoa - levariam suas discussões, já previamente realizadas nesse espaço, para as Reuniões Gerais da comunidade, onde ocorreria a deliberação geral que deverá ser cumprida e encaminhada adiante pelas lideranças do Conselho. Ao representarem sua comunidade "para fora", essas lideranças devem trazer para as reuniões do Conselho tanto informações e deliberações "de fora para dentro", como levar também as de "dentro para fora”. Diante da necessidade de interlocução com distintas instâncias jurua, que cuidam de temas tais como educação, saúde e saneamento básico, demarcação da T.I, projetos de fortalecimento cultural e socioambiental etc., há uma divisão de responsabilidades e de tarefas entre essas lideranças.

Schaden descreve uma forma de "assembleia dos chefes de família”, reunidos em "conselho" como formando uma espécie de "senado informal, de função consultiva e deliberativa”, cuja importância, sugere o antropólogo, "talvez tenha diminuído por influência da instituição do capitanato" (Schaden, 1974 [1954]: 95-6). Em algumas das aldeias 
kaiowá e guarani no MS, de acordo com Pimentel, são organizados processos de eleição do cargo de capitão e outras que, por vezes, já aderiram à “forma conselho", que teria lhes sido "imposta, em alguns casos, pela Funai, em dado momento" e, em outros, adotada "por iniciativa dos próprios indígenas" (Pimentel, 2012: 148). Segundo o antropólogo, há alguns anos, num processo que foi descrito por Mura (2006):

a Funai deixou de reconhecer os capitães, ainda que eleitos, como intermediários que falavam em nome da comunidade - e, por ela, podiam receber e repartir recursos recebidos dos governos. A solução oferecida para substituir os capitães foi a formação de conselhos nas aldeias - estimulados pelos órgãos públicos, em muitos casos. O problema é que, mais uma vez, essa fórmula política foi introduzida sem grandes discussões (e, quando digo isso, estou querendo dizer: sem a formação prévia de um consenso em torno da decisão - o que pode ter desrespeitado a autonomia de alguns grupos), o que ocasionou "traumas" em certas áreas, por assim dizer. Atualmente, depois de algumas reviravoltas (rápidas mudanças de titulares de cargos, conforme relatado na introdução), a Funai deixou de impor quaisquer formas e tampouco legitima eleições para capitão. Alguns órgãos do governo estadual e as prefeituras, contudo, ainda estabeleciam, muito recentemente, políticas públicas e distribuição de recursos em diálogo com capitães, o que torna o quadro algo mais complexo. (Pimentel, 2012: 149-150)

O movimento Aty Guasu ${ }^{203}$, atualmente também adota a forma-conselho:

Eu não diria, "é dirigido por um conselho", porque a concepção imperante é que a assembleia manda, e o conselho executa - claro que as coisas não são tão cristalinas, o tempo todo, mas a ideia é que isso aconteça. Quem executa esse tipo de trabalho pode, por sinal, ser chamado de tembiguái (servidor, funcionário), em alusão a essa condição de servir à comunidade, ao coletivo, por meio do trabalho na política. Por enquanto, na prática, dezenas de milhares de pessoas ainda terão que conviver por algum tempo nas reservas superlotadas, e é preciso chegar a acordos sobre como administrar essa situação, pois não é possível esperar até que as terras sejam ampliadas e a autoridade dos líderes familiares possa se recompor. (Ibidem: 149)

Nesse sentido, a estratégia de criação do "Conselho" de lideranças no Tekoa Tenonde Porã busca subverter, a seu próprio modo a lógica jurua de tornar uno o que é múltiplo, para tornar possível a convivência e aliança entre diversas parentelas e lideranças espirituais confinadas em uma mesma área, através da mobilização do sentimento de pertencimento a um mesmo povo e a uma mesma "comunidade", pela qual procuram se "unir" e "alinhar-se" nas decisões gerais, caminhando juntos em um "único pensamento" (peteĩ rami jaguata) ${ }^{204}$, buscando a produção de consensos (que nem sempre é capaz de atender ou satisfazer a todos), em nome da harmonia entre os grupos (o que, certamente não exclui a movimentação própria a cada família ex tensa e seu teko). Como vimos, essa lógica

\footnotetext{
${ }^{203}$ Podemos fazer um paralelo entre a CGY e o Conselho do Movimento Aty guasu, que também adota a "forma-reunião", e tem caráter executivo, organizando as grandes assembleias que tem como objetivo central a recuperação das terras guarani e kaiowá, encaminhando as demandas consensuais junto aos órgãos públicos (ver Pimentel 2012).

${ }^{204}$ Dooley traduz petẽ rami como "unidos, de acordo" e rami por "semelhante a, como" (Dooley, 2006: 164), já peteĩ $i$ como "somente um, único: peteĩ' $i$ rami anho ijayvu falaram com unanimidade [lit., 'como um só’]” e peteĩ' $i$ rami, "de uma maneira só” (Ibidem: 142).
} 
de representação de uma comunidade una requerida pelos jurua kuery entra em embate direto com a lógica faccional guarani. A respeito disso, Gallois observa que entre os Wajãpi, povo tupi do Amapá:

No Conselho das aldeias wajãpi [denominado “Apina”], os chefes, jovens que assumem
a diretoria, todos estão marcados por relações de dentro, são cunhados uns dos outros.
Quem sabe os filhos deles vão conseguir ter posturas neutras. A política indigenista obriga às
vezes a preparar pessoas muito rapidamente e cria uma ruptura muito grande. Essas
pessoas não conseguem mais escutar as vozes de suas bases nem conseguem voltar. A
perda é deixar de ser parcial. Os indios são parciais, eles não representam o Todo wajãpi, porque
o Todo wajãpi não existe. Então, forçar a barra para que se represente esse todo é fazer-se como
um karai ko (brasileiro), é deixar de ser Wajãpi. (Gallois, 2001: 113, grifos e alterações minhas)

Todos que estão envoltos nessas redes de parentesco, aliança, afinidade e inimizade, em um plano maior, de acordo com o discurso oficial dos meus interlocutores, são "parentes" (-retarã kuery), que diante de uma mesma situação complicada de vida devem lutar juntos por uma vida melhor, "cuidar" uns dos outros e se "unir", estabelecendo alianças entre si, principalmente na luta pela regularização efetiva da demarcação da T.I. Tenonde Porã, para que possam então viver bem de acordo com os preceitos dos ancestrais divinos (teko porã), com mais espaço para desenvolver a autonomia e estilos de liderança de cada uma destas famílias extensas e suas respectivas chefias de parentela. Daí o fato, neste contexto, de haver múltiplas lideranças atuando numa mesma comunidade ${ }^{205}$ - diferente da maioria das aldeias no Estado de SP que contam com poucas famílias extensas -, e que se deve também à grande demanda de trabalho que surge dessa situação, segundo meus interlocutores, implicando uma atuação específica delas a partir dessa relação entre as chefias de núcleo e o cacique, pois não é possível estas figuras resolverem todas as demandas que chegam, tanto internas, como externas, "sozinhas". Por ser muito populosa e de território (ainda, na prática) reduzido, esta aldeia tem uma incidência maior de problemas internos, decorrentes de vários tipos de situações - que decorrem, principalmente, segundo meus interlocutores, da falta de terra e da falta de obtenção de permissão do Estado de SP, responsável pela administração dos Parques Estaduais, para uso dos recursos da mata para sua subsistência -, como também uma procura maior tanto de jurua kuery para doações, visitas, etc., como de pessoas da Prefeitura e do Governo do Estado, uma vez que se situa relativamente próxima à cidade e por estar localizada na capital do Estado de SP, essa incidência aumenta consideravelmente. Esses mecanismos de multiplicação e alternância de chefias seriam algo da natureza das chefias ameríndias,

${ }^{205}$ Sobre a multiplicidade de chefias em grupos de língua tupi-guarani ver Sztutman (2012a: 323). 
próprio à sua recusa em se representar ou se pensar como uma totalidade fechada ou fixa, como algo acabado:

\begin{abstract}
Se representação há, pois o coletivo, ou algum coletivo, deve aparecer de alguma forma, ela jamais se completa, jamais se estabiliza, impedindo a transcendência das formas sociais e políticas, e mantendo um estado de imanência, em que a pessoa do "representante" conta bastante. (Sztutman, 2012a: 323)
\end{abstract}

Assim, nessas paisagens, onde a representatividade se acentua também se acentuam os tais mecanismos de multiplicação e alternância de chefias, promovendo a coexistência de vári@s chefes, ainda que mantidas as gradações de prestígio. De acordo com Sztutman (2009b, 2012a), há uma crítica etnográfica desses povos à noção moderna de representação política que vai ao encontro de uma crítica à ideia de sociedade como totalidade acabada, una, dada a priori. O que parece estar por trás de uma ideia fundamental: o reconhecimento da incompletude de qualquer representação. Por isso, a disposição de cacique demanda a construção de um lugar de frente ${ }^{206}$, de principal referência na condução-orientação de um movimento amplo de famílias que é um tekoa, sendo então considerado comonhanderuvixa ("noss@ chefe(a)"), tekoaruvixa ou mesmo uvixa tenondegua (“aquele(a) que está à frente de outras lideranças”). Entretanto, há uma série de disposições e capacidades-poderes importantes e necessárias ao coletivo demandadas nas frentes de ações cosmopolíticas e também, é pouco provável que os atributos esperados de uma chefia ou liderança possam ser encontrados todos em uma só pessoa. Vimos como a distinção entre planos de comunicação com o exterior (plano vertical e plano horizontal) incorre na diversificação dessas figuras cosmopolíticas que estamos discutindo e, portanto, a chefia de um coletivo mbya, não se resumiria à figura de uma só liderança, compondo antes um coletivo delas que segue a orientação de um(a) tenondegua, se colocando em movimento sob sua orientação.

Aparece aqui então a imagem de lideranças "encabeçando" atividades, quaisquer delas, dentro da aldeia ou mesmo fora dela, e "influenciando" as pessoas a se moverem. Uma importante liderança mbya me explicou que "cada grupinho, pra qualquer coisa na vida, assim, sempre tem alguém que puxa, são os líderes” (Jera Poty, Tekoa Kalipety 2013, grifosmeus). É a figura d@ tenondegua, “aquele[a]que segue na frente, puxando o coletivo”, isto é, influenciando e convencendo através do bom uso das belas-boas palavras (ayvu porã), que devem se converter em ações cosmopolíticas eficazes, daí o seu prestígio e poder de mobilização de pessoas. Segundo meus interlocutores, aquele(a) que vai na frente de um

206 A responsabilidade pelo bem estar-viver do coletivo é toda daquele(a) que vai à frente, seu/sua puxador(a), por isso, se algum “mal” ocorrer, será ele(a) também@ responsável. 
coletivo, inicia ou toma a dianteira em uma ação e é seguid@ nela - evocando a imagem de uma fila-, deve ser capaz de "puxar" as pessoas para trabalhos coletivos, atraindo-as a segui-1@, o que envolve o reconhecimento coletivo de seus saberes-poderes, um “ter fê", "acreditar" e "confiar" (-jerovia) em suas capacidades, respeitando-as. Nesse sentido, teríamos então a disposição daquele(a) que se coloca à frente de um coletivo, no domínio do parentesco, geralmente um casal-chefe de família extensa que, além de cuidar da orientação, saúde e condução de seu grupo, encabeçando ações e movimentos coletivos, distribui tarefas, de acordo com as habilidades de cada pessoa dentre as atividades necessárias ali para a reprodução da vida social, conciliando assim as relações e as boas disposições e ânimos entre parentes. Seriam eles, sobretudo, reconhecidos pela sua capacidade em traduzir saberes-poderes em benefícios e saúde, alegria e satisfação para seu coletivo. Tais capacidades-poderes de liderança podem vir a estender seu prestígio para além do próprio núcleo familiar, podendo ser reconhecidas por outras parentelas - o que se reflete no estabelecimento de alianças entre famílias influentes em um mesmo tekoa -, e assim atuar também no âmbito da "comunidade", auxiliando a "puxar" ações. Tenondegua é literalmente "o que está adiante" ou "primeiro", como os Nhanderu Tenonde e as Nhandexy Tenonde (nosso pai e nossa mãe "primeira") que vão na frente, ou mesma em referência aos nhaneramoĩ e às nhandejaryi tenondegua' ${ }^{207}$, presente nos cantos das crianças e jovens que dão força e coragem aos que os seguem, os xondaro e as xondaria kuery.

Aqui, é interessante um paralelo com a etnografia de Pimentel (2012) que, entende a teoria política kaiowa-guarani como uma "reflexão sobre os movimentos dos coletivos humanos" e a essa ação coletiva, expressa na imagem de uma fila, como demandando uma figura que se coloque à frente, iniciando o movimento. Lá em MS quem toma à frente numa ação, ou tem a iniciativa para realizar algo, conduzindo e puxando a fila, seja no âmbito familiar ou no grupo local de uma área seria a figura do tendotá, que também é uma qualidade desejável daquele que está numa posição de liderança, expressando tanto a pessoa em si como o que se espera que essa pessoa ou outra seja (exatamente como acontece entre os nossos interlocutores Guarani, falantes do dialeto mbya). O tendotá é ainda uma figura do movimento, aquele que "puxa" uma turma, muitas vezes "dando o impulso inicial de deixar o velho e buscar o novo, isto é, sair de um lugar onde as coisas não são boas, onde já não há alegria, para buscar o novo, buscar alegria" (Pimentel, 2012: 130, grifos meus). A ação coletiva expressa pela imagem da fila, demanda então

${ }^{207}$ Como no trecho: "Nhanderu ete tenondegua' $i$, Nhandexy ete tenondegua'i, nhamombaraete nhanderete' $i$ ' ("Nosso pai verdadeiro vai na frente, Nossa mãe verdadeira vai na frente, vamos fortalecer nossos corpos”). 
uma figura que encabece o movimento e, que dentre os "talentos" que necessita, "o conjunto de saberes normalmente tido como ‘xamânico’ é o mais importante (Ibidem: 191). O tendotá precisa deter, ao menos, "um conjunto mínimo desses saberes", uma vez que:

a sanidade geral do grupo local e de seu entorno determina, muitas vezes, o sucesso ou o fracasso de uma empreitada política, e são os saberes xamânicos, justamente, que podem influenciar nesse quadro, por meio das fórmulas verbais que curam, ou mantêm saudáveis pessoas, animais, plantas e o clima. (Idem: 191)

As "lideranças" ali seriam reconhecidas pelas comunidades como "capitães", ou como "mburuvicha”, "tuvicha” ("principal”, "chefe”), dependendo da situação do grupo local, pois há tanto grupos onde o termo "capitão" mantém a "legitimidade, sendo sinônimo de mburuvicha, até outros em que os dois termos se tornaram antônimos” (Ibidem: 129). Também é possível que "se fale, genericamente, em tendotá kuery” (Ibidem: 240):

Não significa que o tempo todo, sempre, as pessoas chamem o chefe de tendotá. Na verdade, é até raro encontrar alguém usando o termo. Mas, as pessoas cobram de um líder uma série de iniciativas, ações e características, de tal forma que, em certos momentos da conversa, evocam essa ideia. Tendotá não é exatamente um título, como os de mburuvichaprincipal - ou capitão. Qualquer homem maduro (e também uma mulher, conforme a situação) pode, em princípio, assumir essa posição de tendotá - isto é, puxar uma fila, iniciar uma ação. (Ibidem: 129, grifos meus)

Por isso, de acordo com Pimentel, "na prática, não basta ser tuvicha, é preciso ter algo de tendotá para manter a posição de principal” (Idem). O antropólogo parece então opor essa disposição de liderança do tendotá que surge a partir de uma iniciativa, de uma ação propriamente dita, ao "título" de chefia que o mburuvixa ocupa em um grupo local:

A liderança também envolve uma série de talentos singulares: hoje, para reconquistar as terras tradicionalmente ocupadas pelo grupo, é preciso que um líder saiba lidar com a Funai, o Cimi, os antropólogos, os fazendeiros, a Justiça etc. Se ele não souber, terá de juntar a seu grupo gente capaz de fazê-lo. Evidentemente, a capacidade para lidar com tantos fatores/agentes diferentes e, ainda, manter as pessoas unidas, mobilizadas, tem certamente algo de especial. Não há muita gente capaz de fazê-lo, é certo, embora, em teoria, muitos se acham capazes de ser tendotá. (Ibidem: 144, grifos meus)

Há também uma "valorização de conhecimentos trazidos de fora” entre os Kaiowá e Guarani, e uma "das ações políticas mais comuns dos coletivos, ali, é atrair para perto de si pessoas dotadas de saberes úteis” (Idem). Tal busca, também entre os Mbya, realizase por meio do estabelecimento de alianças cosmopolíticas úteis, seja entre pessoas e coletivos mbya, seja entre pessoas e organizações jurua, assim como por meio de uma comunicação eficiente com os ancestrais divinos e com outros seres que cuidam do cosmos (ver, nesse sentido, Capítulo III). Além do tenondegua mbya e tendotá kaiowa e guarani, temos também a figura do tenetãmõ ou tenotãmõ ("o que segue à frente”, “o que começa”) entre os Arawete (Viveiros de Castro, 1986: 301) e do tenotara parakanã (Fausto, 2001: 
276), todos eles expressando a ideia de alguém que vai na frente, que inicia uma ação, um movimento. Viveiros de Castro observa que o líder arawete "é o que começa, não o que ordena; o que segue à frente, não o que fica no meio. Toda e qualquer empresa coletiva araweté supõe um tenetãmõ [...] Uma coisa não começa se não houver alguém em particular que a comece" (Viveiros de Castro, 1986: 300-301, grifos meus). Entre os Mbya, quem abriu o caminho foram (e são) as divindades, elas que começaram a caminhada e seguem à frente, orientando seus filhos caçulas.

\section{De inspirações e disposições cosmopolíticas na construção-proteção de um tekoa}

A escolha (jeporavo) ${ }^{208}$ de quem irá ocupar o "cargo" de cacique da comunidade (Tekoa Tenonde Porã), nos dias atuais, se daria pela indicação de alguma família influente na dinâmica política da aldeia ou pelo Conselho de lideranças da comunidade, a partir daí há uma articulação-movimentação entre os núcleos familiares que devem entrar em acordo a respeito da indicação. Por isso, como me explicaram, acontecem reuniões dentro dos próprios núcleos de parentesco para ver se o nome indicado pode vir a ser escolhido, entre eles, para o cargo de cacique. E, só depois disso vai para a escolha definitiva na Reunião Geral Coletiva, na qual devem participar representantes de todos os núcleos da aldeia. Tal decisão deve ser coletiva e por consenso, visto que diz respeito a todos os interessados, em sua multiplicidade. E mesmo não tendo uma duração certa de mandato, a comunidade pode retirar @ cacique do cargo a qualquer momento, porque o importante, segundo me disseram, é que ele(a) faça "alguma coisa pra sua comunidade”, ou seja, manter o contentamento daqueles que estão a seu redor e convivem entre si, já a escolha d@s xamãs, para um interlocutor mbya, seria “diferente”, pois quem decidiria se determinada pessoa merece "iluminação" ou "elevação" para atuar como rezador(a)-curador(a) em um coletivo, seriam mais diretamente os Nhanderu e as Nhandexy kuery (ainda que, para tomar a frente em um coletivo, sejam rezadores ou não, as lideranças devem estabelecer uma comunicação eficiente com os parentes divinos, obtendo daí capacidadespoderes para atuar em um coletivo, sendo também por eles inspiradas).

Uma liderança uma vez me contou: o "poder espiritual é muito mais perigoso do que o poder político", pois "se um grupo está alinhado com uma ideia que não é certa e que é injusta, mas está sendo sustentada por um xeramoĩ, fica muito difícil de impedir". Além disso, comentou também que os xeramoĩ podem utilizar seu "poder espiritual", que vem dos Nhanderu,

${ }^{208}$ De acordo com Dooley, poravo significa “escolher” (Dooley, 2006: 153). 
para "convencer e influenciar pessoas", ainda que para "ideias injustas ou erradas". E mesmo considerando importante a participação das lideranças espirituais no âmbito da comunidade em algumas situações, essa liderança argumentou que se fazem esse movimento, de destacarem muito os xeramoĩ, dando maior poder de decisão a eles, o coletivo de lideranças pode perder o controle da comunidade. Por isso, se questiona como a partir daí poderiam contornar esse tipo de situação, como iriam conseguir retirar o tal xeramoĩ do poder, pois "existem vários tipos de xeramoĩ, que antes de serem pajés, são humanos também”. Mas, diferente dos que "se dizem liderança, e a comunidade logo percebe que não ê", "xeramoĩ é sempre xeramoĩ", sendo "bem arriscado" colocá-los no "poder", ainda mais sem um coletivo suficientemente unido capaz de exercer um controle efetivo sobre suas atividades dentro do âmbito de um tekoa. Se são humanos, não só eles, mas todos estão sujeitos a desejos e doenças desta terra e, por isso, todos podem errar (-avy) ${ }^{209}$ dentro do código de conduta moral guarani (teko), inclusive os deuses erraram quando caminhavam pela plataforma terrestre (yzyrupa) como fica claro na análise de Ramo (2014: 295). O importante é saber errar, aprender com o erro, considerado também como uma espécie de provação, e seguir em frente com a experiência e sabedoria adquirida, sem perder a conexão com os parentes divinos, não esquecendo deles, uma vez que eles constituem o modelo de reflexão e também de ação para os Mbya, aqui na terra.

O xamanismo Guarani se daria então por inspiração primordialmente vertical mas não só, como desenvolveremos melhor no Capítulo III -, pelo agenciamento de capacidades-poderes a partir da relação entre os planos terrestres e celestes. O que não exclui, por sua vez, a apropriação também de capacidades agentivas da esfera horizontal da existência, seja entre os jurua ou outros seres-donos-espíritos (ija kuery) confinados a essa terra. Tais intercâmbios com a esfera terrestre são demasiado perigosos - e, por isso mesmo bastante produtivos -, devendo ser manejados com muito cuidado e precaução e, em muitos casos, evitados ou minimizados. Nimuendaju comenta como só se pode "tornar-se pajé" por inspiração:

O pajé dos Apapocúva é bastante diferente, em vários sentidos, de seus colegas de profissão. Uma diferença muito importante consiste no fato de que alguém não pode tornarse pajé a não ser por inspiração; um pajé nunca pode ser treinado para tal, mesmo que isso se dê por iniciativa das maiores autoridades no assunto. (Nimuendaju, 1987 [1914]: 74-75)

\footnotetext{
209 -Avy pode ser traduzido como "errar" (Dooley, 2006: 23).
} 
Nesse sentido,@s xamãs guarani devem ser inspirados pelos deuses, sem a possibilidade de "escolha", segundo me contaram os Mbya, de como ou quando sua eleição' 110 acontece, e nem mesmo se ela irá, de fato, ocorrer um dia, decisão que cabe aos Nhanderu e Nhandexy kuery. No entanto, a "transmissão" desses saberes-poderes disponibilizados por meio da relação que se estabelece com os ancestrais divinos pode ser maior ou menor ainda que a dedicação a certas atividades possa ajudar nessa "escolha", como o uso intensivo do petỹgua, com a fumaça (-ataxĩ) operando como um veículo de comunicação e de potencial agência, assim como os cantos-reza-danças, que também são um importante canal de comunicação e transmissão de capacidades-poderes divinos. Já a chefia, a liderança "política" (mais "terrenal", digamos) sobre o grupo, é mais controlada horizontalmente, pelo coletivo, sendo mantida sob intensa vigilância e suspeita e, com isso, dependendo sempre da vontade e das demandas do grupo para permanecer no "cargo". Ainda que, as capacidades de uma liderança espiritual também possam estar sempre sob intensa suspeita, como fica claro na fala anterior de uma liderança, principalmente pelos de fora (de seu grupo familiar), podendo não ser legitimada se não for capaz de produzir a requerida eficácia em suas ações dentro de um coletivo sendo, por isso, também controlada por ele em alguma medida, passando tanto por períodos de ascensão, como de queda no prestígio, o que também depende da extensão da rede de relações (ou de seguidores) que consegue manter junto a si. Podemos pensar então, como bem ilustraram Sztutman (2005, 2012a) e Vanzolini (2011), em processos de "mútua constituição" entre chefe e sociedade, nos quais o aumento do poder d@ chefe - acrescentamos aí também lideranças e xamãs -, contraproduz uma comunidade suficientemente unida para controlá-lo(s).

A organização social desta aldeia (Tenonde Porã) conta então, além do cacique e do coletivo de lideranças (-uvixa kuery) - reunidas em forma de Conselho (nhemboaty) que o auxilia, com os xeramoĩ e as xejaryi dos núcleos familiares, com os xondaro e as xondaria kuery - guerreiros-guardiões-auxiliares da comunidade, das chefias de parentela e da casa de reza - e com a opy guaxu, centro social da aldeia, espaço comunitário em que cantam, rezam, dançam e ouvem ensinamentos-conselhos de seus sábios anciões e de outras lideranças. Segundo Timoteo Popygua, a opy seria o "centro da aldeia, é centro da vida do povo guarani e o sentido da vida do povo guarani, a casa de reza, através da dança, do canto dos pajés, é como se fosse uma coluna vertebral, sem isso o Guarani não consegue ter

\footnotetext{
210 Geralmente essa "eleição" decorre de adoecimentos que envolvem a quase-morte da pessoa, capacitando-a transitar entre os mundos de modo mais acentuado que outras pessoas, e o envio de espíritosauxiliares (nhe'ê kuery) para os ajudarem nas curas por sopro, dos parentes aqui na terra.
} 
essa força espiritual" e é por isso que em "qualquer aldeia tem opy", porque "Guarani se perde totalmente sem ela" (Timoteo Vera Popygua, Tekoa Tenonde Porã 2012, grifos meus).

A casa de reza agrega, além de rezas-cantos-danças e rituais de cura, cerimônias tradicionais como o yy karai (atribuição de nomes às crianças), o ka'a nhemongarai (benzimento da erva-mate) e o avaxi nhemongarai (benzimento do milho guarani) - de celebração das colheitas e do nascimento de crianças, pois elas são nominados em todas elas, que devem coincidir com a passagem do ara pyau (período equivalente à primavera e ao verão jurua), época dos "tempos novos" 211 , ao ara yma (período equivalente ao outono e ao inverno jurua), correspondente aos "tempos antigos", em um movimento circular e constante -, assim como reuniões e conversas entre parentes. No caso da opy guaxu, esta pode abrigar cerimônias coletivas tradicionais, ainda que mais raramente, sob a condução de uma ou mais lideranças espirituais da comunidade, mas geralmente é utilizada mais para reuniões políticas da aldeia - tanto as Gerais (espécie de Assembleia), como as do Conselho de lideranças -, assim como para reuniões com parceiros não-indígenas e mesmo representantes do Estado ou município, além também de reunir encontros políticos em que lideranças guarani de outras aldeias vêm discutir questões relacionadas tanto à luta pela terra e busca de melhorias coletivas dentro das aldeias, promovendo o intercâmbio de conhecimentos, saberes, danças, cantos, rezas, além de outros bens - materiais e imateriais - entre elas. Dentro da política interna, é possível perceber a busca pelo fortalecimento da própria cultura, da tradição, e a promoção da continuidade da resistência em relação a jurua reko, através de suas cerimônias, danças, cantos e rezas, que priorizam incessantemente o bem-estar, fortalecimento e proteção coletiva. Em relação à dinâmica política entre aldeias, há uma intensa articulação política nacional através da Comissão Guarani Yvy Rupa (ver Capítulo I) e mesmo entre outras organizações indígenas, locais e nacionais.

\footnotetext{
211 Segundo Ladeira (2001), o "nheemongara" deve coincidir com época do ara pyau, pois há uma associação entre a colheita dos alimentos sagrados, entre eles o famoso avaxi ete'i (milho), as cerimônias de "benzimento" das sementes tradicionais e atribuição dos nomes-almas das crianças que impõe, um calendário agrícola baseado nas fases da lua (jaxy) que define o tempo de permanência das famílias nas aldeias, ao menos, nos períodos de limpeza da área para plantação das sementes e na colheita (ver também Ladeira $2007[1992])$.
} 


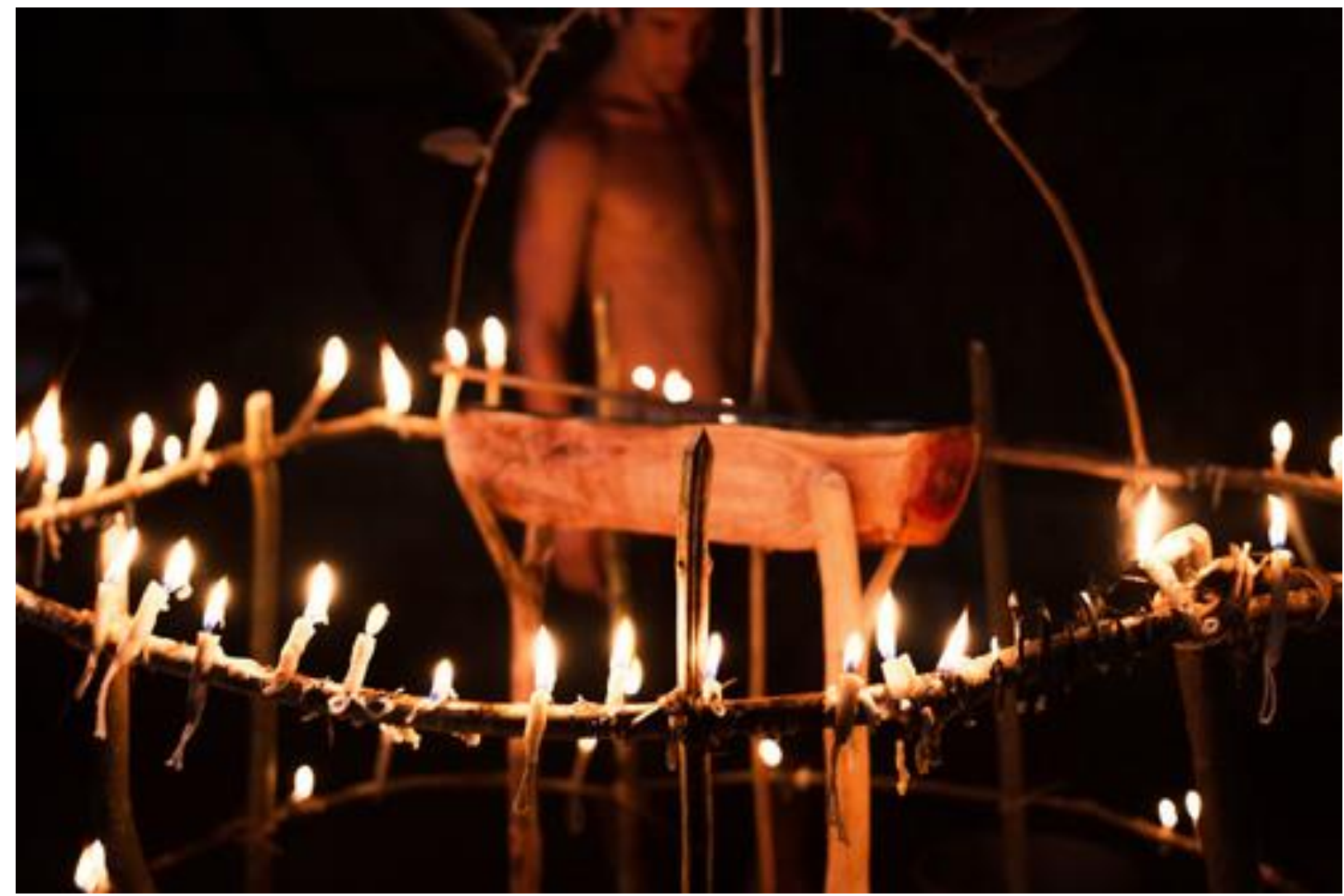

Yykarai. Luiza Calagian. T.I. Tenonde Porã, 2016.

Os xondaro, que estiveram meio apagados da literatura sobre os Guarani por estarem mais relacionados ao domínio da guerra, surgem, mais fortemente, nesse contexto atual de luta pela demarcação e visibilidade da cultura e tradição guarani. Macedo (2010) observa que, a partir da década de 1980 se formam "grupos de xondaro" em algumas aldeias guarani no Estado de SP. Tais grupos buscam o fortalecimento espiritual e físico, através das danças e desafios de destreza cotidianos, tanto dentro da opy, como no terreiro que fica em frente a ela, oka. No Tekoa Tenonde Porã, quando o grupo de xondaro ainda não estava tão organizado e forte como atualmente, eram os “jovens rapazes” que auxiliavam e estavam sempre junto ao cacique, seja para receber ou conversar com os jurua, assim como para receber os parentes ou simplesmente para "agilizar as coisas", como me contaram, no âmbito da comunidade. Nos dias atuais, os xondaro, segundo Timoteo Popygua, teriam que ter "preparação espiritual e física” para participar da discussão política, tanto dentro como fora da aldeia, assim como para incentivar outros jovens a participarem da luta pela conquista de direitos dentro do âmbito jurídico jurua. E como são também considerados “mensageiros" (tembiguai), os xondaro levam mensagens para outras aldeias, para os núcleos, para os xeramoĩ e xejaryi, para os jovens, assessorando tanto@ cacique, como os “os mais velhos”, que podem (ou não) coincidir, assim como a figura do chefe dos xondaro (xondaro ruvixa). 
E se "antigamente" se preparavam para caçar e proteger as comunidades contraataques jurua e também de outros indígenas, além de tomar a frente na interlocução com essas potências de fora do coletivo, cada vez mais eles devem "se formar" para aprender manejar o código institucional jurua, acompanhando tanto as discussões que dizem respeito ao coletivo e que ocorrem também na esfera do município, do Estado, da Federação, se envolvendo, em alguns casos, com outras organizações indígenas e também com apoiadores jurua. Como xondaro e xondaria kuery, "guardiões da comunidade", tais jovens lideranças carregariam um pouco do "espírito de guerreiro", segundo meus interlocutores, indo à luta em busca de benefícios coletivos, devendo estar preparados-concentrados corporalmente e espiritualmente para lidar com jurua kuery (potência muito perigosa e constantemente evitada) e, portanto, sendo fortalecidos e treinados continuamente para suportar o peso nocivo dessa relação:

importando menos pelos resultados e indicadores do que pelas configurações relacionais que engendram, tanto em distinções internas (entre indivíduos e grupos guarani) como no manejo entre descontinuidade e proximidade (incluindo várias ordens de troca) com os jurua. (Macedo 2012a: 21)

O termo - que também é uma relação, como as outras disposições aqui mobilizadas - xondaro e xondaria compreende diversas possibilidades de ação cosmopolítica dentro de um coletivo: há, por exemplo, os xondaro que atuam tanto dentro, na porta da opy como fora daí. São chamados assim também, incluindo dessa vez as xondaria, aqueles que dançam e cantam e, por vezes também auxiliam, no interior da opy acompanhando @ oporaiva (“aquele[a] que canta”) e @ opita’i va'e (“aquele[a] que fuma)". No caso masculino, amplamente discutido pela literatura recente, chamam assim ao xondaro opyregua, auxiliar d@ xamã em rituais, em contraposição ao xondaro vai ${ }^{12}$, capacitado para lidar com os conflitos que dizem respeito a contextos relacionais mais agressivos com subjetividades humanas e não-humanas confinadas a esta terra. Por isso, aqui, pensamos essas funções, que preferimos chamar de disposições cosmopolíticas relacionais, como xeramoĩ, xejaryi, tekoaruvixa, xondaro ruvixa, xondaria ruvixa, xondaro e xondaria mais como relações que como meros substantivos, uma vez que interpenetram-se e muitos podem circular amplamente entre essas disposi(a)ções: os xeramoĩ e as xejaryi podem ser também entendidos como os xondaro e as xondaria de Nhanderu e Nhandexy kuery, assim como os xondaro e xondaria destes seres divinos são como seus auxiliares-guardiães aqui na terra;

${ }^{212} \mathrm{O}$ qualificativo vai é usado geralmente para qualificar algo negativo ou ruim. Nesse sentido, o termo seria usado, não em depreciação aos xondaro, mas para qualificar os tipos de conflitos que eles eram preparados para enfrentar (ver Testa 2014). 
assim como aqueles que seguem o casal-xamã são seus xondaro e xondaria no plano terrestre, e dançam-cantam como os xondaro e xondaria celestes, todos juntos atuando como guardiões de yryrupa.

Nesse sentido, a atuação de coletivos de xondaro e xondaria kuery (auxiliares-guerreir@s-guardi@es), enquanto jovens homens (kunumigue) e jovens mulheres (kunhãtaĩgue) que cada vez mais se colocam e são reconhecidas como lideranças da comunidade, potencializam as capacidades-poderes daqueles(as) que se colocam à frente de um coletivo (tenondegua kuery), seja no âmbito da família nuclear, seja no âmbito da comunidade mais ampla. É importante ressaltar ainda o quanto a relação com o mundo jurua, principalmente no contexto atual, e suas possibilidades de obtenção de prestígio ${ }^{213}$ no âmbito da "comunidade" faz aparecer o protagonismo dessas jovens lideranças e, principalmente e cada vez mais de jovens mulheres que, tendo melhorado o seu desempenho na língua portuguesa, são também em alguns casos professoras das novas gerações na instituição estatal escolar, criando assim algumas das condições necessárias para que venham a desenvolver disposições de liderança coletivas, para além do âmbito familiar nuclear. São, portanto, estes coletivos de jovens que estão assumindo cada vez mais a "linha de frente" na interlocução e negociação com diversas instâncias jurua, mobilizando ações dentro da aldeia, dividindo os trabalhos entre si e promovendo o seu bem-estar coletivo, tarefa que nem de longe se mostra fácil ou tranquila. É possível pensar então em estilos (teko) diferentes de liderança, conduta e condução-orientação de ações cosmopolíticas, diferentes maneiras de influenciar e de convencer, de tomar a iniciativa em uma ação, liderá-la ou ser seguido por outras pessoas que acreditam-confiam (-jerovia) em suas capacidades-poderes, fazendo circular, de maneira controlada, saberes-poderes a partir das configurações relacionais em jogo e das atividades em pauta.

Essa diferenciação de disposições, capacidades-habilidades de atuação cosmopolítica corresponde a uma divisão de responsabilidades na organização e divisão do trabalho coletivo, principalmente no trato com os diversos planos de comunicação com a exterioridade, fazendo aparecer os atributos complementares de chefia e liderança de grupos. Ainda que o coletivo de lideranças tome a frente, muitas vezes, na interlocução com jurua kuery, sendo também considerados tenondegua em algumas movimentações, quem

\footnotetext{
${ }^{213}$ Como, por exemplo, tomar a frente em projetos de fortalecimento cultural, assim como fazer aparecer a comunidade para fora, nos discursos e atos públicos na cidade, como estratégia política recente na luta pela terra e por melhores condições de vida nas aldeias, ganhando o respeito dos parentes e, portanto, prestígio, uma vez que é muito valorizado internamente o empenho dessas lideranças em trazer benefícios para a sua comunidade.
} 
está à frente é sempre um(a) uvixa tenondegua ${ }^{214}$ - liderança que está à frente das outras. Portanto,@s chefes(as)-cacique (tekoaruvixa), nhaneramoĩ e nhandejaryi-atuam à frente do coletivo (tenondegua kuery) e são seguidos em suas movimentações pelos xondaro e xondaria kuery, que seriam melhor preparados-fortalecidos corporalmente para a interlocução com os jurua kuery, potencializando assim sua força-potência. O que, por sua vez, nos leva a pensar essa figura d@s chefes e xamãs como “pessoas modelares”215, que carregariam em si um ideal de humanidade e moralidade e, por isso aparecem como aqueles que "seguem à frente" mostrando o caminho, ou ainda, enquanto figuras complementares empenham-se na constituição dos coletivos por meio da mobilização de certas relações de manejo da alteridade, atuando na construção desse mundo e da possibilidade de existência nele (ver Sztutman 2012b).

As lideranças atuais que atuam no âmbito comunitário podendo ser então pensadas enquanto figuras do movimento que orientam (e são orientadas, seja pelas divindades, seja por outr@s chefes(a) e-ou xamãs inspirad@s pelas belas-boas palavras divinas)e coordenam ações coletivas, centrais tanto nos deslocamentos físicos (pelo espaço-tempo) como nos relacionais, como uma atualização daquelas lideranças-xamãs de outrora. É nesse sentido que buscamos compreender os processos de mútua constituição entre chefia, liderança e coletividade, em que tais personagens desempenham sua capacidade maximizada - porque acentuada - de construção de alianças e de manter pessoas unidas e mobilizadas, promovendo sua magnificação. É curioso, como muito bem apontado por Testa (2014), que a palavra usada para "grandeza" de algo ou alguém seja traduzida como tuvixa, e a palavra usada para designar lideranças seja -uvixa. A palavra tuvixa, acrescida do prefixo causativo - mbo, é usada para descrever a ação de fazer algo ou alguém crescer (Testa, 2014: 213). Nesse sentido, -mbotuvixa significaria “fazer crescer, no caso de humanos, plantas e animais” (Ibidem: 126). Podemos então pensar a disposição de “mburuvich $a^{216}$ " (designação comum ao chefe de guerra entre os Guarani antigos) correspondendo a um "fazer-se ruxiva", a um fazer-se ou ser feit@ líder ou chefe(a), engendrando sujeitos e ações? Acreditamos que sim!

\footnotetext{
214. Podemos pensar então que, tod@ uvixa é um(a) tenondegua, mas o contrário não é verdadeiro, já que, por exemplo, alguém que possa estar conduzindo um projeto ou uma atividade coletiva dentro da aldeia também pode ser chamado de tenondegua de um processo específico, mas não necessariamente será considerado um(a) uvixa por todos.

${ }^{215}$ Que se aproximariam dos protótipos míticos, do modelo de "gente", de deus(a) podendo ser pensados também como fazedores - de parentes, coletivos, festas (ver Sztutman 2012b).

${ }^{216}$ Mboruvixa ou mburuvixa é uma designação correspondente a um "grande líder” (Dooley, 2006: 109).
} 


\section{Capítulo III. Modos de liderar e se movimentar: complementaridade e produção} de diferenciações cosmopolíticas

É necessário aceitar a ideia de que a negação não significa um nada, e de que, quando o espelho não nos devolve a nossa imagem, isso não prova que não haja nada que observar. (Clastres, P. 2003 [1974]: 35)

Enquanto os homens exercem Seus podres poderes Índios e padres e bichas Negros e mulheres E adolescentes

Fazem o carnaval [...] Eu quero aproximar o meu cantar vagabundo Daqueles que velam pela alegria do mundo Indo mais fundo

Tins e bens e tais

(Podres Poderes. Veloso, Caetano. 1984)

\section{Movimentação relacional generalizada entre mundos: parentesco e (re)produção de diferenciações nesta terra}

O casal Clastres (P. Clastres 2003 [1974] e H. Clastres 1978 [1975]) ao descrever as figuras dos profetas e karai históricos e os xamãs do século XX faz aparecer a tensão entre as forças centrípetas e centrífugas que operam na socialidade Mbya: a figura do chefe guerreiro que se utiliza de sua capacidade centrípeta de coordenar membros em uma expedição guerreira por meio de alianças e que, no entanto, possui caráter de poder provisório pois ao fim da expedição é destituído de poder político efetivo, que retorna ao coletivo; a figura do xamã-profeta atuando como força centrífuga que subverte a unificação a uma ordem centralizada, levando multidões a buscar uma outra terra (sem mal e imperecível), ainda que possa se converter também em uma força centrípeta (quando acumula a chefia do grupo). Este é um belo exemplo de disjunção histórica entre os papéis do chefe guerreiro e do xamã profeta atuando na mediação de relações políticas de ordens diferentes, ampliando a noção mesma de política tal qual os (jamais) modernos a percebem, para a de cosmopolítica (em que entra em jogo todo um leque de sujeitos humanos, nãohumanos, sobre-humanos, etc., pensados aqui a partir do ponto de vista Mbya). Seria possível perceber nessa diferenciação do trabalho, atuação ou disposição cosmopolítica a recusa Guarani em totalizar numa única figura centralizadora suas ações cosmopolíticas?

É fundamental atentar também para a cosmologia guarani quando buscamos entender suas disposições cosmopolíticas organizacionais. Daí a possível disjunção "atual" entre as disposições políticas e espirituais em comparação com uma forma "tradicional", que operaria a convergência destas ações numa só figura, a d@ profeta-chefe-xamã, ou 
da liderança política-espiritual (ainda que, como vimos em campo, a figura do cacique enquanto xeramoĩ principal de um tekoa continue produzindo muitas outras disposições e ações eficazes e fundamentais para a manutenção e reprodução do coletivo). Podemos observar também, nas etnografias que tratam de reflexões míticas, que o panteão de divindades mbya é caracterizado em seus discursos xamânicos por diferenciações que operam em diversos níveis, por exemplo, discutindo entre si como irão dividir ou desdobrar (-mbojera: criar, gerar) o trabalho, tanto na criação desta terra como dos novos seres humanos, e no envio posterior dos nhe'ê kuery (ver, neste sentido, Cadogan 1959, Ladeira 2007 [1992], Testa 2014, Ramo 2014). Levando a sério as explicações atuais dos Guarani acerca destas divisões de trabalho, podemos perceber que as divindades continuam se dividindo - ou se desdobrando - no envio de palavras-nomes e na criação de seres com distintos saberes-poderes. E mesmo aos deuses não se impõe uma totalização acabada ou mesmo fixa, e que mesmo entre eles há uma caracterização diferencial por gênero, existindo tanto pais como mães dos nhe'ê kuery.

Por isso, nos atentaremos para algumas dessas comparações que os próprios Guarani fazem, atualmente, na descrição d@s xamãs e lideranças políticas e-ou espirituais, antigas e atuais, a partir das quais podemos observar que segue ainda operando essa dimensão mesma da divisão de trabalhos, atuações e responsabilidades, e na qual aparece também a distribuição das relações e das colaborações entre os gêneros. Por exemplo, lideranças atuando no âmbito comunitário, na representação política externa ou no interaldeias, teriam como atribuição diferentes tipos de relações com os "brancos" e suas instituições, enquanto@s xamãs estariam envolvid@s, sobretudo, em relações com os sujeitos divinos e outros seres não-humanos (os famosos "donos" e as criaturas e domínios sob seus cuidados). No entanto, mesmo no caso de lideranças espirituais que evitam se encarregar mais diretamente da liderança política de um coletivo, seu trabalho envolve, necessariamente, a administração de relações de ordem cosmopolítica, seja entre humanos de um mesmo coletivo ou entre coletivos diferentes, ou mesmo entre estes e outros coletivos não-humanos ou sobrehumanos (Testa, 2014: 207). A liderança - política e espiritual - envolve então diferentes maneiras de se fazer ou lidar com a política. Ambas necessitam da confiança e do prestígio coletivo para poder agir e ser eficaz, e demandam a incorporação contínua, mas controlada de potências exteriores, a partir de uma mobilização e administração eficaz dessas relações com o exterior, para seremconsideradas aptas a atuar na produção-proteção de um coletivo de parentes. São, portanto, figuras diferenciadas e, por isso mesmo, complementares. A cosmopolítica guarani envolve assim 
tanto a negociação com os planos mais "terrenos", como com os planos mais "celestes", ambos conectados pelo xamanismo, que é a própria diplomacia cosmopolítica mbya.

Adriana Testa lembra de um xamã da T.I. Ribeirão Silveira (SP) que, ao comparar as lideranças espirituais antigas e atuais comenta que os antigos obtinham mais eficácia e prestígio justamente pelo modo como distribuíam o trabalho político e espiritual entre os parentes (-retarã kuery), de forma que@s xamãs pudessem se concentrar mais em orientar as ações daqueles que cuidam e protegem (Informação pessoal). É exatamente assim que os meus interlocutores do Tekoa Tenonde Porã me explicaram sobre a divisão do trabalho na gestão e produção das relações da comunidade (ver Capítulo II). Este mesmo xamoĩ, segundo a antropóloga, conta que o xamã principal teria um ou mais assistentes aprendizes e algumas mulheres-xamãs, que seriam também suas esposas e que dividiriam o trabalho entre si (ver Testa 2014). Havia também as figuras dos xondaro, que também se diferenciavam entre si, havia aqueles que atuavam nos rituais dentro da opy e os que cuidavam de trabalhos na aldeia e nas "redondezas", atuando principalmente naquelas atividades ligadas à produção (caça, coleta, cultivo, construção de casas, etc.), e também no cuidado dos problemas políticos entre os diferentes núcleos familiares, seja no âmbito da própria aldeia, no entre aldeias, ou mesmo entre a aldeia e outros coletivos indígenas ou não-indígenas. Dessa maneira, ao descrever o que define como xamãs e lideranças políticas "tradicionais" em comparação com às "atuais", esse xamoĩ acaba por remeter ao modo como os "antigos" também produziam diferenciações, isto é, os modos como distribuíam os trabalhos e responsabilidades produziam diferentes atuações na gestão de um coletivo e, por conseguinte, causavam ações eficazes.

Podemos perceber então que as possíveis "novidades" que as configurações atuais de exercício da chefia e da liderança entre os Guarani-Mbya apresentam em relação às formas compreendidas por eles como "tradicionais", fazem aparecer então uma estrutura e suas possíveis transformações. A partir disso, é possível perguntar: até que ponto as relações atuais dos Mbya com os jurua kuery e os modos de organização política que decorrem dessas (e outras) relações podem ser comparadas ao que se conta, por exemplo, na própria mitologia guarani ${ }^{217}$ ? Nas etnografias que colocam os Guarani em diálogo com povos amazônicos, por exemplo, as relações entre sujeitos e coletivos divinos e não-

\footnotetext{
${ }^{217}$ É importante pensar também as abundantes narrativas míticas mbya em que não-indígenas, como por exemplo, Jesus Cristo (Tupã ra'y, literalmente “filho de Tupã”), figuram como personagens centrais (ver Pierri 2013a e 2014, Testa 2014, Ramo 2014). Na versão guarani do mito da má-escolha, por exemplo, temos uma inversão em relação às versões de vários outros povos, pois são os Guarani que operam a boa escolha em detrimento dos não-indígenas (ver Ladeira 2007 [1992]: 161). Ou seja, os jurua aparecem na mitologia em termos que operam dentro de uma matriz relacional que inclui os Guarani, os deuses e outros seres considerados não-humanos (do ponto de vista Mbya).
} 
humanos são problemas recorrentes. Frequentemente, essas relações são interpretadas pelo idioma do parentesco ${ }^{218}$ para então expressar a diplomacia cosmopolítica da proteção e predação própria a essas paisagens. Não iremos aqui discutir os modelos e casos etnográficos específicos, mas vamos apontar para algumas reflexões sobre alguns aspectos das relações que os Guarani desenvolvem com os deuses e os donos-espíritos nãohumanos, para ver como seu rendimento pode nos ajudar a pensar as relações entre os Mbya e os agentes jurua.

Em relação a alguns dos modos como os deuses aparecem no âmbito do parentesco, podemos observar que, na maioria dos casos, os Guarani se referem às divindades como Nhanderu kuery ("Nossos pais") e Nhandexy kuery ("Nossas mães”). Por outro lado, em relatos sobre os processos de produção da pessoa e em descrições de atividades de caça, coleta e cultivo, o problema da relação com os espíritos-donos-guardiões (-ja kuery) de domínios, criaturas e humores terrestres se coloca o tempo todo e expressa a necessidade de se evitar formas de proximidade excessiva com o exterior, controlando-as de modo efetivo com vistas a produzir uma relação de respeito (-nhemboete $\left.{ }^{219}\right)$ entre eles, já que essas atividades dependem da boa mediação das relações sociais com esses seres espirituais (tanto terrestres, como celestes). Assim, vários tipos de contato com esses sujeitos, por exemplo, seja por atos de comunicação, pelo fluxo descontrolado de substâncias corpóreas, por meio da comensalidade ou mesmo de relações sexuais podem resultar numa relação da ordem da predação. Na pior das hipóteses, um(a) Guarani se torna afim

\footnotetext{
${ }^{218} \mathrm{Em}$ termos de parentesco, poderíamos, num primeiro momento, pensar que esta seria uma esfera menos permeável aos jurua, uma vez que os Mbya evitam e proíbem casamentos com não-indígenas, principalmente com os brancos, o que não significa, no entanto, que isso deixe de ocorrer. Os casamentos com jurua e os filhos que surgem dessas relações - apesar de serem uma espécie de tabu-, é um tema constante nas falas Guarani e fenômenos recorrentes em todas as aldeias, mas geralmente não aparecem com a mesma frequência nas redes de parentesco descritas pelas pesquisas etnográficas.

${ }^{219}$ Em caso de -jepota, segundo Macedo, a palavra -nhemboete pode remeter à interação de corpos dissemelhantes em que está em jogo assegurar a própria perspectiva e, cuja tradução de um de seus interlocutores, seria algo como "impor respeito" ou "tomar forma de humano" (Macedo, 2013: 203). De acordo com Testa, na língua mbya, principalmente, em contextos rituais, "é recorrente o uso dos termos -mboete (fazer verdade/verdadeiro; fazer confiar; fazer respeitar) e -mbojerovia (fazer acreditar, fazer confiar)", em que "se reconhece a veracidade/eficácia dos saberes e capacidades de alguém e, portanto, se desenvolve uma relação de confiança com ele", como por exemplo no uso da expressão "nhambojerovia nhaneramoĩ kuery rẻ (confiamos nos nossos avós/rezadores)" (Testa, 2014: 174-5). Dooley traduz -mbojerovia como "mostrar respeito a (alguém) ou "cultuar", termo este que deriva de -jerovia (confiar) (Dooley, 2006: 109). Pierri traduz a palavra onhemboete como o ato pelo qual "Nhanderu Tenonde Papa mostra sua verdadeira aparência [...] privadamente para a sua amante humana, depois de vê-la chorar", tradução esta que parece articular esses dois sentidos do verbo -mboete (Pierri, 2013a: 61-62). O termo "ñemboete", segundo Cadogan, tem como significado "proveerse de cuerpo, encarnarse, asumir la forma humana" (Cadogan, 1992: 129). Dooley traduz o verbo -mboete como "formar o corpo (de alguém): nhanderyru'i py ma voi Nhanderuete nhanemboete'i va'ekue Deus formou nossos corpos quando ainda estávamos no ventre materno" ou como "ressuscitar", sendo -nhemboete traduzido por "ressuscitar-se" (Dooley, 2006: 40). Outro significado para -mboete pode ser "comportar-se com respeito na presença de alguém; honrar, respeitar" e -nhemboete "ficar sério, grave" (Ibidem: 41).
} 
de um sujeito outro, saindo, assim, das redes de parentesco humanas (Mbya), passando não apenas a produzir parentes não-humanos confinados à esta esfera terrestre (tekoaxy), como se colocando na posição de predador dos próprios parentes humanos-guarani.

A alimentação, aspecto chave na produção de parentes, assim como o cultivo, a caça e a coleta dependem, portanto, das boas relações que se estabelece com os deuses e donos-espíritos não-humanos, e que se dá por meio de transações que podem ser mais pacíficas ou mais predatórias a depender do contexto. Estamos diante então de uma matriz relacional em que a predação, afinidade e proteção-produção do parentesco são aspectos de um mesmo plano cosmopolítico. Com isso em mente, uma das questões que se coloca é: qual o lugar da relação dos Guarani com os jurua kuery nesse modelo? Como tal relação afeta a conexão entre política e parentesco, tomando como objeto de análise as configurações atuais de liderança política e espiritual? Testa (2014) comenta, por exemplo, que um cacique-xamoĩ de uma aldeia no RJ, com mais de cem anos de idade, estava contando para uma liderança mais jovem sobre os diferentes tipos de transformação aos quais os Mbya estão sujeitos desde a criação inicial deste leito terrestre (dada a instabilidade crônica dos corpos ${ }^{220}$ e das relações, como logo veremos). Após descrever os processos de transformação decorrentes das relações de proximidade excessiva com sujeitos não-humanos, o cacique-xamoĩ explicou que, após criar esta terra, a divindade Nhamandu foi embora dizendo aos Mbya: "Eu vou deixar vocês, agora fiquem, já fiz a terra toda. Agora eu vou, vou embora novamente. Agora vocês vão se misturar com os não indígenas, e alguns de vocês, ao se misturarem com eles, não vão mais alcançar o lugar de onde vieram" (Testa, 2014: 61). Parece que, por meio desse exemplo, se levarmos a sério a ideia de que a cosmopolítica está relacionada à produção-proteção de pessoas e parentes, as relações com os jurua, assim como as relações com sujeitos não-humanos provocam transformações que afetam a inserção dos Guarani nessas redes de relações de parentesco (que os ligam uns aos outros e aos seus parentes celestes). Daí que as relações que se estabelecem com os jurua e os seres confinados a esta terra (não-humanos, porque nãoMbya), são comparáveis, pois afetam mais ou menos diretamente a produção-proteção do parentesco-humanidade Guarani ${ }^{221}$.

\footnotetext{
220 Vilaça, partindo das proposições Wari' relativas a corporalidade ressalta o seu interesse pelo caráter eminentemente instável e transformacional dos corpos (Vilaça, 2005: 445).

${ }^{221}$ Segundo os Guarani, a tradução de Mbya por "gente" refere-se à sua qualidade de humanidade, no sentido da coletividade deste grupo (ver Ladeira 2000). Nesse sentido, a categoria analítica etnológica de "não-humanos", aparece aqui em contraposição aos Guarani, isto é, à sua humanidade, ou ainda como criaturas confinadas a esta terra, enquanto os Guarani seriam quase deuses (seus nhe'ẽ pertencem aos amba [morada] dos pais e mães divinos, revelando o seu parentesco com eles).
} 
Em outro exemplo, Testa conta de uma senhora xamã de uma aldeia no ES, neta da kunhã karai Maria Tataxĩ (que liderou o seu grupo em uma migração considerada central na fundação de várias aldeias mbya atuais), que explicou a ela que os deuses criaram uma série de alimentos para os Guarani e ensinaram o que deveriam comer, mas que, atualmente, eles comem "qualquer coisa" (entenda-se também os alimentos jurua) e, por isso, seus corpos (-ete) já seriam outros (Informação pessoal). Podemos pensar que essa afirmação reflete a ideia que o modelo de fabricação destes corpos já não seria como antes, devido principalmente à ingestão de alimentos de outras "gentes", no caso, dos não-indígenas. O que, por sua vez, não exclui a enunciação de toda uma ética da moderação (da boa medida) dentro da socialidade xamânica mbya, em os ensinamentos sobre o que comer e como se comportar seguem valendo e sendo considerados centrais na produção de parentes e na construção da pessoa guarani (ver também Macedo 2010). O que podemos entender a partir daí é que os modos de fabricação dos corpos e relações guarani em contextos de proximidade excessiva com os corpos e comportamentos jurua (jurua reko), são diretamente afetados. Apesar de viverem, em alguns contextos, mais distantes da mata (ka’aguy) e de seus donos-espíritos guardiões, e mais próximos da cidade (tetã), a alteridade jurua opera continuamente como desestabilizadora das relações entre parentes. No entanto, se os jurua kuery agenciam os Guarani, por serem eles os donos do papel, do dinheiro, das armas, e também por se acharem os verdadeiros donos das terras e dos recursos naturais ali presentes, os Guarani também têm agência nessas relações, uma vez que também tentam domesticar e cativar os jurua à sua própria maneira, muitas vezes através da própria potência e fascínio que suas palavras e ações político-espirituais podem despertar nesses corpos outros.

Estamos pensando aqui nas capacidades singulares dessas disposições de liderança, em sua interlocução diplomática com outras figuras cosmopolíticas, nesses sujeitos magnificados que são e mobilizam muitos, pois tornam essas relações eficazes para o bem-estar de um coletivo, pois contêm em si suas famílias, alianças e muitas outras relações, controlando-as de certo modo. Assim, se a pessoa, entre os ameríndios e outros povos não-ocidentais, é composta de redes de relações, seriam então estas redes que comporiam seu valor. $\mathrm{O}$ valor desses sujeitos está justamente em sua grande capacidade-habilidade de cativar-enredar pessoas e mediá-las para produzir-proteger um grupo. E, quanto maior o prestígio adquirido nestas movimentações, maior é a sua capacidade de magnificação. Geralmente, esta implica (ao menos no caso guarani) na própria disposição de um casal em constituir família-grande e multiplicar sua rede de relações, podendo vir 
a ser reconhecido como casal-chefe-xamã de parentela. No entanto, eles também dependem da relação de mediação eficaz que estabelecem com os seres divinos e espíritos-donos e outros seres terrestres e do que produzem a partir daí, fazendo crescer e durar um coletivo de parentes e agregados que, para tanto, também deve estar disposto a seguir a sua orientação, ou então, buscar outra alternativa.

Daí que, no caso mbya (e talvez em toda parte), tal magnificação seja tanto masculina como feminina, pois um(a) agente cosmopolític@ ao tornar-se capaz de conter muitos outr@s em si, pode influenciar e controlar suas ações e comportamentos, usando seu poder para cuidar-proteger um coletivo. O que pode causar um certo estranhamento numa perspectiva androcêntrica (profundamente enraizada em nossas análises e entendimentos), pois ainda que a liderança feminina sempre tenha existido no interior da família extensa entre os Guarani-Mbya, o que ocorre é que a literatura guaranióloga, mesmo, em alguns casos, reconhecendo a unidade política-econômica da família nuclear ou extensa (geralmente, sob a liderança de um casal-chefe com habilidades xamânicas mais desenvolvidas na proteção do grupo familiar), não dava tanta importância à orientação da liderança feminina - seja no ritual, seja ao nível das relações cotidianas entre parentes -, na descrição etnográfica ou mesmo na interlocução da pesquisa, o que, por sua vez, não quer dizer que os próprios Mbya não reconhecessem sua liderança ou orientação ou que não as valorizassem enquanto tal. Ressaltamos também que, entre os Guarani, assim como entre outros povos indígenas, ritual e cotidiano não se separam, não há uma ruptura. Essa conjunção entre cotidiano-ritual é importante pois é possível perceber aí, a produção das relações de gênero, parentesco e poder. Isso fica explícito no critério cosmológico de complementaridade do casal, que é a unidade capaz de guiar seu grupo de parentes até yoy apy ("extremidade do mundo, na beirada do oceano, onde é possível retornar ao infinito”) (Ladeira, 2007 [1992]: 93). Pissolato também afirma que "a figura do casal parece ocupar um lugar privilegiado, por ser o lugar por excelência da definição de habilidades distintas - generizadas -, que se põem em relação e se complementam na produção e reprodução da vida social” (Pissolato, 2012: 99). Daí a urgência em enunciar também a força das mulheres e suas capacidades-poderes (-po’aka) na gestão das relações cosmopolíticas cotidianas-rituais, principalmente no controle dos comportamentos guarani, a sua (dis)posição central na (re)produção, proteção e manutenção das relações corporais de parentesco-humanidade da socialidade xamânica mbya, que se reflete na produção de boas-belas-eficazes (porã) disposições, diferenciações e movimentações nas ações de diplomacia cosmopolítica guarani. 
Para nos aproximar mais do entendimento dessa filosofia cosmopolítica guarani, é mais do preciso aprender junto a eles como eles mesmos entendem as relações de poder e lidam com elas, isto é, como articulam as relações, jamais desconectadas entre saber(es), poder(es), parentesco, xamanismo, gênero, geração e reciprocidade. Nosso objetivo de fundo aqui é oferecer uma contribuição para um possível entendimento da teoria guarani da relação, isto é, da sua filosofia cosmopolítica de administração das relações entre corpos e domínios de ação visando a produção de saúde, alegria, leveza, força e a evitação de doenças e agressões, via idioma da proteção-predação entre parentes (humanos e divinos) e muitos outros seres (os jurua kuery inclusos) desse cosmos. Partindo de uma imagem-tradução propriamente guarani, na qual "movimentar-se" poderia ser compreendido como o próprio fazer(-se) polític@, tomamos a política aqui então enquanto um movimento relacional, em que muitos mundos e corpos se comunicam e negociam continuamente entre si, de modo a buscar amenizar potenciais agressões de seres confinados à esfera terrestre, como os jurua kuery e outros donos-espíritos (-ja kuery) e seus domíniosação que (co)habitam esta terra, visando proteger e manter a continuidade da perspectiva humana daqueles que vivem entre si, no caso, os Guarani-Mbya. O idioma da consubstancialização, como veremos, revela também potências e perigos na produção do parentesco e da humanidade, pois se insere nesse regime cosmopolítico de administração e controle de movimentos, relações e comunicações, o que implica também um regime específico de cuidados corporais e, principalmente, alimentares para a fabricação de corpos propriamente humanos, aptos e preparados para a inscrição de saberes-poderes, potentes e perigosos (que agem e afetam-se entre si), pois é por meio da corporificação destes, que se fortaleceria a necessária conexão entre corpo e nhe'ẽ.

A ideia aqui, portanto, é pensar as movimentações desempenhados pelos diversos sujeitos políticos guarani, correspondendo mais a disposições cosmopolíticas relacionaisdiferenciantes do que a funções ou (o)posições propriamente ditas ou mesmo fixas, a capacidades singulares de agir, fazer agir, afetar e ser afetado, contando com diferentes modalidades, estilos de liderança e áreas de atuação, influência e prestígio. Tais disposições diferenciais têm a ver com o caminho-trajetória iluminado pelos parentes divinos, da missão de cada pessoa aqui na terra, que também é traçado pela pessoa em sua relação com outros seres do cosmos, da experiência-comunicação estabelecida nesta terra (e para além dela) por cada um e das capacidades adquiridas a partir daí, pois os caminhos possibilitam relações e permitem acessar saberes e pessoas. O interesse então é compreender como tais disposições e modos de ação cosmopolítica se relacionam aos processos mbya 
de produção-proteção de pessoas e coletivos que têm como fim a continuidade e o fortalecimento (-mbaraete) da existência nesta terra, em que tudo se corrompe e perece, e se dá pela reprodução corporal do movimento-comportamento das divindades, especialmente, em suas práticas de relação de respeito-convivência em equilíbrio-tensão com outros seres, espaços, domínios e poderes que habitam e cuidam de uma mesma plataforma terrestre. Essa terra tekoaxy seria como uma imagem imperfeita da tão almejada “terra sem mal” (yvy marã e’y)), onde os seus corpos-palavras-espíritos (nhe'ẽ) não estariam mais sujeitos ao sofrimento e adoecimento (-axy), alcançando a imperecibilidade.

A produção do parentesco, ou seja, da própria humanidade guarani, é aqui pensada então como a fabricação de relações corporais que tem por finalidade mesmo fortalecer e produzir pessoas saudáveis, alegres e fortes, daí seu investimento no desenvolvimento de disposições e práticas de diplomacia xamânicas que passam pela fabricação de um corpo leve e ao mesmo tempo forte. O objetivo é aumentar o “despojamento" da porção "perecível” do corpo, justamente para não sucumbir aos "maus encontros" e durar nesta terra [tekoaxy] (Macedo, 2013: 190-1). Esta também é uma chave interessante pela qual podemos mapear os comportamentos e as especializações dos corpos em relação nesta terra, suas capacidades-poderes de ação e produção-proteção coletiva e, com isso, a produção, controle e manutenção de relações sociais neste mundo. Vê-se aí a importância de se pensar a construção da pessoa-parente e das diferenci(ações) de gênero a partir da fabricação de seus próprios corpos, para entender como se constroem as relações mesmas entre os Mbya. Por isso, propomos que, na teoria guarani da relação, o parentesco é também fabricado (assim como a pessoa e o corpo) e passa diretamente pela produção da conexão entre os corpos (-ete) e seus nomes-espíritos (nhe'ẽ) e não, necessariamente, por relações de consanguinidade, mas pela circulação e compartilhamento de substâncias, afetos, saberes-poderes e memórias, por meio das quais todos criam relações. A construção do corpo e da pessoa guarani é aqui então entendida como uma produção coletiva de relações de identidade corporal ${ }^{222}$ que visam o fortalecimento do corpo-espírito e do seu ponto de vista (humano), evitando, através de uma série de procedimentos de proteção xamânico-corporais, a transformação corporal em animal (-jepota), ou mesmo o trânsito desmedido deste corpo-espírito entre subjetividades outras, consideradas perigosas.

\footnotetext{
${ }^{222}$ Entre os Suyá, Seeger (1980) afirma que a formação de grupos se dá pela produção de laços de identidade corporal ou de relações corpóreas, construídas a partir do compartilhamento e circulação de substâncias entre os parentes, idioma central para organização da vida social, importante tanto para a construção da pessoa quanto para a tessitura das relações domésticas (ver também, nesse sentido, Viveiros de Castro 1979). Seria, portanto, por meio do processo de "assemelhamento corporal" que a fabricação do parentesco construiria o que é humano (Coelho de Souza, 2004: 43).
} 
O principal motor aqui, como entre outras socialidades ameríndias, é a produção e proteção de pessoas, o que se dá por meio da necessária inscrição no corpo de uma infinidade de relações com a alteridade, que não se circunscreve apenas a grupos humanos, mas inclui toda uma série de sujeitos e espíritos-donos outros, além das divindades, que cuidam de alimentos, plantas, animais e mesmo de humores. Há aí também o perigo eminente de adoecimentos e de "encantamentos" como o -jepota, que consiste na "captura do desejo e a mudança no habitus de um sujeito por ação de um dono extra-humano, quase sempre animal, mas podendo ser também de árvores (yoyra nhe'e) ou outros corpos-afetos" diminuindo a potência de agir da pessoa, que pode sucumbir às afecções desse outro, desconectando-se de seu nhe'ẽ (Macedo, 2013: 186). O importante é aprender a direcionar essa exterioridade para o vetor da humanidade ou da divindade e não para o da animalidade, isto é, para o vetor da convivência e de proteção entre humanos-parentes-deuses, mantendo sob controle o vetor da agressão-predação dos (não)parentes.

É nesse sentido que, de acordo com Pissolato (2007), o grande desafio da pessoa guarani seria fazer com que o nhe'ẽ se acostume no corpo, através da busca constante de modos de fortalecimento e de satisfação da existência nesta terra ruim (yvy vai $\left.{ }^{223}\right)$. Por isso, é mais do preciso para os Guarani, seguir se fortalecendo espiritualmente-corporalmente para estar preparado e concentrado (-japyxaka) para a continuidade da luta pela demarcação de suas terras, pela recuperação de parte de sua territorialidade (práticascaminhos) - que se opõe radicalmente, em seu modo de ser-agir-viver-pensar (nhandereko), à noção jurua de território (espaço-propriedade privado) -, fazendo a vida nesta terra em que tudo se corrompe, adoece e perece, durar mais e ser menos difícil e dolorosa.

\section{De encontros e desencontros cosmopolíticos: o perigo-potência da transformação}

Através da fabricação de corpos humanos específicos, constituídos por e pelas relações, pessoas, coletivos e coisas são construídas. Em uma cartografia dos corposafetos guarani, Macedo e Sztutman (2014) ressaltam o quanto esse universo conceitual se preocupa mais com a ideia de imanência e de movimento ou multiplicidade do que com uma transcendência, demonstrando como aí a individuação e a divinização são processos que ocorrem paralelamente. Baseando-se em uma fala guarani que discorre sobre "a parte de que cada um é parte” e remete ao nome próprio de cada pessoa aqui na terra, isto é, a

${ }^{223}$ Esta é uma dentre as várias acepções conceituais do termo vai que, além de "ruim", "mau", "feio", também pode denotar, atitudes marcadas pelo "excesso" ou agressividade", o avesso do ideal entre parentes. 
relação com o domínio celeste a que seu nhe'ẽ está vinculado e a anima com sua respectiva potência de agência nesse mundo, os autores compreendem a nomeação, entre os Guarani, como "parte de um assentamento de forças" em que:

a sucessão de engendramentos de divindades presente na cosmogonia mbya e atualizada na produção de pessoas nesta terra pode ser lida como individuações de um fundo de multiplicidade, ou modulações de forças que conectam e diferenciam, fazendo e desfazendo corpos. (Macedo e Sztutman, 2014: 288-9)

Esses antropólogos ressaltam a centralidade que os deuses ocupam na composição da pessoa, o que se manifesta por meio de um idioma da filiação que é acionado nas relações entre deuses e humanos, mas que estaria menos associada à consanguinidade no sentido genealógico do termo, que a uma intensidade ou um devir-deus (Ibidem: 295). Sem essa ideia de devir, que transversaliza o cosmos, não haveria como constituir a pessoa guarani, pois a sua individuação já pressupõe a sua divinização (Ibidem: 299). Nesse sentido, até mesmo elementos considerados imateriais (para o mundo ocidental) como, por exemplo, os nomes, podem ser pensados como constituintes da pessoa e do parentesco enquanto relação corporal (Coelho de Souza, 2004: 29). O papel do pai (-ru) e da mãe (-xy) na concepção de uma criança ${ }^{224}$ mbya, os aproximaria dos Nhanderu e Nhandexy ete kuery:

com a diferença fundamental de que aos pais humanos cabe a concepção da criança por meio da conjunção e troca de substâncias através de atos sexuais, assim como seu bom desenvolvimento durante e após a gestação, por meio da observação de resguardos, enquanto aos verdadeiros pais divinos é atribuída a existência dessa pessoa, por meio do envio de seu -nhe'ẽ (princípio vital), cuja origem e identidade (nome) serão revelados quando este -nhe'ẽ estiver mais seguramente ligado a um corpo devidamente produzido pelos parentes humanos da criança. (Testa, 2014: 123)

Entretanto, segundo Testa (2014), os "pais humanos" teriam um investimento maior na produção dos corpos dos filhos, enquanto os "pais divinos" estariam mais ocupados em gerar os seus princípios vitais. Essas partes da pessoa mbya se desenvolveriam continuamente, contando tanto com contribuições dos parentes terrestres, como dos celestes. O processo de fabricação do corpo humano, que envolve uma série de cuidados e medidas de proteção, também aproximaria o papel dos pais humanos ao dos “donos” 225

\footnotetext{
224. Todas as crianças têm nhe ẽ porã ("espírito bom-belo”) e, seria por isso que, segundo os Mbya, enquanto continuar nascendo crianças, Nhanderu não irá acabar com o mundo (ver Ramo 2014). P. Clastres, baseando-se em uma narrativa recolhida por Cadogan (1959), cita as palavras divinas, feitas circular por um karai mbya, em que se comenta que a vinda de um novo espírito para a terra "é para que possam possuir bela grandeza de coração", uma vez que "gerar uma criança é uma das condições de acesso ao estado de aguyje, de totalidade acabada, pois é dispor de um espaço - o corpo que vai crescer - apto a receber uma pequena parte da substância divina, uma Bela Palavra, uma alma. As crianças constituem, assim, uma mediação entre os adultos e os deuses" (Clastres, P. 1990 [1974]: 112). Ver também, Cadogan (1959). 225 A tradução do termo -ja como "dono" é recorrente na literatura e frequentemente utilizada pelos próprios Mbya, mas segundo Testa, não é completamente satisfatória uma vez que "o que é central para o entendimento desta categoria não é uma relação de posse, mas as relações de cuidado e controle que os -
} 
não-humanos (ija kuery), segundo a antropóloga, ainda que ela nunca tenha ouvido os Mbya se referirem aos pais de uma criança como seus “donos”. Essa comparação se faz possível, uma vez que, de acordo com os relatos guarani, os ija kuery "não são os 'inventores' ou criadores originais desses seres, mas assumem a responsabilidade de cuidar e controlar seu desenvolvimento", restringindo o acesso que outros sujeitos possam ter a eles (Ibidem: 124). Essa disposição fica clara na fala de um dos interlocutores de Testa:

Tudo que tem nesse mundo, em todo lugar, tem um dono, esses seres que cuidam de cada coisinha [...] Eles não são os Nhanderu kuery (divindades criadoras). Eles são invenção, quer dizer, eles também foram criados por Nhanderu. Eles são criação dele pra cuidar de cada coisinha e cada lugar [.... Então, tudo que tem nos rios, todas as árvores, cada florzinha, tudo tem dono. Eles que fazem cada coisa crescer e cuidam. Eles colocam lá pra gente ver e achar bonito, mas não pode mexer, não pode arrancar, porque ele protege, então, ele fica bravo. Quer dizer, pode, mas primeiro tem que pedir. (Vera Popygua apud Testa, 2014: 109, grifos meus)

A respeito da relação de maestria-domínio ${ }^{226}$, Fausto destaca que um dos traços “importantes da relação é a assimetria: os donos controlam e protegem suas criaturas, sendo responsáveis por seu bem-estar, reprodução, mobilidade. A assimetria implica não só controle, mas cuidado" (Fausto, 2008: 333, grifos meus). Tal relação entre os donosguardiões e as criaturas sob sua proteção, não deve ser entendida então como "posse", mas antes como uma "capacidade de cuidar" e, portanto, de controlar, de certo modo, essas criaturas, revelando assim uma certa assimetria de poder entre elas. Os ija kuery atuando, portanto, como espécies de guardiões-xondaro daqueles que se encontram sob sua proteção (Testa, 2014: 114-115). No caso Guarani, como viemos argumentando, o processo de individuação e fabricação da pessoa envolveria também a incorporação de capacidades outras além daquelas adquiridas nas relações com as divindades, como aquelas de animais, plantas, inimigos, entre tantas outras subjetividades importantes. O sujeito, correspondendo aqui, como em muitas outras paisagens, a uma configuração relacional que inclui outros agentes para além do nhe'ẽ porã ("alma-palavra”, "palavra-habitante", "linguagem-afeto”), como por exemplo, o agenciamento de espíritos-donos, responsáveis por diferentes estados de espírito ou mesmo de sentimentos melancólicos, afetos ou humores agressivos que os corpos-espíritos Guarani experimentam nesta terra, tais como poxyja

\footnotetext{
ja desenvolvem em relação às criaturas sob sua responsabilidade" (Testa, 2014: 108). Por isso, uma tradução mais adequada ao termo seria a de "guardiões" (de objetos, domínios, seres, sentimentos, etc.). ${ }^{226}$ A capacidade de unir, tomar conta pode remeter à noção de "dono" ou "mestre", assumindo muitas vezes o idioma da "filiação adotiva", como sugeriu Fausto (2001). Entre os ameríndios, alguém pode ser considerado "dono" de uma casa ou de um local, de uma festa, ritual, de certos objetos, domínios e-ou certas prerrogativas. Nesse sentido, a noção de maestria seria "uma noção cosmológica que inflete sobre o plano sociopolítico e indica uma capacidade de conter, apropriar-se, dispor de pessoas, de coisas, de propriedades; uma capacidade de constituir domínios, nichos, agrupamentos etc." (Sztutman, 2009b: 32, grifos meus). Maestria corresponde, portanto, antes a um domínio que à dominação (Sztutman, 2012a: 312).
} 
ou vaija ("dono da raiva", "dono da braveza"), takãte 'yja ("dono do ciúme”), taryreija ("dono do desejo sexual exacerbado", da "sacanagem”, "luxúria”), ate’ỹja (“dono da preguiça”), entre outros. Tais afecções, por possuírem "donos" têm origem fora da pessoa, são extrínsecos ao corpo e, por isso mesmo o afetam, o deixando vulnerável, e dizem respeito, sobretudo, aos efeitos de um olhar: "o que faz o mbya sentir raiva, ciúme ou ter preguiça (estar alegre ou triste também, mas em um sentido diferente) de acordo com esta teoria é o fato de 'ser olhado por' um dos donos destas afecções” (Ramo, 2014: 136-37).

Essas agressões seriam então operadas pelos seres invisíveis, por "aqueles que não vemos” (jaexa va'e’ỹ kuery) que, segundo Pierri (2013a), estão associados, de maneira geral, aos "donos" dos elementos terrestres (ija kuery), que cuidam tanto de alguns domínios espaciais, como de animais, vegetais ou mesmo de comportamentos, atitudes, temperamentos e humores, assim como dos espectros patogênicos dos mortos, conhecidos por -mbogua ou ãgue, que têm como "dono", Xariã ou Anhã, personagens ${ }^{227}$ considerados inimigos dos heróis míticos e relacionados ao exagero, à raiva e agressividade, à predação e às doenças. Por isso, sentimentos como o "ciúme" (-akãte'ỹ) e a "raiva” (-poxy) são veementemente repelidos entre os Mbya, pois geram comportamentos, estados excessivos e descontrole, que são, por isso mesmo, passíveis de crítica e relacionados à "noção de corpo pesado, quente/akû" (Prates, 2013: 181). Há aqui, uma forte relação entre estados afetivos, corpo e transformação, daí a importância de se proteger os sentidos, sobretudo a audição e a visão. Esses -ja das emoções exercem uma constante tentativa de enfraquecer o "pensamento" mbya, causando neles "estados afetivos que favoreçam a preponderância de uma outra perspectiva de mundo" que não a do sujeito que se encontra enfraquecido ou vulnerável (Ibidem: 195).

Além dos donos das emoções, os corpos podem sofrer efeitos do potencial patogênico de donos de diferentes domínios espaciais desta terra como, por exemplo, os

\footnotetext{
${ }^{227}$ Em contraste a um recém-nascido, que é só nhe'ẽ, o morto é só corpo, "ou melhor, aquilo que foi a sombra do seu corpo (ãgue) ( $\tilde{a}$ - sombra do corpo + gue - sufixo nasalado que indica condição pretérita)" (Testa, 2014: 253). Xariã seria o “adversário mítico de Deus” (Dooley, 2006: 194). Já “anha” é traduzido com um "espírito mau, diabo: anha kuery os demônios" (Ibidem: 12). O termo -mbogua além de poder ser traduzido como "esquivar-se: tembiporu nhamboguapa nhama'ẽ atã vy esquivamos da arma por olhar atentamente", pode significar também "passar na peneira” ou “deixar cair" (Ibidem: 108). Cadogan, no entanto, traduz mbogua por "espiritu temido en el que se convierte el 'alma telúrica' al morir el ser humano, llamado ãngue en diversas lenguas guaraníes” (Cadogan, 1992: 110). Os anhã, de acordo com Macedo, seriam os "espíritos patogênicos", a "agência maléfica (vaikue)", sendo associados também "ao demônio do repertório cristão” (Macedo, 2010: 141; 242). Ramo comenta que alguns Guarani dizem que Anhã seria o próprio "Xariã, o irmão mais velho de Nhanderu Pa-Pa, outros, como o pessoal de Araponga, dizem que não. Em qualquer caso, ele forma com Nhanderu um par ao estilo dos 'gêmeos dessemelhantes', atuando sempre de forma oposta à de Nhanderu. Assim, se o primeiro determinou que o mborayu (reciprocidade, amor) fosse o princípio que deve reger todas as relações, Anhã é aquele que promove o mboxyja, ou seja, tudo aquilo que tem a ver com a doença e a raiva" (Ramo, 2014: 37, grifos meus).
} 
ka'aguyja ("donos da mata”), yakãja ("donos das nascentes dos rios"), itaja ("donos das pedras"), entre outros (Macedo e Sztutman, 2014: 301). Se apropriar desses outros corpos para incorporar suas afecções, seja através da alimentação ou mesmo pela manipulação de substâncias ou confecção de adornos ${ }^{228}$ pode vir a despertar a ira desses seres "que regem a subjetividade associada ao corpo utilizado", implicando uma constante negociação com eles (Pierri, 2013a: 198). A maioria desses espíritos-donos são tidos como "inimigos" ou "contrários" (-ovaigua ${ }^{29}$ ) dos Guarani, pois alguns deles "têm um temperamento particularmente agressivo" (Ibidem: 199). E, por conta de sua "composição corporal, que é distinta da dos brancos, os Guarani são muito mais suscetíveis a esses infortúnios” (Ibidem: 156, grifos meus). Segundo Pierri (2013a), a condição tekoaxy tem relação estreita com o conceito de mba'eaxy, que remete a doenças ${ }^{230}$ e infortúnios, especialmente quando se tratam daquelas derivadas de agressões invisíveis. Quem saberia lidar melhor com esses espíritos-donos-guardiões seriam @s xamãs, que por sua experiência de vida e comunicação privilegiada com as divindades, conhecem e adquiriram suficientes capacidades-poderes de atenuar e desviar os efeitos de interação com esses seres invisíveis, negociando constantemente com esses sujeitos o cessar das agressões.

Daí que o estado de "maturação corporal” do qual depende o devir-deus(a) (ijaguyje), imanente a toda pessoa guarani, seja intensamente perseguido por eles por meio da imitação do comportamento dos deuses, uma vez que para este povo, seus corpos são como “imagens dos corpos das divindades" (Ibidem: 41-45). Os Mbya contam que as

228 Dentro dessa "lógica da predação de potencialidades vitais, em que os Mbyá capturam qualidades de Outros para comporem a si mesmos, as crianças recebem especial atenção na constituição de seus corpos” (Prates, 2013: 146). Entre alguns exemplos citados por Prates, temos: "pequenos caramujos pendurados em colares de bebês pequenos: são trazidos para os corpos pela qualidade de não urinarem; já os ossos da ave saracura são utilizados no feitio de tornozeleiras a fim de garantir que as crianças adquiram a graça e a leveza para caminharem como esse animal" (Idem). O nome dessa ave saracura em mbya, de acordo com Dooley é araku (Dooley, 2006: 18). É interessante notar que o termo -arakua é uma variante de arakuaa que significa "comportar-se corretamente" (Idem). Esse termo acrescido de causativo, mboarakuaa, é traduzido como "disciplinar para comportar-se corretamente" (Idem). Testa comenta também que desde a infância os pais das crianças, assim como os avós e parentes próximos, se preocupam em "tomar medidas para que não se tornem pessoas preguiçosas (-ate’ $\tilde{y} v a$ ' $e$ - lit. aqueles que têm preguiça)” (Testa, 2014: 267). Em campo, ouvi algumas vezes que mesmo durante a gestação os pais não podem dormir muito para a criança não ficar preguiçosa e demorar muito para nascer, além não poderem amarrar nada, nem usar pulseiras, colares e brincos para que o bebê não os imite e possa se enrolar com o cordão umbilical ou se machucar no parto.

${ }^{229}$ O termo -ovaigua "pode significar aquele que replica o comportamento de alguém em outro domínio ou outro contex to”, assim como um contrário, um inimigo (Pierri, 2013a: 199). Segundo Pierri, o sentido é o mesmo, ainda que no caso de um inimigo tal replicação se realize contra a pessoa de quem se está replicando esse comportamento (Idem). Dooley também traduz -ovaigua por “inimigo, contrário” (2006: 134). 230 As doenças, de modo geral, de acordo com Belaunde, "são concebidas como um desequilíbrio de volume, velocidade, temperatura, cor, cheiro e/ou espessura do sangue de uma pessoa”, além disso, os estados emocionais seriam também "estados do sangue e podem terminar em enfermidades" (Belaunde, 2006: 214). Ela dá atenção particular à "raiva”, que leva a "uma aceleração e ao aquecimento do sangue, e deve ser tratada com cuidado” (Idem). 
coisas que existem neste leito terrestre seriam “imagens (-a'anga) do que existe nas moradas celestes, por exemplo, os alimentos, adornos e até mesmo as tecnologias usadas pelos brancos" (Testa, 2014: 136-37). Um dos interlocutores de Testa faz um comentário sobre isso: “'Xeru ete oĩ yvate, xexy ete oĩ yvate. Ha'e ae ri gui ma xee arova' (Meu pai verdadeiro está lá em cima, minha mãe verdadeira está lá em cima. São eles que eu copio/traduzo)" (Karai Tataendy apud Testa, 2014: 137). No entanto, justamente por possuírem corpos perecíveis e mortais, "feitos de carne e osso", por serem tekoaxy, confinados à condição humana, sujeitos às dores e doenças terrestres, a ênfase guarani na continuidade que compartilham com as divindades, pelo vínculo de filiação que afirmam ter com os parentes divinos ou mesmo pelos modos de agir semelhantes aos deles, não quer dizer que essa suposta (des)semelhança "seja uma cópia idêntica, pois envolve formas de relações que implicam transformação" (Ibidem: 138). Os corpos (-ete) guarani como imagens dos corpos divinos constituiriam, portanto, algo "plenamente material”, pois transmitiriam capacidades e afecções seja através de substâncias ou da própria replicação desses comportamentos (Pierri, 2013a: 185).

Por isso, embora os Guarani, assim como os jurua, possuam corpos perecíveis e mortais, foi lhes reservado a possibilidade de superar tal condição, transformando seus corpos em corpos imperecíveis, semelhantes aos dos deuses, através da emulação de suas práticas corporais que os levariam a alcançar yvy marãe'ẽy. Daí que, entre os Guarani, a comunicação entre seus nhe'ẽ e os deuses não seria o problema, mas a descontinuidade a ser superada reside na diferença entre seus corpos (Ibidem: 167). Seria a própria instabilidade desses corpos que traria a possibilidade de superação da condição tekoaxy. No entanto, as condições da vida nesta terra, principalmente com as dificuldades que aparecem no contexto atual de constrangimento territorial, de estreitamento das relações com os jurua, suas instituições e costumes (jurua reko), especialmente aqueles relacionados à alimentação, com muito óleo, sal e açúcar, percorrem cada vez mais o cotidiano das aldeias, tornam tal possibilidade praticamente inviável: "seu corpo adquiriu um peso invencível devido ao consumo de alimentos europeus (sal, carne de animais domésticos, cachaça, etc.), bem como pelo uso de vestimentas europeias" (Nimuendaju, 1987 [1914]: 104).

A noção de corpo leve que os interlocutores mbya de Prates (2013) traduzem como “-etevevuipa”"231, necessária para alcançar aguyje (maturação-perfeição), ocorre a partir de

231 O termo -vevui que tem como variante a expressão veryi e significa "estar ou ficar leve", como por exemplo, o termo nhandevevuipa que pode ser traduzido como "estamos todos (com corpos) leves (e assim prontos para experimentar efeitos sobrenaturais)” (Dooley, 2006: 190). O uso do radical -pa indica totalidade. Sobre a importância da relação entre corpo e leveza, ver também Montardo (2002), Mello (2006), Pissolato (2007), Macedo (2010, 2012a). 
rigorosas prescrições e interdições alimentares que visam a moderação e o controle de certos estados afetivos marcados pelo excesso e corruptibilidade. O objetivo guarani nesta terra é não deixar que o corpo terreno seja um obstáculo ao pensamento, à conduta moderada e às danças. Isso se relaciona a um tema amplamente comentado na etnologia, aquele da "ascese e medida" (Cadogan 1959; Clastres, H. 1978 [1975]; Viveiros de Castro 1986: 596) que caracterizaria os ideais éticos-xamânicos guarani de corpo-comportamento. $\mathrm{O}$ xamanismo guarani se fundamenta então nessa busca de proteção à saúde $\mathrm{e}$ evitação de doenças nesta terra corruptível, através da promoção de alegria (-ry'a), leveza (-vevui), força (-mbaraete), coragem (-py'a guaxu), em suma, de bons ânimos aos parentes, consanguíneos ou não, neste e noutro mundo (além-mar). E se dá por meio da mobilização controlada de uma série de relações entre corpos-espaços-domínios, que tem na reprodução criativa do movimento e comportamento das divindades o seu princípio e fim.

Essas atitudes fariam os parentes divinos "olhar" e "cuidar" deles, seus filhos caçulas (nhandera'y ijapyrepyre'i) e disponibilizar saberes-poderes a serem empregados na manutenção da vida nesta terra tekoaxy. No que reside a própria diplomacia cosmopolítica guarani: estratégias sempre renovadas e criativas, de fazer a vida nesta terra durar, cumprindo a sua missão mais fundamental, a de produzir-proteger parentes de alteridades perigosas outras, podendo envolver também, disposições agressivas em relação aos seres de fora do coletivo (quando necessário). Pois, mesmo que haja todo um investimento na troca de gentilezas entre parentes (mborayu ou mborayvu = generosidade, solidariedade ${ }^{232}$ ), o seu avesso, a prática de feitiçaria e a ação dos ija kuery, se faz constantemente presente. No entanto, a utilização de práticas xamânicas apenas visando a agressão, violência desmedida, a morte ou alguma doença ou infortúnio, principalmente quando direcionado a algum parente, ou alguém de dentro do coletivo, é considerado pelos Guarani como "feitiçaria" 233 . O vetor de produção-proteção da pessoa guarani seria como uma

232 A "ética da humildade (-nhemboriau)", de acordo com Pierri, reflete que "a valorização da vida na terra deve ser um esforço constante de 'produzir em si mesmo a humildade' (-nhemboriau), através de práticas corporais” (Pierri, 2013a: 168; 256). Daí que, a ética do -nhemboriau seja entendida, pelo antropólogo, como “a negação do Um” (Ibidem: 260). Mboriau seria a forma não-relacional do radical -poriau, "estar triste”, e é traduzida como "tristeza, angústia” (Dooley, 2006: 109). Já -momboriau é traduzido por Dooley como "afligir” e -nhemomboriau por “afligir-se, ter compaixão ou dó (de alguém)” (Idem).

233 Testa realiza uma descrição sobre os objetos patogênicos enviados na agressão xamânica, seja via "donos” de determinados domínios e emoções ou mesmo por parentes humanos (Testa, 2014: 84-85). Cretton Pereira comenta que nessa terra tekoaxy, além dos humanos serem constantemente acometidos por comportamentos anti-sociais, que podem levar à transformação transespecífica (-jepota), também podem ser vítimas de "feitiçaria por parte de outrem, um ex-cônjuge, um futuro (potencial) cônjuge, um cunhado, um desafeto qualquer ou simplesmente um mba'erykya, isto é, alguém que 'brinca' com as pessoas” (Cretton Pereira, 2014: 193-94). O termo mba'eryky é traduzido por Dooley como "brincar, praticar feitiçaria (lit., 'algo maltratar')" onde mba'e significaria “coisa não-humana” e ryky "maltratar”, mba'eryky podendo também ser entendido como "brinquedo", "feitiço" (Dooley, 2006: 103, 105). Feiticeiro é traduzido pelo linguista como imba'eryky va'e que também remete à "mexeriqueiro: ka'i ma imba'eryky raxa va'e o macaco é 
contra-ação ao ataque de outros (Prates, 2013: 210). Daí que, tanto os "donos-afetos" podem atingir um corpo humano com uma pedra "invisível”, por exemplo, como um corpo humano pode agredir ou desrespeitar um "domínio" outro, revelando assim a interface entre o agenciamento agressivo e patogênico dos donos e o agenciamento agressivo-abusivo dos humanos, ambos "sujeitos de e sujeitos $a$ afecções" (Macedo, 2013: 193). Macedo ressalta ainda a recusa guarani em não substantivar a maldade ou a bondade, visto que "tudo depende da configuração em jogo” e, nesse sentido, doenças ou infortúnios seriam antes o resultado de um "mau encontro" que uma "maldade intrínseca ao dono" (Idem).

Na socialidade xamânica guarani, os ensinamentos vêm aos poucos, sendo revelados pelos deuses quanto mais se investe nas vias de comunicação com eles, mas feitos circular - de maneira controlada - principalmente através de aconselhamentos belosbonitos-eficazes (porã), inspirados e inspiradores, de seus sábios anciãos que seriam aqueles que estariam mais maduros nessa aquisição sempre contínua de saberes-poderes, repleta de "provas" pelo caminho, que acabam por fortalecer a sua capacidade de ver-ouvirsentir-falar-curar. Em suas falas, os Mbya reiteram continuamente “Nhanderu kuery toma'ẽ nhande rẻ (deixe que os deuses nos olhem/ajudem)", relação esta que exige que ajam de maneira que os deuses "olhem” (-ma'ê) para eles, que os ajudem e cuidem deles (Testa, 2014: 136). O agir de modo semelhante aos parentes celestes nesta morada terrestre expressa e reforça a continuidade da relação de parentesco e de cuidado entre eles, pois suas atitudes demonstram que são verdadeiramente seus "filhos caçulas" (Nhanderu kuery ijapyrepyre’`), “pedaços” deles, como uma extensão metonímica de seus corpos (Idem).

É necessário que essa relação de aproximação seja constantemente produzida, pois além de ser olhado e cuidado pelos parentes divinos, também se pode "ser olhado por" seres outros, como os donos-espíritos, por exemplo, que sendo "objeto da atenção e do desejo do outro, princípio da transformação", inaugura "seduções, enfermidades e roubo de perspectiva", além do início de uma relação de troca, "para o bem e para o mal, dado que o olhar abre caminhos para que palavras, pedras, alimentos e objetos de todo tipo possam passar" (Ramo, 2014: 137). Trocam-se "olhares, palavras, alimentos, e, por fim,

mexeriqueiro demais" (Ibidem: 105, grifos meus). É interessante perceber que a frase traduzida por Dooley a respeito do "mexerico", que podemos também entender como "fofoca”, está associada, de alguma forma, ao feitiço. Cretton Pereira comenta que chamar um "feiticeiro" de mba'erykya "coloca em evidência a possibilidade de estes 'sábios' às avessas estarem 'brincando' com a vida de outros Mbya, muitas das vezes sem motivo maior que o seu próprio desejo de fazê-lo" (Cretton Pereira, 2014: 194). Cadogan traduz o radical -avyky por "tocar (furtivamente o ligeramente): en composición, embrujar, herir furtivamente con hechizos; ijavykya su agente heridor, agente de que se vale el hechicero para herir furtivamente; [...] mba'evyky; mba'evykya" (Cadogan, 1992: 35). 
corpos e almas", a troca entendida aqui como o "movimento de pessoas, palavras e objetos" (Ibidem: 137-38). Seriam os comportamentos considerados anti-sociais, terrestres demais, que se afastam dos ensinamentos divinos, que fariam os deuses deixarem de olhar-cuidar de seus filhos caçulas, como fica claro na fala do xeramoĩ Augustinho: "Temos espírito bom, que trabalha com Nhanderu e tem espírito ruim que anda à noite" (Ibidem: 138). Por isso, quando a pessoa deixa "a sua sombra muito solta, ela estabelece alianças indesejáveis que fazem com que Nhanderu deixe de olhar”, pois se as pessoas esquecem dos deuses, eles também esquecem delas (Idem). Assim, longe do seu "olhar", a perspectiva humana (Mbya) fica em uma posição vulnerável, sujeita aos olhares de outros, que com este olhar podem cooptar a sua perspectiva, daí a recorrente desconfiança em relação aos outros, confirmada também pelo comentário de outro interlocutor de Ramo: "se você não desconfiar aí Nhanderu também vai falar 'Poxa, ele não está se cuidando', e aí também não vai olhar, pra ajudar” (Ibidem: 154).

A teoria da alma bipartite ameríndia é bastante presente na etnologia tupi-guarani. Entre os Guarani, Nimuendaju comenta sobre a oposição fundamental entre duas frações da alma que compõem a pessoa “apapocúva”: a porção “ayvucuê" ("o sopro brotado [da boca]" ou "alma surgida [do corpo]”), correspondente à “alma celeste” e identificada à linguagem (ayvu), às "disposições boas e brandas" como a "calma” e ao "apetite por alimentos vegatais e leves", e a parte "acyiguâ" ("alma animal”), associada às disposições "más e violentas" como o "desassossego" e o apetite por "carne" (Nimuendaju, 1987 [1914]: 29-34, alterações minhas). Na morte, a alma celeste retornaria aos patamares celestes, sua morada originária e a alma animal permaneceria na plataforma terrestre. Outros autores clássicos que também escreveram sobre os Guarani, como Cadogan (1959) e H. Clastres ${ }^{234}$ (1978 [1975]), também registraram esse dualismo que opõe uma alma celeste a uma alma terrestre. Prates (2013) também comenta como a sombra (ãgue) é o outro lado do nhe'ê, o seu verso. Como uma importante interlocutora mbya, que é professora, liderança da linha de frente e também já foi "cacica” em SC, me explicou:

a gente não fala é que o nhe'ẽ nosso é alma ${ }^{235}$, a gente fala que o nhe'ẽ nosso é o espírito mesmo, que é esse verdadeiro [...] pra nós assim alma é algo que fica vagando, é algo fantasmagórico, então quando eu me refiro à palavra nhe'ẽ para mim é espírito, então pode

\footnotetext{
234. A respeito do tema, a autora comenta: "Se os homens são dotados de uma alma-palavra, ligada ao esqueleto, também possuem uma 'alma' ou 'natureza' animal, vinculada ao sangue e à carne: teko achy kue é o produto da existência má, aquilo pelo que participam da animalidade. Depois da morte, esta 'alma' tornase 'angue' (ã = verticalidade; kue = pretérito), um ser destinado a errar pela floresta e que deve ser afastado (pela fumaça de tabaco, pela dança) dos vivos, pois faz pesar uma ameaça precisa sobre estes: a ameaça do tupichua" (Clastres, H., 1978 [1975]: 93).

235 Para os Wari', segundo Vilaça, “alma” (soul) não diz respeito a um princípio vital, correspondendo antes a um conjunto de qualidades (Vilaça, 2005: 452). Aí também não se pode falar de corpo sem falar de alma,
} 
ser espírito bom ou mal [...] a alma já é uma coisa que é a parte, não sei se é bom ou ruim, ele é daqui mesmo, é algo daqui, é isso que movimenta, isso daqui é a alma, o meu espírito, não, ele é puro, e ele volta [para a sua morada celeste]” (Kerexu Yxapyry da T.I. Morro dos Cavalos, Local: Tekoa Tenonde Porã, 2015, grifos e alterações minhas).

A pessoa guarani sendo composta assim tanto de osso e sopro, como de carne e sangue (-uguy $)^{236}$, animada tanto por nhe'ẽ porã quanto por nhe'ẽ vai, associados respectivamente à divindade e à animalidade, ou seja, aos eixos vertical e horizontal da alteridade (ver Macedo 2010, 2012a). Há, portanto, uma forte oposição entre a potência divina e a potência animal, e uma certa ambiguidade da pessoa guarani, que possui a dualidade do divino e do animal, pois apesar de nascer com a potência divina, sofre sob o paradoxo de tornar-se humano ${ }^{237}$. Nesse sentido, enquanto nhe'éé alimentado pelas belas palavras divinas que@s xamãs fazem circular, ãgue e suas afecções terrestres promovem, uma certa perturbação, o avesso da vida entre parentes. Aqui, nessa "terra má” (yvy vaı), marcada pela corruptibilidade, pelo excesso desmedido e pelo definhamento, onde vigoram relações agressividade e de predação, a vida é uma "guerra de perspectivas", por isso, "evitar a guerra com uns só se faz bancando a guerra com outros" (Ramo, 2014: 137).

Assim, a construção da pessoa e das relações, entre os Mbya, se dá então, coletivamente, via parentesco, e se articula à sua noção de corpo. Esta concepção do corpo em constante fabricação, que não se pensa enquanto um sistema fechado tal qual concebido pela biologia moderna, mas como um "feixe de afecções", nos permite articular sua constante instabilidade à necessidade de ser também produzido pela incorporação contínua, ainda que controlada - uma vez que se está sujeito a uma série de riscos de transformação corporal -, de afecções provenientes de outros corpos. Daí parte a preocupação com o controle dos desejos e emoções nos encontros e desencontros com corpos outros, isto é, do controle mesmo das relações para que estas não se tornem potencialmente prejudiciais à pessoa e seus parentes. Nesse sentido, a fabricação da pessoa guarani é um processo constante que busca atualizar reiteradamente o vínculo do nhe'ẽ com o próprio corpo, e se dá por meio de práticas e cuidados xamânicos que visam manter a conexão e proteção

pois é ela que dá ao corpo sua instabilidade, permitindo a transformação, por isso, qualquer "totalização” aí é impossível, porque esses corpos são "cronicamente instáveis” (Ibidem: 452-3, 458). Tal vulnerabilidade, ressalta Vilaça, não se resumiria aos encontros na floresta, sendo um aspecto intrínseco das relações entre os corpos (Ibidem: 457). A subjetividade, de acordo com Taylor, ao menos dentro do contex to das relações domésticas (e talvez para além) seria "primariamente uma questão de refração: ela se origina na noção que alguém tem da percepção que outros têm de seu próprio Eu” (Taylor, 2012 [1996]: 217).

${ }^{236}$ No entanto, ao comentar sobre a relação entre a mistura de sangue e geração do corpo de um novo ser, Pierri, considera que o "sangue é a substância celeste e imperecível do corpo dos Guarani” (2013a: 177). ${ }_{237}$ Nessa terra em que vigora o idioma da predação, a vulnerabilidade é um estado latente da experiência nesse mundo, "repleto de esquivas, enganos, provações e predações”, pois “invulneráveis" seriam apenas as divindades (Keese dos Santos, 2017: 165). Keese sugere que o par vulnerável/invulnerável seria como um “correlato político mais ou menos próximo do par marã/marã e’ỹ (perecível/imperecível)” (Idem). 
dos deuses, as quais não só a pessoa como também seus parentes devem se atentar, impedindo que o nhe'ẽ se afaste e isso incorra em adoecimentos ou afecções outras que possam fazer com que a pessoa deixe de partilhar, com seus parentes, a perspectiva humana. A pessoa guarani pode ser pensada então como uma "multiplicidade individuada, habitada ou atravessada por muitos" (Macedo e Sztutman, 2014: 291).

Os movimentos desempenhados por todos esses corpos podem ser vistos como a própria teoria guarani da relação e da política, que se desdobraria em uma recusa ativa contra ser capturado plenamente por uma subjetividade outra, desta terra, e ter seu corpo-afeto metamorfoseado por uma potência perigosa, terrestre. E, nessa intensiva e inconstante produção do corpo e do espaço, os Mbya atuam também na manutenção dessa terra tekoaxy, podendo ser entendidos, de maneira geral, como os guardiões de yoyrupa ${ }^{238}$, auxiliares dos Nhanderu e Nhandexy kuery e, os seus tekoa como cinturões de proteção que sustentam esse mundo e que funcionam como pontos de passagens, produtivos, de fortalecimento e proteção para as caminhadas em direção à terra sem mal (yvy marã e'̃y), no além-mar, onde desejam recobrar, integralmente, a divindade e imperecibilidade de seus corpos-espíritos.

\section{Sem palavra mítica, não há movimento ${ }^{239}$ : a palavra-nome e a produção de boas disposições na organização coletiva}

Cada pessoa guarani, segundo meus interlocutores mbya, viria com um "caminho" traçado ou iluminado por Nhanderu, que seria quem "põe no caminho" ou quem o “mostra”, “ilumina” (Nhanderu omo'exakãa) ${ }^{240}$. Para os Mbya cada um possui um “dom”, ou uma "disposição" potencial, algo como um caminho-iluminação, uma "missão", ou seja, determinadas capacidades potenciais para realizar algo e ser eficaz que devem ser desenvolvidas ou aprimoradas ao longo da experiência-caminho de vida de cada pessoa. Assim,

\footnotetext{
238 Com a partida de Nhanderu Tenondegua para a morada celeste, os humanos tiveram que achar (-jou) as coisas criadas por ele e os heróis míticos (Sol e Lua) para sobreviver na plataforma terrestre. Por terem sido enviados para cá, longe dos parentes divinos, os Mbya "tiveram de assumir grande parcela da responsabilidade por cuidar daquilo que foi criado e deixado aqui para eles” (Testa, 2014: 135-36).

${ }^{239}$ Frase de Bartomeu Melià no Prefácio ao livro "O caminhar sob a luz - Território mbya à beira do oceano" que corresponde à dissertação de Maria Inês Ladeira (Melià apud Ladeira, 2007 [1992]: 13). Como viemos argumentando, há uma intensa relação entre o movimento desempenhado pelos personagens míticos e a reprodução do movimento atual dos Guarani na manutenção e proteção de yryrupa.

240 Apesar de entenderem que Nhandexy também ilumina, os Guarani com quem convivo, utilizaram muitas vezes a expressão “Nhanderu omo'exakâ" para explicar para mim em português da iluminação do caminho pelas divindades, usando a referência ao seu demiurgo, sua divindade maior. Entretanto, como sabemos, Nhanderu Tenonde tem uma companheira, Nhandexy Tenonde, e todos os outros seres divinos que surgiram dele também possuem uma esposa, que são as mães das almas-palavras-sopros de cada morada celeste $(a m b a)$ que cuidam-protegem.
} 
caso a pessoa tenha uma disposição a tomar a frente de um coletivo, como uma liderança, seja dentro ou para além do grupo local de parentes ${ }^{241}$, seus parentes devem buscar incentivá-la a desenvolver essas suas potencialidades ao longo da sua vida. Em relação aos cuidados que os pais devem manter em relação às crianças e seus nhe 'ẽ, uma interlocutora que é liderança, professora e cineasta conta que "o líder espiritual já fala para os pais, para que quando ela for grande ela consiga fazer o que ela veio fazer, então tem a participação dos pais para cumprir com a missão" (Para Yxapy do Tekoa Koenju [RS], Local: São Paulo, 2016). Além disso, como eles sempre dizem, "cada um tem o seu jeito de ser" (Karai Poty, Tekoa Tenonde Porã 2016). Nesse sentido, o “dom” teria a ver com a própria disposição da pessoa aqui na terra: "pensando no teko ele fica meio que junto né, eu tenho sistema, eu tenho o meu próprio sistema [...] que é a minha função" (Kerexu Yxapyry da T.I. Morro dos Cavalos [SC], Local: Tekoa Tenonde Porã, 2015).

Em conversas com meus interlocutores, ouvi que em "primeiro lugar", tudo o que os Guarani fazem "sempre vem por iluminação de Nhanderu” ou pelas comunicações entre eles e os xeramoĩ e xejaryi kuery. Karai Jekupe, educador e liderança, comenta que os Guarani foram enviados ao mundo por Nhanderu, que já "tem uma missão para cada um", por isso eles devem seguir essa missão e buscar "sempre se desenvolver cada vez mais" (Karai Jekupe, Tekoa Kalipety 2015). Nesse sentido, "a experiência que cada um tem em alguma coisa” vem de Nhanderu, pois "sem ele não fazemos nada” (Idem). Outra interlocutora conta: "a gente é escolhido, essa parte física nossa é escolhida para exercer uma função, a gente é escolhido por Nhanderu mesmo" (Kerexu Yxapyry da T.I. Morro dos Cavalos [SC], Local: Tekoa Tenonde Porã 2015). O nome-espírito tem relação direta com a sabedoria divina recebida:

\begin{abstract}
pra nós Guarani a gente têm uma essência de formação, de identidade ou de uma profissão mesmo no momento em que a gente recebe o nome, porque quando a gente recebe $o$ nome já vem com toda uma função junto, então é a partir dali que a criança começa a praticar, a ouvir, a praticar e ele mesmo se tornar né [...] a partir do momento que eu recebo o meu nome, e que eu começo a exercer a minha função, que esse nome também é um espírito né, um espírito sagrado que vem já pronto, a gente já ganha um pacote completo aqui, e a partir daí vai ter que chegar o momento que [eu vou falar] "eu sei que é isso" né (Idem, alterações minhas).
\end{abstract}

Kerexu comenta que "os xamoĩ sempre falam que quando Nhanderu manda nhandekuery para a terra, ele manda com uma missão na terra porque você vem com o dom de fazer o que você gosta e isso é Nhanderu que mandou para vocêe" e, é por isso que:

\footnotetext{
${ }^{241}$ Ainda que tenhamos diferentes disposições (e mo[vi $]$ mentos) na atuação mesma das lideranças, como por exemplo, um líder, xondaro que pode tornar-se xondaro ruvixa, tekoaruvixa e também um xeramoĩ ao longo de sua trajetória, ou mesmo uma xondaria que pode tornar-se xondaria ruvixa, tekoaruvixa e xejaryi.
} 
faço o que eu gosto, eu faço o que eu tenho vontade, xepy'apy pe ["o que está dentro do meu coração”], dentro de mim, no meu coração, o que eu quero fazer, o que é bom para eu fazer, então isso vem do dom que Nhanderu mandou pra mim, eu não vou fazer uma coisa, outra coisa que eu não gosto de fazer [...] sem vontade, sem ânimo né [...] na nossa aldeia o que a gente faz é tudo o que a gente gosta de fazer, então ninguém faz aquilo que não gosta" (Kerexu, Tekoa Tenonde Porã 2015, grifos e alterações minhas).

Essa ideia vai de encontro ao que um xeramoĩ, interlocutor de Ramo conta: "O mesmo que você trabalhou lá em cima $[\ldots .$.$] você vai trabalhar aqui” (Augustinho apud$ Ramo, 2014: 68). Os nomes se referem então a capacidades-poderes que habilitam a pessoa para determinadas atividades aqui na plataforma terrestre, uma vez que com os nomes, que são também espíritos-palavras vem todo um corpus de saberes referentes às moradas de origem que correspondem a "costumes" (teko) e "trabalhos" específicos que já realizavam nos amba das divindades a que eram vinculadas. Um interlocutor de Macedo também conta que "cada nome tem um modo de ver" (Karai Poty apud Macedo, 2010: 230). Alguns desses "trabalhos", por sua vez, seriam prerrogativas de certas moradas, correspondendo, portanto, a filiações determinadas, assim como ocorre com os pais e mães dos nhe'ẽ que ao serem nomeados por Nhanderu Tenonde, são diferenciados pelos elementos, objetos que guardam-cuidam e fazem agir neste mundo.

Cadogan (1959), transcreve a fala de seus interlocutores guarani sobre o processo de desdobramento, o "desabrochar" (-mbojera) das divindades, que se inicia com Nhanderu Tenonde que desdobrou a si mesmo e gera a partir de si as demais divindades. Destas últimas viriam, o que o autor denomina de "lugartenientes"242, os "filhos" dessas divindades, espécie de auxiliares, algo como seus xondaro e xondaria. Assim, após se instalarem nos lugares em que Nhanderu Tenonde criou as "palmeras eternas", cada um dos Nhe'ẽ Ru Ete e Nhe'ẽ Xy Ete ("verdadeiros pais e mães dos nhe'ê") recebeu do demiurgo a tarefa de cuidar de um elemento: Karai, por intermédio de seus filhos, "los Karai valerosos" ("nde ra’y Karai Py’aguachu”), fará vigiar as "hileras de llamas inasequibles” ("tataendy ñeychyrõ rë") a partir das quais o próprio Nhanderu Tenonde se "inspira", e serão chamados "los Señores dueños de las llamas" ("Karai Tataendy ja”); Jakaira irá fazer com que seus filhos, "los Jakaira de corazón grande” (“nde ra’y Jakaira Py'aguachu”) vigiem a “fuente de la neblina que engendra las palabras inspiradas" ("tatachina ñe'engatu rapyta rã i re") e, por isso, serão chamados “dueños de la neblina de las palabras inspiradas” ("tata-

\footnotetext{
${ }^{242}$ Esse termo aparece no título do Capítulo III, que fala da criação da primeira terra (yry tenonde): Creación de la Primera Tierra y los siete Paraísos. Ñande Ru entrega la Primera Tierra a sus lugartenientes y se retira a las profundidades del Paraíso. Instrucciones de Ñande Ru a sus lugartenientes referentes al gobierno del mundo" (Cadogan, 1959: 215).
} 
china ñe'engatu já rã i”); e Tupã irá se encarregar do "extenso mar en su totalidad”, enviando "repetidamente a la morada terrenal" por intermédio de seus filhos, "los Tupã de corazón grande” (“nde ra’y Tupã reta py’aguachu”), "aquello que refresca” (“mba'e ñemboro'y”) (Cadogan, 1959: 33, 31). Essas dádivas se inscreveriam nos corpos Mbya, constituindo-os como os seus próprios territórios aqui na Terra: a neblina vivificante no topo da cabeça ("coronilla”, "apytére”) que farão seus filhos e filhas prosperar; as chamas sagradas (“tataendy mba'e porã $\imath$ ”) que se hospedam em seus corpos; aquilo que refresca, a "moderación”, e deve se alojar no centro do seu coração (“py’a mbyte py”) (Ibidem: 32).

Há, portanto, toda uma diferenciação de capacidades e ações inscrita nos corpos dos nomes-espíritos. Para Poty, jovem liderança e professora, comenta que foi após começar a dar aulas que passou a participar mais ativamente das questões internas da aldeia: "é Nhanderu mesmo que diz que você vai nesta terra para fazer essas coisas, proteger sua comunidade e seus parentes [...] Nhanderu marca cada um, qual a função que vai ter nesta terra” (Para Poty, Tekoa Tenonde Porã 2015). Mas “não basta só querer”, é algo que "vem de dentro" e que se vai desenvolvendo e "aprendendo junto", caminhando junto e acompanhando os parentes ao longo da vida (Idem). Esta reflexão enfatiza o aprendizado que vem do ficar perto-junto, acompanhar os mais velhos e aprender ouvindo-sentindo, observando, imitando suas ações e comportamentos para juntos se fortalecerem na busca pelo bem-viver (teko porã) coletivo.

Segundo levantamento dos nomes-espíritos, e dos possíveis casamentos ideais entre eles, realizado por Ladeira, é possível mostrar como os Mbya "articulam o sistema de atribuição dos nomes em função das necessidades sociais e políticas de cada tekoa", pois para se “atingir Yvy Maraẽy" seria preciso um “empenho coletivo” [...] que está de forma bastante nítida relacionada com a origem das almas dos integrantes de cada família, e do tekoa como um todo", daí ser "necessário que as cinco regiões celestes e os respectivos pais das almas estejam representados, em cada aldeia, por meio dos nomes-almas que enviam" (Ladeira, 2007 [1992]: 129). Cada um dos Nhe'ẽ Ru Ete e das Nhe'ẽ $X y$ Ete, se instala em uma região que os alocam em relação à Nhanderu e Nhandexy Tenonde e que corresponde aos pontos cardeais (Norte-Sul-Leste-Oeste). É a partir da referência ao Sol nascente (nhanderenondere), para onde as opy e os cantos-danças-rezas devem se voltar de frente em reverência, que Ladeira descreve a localização das moradas das divindades:

A cada região corresponde um Nheẽ Ru Ete. Assim, nhandekupére é comandada por Tupã Ru Ete; nhandekerovái por Jakaira Ru Ete; nhandekére por Karai Ru Ete; ara mbyte por 
Kuaray Ru Ete. Nhanderu "criou esses quatro seres", como diz Cadogan, para enviar almas à terra, para as criaturas que irão nascer. Entretanto, é o próprio Nhanderu o responsável pelas almas de nhanderenondére, região do nascimento de Kuaray. (Ibidem: 113)

Seriam esses casais, guardiões dos diferentes domínios celestes, que enviaram os nhe'ẽ kuery para viver nesta terra, cada pessoa guarani possuindo algo como um "dom" ou uma "missão", transmitido por essas divindades que cuidam e protegem seus nhe'ẽ cada qual em sua morada. É através desse principio vital que se estabelece a capacidade de se comunicar com a esfera divina, receber proteção, ensinamentos, mensagens, conselhos, capacidades-poderes, força e coragem, isto é, boas disposições para cuidar, proteger e fortalecer os parentes terrestres ${ }^{243}$. Daí que, esses duplos ou “anjos”, os nhe'ẽ, possam ser descritos também como os xondaro ou as xondaria de Nhanderu e Nhandexy kuery. A questão da onomástica, da palavra-nome-espírito - que também pode ser entendida como uma substância ${ }^{244}$ a ser ativada continuamente através do compartilhamento entre parentes terrestres para fazê-los se acostumar nesta terra (yvy vaı) - revelada pelos pais e mães dos $n h e^{\prime e}$ aos xeramoĩ e às $x e j a r y i^{455}$ (e, eventualmente, aos próprios pais, tios e avós das crianças), pode então ser entendida como tendo a ver com o lugar ou a "missão" da pessoa dentro de um coletivo. A participação dos parentes terrestres na missão do nhe'ẽ aqui em yryrupa se dá pelo compartilhamento de boas substâncias e de bons ânimos entre eles, com o objetivo de fortalecê-lo para que seu nome-espírito passe a desejar aqui permanecer ${ }^{246}$ e, com isso, continuar alegrando e fortalecendo os parentes que o receberam e cuidaram dele carinhosamente. Essa "missão" pode ser compreendida também como uma predisposição a alguma "função" na organização coletiva de cada nhe'ẽ, ou mesmo como uma escolha da pessoa em desenvolver tais potencialidades (ou não). Mas há também a percepção, em relação a estas habilidades disponibilizadas pela relação que

\footnotetext{
${ }^{243}$ É como uma via de mão dupla: as capacidades celestes desenvolvidas nesta terra fortalecem a relação com os parentes celestes e terrestres, o que os capacita a desenvolverem suas missões e fazer a vida nesta terra durar.

244. A substância enquanto corpo ou sua formadora, capacita agentes e compõe ações, devendo ser ativada por meio do compartilhamento e no convívio entre parentes.

${ }^{245}$ Tal disposição faz aparecer a importância da relação entre avós e netos. Geralmente, são os avós que recebem a revelação dos nomes de seus netos e netas, além de ocuparem posição central na circulação de conhecimentos entre os seus, cuidando ativamente de seu crescimento, orientação e criação. Podemos pensar também que o acúmulo de nomes-nhe'ẽ e, portanto, de relações para cuidar-olhar, torna esses avós ainda mais potentes, promovendo a sua magnificação. Essa disposição presente nos avós pode ser traduzida como onemboery va'e ("aquele que encontra/descobre os nomes mbya" (Ramo, 2014: 71). Segundo Dooley, - mboery é o ato de "dar nome a (alguém ou algo): ava’i omboery Vera ao menino deu o nome de Vera" (Dooley, 2006: 40). O termo - mboery vem do radical - ery, "nome", acrescido do causativo mbo (Ibidem: 39).

${ }^{246}$ Entre os Guarani, a chegada do nhe'ẽ ao corpo de uma criança é referida pela expressão guemimboapyka ("tomar assento") (Macedo e Sztutman, 2014: 293). A linguagem entre os Guarani, pode ser entendida então, como um potencial afetivo que seria "assentado" diretamente no corpo dos sujeitos através dos nomes, que aludem à proveniência celeste do nhe'ẽ e maximizam naquele corpo a sua potência de agir e transitar pelo mundo, fazendo parte do processo de construção da pessoa guarani (Ibidem: 291).
} 
se estabelece com a esfera divina, da "opção" da própria pessoa em escolher seguir o caminho iluminado ou se enveredar para outro, desviando-se e sofrendo as consequências da sua (má) escolha. O que também não quer dizer que seguir o "bom" caminho, aquele de Nhanderu Ete e Nhandexy Ete, seja fácil, já que, segundo me explicaram os Guarani, é um caminho bem "estreito" e repleto de "provações" 247.

Há, portanto, o entendimento entre meus interlocutores, de que todas as pessoas, independente do gênero, nascem com certas habilidades em determinados tipos de atividades, que pode ter relação direta com o local de origem de seu nhe'ẽ. Os nomes-espíritos de Tupã kuery, por exemplo, seriam “a expressão explícita da função de guardiões”, uma vez que seu "trajeto" acontece em todas as direções do cosmos mbya, "para que possa controlar a sociedade" [...] Tupã foi enviado para ser "guarda-costas do mundo"”248, e estaria relacionado à "frequente mobilidade masculina, pelos diversos tekoa" que, por sua vez, “está impregnada de sentido 'político’ por trazer conhecimento e possibilitar o controle da situação social dos tekoa mbya", ainda que sejam "especialmente os solteiros à procura de cônjuges" e de "troca de informações", atuando como "informantes" nestes deslocamentos ${ }^{249}$ :

A função de Tupã de "guarda-costas do mundo" implica uma atitude permanente de controle da situação do território guarani. Já a "escolha do lugar" para organização do Tekoa, princípio dos movimentos migratórios, é movida por um sentido de definição e fixação peculiar às mulheres, na medida em que pressupõe produtividade, produtividade esta que advém principalmente das roças de milho e do nascimento das crianças. (Ladeira, 2007 [1992]: 130, grifos meus)

A expressão "ficar no lugar, com referência à mulher", significaria segundo um interlocutor de Ladeira, que "ela não deve circular como Tupã, para errar menos e, assim, preservar mais seu corpo. Deve seguir caminho reto como aquele orientado por Kuaray, em direção à nhanderenondére, lugar de nascimento de Kuaray” (Idem, grifos meus). Daí que “a

${ }^{247}$ De acordo com Cadogan, ao se referirem à humanidade nas "plegarias" os Guarani se utilizam da expressão "tape rupa reko achy" que significa literalmente "el lecho de las sendas de la imperfección, v.g., los caminos de la peregrinación terrena que debe seguir la humanidad", além do termo "teko achy", a "vida, naturaleza imperfecta” (Cadogan, 1959: 67). Além disso, é possível fazer um paralelo com as narrativas míticas que contam das más escolhas ou "erros" dos heróis divinos que inspiram os comportamentos erráticos atuais, na chave da interpretação presente no aconselhamento dos anciões para possíveis desvios de comportamento que seriam moralmente reprovados pela cultura guarani, e servem como uma moral do por que não se deve seguir tal caminho e o que acontecerá se o fizer (ver, nesse sentido, Ramo 2014).

${ }_{248}$ Entre os Guarani, há uma referência recorrente à divindade Tupã, como fica claro na fala de um interlocutor de Ciccarone: "A gente esquece de pedir ajuda para Tupã e esquece seus ensinamentos, antigamente Tupã cuidava da aldeia, espantava os maus espíritos e a aldeia tinha mais proteção, por isso Tupã não vem mais frequentemente. A gente mostra que não precisa dele, por isso a terra, e a aldeia, estão nesse estado hoje" (Karai Tataendy apud Ciccarone, 2001: 346). Entretanto, já ouvi uma interlocutora mbya dizer em tom jocoso, "às vezes a gente tem que mandar um zap (Whatsapp) para Tupã kuery".

249 É importante ressaltar que, nos dias atuais, nos intercâmbios realizados entre aldeias, muitas mulheres, casadas ou solteiras, acompanham e muitas vezes, atuam como protagonistas nesses encontros de troca de saberes, especialmente as anciãs, ainda que, cada vez mais as jovens lideranças estejam também se fazendo aparecer, principalmente aquelas que atuam também como professoras das novas gerações. 
mobilidade entre aldeias para manutenção das relações sociais, econômicas e políticas" seja "de caráter masculino, acentuadamente entre as almas de Tupã. Já os movimentos migratórios contam necessariamente com a adesão de almas femininas" (Idem, grifos meus). Nesse sentido, de acordo com a antropóloga, parece que "todas as funções e atividades cotidianas que dizem respeito ao mundo mbya são regidas por um pensamento no qual se distinguem duas características: a da direção, que cabe aos homens, e a da orientação, feminina” (Ibidem: 131, grifos meus). É importante ressaltar que ambas características podem se desenvolver, de acordo com o interesse de cada um, entre ambos os gêneros, o que também não quer dizer que cada gênero não invista com mais intensidade em certas disposições no cuidado-proteção entre parentes (-retarã kuery), se especializando mais em certas atividades (o que não exclui todas as outras) que outras, se complementando entre si em busca de práticas que atualizem criativamente, mas moderadamente, o bem-viver (teko porã) entre parentes. Um grande xeramoĩ de um tekoa no RJ comenta:

Então, pra vocês conhecerem essas histórias, é bom que eu conte e vocês mostrem pra todo mundo. Quando Nhanderu se gerou, ele estava sozinho, ele não tinha pai nem mãe. Quando ele veio neste mundo, ele tinha um popygua e veio através dele, vagando pelo mar. Mesmo sendo um deus, ele também passou dificuldade $e^{250}$ porque só vivia através do popygua e do Kuaray jexaka, que é o reflexo do Sol. Ele conseguia a força só através desses dois. Como ele vivia sozinho, pensou em fazer uma companheira pra ele. Foi assim que gerou a companheira dele! Mas, mesmo sendo ele Nhanderu, ela não queria ser mulher, não queria se levantar. Meus avôs diziam que, quando ele fez a mulher, ela não tinha força pra se levantar, caía. Então, ele tirou um osso da parte da costela, pra fazer a mulher ficar forte, pra levantar. Tirou aquele pedacinho e colocou na mulher, na companheira dele, pra viverem juntos até hoje. Nhanderu fez a companheira pra ele de seu osso ${ }^{251}$ [...] Foi isso que eu ouvi. Já aquela história do homem que veio do barro, não é nossa; ela veio através do conhecimento dos não indígenas, por meio do kuatia (livro). A história do barro, eu escuto dos não índios. A história que eu contei é a única que eu sei, a que os meus avôs me contaram. Mas a nossa gênesis, o nosso início, ninguém sabe certo, ninguém vai saber certo como é que aconteceu. (Xeramoĩ João Silva - Vera Mirim, Tekoa Xapukai/Brakui. In: Guata Porã - Belo Caminhar, 2015: 10, grifos meus)

Todas as pessoas, em cada aldeia, que entram na $O p y$ rezam pedindo para todas as aldeias que se espalham pela Yryrupa. É necessário lembrar e pedir, pois é através disso que nós, Guarani, temos força. $\mathrm{Na} O \mathrm{Opy}$, é a mulher que pode dar mais força para os homens. Nhanderu mandou as mulheres na Terra e, para elas, é mais fácil rezar para Nhanderu. Sendo mulher, Nhanderu mesmo vai ensinar mais. (Ibidem: 89, grifos meus)

Pierri, a partir de uma narrativa guarani que conta a respeito da origem dos homens não-indigenas, das relações homossexuais e das mulheres não-indígenas, confirma

\footnotetext{
250 Afirmação central para pensar as dificuldades atuais e os modelos de ação a serem empreendidos pelos Guarani atuais, se inspirando nas histórias dos antigos (ver, nesse sentido, Ramo 2014).

${ }^{251}$ A primeira mulher foi gerada a partir de uma parte do corpo de Nhanderu Tenonde, de seu próprio osso, talvez seja por isso que recebam mais ensinamentos dos seres divinos e assim, seriam ensinadas e repreendidas por todos a errar menos. Talvez também venha daí a necessidade de preservarem mais seus corpos, pois eles detêm a capacidade de gerarem novos parentes, como um depósito-cesto de um novo nhe'ẽ a ser recebido pelo grupo de parentes, além de serem elas mesmas, peças centrais tanto em sua produção, como em sua proteção e desenvolvimento.
} 
também que a mulher guarani surge do corpo de Nhanderu: "no início do mundo mesmo, eram só homens, e da batata da sua perna Nhanderu criou a mulher. Por isso é mais fácil para as mulheres se aprofundarem na opy [casa de rezas] pois seu corpo é feito do corpo de Nhanderu” (Pierri, 2013a: 83, grifos meus). Um xamã, interlocutor de Ramo, conta que Nhanderu Pa-Pa (cf. Cadogan 1959) errou quando trouxe só homens para a Terra:

\begin{abstract}
Quando Nhanderu Pa-Pa terminou de trabalhar na Terra, deixou os homens para continuar trabalhando [...] Só que naquela época os homens dormiam todos juntos [...] Aí Nhanderu Pa-Pa tirou duas costelas de si mesmo para criar a mulher. É por isso que nos homens, todos, falta um pedacinho de costela, é só procurar; já na mulher não falta. Diz Augustinho que a mulher é mais "fraca" do que o homem. Os homens são mais "fortes" porque os homens não foram criados por Nhanderu na Terra, enquanto que a mulher foi criada da própria costela dele. Para fazer os homens Nhanderu só fez um bolo com a terra [...] E por isso, a mulher é mais sagrada do que o homem, "porque se criou mesmo, foi criada mesmo na costelinha do Nhanderu”. (Ramo, 2014: 33, grifos meus)
\end{abstract}

Assim, de acordo com Ladeira:

O fato de serem os homens, em geral, os dirigentes das cerimônias religiosas, não implica que as mulheres não sejam também portadoras do dom das premonições e suscetíveis às revelações. A equivalência em termos de "graus de importância", dos papéis femininos e masculinos não é posta em dúvida no pensamento mbya. (Ladeira, 2007 [1992]: 131-2)

Um necessita do outro para existir, isto é, para passar pelas duras provações no caminho até yvy mara e'y, como exige o critério cosmológico mbya da complementaridade dos papéis masculinos e femininos. Ao que parece, e que viemos argumentando ao longo dessa Dissertação, somos nós - e nossas teorias baseadas na dominação masculina ou na desigualdade de poder entre homens e mulheres - que insistimos em separar ou segmentar o que, em outras sociedades é visto e entendimento como complemento vital (embora diferentes) para a manutenção da existência. Isso não exclui que, em alguns casos, as relações construídas cotidianamente (e ritualmente) se revelem mais ou menos assimétricas, a depender de cada contexto de (enunci)ação, isto é, da rede de relações em questão em dado mo(vi)mento. Nesse sentido, complementa Ladeira:

A maior exposição do homem na sua função de dirigente espiritual, que exige uma performance física mais exuberante, não é mais valorizada, enquanto gênero, do que o perfil orientador (as sugestões e orientação da mulher ao próprio dirigente são sempre determinantes) $e$ a preservação do fisico feminino. (Ibidem: 132, grifos meus)

Ela então conclui: "A sociedade guarani, apesar da aparente supremacia masculina, pois são os homens que se relacionam mais abertamente com a sociedade envolvente, é sustentada pela complementariedade efetiva dos papéis e valores masculinos e femininos"252 (Idem, grifos

${ }^{252} \mathrm{E}$ que nos dias atuais se mesclam cada vez mais e mais cedo que antes, com a proximidade intensiva e extensiva de jurua kuery e suas tetã (cidades), ainda mais com projetos culturais apoiados por parcerias com governos estaduais, municipais e federais incidindo grandemente na vida em comunidade. Nesse contexto, 
meus). Ladeira comenta ainda de sua dificuldade em obter dos Mbya, até mesmo por meio de "conversas informais", "julgamentos sobre a importância de seus respectivos papéis e atividades desenvolvidas no âmbito da comunidade", não conseguindo nada "além de risos por tão estranha conversa", até mesmo quando questionava a importância do "perfil orientador das mulheres", principalmente aquelas que portavam espíritos-nomes que tinham como função orientar os seus à yoy marã e’ $\tilde{y}$ (Idem). No entanto, esse perfil "não é potencial exclusivamente feminino", pois assim como "as premonições, o poder de cura, a obtenção dos cantos são de alcance feminino e masculino” (Idem). Insistimos aqui que, como a socialidade mbya é xamânica, cada pessoa pode desenvolver capacidades de acordo com seu "esforço" ou "interesse" e sua persistência em "saber pedir”, isto é, em aprimorarse nessas artes de comunicação e ação cosmopolítica disponíveis a todos Mbya que desejem se aventurar em maior ou menor intensidade nessas atividades. Nesse sentido, ainda que hajam "diferenças formais, observadas no comportamento, nas práticas rituais e em diversas esferas do cotidiano, são estruturais e são respeitadas, mas não estão impregnadas de conceitos valorativos" (Idem, grifos meus), tal como ocorre na sociedade jurua e é de tabela reproduzido nas etnografias que passam por cima da discussão de gênero e política.

Ladeira confessa que sua intenção nunca foi recorrer a "qualquer recorte sobre a questão de gênero" em seu trabalho ${ }^{253}$, mas que não pôde deixar de pensar nisso, "pelo fato de a maioria dos tekoa hoje existentes no litoral" terem sido "fundados tendo à frente uma mulher ${ }^{254}$ " (Idem, grifos meus). Essas kunhã karai, seriam figuras-chave na definição do lugar de permanência do grupo durante suas caminhadas (oguata), cujas "almas", geralmente, seriam provenientes da região de nhanderenondere (“nascente”) ${ }^{255}$. O que é im-

a atuação das mulheres no âmbito da comunidade, para além do núcleo familiar, acaba aparecendo aos nossos olhos muito mais do que antes, o que, por sua vez, não quer dizer que antes desse contexto de relação mais intensiva com os jurua, elas não atuassem na liderança interna do grupo de parentes.

$253 \mathrm{O}$ que acaba refletindo também um sentimento comum da etnologia guarani que, por muito tempo não se preocupava necessariamente com esse enfoque, apesar de Ladeira, enquanto mulher e antropóloga, já começar aí a se questionar o paradigma de só aparecerem homens na frente, lidando com a política externa. 254. Ciccarone também comenta que uma importante variável nas histórias das migrações "é que, desde a década de 50, o empreendimento indígena de ocupação e reconquista de espaços ficou a cargo principalmente de líderes femininas: além de Catarina e da filha Rosa, que se assentaram na área de Ubatuba, o tekoa de Barragem (Morro da Saudade), na Grande São Paulo, originou-se pela atuação de uma mulher, dona Vitalina, líder de um grupo proveniente do Paraná, que chegou ao litoral paulista antes de se instalar na Barragem, sem esquecer que num período posterior, Jandira e Helena, nora de dona Vitalina, retomaram a área de Aguapeu” (Ciccarone, 2001: 277).

${ }^{255}$ Região de Nhanderu retã, na qual existem "mais almas femininas", de acordo com Ladeira (2007 [1992]). Seriam estas “almas”, que vêm para “ajudar a 'tirar do perigo' a família, conduzindo-a para algum lugar verdadeiro", sendo necessário, que cada família tenha alguma "alma feminina” desse lugar, para ser "sua guia" (Ladeira, 2007 [1992]: 122). Assim, "as almas femininas de Nhanderu retã possuem a qualidade de reunir harmoniosamente a comunidade", não podendo "se ausentar muito do tekoa, para que possam cuidar 
portante reter aqui, é que os diferentes "papéis masculinos e femininos", seriam "regulados pelos próprios Nheẽ Ru Ete e Nheẽ Xy Ete (pais e mães das almas, respectivamente), que retêm as almas em sua região, conforme o sexo” (Ibidem: 133). Cada nome-espírito possui, portanto, tanto um "pai” e uma "mãe” divino como terrestre, que@ auxilia a cumprir sua missão aqui na terra, e que corresponde também à especialização (que pode variar) de cada gênero na produção-proteção do parentesco.

\section{Os problemas com as mulheres indígenas ${ }^{256}$ na Antropologia e entre os Guarani}

A Antropologia e seu histórico androcêntrico ${ }^{257}$ tem atribuído relevância secundária, chegando até mesmo a invisibilizar ou mesmo criar esteriótipos para os papéis e as produções das mulheres, principalmente as mulheres indígenas. Lasmar atenta para a quase total invisibilidade das mulheres indígenas da Amazônia na produção etnográfica de gênero, nas décadas de 1970 e 1980 (Lasmar, 1999: 147). A pouca visibilidade dada à temática era reflexo, segundo a antropóloga, em grande parte, da hegemonia da perspectiva masculina nas Ciências Sociais. Como alerta Overing, as mulheres serem ignoradas como "informants during the fieldwork process is, without question, a sad commentary both on lack of ethnographic objectivity and male bias in anthropological thinking" (Overing, 1986: 135-136). Ela questiona então a pretensão de "universality of such a bias": "Is male bias universal, or it is a more restricted 'problem' created by our own Western prejudices?” (Ibidem: 136). Para a antropóloga, tal viés parte da "ideology of the Western paradigma of power relations" (Idem). Seria por impor (imposing) "our own peculiar obsessions upon others" que apenas podemos ver "the others [...] as a (poor) reflection of ourselves” (Ibidem: 137). Dentro desse paradigma de poder e noção de política ocidental, estaria incluso "very specific notions about relations of domination and subordination, exploitation, coercion, control, and, of course, inequality” (Idem). A presença desse bias masculino nas descrições e análises antropológicas acaba então por deixar de lado a voz das mulheres, tendo sido denunciado e criticado já na década de 1970 por autoras como Rosaldo e Lamphere, na coleção de ensaios Woman, Culture and Society:

dele", além de ter "boa voz para o canto" obtendo destaque "ao dirigir as rezas coletivas", com boas "condições de organizar o grupo, de liderar e ensinar", podendo também “orientar o caminho para que o grupo possa encontrar Yry Maraẽy" (Idem).

${ }_{256}$ Esta é uma pequena homenagem-referência ao título do livro de Marilyn Strathern (2006 [1988]): “O gênero da dádiva: problemas com as mulheres e problemas com a sociedade na Melanésia”.

${ }^{257}$ Não podemos nos esquecer aqui das pioneiras nos estudos de gênero na Antropologia, Ruth Benedict e Margaret Mead. Para um balanço do histórico androcêntrico na Antropologia, ver Corrêa (2003). 
Because men everywhere tend to have more prestige than women, and because men are usually associated with social roles of dominance and authority, most previous descriptions of social processes have treated women as being theoretically uninteresting. Women who exercise power are seen as deviants, manipulators, or, at best, exceptions. (Rosaldo e Lamphere, 1974: 9 apud Overing, 1986: 135)

Dado o pressuposto implícito de uma desvalorização universal do domínio doméstico aos olhos dos etnólogos, a experiência social das mulheres era considerada de importância menor (Overing, 1986: 140). Por isso, de acordo com Overing, nós devemos "be wary about projecting our own value of 'the political' upon others", inclusive porque "all political ideologies are male biased', nos questionando se:

"the private/public" and the "domestic/political" dichotomies are universal contrasts and hold the same value as in the West. The assumption is that women are tied to the domain of the private and the domestic, and that this domain is devalued vis-a-vis the male public and political domain” (Idem, grifos meus).

Para a antropóloga, o que "is never recognized is that a principle of 'difference' can be just as much a mechanism for creating equality and complementarity as for creating hierarchy” (Ibidem: 141). A polaridade entre os gêneros, portanto, não implica, necessariamente, antagonismo (Lasmar, 1999: 150). E, muito menos, uma necessidade de dominação masculina (ver, nesse sentido, Overing 1986 e Strathern 2006 [1988], 2014a [1984]). Para Lasmar, a presença real ou virtual de violência nas relações entre os gêneros favoreceu “a aplicação de uma fórmula automática que transforma antagonismo em assimetria, assimetria em hierarquia e esta em dominação masculina”, dada a visão da violência como exercício do poder e do poder como valor (Lasmar, 1999: 152). Como argumenta Overing, "Western academic notions of order and rationality favor the play of dominance and subordination" e a partir disso:

they asume the (universal) authority of the logic of such hierarchical oppositions as reason over emotions, mind over the body, the universal over the particular, culture over nature, man over nature, man over woman - and of special importance to anthropological analysis, the political over the domestic and the public over the private. (Overing, 1986: 136, grifos meus)

No entanto, "ethnographic evidence supports the view that this particular package of values is not a universal” (Idem). A influência hegemônica, implícita ou explícita, da noção de dominação masculina, de acordo com Lasmar, contribuiu para tornar "menos acessível o ponto de vista das próprias mulheres indígenas sobre os processos sociais envolvidos na constituição das relações entre os gêneros” (Lasmar, 1999: 154). Diante dessa invisibilidade analítica das mulheres na Antropologia, a única maneira de "combater os efeitos das representações estereotipadas" é garantindo-lhes "visibilidade" (Idem). Inspirada pelo artigo de Overing (1986), que passa a pensar e entender a diferença e a 
igualdade a partir das ideias nativas e suas noções políticas e que sugere que as relações sociais entre os ameríndios seriam articuladas a partir de uma "noção filosófica sobre o que significa ser diferente e ser igual”, Belaunde entende que tal noção seria como "um princípio pan-amazonense que define a mistura adequada de coisas diferentes e iguais para a criação da existência social” (Belaunde, 2006: 208). Essa mistura de diferença e semelhança seria o que "mantém todas as relações de reciprocidade, incluindo relações entre pessoas do mesmo gênero e parceiros de gênero diferente", daí que ser "homem ou ser mulher não é uma dicotomia rigidamente definida”, antes tais relações correspondem a "uma dinâmica de igualdade dentro da diferença, e diferença dentro da igualdade" (Ibidem: 208, 233, grifos meus).

Franchetto (1996) busca também conferir visibilidade à experiência das mulheres Kuikuro, revelando suas ideias sobre corpo, poder, sexo, dor, amantes, a potência do rito das hiper mulheres e, sobretudo, sobre diferença entre os gêneros. Baseada em seus próprios dados etnográficos e a uma perspectiva que atribui às mulheres kuikuro, a antropóloga afirma que estudos etnográficos anteriores, embora importantes, silenciam o discurso dessas mulheres, pois ainda que, por exemplo, as próprias kuikuro falem da sua diferença em relação aos homens, elas discorrem ao mesmo tempo "sobre a sua posição desigual em uma relação hierárquica que elas não interpretam como dominação ou opressão, conceitos e sentimentos de uma condição feminina e de um discurso feminista que são produtos históricos e culturais específicos, ocidentais e modernos" (Franchetto, 1996: 53, grifos meus). De acordo com Franchetto: "A força da oposição homens/mulheres, operativa na sociedade [...] é tão produtiva quanto a famosa complementaridade. Aliás, não há complementaridade sem oposição" (Idem, grifos meus).

Gênero e sexualidade, de acordo com McCallum (2013), fazem parte dos modos de conceber e constituir (ou não) as relações sociais com seres marcados pela alteridade. Em seu estudo da noção de pessoa entre os Kaxinawa, a antropóloga afirma que o "gênero é conhecimento corporificado", uma vez que gênero e corpo seriam inseparáveis (McCallum, 2001: 5 apud Belaunde, 2006: 215). Os conceitos melanésios de atividade coletiva e corporal seriam, nessa mesma linha, "equivalentes a uma teoria da ação social" (Strathern, 2006 [1988]: 151). A ação, de acordo com Strathern, é uma atividade que possui gênero (Ibidem: 22). Ao se perguntar sobre o "gênero da dádiva", a antropóloga, além de se questionar sobre a situação da troca de presentes nas socialidades melanésias, também se indaga "sobre o 'gênero' dos conceitos analíticos, sobre os mundos sancionados por hipóteses específicas” (Idem). Pois, nos anos 1970, a separação entre os domínios 
"público" e "doméstico" serve "como uma ferramenta de discriminação analítica com potencial universalizador" (Ibidem: 126-7). Daí que, o gênero, para ela:

demarca diferentes tipos de atuação [agency]. As pessoas impactam [impinge] umas às outras de maneira diferenciada, e imaginar âmbitos de eficácia "masculinos" e "femininos" tornase uma maneira de trazer à tona esses diversos tipos (Wagner, 1974, p. 112). Por um lado, a eficácia deriva da ação coletiva, baseada no compartilhamento de identidade; por outro, de relações particulares, baseadas na interdependência e na diferença entre pessoas. Assim, as imagens de gênero diferenciam a socialidade que, por conseguinte, é concebida como assumindo sempre uma de duas formas. (Ibidem: 152-3, grifos meus)

Gênero é visto então como uma fonte poderosa de simbolismo, uma vez que os contrastes entre o que as mulheres fazem e o que os homens representam são entendidos como os contrastes entre a ação doméstica e a ação política, ou entre estados mundanos e estados espirituais (Strathern, 2014a [1984]: 110). Sua ênfase nas relações parte do fato de que construções simbólicas desencadeiam o gênero e a "posição"258 dos homens e das mulheres uns em relação aos outros, uma distinção analítica importante a seu ver, apesar da grande confusão a respeito dessa relação no registro etnográfico (Idem). Sobre a teoria do gênero proposta por Strathern, Viveiros de Castro (2011c) reflete:

Acho que Strathern é infinitamente mais próxima de Lévi-Strauss do que Héritier, porque ela tem, de fato, uma teoria estrutural de gênero. Tal como entendo a concepção de gênero de Strathern, o gênero não é uma relação entre dois sexos, mas é uma relação entre duas relações, uma relação de tipo "mesmo-sexo" e uma relação de tipo "sexo-oposto", o que é uma ideia que se pode deduzir de Lévi-Strauss. (Viveiros de Castro, 2011c: 21-22)

Contra a metáfora ocidental organizadora de "sociedade" que "induz a questões relativas à razão pela qual os homens estariam numa posição privilegiada de determinar a ideologia ou de criar os próprios fundamentos da ordem social em seu proveito” e, que não serve para a compreensão das formas de vida coletiva melanésia, Strathern sugere:

as ações coletivas deveriam ser vistas como um tipo de socialidade que, como tal, coexiste com outro, a saber, a socialidade manifesta nas relações domésticas, particulares. A relação entre as duas é de alternância, não de hierarquia. Os valores de uma estão sempre em contraposição aos da outra. Mas o que talvez mais nos confunda é que uma só pode ser conhecida como uma transformação da outra. (Strathern, 2006 [1988]: 459)

Por isso, se na máxima de Mauss (2003 [1925]), “a coisa dada é personificada”, uma vez que os itens de troca criam vínculos entre as pessoas, “a própria coisa é uma pessoa ou pertence a uma pessoa”, a máxima de Strathern parte da ideia que, além disso, também é importante se atentar para "maneira como a própria pessoa é construída" (Strathern, 2014a [1984]: 119; 132). Daí que, ao utilizar aqui o termo "mulheres" genericamente, não pretendo tomá-lo enquanto uma categoria universalizadora, sem suas

${ }^{258}$ Cada gênero possui uma "posição a partir da qual agir. Cada posição é uma posição específica ocupada com relação a outras posições específicas” (Strathern, 2006 [1988]: 460). 
próprias nuances e contextos de enunciação e entendimento, uma vez muito da teoria antropológica feminista, principalmente, da literatura pós-colonial, já discutiu sobre essa questão e não cabe a mim, aqui, retomar, mas apenas refletir sobre maneiras possíveis de se pensar, construir ou de se fabricar enquanto uma mulher mbya. A intenção aqui, portanto, é estabelecer um diálogo com as mulheres mbya que são distintas não só entre si, mas também em relação a outras mulheres como, por exemplo, as xaryi (mulheres nãoindígenas), sendo ambas construídas a partir de vivências e socialidades diversas que podem se comunicar entre si, mas com cuidado, respeitando suas particularidades.

A partir do que viemos mostrando até aqui, podemos perceber que a importância das lideranças espirituais é amplamente discutida pela produção etnológica sobre os Guarani, ainda que raramente a centralidade das mulheres no xamanismo seja abordada, revelando uma série de lacunas teóricas e etnográficas a esse respeito. O xamanismo foi então pensado a partir de um "discurso centrado nos critérios dominantes da masculinidade, tornando invisível a dimensão feminina” (Ciccarone, 2001: 226). Como alerta Ciccarone: "no se ha dado importancia al papel de las mujeres como líderes chamánicas y como articuladoras de la vida social y de las redes familiares" (Ciccarone, 2004: 81). Daí que, o predomínio de um olhar androcêntrico da tradição etnológica tenha resultado no "escasso interesse pela dinâmica da vida social e pelas formas de poder gerido pelas mulheres" (Ciccarone, 2001: 226). Segundo a antropóloga, se escutarmos os Mbya:

em vez de continuarmos com nossa atitude de surpresa diante de um acontecimento apa-
rentemente tão extraordinário, descobriremos que, para eles, trata-se de um evento ab-
solutamente normal, pois não há, na sua organização social flexível e frouxa, divisões sociais
rígidas, nem diferenças de gênero quanto à inspiração xamânica, e nem tampouco na ocupação
de cargos de liderança. Masculino e feminino são ordens de representações e universos de socia-
bilidade não contrapostas, mas complementares, e garantem a possibilidade de uma transfe-
rência de funções, como princípio que preside a organização da sociedade. (Ibidem: 278 ,
grifos meus)

O que fica evidente na fala de uma liderança guarani para Ciccarone:

\begin{abstract}
Antes tinha bastante mulher, cunha karai que a gente fala. Elas tinham força, bastante força, como cunha karai; não tinha, não tinha machismo, essas coisas também não existiam dentro de uma aldeia. Se ele não tiver fé, por exemplo, cunha karai está ali, está percebendo, eles (os homens xamã) tinha conselho das mulheres que são somente cunha karai, eles sentavam, conversavam, quer dizer, não tinha divisão nenhuma. (Timóteo Vera Popygua apud Ciccarone, 2001: 223-224, grifos meus).
\end{abstract}

Essa disposição de estar à frente, viria a partir do próprio nome-espírito, que funciona como uma "regra" recebida pelas divindades, segundo uma interlocutora:

a partir do nome da pessoa ela exercia uma função, então existiu grandes líderes mulheres no passado que lideravam uma comunidade toda né, e não era uma política imposta pelo homem, era uma lei, uma regra recebida diretamente de Nhanderu, então todos que estavam nessa função, recebia o chamado [...] [como a kunhã karaı] Tataxĩ, que fez a 
caminhada dela desde o Paraguai até o Espírito Santo, e ela passou pelo Morro dos Cavalos [...] ela liderou em nome de Nhanderu, eu já sou mais política mesmo. (Kerexu Yxapyry da T.I. Morro dos Cavalos [SC], Local: Tekoa Tenonde Porã 2015, grifos e alterações minhas)

No Tekoa Boa Esperança (ES), Ciccarone observa que ao redor da grande líder xamânica Tataxĩ, formou-se um grupo de mulheres que detinham e articulavam posições de poder e prestígio dentro da aldeia, e que pela sua maior visibilidade e abertura à sociedade regional facilitou seu contato com elas. E é pelo que ela qualifica de "poder dos afetos" que estas mulheres revelavam o "desejo de serem ouvidas" (Ciccarone, 2001: 20). Daí o despertar do seu desejo, como mulher e antropóloga, de "olhar para a vida familiar e o mundo cotidiano, que cabia às mulheres salvaguardar, administrar e gerir, como guardiãs da ordem social, junto aos/às xamãs" (Idem). Daí também ser possível pensar as kunhãgue como xondaria, guardiãs do corpo de parentes, em sua disposição central de nutrir-cultivar-cuidar do coletivo. Por isso, em sua tentativa de qualificar melhor a posição das mulheres no sistema guarani, Ciccarone observa nas análises jurua das versões míticas, o mundo dos deuses sendo marcado pela ênfase na masculinidade e em uma predominância do discurso cosmológico sobre a análise da vida social:

apesar de fundamentarem-se na relação de complementaridade entre o masculino e o feminino, na ambivalência constitutiva do ser criador e no princípio vital feminino [que, segundo Ciccarone, estaria associado ao elemento líquido simbolizado pela divindade "Jachuka"259], as narrativas míticas aparecem em segundo plano numa perspectiva centrada na masculinidade do extraordinário mundo mbya. (Ibidem: 19, alterações minhas)

Apesar de reconhecer que muitas mulheres que não ocupam cargos "oficiais" como, por exemplo, o cargo de "cacicas", são consideradas como lideranças centrais na organização política das aldeias, desempenhando um importante papel decisório aí, o trabalho de Rebelo tem como foco a atuação das "mulheres cacicas", e não essas outras mulheres "influentes, como as esposas dos caciques, lideranças religiosas femininas ou mulheres mais velhas e, portanto, mais sábias das aldeias” (Rebelo, 2015: 35). A autora assinala que a "naturalização" da ocupação de cargos e posições de liderança ou chefia como sendo exclusivamente masculinas se consolidou com a teoria sobre chefia de P.

\footnotetext{
${ }^{259}$ A respeito disso Cadogan, baseado no relato dos seus interlocutores guaraní, comenta: "El lugar donde vivió originariamente nuestra abuela se llama el lugar de las aguas surgentes. Dicho lugar es el centro de la tierra, el verdadero centro de la tierra, el verdadero centro de la tierra de nuestro padre Pa-pa Mirî" (Cadogan, 1959: 72). O termo ygua é traduzido como "fuente", mas também expressa o nome "Ygua Yvu 'Lugar de las Aguas Surgentes", situado en 'Yvy Mbyte, el Centro de la Tierra llamado por algunos Yvy Puru'ã Ombligo de la Tierra; fue en este lugar sagrado donde apareció Ñande Jarýi Nuestra Abuela, madre del héroe solar, y ete" (Cadogan, 1992: 193). "Jachukáva”, na linguagem ritual, seriam "las que llevan el emblema de la feminidad" (Cadogan, 1959: 28). No vocabulário "religioso", "jachukáva vyapu = himno o canto sagrado de la mujer", tendo como "equivalente" na linguagem "ordinaria" o termo "akãoja poty = las flores que adornan la cofia de la mujer" (Idem). Ja os homens, seriam chamados ritualmente de "Jeguakáva", "los que llevan el emblema de la masculinidad" (Idem).
} 
Clastres, uma base teórica central na literatura etnológica clássica sobre os Guarani. Nesta obra, o "termo poligamia - casamento de uma pessoa de ambos os sexos com mais de uma pessoa ao mesmo tempo - foi muitas vezes usado como sinônimo de poliginia casamento entre um homem e mais de uma mulher ao mesmo tempo -, sem qualquer reflexão crítica”, colocando a chefia como atributo exclusivamente masculino (Ibidem: 45). As etnografias clássicas sobre chefia também omitem ${ }^{260}$ a contribuição das mulheres, daí as extensas lacunas teóricas (e etnográficas) não apenas sobre a (dis)posição das mulheres indígenas como lideranças, mas também sobre as mulheres indígenas em geral.

De acordo com Passes (2004), a prolongada ênfase dos estudos etnográficos sobre sociedades "tradicionais" na importância dos homens enquanto aqueles que falam, considerados como os únicos "agentes" políticos e sociais, persiste eclipsando a agência política das mulheres, apesar de pesquisas atestando justamente o contrário ${ }^{261}$. O autor atesta que muito, se não a maioria, do trabalho antropológico em linguagem política coloca-a em termos apenas de "discurso formal", tomando como objeto de estudo apenas os falantes instituídos nessa arena (Passes, 2004: 1). O foco das pesquisas insiste em permanecer, tratando as mulheres enquanto audiência ao invés de verdadeiras agentes políticas, apesar dos dados regionais a respeito de suas falas públicas e evidências indicando a existência de chefes femininas (Ibidem: 1-2). Seria a partir da suposição de que apenas

${ }^{260}$ É importante ressaltar que os autores dos estudos clássicos acerca dos Guarani se inserem dentro das tendências teóricas e metodológicas de um projeto androcêntrico de Ciência, que não ex clui a Antropologia (ver, neste sentido, Overing 1986). P. Clastres, no entanto, realiza um importante estudo de gênero, ainda que marcado pelo viés masculino presente na etnologia da época (O arco e o cesto, 2003 [1966]). Ao final do Infortunio do guerreiro selvagem (2011 [1977]), o autor também traz questões interessantíssimas sobre gênero, como por exemplo, a ideia das mulheres (nessas sociedades contra o estado e para-a-guerra) como seres-para-a-vida e os homens (seres-para-a-guerra) como seres-para-a-morte, ressaltando "uma proximidade essencial entre masculinidade e morte" e "uma proximidade imediata entre vida e feminidade (Clastres, P. 2011 [1977]: 286-287). O autor comenta então sobre o "controle sociológico" das mulheres sobre a "produção de filhos" e, portanto, sobre o futuro mesmo da sociedade, reconhecendo aí uma espécie de "superioridade" das mulheres, baseando-se para isso, em mitos, ritos e na observação da vida cotidiana, mas não entra em muitos detalhes sobre, apenas levanta a importância de se realizar "longos" e "sérios" estudos a respeito disso. Ainda assim, é importante nos atentarmos que as mulheres não são apenas reprodutoras biológicas ou as únicas criadoras do social nessa produção-criação-cuidado d@s nov@s guerreir@s (ainda que tenham papel absolutamente central aí), e nem precisam ser lidas apenas como seres que tem uma espécie de "vocação" natural para ser mãe, mas é importante atentar também para essa capacidadepoder social das mulheres sim (ainda que isso levante grandes responsabilidades e, por isso mesmo, inúmeras cobranças sobre elas), sob o risco de cairmos (mais uma vez) naqueles cortes profundos entre natureza e sociedade que tanto criticamos aqui! Sua disposição social de mãe, tia, avó e-ou sogra (junto a seus companheiros) é extremamente fundamental na produção (e dissolução) das socialidades ameríndias. A intenção de P. Clastres, ao final desse artigo é demonstrar a intencionalidade política das mulheres, colocando-as na mesma linha de valor-poder que os homens. Nesse sentido, tanto as mulheres como os homens podem ser entendidos como seres-para-a-vida e como guerreir@s que são, ambos são preparados-treinados tanto para a morte como para a vida. Tanto a guerra é importante para a vida, como a vida é importante para a guerra, ambas atuam assim na produção-proteção do coletivo.

${ }^{261}$ Sobre a importância da fala das mulheres, ver também Kulick (1993). 
a fala pública é política que frequentemente se presume que as atividades femininas seriam limitadas à arena doméstica ou privada (mesmo em sociedades igualitárias), silenciando-as politicamente e tornando-as politicamente silenciosas (Ibidem: 1). Haveria então, segundo Passes, uma relativa falta de preocupação da Antropologia na conversa cotidiana (Ibidem: 2). Permanece a visão de que os homens, supostamente os "únicos" autorizados pelo grupo para falar, estariam de algum jeito separado do mundo de todo dia que eles falam para e pelo qual eles atuam, através de suas palavras (Idem). Por isso, neste artigo o autor, ao explorar ideias sobre poder, discurso e fala, argumenta que entre os Palikur (Pa’ikwené da Guiana Francesa), povo de língua aruak, a esfera verbal-oral cotidiana e feminina tem tanto efeito político no processo da vida comunitária como os discursos oficiais (Ibidem: 1). Nesse sentido, o discurso político não seria só prerrogativa de líderes ou de homens, institucionalmente autorizados ou não. A fala cotidiana, comum aos aldeões, segundo Prates, é no caso das mulheres, entre outras coisas, integralmente política e não mais "impotente” que a chamada "fala vazia262" postulada por P. Clastres.

Passes se concentra então em um gênero verbal específico, o "scolding” "bronca”, "repreensão"), para mostrar como as mulheres amazônicas Palikur, não só contribuem produtivamente, como publicamente, assim como os homens, na vida social (Ibidem: 2). Seus interlocutores Palikur, parecem considerar as mulheres politicamente iguais aos homens, e seus atos, ações, feitos e palavras tão importantes quanto na criação e manutenção da socialidade e da “ordem”. Ele observa, então, como as mulheres Palikur constroem gênero na pragmática e performance do ato interpessoal do "scolding" como uma forma de controle de comportamentos, como um meio para manter o equilíbrio quando tendências masculinas anti-sociais ameaçam desestabilizá-lo. Nesse sentido, o poder feminino Pa’ikwené não é só dramaticamente representado nessa performance: "it is embodied behaviour (re)productive of the polity, and 'heard-understood' as such by both parties" (Ibidem: 11). O autor comenta também como a "fofoca" (gossip) é uma forma de controle social, chamando atenção para o caráter político intrínseco à esfera doméstica e para o poder das mulheres aí e além (Idem). Nesse contexto, a fala cotidiana das mulheres também pode ser considerada como fala política (“political speech”). Assim, de acordo

\footnotetext{
262 O "poder" do qual as palavras d@ chefe(a) ou da(s) liderança(s) encontram-se esvaziadas é de poder coercitivo, o que permitiu P. Clastres afirmar que estes personagens não dispõem de uma autoridade autoritária, regida pela lógica do comando-obediência, próprio às sociedades com Estado. É muito importante não confundir "poder com coerção e autoridade com autoritarismo", uma vez que é "possível encontrar nas palavras das lideranças mbya um poder (ou potência) notável, que está, inclusive, no cerne da constituição da autoridade ou capacidade reconhecida para se colocar à frente de um coletivo" (Testa, 2014: 207-208).
} 
com Passes, o “Pa’ikwené women’s scolding” não só corporifica seu próprio poder político como também gera relações de gênero simétricas e, por conseguinte, o sistema Palikur ele mesmo.

Falar caminhando no meio da opy (ou mesmo em outro local que estão reunidos entre si), por vezes segurando o petỹgua nas mãos, é um costume guarani, por sinal muito valorizado, sendo possível perceber aí a dinâmica da fala não-impositiva, que conversa e aconselha e que não se sobrepõe às demais, onde todos (homens e mulheres) idealmente têm direito à fala e a utilizam se acharem necessário, visto que há uma relação direta entre a palavra falada e a inspiração divina. Ainda assim, em articulações inter-aldeias ou mesmo extra-aldeias, algumas lideranças se destacam, e teriam maior acesso à fala (espera-se que eles falem) do que os demais, pois há o entendimento de que sabem manejarcontrolar melhor tanto seus saberes-poderes, como suas opiniões e argumentos, iluminando os presentes através da sua fala inspirada ${ }^{263}$ - a figura d@ cacique e das lideranças espirituais, masculinas e femininas desempenhariam, portanto, tal capacidade de forma maximizada. A respeito da fala política Pimentel observa que, nos últimos anos, as mulheres kaiowa e guarani têm se imposto cada vez mais nas assembleias da Aty Guasu, e diante das suas insistentes reivindicações por maior espaço para discutir temas de seu interesse, em 2012 dão início às Kunhã Aty Guasu, ou “Aty Guasu das mulheres”. Essas reuniões, surgem a partir de uma “espécie de 'rebelião’ das mulheres” em uma Aty Guasu ocorrida em 2012, na qual "acusando os moderadores do conselho de cercear-lhes a palavra, um grupo de mulheres tomou o microfone e, diante de representantes da Funai, elas passaram várias horas em discursos inflamados" (Pimentel, 2012: 241). Nesse mesmo movimento, classificado pelo antropólogo como uma "novidade", surgem também as "Aty Guasu dos jovens".

Tais iniciativas sinalizam “a necessidade de ‘fazer públicas' outras vozes e outros temas", daí que "o dilema atual das mulheres” passa, na avaliação do autor, pelas dificuldades de colocar em pauta temas centrais para o coletivo como saúde, educação, alimentação, "sem tornar-se refém do discurso do governo do Estado" que, a seu ver institucional, considera que essa discussão a respeito do acesso às políticas públicas deverá acabar se sobrepondo ou mesmo substituindo a reivindicação pela demarcação de terras (Ibidem:

\footnotetext{
${ }^{263}$ Sobre o "dom” da palavra meus interlocutores mbya traduziram como ayvu reno'ã, "aqueles que sustentam a palavra”. Para ser liderança, no sentido amplo do termo deve-se que possuir o "dom da palavra”, os únicos que seriam mais "dispensados" desse dom seriam os xondaro, como comentou comigo certa vez uma interlocutora. Dooley traduz o radical -eno'ã por "levantar algo enquanto levanta a si mesmo: orerete' $i$ rogueno'ã levantou os nossos corpos (expressão tradicional referente a uma pessoa com mal espiritual)” e por "levantar (outra pessoa junto consigo, uma parte do próprio corpo, ou o corpo inteiro, etc.): xepo re ava ojopy vy xerereno'ã o homem pegou na minha mão e me levantou (junto consigo)” (Dooley, 2006: 3, 36).
} 
240-241). Segundo Pimentel, "uma mulher pode assumir a liderança de um grupo familiar, com auxílio dos filhos homens", ou "em função da morte do marido", além dos cargos ocupados por elas nas escolas que podem, por exemplo, "dar a certas mulheres a possibilidade de uma tal atuação política que pode "puxar uma fila” (Ibidem: 129). No entanto, ele alerta: "essa posição expõe muito a pessoa a disputas políticas de toda ordem, de tal forma que, ao menos nos casos em que observei, a mulher procura resguardar-se" (Idem).

Mello busca oferecer um contraste às etnografias que registram as palavras de "homens, líderes políticos e religiosos, em detrimento da perspectiva das mulheres" (Mello, 2006: 21). Segundo a antropóloga, é importante lembrar, no caso Guarani, que estamos diante de um "sistema de autoridade xamânica e etária", em que aqueles[as] que ocupam uma posição de autoridade, atuando com uma liderança "política" ou "religiosa", a exercem “através de conselhos e não de ordens”, uma vez que o poder aí se dá pelo "reconhecimento social" da sabedoria ("arandú porã"), "reflexo da capacidade de comunicação com outros planos" (Ibidem: 100-101). Nessas posições de autoridade interna, "a figura feminina é recorrente, explicitando uma divisão sexual do trabalho político, no qual os homens cuidam de assuntos externos e as mulheres de assuntos internos" (Ibidem: 101). Enquanto lideranças espirituais da família extensa, a xejaryi e o xeramoĩ, "figuras centrais na estruturação social, política e religiosa de uma aldeia”, seriam aqueles que decidiriam, "as estratégias e as tarefas que cada membro da família deve desempenhar para garantir a subsistência material e a manutenção das regras morais e de comportamento das pessoas do grupo" (Idem). A essas figuras, chamadas no plural pelos interlocutores de Mello de “karaikuery”, caberia assegurar que os nhe'ẽ enviados para a terra pelas divindades, aqui permaneçam, garantindo também a manutenção da humanidade dos seus parentes, no que consiste o fundamento mesmo do seu "trabalho".

É interessante notar também que uma ideia que perpassa as ideias mbya a respeito do desvio de caminho e a predação nessa terra tenha também origem mítica, com a criação da plataforma terrestre atual, e envolva a mãe de Kuaray (Sol), Nhandexy Tenonde. Na narrativa de criação da Segunda Terra ( vy Pyau), a caminhada é "inaugurada por uma mulher na condição humana e grávida, futura mãe de Kwaray o Sol” (Ciccarone, 2004: 85). Que, ao "desviar de seu caminho retilíneo, é devorada pelos seres malignos, as onças", enquanto seu filho, o Sol, desvia da morte, sendo criado pela avó das onças, e num movimento de desdobramento, dá origem ao seu irmão, Lua (Idem). Seria dessa mulher terrena que gesta e dá vida ao "herói civilizador", um ser divino, que se origina 
"a vida da sociedade, mas a ênfase no desvio na caminhada que a conduz para a morte ${ }^{264}$, a transforma na responsável da transgressão" (Ibidem: 90, grifos meus). Trata-se da origem mítica desta terra tekoaxy, marcada pela desordem e pelo anúncio de sua destruição.

Em sua reanálise dos mitos, Ciccarone comenta que a "mulher é antes um personagem humano, mortal e imperfeito do que divino e eterno", apesar de ser ela "que inaugura o movimento da caminhada que dá origem ao mundo terreno, ao mesmo tempo que, por excesso de afeto materno, torna-se responsável pelo desvio do percurso que conduz à morada divina" (Ciccarone, 2001: 15). Entretanto, a autoria da criação do mundo terreno é atribuída a "seu filho, divindade solar, assim como as migrações - interpretadas como refundações do mundo - são conduzidas, segundo os relatos etnológicos, na grande maioria, por homens xamãs" (Idem). Como uma interlocutora mbya enfatiza:

existiu [lideranças] mulheres no passado, mas depois do contato que começou a vir mais esse preconceito, começou a criar um mito em cima dessa questão né [.... a gente tem o mito do Kuaray e Jaxy, que é a história do Sol e da Lua, que fala que a mulher errou lá no passado e a que a mulher vai fazer de novo, que a mulher vai errar e vai perder toda a aldeia, ou vai se perder né, então é um mito que foi criado pelo homem, não foi Nhanderu que fez o mito, foi o homem né, porque Nhanderu quando criou a mulher, ele fez a mulher pra ser ajudante dele, então "nossa" que poder maior que a mulher poderia ter de que ser uma ajudante de Nhanderu né [...] e foi ela que gerou o Kuaray que é o Sol, que a gente tem até hoje né, então foi ela que fez tudo isso né [...] e a partir dali da história de Kuaray e Jaxy que vem todas essas provações pra cima da mulher. (Kerexu Yxapyry da T.I. Morro dos Cavalos [SC], Local: Tekoa Tenonde Porã, 2015, grifos e alterações minhas)

Ciccarone ressalta a imagem ambivalente da "mulher terrena que, na origem da construção da sociedade mbya, é ao mesmo tempo objeto de desconfiança e suspeita”, assim como uma aliada-companheira de Nhanderu Tenonde (Ciccarone, 2001: 68). Em algumas versões das narrativas míticas a esse respeito, é possível perceber a relação estabelecida entre a mãe de Kuaray, Nhandexy, e a desobediência ou desconfiança em relação à palavra de Nhanderu, como por exemplo, na versão apresentada por Nimuendaju (1987 [1914]: 47-49), que comenta que "por causa da incompreensão desta [Ñandecý], tal convivência [com Ñanderuvuçú] não dura muito":

O criador havia erguido sua casa no centro da terra, e perto dali iniciou sua plantação. À medida que $\tilde{N}$ anderuvuçú avançava, derrubando a mata, a roça atrás dele plantava-se sozinha, brotava, e quando ele retornou do trabalho já havia milho verde. Ele mandou que

${ }^{264}$ Há uma certa relação entre essa morte e a metamorfose animal, uma vez que a mãe de Kuaray, Nhandexy Tenonde, ao não conseguir voltar à vida apesar das tentativas de Kuaray em ressuscitá-la a partir de seus ossos. A impaciência de Jaxy em mamar em seu peito, deixa-a ainda mais fraca, e ela acaba sendo metamorfoseada em paca (jaixa), caça superestimada e sagrada entre os Mbya. No entanto, na versão do mito descrita por Nimuendaju, diferente de algumas versões Mbya, a mãe não se metamorfoseia em animal sagrado, mas adquire a condição divina, sendo conduzida por Nhanderu à sua morada: "Ñanderyqueý, o gêmeo filho de Ñanderuvuçú, esforça-se em vão para reconstituir o corpo de sua mãe com os restos que encontra, mas seu próprio pai leva a alma dela consigo e 'a torna forte de novo para si'; e assim ela vive ainda hoje no longínquo Oriente, além do mar, na "Terra sem Mal”' (Nimuendaju, 1987 [1914]: 49). Sobre o mito dos irmãos Sol e Lua, ver também Cadogan (1959: Capítulo VIII) e Pierri (2013a: 35-38). 
Nandecý fosse buscar milho à roça, mas esta, não querendo crer que já houvesse frutos, e irritada por uma solicitação que lhe parecia insensata, acrescentou maldosamente: "Não estou grávida de ti, mas de Mbaecuaá [auxiliar de Nanderuvuçú]?”. Aí Ñanderuvuçú se revela um verdadeiro Guarani: não responde, e muito menos castiga diretamente a desobediência; mas quando $\tilde{N}$ andecý afinal apanha seu cesto e vai à roça, ele põe seu enfeite de penas, toma o maracá e a cruz e se vai, para nunca mais voltar de modo duradouro. Ali onde seu caminho para o céu se separa daquele que conduz à morada do Jaguar Originário, finca no chão a cruz, torcendo os braços desta de modo a fechar o caminho que tomou e a deixar aberto o que leva ao Jaguar. [...] A mulher fica completamente entregue à sua sorte, e quando procura seguir a pista do marido, é devorada pelos jaguares. (Nimuendaju, 1987 [1914]: 48-49, alterações minhas)

Segundo Prates, o mundo mbya atual foi criado por Nhandexy:

se pensarmos que decorre das consequências de suas atitudes. Foi por conta de seu gesto que toda sorte de acontecimentos se passou com Kuaray e Jachy. Podemos também pensar que foi graças a ela que a morte e a instabilidade da forma foram instauradas na vida mbyá. Ela agiu de maneira anti-social, não respeitando o bom uso da oratória e agredindo ${ }^{265}$ verbalmente seu marido e seu filho. Seu destino foi o encontro com o jaguar (chivi/onça). (Prates, 2013: 214-215)

Dessa personagem ambivalente da qual origina-se o poder de dar a vida ao ser divino, também é atribuída a responsabilidade pelo desvio de conduta que a leva à morte, instituindo, ao mesmo tempo, a "função sagrada da maternidade e a transgressão" na caminhada da socialidade mbya ao longo de sua existência terrena (Ciccarone, 2001: 66). No entanto, aqui nesta terra tekoaxy, seriam os homens que sofrem de maior "fraqueza", transgredindo normas sociais e impondo grandes dificuldades na superação dos momentos de crise pelo qual pode passar o grupo: "Os homens geralmente esquecem as regras, os filhos, a esposa. Nós mulheres, entendemos mais todas as coisas, então a gente tem que suportar e dar conselhos para eles, para que um dia eles vão melhorar” ("Dona Maria” [Tatatĩ] apud Ciccarone, 2004: 91, grifos meus).

\footnotetext{
${ }^{265}$ A versão registrada por Prates comenta que "Ñandesy, mulher de Ñanderu Papa, respondeu grosseiramente a um pedido de seu marido para que aquecesse a água para o chimarrão. Ele estava sentado à beira do fogo e ficou bastante triste com o tom de voz empregado por sua mulher. Ficou tão triste que resolveu partir", abandonando-a (Prates, 2013: 213). Ao tentar segui-lo, em sua caminhada foi orientada por seu filho, Kuaray, que lhe pedia recorrentemente flores de presente, o que ela lhe dá prontamente, correspondendo a seus pedidos, o agradando, mas que, em certo momento, se irrita com tantos pedidos, pois é picada por uma abelha: "Respondeu, então, aos gritos que estava cansada de ter que agradar ao filho. Assim como fora grosseira se deixando levar pela fúria com seu marido Ñanderu Papa, Ñandesy repete a atitude provocando o silêncio de seu filho Kuaray. Triste, ele se cala e não responde aos pedidos de orientação que sua mãe lhe faz. Por não saber escolher o caminho que a levaria a Ñanderu Papa, Ñandesy toma o caminho que a leva ao encontro das onças (chivi)" (Ibidem: 214). Na versão do mito apresentada por Cadogan (1959), ainda que haja uma certa desconfiança da mãe de Kuaray - cujo nome nessa versão é Pa’i Rete Kuaray -, em relação à palavra de Nhanderu, não há uma agressão verbal direta a ele: "Nuestro Padre [chamado, segundo os interlocutores de Cadogan, 'Pa-pa Mirĩ ou 'Namandu'] sentó precedentes para nuestra futura conducta. Producidas estas cosas, quiso abandonar su tierra. -Vamos a mi morada, dijo a su esposa. - No quiero ir; será mala tu esposa, la verdadera madre de tus hijos que está en los paraísos. Y diciendo ésto, se quedó" (Cadogan, 1959: 71, alterações minhas). No entanto, ela se irrita com seu filho, depois de ser picada por uma abelha, sendo também "abandonada" por ele: "Volviendo a coger aquella, pico a su madre un abejorro, enojándose su madre por ello, y dijo: - Solamente despues de estar entre la gente debemos pedir juguetes [...] Preguntó la mujer acerca del caminho que habia seguido su padre, pero no le contestó" (Ibidem: 73).
} 
Os desvios de conduta estão no horizonte da vida coletiva, mas a transgressão ligada à sexualidade, "é provavelmente o mais difícil desafio para o caminho do fortalecimento espiritual e nessa situação é mais evidente a fraqueza dos homens": "Quando chega a prova das mulheres, os homens dificilmente conseguem superá-la”, segundo um interlocutor de Ciccarone (2001: 93). Nessa "representação masculina” desse interlocutor, a mulher simbolizaria "a fonte da desordem, o poder da morte”, segundo a antropóloga (Idem). No entanto, o desafio do desejo se impõe a ambos, tanto para os homens, como para as mulheres, podendo atingir até mesmo@s xamãs, ainda que seja “maior a cobrança coletiva sobre a conduta feminina, pois, o Karai pode encontrar, diante da ameaça do desejo, apoio na sua esposa”, mas o mesmo não ocorre com as kunhã karai (Idem). No discurso da kunhã karai Tatatĩ fica claro que os erros das lideranças espirituais, modelo de conduta e de legitimidade às normas coletivas, afetam toda a comunidade:

Os homens geralmente esquecem as regras, os filhos, a esposa, quando tem esta prova (das mulheres) por isso acontece de um Karai (xamã) deixar o espírito ir embora, voltar ao lugar onde fica o Pai. Com isso geralmente a morte ataca, então ele deixa os filhos e tudo por uma cunha recore-i (mulher que não tem compromisso com o bem). Quando se chega nesta prova da mulher, a maioria dos Karai ficou para trás, não conseguiu superála. Que os Karai sejam fortes, principalmente aqueles que já têm mulher, pensem muito na esposa, encontrem força nela. Para as cunhangue-i, as cunha Karai (mulheres xamã) é a mesma coisa, tem a prova do ava recore- $i$ (o homem que não tem compromisso com o bem). As mulheres também quando não conseguem passar a prova, o espírito delas sai do corpo, a gente fica fraca, pode atacar a morte, ela chega mais rapidamente, chega a doença e todo o tipo de mal afeta mais. E quando os Karai e Cunha karai erram, isso afeta toda a comunidade. (Tatatĩ apud Ciccarone, 2001: 93, grifos meus)

Muitas das representações tidas como "nativas" a respeito das mulheres são, na maioria das vezes, de autoria de figuras masculinas, interlocutores privilegiados pel@, antropólog@, de acordo com Ciccarone (2004: 91).É nesse sentido que imperam as acusações, reservadas às mulheres, "enquanto responsáveis da desordem introduzida pela transgressão, principalmente das normas dos casamentos, provocando o crescimento da população mestiça na aldeia” (Idem). Talvez venha daí a conduta das mulheres mbya ser submetida a um intenso e "contínuo controle e cobrança, principalmente das mais velhas", cujos “excessos” eram apontados, por estas anciãs, como "os indicadores mais graves do processo de deterioração do modo de vida da sociedade" (Idem). No entanto, como comentamos antes, as "transgressões sexuais", das quais as mulheres carregavam todo o peso, eram comuns também aos homens (Ciccarone, 2001: 61). Por isso, ainda que a coletividade pareça ser "mais tolerante com os desvios dos homens", caberia às mulheres, internamente, o papel de torná-los explícitos e cobrar sua responsabilidade na crescente desordem coletiva (Idem). Daí a ambivalência da sua imagem como "agente da desordem" e "reprodutora da ordem". 


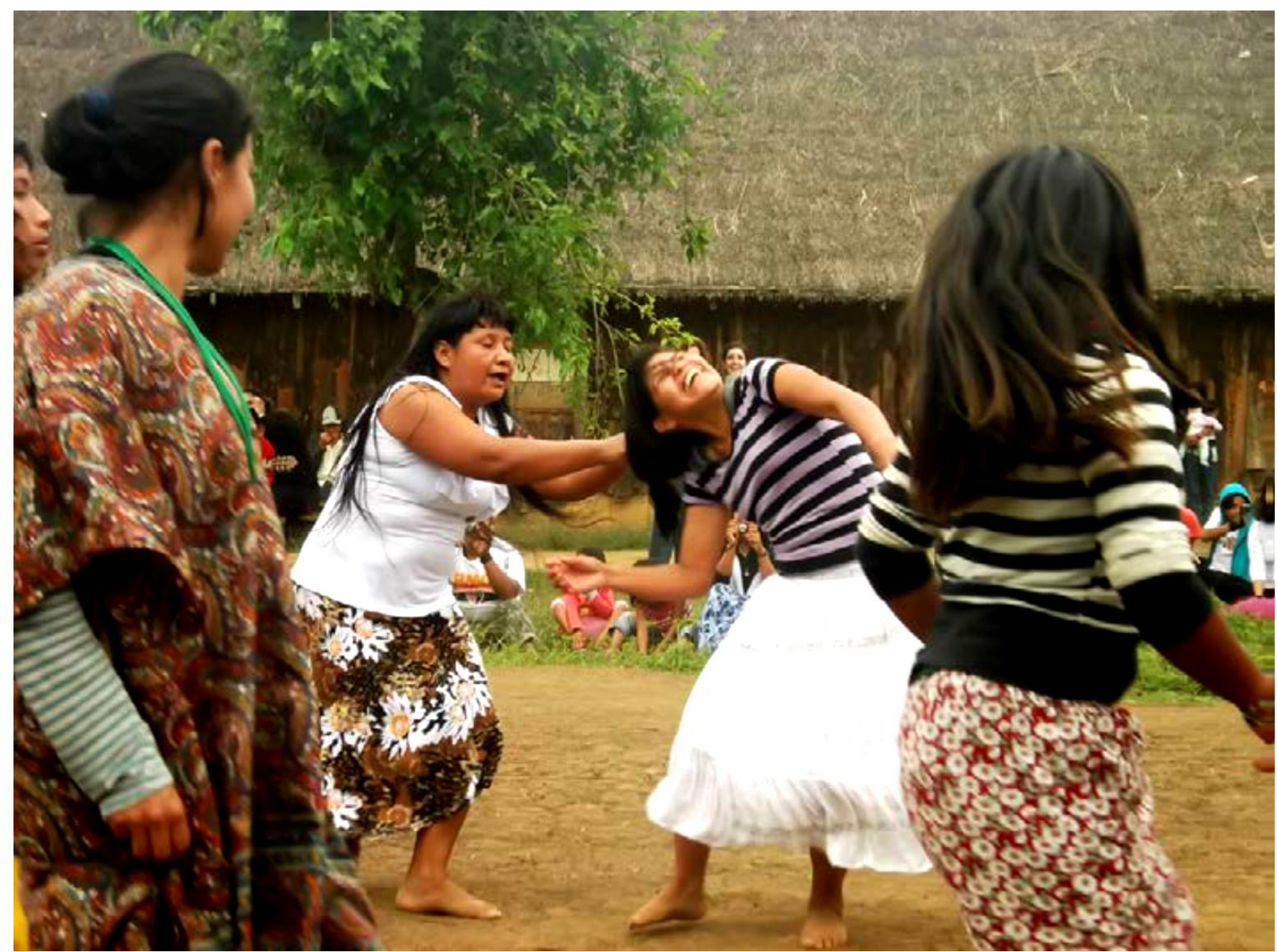

Xondaria jeroky. Wera Alexandre. T.I. Tenonde Pora, 2012.

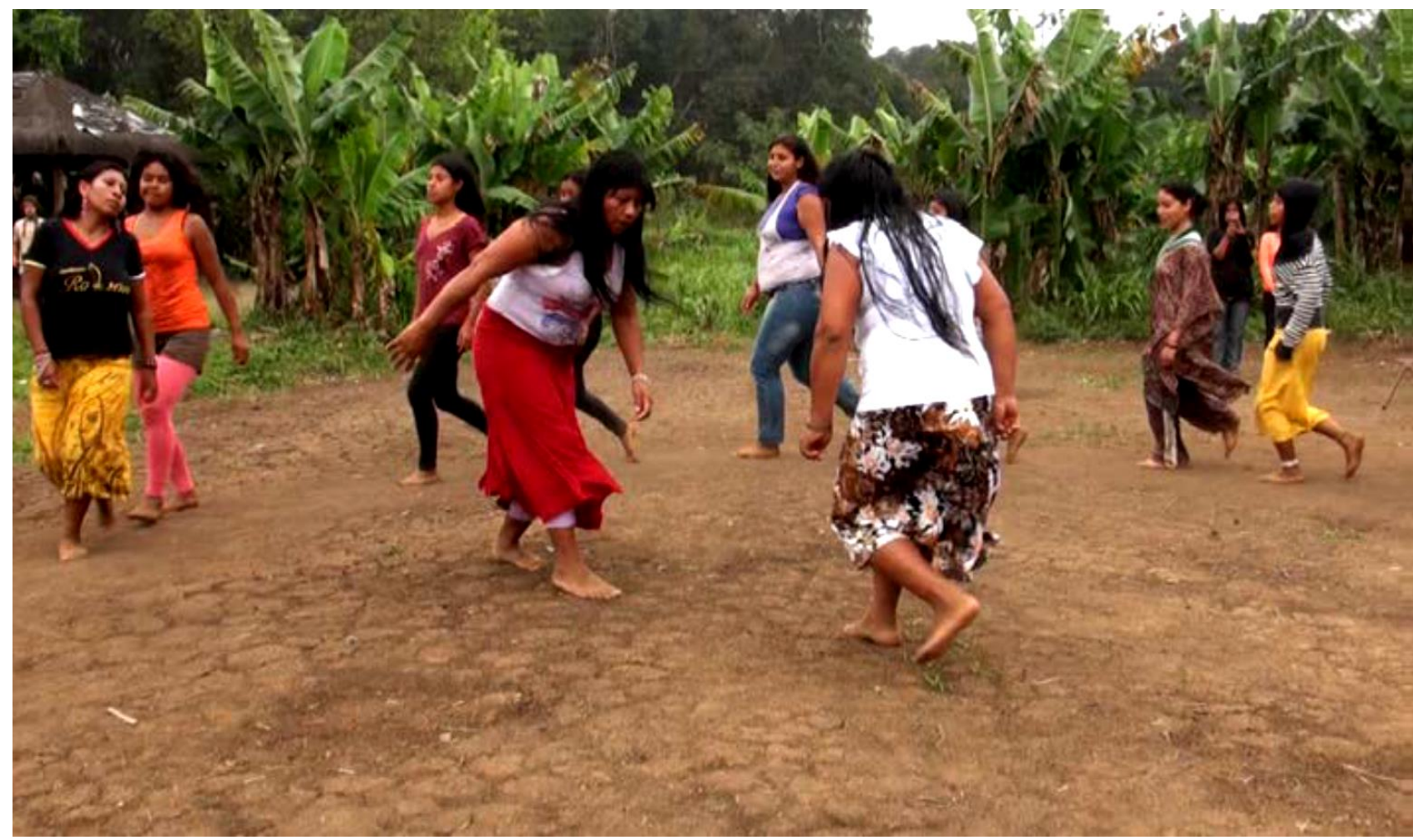

A dança das guerreiras. Arquivo Tenonde Pora, 2012. In: Keese dos Santos (2017). 
Acerca da “irreligiosidad” dos homens que “comienza a irritar al Ñe’eng Ru Ete”, Cadogan reproduz a fala inspirada de um dirigente espiritual "en forma de himno", no qual ele transmite aos seus compatriotas a conversa entre "el Padre y la Madre de los dioses", que consiste em uma "advertencia a los hombres": "Bien, mis hijos ['che ra'y kuéry' , aquellos a quienes puse la insignia de la masculinidad no proceden de acuerdo a los cantos que yo les inspiré, así (habló) nuestro Primer Padre ['ñande Ru Tenonde gua']” (Cadogan, 1959: 99, alterações minhas). Sua "ira ha sido desviada mediante la religiosidad de las mujeres y niñas, cuyas preces han sido escuchadas por la Madre de los Dioses, quien se prepara para recibirlas, cuando retornan a la morada de ella, con miel de eichu y canastillas indestructibles o eternas" (Idem, grifos meus). Como um interlocutor guarani, contou para Ciccarone:

As mulheres são mais fortes quando passam pelas provas, a mulher se segura mais nas coisas, tem mais possibilidade de conseguir a eternidade porque Deus tem mais carinho por elas, porque ele começou a gerar a mulher, as mulheres têm mais dedicação aos ensinamentos, estão mais perto dos ensinamentos de Deus. Para nós, os homens, é mais difícil porque nos homens a parte animal é mais forte. (Karai apud Ciccarone, 2001: 346)

Esse interlocutor complementa: "Deus gerou a mulher para ficar ao lado dos homens, as mulheres têm mais energia por ser mais segura nas coisas, se segurar mais ${ }^{266 "}$ (Karai apud Ciccarone, 2001: 224). Talvez seja devido a essa tendência da "alma animal" se manifestar mais fortemente nos homens que haveria maior tolerância em relação aos excessos cometidos por eles do que aqueles que dizem respeito às mulheres, havendo referências à “irreligiosidade” dos homens inclusivenos ensinamentos míticos. É importante reconhecer também a resistência peculiar atribuída pelos Mbya às mulheres diante dos desafios ou provações pelo caminho, que decorre talvez do seu maior desenvolvimento do poder de autocontrole, e se reflete em seu maior grau de controle na orientação coletiva. Pelo "alto grau de investimento no controle e na expressão do corpo 267 ", seria justamente nos corpos da xamã e da mulher "que se reproduzem e se representam os deuses e a sociedade", sociedade esta que são elas as incumbidas de "alimentar, cuidar e perpetuar" (Ciccarone, 2004: 94).

\footnotetext{
${ }^{266}$ Segundo um xamã, interlocutor de Ramo, a mulher “é menos 'safada' porque foi criada por Nhanderu” (Ramo, 2014: 34).

${ }^{267}$ Seria o "corpo feminino, cuja facilidade reprodutora confere à mulher a sua fundamental responsabilidade social, [que] exige dela plena consciência de sua função e de seu corpo, além dos cuidados especiais durante a gestação" (Ladeira, 2007 [1992]: 131, grifos e alterações minhas).
} 


\section{Dinâmicas cosmopolíticas entre convivência, cuidado e liderança mbya}

A morada terrestre guarani aparece muitas vezes representada por um fogo familiar. A expressão tataypy (ou tatapy) rupa, significa "asiento de fogones, población”, de acordo com Cadogan (1959: 105). Essas fogueiras qualificam o que se considera um tekoa. Este, idealmente deve contar com uma terra boa para plantar e uma boa mata com muitas frutas e remédios, que provenha também boa água, boa pesca e caça. Este fogo que é cuidado, alimentado e manejado pelas kunhãgue, oferece calor, abrigo, conforto, é ali onde escutam os aconselhamentos dos mais velhos pela manhã a respeito dos sonhos e sobre as atividades coletivas a serem desenvolvidas ao longo do dia, além de ser um espaço ao redor do qual se reúnem para comer (-karu) juntos (-jopyte) o alimento (tembi’u) preparado pelas kunhãgue e, pela noite para ouvir as histórias-conselhos dos antepassados e tomar erva-mate $\left(k a^{\prime} a\right)^{268}$. É também ali onde as mulheres aquecem a água e cuidam da preparação do chimarrão e do acendimento dos petỹgu $a^{269}$ para as sessões noturnas de curas, e

\footnotetext{
${ }^{268}$ Há uma relação entre a origem da erva-mate e a geração da mulher na primeira terra (yøy tenonde): “Takuá e Ka’a são filhas de Nhanderu. Ka’a é a erva mate. Quando Nhanderu andava pela terra, pegou um galhinho de cedrinho e assoprou, fazendo uma criança que brincava e urinava por todo canto. Então nasceu um brotinho de erva mate. Era uma menina, e ela já cantava com takuapu, por isso até hoje as mulheres cantam batendo o bastão de taquara no chão. Takuá e Ka'a foram embora com Nhanderu quando o mundo pegou fogo, veio a água, acabou. Mas a gente tem até hoje erva mate para fazer chimarrão e taquara para o takuapu, e para trançar a palha para peneira, balainho, tipiti” (Fernandes (Kunhã Tatá), 2011: 29). Em vários aspectos da vida cotidiana-ritual mbya há marcações de ações de gênero, como por exemplo, o instrumento ritual exclusivo das mulheres, chamado takuapu (bastão ritual de percussão, feito de bambu, que as mulheres tocam contra o chão produzindo um som grave, durante as rezas-cantos [tarova] marcando seu ritmo). Segundo Dooley, $p u$ corresponde a "produzir estalido" ou "produzir música: $m b a$ ’epu ipu o instrumento produziu música" (Dooley, 2006: 153). Já "takua pu” é traduzido como "taquara grossa usada como instrumento musical para acompanhar danças” (Ibidem: 173).

${ }^{269}$ A fumaça (-ataxĩ) atua como o canal por excelência de comunicação e proteção entre os Guarani e os pais e mães dos nhe'ẽ, sendo considerado como um dos principais veículos de transmissão de capacidades e conhecimentos, além de funcionar como uma proteção contra "agenciamentos patogênicos e outros infortúnios” (Macedo, 2013: 188-9). A fumaça torna as pessoas imperceptíveis a determinados sujeitos e seu odor contribuiria para afastá-los. Ela pode ser obtida tanto pelo fogo caseiro, como pelo petỹgua, assim como na queimada na agricultura, atuando também nas cerimonias de consagração e nominação de bens alimentícios e crianças, e nos rituais cotidianos de reza-canto-dança-cura na opy, onde se enfumaça também os instrumentos musicais sagrados (mba'epu ete' $i)$, fazendo-os adquirirem agência própria. De acordo com Cadogan, o "nombre religioso del humo de tabaco es: tatachina reko achy, la neblina mortal, imperfecta" (Cadogan, 1959: 67). O petỹgua é considerado o próprio “caminho do saber (arandu rupa)”, pois fortalece e cura as pessoas: "O petygua é caminho; caminho no qual os pensamentos, as palavras silenciosas se movimentam. Fumar o petygua, espalhar a fumaça (-nheovanga tataxina), é pôr em movimento palavras silenciosas" (Ramo, 2014: 271). Omoatãxĩ, literalmente "fazer fumaça", é como os Mbya traduzem "fazer oração", de acordo com Ramo (Ibidem: 271-2), daí a importância de "se concentrar", "meditar" (-japyxaka), como meus interlocutores falam, quando se fuma petỹgua. Por ser um meio para acessar saberes-poderes, a capacidade de controlar o seu uso é pensada como algo que se deve aprender, pois não se deve "fumar sem motivo" " "epita rive eme" = "não fume à toa") (Testa, 2014: 162). Em campo ouvi diversas vezes os Guarani falando para os jovens não fumarem “à toa”, pois ao fumar o petỹgua é preciso "se concentrar”, pensar em Nhanderu e Nhandexy Ete, em "coisas boas", ter "bons pensamentos”. O petỹgua geralmente é usado, com maior frequência, ao despertar, após o almoço e ao anoitecer, quando o Sol (Kuaray, Nhamandu) se recolhe, assim como os Guarani.
} 
da força e potência dos cantos-rezas, elevando-os, assim como seus corpos-espíritos, em direção-caminho à morada dos parentes divinos para que estes "olhem” por eles, ou seja, para que cuidem dos Guarani. O canto das mulheres, principalmente no tarova'i, é agudo e alto pois eles devem subir bem alto ${ }^{270}$ (ao encontro dos deuses), se complementando à música geralmente puxada por uma liderança masculina com o violão (mbaraka) e o mbaraka mirĩ (chocalho) que acompanha a marcação de ritmo dos takuapu (instrumento ritual de uso feminino). As kunhãgue atuam então como cuidadoras e puxadoras de canto-reza na disposição de kunhã karai ou, como auxiliares, na disposição de xondaria, atuando, junto a seus companheiros, do enfumaçamento (-moataxĩ) da opy’i e do amba (“altar")271.

O fogo, pode ser pensado então como o centro ao redor do qual são gestadas e distribuídas as atividades coletivas guarani, femininas e masculinas, centro este administrado pelas kunhãgue, que têm sempre uma mais sábia - geralmente xejaryi - à sua frente. Essa mulher que vai na frente (tenondegua'i), junto a seu companheiro, é o centro de autoridade-respeito da vida ao redor dos fogos-aldeias, cuidando e fazendo crescer crianças, netos e os filhos que escolhem permanecer a seu redor, seguindo a sua orientação. $\mathrm{O}$ artigo de Cadogan e Melià (1971), chamado Che Retambipe, cuja tradução que melhor qualificaria semanticamente tal expressão, de acordo com os autores, seria "la mujer junto al fuego", parte da proposta de um estudo da mulher entre os Guarani. Por ser tão comum encontrar uma mulher mbya junto a um fogo acesso em uma aldeia, os autores pensam que a frequência dessa cena permite definir a "função" mesma da mulher dentro da cultura guarani, ainda que o fogo seja entendido, pelos antropólogos, como algo que é produzido pelo homem, a mulher atuando apenas como uma mera "guardiana” sua : "Siempre en relación con el fuego y junto a él, la mujer guaraní define sus funciones dentro del sistema cultural y ritual de su pueblo" (Cadogan e Melià, 1971: 113, 117).

\footnotetext{
270 Quando os Guarani dizem que o canto-reza não "sobe”, não vai para o "alto” (ao encontro das divindades), que "fica no chão", querem dizer que as pessoas não sabem cantar, não tem fé ou não acreditam suficientemente naquilo que estão fazendo na opy'i, podendo até mesmo atrapalhar as curas e benzimentos a serem realizados naquele espaço sagrado, além de constituir também uma espécie de acusação. Por isso, deve-se estar bem concentrado ao entrar na opy’i e pensar só em "coisas boas”, como insistem em dizer. 271 Além de amba significar "morada” dos deuses, é a tradução Guarani para o local onde ficam depositados os instrumentos musicais e demais objetos sagrados de conexão com Nhanderu e Nhandexy kuery, constituindo um canal de comunicação intermundos.
} 


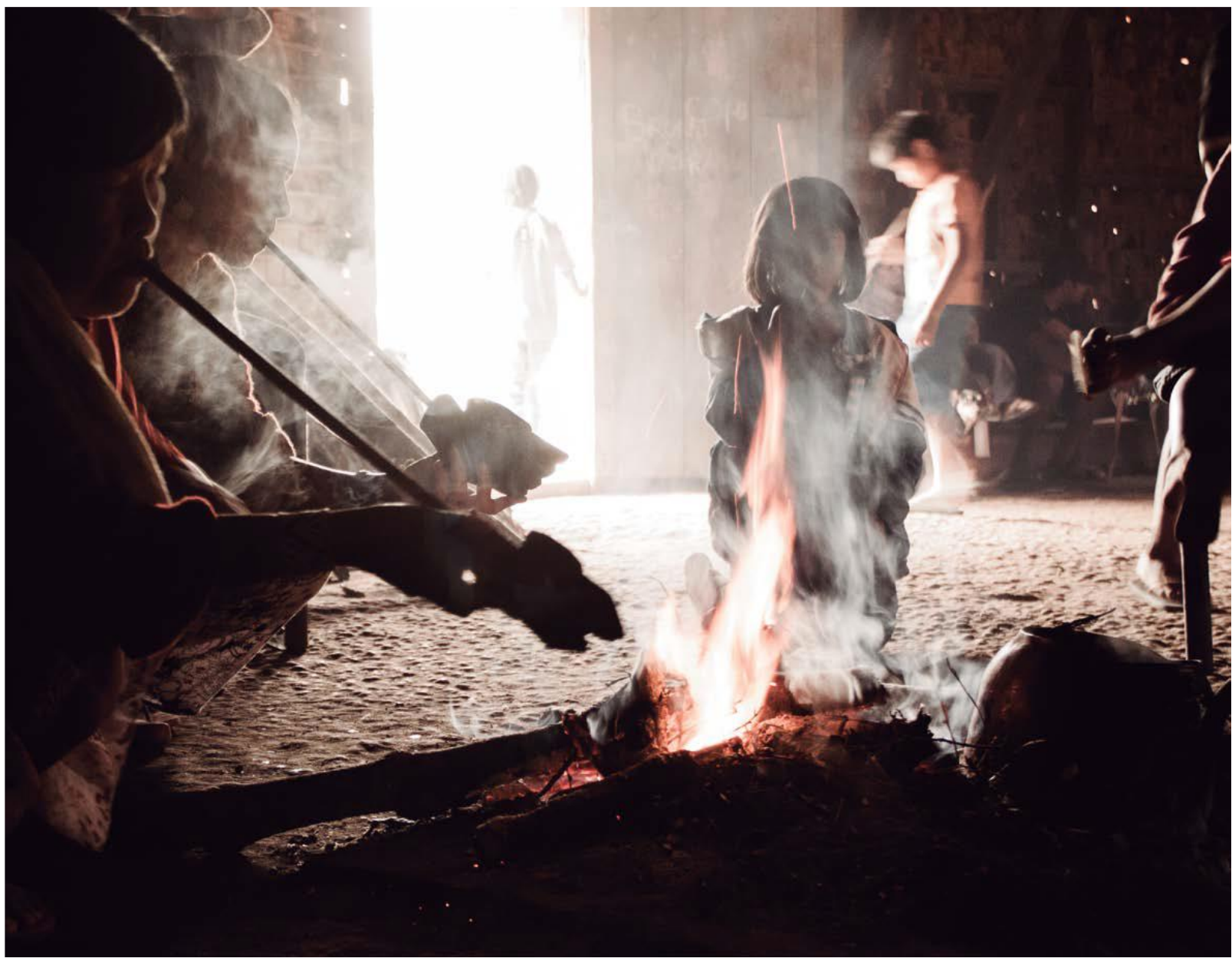

Kunhãgue’i acendendo e fumando petỹgua na opy. Luiza Calagian. T.I. Tenonde Porã, 2014.

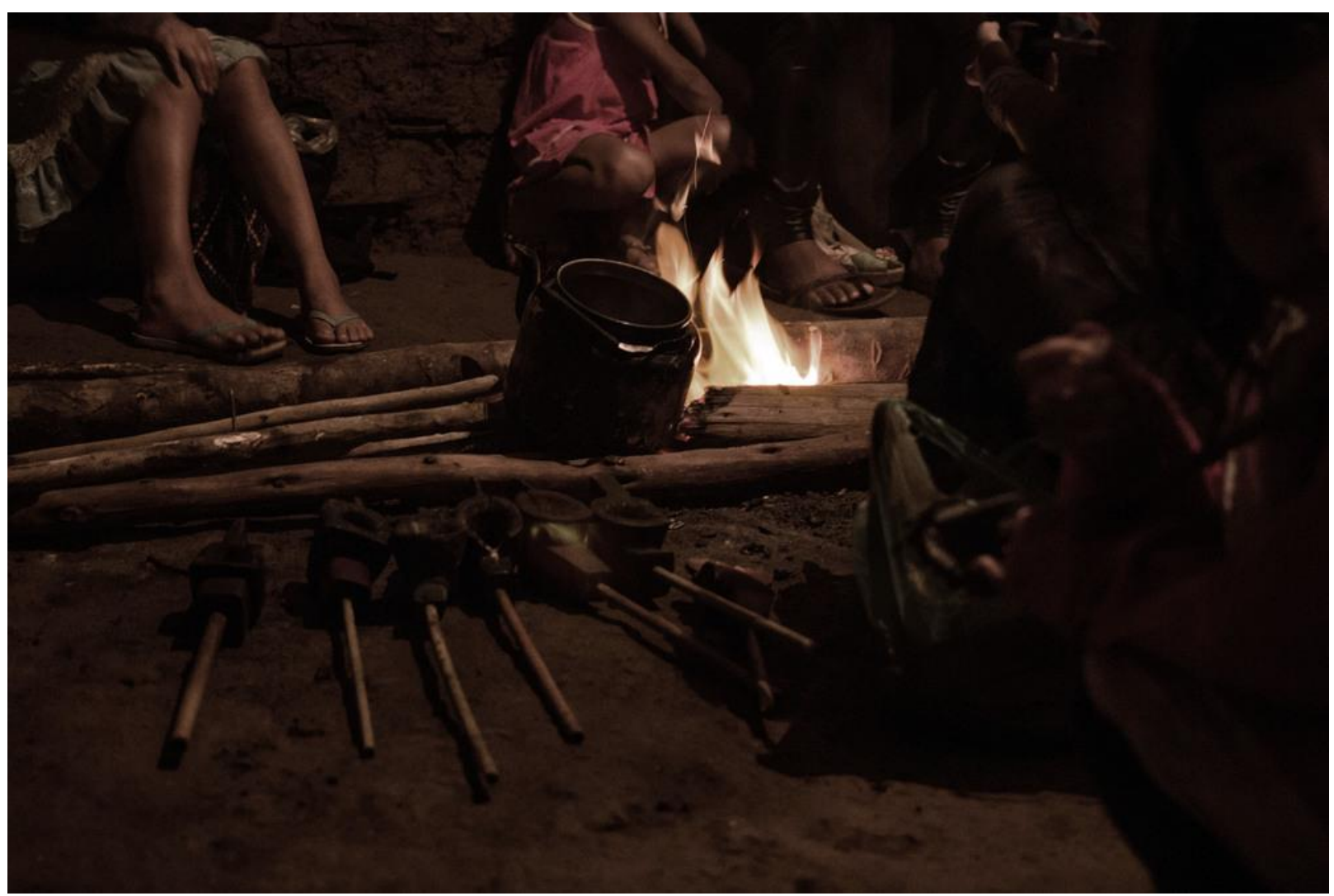

Kunhãgue’i esquentando água e preparando os petỹgua. Luiza Calagian. T.I. Tenonde Porã, 2016. 


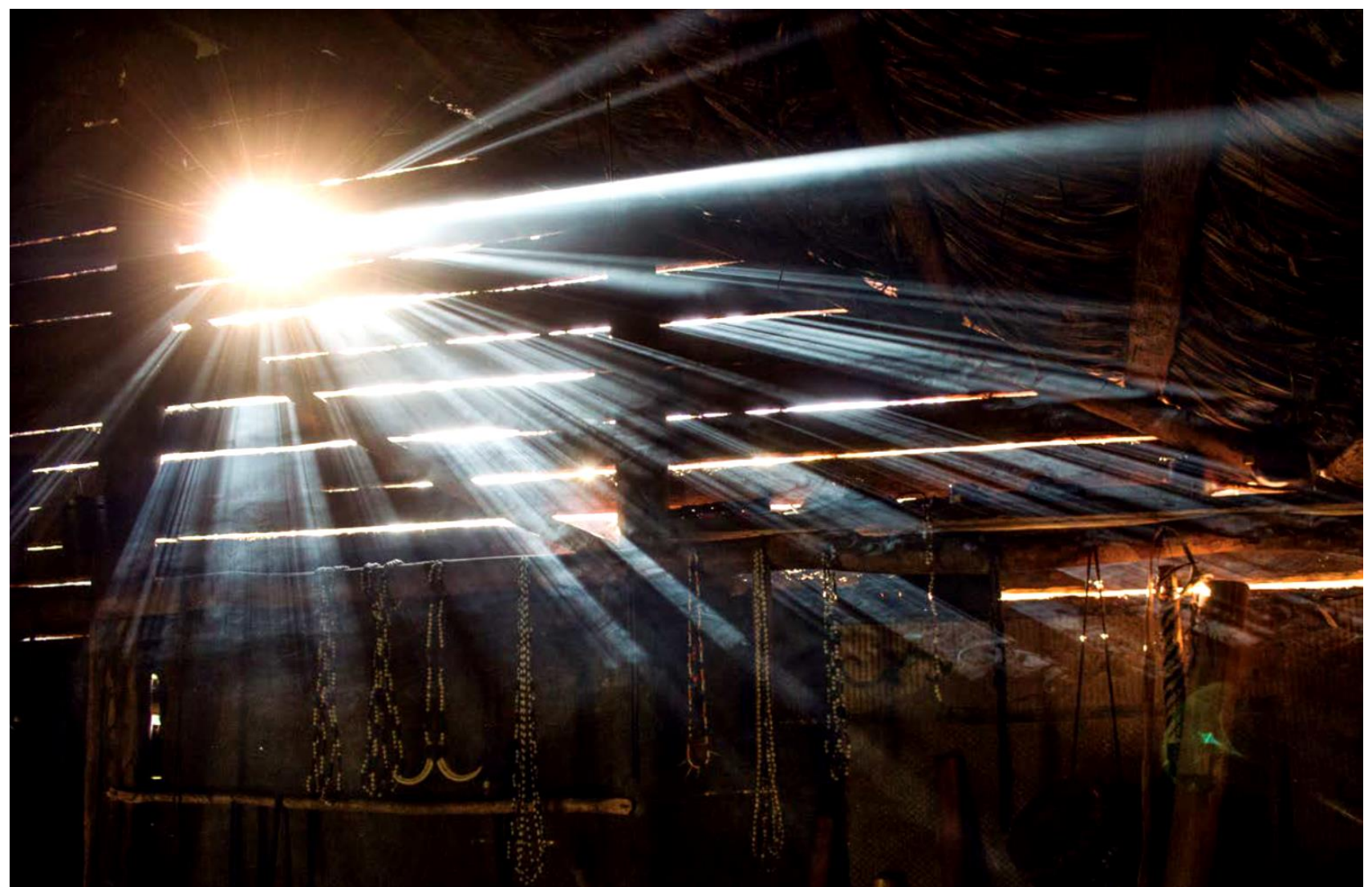

Opy’i e os raios do Sol. Vinicius Toro. T.I. Rio Silveira, 2014.

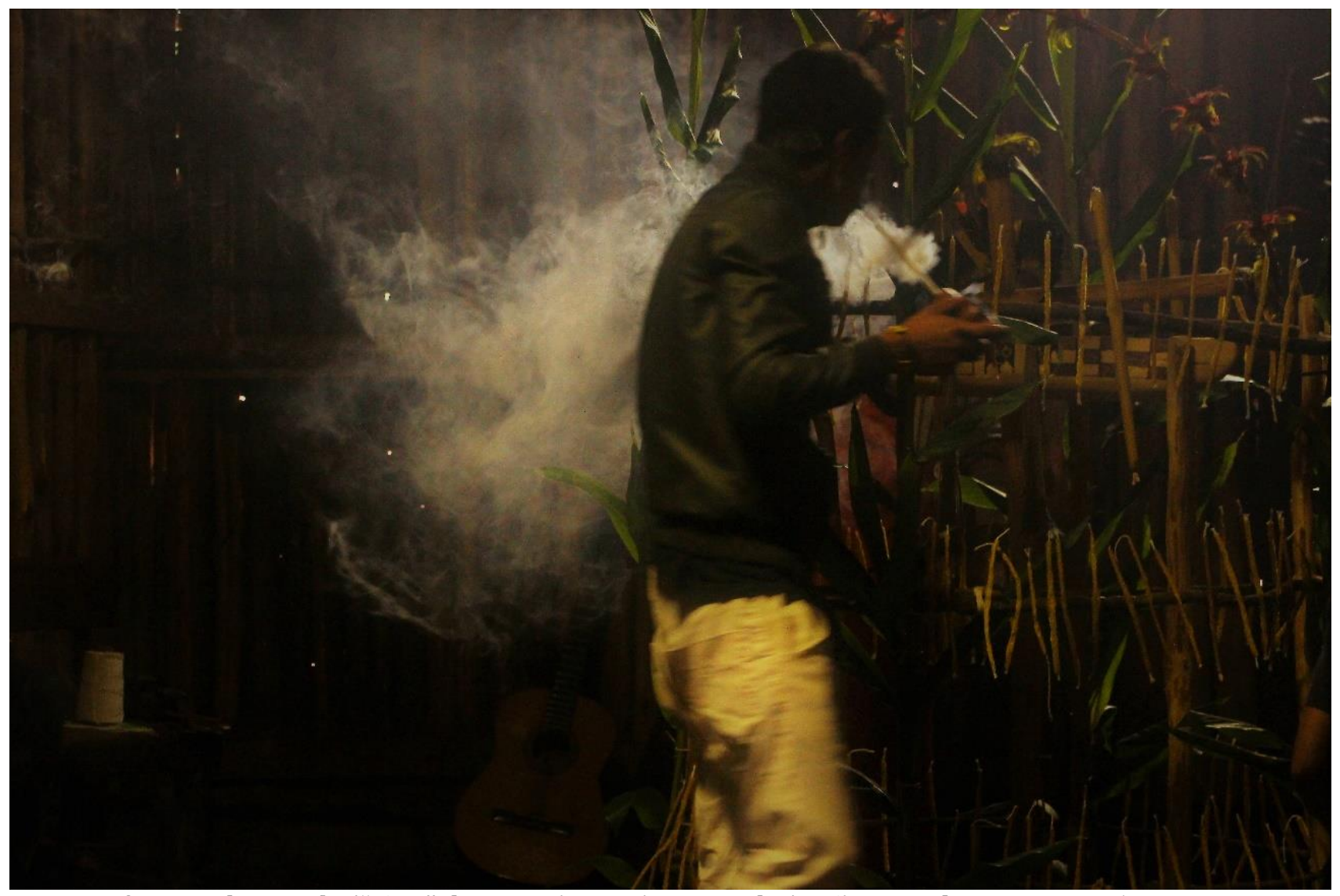

Enfumaçando o amba (“altar” de comunicação intermundos). Aline Aranha. T.I. Jaraguá, 2016. 


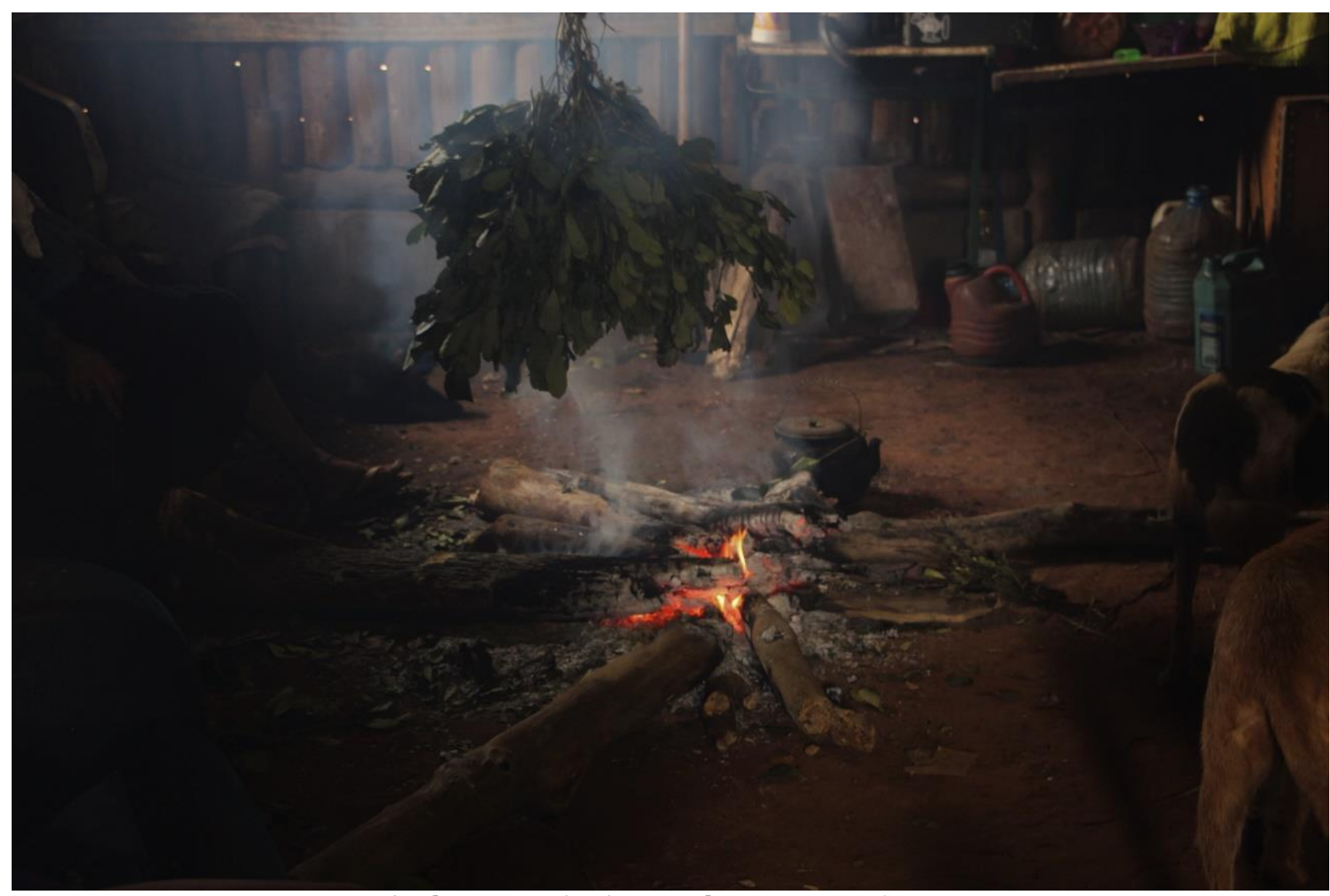

Ka’a nhemongarai. Aline Aranha. T.I. Jaraguá, 2016.

No entanto, nesse estudo, os autores se utilizam de sua observação e ótica masculina, além de alguns homens mbya como "informantes", para falar das mulheres e de suas funções sociais. Por isso, apesar de tal estudo oferecer uma sequência de imagenssímbolos que articulam alguns dos referenciais míticos com as funções sociais das mulheres, não se encontra "nesse singelo estudo seres vivos, ou seja, mulheres que sentem, vivem e pensam, bem como seu olhar sobre si mesmas e a sociedade, elementos emergentes quando deslocamos nosso interesse para as formas de sociabilidade da vida cotidiana" (Ciccarone, 2001: 20). Cadogan e Melià reconhecem que cozinhar é uma ocupação exclusiva das mulheres, mas fazem referência ao ato de assar sobre o fogo ou as cinzas legumes como mandioca, batata, milho ou alguma presa de animal silvestre, como uma atividade que ambos os sexos realizam. Os autores ressaltam também que além da mulher guarani estar sempre junto ao fogo da cozinha, estão junto ao fogo "ritual” da $o p y^{272}$, cuidando dele e do acendimento dos cachimbos (Cadogan e Melià, 1971: 114-115).

${ }_{272}$ É ali nesse ambiente da opy que realizariam diante de muita fumaça, a dança da "grande reza”, designada de "ñembo'ete" pelos antropólogos, que propiciaria a chegada da "llama divina que es signo de elección y que lleva hasta la posesión que es también purificación del mal natural. Teko achy overa nde ree, le dicen a uno: lo malo brillaba en tí (y salía)" (Cadogan e Melià, 1971: 115). 
O fogo doméstico kaiowa, segundo Pereira, "constitui a unidade sociológica mínima no interior do grupo familiar extenso ou parentela, composta por vários fogos, interligados por relações de consanguinidade, afinidade ou aliança política”, sendo, portanto, "pré-condição para a existência humana entre os kaiowa” (Pereira, 2008: 7). Por ser representativo da comensalidade entre parentes é, em certo sentido, uma noção próxima à nossa ideia de "lar", que é associada à força atrativa e protetora do calor do fogo, “que aquece as pessoas em sua convivência íntima e contínua”, devendo prevalecer, entre seus membros, um "sentimento de proteção e cuidados recíprocos" (Idem). Esse fogo "era e continua sendo controlados por mulheres, o que lhes assegura o poder de unir e alimentar seus integrantes. Sem mulher não há fogo, reconhecem os Kaiowa” (Ibidem: 9, grifos meus). Assim, é impossível pensar um fogo sem a presença da figura central da mulher:

A solidez e estabilidade de um fogo dependem diretamente da mulher comunicar o tempo todo seu cuidado e capacidade de controle de todos os eventos que envolvem a vida dos integrantes de seu fogo. Disto resulta que a mulher tem o direito e, em certo sentido a obrigação, de se envolver em todos os assuntos que dizem respeito à vida de seu marido e filhos. (Ibidem: 14)

Daí que, entre os Kaiowa, Pereira reconheça que o homem "parece estar condenado à dependência do fogo" doméstico, controlado pela "mulher, seja ela sua esposa, mãe, irmã, cunhada ou filha” (Idem). Tal “dependência” pode ser observada inclusive nos mitos, onde aparecem relatos do cotidiano de convivência dos deuses ao redor de seus fogos, onde realizam tarefas complementares, segundo a divisão sexual dos papéis:

Como explicou um xamã, os homens com suas rezas derrubam a mata estendendo um fio por entre as árvores, rezando e depois puxando. Tudo é feito sem esforço e sem necessidade do machado. Uma vez preparada a terra, enviam as mulheres para semearem, em seguida os homens rezam para a lavoura crescer e poucas horas depois as mulheres já podem retornar a roça para realizar a colheita, pois as plantas já amadureceram. $A$ diferença em relação às roças dos humanos é que tudo aí é realizado sem muito esforço e a colheita é farta e rápida, mas as distinções e complementaridades nas tarefas em relação aos papéis sexuais são idealmente idênticas. (Ibidem: 15-16, grifos meus)

A administração da economia doméstica, no geral, seria também responsabilidade das mulheres, independentemente se desenvolvem, ou não, atividades remuneradas, uma vez que seu compromisso, socialmente reconhecido, com o bem-estar dos parentes e sua maior preocupação com os cuidados com a casa e seus integrantes favorece, de acordo com a concepção kaiowa, "uma administração mais racional e previdente dos recursos, enquanto os homens tendem sempre ao excesso e ao esbanjamento" (Ibidem: 16). Pereira adverte que "se depender da maioria dos homens, o dinheiro é gasto com demonstrações públicas de generosidade e de status econômico elevado", mesmo entre aqueles que não 
são parentes (Idem). Tal "propensão dos homens ao excesso" se expressaria tanto na generosidade quanto na violência que, em geral, é intensificada pelo consumo de álcool [que, de acordo com os Mbya, deixam ainda mais vulneráveis os corpos-espíritos à ação de donos-espíritos de humores terrenos, agressivos] (Ibidem: 17, alterações minhas). As mulheres buscam então, restringir a participação dos homens na economia doméstica enquanto "produtores" e "consumidores de produtos distribuídos" por elas, uma vez que há aí, por conta dessa "propensão" masculina ao excesso, o entendimento de que "o dinheiro ganho deve ser destinado à mulher, encarregada da compra e distribuição dos produtos" (Ibidem: 16). Assim, "sem uma mulher para organizar sua vida cotidiana ele [homem] está condenado à ruína” (Ibidem: 17, alterações minhas).

Em campo também observei que quando recebem o salário ou algum "dinheirinho”, alguns homens primeiramente separam uma parte para a mulher poder comprar a alimentação do mês e o restante gastam com bebidas, refrigerantes, churrascos e torneios de futebol, tanto dentro como fora da aldeia, emviagens para outras aldeias que irão promover campeonatos de futebol e que, geralmente, promovem "forró” à noite, após as partidas, com venda de bebidas alcoólicas. Pude observar também que são as mulheres as pessoas encarregadas de distribuir os bens, produtos e serviços, dentro das aldeias, sejam eles alimentos, tarefas domésticas e, em alguns casos, trabalhos cosmopolíticos. Essa disposição central das kunhãgue vai desde a distribuição de doações de alimentos para o próprio núcleo familiar - ou, no caso das lideranças "linha frente", na distribuição das doações para todos os núcleos da comunidade -, à montagem dos pratos de comida para seus familiares, especialmente os maridos, filhos pequenos, solteiros e netos, etc., sendo também elas as responsáveis por distribuí-los nos eventos políticos, de intercâmbio entre aldeias ou mesmo quando recebem visitas jurua. É importante frisar também que, várias das relações que se desenrolam ao redor do fogo doméstico se dão entre pessoas que pertencem a distintas gerações e gêneros (mãe-filh@(s); pai-filh@(s); avós-netos, etc.), revelando toda a sua imbricação na produção da socialidade xamânica guarani.

A relação entre convivência-cuidado-liderança se estende assim, em magnitude ao longo de toda organização social Mbya (Testa, 2014: 212). Enquanto a disposição cosmopolítica de cada pessoa estaria mais bem relacionada a seu nome-espírito e experiência-missão nesse mundo do que propriamente ou, necessariamente, a seu gênero. $O$ ideal de maturidade seria o mesmo para ambos os gêneros: aquele que prioriza a ênfase no controle-moderação sobre seus próprios corpos-afetos e a promoção da generosidade e reciprocidade entre parentes. A etiqueta guarani, dessa maneira, prescreve os modos de se comportar dos gêneros através da ética xamânica da moderação, assemelhando 
seus corpos aos corpos imperecíveis das divindades, através da replicação destes comportamentos, inspirados pelos ensinamentos dos ancestrais divinos que circulam tanto via kaujos ("causos"), contos míticos e histórias de vida de seus anciões, e prescrevem a sua boa medida, o cuidado com excessos ${ }^{273}$ em qualquer relação, que demandam constante atenção e controle aos modos de se relacionar, que devem se dar, idealmente, com serenidade, calma (jaiko rive), cautela, paciência (nhaarõ kuaa) ${ }^{274}$ e tranquilidade. E, uma vez que a "liturgia terrestre no hace sino reflejar la liturgia celeste", Cadogan e Melià qualificam tal esquema relacional guarani como "platónico" (Cadogan e Meliá, 1971: 115; ver também Pierri 2013a). Isso revela todo um esforço coletivo de diplomacia cosmopolítica mbya, com vistas a produção de um espaço bom e saudável para se viver bem (teko por $\tilde{a}^{275}$ ) entre si. Em suma, tal objetivo seria perseguido por meio do controle das emoções-desejos tanto nas relações entre parentes, como nas relações com outros seres-donos-espíritos, que estão espalhados por toda parte do cosmos e deve-se respeitar para não sofrer retaliação-vingança, correndo o risco de afetar todas relações de substância-corporal que se mantém neste mundo (entre parentes-humanos), o que ocorre ao "se deixar levar" por uma perspectiva outra, confinada a este mundo terreno, transformando-se tanto substancialmente, como corporalmente (-jepota) em outro ser. Como comenta uma interlocutora em relação aos ija kuery e o perigo de transformação corporal:

\begin{abstract}
a gente tem vários nhe'ẽ na terra, a gente tem o nhe'ẽ que é o espírito humano, a gente tem o nhe'ẽ que é o espírito das plantas, e tem o nhe'ẽ que é do espírito dos animais também, aí cada um tem que ter o seu espírito, a partir do momento que se mistura, por exemplo, eu sou humana e vou começar a me comportar de uma forma mais agressiva, ruim e tal, eu já começo a adquirir o espírito de algum bicho, de algum animal, e aí ele se torna ruim pra mim, porque não é o meu espírito, que é o nhe'ẽ vai né, que é o espírito ruim né, que não é o meu espírito mesmo. (Kerexu Yxapyry da T.I. Morro dos Cavalos [SC], Local: Tekoa Tenonde Porã 2015)
\end{abstract}

É possível a incorporação de potências exteriores, mas não se deve adquirir seu espírito, por isso, há que se tomar muito cuidado:

eu posso adquirir o conhecimento das plantas e dos animais; eu posso adquirir força de alguns espíritos, eu posso pedir ajuda né pra alguns espíritos pra me dar força, mas eu não posso adquirir aquele espírito $[\ldots]$ o meu espírito ele não se contamina com outro espírito, o meu corpo sim, o meu espírito verdadeiro, se eu não der lugar pra ele, ele volta de novo [...] se eu não tiver a "alma” eu não movimento ele [o corpo], e se eu não tiver o espírito eu não tenho a sabedoria de dominar o meu corpo. (Idem, alterações e grifos meus)

\footnotetext{
${ }^{273}$ A moderação na fala e no consumo de alimentos é algo muito valorizado pelos Guarani, sendo os jovens sempre orientados a falarem comedidamente, principalmente quando estão na presença dos "mais velhos", que possuem "a prerrogativa das palavras abundantes" (Testa, 2014: 270).

274. Dooley traduz o radical -arõ are kuaa por "ter paciência e -arõ kuaa e -nhearõ kuaa por "ficar alerto, acautelar-se” (Dooley, 2006: 19). Já -iko rive é traduzido como “viver sem muita preocupação” (Ibidem: 58). 275 É interesante notar que a expressão teko porã ja, traduzida por Cadogan como "los dueños del buen vivir", corresponde aos medicamentos "que producen el normal funcionamento de los órganos de reproducción de la mujer” (Cadogan, 1992: 172-173).
} 
Macedo (2013) reflete sobre a alteridade experimentada no -jepota na chave de um "mau encontro", e seu contraponto, o fortalecimento dos corpos visando intensificar a conexão entre o próprio corpo e o nhe'ẽ através de práticas xamânicas, na chave dos "bons encontros". Esses encontros, "bons" ou "maus", decorrem de relações de afecção que passam diretamente pelos corpos guarani, aumentando ou diminuindo sua potência de agir. O maior desafio da pessoa aí seria o de buscar reiteradamente se "fortalecer" ou "fazer corpo" (-mbaraete $\left.{ }^{276}\right)$ ou "ser fortalecido" (-mombaraete), compondo com ajuda de outros um corpo mais potente, para impor-se como sujeito (-nhemboete), pois há sempre o perigo desse corpo ser desfeito ou feito outro. Os interlocutores de Macedo costumam traduzir -jepota por "se encantar em", vinculado a um "se encantar por", "convergindo o desejo pelo outro com o desejar como outro", remetendo a narrativas que expressam geralmente "tramas de namoros, ou desejos envolvendo sujeitos de diferentes sexos e 'espécies', em sua maioria animais, como onças, antas, peixes ou sereias" (Macedo, 2013: 194, grifos meus). Pelo sufixo -pota ter como significado, “querer", e a partícula -je ser de função tanto reflexiva, como passiva, Macedo se permite a interpretação do termo -jepota como uma afecção que decorre do "ser desejado" por outro corpo, e que também pode ser traduzida como "desejar-se", uma vez que atua como uma "alteração do ponto de vista, de modo a não reconhecer os parentes e desejar sua carne” (Idem).

Nesse “idioma da sedução", o "espírito-dominador”, de acordo com Pierri, pretende cativar a vítima para viver junto ao seu coletivo, como parente (Pierri, 2013a: 173). Nesse sentido, a expressão “imbotarya kuery” ("seres que enganam”) - também chamados tupixua ${ }^{277}$, segundo Pierri - remete diretamente a esses seres que, geralmente aparecem

\footnotetext{
276 Apesar de alguns de seus interlocutores guarani não reconhecerem a tradução de -mbaraete por "fazer corpo", Macedo opta por traduzi-la assim, encontrando seu rendimento (Macedo, 2013: 191).

${ }_{277} \mathrm{O}$ termo "tupichúa, tupichua", de acordo com Cadogan, é "sinónimo «ivaikue jepotaa 'ser del que se ha prendado el maligno, el jaguar', en el que se ha encarnado el alma de un jaguar; se caracteriza por su afición a la carne cruda, y el ente maligno que se encarna en ellos es llamado también «cho'o pyrygua ñe’ẽ 'el alma de la carne cruda” (Cadogan, 1992: 182). A ameaça do "tupichua", de "transformação animal”, segundo H. Clastres, decorre da ação dos espectros dos mortos (ãgue): "Tupichua provém da carne crua e do sangue em geral, e é alguma coisa que pode encarnar-se na carne e no sangue humanos: provoca então um mal mortal, que pode acarretar a transformação em jaguar de quem for atingido por ele. [...] Quem comer carne crua verá sem tardança o tupichua encarnar-se e agarra-lo completamente. [...] Quem assa a sua carne e a come na floresta atrai irresistivelmente o tupichua e se deixa enganar por ele. Nesse caso, com efeito, tupichua pode frequentemente tomar a aparência de uma bela mulher, enfeitada com pinturas atraentes; ela faz perder a razão" (Clastres, H. 1978 [1975]: 93-94, grifos meus). Essa bela mulher, entretanto, no momento da copulação começa a "cobrir-se de manchas e já aparece diferente de uma mulher, põe-se a unhar a terra e a rosnar e unhar", tomando as feições de uma mulher-jaguar (Ibidem: 94). Daí que "tupichua, a transformação em jaguar, é portanto o castigo de quem não sabe se conduzir como eleito, isto é, segundo as normas culturais. [...] Quem deixa triunfar em si o teko achy kue em detrimento do ñe $\dddot{e}$, a natureza animal em prejuízo da alma-palavra divina, deixa-se apanhar na cilada das aparências: ceder à sedução enganadora da mulher-jaguar - do tupichua - é confundir a beleza com o que é apenas uma sua imitação bufa (sentido forte de mba'emeguä), tomar as manchas do animal por um ornamento, confundir a natureza e o sobrenatural' (Idem: 94, grifos meus). Viveiros de Castro também associa o tema do jepota ao do tupixua, baseando-se na
} 
aos Guarani enquanto "belos rapazes ou belas moças ${ }^{278 " ~(I b i d e m: ~ 172-173) . ~-J e p o t a ~ d e-~}$ corre, portanto, da comensalidade ${ }^{279}$ com sujeitos não-humanos, “o inverso da comensalidade característica do 'grupo de substância”' (Ibidem: 186).

Esses casos de -jepota (transformação corporal trans-específica) ocorrem sempre a partir de uma "sedução por engano", já que a pessoa se equivoca ao ver a "imagem humana daquilo que, no fundo, é um animal (ou vê o fundo humano ${ }^{280}$ de quem só se deveria ver a forma animal)" (Ramo, 2014: 53). Tal sedução, envolve então um "se apaixonar" ou "se encantar", onde a troca de olhares é determinante para iniciar a relação de troca de substâncias e a transformação consequente. Prates (2013) relaciona a "ausência de alegria" (ndory'ai) com o "não controlar os pensamentos" e o se deixar capturar por uma perspectiva outra ${ }^{281}$. Tais circunstâncias "fazem com que a atenção que se deve dar diariamente para o fato de Outros estarem à espreita seja deixada de lado" (Prates, 2013: 191). Há então uma relação entre "se deixar olhar" 282 e deixar-se desejar por outros seres-poderes terrestres, com o "não controlar pensamentos" e, consequentemente, as emoções e o próprio corpo que possui uma ligação instável com o princípio vital (nhe’ê) por sua natureza dual (celeste e animal), o que nos remete à predação enquanto esquema

análise da obra de Cadogan (1962, 1965) (ver Viveiros de Castro, 1986: 641). De acordo com o autor, “entre os Ñandeva e os Kayová-Guarani, o odjepotá, transformação em animal, que pune aqueles que se aventuram no mato durante a couvade e a menstruação, é principalmente atribuído ao karuguá, Arco-Íris, que entre os Araweté, Wayãpi e Aché é uma cobra de grande sensibilidade olfativa” (Ibidem: 446). Segundo Cadogan, karugua é “un genio llamado también a veces Yyyra’ija: Karugua Jy’y el Arco Iris” (Cadogan, 1992: 80). Dooley traduz karugua tanto por "louva-a-deus" como "arco-íris", já o termo karugua aju'y é traduzido apenas por “arco-íris” (Dooley, 2006: 81). Sobre a relação entre tupixua e -jepota, ver também Pissolato (2007), Macedo (2010), Prates (2013).

${ }_{278}$ É importante se atentar também que o belo pode, muitas vezes, estar associado ao perigo; quanto mais bel@,mais perigos@.

279 A comensalidade cumpre também aqui um papel fundamental, não apenas por marcar a similaridade dos corpos, mas porque compartilhar alimentos é um importante sinal de identidade, confirmando que aqueles que comem juntos compartilham pontos de vista em oposição àqueles que comem uns aos outros. 280 Se o fundo humano é o animal, o do animal é o humano (Prates, 2013: 297; ver também Viveiros de Castro 1996, 2002a).

281 Tal acontecimento, que é entendido pelos interlocutores de Macedo tanto como uma "ausência de alegria” como um "não se acostumar” (ndory'ai), decorre do afastamento do nhe ẽ que pode até mesmo partir em caso de desconforto aqui na terra (Macedo, 2013: 186). A alegria (-ry'a), nesse sentido, seria o sentimento mais perseguido pelos Guarani, estando diretamente associada à presença do nhe'é e servindo de justificativa para estar e permanecer em um lugar ou coletivo (ver, nesse sentido, Pissolato 2007). O termo ndory'ai é também usado pelos meus interlocutores mbya para expressar quando eles estão sentindo "saudades" de algo ou alguém. O verbo -exa nga'u também é usado para expressar esse sentimento de "ter saudades", ainda que esteja “se tornando um arcaísmo; mais comum é ndory’ai” (Dooley, 2006: 43).

282 O olhar é veículo do desejo e um instrumento de sedução, não só entre pessoas, mas tambem entre aqueles que não vemos, de acordo com Ramo (2014). "Ser olhado por" é converter-se em objeto de desejo do outro, "é ser antecipado como companheiro, alguém pra andar junto” (Ramo, 2014: 154). É nesse sentido que, tanto as meninas-moças como os meninos-rapazes "devem aprender, durante a puberdade, a controlar a sua exposição, a dominar a arte do ocultamento e as regras do jogo de se disponibilizar e se retirar ao olhar do outro, pois a troca de olhares antecipa outras trocas" (Idem, grifos meus). 
relacional privilegiado nessas paisagens. A distração coloca a pessoa em situação de vulnerabilidade diante de outros, em contraste com a desejada atenção, controle e força espiritual-corporal. A possibilidade de perder o controle sobre si e sobre os outros se dá em ações cotidianas, tais como se alimentar, falar, pensar, de acordo com Prates. Nessas ações, é possível perceber:

o papel central das mulheres, às quais cabe gerir a produção e reprodução da sociedade: são elas que carregam os filhos no ventre, as sementes e os alimentos no cesto, são elas que cuidam dos plantios, do fogo e da cozinha e são elas que nutrem e dão vida à sociedade. Se é a busca de terra cultivável que movimenta os grupos familiares migratórios, não são as mulheres, tradicionalmente, as responsáveis pelas plantações? É através da relação entre xamanismo e mulheres que a migração ganha sentido como um processo de reconquista do mundo para o fortalecimento dos indivíduos e da sociedade, ao mesmo tempo em que os Mbya, migrando ou não, continuam à procura do destino da imortalidade. [...] Nessa perspectiva, esvazia-se de sentido explicar porque é uma mulher xamã que guia o grupo migratório, mas interessa compreender como, na emergência da interdependência entre xamanismo e mulheres, as grandes mobilizações de grupos familiares mbya são processos complexos que, além de não redutíveis a uma única motivação (preferivelmente religiosa), ao invés de negarem a sociedade, como pretende H. Clastres, são dirigidos ao seu fortalecimento. (Ciccarone, 2001: 278)

Entre os Araweté, "no contexto da vida aldeã, a mulher predomina sobre o homem, na medida em que a aldeia é função do milho, e o milho é 'coisa das mulheres'” (Viveiros de Castro, 1986: 272):

$A$ vida cotidiana Araweté é feminina. E o seria inteiramente, não fossem duas funções que cabem exclusivamente aos homens: o xamanismo e a guerra. Pois a primeira fonte de autoridade de um homem [...] a saber: a de líder de família extensa, que controla filhas e assim genros, é uma fonte "feminina", naquilo que controla e no modo de controle - a roça, e em sua associação a uma esposa, o verdadeiro centro da unidade social Araweté. $\mathrm{Na}$ tripartição funcional Araweté [...] a condição de líder de família extensa remete à agricultura e ao mundo feminino; já a força mágica e o poder guerreiro são integralmente masculinos. Só que eles exprimem um movimento para fora da Sociedade. Os homens têm com a exterioridade e a morte a relação que as mulheres têm com a interioridade e a vida. A importância ou dominância dos homens se funda nisso”. (Ibidem: 463, grifos meus)

Entre os Guarani, a agricultura do milho “verdadeiro” (avaxi ete’ i) e o xamanismo são elementos centrais e caminham juntos, mas diferentemente dos Araweté, o cantoreza, a "música dos deuses", uma das principais expressões xamânicas, não seria algo exclusivo aos homens, mas de usufruto e de especialização comum à sua própria socialidade. Às mulheres, responsáveis por cuidar e nutrir a relação entre as criações do mundo terrestre e os Mbya, caberia a tarefa de cuidar do plantio e da colheita, da escolha e preparação dos alimentos, geralmente, sob orientaçãodas mais velhas, especialmente, das kunhã karai. Por ser fonte de produção e reprodução da pessoa e do coletivo tanto materialmente, como simbolicamente, enquanto provedora dos alimentos que plantam, colhem e cozinham, seriam elas também produtoras e cuidadoras daquilo que se celebra na festa: "São elas que querem ter certeza de que o xamã não erre a atribuição do nome para 
seus filhos, assim como cuidam da observação das regras nos preparativos rituais do alimento sagrado" (Ciccarone, 2001: 92).

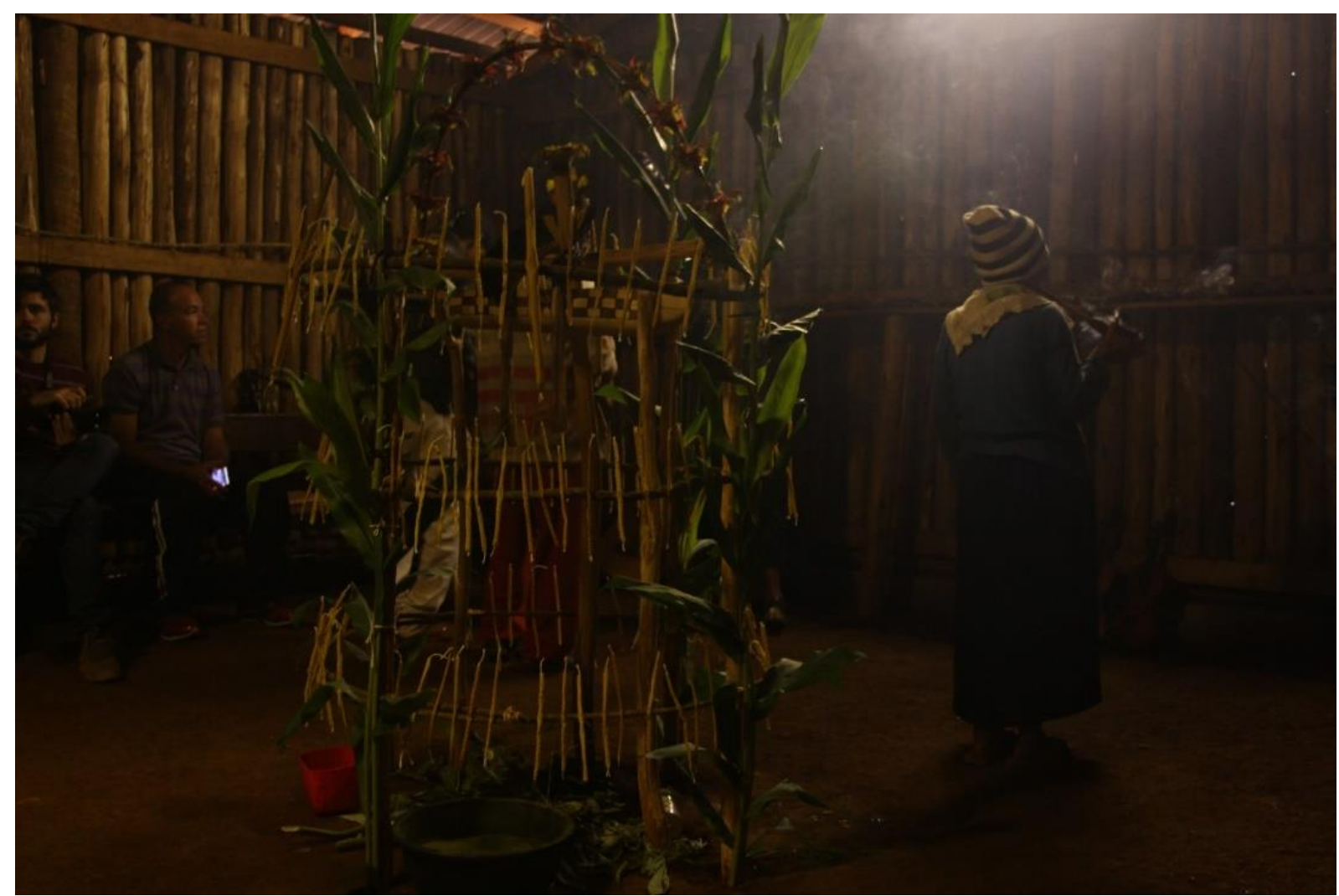

Kunhã Karai meditando na opy’i. Aline Aranha. T.I. Jaragua, 2016.

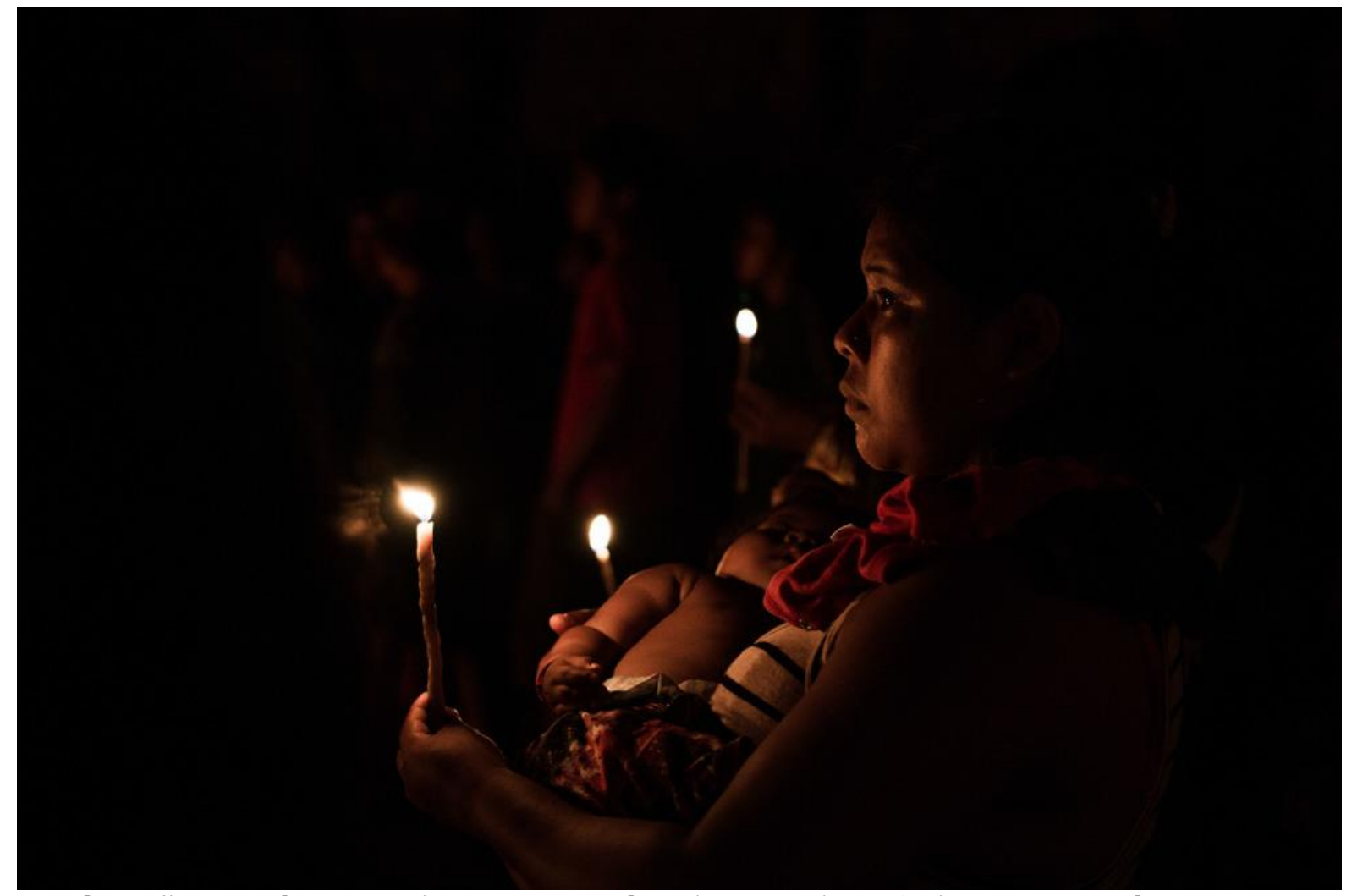

Kunhãgue’̉ esperando para ouvir o nome-nhe'ẽ das crianças. Luiza Calagian. T.I. Tenonde Porã, 2016. 


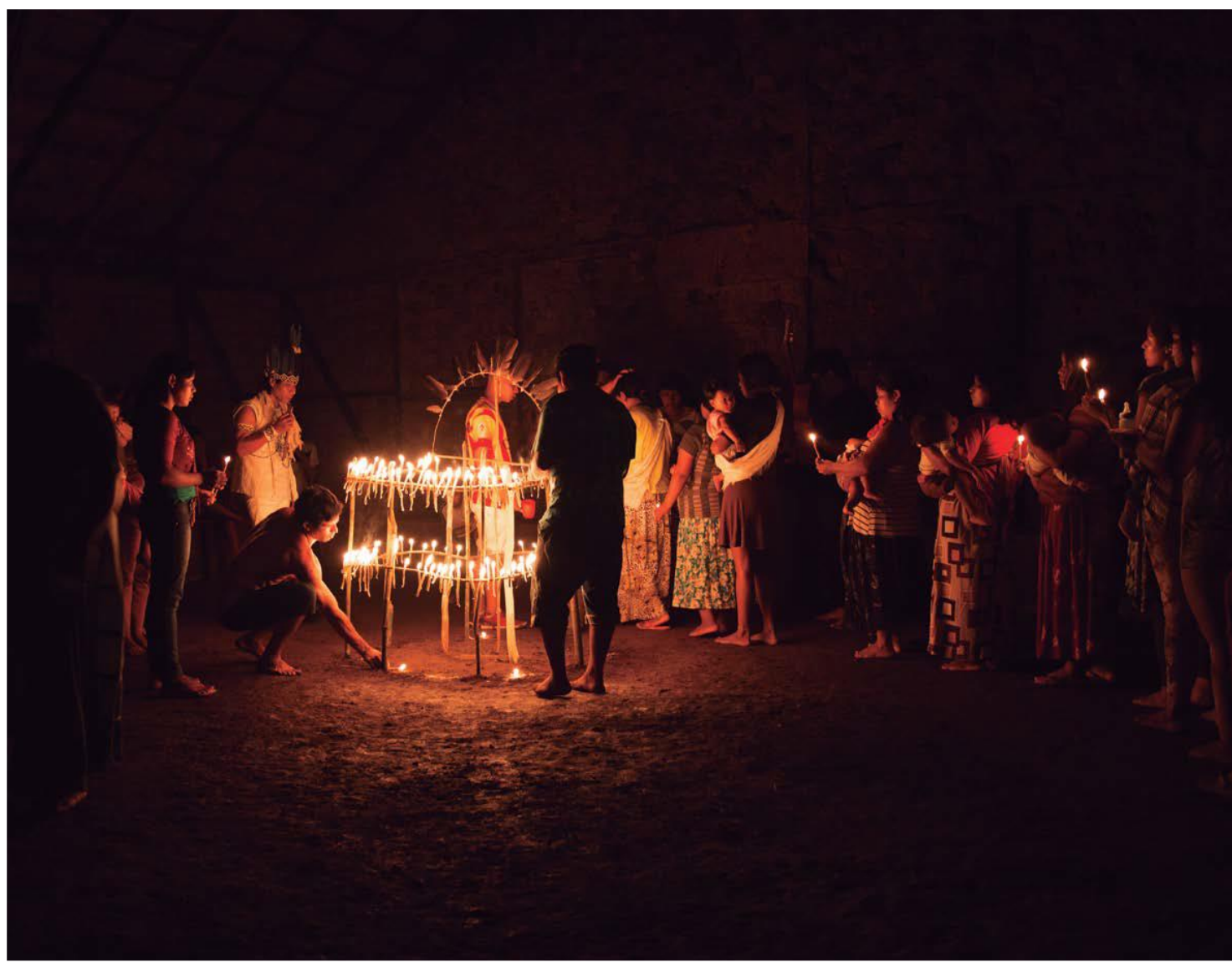

Ykarai. Luiza Calagian. T.I. Tenonde Porã, 2016.

A preocupação com a alimentação e a memória da sua tradição são temas constantes nos discursos xamânicos (Ibidem: 38). As grandes mudanças nos hábitos alimentares afetam diretamente o ideal mbya de leveza (-vevuı) corporal que tem a ver com o fortalecimento do temperamento ligado à potência divina do nhe'é. Os alimentos dos brancos são fontes potentes de enfraquecimento físico-espiritual, pois promovem o aumento da potência animal, responsável pelos desvios no bom modo de viver e se comportar, tornando a pessoa (e sua família) suscetível a doenças. Daí a importância do "alimento verdadeiro" (tembi’u ete’i) que permite a "manutenção do equilíbrio do indivíduo", uma vez que "todas as fases críticas da vida social (nascimento, parto, iniciação, doenças, morte) são cercadas de tabu e prescrições alimentares" (Idem: 38), que visam fortalecer a integração entre corpo e nhe'ẽ porã. Essas mudanças também se relacionam às dificuldades cada vez maiores que os xamãs têm enfrentado na atualidade ao tentar desenvolver e aperfeiçoar seus saberes-poderes, como apontam bem uma série de reflexões dos próprios Mbya sobre o presente (Ibidem: 226). No entanto, o xamanismo, enquanto um repertório de saberes e práticas (que também se atualizam) é constantemente acionado para enfrentar a "desordem”, nem que seja pela memória de tempos outros (Ibidem: 227). 
Na dinâmica das relações internas as mulheres têm uma potência considerável: "O riso é constante e poderoso entre elas. Ninguém escapa de suas chacotas à beira do fogo, onde comentam o que se passa em outras aldeias, de reuniões a viagens de caciques e repercutem eventos ocorridos nos 'bailes"” (Prates, 2013: 137). O riso ${ }^{283}$ das mulheres tem grande impacto na aprovação e desaprovação de comportamentos entre parentes: "riso que não somente diverte, mas também adverte, nas reticências, nos jogos da ambiguidade e nos deboches nas palavras, derrubando no ridículo os exageros que apareciam nos comportamentos dos indivíduos" (Ciccarone, 2004: 92-93). Seria na performance do riso e de seus duplos sentidos verbais, e por meio de seus relatos sobre o ritmo da vida diária, no qual tornam explícitos os conflitos internos entre parentes, envolvendo, inclusive, os líderes e anciãos, que as mulheres conferem visibilidade aos conflitos familiares e à fragilidade do poder político instituído, explicitando as contradições entre as condutas e os discursos masculinos, exercendo assim a sua autoridade no interior da família (Ciccarone, 2001: 61).

As kunhãgue, enquanto grandes observadoras dos comportamentos alheios seriam mais atentas em perceber-sentir outras pessoas e, talvez, por isso, façam maior uso de críticas desse tipo, o que também funciona como um meio de controle do corpo familiar, podendo obter aí grande prestígio, uma vez que sua fala, geralmente é muito respeitada no interior da família. No entanto, entre as estratégias políticas de controle familiar acionadas pelas mulheres, também podem ocorrer excessos, como a "fofoca" 284 (ayvuxe rei), por exemplo. Assim, se as boas e verdadeiras palavras (ayvu porã) funcionam como conselhos, curam como remédios, palavras carregadas de estados e humores excessivos, exageradas, maldosas, são vazias de sentido, sem boas intenções, de ajudar-curar, soam como agressão e agem como feitiço ${ }^{285}$, podendo incorrer em inúmeros conflitos. A fofoca geralmente circula mais livremente entre os jovens e crianças, que não aprenderam a controlar o fluxo da fala, podendo mais facilmente cometer excessos, e têm um trânsito

\footnotetext{
${ }^{283}$ Segundo Perrone-Moisés (2015), os índios gostam de rir e de provocar risadas e, correlativamente, gostam de gente que ri e, principalmente, que faz rir. Sobre a importância do riso entre os ameríndios ver: De que riem os indios? [1967] (Clastres, P. 2003 [1974]).

${ }^{284}$ No entanto, reduzir a intencionalidade política das mulheres apenas à fofoca ou à dimensão domésticacotidiana empobrece muito a análise, ainda mais quando nos damos conta do quanto esse aspecto d@ polític@ revela sua potência no fazer e desfazer coletivos.

${ }^{285}$ A questão da feitiçaria (ipaje vaikue) é um grande motor de acusações, vinganças e doenças entre parentes e os outros grupos, por isso, muitos Guarani preferem ir embora para outro lugar a depender da situação ou, que a pessoa acusada (e, de algum jeito, "reconhecida" pelo coletivo) assim o faça. Para evitar vinganças desmedidas os xeramoĩ e as xejaryi preferem não revelar a "autoria" das agressões espirituais que curam para evitar conflitos internos, na tentativa de apaziguar e conciliar os parentes e não gerar mais enfermidades.
} 
mais livre entre os núcleos familiares e dentro da própria aldeia, pelo ambiente de socialização que a Escola acaba trazendo, mas não se restringe só a eles (elas circulam também entre os homens, é importante lembrar, eles também falam demais). Essa circulação de falas "maldosas", que têm intenção de ferir ou de vingar, seja entre as mulheres, jovens ou homens, pode causar grandes problemas internos. Há aí, no entanto, uma espécie de dimensão ética-estética operando nessa dinâmica de circulação de críticas-conselhos, que parte um conjunto de instruções, de convenções culturais a respeito da vida coletiva, que são geridos principalmente pelas anciãs para desencadear no cotidiano, "momentos de reflexividade" entre os seus (Ibidem: 89-90).

As mulheres guarani, principalmente, as sábias anciãs e avós (nhandejaryi kuery) que já passaram por grande parte das fases de maturação na relação cuidado-criação de parentes, são muito valorizadas no interior das famílias extensas, por sua (dis)posição de mãe, avó e sogra ${ }^{286}$, atuando como figura chave em aconselhamentos, e dotadas de autoridade-respeito e prestígio por conta da potência que suas palavras belas-bonitas-verda$\operatorname{deiras}^{287}$ (ayvu porã), cheias de espiritualidade, sabedoria e experiência, têm de fazer agir (para o bem do coletivo). São elas quem cuidam da coordenação e distribuições de tarefas dentro da família extensa - junto a seus companheiros, ou mesmo, sozinhas ${ }^{288}$-, assim como da gestão, produção, preparo e o compartilhamento de alimentos, elemento central

${ }^{286}$ É importante uma atenção maior da etnologia guarani acerca da autoridade da sogra nas relações entre parentes, mas sua importância é central na liderança do grupo local, pois são os filhos homens que, geralmente circulam ao contraírem casamento, as filhas permanecendo junto aos pais, compondo regra de residência matrilocal, ainda que o parentesco seja, entre os Mbya, cognático-bilateral. A matrilocalidade contribui também para a força e poder das mulheres, uma vez que se não estiver perto de sua família, principalmente de outras mulheres de sua confiança, como suas irmãs, primas e filhas, pode ficar enfraquecida na relação com o marido e os parentes dele, ainda mais quando são jovens e estão distantes da aldeia de seus consanguíneos (Prates, 2013: 137). As filhas que o casal-chefe de família consegue manter perto de si também significam mais genros e, portanto, mais afins e poder de magnificação. De acordo com Prates, jepokuaa ("acostumar") e ambory'a ("alegrar") são as designações mbya para se referir à chegada de um novo genro para morar próximo, e também quando uma criança nasce, uma vez que ambos precisam "querer ficar" e, para tanto, não só devem ser "acostumados", como "alegrados" (Idem). No entanto, se o "genro é um afim, a criança que chega é parte de uma divindade", ambos carregando consigo "a vitalidade de um Outro, que deve ser retida com consentimento" daqueles que os recebem (Idem). Dooley traduz jepokuaa por “acostumar-se, aprender o jeito de" (Dooley, 2006: 66). Já mbory’a é traduzido como "alegrar" (Ibidem: 110). O termo ambozy'a, entre os interlocutores de Prates, aparece tanto como "amansar" quanto como "se acostumar" (Prates, 2013: 138).

287 Ainda que saibam usar palavras duras para aconselhar (-mongeta), nas horas necessárias, constituindo essa também uma ação que faz com que as mulheres, assim como os homens guarani, ganhem prestígio pela agência que suas falas-palavras têm em "tocar o coração" das pessoas.

${ }_{288}$ É interessante notar que é muito comum encontrar xejaryi e-ou kunhã karai viúvas ou separadas, isto é, sozinhas exercendo a liderança de um grupo de parentes (não sem contar com o auxílio de familiares), que o contrário, algum xeramoĩ e-ou karai sem par, assumindo essa disposição de liderança sozinho. 
na produção de saúde, alegria e satisfação ao coletivo de parentes e na reprodução e manutenção da vida e do seu bem-estar espiritual-corporal ${ }^{289}$, nesta terra. Destaca-se também sua atuação como parteiras (e "madrinhas" das novas gerações por ao serem escolhidas para cortar o cordão umbilical no parto) e como "donas" ou "guardiãs" de roças $(k o k u e)^{290}$, plantando e cultivando-criando-cuidando tanto de pessoas, alimentos, plantas, "remédios do mato" (poã ou moã) ${ }^{291}$ como de animais e, portanto, de relações sociais.

Além disso, elas também fazem circular a memória e os ensinamentos-conselhos dos bons comportamentos e boas ações dos parentes divinos e dos "antigos", em equilíbrio com a terra e todos os seres que a habitam, visando proteger os parentes de corposespíritos outros. A palavra em forma de "conselho" é a "alteridade divina veiculada através da fala”, uma contra-ação aos ija kuery, que seriam os enfraquecedores por excelência da cabeça-pensamento (akã) (Prates, 2013: 209). O carinho-cuidado-atenção aos ânimos, humores e disposições daqueles que mantêm vivendo perto-junto de si, fazem essas kunhãgue investirem diariamente contra a iminente dissolução-agressão de seres-corposespíritos-poderes outros através da administração diplomática das relações sociais nesse mundo, através da mobilização de uma série de técnicas xamânicas como a reza-cantodança na $o p y ’ i$, a alimentação tradicional, o trato com os remédios do mato (que podem necessitar de reza-canto especial e muita fé-confiança (-jerovia), tanto de quem faz,

${ }^{289} \mathrm{O}$ que não quer dizer que homens não se preocupem ou que não estejam atentos também, mas que por observaram mais os próprios comportamentos, as mulheres seriam mais sensíveis aos comportamentos alheios e, portanto, às disposições dos outros. Isso também não quer dizer que tais qualidades sejam estanques ou estáveis, mas é notável tal comportamento, assim como o aprendizado desta atenção-preocupação entre as mulheres mais jovens, ou entre os "mais velhos" e mais experientes na arte da percepção.

290 Dooley traduz kokue como "roça plantada" (Dooley, 2006: 85). Entre os Kaiowa e Guarani, há toda uma "negociação cósmica com o jara” para que as práticas agrícolas sejam fecundas através da reza-canto e de outras práticas xamânicas que têm um "poder profilático e fertilizante sobre as plantas cultivadas, garantindo seu crescimento rápido e livre do ataque de pragas e doenças” (Seraguza, 2013: 118).

291 A fabricação do corpo entre os Guarani também está muito relacionada ao uso de substâncias do mato, chamadas em guarani de poã ou moã, traduzidas por eles como "remédios do mato" ou "remédios tradicionais". Moã seria a forma não-relacional de poã, "remédio" (Dooley, 2006: 114). Esses remédios são feitos a partir de substâncias e processos relacionados a plantas, frutos, flores, troncos, resinas e partes do corpo de animais do mato, guardados por espíritos-donos (ija kuery), que irão garantir (ou não, dependendo da negociação) a eficácia do remédio. As mulheres são as principais responsáveis pela preparação de "remédios do mato", tornando-se especialistas, geralmente, quando atingem a condição de xejaryi. Em campo, um xeramoĩ me contou que ele havia aprendido o preparo dos remédios com sua avó. Testa também comenta que homens que sabem prepará-los, "frequentemente contam que aprenderam com suas avós" (Testa, 2014: 158). Segundo um interlocutor, ainda que o xeramoĩ seja quem possa entender da "medicina", "quem faz, não é ele quem faz, é a xaryi que vai preparar e tudo, faz aquele ritual e tudo, então aí parece que passa o conhecimento, e depois é ela, com o tempo, vai ensinando a mulher mais jovem" (Karai Poty, Tekoa Tenonde Porã 2016). As xejaryi acabam revelando os segredos somente para aquelas mulheres que elas sentem que desejam aprender "de verdade" e que irão "saber cuidar bem" desses saberes. Essa preocupação é constante, justamente porque envolve todo um cuidado para que tais saberes não caiam em mãos erradas, acabando assim com a eficácia “verdadeira” dos remédios (para o "bem”), podendo ser utilizados para fins de agressão. Aqueles que têm “mão boa” ou "mão bonita” (ipoporã), segundo meus interlocutores, são tidos como bons conhecedores das ervas medicinais do mato. Para mais reflexões sobre o tema dos poã entre os Guarani ver também Montardo (2002), Mello (2006), Macedo (2010), Prates (2013), Testa (2014). 
quanto de quem recebe, para serem ativados e tornarem-se eficazes), a fumaça (-ataxĩ) de seus petỹgua que protegem e trazem inspiração, os sonhos que iluminam (-moexakã) o que irá acontecer, assim como os ensinamentos-poderes revelados em vigília pelos parentes divinos, veículo de aconselhamentos e curas diversas, etc.

A força de sua atuação diária no cuidado-proteção-criação dos parentes faz circular entre os seus os saberes-poderes-capacidades conquistados ao longo dos caminhos percorridos, fortalecendo a conexão entre seus corpos e nhe'ẽ e os próprios laços de parentesco e humanidade entre aqueles que vivem perto-junto, inspirando assim bons pensamentos e moviment(ações). As mulheres, principalmente as xejaryi são, portanto, fonte de inspiração para seus filhos, filhas, netos e netas e agregados, e também em alguns casos, para jovens de outras famílias, quando seu prestígio ultrapassa o grupo local. Ouvi diversas vezes em campo que as kunhãgue são "mais espiritualizadas" que os homens, tendo até mesmo mais facilidade de se tornarem rezadoras que eles, como vimos em algumas falas guarani aqui reproduzidas. Há, no entanto, uma espécie de divisão das atividades xamânicas entre elas (assim como entre os homens), com a distribuição de trabalhos específicos - em alguns casos -, visando a boa disposição entre elas mesmas, para que nenhuma fique sobrecarregada ou insatisfeita, assim como ocorre entre os parentes em geral. As kunhãgue desempenham assim papel central na administração, proteçãoprodução e ativação cotidiana-ritual das relações de parentesco corporais, tornando visíveis nessas atividades suas capacidades-poderes de fazer crescer (-mbotuvixa) e mobilizar pessoas, ações e relações.

Um problema fundamental nesses processos de criação de relações, saberes, pessoas, ou produtos da roça e lugares habitados, segundo Testa, é o desenvolvimento gradual da capacidade de "saber cuidar" (-erekokuaa) do crescimento de algo, isto é, daquilo que é criado ou necessita cuidado-atenção ${ }^{292}$ (Testa, 2014: 126). As meninas-mulheres seriam especialmente criadas e ensinadas a estarem mais atentas aos ânimos das pessoas, principalmente, dos seus parentes ${ }^{293}$ (ainda que os meninos-rapazes também precisem aprender a desenvolver alguma percepção dos afetos alheios). Tal aprendizado começa tão logo se percebe que as meninas já são capazes de aprender a cuidar de suas irmãzinhas

\footnotetext{
292 A palavra frequentemente usada pelos Mbya para se referirem ao ato de “olhar” (-ma'ê) também envolve a "capacidade de cuidar de algo/alguém" (Testa, 2014: 166, grifos meus). Daí que "não perder os saberes xamânicos implica desenvolver a capacidade crescente de ver e cuidar, ou seja, colocar estes saberes em uso para que possam continuar a circular nos diferentes caminhos de relações” (Idem).

${ }^{293}$ É possível observar o cuidado-carinho entre mulheres de um mesmo núcleo familiar, procurando piolhos umas nas outras e nos filhos, sobrinhos, netos, quando sentam para conversar sobre a vida entre parentes. As meninas-mulheres também imitam esse comportamento entre si, quando sentam juntas em fileira ou mesmo em pé, olhando-cuidando dos piolhos e trançando cabelos umas das outras.
} 
e irmãozinhos, ou mesmo de seus priminhos e priminhas, "olhando" eles sempre sob a supervisão de alguma menina mais velha ou de uma mulher adulta. O que ocorre também quando elas começam a se interessar em auxiliar nas tarefas domésticas - cortar e picar alimentos e cozinhá-los, buscar lenha, acender e soprar o fogo, picar fumo, acender petỹgua, entre tantas outras atividades - enquanto as adultas preparam a refeição, ou buscam algo para cozinhar. Também acontece das meninas mais "mocinhas", olharem os irmãos mais novos enquanto a mãe trabalha para "fora" (do grupo local), exercendo alguma atividade remunerada dentro da aldeia mesmo, seja como professoras, merendeiras, faxineiras, e até "vigias" na Escola Estadual, no CECI e, também no "postinho" (UBS) como agentes de saúde, ou atuando ainda nos projetos de fortalecimento cultural e socioambiental que, cada vez mais, contam com a participação feminina e, em troca, auxiliam as kunhãgue com alguma ajuda financeira ou com alimentos e produtos cotidianos-rituais (em geral, fumo de corda e erva-mate).

A constante atenção-preocupação aos ânimos e à saúde-alegria de seus parentes mais próximos visa proteger aqueles que vivem juntos, enfatizando o aprendizado sempre contínuo da moderação nos comportamentos e temperamentos de seus corpos-espíritos, seus desejos, emoções, assim como aos próprios fluidos corporais, principalmente a urina, o suor e o sangue (-uguy) menstrual, que têm cheiro ${ }^{294}$ forte que pode se espalhar de modo descontrolado pelo ar. Os corpos dos jovens, em especial, devem aprender a controlá-los mais intensamente, recebendo de modo mais acentuado nessa época uma série de conselhos de seus pais e avós - no entanto, ainda que a preocupação seja comum, são verbalizadas com mais intensidade pelas mulheres -, uma vez que essas substâncias costumam atrair ou incomodar espíritos-donos de domínios outros do cosmos e incorrer em retaliação-vingança ${ }^{295}$, afetando assim todos os seus parentes corporais. Tal preocupação se intensifica nesses momentos de passagem, nesse entre "fases", como a primeira menstruação das meninas-mulheres, o engrossar da voz dos meninos-homens, o nascimento do primeiro filho do casal, assim como no pós-parto em geral, por conta do perigo que o descuido em tais eventos pode ocasionar na rede de relações de parentesco, colocando em risco a sua própria proteção-produção incessante. O que decorre dada a suscetibilidade de todos os corpos-espíritos confinados nesta terra, que em momentos como

${ }^{294}$ Esses cheiros fortes expelidos pelos corpos dos jovens contrastam com o que os Mbya dizem a respeito dos corpos das pessoas idosas, e precisam de alguns cuidados a mais para serem "encobertos" e "disfarçados" e não atrair a atenção desses sujeitos outros, o que se dá, geralmente, através da fumaça ou pela aplicação de diferentes plantas e resinas do mato (Testa, 2014: 264).

${ }^{295}$ Este tipo de relação envolve ações de desejo e sedução recíprocas, embora sejam permeadas por uma série assimétrica de equívocos e enganos, que podem desencadear uma série de retaliações aos envolvidos. 
esses podem estar desatentos e desnortear-se facilmente aos chamados de outros seres, aumentando o risco (sempre) potencial de metamorfose corporal (-jepota), inspirando assim grande atenção e controle aos comportamentos e interdições de cada gênero ${ }^{296}$, em cada relação.

Estes ensinamentos e estratégias xamânicas de diplomacia cosmopolítica fazem parte de uma ética guarani da moderação, que diz respeito sobretudo aos comportamentos e afetos. Seu aprendizado se dá, com maior ênfase, na transição para a vida adulta, incidindo no maior cuidado-controle dos sentidos-percepções visando proteger e fortalecer a própria perspectiva-humanidade (e por extensão, a de seus parentes). Tal aprendizado viria acompanhado de um sentimento de respeito dos mais jovens, principalmente das mulheres, evitando falar sobre aquilo que ainda não sabem o suficiente e que, portanto, não seriam ainda capazes de "cuidar" bem, correndo o risco de fazer certos conhecimentos circularem indiscriminadamente, e que é, frequentemente, traduzido em português pelos Mbya como "vergonha”. Esse sentimento "não carrega [em si] um sentimento de culpa, mas o receio de se exibir demasiadamente diante daqueles que sabem mais" - o que, por sua vez, vai diminuindo com o avançar da idade e da experiência de vida de cada um (Testa, 2014: 270, grifos e alterações minhas). A preocupação em não se exibir enquanto detentor de muito(s) conhecimento(s) e capacidades-poderes é um comportamento ideal entre os Guarani e a maneira correta de controlar a circulação 297 e a concentração de

${ }^{296}$ Nesta fase em que meninos e meninas saem da categoria geral kyrĩgue (crianças), em que o gênero não é tão fortemente marcado, para a categoria fortemente marcada pelo reconhecimento da divisão dos sexos, kunhãtaĩgue (para as jovens mulheres) e kunumĩgue (para os jovens homens), se intensificam as orientações recebidas sobre como devem agir nas "relações conjugais" e entre parentes, em relação aos mais velhos e em relação a outras famílias (Testa, 2014: 278). Em campo, pude perceber a transformação de meninas em jovens mulheres, e de como mudaram seu comportamento rapidamente: pararam de brincar e sorrir tanto, ficaram mais sérias e começaram a ajudar mais nas tarefas domésticas e a se enfeitarem mais, apesar de, em alguns casos, continuarem tendo algumas atitudes infantis, como reclamar do trabalho, ou não auxiliarem tanto quanto deveriam suas mães, tias e avós, sendo constantemente aconselhadas a crescerem "de uma vez", e aprender a importância do trabalho das mulheres. Acredito também que os efeitos da educação escolar jurua contribuam para o aprendizado tardio de algumas das disposições femininas mais centrais, pois as jovens devem passar um período longo na Escola - que provém, inclusive, alimentação, trazendo um outro motor de socialização, para "fora" -, participando de atividades coletivas fora de seu núcleo familiar, o que contribui para não passaram mais tanto tempo, como antes, em casa, aprendendo com as mulheres de sua família. O futebol feminino e o intercâmbio de jogos e festas entre aldeias também são uma grande oportunidade de contrair casamento e, cada vez mais, as jovens passam tempo treinando durante os finais de semana para enfrentarem outros times. O uso da tecnologia, através dos celulares e Internet também contribui em muitos casos, negativamente, para a "rebeldia" de muitas jovens que, segundo os Mbya, "não sabem usar" essa ferramenta e acabam passando mais tempo que o esperado nas redes sociais, gerando muitas intrigas dentro da própria família, pelo seu comportamento ousado nas redes e pela desatenção que isso gera no cuidado aos próprios parentes.

297 Também se desconfia das capacidades ou das intenções de quem não põe seus saberes à disposição do coletivo, pois mesmo que estes devam ser controlados, eles também têm que circular em benefício do coletivo, em nome de sua saúde, alegria e bem-estar (ver, nesse sentido, Testa 2014). 
saberes-poderes entre parentes. Certos saberes devem surgir ou serem revelados no momento correto para que as pessoas possam assim compreendê-los e, com isso, aprender como cuidar deles e usá-los em benefício do coletivo. Seria por isso que lideranças mais jovens, quando questionadas sobre assuntos que dizem respeito, sobretudo, à "espiritualidade" recorram sempre aos seus anciões, dizendo não saberem tanto a respeito e que o "pouco" que sabem aprenderam ouvindo seus avós, o que também se revela uma estratégia poderosa de preservação e manutenção desses saberes sagrados, pela sua circulação restrita e amplamente controlada entre não-parentes:

os jovens aprendem a falar pouco quando estão diante dos mais velhos e sempre deixar que estes falem primeiro e completamente antes de eles mesmos se expressarem. Também aprendem a falar e agir de modo diferenciado entre seu grupo de parentes próximos e outros grupos. Restrições e modos da moderação da fala e da alimentação gradualmente se alteram e até relaxam conforme a pessoa mbya é reconhecida como mais velha e sábia. Quando isso ocorre, seu controle sobre os saberes e as substâncias (próprias e aquelas que recebe de outros sujeitos) é tal que ela já é capaz de fazer uso proveitoso de um fluxo mais abundante de palavras e substâncias. É também nesta fase da vida que ela pode ser reconhecida como uma pessoa apta a orientar seu grupo de familiares, seja em atividades cotidianas de trabalho, alimentação ou reza, seja nas práticas de mobilidade e busca por novos lugares. (Ibidem: 270-271)

É interessante notar também que há cada vez mais, nos dias atuais, a atuação e envolvimento de jovens lideranças nas incursões de "retomadas" de terra, inclusive, jovens mulheres que estão também aprendendo na prática a plantar os gêneros alimentícios guarani, os cuidados com a terra e seus frutos de acordo com o seu código de ética xamânica, enquanto os jovens xondaro ficariam mais responsáveis pela limpeza dos solos, corte de lenha, caça, pesca e a segurança física do novo tekoa e dos parentes e agregados. Como viemos mostrando, tanto as mulheres, como os homens, são mediadores de relações cosmopolíticas. Entretanto, por sua disposição central no preparo de alimentos, nos aconselhamentos a respeito das condutas a serem seguidas, pelos cuidados constantes com os filhos e parentes e pela promoção de ações que buscam o equilíbrio do cosmos e dependem, em grande parte, das mulheres, há um certo protagonismo delas em cena, como bem aponta Prates (2013). Há também o contraponto masculino, com atividades e relações que se voltam para "fora” da aldeia, a partir das quais eles também se colocam em perigo, principalmente, ao assumirem disposições de liderança que promovem uma maior proximidade com jurua kuery. A diplomacia cosmopolítica guarani é assim imprescindível à manutenção da vida entre parentes (-retarã kuery), e a máxima guarani “sem terra não há teko" tem aí grande impacto, a falta de terras demarcadas afeta diretamente o equilíbrio buscado nessa produção-proteção do parentesco, e incide diretamente em seu cotidiano, principalmente no das mulheres, responsáveis pela gestão do fogo doméstico-ritual, pela produção de alimentos, do corpo saudável e e alegre. 


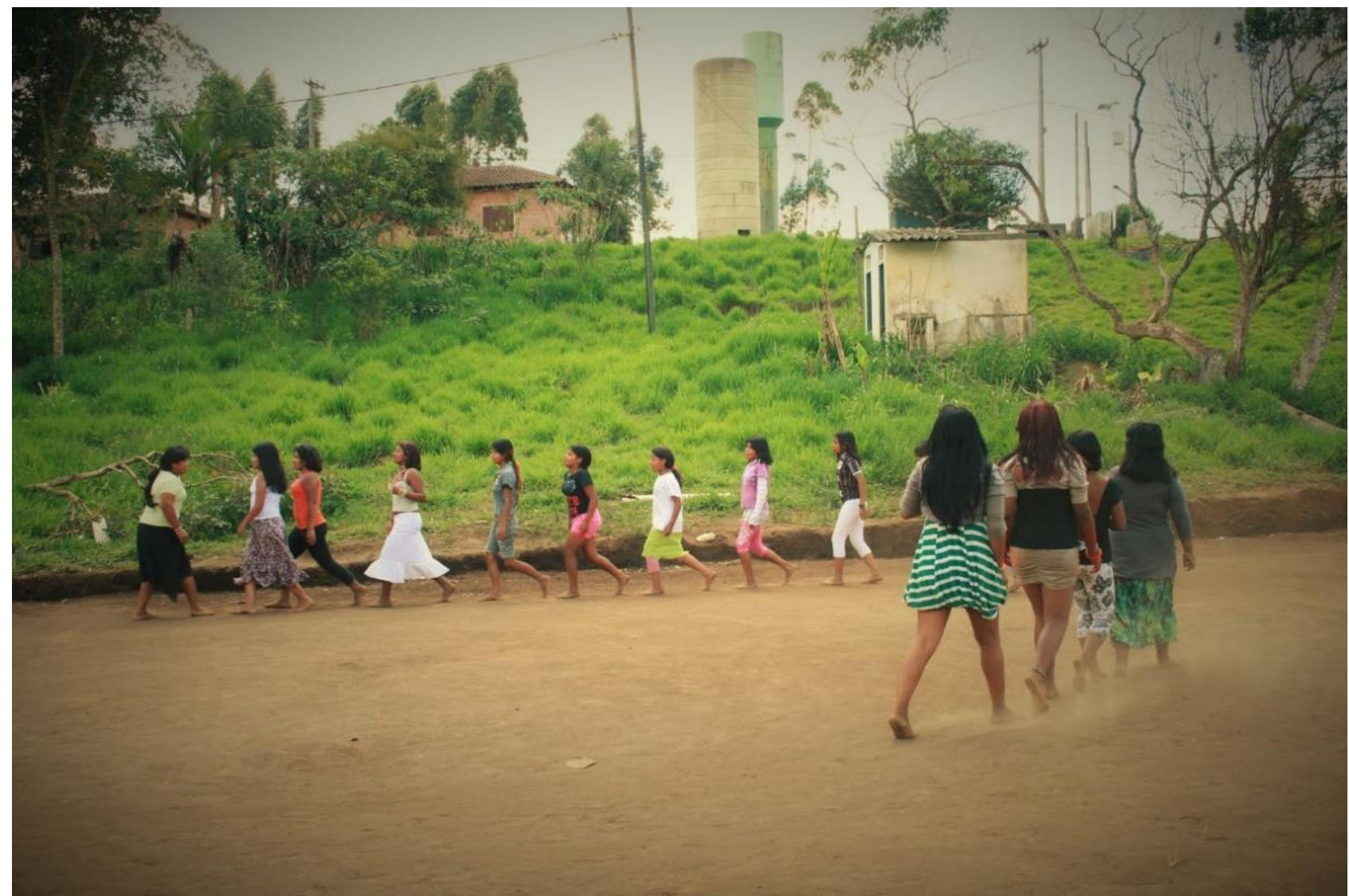

Xondaria jeroky. Aline Aranha. T.I. Tenonde Porã, 2012.

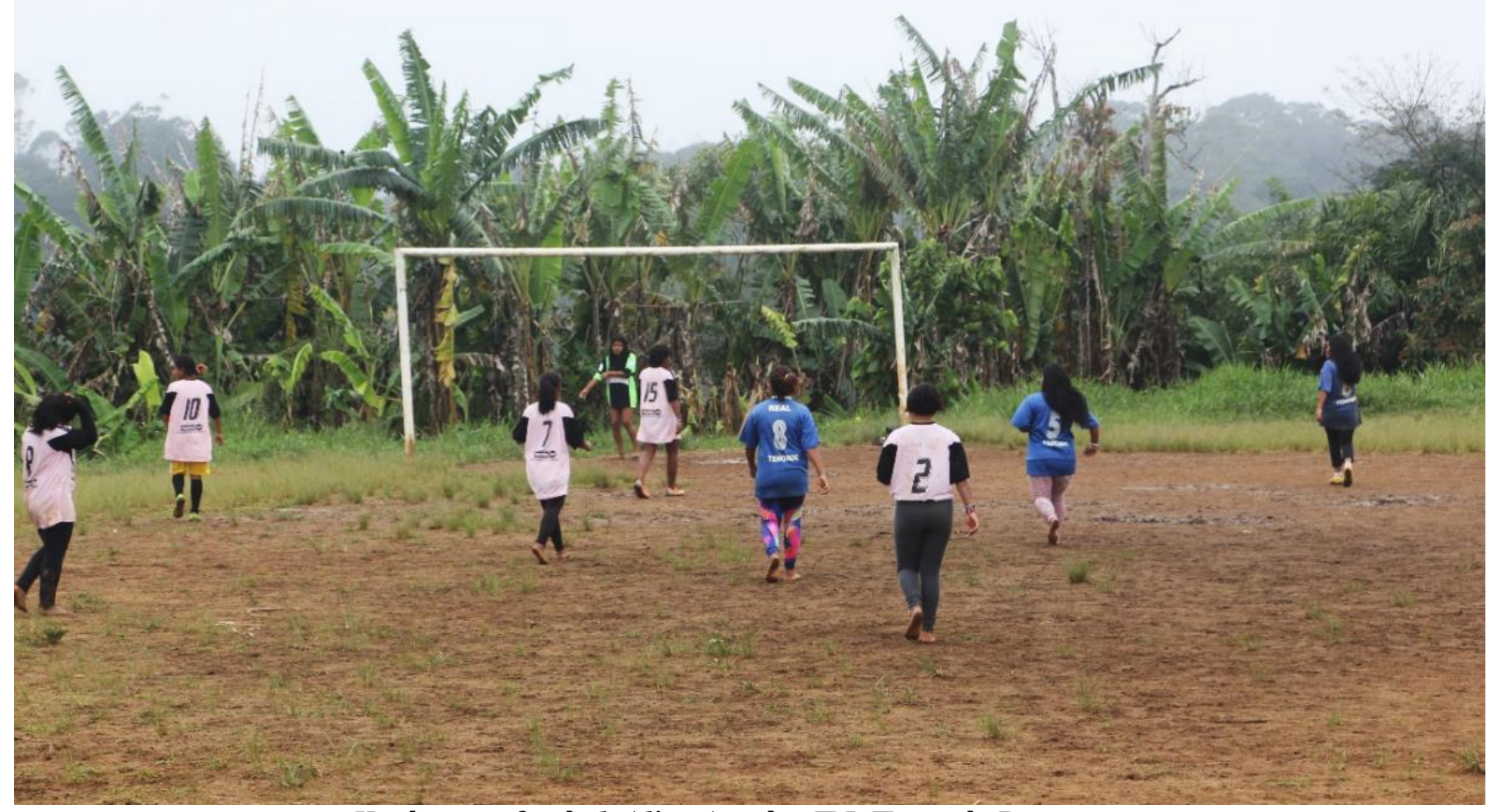

Kunhãgue e futebol. Aline Aranha. T.I. Tenonde Porã, 2016. 


\title{
A fabricação do gênero do corpo: entre o (des)controle e o desejo desmedido
}

\author{
Apesar dos protagonistas da caminhada originária serem ambos masculinos (de \\ acordo com a literatura), segundo Ciccarone, “à medida que fundam o mundo, a lua ganha \\ cada vez mais o simbolismo do ser feminino 298 ", e mesmo ocupando um "papel secundá- \\ rio", de "irmão trapalhão", é a Lua (Jaxy) quem regularia os "ciclos da agricultura e os \\ meses da mulher", estando "intimamente ligada a dimensão feminina da sociedade" (Ci- \\ ccarone, 2001: 279). Prates relata, a partir da versão de seus interlocutores, a relação \\ incestuosa ${ }^{299}$ entre Lua e sua tia paterna, dando origem à menstruação entre as mulheres:
}

\begin{abstract}
Um dia Jachy, que era muito arteiro, aproveitou que sua tia dormia para lhe forçar a fazer sexo com ele. Durante a relação, a mulher não conseguiu ver o rosto de quem a forçava ao ato e por isso teve a ideia de marcá-lo com cera de jate' $i$ ("abelha do mato") a fim de poder reconhecê-lo nos dias seguintes. A tia de Jachy, que era irmã de seu pai, alertou aos parentes próximos o que lhe acontecera. Em decorrência da relação sexual forçada, ela sangrou. Todos puderam ver o rosto marcado de Jachy e nos dias atuais, quando a lua está em sua fase cheia, vemos as marcas feitas por sua tia que denunciam o ato incestuoso que deu origem ao sangramento menstrual das mulheres na vida terrena. A cada "volta de lua" as mulheres menstruam e as meninas púberes são iniciadas sexualmente por Jachy enquanto dormem. (Prates, 2013: 215)
\end{abstract}

De acordo com Belaunde (2006), existe uma lacuna importante em relação ao tema mítico ${ }^{300}$ amazônico, por ela denominado de "estória do incesto de Lua". Seriam

\footnotetext{
${ }^{298} \mathrm{Na}$ mitologia guarani esse ser mítico está relacionado ao plantio, já que só se pode plantar e-ou carpir em certas luas, e como plantar é uma atividade geralmente feminina, associada talvez à capacidade das mulheres de produção e criação de crianças, Lua acaba ganhando esse simbolismo (sobre o sexo dos astros, ver Lévi-Strauss 2013 [1973]). Além disso, no mito, Lua "mexe" (como meus interlocutores dizem) com a sua tia paterna ou sobrinha (a depender da narrativa), e como em decorrência dessa relação elas sangram, ele é considerado o primeiro homem ou marido das meninas-mulheres aqui na terra. É porque ele as "visita" mensalmente que elas menstruam.

${ }^{299}$ Cadogan faz referência ao incesto de Lua e sua tia paterna: "Luna se introducia subrepticiamente en la habitación de su tía paterna (con intención de fornicar). Queriendo saber quién era el que se introducía junto a ella, embadurnó sus dedos con resina y de noche, mientras a tientas la buscaba, le embadurnó a Luna el rostro. Al día siguiente Luna fue a lavarse la cara a fin de quitarse la resina. No salió, no salió todo; solo se le ensució más la cara. Para que hasta el presente lleve la cara manchada acontecieron estas cosas, sentando en esta forma, efectivamente, precedentes para nuestra conducta" (Cadogan, 1959: 79-80, grifos meus). Mello também comenta a relação entre menstruação e o intercurso sexual com Jaxy que vem desde o tempo em que os irmãos míticos caminhavam por esta terra, a partir do relato de uma interlocutora: "Contrariado por ter que partir deste mundo e aqui deixar suas namoradas humanas, Djatchi exige ao irmão e aos outros deuses, seus parentes que chamavam sua presença, que em troca de sua partida, todas as mulheres deveriam ser suas esposas, antes de terem seu primeiro marido. Daquele dia até hoje, as mulheres menstruam porque Djatchi 'mexe' com as moças quando elas estão se tornando mulher. O sangramento mensal que as mulheres têm é um reflexo, um sinal da ação sobrenatural de Djatchi, o 'primeiro marido' das mulheres. [...] Quando uma mulher queixa-se de dores, fica brava, ou recusa ter relações sexuais, seu marido zomba, rindo e comentando em público que [...] seu primeiro marido voltou para ela" (Mello, 2006: 170). Em campo também ouvi os homens falarem em tom jocoso com suas esposas que elas estavam "traindo" eles com Jaxy, quando elas estavam no período menstrual. O fato de, nesse período, os casais não poderem manter relações sexuais, pode ter a ver com o motivo da "vagina dentada", amplamente recorrente na mitologia ameríndia (ver, nesse sentido, Mitológicas, Lévi-Strauss).

${ }^{300}$ Lévi-Strauss chama este mito de "vulgata americana", por estar espalhado por toda parte (ver LéviStrauss 2006 [1968] e $1986[1985])$.
} 
inúmeras as narrativas indígenas que fazem referência a origem do sangramento feminino relacionando-a uma relação incestuosa entre Lua e sua irmã:

Lua visita sua irmã à noite, escondendo sua identidade no escuro. Querendo descobrir quem era seu amante, ela mancha o rosto dele com tinta preta (Genipa americana). As façanhas incestuosas são reveladas quando, sob a luz do dia, ela reconhece sua própria marca na face dele. Lua então é envergonhado e/ou morto, geralmente por decapitação, literalmente perdendo seu rosto e colocando sua cabeça cortada no céu como lembrança de seu feito. (Belaunde, 2006: 223)

Segundo essa versão amazônica comentada por Belaunde, "antes de partir para o céu, Lua deixa o sangue de sua morte como lembrança para as mulheres e vingança pelo fato de uma mulher ter escrito a sua palma no rosto dele” (Ibidem: 224, grifos meus). A própria menstruação seria assim um "efeito da afinidade de sexo oposto", fruto de uma relação sexual com Jaxy"301, "que com seu enorme pênis penetra as meninas (aliás, todas as fềmeas) fazendo-as sangrar" (Ramo, 2014: 106). Jaxy anuncia com tal ato, "não só a sexualidade, como também a afinidade” (Idem). Este momento de abertura para a afinidade é de aconselhamento intensivo, onde a menina-moça irá “aprender as habilidades para ser considerada uma mulher (-mbokunha)" (Idem). Há uma série de conselhos, saberes e práticas que são dirigidos às meninas-moças nesse período da menarca (-nhẽgue $\left.e^{302}\right)$, principalmente pelas mulheres mais velhas e sábias da família, que passam sua experiência a respeito dos cuidados com o corpo e com os parentes, e contam muitas histórias míticas que ensinam sobre os comportamentos ético-xamânicos que devem ser por elas adotados

${ }^{301}$ Entre os Kaiowa e Guarani do MS, ao pensar as relações entre mulheres indígenas, poder e perigo, Seraguza (2013) passa necessariamente pela cosmologia, partindo do poder de atração que Jasy (Lua) e a sua manifestação terrena, Jasy Jatere (figura não-humana associada ao Saci Pererê), têm em relação à menstruação e à gravidez inesperada, incidindo diretamente sobre o cotidiano destas mulheres, principalmente nos momentos em que elas estão mais suscetíveis ao perigo de transformação (tensões estas fortemente presentes em sua vida social). Jasy Jatere, de acordo com Seraguza, seria filho de Pa'i Kuara (Sol) e o sobrinho de Jasy que foi "expulso dos patamares celestes e condenado a viver e se reproduzir a partir das relações estabelecidas com as mulheres humanas, incidindo diretamente na produção da corporalidade kaiowa e guarani”, atuando como um "deus punido à eternidade terrena, diante de um comportamento pochy [bravo, mau comportamento] na primeira terra” (Seraguza, 2013: 67; 170, alterações minhas). Além disso, é "vinculado à parcela animal da alma" e, em português, esse nome significaria "fragmento, pedaço de lua", sendo também conhecido "como o protetor dos animais das florestas" (Ibidem: 68, 70, 72).

$302 \mathrm{O}$ radical -ẽgue pode ser traduzido, de acordo com Dooley, por "regras, menstruação: kunhataĩgue’ $i$ inhẽgue ypy'ia py omonhimbea yvate raka'e, omongetaa guive mba'emo ojapo kuaa aguã re quando meninas começavam a menstruar, elas eram postas numa cama alta, e eram aconselhadas sobre como fazer certas coisas" (Dooley, 2006: 30). É interessante notar que a palavra "menstruação" também é associada ao termo -mba'eaxy que, segundo Dooley, vem de “mba'e 'algo não-humano' mais o adjetivo axy 'doído” e significa "doença, dor", além de ser este também um modo de se referir também à menstruação: “xemba'eaxy ou vaipa tive fluxo forte” (Ibidem: 104). Sobre inhẽgue, ver também Cebolla Badie (2014). 
a partir de então, para seguir um bom caminho, com sabedoria, saúde e alegria. A menina-moça deve aprender a moderar ${ }^{303}$ seu temperamento e modos de agir, ou seja, o próprio comportamento e, consequentemente o próprio corpo: "Ela não vai ficar preguiçosa, ciumenta, ou brincalhona demais. Nada demais" (Idem, grifos meus). Segundo Schaden, o "tempo do resguardo representa para a adolescente um período de habilidades manuais, uma espécie de escola de economia doméstica”, ou como dizem alguns de seus interlocutores esse período “é para aprender”, reforçando então as suas condutas e comportamentos que são esperados pelo coletivo, assim como o seu pertencimento a ele (Schaden, 1974 [1954]: 87). O autor reforça ainda que, entre os Mbya, tal ensino é realizado principalmente pela avó (Ibidem: 88).

Elas deverão aprender, junto às mulheres da família, a fazer artesanato, a preparar comida e distribuí-la generosamente entre os parentes. Além disso, nesse período, são submetidas a um controle rígido de condutas, no qual lhes é proibido aparecer em público e "dirigir a palavra e relacionar-se com homens, inclusive os de sua família" (Ciccarone, 2001: 62). Elas passam também por uma dieta rigorosa na qual "não devem ingerir açúcar, sal, frutas ácidas, leite ou carne vermelha, sendo orientadas a consumir comidas que contribuam para manter seu corpo leve e evitar o fluxo intenso de sangue”, além de evitar alimentos e bebidas gelados, uma vez que "estes retêm ou 'congelam' o sangue no corpo, impedindo que ele saia” (Testa, 2014: 271). Podem também ser preparados remédios para que o fluxo menstrual seja de curta duração e menos intenso, "geralmente a partir de plantas que crescem nos troncos das árvores” (Idem). Nesse sentido, embora a primeira menstruação marque um momento importante para o desenvolvimento do novo papel que irá ocupar, deve-se aprender a partir dali a controlar o sangramento menstrual e o seu cheiro, e evitar a sua circulação descontrolada, para não chegar a afetar outras pessoas próximas, lugares ou objetos com os quais ela tiver contato nesse período, o que poderia deixar tanto ela quanto seus parentes próximos vulneráveis à ação de outros seres-poderes perigosos, terrestres. É por isso que as mulheres, nesse período, não devem preparar alimentos ou o tabaco (petỹ) a ser servido aos homens, além de não poder andar pelas matas ${ }^{304}$ ou pelas roças, pois "se, no primeiro caso, o cheiro do sangue

\footnotetext{
${ }^{303}$ No período de transição da infância para a vida adulta, tanto as jovens moças, como os jovens rapazes, seriam "ensinados a moderar suas palavras, o consumo de alimentos, suas atitudes e os modos de se relacionarem em diferentes contextos” (Testa, 2014: 89-90). A intenção é ensiná-los a falar com moderação e primeiramente escutar, principalmente aos mais velhos, antes de se pronunciar.

${ }^{304}$ Schaden comenta sobre os cuidados com as jovens moças para não serem vítimas dos donos-espíritos: “Os Mbüá não permitem à jovem caminhar pelo mato, para não ser vítima de cobras nem do yzyrádjá ('espírito das árvores'), não a deixam atravessar o rio, para não ser agarrada pelo ýdjá ('espírito das águas'), nem tocar em alguma pedra, por causa do itádjá ('espírito da pedra')" (Schaden, 1974 [1954]: 87).
} 
atrai habitantes da mata, no segundo, ele prejudica o crescimento dos cultivos, por incomodar os donos não-humanos destes” (Ibidem: 271-272).

Além disso, as kunhãgue tampouco devem deixar que o sangue menstrual e o seu cheiro sejam levados pela água corrente, desencadeando a sua circulação descontrolada. Por essa razão, nesse período, todo seu contato com água "deve ser mediado pelo cozimento da água, que também pode ser misturada com plantas aromáticas e cinzas de madeiras escolhidas para disfarçar o cheiro do sangue" (Ibidem: 272). Daí que uma das maneiras de se referir à menstruação seja “ndajauvei (não posso me banhar mais)", além de não poderem lavar a cabeça, somente do pescoço para baixo, de acordo com uma interlocutora de Testa (2014). Seraguza comenta que este estado quente (-aku) que as mulheres guarani e kaiowa passam deve ser resfriado (mboro' ${ }^{305}$ ), uma vez que o cheiro do sangue menstrual "adverte os seres sobrenaturais que aí se encontra um corpo suscetível, aku, que precisa ser esfriado, mboro'y, disfarçado, protegido com as rezas/cantos, as ervas, os banhos, a reclusão da vida social, os interditos alimentares" (Seraguza, 2013: 99-100). O sangue funciona, portanto, como um potente agenciador da transformação, por estar associado à ãgue e ao corpo pesado, quente (-aku) (Prates, 2013: 193). Por isso, quando menstruada, a mulher é fonte de perigo-potência tanto para si mesma quanto para seus parentes próximos, cumprindo uma série de interdições para sua própria proteção. Os cuidados que os homens também devem observar no controle das próprias substâncias corpóreas, principalmente quando na mata são, contudo, redobrados para as mulheres, que precisam evitar qualquer contato com a mata e seus habitantes (ka'aguy rupigua kuery) quando estiverem menstruadas (Testa, 2014: 263).

As mais importantes "situações de crise", de acordo com Schaden, seriam aquelas em que a pessoa está “(h)akú ou odjékóakín ${ }^{306}$, estando sujeita a perigo de encantamento sexual, a que se denomina odjépotâ", devendo observar uma série de medidas e de cuidados especiais denominada "resguardo", para evitar e também se defender dos "perigos sobrenaturais decorrentes de tão melindroso estado" (Schaden, 1974 [1954]: 79; 84). Esses "estados de crise" à que Schaden faz referência, são experimentados pelos pais e pelo recém-nascido, pela menina-moça durante a primeira menstruação e pelos jovens rapazes após o engrossar da voz. Quando menstruam pela primeira vez, as meninas-

\footnotetext{
${ }^{305}$ Dooley traduz - moro'yxã ou -moyro'yxã por “esfriar, gelar”, termos estes que vêm de ro'yxã, traduzido como "frio: yy ro’yxã água fria; yoytu ro’yxã vento frio” e que deriva do radical -ro’y “(estar) com frio': xero'y estou com frio" ou simplesmente "frio" (Dooley, 2006: 170). O termo -akuro’y também é traduzido como “esfriar(-se), perder o calor”, assim como -mboakuro'y, “esfriar, refrescar” (Ibidem: 9).

${ }^{306}$ Cadogan traduz jeko aku por "someterse a régimen, a tratamiento; couvade; «aku; (i)ko'; ko aku” (Cadogan, 1992: 67). Já o radical -ko aku é traduzido como "abstenerse de ciertos alimentos, y observar algunos tabúes; couvade”" (Ibidem: 83).
} 
moças devem se submeter a banhos aromáticos, de cinzas e a muita fumaça para encobrir o cheiro do sangue, além de ter que "se cobrir completamente ao sair de casa" ${ }^{307}$, para tornar-se menos perceptível e suscetível a seres-espíritos outros, sendo ensinada a se concentrar bastante para "não se deixar levar pelos sons que vêm do mato", como ressalta uma interlocutora (Jera apud Testa, 2014: 265). Uma das formas que a meninamoça é ensinada a contar a suas parentes quando menstrua pela primeira vez, segundo Jera, é aexa Jaxy ra'u ("acordei com a lua, eu vi hoje a lua, sonhei com a lua") ou Jaxy re ma amenda ("estou casada com Jaxy") (Ibidem: 272). O pai ou algum parente próximo deve então fazer o nhimbe $e^{308}$, uma caminha alta, com uma escadinha para subir e descer. A partir daí ocorre o ritual de corte do cabelo (-'a) da jovem moça que, de acordo com Jera, tem um significado muito importante "para toda a vida dela depois":

A primeira coisa que acontece quando corta o cabelo é que, como o cabelo é uma coisa viva e está no nosso corpo, ele não para de crescer. Então, desde que nasce até os 13, 14 anos, tudo que você já viveu durante essa vida está no seu cabelo. Esse cabelo é cortado e junto com esse cabelo cortado, se a menina era brava ou desobediente, vai todo esse mau comportamento [...] e, então, pode virar tetymakua (uma corda trançada com o cabelo que foi cortado), que é o que os mais velhos amarram na perna assim. Daí, não tem mais nenhum fluído ruim; ele se torna uma proteção que os mais velhos nunca tiram. São só os mais velhos que usam, sempre os avôs e as avós. Normalmente, é o pai da menina que corta seu cabelo e depois quem faz o trançado é a mãe. (Jera apud Testa, 2014: 272-273, grifos meus)

Por esse cabelo conter tanto suas substâncias como as suas experiências, comportamentos e estados, quando cortado, está se cortando também o seu fluxo anterior e a continuidade dele, o que possibilita que a primeira menstruação seja um momento chave para "transformar os modos como ela se relaciona com outras pessoas" (Ibidem: 275). Além disso, esse cabelo cortado das meninas-moças se transforma em um adereço chamado tetymakuaa ${ }^{309}$, que é um "veículo de força e proteção para aqueles que passarão a carregá-lo” em seus próprios corpos (Idem).

307 "Quando sai para satisfazer uma necessidade, a jovem deve ter a cabeça e o corpo envolvidos num pano; não se afasta muito da habitação e, pelo menos entre os Ñandéva, vai acompanhada da mãe. Entre os Mbüá, sai sozinha, mas olhando apenas para o chão e caminhando depressa” (Schaden, 1974 [1954]: 86).

${ }^{308}$ O termo nhimbe é traduzido por Dooley como "cama de armação", no entanto, a "palavra mais genérica para 'cama' é tupa” (Dooley, 2006: 127). Segundo Schaden, “os Mbüá têm a precaução de construir para a menina um jirau bem alto para ficar bastante afastada do chão e não ser atingida pelo yvýdjá, espírito da terra" (Schaden, 1974 [1954]: 85).

309 Schaden comenta que entre os Mbya caberia ao "pai a tarefa de cortar o cabelo da jovem, logo no primeiro dia do incômodo" (Schaden, 1974 [1954]: 91). Com esse cabelo, "a menina faz - para o pai, irmão ou outra pessoa da família” um adereço ritual que pode ser usado tanto nos pulsos, levando o nome de "pókuaa”, como nas pernas: "os homens acima, as mulheres abaixo das panturrilhas, tetýmãguá ou tetýmãkuáá, interpretam o uso como instituição divina para os 'Guarani’ se distinguirem de outros índios. Mas indicam também a finalidade mágica de evitar o cansaço da musculatura dos braços e das pernas, sendo, por isso, o tetýmãguá tido como indispensável nas caminhadas" (Ibidem: 91-92). Segundo os interlocutores de Mello, a "trança tetymakuaá é um marcador de identidade humana", um símbolo de "fertilidade feminina", que se reverte em "importante objeto de poder masculino, usado como proteção contra espíritos da mata, indispensável em caçadas e caminhadas” (Mello, 2006: 153). Ciccarone também comenta que é o pai quem corta 


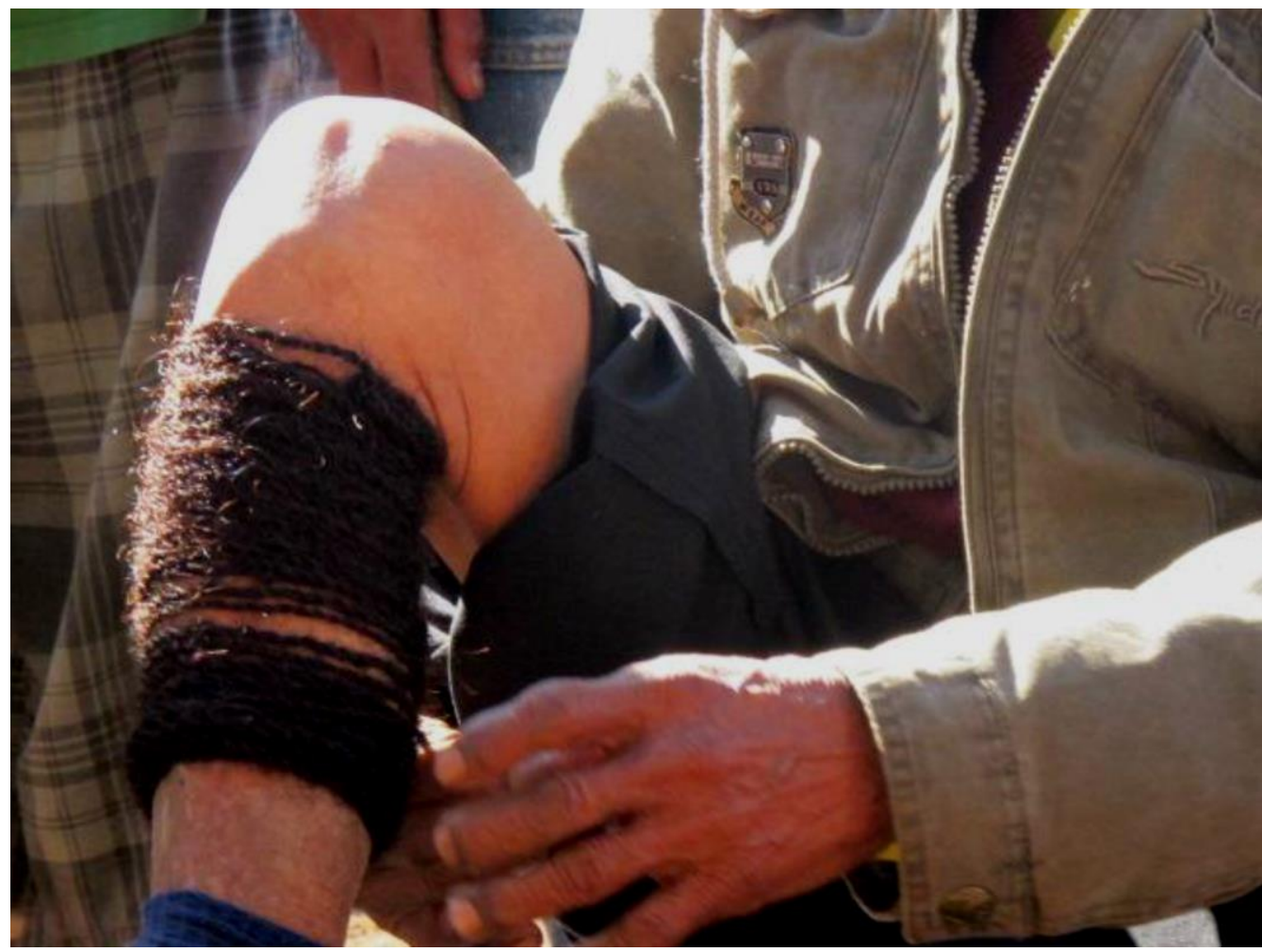

Tetymakua. Centro de Trabalho Indigenista, 2010. In: Pierri (2013a).

É, por isso que, nessa fase de resguardo-reclusão, a menina-moça recebe muitos conselhos de seus parentes mais velhos a respeito da nova fase e disposição social que irá desenvolver, tanto no âmbito do casamento, como com a criação dos filhos que virão. Há uma descrição especial de um desses momentos de aconselhamento em que, segundo uma interlocutora, a avó da moça junta todos os parentes na casa que ela está se resguardando para que ela desenvolva o comportamento de generosidade para a vida toda:

para ela aprender a ser generosa para o resto da vida, com todas as coisas, não ali só naquele momento para seus parentes, mas depois para ser generosa com o marido e principalmente com os filhos. Nesse momento que está todo mundo junto, a avó traz uma espiga de milho e faz a menina assar o milho. Ela pede para a menina olhar todos os irmãos e parentes que estão do lado dela e fala para ela fazer com que uma só espiga chegue para todo mundo. A única pessoa que pode ficar sem comer o milho é a própria menina. (Jera apud Testa, 2014: 276)

Uma anciã, interlocutora de Testa, conta que o cabelo das moças é cortado durante a primeira menstruação para que elas "não se percam (-mokanhy aguã e’ y) $)^{310^{\prime}}$

o cabelo da menina, "cujas tranças enroladas nas pernas (tamakua) eram marca de status e proteções mágicas masculinas” (Ciccarone, 2001: 62). O tetymakua ou tetymakuaa, segundo Pierri também é um termo geral para qualquer adorno usado nas pernas, "presos embaixo dos joelhos, e as meninas no tornozelo" ("tety = pernas, kuaa = sabedoria”) (Pierri, 2013a: 179). De acordo com Dooley, um dos significados de kua é "amarrar", daí que o termo -etyma kuaa seja traduzido como "ornato circular usado no tornozelo [lit., ‘o que amarra a perna']” e po apy kuaa como “pulseira [lit., 'o que amarra o pulso']” (Dooley, 2006: 86). 310 Dooley traduz o verbo -mokanhy por "perder (por extravio, morte, etc.)” e "acabar com”, ele vem do verbo -kanhy, literalmente, "perder-se, sumir”, "ficar perdido” e “acabar-se” (Dooley, 2006: 79). 
(Jaxuka apud Testa, 2014: 275). Nesse estado, ela estaria ainda mais instável que o habitual, pois o cheiro do sangue ${ }^{311}$, é um potente atrativo para animais e seres-espíritos terrestres, daí a necessidade de camuflar bem esse cheiro pois são nos "momentos de descuido que um Outro aparentando, na maioria das vezes, ser um(a) jovem bonito/a e sedutor(a) 'leva junto' a mulher/homem para viver com ele(a)” (Prates, 2013: 193). Ao se "encantar" por um outro, a pessoa "vira o pensamento", como traduzem os interlocutores de Prates. E a "imagem que seduz é de alguém muitas vezes já conhecido da pessoa, como um marido ou esposa que partiu ou morreu" (Idem). Um desses interlocutores também contou a Prates que nesse período da puberdade é preciso "fazer as crianças dançarem para fazer o tigre que está nascendo morrer” (Ibidem: 177). Por isso, os resguardos devem ser seguidos pelos jovens, para “evitar que eles 'se percam', por exemplo, em relações de proximidade excessiva com sujeitos não-humanos": "Perder a si, nestes casos, significa perder a condição de humano e inverter os signos da equação [...] Isto é, tornar-se excessivamente diverso (adverso) aos próprios parentes humanos e excessivamente semelhante (afim) a um sujeito não-humano” (Testa, 2014: 275).

É durante os chamados "estados de crise", tais como a gravidez, parto, nascimento ${ }^{312}$, puberdade, doença e morte, que as pessoas mbya tornam-se mais suscetíveis

\footnotetext{
311 O sangramento, embora necessário para a fertilidade e a renovação, também torna homens e mulheres "vulneráveis ao ataque dos espíritos sedentos de sangue", daí a importância de se observar um "período de resguardo, com dieta e reclusão", incluindo aí a abstinência sexual, técnica que visa a regulação do fluxo sanguíneo e de seu cheiro, tentando evitar a dinâmica transformacional do corpo (Belaunde, 2006: 210). $312 \mathrm{O}$ nhe'ẽ das crianças, de acordo com os interlocutores de Pierri, vem à terra antes do nascimento, e assenta-se em seu corpo apenas algum tempo após o seu nascimento, por intermédio de procedimentos específicos de fabricação corporal (Pierri, 2013a: 178). Daí a importância da produção do corpo para a formação da pessoa mbya, desde o início da sua existência, na infância mesmo. O recém-nascido "é quase todo -nhe'ê", seu corpo é “fraco, mole e frouxamente conectado ao -nhe'êe, por isso, é necessário investir com empenho na fabricação desse corpo, assim como em sua integração ao -nhe'ẽ, motivo pelo qual seus pais, irmãos e parentes próximos, principalmente aqueles que participaram do parto, tenham que se manter todos em resguardo, uma vez que o nhe'ẽ da criança estaria ligado aos corpos-espíritos deles (Testa, 2014: 253). Assim, o parto e os cuidados com o recém-nascido também possibilitariam a criação de relações de parentesco, pois as pessoas chamadas para participar dos cuidados com as partes da criança (placenta, umbigo, e resíduos do parto) ou já são parentes dela ou passam então a ser consideradas como (Ibidem: 252). Segundo os interlocutores de Macedo, o nhe'ẽ do recém-nascido estaria junto a seus pais, podendo se perder ou sofrer danos caso eles se afastem muito dele, comam de modo inadequado, ou realizem trabalhos que demandam muito esforço ou oferecem perigo, como por exemplo, a caça (Macedo, 2013: 199). As crianças, de acordo com meus interlocutores, seriam como presentes enviados pelos mães e pais dos nhe' $\tilde{e}$ para alegrarem a vida de seus parentes terrestres, daí sua importância. Devem, portanto, ser muito bem cuidadas, isto é, "alegradas", a fim de que esse nhe 'é "queira ficar" neste mundo (ver Pissolato 2007, Prates 2013). Mello também comenta que é o útero da mulher - que seus interlocutores traduzem como membyque recebe o leite (kamby), "que já vem [junto] com o nhée do mintãim [bebê] do outro mundo", como uma "dádiva que os nhéerukuery enviam para esta mulher com o propósito de auxiliá-la a reter o nhée de seu bebê neste mundo" (Mello, 2006: 155, alterações minhas). Segundo Dooley, o nome em mbya para útero seria -memby ryru (Dooley, 2006: 113). O útero também poderia ser chamado de -yru'i com o significado adicional de "ventre: xeryru'i o ventre de onde nasci [lit., 'meu ventre']" (Ibidem: 201). Em campo, ouvi que o nome em guarani para útero é imemby’i ryru. Além disso, -memby é o termo usado pela mãe para se referir a seus filhos: "filha (de mulher)" ou "filho ou filha mulher: xememby kuery meus filhos" (Ibidem:
} 
ou vulneráveis à comunicação e aos ataques predatórios de alteridades não-humanas, necessitando se resguadar adequadamente. No entanto, a puberdade é considerada um período de maior suscetibilidade ao -jepota, uma vez que o corpo está se reconfigurando e sendo ao mesmo tempo acometido por apetite sexual, tornando-se particularmente, mais vulnerável a ataques desse tipo, correndo um risco maior de estabelecer uma relação de troca com tais alteridades, e virar-se contra os próprios parentes (ver, nesse sentido, Macedo 2013). Daí que o constante investimento em aprimorar e aprender a controlar a percepção (ver-ouvir-sentir), o corpo e os sentidos, tenha uma atenção maior nessa fase.

Como me contou Para Poty, na cultura guarani, a menina na primeira menstruação deve observar um rígido resguardo ${ }^{313}$, sem poder “sair para fora de casa”, pois "tudo o que se mexe, independente de qualquer coisinha, bichinho, tudo o que você vê se mexendo tem dono ${ }^{314}$ (ija), é que o sangue cheira forte aí dizem que eles sentem, sendo um perigo para jepota ou jekome 'ể ${ }^{315 ”}$ (“entregar a própria vida”), e que “antigamente era muito forte”, mas nos dias de hoje, os moradores da aldeia "nem sabem se a menina já passou pela primeira menstruação ou não", porque elas se resguardam por no máximo quinze dias - o que, certamente, decorre também, da situação de interferência que a Escola dentro da aldeia $\operatorname{traz}^{316}$ (Para Poty, Tekoa Tenonde Porã 2015, grifos meus). E, pelo fato de que "tudo que se mexe pode fazer mal às meninas", neste resguardo os pais devem "fazer uma caminha alta para ela" (nhimbe), além da jovem moça não pode tomar "banho em água corrente", e ter que passar "cinzas no corpo" para disfarçar o "cheiro do sangue" (Idem, grifos meus). Além disso, ela não deve "comer carne vermelha, nem muito sal, nem muito açúcar" (Idem). E quando estiver menstruada, "não pode fazer nada dentro de casa”, principalmente "cozinhar" para seu pai ou irmãos ou mesmo para seu marido. Eles não poderiam comer o que ela faz nesse período, pois os mais velhos dizem que "faz mal", e segundo

\footnotetext{
112). Já o termo -kamby significa literalmente "leite" (Ibidem: 79). Uma interlocutora mbya me traduziu "leite materno" por kãry, traduzido por Dooley como "leite do seio" (Ibidem: 78).

${ }^{313} \mathrm{O}$ resguardo, de acordo com Belaunde, seria observado "individualmente por homens e mulheres e, até certo ponto, coletivamente por todos aqueles próximos a eles" (Belaunde, 2006: 214).

${ }^{314}$ Como os Guarani já me disseram, "até flor tem dono" ou "até pra cortar madeira tem que pedir". Por isso, antes de qualquer ação predatória deve-se primeiro pedir "permissão" ou "licença" para o dono, como por exemplo, ao entrar na mata, caçar ou "tirar" algo dali. Além disso, eles são ensinados a agradecer às divindades por terem conseguido "alguma coisinha" para comer ou alguma boa disposição alcançada.

315 Segundo Cadogan, “teko me'ê" seria "entregarse: mborayu omboakãmby va'e ojeeko me'ẽ opa marãnguápy quien permite que su amor se bifurque se entrega a 'todo lo maligno', se convierte en brujo, hechicero maligno" (Cadogan, 1992: 172). Já Dooley, traduz jeko me'ẽ por "entregar a própria vida: ixupe ajeko me'ẽ entreguei-lhe a minha vida" (Dooley, 2006: 31).

${ }^{316}$ Isso fica claro no comentário de uma interlocutora: "hoje o que acontece mais é que ela fica no máximo uma semana, porque tem todas as outras situações de interferência, por exemplo, a escola. Mas, antigamente, ficava um mês" (Jera apud Testa, 2014: 276).
} 
sua mãe conta, dá uma “dor na barriga que parece cólica ${ }^{317 ” ~(I d e m) . ~ P o r ~ i s s o, ~ n e s s e ~ p e r i ́-~}$ odo, seriam os homens que deveriam cozinhar, ainda que nos dias atuais, na prática, só o façam poucas vezes, preferindo comer em outro lugar ou na casa de algum parente.

Já na iniciação masculina, quando os meninos passam da "infância para a vida adulta”, de criança para jovem homem, o que ocorre quando a "sua voz começa a mudar", a "engrossar" (nhe'ẽ nguxu ${ }^{318}$ ), em vez de "ficar só em casa", em resguardo, eles devem trabalhar junto com seu pai, "aprendendo a capinar, a trazer lenha, a fazer força”, entre outras coisas, como me contou essa jovem liderança (Idem). Para Poty comenta também que seu pai sempre fala que nessa fase, os meninos "têm que fazer bastante força" e "trazer lenha para que o osso do ombro não fique saindo para cima”, e se ocorre indicaria que não fizeram muito esforço na passagem para a fase adulta, que "não trabalhou bastante, não fez nada” (Idem). Além desses resguardos, ela conta que quando um casal tem seu primeiro filho ou mesmo algum filho recém-nascido, a família nuclear toda tem que se resguardar ${ }^{319}$ e observar certos cuidados com alimentação e o corpo-espírito durante o período de um mês (Idem). Assim, existem três momentos na vida guarani em que é preciso se resguardar, por estar ainda mais suscetível a ataques dos "seres que não vemos": quando se tem irmãos recém-nascidos, quando está tornando se adulto e quando nascem os próprios filhos (ver também Macedo 2013). O resguardo podendo ser entendido então como um estado de concentração (-japyxaka) para não deixar escapar nhe’ẽ.

Mello comenta que na iniciação dos jovens rapazes durante a puberdade, cujo principal sinal de passagem à fase adulta é percebido com o engrossar da sua voz, perfura-se o lábio inferior, inserindo ali um filete de bambu, o “tembekuaâ" (Mello, 2006: 153154). Isso ocorre, de acordo com a antropóloga, para que as boas palavras (ayvu porã) sobreponham-se às palavras sem espírito (Ibidem: 153). A perfuração do lábio do jovem rapaz, denominada por Testa tanto de tembetykua ${ }^{320}$ como -embekua ${ }^{321}$, gera desconforto para falar e comer durante o tempo de cicatrização, e seria uma "medida que contribui

\footnotetext{
${ }^{317}$ Mello (2006) também comenta que nesse período, as mulheres não devem fazer comida para os homens, pois isso dará "gases" neles.

${ }^{318}$ É por -nhe'é nguxu que Dooley traduz “rapazinho (referindo-se à mudança de voz na puberdade): avakue’ $i$ inhe'ẽ nguxua py omombu raka'e hembe quando um menino chega à puberdade furavam o seu beiço” (Dooley, 2006: 127). O termo nguxu seria uma variante de guaxu, "grande" (Ibidem: 121).

${ }^{319}$ Essa evitação, além de abranger outros moradores da mesma casa, parentes muito próximos e aqueles que participaram do parto e dos primeiros cuidados com a criança, remete a ideia de "comunidade de substância” (Seeger, Da Matta e Viveiros de Castro 1979 e Viveiros de Castro 2002a). As relações corporais de parentesco afetam todo o grupo de substância, assim, mesmo os estados e a vulnerabilidade das pessoas também são compartilhados (ver Seeger 1980).

320 Schaden chama de tembetá, o "adôrno labial” dos jovens rapazes (Schaden, 1974 [1954]: 88). Dooley traduz -embe'a como "estar de lábio inferior caído (beiçudo ou de boca semi-aberta)" (Dooley, 2006: 33).

${ }^{321}$ De acordo com Dooley, -embe é o nome mbya para "beira” ou "lábio, beiço", assim, -embekua seria o ato de "amarrar a beira (de uma peneira, etc.)" (Idem: 33).
} 
para que o rapaz aprenda a falar e comer com moderação", assim como a "escutar mais" e "só falar quando tem algo muito importante para dizer" (Testa, 2014: 90, 267), constituindo uma tentativa de domesticação da fala, estimulando assim a sua audição. Atualmente, no entanto, a perfuração do lábio dos rapazes não ocorre em todos as aldeias como antigamente.

Apesar de não sofrerem reclusão como as jovens moças, são observados alguns cuidados para evitar que os rapazes sejam vítimas de "espíritos malignos", pois eles passam a exercer de maneira mais recorrente, atividades que já vinham gradativamente aprendendo enquanto acompanhavam o pai e os outros homens adultos da família desde pequenos como, por exemplo, o "preparo de armadilhas para a caça, coleta de matériasprimas e confecção de artesanato, além do preparo das roças, e a participação de reuniões” (Ciccarone, 2001: 62). Em campo, observei que os jovens rapazes nessa fase, além de acabarem acompanhando ainda mais seus pais, tios e avôs, saindo mais para o mato, ajudando mais nas tarefas que demandam maior uso da força física e que, em geral, competem aos homens realizar tais como buscar, cortar e trazer lenha para os fogos familiares, ou mesmo na limpeza de solos para plantio, indo também mais para a cidade ajudar seus parentes a buscar materiais para fabricação de artesanato que já não encontram na mata (ou são impedidos de coletar, devido a intensa fiscalização estatal) e, acompanhando as lideranças em reuniões, eventos e apresentações, tanto internas, como externas. Nesse sentido, podemos perceber que enquanto os jovens rapazes se fazem ver circulando mais (com ou sem lábio perfurado), não sem cuidados, as meninas devem se esconder, interrompendo a circulação nesse período em especial. Mello também comenta sobre esse contraste entre as dinâmicas de movimentação presentes nas disposições de gênero ${ }^{322}$ entre os Mbya: do jovem rapaz espera-se que ele viaje bastante entre as aldeias, principalmente se for "aprendiz de assuntos políticos ou de agricultura" e que, nessas "andanças", encontre sua esposa, elegendo seu novo local de residência; da jovem moça esperase "mais recato, menos viagens, sobretudo sozinha, quando solteira", ainda que na prática esta regra não se efetive de fato, uma vez que muitas mulheres solteiras circulam pelas

\footnotetext{
${ }^{322}$ Ramo também comenta sobre o contraste entre o resguardo do jovem homem e da jovem mulher, entre público e privado: enquanto a menina, "antigamente", passava cerca de um ano "em cima de uma cama, sem ser vista, como que para ser esquecida", o jovem rapaz, se quisesse casar com alguma jovem, teria que "se mostrar aos pais: cortar lenha, levar uma comprinha, trabalhar muito"; dessa maneira, "enquanto ela precisa se esconder, ele é impelido a se mostrar", suas intenções devem tornar-se "públicas", enquanto "o cheiro dela deve permanecer privado" (Ramo, 2014: 107, grifos meus). A antropóloga ressalta que a lenha a ser cortada pelo pretendente à genro "é para a sogra, e a ela cabe decidir se vai ou não aceitar essa lenha", já que é ela quem entrega a filha no casamento, nesse sentido, ele trabalha não "para" o sogro, mas "com" ele e "para" a sogra (Idem: 107, grifos meus).
} 
aldeias $^{323}$, sejam elas jovens que ainda não contraíram casamento, ou aquelas que "romperam o casamento e buscam uma nova vida" (Mello, 2006: 79-80). O contraste entre essas dinâmicas, entre exterior e interior, permanece, no entanto, uma constante entre as disposições de gêneros, pois ao longo de suas vidas, os homens circulam e viajam muito mais do que as mulheres que costumam estabelecer "um vínculo mais duradouro e efetivo com o lugar em que vivem" (Ibidem: 80).

A fase da puberdade, para os jovens de ambos os sexos, também é descrita por Testa como um "momento em que devem omboguapy" oy oendu aguã (ser conduzidos a sentar para ouvir)" (Testa, 2014: 90). Em campo ouvi que o resguardo da menina-mulher pode ser chamado de -guapy que significa, literalmente, "sentar": kunhataĩ va'e inhegue jave nhamboguapy inhimbe py, "fazemos sentar a moça na cama de armação quando ela está na primeira menstruação”. Ciccarone também comenta que a época da primeira menstruação é denominada de "ogwapy", período no qual a menina-mulher "estava sujeita a um longo ritual de iniciação na passagem à função sagrada da maternidade e ao controle de sua sexualidade” (Ciccarone, 2001: 62). Já a iniciação do jovem rapaz me foi traduzida pelos Guarani, em campo, como oiko rive ${ }^{325}$ : kunumi va'e inhe'ẽ nguxu jave oiko rive, "o rapaz que começa a mudar a voz fica tranquilo", "sem bagunçar" e "falar muito". E como os jovens rapazes vão mais para o mato, seja para caçar, pescar, carpir e buscar lenha, devem aprender, desde cedo, a desenvolver a capacidade de distinguir entre diferentes sons, de modo a evitar a comunicação desnecessária com os sujeitos da mata (ka’aguy rupigua kuery), principalmente em momentos de maior vulnerabilidade corporal-espiritual. Nesse sentido, enquanto os meninos teriam maior liberdade para ir ao mato (ka'aguy) com uma certa frequência, ainda que acompanhados dos parentes mais velhos, as meninas seriam ensinadas desde pequenas a não sair muito, especialmente para a mata:

Desde cedo, não deixam sair muito, não vai muito para a mata, já pensando na situação de que uma hora ela vai menstruar. Daí, ela não pode ter esse costume como um menino, que vai mais cedo e com mais frequência para o mato com o pai pra caçar ou pra fazer qualquer outra coisa. Se a menina pega esse mesmo costume, ela pode ir um dia e menstruar dentro do mato ou dentro da água. Por vários motivos, ela é mais presa na família e nas coisas da casa do que o menino é. (Jera apud Testa, 2014: 264)

\footnotetext{
${ }^{323}$ Em campo pude observar que as jovens mulheres, solteiras ou casadas, cada vez mais se animam a participar de campeonatos de futebol, mesmo em outras aldeias e que, geralmente, promovem "baile" de "forró" pela noite, no qual todas, idealmente (a depender do controle da família), podem participar e como de costume, dançar com todos aqueles que as convidam para a dança.

324. O termo - mboguapy pode significar tanto "sentar, fazer sentar-se", como "administrar os ritos de (a uma moça)", e vem do radical -guapy, "sentar-se” e "passar pela puberdade (dito de moça)" (Dooley, 2006: 47). 325 Meus interlocutores traduziram oiko rive como "viver tranquilamente", coisa que os jovens precisam muito aprender nessa época. Já Dooley traduz oiko rive como "anda sem se esforçar" onde rive, enquanto um intensificador geral, pode significar "apenas, meramente” (Dooley, 2006: 169). No entanto, uma das traduções do radical -iko rive, de acordo com o linguista, seria "viver sem muita preocupação” (Ibidem: 58).
} 
As mulheres guarani, principalmente quando menstruadas, de acordo com Mello, não devem "conversar muito e nunca falar em outra língua", uma vez que os riscos de predação para elas seriam "mais evidentes" e, tanto a linguagem, a audição, como a visão, "são os caminhos de intercâmbio com os seres dos outros mundos", sendo estas algumas das "formas usadas pelos espíritos predadores mais poderosos para capturar nhe'e de humanos", dando assim início ao processo de transformação (Mello, 2006: 153-154; 164). Além de ver, ouvir e falar, "alimentar-se com a comida do Outro, com o Outro, transforma em Outro" (Ibidem: 164). As narrativas sobre -jepota falam justamente sobre a comensalidade com sujeitos não-humanos, o inverso daquela idealmente característica dos grupos de compartilhamento de substâncias, afetos e memórias, entre parentes-humanos. E tanto os homens, como as mulheres podem ser "encantados" e seduzidos por esses seres terrestres. No entanto, as mulheres seriam mais susceptíveis a esse tipo de sedução, "por sua natureza de produtoras de corpos" e quando menstruadas seriam "muito atraentes para seres ou espíritos poderosos", pois nesse período, "seu sangue a conecta com sua essência mais terrena, tornando-a vulnerável ao odji potâ"' (Ibidem: 170).

$\mathrm{O}$ alimento sendo um elemento central na fabricação e proteção do corpo-espírito e na produção-criação de parentes, é também através dele que pode ocorrer uma das formas de sedução-captura de um espírito outro, levando à transformação corporal (ainda que, no caso da sedução ou imitação da alimentação e comportamento das divindades, leve, idealmente, à transformação em deus[a] [-aguyje], um ideal amplamente perseguido pelos Mbya). Daí a preocupação constante com a alimentação correta, pois comer como deus(a) ou como um ser-espírito animal leva a pessoa a imitar seus comportamentos, isto é, atingir a desejada potência do devir-deus(a) ou a perigosa, ainda que de certo modo necessária, potência de devir-animal. A pessoa mbya é, portanto, "um ser-estar entre o divino, identificado com o nome-alma, a palavra, e o animal, o corpo e suas afecções" (Ciccarone, 2004: 93). É a partir do corpo que ocorrem essas interações entre as potências divinas e animais, onde as primeiras devem ser complemente incorporadas enquanto as potências animais, rigidamente controladas e, quando incorporadas em excesso, devem ser excorporadas através de uma série complexa de procedimentos xamânicos que cabe aos karai kuery definir caso a caso. Aqui, o "virar bicho equivale a perder o sentido da vida presente e futura, a orientação guiada pela sensibilidade, pelo olho do coração" (Ibidem: 94, grifos meus). Essa orientação está inscrita em um código espírito-corporal, é um modelo de conduta xamânica, como narram os mitos inaugurais: "é do coração, como fonte e reflexo, que surgem o saber-poder dos(as) xamãs, e os elementos divinos que fundam a humanidade 
e a interação social” (Idem, grifos meus). Como ressalta um karai, interlocutor de Ciccarone, "tem que ouvir dentro, no fundo do coração. A gente está aqui na terra não para ficar quieto, mas para se movimentar, fazer o que eles, que nos enviaram, gostariam que a gente fizessê" (Perumi apud Ciccarone, 2001: 218, grifos meus). O importante então é ouvir e falar do fundo do coração: "Para [a kunhã karai] Tatati e os grandes pajés, o minimo detalhe é o mais importante de todos: as coisas do dia-a-dia, a solidariedade, o coração livre de ódio, do mal. Eles não querem convencer, falam, falam do fundo do coração" (Leonardo Karai Mirĩ apud Ciccarone, 2001: 218, grifos e alterações minhas). O coração, traduzido pelos interlocutores de Mello como "piá guatchü", seria "responsável pela sustentação do corpo e do equilíbrio entre o nhée e o ã̃ [ou 'nhe'é vaé'kué'326]' (Mello, 2006: 156).

Testa alerta também para a importância de sentar (-guapy) para ouvir (-endu) os conselhos dos anciões na opy e "pegar" (-jopy) suas palavras, pois esse aprendizado (nhembo' $e^{327}$ ) envolve se concentrar para escutar atentamente (-japyxaka), para deixar as palavras penetrarem seu corpo através da parte superior da cabeça (-apyte) $)^{328}$ e assim conseguir guardar-cuidar (-ereko) delas, sem esquecer (Testa, 2014: 152). Como um rezador mencionou a ela: "A palavra tem que entrar" para, justamente, "ficar no coração ${ }^{329}$ ou no pensamento da outra pessoa" (Ibidem: 151). Uma jovem liderança também comentou comigo que "a palavra é muito sábia, as palavras que a gente fala [...] é necessário que toque o coração das pessoas, o objetivo mesmo é tocar o coração das pessoas, então para lutar eu tento fazer isso" (Para Yxapy do Tekoa Koenju [RS], Local: São Paulo, 2016, grifos meus). Há, no entanto, sempre uma busca por certa moderação em relação ao uso dessas palavras, visto que estas devem partir de uma boa e verdadeira inspiração:

\footnotetext{
${ }^{326}$ De acordo com os interlocutores de Mello, “nhe'é vaê’kuê" é “a parte mundana da alma, ligada ao corpo, ao sangue e à carne, um duplo terreno do nhe'e, cuja presença se manifesta através da sombra do corpo [...] é altamente corrompível e perecível, sujeito a contaminações através de fluídos, substâncias ou palavras de outros seres deste mundo. É o canal para a comunicação com os espíritos predadores ou animais, para a consubstancialização com humanos e não humanos e para o transformismo" (Mello, 2006: 143). O termo que semanticamente mais se aproxima a essa expressão é vaikue, traduzido por Dooley como "ser feio: ivaikue raxa va'e um que é feio demais" ou ainda, como "de uma maneira má: aa vaikue rai quase fui pelo caminho errado; oguata vaikue'i va'e coxo [lit., 'quem anda de uma maneira má'], ou simplesmente "feio: ka'aguy vaikue mata cerrada, feia” (Dooley, 2006: 185-86).

${ }^{327}$ É interessante notar que a palavra para rezar, -nhembo'e, também significa "estudar" ou “treinar-se” e vem do radical, mbo'e, que é literalmente "ensinar [lit., 'fazer falar']” (Dooley, 2006: 125, 111). Testa (2014) traduz - nhembo'e como "aprender".

${ }^{328}$ Esta região da cabeça, “que nas crianças recém-nascidas é dita estar 'aberta' ou 'mole', é entendida pelos Mbya como uma das aberturas pelas quais o corpo recebe saberes, mesmo quando se é adulto e esta parte já está mais firme [...] É também sobre esta parte da cabeça que as pessoas sopram fumaça, quando iniciam uma intervenção terapêutica ou nas rezas cotidianas" (Testa, 2014: 151-152).

329 O coração, segundo Belaunde, é o "centro a partir do qual os pensamentos são impulsionados, alcançando todos os órgãos e permitindo que uma pessoa aja sobre o mundo em interação com outros" (Belaunde, 2006: 211). Nesse sentido, tanto a produção de comida, como de "objetos, palavras, música, cheiros e crianças” seriam “manifestações da boa circulação dos pensamentos de uma pessoa” (Idem, grifos meus).
} 
falo somente o necessário [...] [as palavras] tem que ser verdadeiras [...] tem que ter uma inspiração para falar [...] até mesmo para falar coisas do dia a dia assim [...] e é um pouco mais difícil a inspiração quando você está nessa idade, mas tem que pedir, tem que meditar [-japyxaka] um pouco, mas tem que ser sempre com o coração. (Idem, grifos e alterações minhas)

Há também, de acordo com Testa (2014), um certo cuidado entre os Mbya, principalmente entre os anciões, para não "passar” (-axa) mais palavras do que o ouvinte é capaz de "pegar" (-jopy) e "cuidar" (-ereko). Isso ocorre, especialmente em relação aos saberes-poderes relacionados à cura e agressão. Por isso, não seriam passados para qualquer pessoa, nem em qualquer momento, como comentou comigo um ancião mbya:

aí depende de uma pessoa de responsabilidade né [...] tem vários jeitos de medicamento, então às vezes a pessoa pede só por pedir, só pra ver o que acontece, a pessoa não tá necessitada, só por farra, vamos dizer assim, então tudo isso eles [nhaneramoĩ e nhandejaryı] cuidam né, eles veem se a pessoa realmente está afim de fazer alguma coisa [boa], se não, não [...] tem coisas que eles só falam né, a gente faz assim, se cuida pra não acontecer isso, mas não mostra, quando acha que a pessoa tá madura o suficiente, tá entendendo o suficiente, ele leva a sério, aí sim, aí que você dá, pra não fazer, de repente quer aprender logo pra fazer maldade pra outro, por isso é complicado (Tekoa Tenonde Porã 2016, grifos meus).

A possibilidade de agressão é uma constante na vida Mbya, e uma vez que a instabilidade do corpo reside em sua frágil imbricação com o duplo divino e animal da pessoa, a possibilidade de transformação corporal também é uma constante. É nesse sentido que, segundo Prates, a menina após o resguardo (denominado por seus interlocutores de "jekoaku, estado quente”), deva ser "cozinhada assim como a carne de caça, que também precisa ter suas potências (tapichuá) neutralizadas" (Prates, 2013: 297). Os cuidados com o sangue menstrual fazem parte do cotidiano das mulheres e dos homens, pelo seu caráter cíclico e contínuo: “a impureza do sangue reitera-se ao longo da existência da mulher", daí que os “tabus ligados ao medo do contágio ${ }^{330}$, como fazer comida e ter relações sexuais, exigem que sejam periodicamente renovados como medidas cautelares contra a desordem” (Ciccarone, 2001: 63). Partindo da etnografia entre os Airo-Pai para lançar as bases de uma hematologia amazonense e decifrar o significado do sangue em relação a gênero, conhecimento e cosmologia, Belaunde defende que "o sangue constitui o principal veículo para a igualdade de gêneros assim como para a diferença”:

é uma relação que tanto une quanto divide os seres humanos em homens e mulheres. De fato, uma variedade de etnografias mostra que o sangue é concebido como uma relação porque ele circula pelo corpo, pondo todas as suas partes em comunicação e enchendoas de pensamento e força para a ação intencional. (Belaunde, 2006: 210)

\footnotetext{
${ }^{330} \mathrm{O}$ sangue menstrual é associado à ideia de poluição em muitas sociedades, discussão consagrada na obra "Pureza e perigo" de Mary Douglas (2012 [1966]). A percepção do sangue menstrual como elemento poluidor e de caráter transformatório é comum entre os ameríndios (ver, nesse sentido, Belaunde 2006).
} 
Como uma "evidência etnográfica abundante" entre uma diversidade de grupos culturais, "o sangue é concebido como um fluido que corporifica e atribui gênero às pessoas, ao pensamento e à força, transportando conhecimento a todas as partes do corpo", operando "tanto dentro do corpo de uma pessoa quanto fora dele" (Ibidem: 207, grifos meus). Segundo Belaunde, por toda a Amazônia, sangrar seria uma “'troca de pele/corpo’ par excellence", e são as mulheres quem mais fazem isso, através da menstruação e pelo parto de crianças (Ibidem: 208). Então, se o corpo é o local das perspectivas diferenciantes, de acordo com Viveiros de Castro (1996: 131), Belaunde sugere então que "o sangue é um operador de perspectivas" (Belaunde, 2006: 232). O “cheiro do sangue”, denuncia o sangramento mesmo quando este não pode ser visto ou mesmo tocado, colocando em movimento a "multiplicidade transformacional da vingança de 'outros' espaços-tempos cosmológicos, trazendo o perigo de perda da memória humana, semelhante à perda de humanidade narrada em mitos onde/quando pessoas foram transformadas em animais/plantas" (Idem). Nesse sentido, o sangue, por seu "efeito transformador sobre a experiência vivida", abriria as cortinas da comunicação e da percepção que geralmente separam a experiência cotidiana da experiência de outros tempos-espaços, daí seu entrelaçamento com o xamanismo (Ibidem: 208).

Os (des)encontros com subjetividades outras, como viemos mostrando, perpassam amplamente os corpos guarani em sua incessante fabricação corporal, os investindo de potências e afetos poderosos-perigosos que devem ser controlados em nome do bem viver entre parentes. Enfatizamos as dinâmicas de aproximação e afastamento que operam as redes de relações de parentesco e aliança, envoltas que estão na possibilidade latente de transformação corporal. Cretton Pereira (2013) discorre sobre como o desejo é crucial para manutenção da saúde e do ponto de vista humano guarani, mas alerta também para o quão perigoso é, uma vez que desejar "demais" algo ou alguém pode alterar a constituição da pessoa a ponto de fazê-la perder a própria perspectiva e, por consequência, o próprio corpo. A lógica do “conter-se” (jejoko $0^{931}$ ), atua como uma etiqueta mbya geral que é, portanto, fundamental ao xamanismo: é central saber aí o que se quer e como querer. E, se o xamanismo mbya se refere tanto à agência maximizada d@ especialista quanto à potência latente, mais ou menos distribuída ou acessível a todos os Mbya, denominada de "função xamânica" (Pissolato, 2007: 339), esta função, de maneira geral, também pode ser entendida, enquanto uma multiplicidade de modos pelos quais se pode aprender a evitar aproximações indesejadas com outros através de posturas tais, como:

${ }^{331} \mathrm{O}$ termo -jejoko pode ser traduzido também como “controlar-se, dominar-se” (Dooley, 2006: 72). 
“querer saber" (-kuaa pota ${ }^{332}$ ), "saber viver" (-iko kuaa"), "se fazer inteligente/sábio" (nhemoarandu), "prestar atenção” (-japyxaka), "ouvir/sentir”ss3 (-endu), "saber comer” (karu kuaa), "saber acordar/se levantar” (-vy kuaa), entre outras, as quais atualizam em cada indivíduo a capacidade de recepção de saberes advindos das divindades. (Cretton Pereira, 2014: 178, grifos meus)

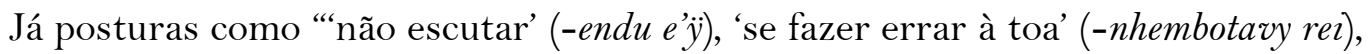

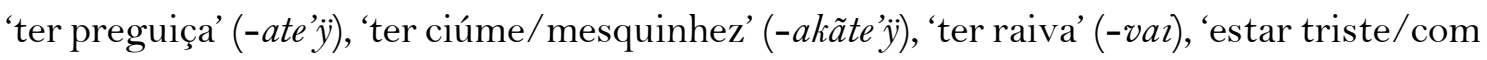
saudades' (-ry'a e'ÿ)" entre tantas outras atitudes terrenas demais, colocariam a pessoa mbya em uma posição vulnerável à ações maléficas e indesejadas de espíritos dos mortos, "donos", animais, etc., podendo incorrer na transformação em outro (Ibidem: 178-79). Cretton Pereira ressalta assim a positividade da predação como princípio organizador ou de “(des)organização" da pessoa e da sociedade mbya (Cretton Pereira, 2013: 5). Ramo, ao discorrer sobre o jogo de deslocamentos das posições de parentesco (parente/não parente) e da predação (caçador/caça), argumenta também que o parentesco só pode ser feito pela predação, já que “é preciso alimentar os parentes, tanto para tê-los como para fazê-los" (Ramo, 2014: 53). No mesmo sentido, "a predação só pode acontecer pelo parentesco (é preciso que haja parentesco para que os corpos, a predar, se façam)” (Idem). Um xeramoĩ contou a ela: "desde o começo da Terra o que vai acontecer hoje já tinha acontecido" (Augustinho apud Ramo, 2014: 34). Ele estava contando a respeito das caminhadas das divindades pela Terra, segundo Ramo, e "tentando exprimir um detalhe crucial da condição humana na Terra, a condição tekoaxy", além da "máxima mbya sobre a natureza dos atos dos Nhanderu como, em certo sentido, inescapavelmente repetíveis" (Ibidem: 53-54, grifos meus). Igual contava o xeramoĩ para Ramo, uma interlocutora comentou comigo, que é como o seu avô costumava dizer: "Tupã ou os deuses já sabiam o que ia acontecer, o que que a gente ia passar, já sabia, então tá acontecendo tudo não é por acaso" (Para Yxapy do Tekoa Koenju [RS], Local: São Paulo, 2016, grifos meus).

A partir de narrativas de interlocutores guarani sobre a criação do primeiro mundo e o retorno do demiurgo para "el Paraiso", Cadogan descreve como "Nuestro Padre sentó precedentes para nuestra futura conducta” ("Ñande Ru ñande reko rã ra'anga") (Cadogan, 1959: 71). Isso expressa um ideal muito comum entre os Mbya, que toma lugar central em suas falas na $o p y$, de que são as divindades que enviam as palavras-

\footnotetext{
332 O radical -kuaa pota pode ser traduzido como "prestar atenção para saber (algo), investigar, pesquisar" e deriva de -kuaa, "saber, aprender", "conhecer" ou "saber (como fazer algo)" e -pota, "querer" alguma coisa ou "que alguém faça algo" (Dooley, 2006: 87, 150). Daí que o termo -jekuaa pota seja traduzido como "ter cuidado, ser cauteloso", -jekuaa pota uka por "pedir ajuda (de alguém) para fazer o certo, tomar as decisões certas", enquanto -kuaa pota rei seja compreendido como "interessar-se em algo por motivos errados, cobiçar (algo): oikuaa pota rei nhomba'e rei-rei re tem cobiça das coisas alheias” (Ibidem: 87).

${ }^{333} \mathrm{O}$ "saber ouvir", na acepção mais ampla do verbo -endu, passa pelo mesmo movimento de "perceber" e "sentir" (ver Capítulo II).
} 
espíritos e os saberes-poderes aos Mbya e, com elas, as normas para sua conduta aqui na plataforma terrestre (yvyrupa) ser menos doente e dolorosa (tekoaxy). Daí o conceito de "erro" (-javy) $)^{334}$ ter uma importância crucial para a compreensão da pessoa, entre os Mbya. Ramo aproveita aquela mesma fala do xeramoĩ, para situar a problemática do "erro" em relação à temática da "regra" (-teko), uma vez que seria na complexa confluência entre tais conceitos que se situaria a humanidade mbya (Ramo, 2014: 54). A antropóloga ressalta a importância de repetir ou imitar aqui na terra “o que o 'povo do alto' (yvategua va'e) faz no seu amba", isto é, os seus comportamentos que, por sua vez, instituiriam as "regras" 335 a serem reproduzidas pelos Mbya e que são recorrentemente veiculadas pelos mais velhos em seus discursos (Ibidem: 64). Mesmo as imagens-erros desses seres divinos em sua passagem por yvyrupa seriam repetidas-imitadas pelos Mbya, dificultando a passagem da condição humana, perecível (marã), para a condição divina, imperecível (marã e’ỹ). Assim como na caminhada dos seres míticos pela plataforma terrestre, os seus filhos caçulas (nhandera'y ijapyrepyre’i), também devem passar por uma série de “prova-

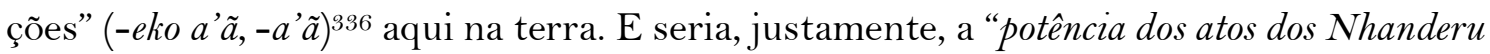
que os torna intensivamente imitáveis, para bem e para mal” (Ibidem: 77, grifos meus).

O termo a'angaa, "imagem”, "semelhança”, vem de -a'ã, de acordo com Dooley, e é também uma variante de a'anga, que se refere a "imitar", segundo Cadogan (1992: 16), mas que o linguista prefere traduzir como "experimentar, provar, testar" ou "marcar" (Dooley, 2006: 27). Já Ramo opta por traduzir a’anga como “imitação”, ainda que a entenda também como "uma repetição com variação" (Ramo, 2014: 77). As imagens devem ser pensadas aqui enquanto "modulações de afecções provenientes de outros corpos" (Pierri, 2013a: 252). Seria através da sabedoria divina adquirida e praticada que se aprende-

\footnotetext{
${ }^{334}$ De acordo com Pierri, ojeavy seria uma variante da expressão ojazy, e remeteria “à expressão nativa para o tema da má escolha" (Pierri, 2013a: 250).

335 Socialidade esta que "está longe de ser homogênea a todos eles; a diferenciação de jeitos (de gostos, costumes e desejos), de teko, é o signo da vida no amba de Nhanderu” (Ramo, 2014: 65, grifos meus), ocorrendo uma diferenciação tanto de disposições, como de capacidades-poderes entre eles.

${ }^{336}$ Ramo opta, em sua etnografia, por traduzir as "barreiras" que aparecem pelo caminho por "teko'a â" (Ramo, 2014: 76). Já Keese informa que essas “provas” são traduzidas pelos Guarani como “-a'a, rekora'a” (Keese dos Santos, 2017: 159). O termo - a'ã que, de acordo com Dooley, remete tanto a "arremedar, imitar", como a "provar" e "medir", como por exemplo, nhoa'ã que é traduzido como "imitar uns aos outros: nhoa'ã va'e um que imita outros", e também pode remeter à realização de "prova de coragem (entre duas pessoas)" (Dooley, 2006: 27). Segundo Cadogan, tanto o termo py'a ra'ã como teko ra'ã pode ser traduzido como "tentar, someter a prueba" (Cadogan, 1992: 147; 173). Ja o termo tekorã, corresponderia às "leyes, normas futuras: ñande rekorã oeja va'e Nande Ru Jukuéry normas o leyes que nos dejaron Nuestro Padres Áureos", onde o termo tekorã ra'anga é entendido também como "sentar precedentes para nuestra futura conducta: todo lo que hizo el héroe solar. Pa’i Rete Kuaray en la tierra: 'teko achy oekorã ra'anga' 'sentó precedentes para la futura conducta de la humanidad” (Ibidem: 173).
} 
ria a viver neste mundo, por isso, a sabedoria "parece ser, para os Mbya, menos um substantivo do que uma modalidade de proceder", sempre tomando como foco a observação das atitudes pessoais dos parentes, já que se trata de se manter saudável e alegre neste mundo povoado por subjetividades potentes-perigosas (Cretton Pereira, 2014: 179, grifos meus). A importância do corpo - ou das atitudes corporais - reside então no fato deste ser tanto foco de percepção como alvo de ações, humanas e não-humanas, pois é a partir dele que "se pode sentir as aproximações indesejadas, mas também as conexões com Nhanderu, objetivo para o qual é preciso 'pôr o corpo a perguntar' (-roporandu nhanderete’i), ou simplesmente 'entregar o corpo' à ação das divindades” (Ibidem: 184). Controlar (jejoko) os próprios desejos seria a forma pela qual os Mbya tentam evitar os "maus encontros" com essas alteridades, enquanto a conexão com as divindades, a alteridade ideal para os Mbya, seria s sua fórmula do "bom encontro" (Cretton Pereira, 2013: 9-10). Esses "bons encontros" são percebidos através da circulação de bons afetos que perpassam os corpos-espíritos guarani e implicam um estar sempre se "lembrando" (-ma'endu'a) das divindades: "As afecções ditas divinas na pessoa, algumas vezes objetificadas como características do próprio nhe’e, seriam: 'força' (mbaraete), 'coragem' (mby'a guaxu, lit.: 'coração grande’337), 'alegria' (-vy'a), 'sabedoria' (iarand $u^{338}$ ), entre outras” (Cretton Pereira, 2014: 184). No entanto, embora essas boas afecções aproximem os Mbya dos seres divinos, "a 'doença' (mba'e axy) é, a um só tempo, afastamento ${ }^{339}$ em relação à Nhanderu e aproximação 'daqueles que não vemos"” (Ibidem: 185).

O que ocorre entre aqueles que não sabem se comportar adequadamente como seres humanos (Mbya) mas, segundo os interlocutores do autor, mesmo "errando" ou “não sabendo viver” a pessoa deve “"pedir para Nhanderu' (-porandu Nhanderu pe)” para "melhorar", pois se não o fizer estará sujeita a perder o princípio vital que a anima, morrer ou se transformar e viver como um animal (ojepota va'e), potência perigosa para seus parentes humanos (Ibidem: 187). O que coloca em questão, por sua vez, a própria perspectiva mbya em termos do "viver entre si”, apoiada pela lógica do parentesco, e o “viver

\footnotetext{
337 Alcançar -mbaraete (“fortalecimento”) e -py'a guaxu (“fígado ou coração grande, coragem”) seriam as finalidades principais de todas as "rezas” guarani (Ramo, 2014: 323).

${ }_{338} \mathrm{O}$ termo moarandu, segundo Cadogan, corresponde ao ato de "impartir sabiduría. conocimiento; enseñar: parakáo ñeẽngatu omoarandu Ñande Ru Pa’ipy el loro de las discretas palabras impartió sabiduría a Nuestro Padre Pa’i (revelándole quién había devorado a su madre)" (Cadogan, 1992: 96). Dooley traduz o mesmo termo, com a grafia diferente, mo'arandu, enquanto "ensinar a sabedoria a alguém" ou "disciplinar para andar corretamente: xeru xemo'arandu meu pai me disciplinou” (Dooley, 2006: 18).

${ }^{339}$ Segundo os interlocutores de Cretton Pereira: "Quando alguém está com este tipo de companhia, se diz que 'eles' querem levar a pessoa (ogueraa xe), e o doente sente toda uma série de sofrimentos corporais como dores, tonturas, sensação de estar distante, escuta vozes, não come bem, não dorme direito" (Cretton Pereira, 2014: 185).
} 
entre outros", lógica da predação (Cretton Pereira, 2013: 6-7). Nesse sentido, "se segurar" (jejoko) seria justamente o "modo sábio" de "saber viver" (-iko kuaa), que resultaria “não somente de uma 'escuta' (dos mais velhos, dos deuses, do corpo, dos afetos, etc...), mas também de um investimento no 'controle' (-joko) dos desejos, isto é, evitando excessos ou extremos" (Ibidem: 186). Por isso, aquele(a) que "sabe se segurar" (“jejoko kuaa") representaria “o simétrico inverso daquele que se deixa levar pelo desejo desmedido", que pode transcorrer em transformação corporal (Idem). Como meus interlocutores me explicaram em campo, é por "não sabemos viver" (ndajaiko kuaaı) nessa terra corruptível, imperfeita (yvy vaı), da onde vem todo tipo de doença e sofrimento, que temos essas condutas poluidoras, que podem levar ao -jepota. Toda essa dialética entre desejar e saber controlar os desejos parece então se centrar na natureza mesma dos encontros: a diferença entre um "bom" ou "mau" encontro residiria justamente nos efeitos da relação, isto é, especialmente nos maus encontros trata-se sempre de tentar impor respeito primeiro, tornando-se o sujeito da relação, ou melhor, de aprender por quais subjetividades se pode ser capturado e como se proteger contra delas, controlando o perigo-potência que pode resultar dessa relação. Por isso, Cretton Pereira propõe que analisemos o xamanismo entre os Mbya através do estudo das condutas pessoais, e estas enquanto formas de "saber viver” ou de um “'saber ter o corpo' (-reko kuaa nhanderete'ı)” (Ibidem: 176).

O corpo, utilizado intensamente como superfície para circulação dos valores sociais ameríndios, seria o lugar da definição e diferenciação entre os diversos seres do cosmos. A partir de toda essa discussão mobilizada aqui, podemos perceber que temos modos diferenciados de fabricar tanto os corpos, como os gêneros, o xamanismo enquanto uma estratégia de diplomacia cosmopolítica tendo um aspecto central aí. Corpos específicos, com potencialidades distintas, são assim produzidos para "perseguir um devir-mãe, um devir-caçador ou um devir-xamã” (Pierri, 2013a: 184). Se como escreve Pierri, "toda imitação é uma transformação" (Ibidem: 253), podemos acrescentar que corpos distintos produzem imagens-afecções-potências distintas, daí o perigo-poder envolvido em imitar comportamentos outros, transformar-se e afetar, negativamente, a dinâmica de parentesco-predação mbya. Corpo cria, então, o chamado gênero ou, o que diferencia gênero é o chamado corpo que nada mais é que "conhecimento corporificado", a que corresponde uma disposição ou algumas disposições e capacidades-poderes específicos na organização coletiva. É a partir de cada comportamento, portanto, que os corpos se diferenciam entre si, como versa a própria teoria perspectivista ameríndia e, entre os Mbya não é diferente. 


\section{Sobre a gestão de relações cotidianas-políticas, entre gêneros e a formação das novas gerações}

Dentre os modos esperados de saber viver e ter um corpo, a "cautela", a "calma" e a "generosidade" seriam qualidades e atitudes muito valorizadas, de acordo com meus interlocutores mbya e, portanto, fundamentais para se tornar uma liderança, já que despertam "respeito" coletivo por serem consideradas disposições sensatas e ideais entre parentes. Daí que aquele(a)s que seguem à frente (tenondegua kuery) de um coletivo, devem "saber levar as pessoas" (Karai Jekupe, Tekoa Kalipety 2015, grifos meus). Além disso, devem inspirar "confiança” (-jerovia) ao coletivo pelos "conselhos" que distribuem e que devem "tocar o coração" dos parentes, levando-os a sentirem em sua fala, palavras verdadeiras, e assim se motivar ou mesmo "sentir no coração" que devem seguir suas orientações e movimentações. Entretanto, o “dom da palavra”, inspirado por capacidades-poderes disponibilizados na relação com a esfera divina, também pode se converter em uma forma de controle exagerada das ações e comportamentos dos parentes ${ }^{340}$ e agregados, dentro de um coletivo. E para ser reconhecida como uma liderança "política"341, a pessoa deve apresentar algumas dessas qualidades morais, transformando-se - ou ao menos esforçando-se ao máximo para - em uma pessoa exemplar, que deve "acima de tudo, não agir por interesses próprios” ou por "ganância”, como me ensinou Karai Jekupe, mas pensar "sempre no coletivo", além de ter "algo de ação, gostar e se interessar por política, ter paciência para lidar com a burocracia, estudar, tem que estar sempre saindo [da comunidade]”, por isso, "tem que ter disposição" (Idem, grifos e alterações minhas). Tais figuras devem também "saber equilibrar" tais qualidades, já que, segundo Para Poty "se você for muito bonzinho também não dá, aí as pessoas não respeitam, também não pode ser muito bravo porque daí as pessoas se distanciam de você" ${ }^{342}$ (Para Poty, Tekoa Tenonde Porã

\footnotetext{
340 Por meio da fala se pode influenciar parentes adquirindo um certo controle sobre suas ações. O uso negativo desse dom, para convencê-los a realizar coisas que não necessariamente irão produzir boas ações ou disposições coletivas, pode incorrer na perda dessas capacidades-poderes e em infortúnios diversos.

${ }^{341}$ Como dito logo no inicio da dissertação, ao utilizamos o termo "liderança" sem especificar, estamos nos referindo à liderança política, linha de frente na interlocução com os brancos, de um coletivo grande, um tekoa. Todos, em alguma medida, podem ser lideranças a partir de qualquer contexto de ação, iniciando uma ação e sendo seguido nela, principalmente, dentro do contexto de relações da família extensa. Quando necessário, iremos especificar que essa liderança é também espiritual, pois os Mbya consideram que um(a) xamã será sempre uma liderança política, mas o contrário não é totalmente verdadeiro, pois envolve em certo sentido, uma questão de saber-poder e experiência que algumas pessoas ainda não alcançaram. No entanto, é importante ressaltar, mais uma vez, que na socialidade xamânica guarani, a espiritualidade perpassa todos os âmbitos de sua vida e, portanto, não constitui algo separado ou fora da política.

${ }_{342}$ Sua família está na liderança da comunidade há bastante tempo lutando pela demarcação da área e, por isso, "puxam bastante os outros", procurando "trazer o máximo de pessoas" para essa luta. A capacidade de puxar pessoas é então um elemento fundamental daqueles que se dispõem a tomar a frente em ações de diplomacia cosmopolítica.
} 
2015). Há também o entendimento de que se engajar ou não na "linha de frente" da "comunidade", vai do "interesse" ou "disposição" de cada um(a), pois quem o faz seriam "pessoas interessadas em ajudar a sua comunidade", que buscam "melhorias para todos e não para si próprios". Ainda assim, mesmo que algumas pessoas tenham o "potencial” para ser uma liderança, elas podem preferir seguir por outro caminho, uma vez que, segundo meus interlocutores, é “muito difícil se interessarem" justamente pelas "dificuldades" que esse tipo de trabalho impõe, preferindo realizar outras ações dentro do tekoa ou mesmo da família extensa, o que não significa que deixam de atuar em benefício do coletivo:

pra ser uma liderança tem de ter coragem pra todas as coisas que vierem acontecer e tem de estar a todo momento a disposição da comunidade, não tem sábado, não tem domingo, não tem feriado, nem a noite, nem madrugada, tem de sempre atender a demanda da comunidade, daí que muitas pessoas não conseguem [levar durante muito tempo]. (Kerexu, Tekoa Tenonde Porã 2015, grifos e alterações minhas)

Essas dificuldades da disposição de liderança, se acentuam nos dias atuais, fazendo com que muitos sujeitos não desejem mais se envolver nessa esfera, "abandonando" as atividades após um período, podendo voltar, ou não. Como comentam os Mbya, a maioria das lideranças que ingressam na "carreira” cansam “muito rápido”, pois nem sempre lidam com "coisas legais", participando de reuniões de todos os tipos, toda semana, desde questões matrimoniais que chegam a durar horas, sem qualquer chance de solução, até mesmo reuniões sobre "coisas de jurua" que também costumar prolongar-se durante muito tempo, e que, muitas vezes, não compreendem completamente, sem contar as muitas "viagens" que têm de fazer e mesmo o trânsito constante à "cidade", nas reuniões com órgãos governamentais e instituições da sociedade civil, além de diversas outras demandas relacionadas à comunidade e à própria família ou núcleo. É comum também o comentário entre as lideranças das dificuldades sofridas em relação a essas viagens e de como muitos dos parentes que permanecem na aldeia não reconhecem seu "sacrifício" pela comunidade, apenas levantando suspeitas ${ }^{343}$ a respeito dos privilégios (geralmente, se acusa o recebimento de "diárias") que receberiam nessas incursões, estando inclusive sujeitos a retaliações, seja dos próprios parentes ou de outras famílias (ver Capítulo II). Além disso, há a questão de que a maioria das "reuniões" (relacionadas à questões da área

\footnotetext{
${ }^{343}$ Keese observa uma certa proximidade entre as figuras da liderança viajante (um "emissário constante ao exterior") e do xondaro vai (responsável por "lidar com os conflitos mais violentos"), que desempenham tarefas que são consideradas importantes ao coletivo mas que também os afastam da convivência com os demais, conferindo-lhes posições sociais, em certo sentido, negativas, seja pela ausência constante ou pelo uso da agressividade, abalando, de certo modo, as dinâmicas entre parentesco e reciprocidade (Keese dos Santos, 2017: 206). A respeito dessas "lideranças viajantes", ele então comenta: "Se parte de seu prestígio foi construído e está atrelado a essa dinâmica constante, os laços de parentesco e reciprocidade, que são construídos no dia a dia da aldeia, ficam significativamente comprometidos” (Ibidem: 204).
} 
de saúde, educação, demarcação, problemas internos entre famílias, entre casais, etc.), entre outras atividades que as lideranças devem participar cotidianamente não geram, segundo meus interlocutores, "remuneração", somente quando conseguem alguma participação em um "projeto" dentro da aldeia, colaborando então nessa frente somente aqueles que têm o "interesse em ajudar a comunidade", em seu "desenvolvimento" e na luta por "melhorias" coletivas. Em alguns casos, tais atividades podem gerar prestígio-poder suficiente para levantar suspeitas de estarem privilegiando ou beneficiando, de alguma maneira, a própria família ou algum outro grupo. As lideranças têm que lidar então constantemente com a "insatisfação" e "desconfiança" coletiva, mesmo que haja no discurso oficial o horizonte ideal de benfeitorias coletivas para todos, a promoção de igualdade de condições e de distribuição dos bens, serviços e recursos.

Por essa razão, o coletivo de lideranças do Tekoa Tenonde Porã busca sempre ter um contato efetivo com a comunidade e as lideranças dos núcleos familiares. Seria por meio dessa "abertura" ao diálogo ${ }^{344}$ para as demandas coletivas, segundo meus interlocutores mbya, que se estabeleceriam as relações de confiança (-jerovia) entre essas lideranças e o coletivo, que nunca se estabilizam em definitivo, dada a vigilância e controle constante da verdadeira eficácia, por parte da comunidade, das ações desempenhadas por aqueles que estão assumindo a frente. Nessa constante vigilância coletiva não importam, como me contaram, as suas boas ações, nem as já realizadas, só a conjuntura em questão, pois "tudo é uma questão de [dis]posição e mo[vi] mento" (Pimentel, 2012: 160, alterações minhas). Essa avaliação incessante do bom uso ou exercício da liderança em um coletivo aumenta muito em contextos de multiplicação de parentelas e interesses em um espaço físico restrito de convivência, que mantêm sua própria lógica política "tradicional" de autonomia de pensamento e liderança de casais-chefes-xamãs de família extensa, com estilos próprios de condução e orientação (ainda que inspirados no código de condutas mbya, compartilhado por todos). Desse modo, assim como as lideranças espirituais, as jovens lideranças devem aprender a manejar e a equilibrar o uso, o grau e qualidade da incorporação das potências exteriores - divindades, “donos-espíritos”, jurua kuery - e as dinâmicas entre parentesco e reciprocidade guarani (ver Capítulo II). Se não o fizerem, podem se aproximar demasiado de alteridades donas de humores negativos-agressivos

\footnotetext{
${ }^{344}$ Karai Jekupe me explicou que “antes esse diálogo não era possível, até mesmo entre os homens” (Tekoa Kalipety 2015). Acredito que o que ele quis dizer é que, por conta do ideal Guarani de bem viver, que preza pela política da boa distância-vizinhança, há a busca pelo distanciamento espacial entre parentelas, cada qual sob a sua liderança, que segue um estilo próprio de condução-orientação.
} 
que podem enfraquecê-las e dominá-las, causando infortúnios ${ }^{345}$ a todos seus parentes corporais e os que estão próximos a eles. É por isso também que o coletivo deve controlar o prestígio-poder das lideranças, para que essa potência não vire completamente o vetor porã da proteção, solidariedade-generosidade entre parentes (vetor coletivo) para o vetor vai da predação e agressão (vetor individual).

Assim, quando falam sobre as qualidades a serem desenvolvidas para se tornar uma liderança, meus interlocutores as associam com algo que "parte da própria pessoa", “independente de gênero", e que "quando é uma liderança feminina” geralmente lhe são colocadas situações que estejam mais relacionadas com as outras mulheres ou com as crianças. Entretanto, ainda há "resistência de algumas famílias" que acabam "impedindo" que as mulheres de seu próprio núcleo participem mais das "atividades coletivas" para fora dali. Estas famílias que acabam impondo "algumas barreiras" para as mulheres participarem de atividades no âmbito da comunidade, acreditam, segundo a percepção de alguns de meus interlocutores guarani, que quando as mulheres se casam, devem "ser esposa", isto é, atuar como uma, o que significaria:

cuidar do marido, cuidar dos filhos, cuidar da casa, e se comportar como uma mulher casada [...] você deixa de fazer muitas coisas coletivas, como ter um círculo de amizades grande, ou passear, tem que se concentrar mais na família para evitar problemas, para evitar falatório [ayvuxe rei] e isso acaba comprometendo bastante a atuação das mulheres nas ações políticas.

Como me contaram algumas interlocutoras, ainda existe o pensamento de que a "mulher casada tem que cuidar da casa, que tem que fazer tudo e só ficar em casa, enquanto os maridos saem para se divertir", além de casos em que "se a mulher não estiver em casa, o marido pode ficar dias sem comer porque não quer cozinhar, por achar que não é sua função". No entanto, também há “muitos homens dividindo as tarefas” com suas companheiras e, em alguns casos, "cuidando da casa e dos filhos enquanto a esposa trabalha”, dependendo então em cada caso, na visão desses interlocutores, da "criação" familiar e da disposição de cada gênero na relação conjugal. E mesmo considerando este tipo de atitude masculina como "machista" (eles mesmos assim denominaram), a compreendem como uma "influência” da cultura jurua, pois nos relatos dos mais velhos, os

\footnotetext{
${ }^{345}$ De acordo com Macedo, as chamadas “doenças espirituais”, mba'eaxy (“o que é sofrimento, dor”), seriam recorrentes entre os Guarani, especialmente entre os jovens e entre aqueles que ocupam cargos de liderança ou postos assalariados. Neste último caso, são inúmeras as acusações a respeito da inveja de outros parentes por seus cargos, salários e-ou prestígio, ainda que, com frequência tais adoecimentos sejam diagnosticados pelos xamoĩ como sendo associados à "proximidade excessiva dos brancos, suas coisas e saberes, gerando insatisfação e afastamento do nhe'e porã do corpo” (Macedo, 2012a: 20). Essas doenças também podem ser relacionadas a outras causas como a tristeza (ndozy'a ), seja por separações entre cônjuges ou de parentes próximos, ou mesmo por agenciamentos patogênicos enviados por outras pessoas, chamados ipaje ("feitiço").
} 
homens "sabiam fazer e cuidar de tudo o que as mulheres cuidam", o que ainda se mantêm nas "famílias mais tradicionais", que não têm muito contato com os jurua, sendo pessoas mais "reservadas", que "ficam mais entre família e não saem muito", e o casal acaba se ajudando mais nas tarefas domésticas. Na visão de alguns interlocutores, tais "mudanças", se devem aos "novos tempos", pois seriam as novas gerações que pensam que as tarefas domésticas correspondam somente às mulheres, e em sua percepção, a "TV” acaba “influenciando muito" nesse sentido. A questão dos conflitos geracionais ${ }^{346}$ e os costumes atuais acabam gerando embate direto com famílias mais "tradicionais", mais "fechadas" a novas ideias, especialmente, aquelas ideias e práticas que são consideradas mais distantes ao universo indígena e seus modos de pensar e agir, em geral.

Jera Poty ${ }^{347}$, importante liderança mbya, reconhecida tanto na articulação interna da T.I. Tenonde Porã, como na articulação entre as aldeias guarani de SP e na frente de interlocução com os jurua e suas instituições, além de ser professora, atuar na frente da área de Educação Escolar Indígena, esteve na frente da criação do Conselho de lideranças da aldeia, atuando em sua gestão e no trabalho burocrático decorrente, assim como na produção e encaminhamento de projetos de fortalecimento cultural e socioambiental, além de articular também encontros e intercâmbios culturais tanto no âmbito interno da T.I., como no inter-aldeias e participar de eventos e reuniões extra-aldeia, ajudando diretamente o coletivo do qual faz parte na salvaguarda de seus direitos constitucionais. Jera sempre comenta que não tem a "intenção" de "ser cacica”, não acha que seja esta sua "função", demonstrando preocupação em "estar sempre na frente" e de "ser muito procurada e requisitada" para ajudar a resolver inúmeros "problemas", o que ocorre justamente por sua atuação reconhecidamente diplomática de articulação entre os dois mundos (mbya-jurua), sem perder sua essência e determinação guarani. A intenção em não acu-

\footnotetext{
${ }^{346}$ Esses conflitos e a produção de atualizações nas disposições de gênero internas e em relação aos jurua necessitam de mais estudos etnográficos.

347 "Faço parte da liderança interna, já tô fechando 10 anos de atuação na liderança. Há três anos era só eu, Jera, no meio dos homens, enfrentei muitas coisas internamente também porque as aldeias guarani não estão acostumadas ainda [...] com a mulher liderança, essa mulher que também sai pra fora, que também lidera o grupo fora e dentro da aldeia. Mas hoje não é mais só eu também e aí toda essa estranheza da comunidade que também influenciou outras aldeias, já é mais tranquilo. Hoje tem muitas mulheres atuando, falando, gritando, aí hoje na Tenonde tem mais de 15 mulheres atuando ativamente, onde os homens Guarani também falam 'vocês agora mulheres, qual é a opinião de vocês, qual o ponto de vista de vocês' [...] abertura muito bonita e muito forte que eu acho que vem só pra somar a luta pelo direito, a luta pela cultura, a luta pela dignidade e pela sustentabilidade desse povo que, como outros povos foi tão massacrado e judiado com intolerância, com ignorância, tudo de ruim que a gente já sabe que viveu e vive até hoje. Essa é a minha luta" (Poty, 2016, grifos meus).
} 
mular tantas funções de "frente", seria uma maneira de "desabrochar mais as outras meninas" ${ }^{448}$, de ampliar o "leque de lideranças", para que as mulheres, principalmente, "ocupem a frente", pois mesmo quando ela não está presente "fazem a coisa acontecer, e fazem bem” (Jera Poty, Tekoa Kalipety 2015).

O Tekoa Tenonde Porã, de acordo com meus interlocutores, se destaca, entre outras aldeias guarani, no sentido de mulheres guarani atuando enquanto lideranças políticas locais, isto é, no âmbito interno comunitário, com disposição de "se colocar" à frente, “tomar iniciativas", e "pensar junto" às outras lideranças, atuando também em articulações entre aldeias que ocorrem dentro do tekoa ou da T.I. e cada vez mais também nos intercâmbios e encontros que ocorrem em outras aldeias, que se encontram em outras cidades e-ou Estados. Entretanto, mesmo esta aldeia tendo muitas mulheres na liderança, não seria “muito forte” a “presença feminina na articulação política” extra aldeia ${ }^{349}$. A participação feminina liderança coletiva não vem de hoje, como comentou comigo Kerexu, importante liderança interna ${ }^{350}$, além de destaque nas mobilizações na cidade e nos

\footnotetext{
348 Percebe-se aqui a reflexão da própria Jera sobre a sua "função" nesta terra. Isso poderia estar relacionado ao seu desejo de -mbojera ("criar", "gerar”) ou, em suas próprias palavras, "desabrochar” outras pessoas? Segundo Testa (2014), entre os Mbya há uma série de mecanismos coletivos de controle da circulação de saberes, que devem também contribuir para distribuí-los entre diferentes sujeitos, pois colocar-se excessivamente em evidência carrega o risco de interromper o fluxo desses saberes e desencadear a circulação de doenças e infortúnios. Segundo Pierri, ombojera remete a um processo de transformação que parte da própria etimologia da palavra composta por -mbo (causativo), -je (reflexivo), $-r a$ (abrir), que indica que se trata não apenas de um ato de criar, mas também de transformar, como no caso da transformação do botão em flor (Pierri, 2013a: 101). Cadogan traduz o termo "ñembojera" como "crearse a sí mismo; Ñande Jarýi a’e ae oñembojera Nuestra Abuela se creó a si misma” (Cadogan, 1992: 129). Dooley traduz o termo -jera por "desamarrar-se" e -mbojera tanto como "fazer o espírito de (alguém) viver de novo, depois de morrer", quanto "criar (algo ou alguém) do nada, ou transformar em outra coisa” (Dooley, 2006: 67-68). O radical -ra vem do verbo "desamarrar, desatar" ou "desamarrar(-se)" (Ibidem: 70, 162).

349 Segundo uma interlocutora mbya, não há políticas públicas específicas para mulheres indígenas na aldeia e, pela maioria delas ainda "não sair muito", não estariam inseridas nessas "reflexões" e "ações". Mesmo com convites de não-indígenas para participarem de eventos que buscam promover reflexões acerca da "autonomia e independência das mulheres", as próprias kunhãgue ainda não têm o desejo em participar de eventos para fora, participando mais do "movimento local”, dentro da própria comunidade, o que acaba ajudando a fortalecê-las internamente. Esse é o objetivo principal do coletivo nesse momento, mas há o desejo expresso de algumas lideranças de que em um "futuro próximo" elas possam se sentir "mais à vontade em sair para lutar fora", pelos "direitos” de seu povo e por "melhorias" sociais. O “espelho" que algumas mulheres guarani têm, é "que quem sai para fora é na verdade o que já tá fora, são principalmente as mulheres indígenas que são desaldeadas, que moram na cidade, que participam de movimentos sociais", e estariam mais acostumadas a agir nesses ambientes e contextos que elas, e talvez venha daí um pouco do seu respeito-vergonha. Mas há a "expectativa bem promissora" de que "com o tempo as mulheres guarani também irão sair, de forma controlada e cautelosa, porque como os homens, não estão muito acostumadas a ficar um longo tempo na cidade".

${ }^{350}$ Mesmo sendo parte do coletivo de lideranças, quando acontece algo dentro de sua família, por exemplo, algum problema com algum "genro", Kerexu comenta que acaba conversando ela mesma com eles, em sua própria casa, ressaltando a autoridade-respeito que a sogra enquanto matriarca da família tem sobre seus afins, assim como a (dis)posição que ocupa no interior da família extensa. Isso se deve também, segundo Kerexu, pela própria "postura" dela em sempre "tomar a frente" e conversar-aconselhar sobre os problemas que ocorrem dentro de sua família. A seu ver isso tem a ver com o seu "jeito” (xereko), que é o modo como eles traduzem em português, as maneiras com que cada um age, sua singularidade. Como me contaram, tradicionalmente, quando casam, são os genros que viriam morar com a sogra e o sogro, a família toda vivendo dentro de uma mesma casa ou em casas anexas, após o nascimento do primeiro filho.
} 
vídeos de divulgação da luta pela demarcação de terras (yəy re jajoguero’a). Ela lembra que quando era ainda criança as mulheres "participavam de muitas reuniões que os caciques chamavam" e muitas delas "eram também lideranças" e "ajudavam os caciques a conversar com a comunidade, dar conselho" (Kerexu, Tekoa Tenonde Porã 2015). Por isso, mesmo que ainda desejem contar com o apoio de mais mulheres na liderança da comunidade, a "participação é maior que antigamente", segundo Kerexu. O que ocorre seja por conta do volume populacional que aumentou bastante desde a sua "fundação", ou mesmo pelo reduzido tamanho da terra efetivamente homologada pelo Governo, uma vez que com o avançar das cidades e tomada do controle das matas pelo Estado, os Mbya já não podem se dispersar como antigamente, concentrando assim mais famílias extensas em uma mesma área, e com elas vêm a necessidade de um número maior de lideranças cuidando da "representação" dos interesses e da articulação dos pensamentos e estilos próprios a cada núcleo familiar.

Com a introdução da educação escolar dentro da aldeia e da presença obrigatória dos alunos ali matriculados para recebimento dos benefícios financeiros dos programas de transferência de renda governamentais, também avançou o aprendizado do português ${ }^{351}$, levando as kunhãgue a terem um contato maior e continuado com outras famílias e mesmo com os jurua, e faz com que elas tenham maiores possibilidades, hoje em dia, de se engajarem na liderança da comunidade, acompanhando outras lideranças nas atividades de gestão coletiva. A Escola Estadual atua, nesse sentido, enquanto espaço que propicia uma interlocução maior entre os mais jovens e, também entre as famílias, funcionando aqui como ponto de articulação e de integração entre parentelas e entre os Guarani e os jurua. Nesse sentido, por aprenderem mais a língua portuguesa que geração anterior, facilita-se a atuação das mulheres na liderança coletiva para fora do grupo de parentes, que acabam se envolvendo também e cada vez mais na interlocução com alguns jurua, seja saindo para a cidade desde pequenas para apresentações culturais de corais e danças guarani, onde negociam também a venda de artesanatos, além de serem elas que recebem, muitas vezes, os jurua que chegam às aldeias com doações de roupas, alimentos, etc., pois são responsáveis pela sua distribuição, e em alguns casos, são escolhidas para recepcionar também, junto a outras lideranças, o turismo de escolas, faculdades, entre outros, que buscam conhecer um pouco da cultura indígena e comprar seus artesanatos

\footnotetext{
351 Como meus próprios interlocutores mbya dizem, as crianças "desde a barriga da mãe já aprendem português" e sobre jurua reko, seja escutando os programas que os pais assistem pela televisão ou pelo rádio, ou quando pequenos, assistindo as novelas e outros programas televisivos jurua, somada à recente introdução dos tablets, celulares, etc., que crianças bem pequenas sabem manejar perfeitamente, sem nem mesmo falar uma única palavra em português.
} 
como lembrança da visita. Além disso, cada vez mais as kunhãgue ocupam cargos assalariados dentro da própria aldeia e dos projetos que ali circulam, participam também de muitos eventos e feiras culturais na cidade, onde podem realizar falas públicas ou acompanhar outras lideranças que o farão e, expor para venda os artesanatos da família.

Mas, mesmo com o "movimento de xondaro" que teve início em 2010 na Tenonde e inspirou muitas outras aldeias guarani, com as danças e fortalecimento das figuras das xondaria e dos xondaro, estes últimos, segundo meus interlocutores, "sempre acabam ficando em um destaque maior", seja porque são "muitos" homens que participam ou pela visível “demonstração de sua grande agilidade nos movimentos”, estimulando mais jovens e crianças a participarem, o que já não ocorre tanto com as xondaria, que por não terem uma "chefa" (xondaria ruvixa) definida, aquela "liderança que puxa a fila, a dança e coloca os obstáculos, o movimento das xondaria acabou enfraquecido em relação ao movimento cultural da dança e do seu significado", que reflete a "importância de viver na prática e de proteger a cultura" ${ }^{52}$. Uma interlocutora avalia que as kunhãgue na Tenonde se fortaleceram bastante nesse processo e acabaram influenciando outras aldeias em muitos aspectos, "mas a parte específica de lideranças mulheres entre os homens nas ações políticas [para fora] ainda não surtiu muito efeito". Para ela, a Tenonde é "uma aldeia que tende a se fortalecer e de repente um dia ter uma cacica de fato, em uma aldeia grande", e “que não fique só de nome”, já que "ser liderança da frente não é só nome, é fazer as coisas acontecerem, é a pessoa estar preocupada com o coletivo, não pensar só em si ou na família”. Em outras aldeias mbya do Estado de SP, na avaliação de alguns interlocutores, apesar de poderem participar das decisões coletivas tanto do grupo local, como da comunidade, as kunhãgue não atuariam tanto como "lideranças na linha de frente" ${ }^{553}$, mas não entraram em detalhes do por quê isso ocorreria, o que só nos faz perceber que esta é uma reflexão que eles, assim como nós, ainda estão começando a realizar.

Todavia, é possível observar que cada vez mais as kunhãgue estão tomando a frente na luta pela regularização da demarcação de suas terras, atuando "para fora" de

\footnotetext{
${ }^{352}$ Segundo Kerexu, o movimento de fortalecimento da dança-luta das xondaria não ficou tão forte quanto a dança-luta dos xondaro porque eles têm um "jeito para puxar as pessoas", "têm quem chamar e levar pra participar, já as mulheres tem mais dificuldade para sair porque não têm alguém [como uma xondaria ruxixa ] para articular", que seja uma "liderança forte que possa chamar, levar, articular todo mundo" (Kerexu, Tekoa Tenonde Porã 2015, grifos e alterações minhas).

${ }^{353}$ Segundo uma interlocutora mbya, as mulheres não atuariam tanto para fora do grupo familiar justamente para se "preservarem", o que pode ter a ver também com o ideal mbya de maior preocupação com a preservação dos corpos femininos, e de suas funções de (re)produção dos novos seres humanos, o que não quer dizer que elas não atuem como lideranças em seu núcleo local de maneiras diversas, seja iniciando uma ação coletiva, dando conselhos, tomando a frente nos momentos e ações importantes na opy ou atuando politicamente na articulação entre os diferentes pensamentos ali dentro.
} 
seus tekoa, figurando junto às outras lideranças em vídeos-manifestos de divulgação da luta e em atos políticos na cidade ${ }^{354}$, em que levam seu o canto de força (-mbaraete) e coragem ( $p y^{\prime} a$ guaxu) para somar junto a seus parentes, com algumas lideranças mais velhas e experientes servindo de inspiração mesmo para as novas gerações que estão se formando, fortalecendo muito a participação da "mulherada" nas ações políticas, tanto "dentro" como "fora" das aldeias. Sua voz é muito prestigiada nas decisões coletivas, suas palavras são "bem recebidas" tanto no âmbito doméstico da família extensa, como em reuniões coletivas gerais da comunidade. Suas falas são entendidas como "mais coerentes", por conta de sua capacidade acentuada de "ouvir" e de "pensar bem" antes de se pronunciar publicamente, o fazendo somente se acharem necessário e para o bem do coletivo, enquanto os homens têm "mais facilidade em falar" e "sair para fora" do grupo familiar e "ter mais contato" com os jurua, enquanto para elas seria mais "difícil de sair".

Sua "cautela" diante de situações e o maior cuidado-controle-moderação que têm de seu próprio comportamento, tanto nas falas, quanto nas posturas-atitudes, é algo muito admirado entre os Guarani, que buscam estimular sua maior participação nas reuniões gerais, fazendo-as se sentirem valorizadas e importantes tanto para o coletivo de lideranças, na distribuição de competências e trabalhos que demandam iniciativa e ação, quanto para a comunidade, na composição da luta pela reconhecimento da terra e pela garantia dos benefícios e melhorias coletivas gerais a que têm direito dentro da aldeia. Há aí, a percepção de que as mulheres seriam pessoas "mais preocupadas com o coletivo" (mesmo que entendam que muitos homens, especialmente os mais velhos, também se preocupem e auxiliem no cuidado-proteção coletivo), pela diferença mesmo em seu cuidado com a própria postura, seus comportamentos e os dos parentes, que se reflete tambem na "delicadeza" de suas ações e atitudes, "até nas palavras", elas "agem diferente" diante das situações, geralmente são "bem mais cautelosas e calmas" e "muito protetoras, sempre pensam no coletivo”, motivo pelo qual o coletivo de lideranças busque tanto fortalecê-las e abrir espaço para sua participação. Considera-se então que “a voz da mulher é bem mais ativa do que a do homem, ela impõe mais respeito" por ser mais "tranquila" e "sossegada no seu canto", e quando fala, "pensa antes” e "fala a coisa certa e pouco”, “o homem já é mais bruto“, "quer sempre falar mais alto”, "age sem pensar” muito (Karai

\footnotetext{
${ }^{354}$ É interessante notar que mesmo nas mobilizações políticas pela demarcação de suas terras que acontecem fora da aldeia, na cidade, as mulheres e seus companheiros de luta só vão para os atos quando têm uma estrutura toda esquematizada e garantida de transporte e alimentação para levá-los e trazê-los de volta, geralmente, no mesmo dia, aos tekoa. Isso torna evidente o intenso planejamento mbya dos atos que irão realizar na cidade e mesmo dentro da política interna, com longas discussões coletivas a respeito de como irão agir, se comportar, tanto ali dentro, como fora dali. Também há uma intensa preparação corporal-espiritual via ritual na opy para esses atos ou eventos políticos, seja na cidade ou em outros tekoa.
} 
Jekupe, Tekoa Kalipety 2015). É aí, de alguma maneira que, segundo Karai, "entra a questão do equilíbrio" entre os gêneros, pois "uma liderança feminina sempre vai tentar acalmar os ânimos" de modo que as conversas não passem "do bom senso para outra coisa".

Mesmo assim, as mulheres "mais jovens" teriam um pouco mais de "vergonha" ("tradução" guarani para respeito, cf. Testa 2014) de falar nas reuniões do coletivo, o que ocorre segundo me foi relatado, pela sua "insegurança” de não "saberem muito" ainda sobre os temas discutidos ou por elas mesmas pensarem que não têm "nada para contribuir", e que sua fala-ação não será "boa” ou "bonita” o bastante, uma vez que ainda estão "aprendendo". No entanto, algumas delas "falam quando sentem que devem" 955 e têm algo a contribuir, “ajudando muito na discussão também”. Daí que, nos dias atuais as mulheres mais jovens estão "começando a se soltar e se comunicar bem mais", seja entre si ou mesmo com os jurua, pois sua "comunicação em português têm melhorado bastante e já não têm tanta vergonha como antes, muitas têm coragem de falar", sendo sua performance na fala "bem vista e incentivada" pelo coletivo de lideranças. Já as lideranças e mulheres "mais velhas", geralmente sábias anciãs, rezadoras, fazem maior uso da palavra nestas reuniões e se dedicam mais que os homens a aconselhar e a orientar as discussões coletivas, o que reflete sua maior "confiança" (-jerovia) e disposição na distribuição das palavras entre os parentes, por conta também de sua "experiência" de vida e trajetória de aprendizado pelos ensinamentos dos "mais antigos", colocando mais em circulação suas palavras inspiradas, o que faz com que adquiram grande prestígio coletivo justamente por serem reconhecidas, junto aos xeramoĩ, como aquelas que melhor desenvolveram essas capacidades-poderes de fala que aconselha e, o controle mesmo sobre esse fluxo de saberes-poderes. Isso reflete também a postura ética-moral guarani, de respeito geracional, onde os mais jovens são ensinados a primeiro aprender a ouvir e respeitar as palavras-conselhos das lideranças mais velhas e, portanto, mais sábias. Os mais jovens estariam ali então mais para "acompanhar" as discussões, e aprender com elas, que propriamente expressarem suas opiniões, ainda em formação. Um interlocutor de Rebelo comenta sobre essa relativa dificuldade das kunhãgue com o idioma jurua, visto que "quem se destaca na língua portuguesa é o homem" que era quem "ia buscar mais longe o trabalho” (Adão Antunes apud Rebelo, 2015: 65). Tal dificuldade, na visão de Adão e que também vai de encontro com o que ouvi dos Guarani em campo, tem a ver com o violento processo de colonização e o medo do abuso presente no contato com os jurua:

\footnotetext{
${ }_{355}$ Essa fala inspirada que surge a partir da relação de proximidade que se estabelece com a esfera divina,
} aparece como um "sentir no coração", como já comentamos, e deve ser compartilhada entre parentes. 
Depois do contato, se for ver a história, em 1.500, do contato com os portugueses, as mulheres foram violadas, estupradas, mortas. Então, ficava esse medo também. As mulheres começaram a ficar mais longe. Com certeza, no contato com os portugueses, se a mulher chegasse lá pra falar com ele, ela ia tá nua. Então, primeira coisa, ele ia pegar a força, levar pro mato, violentar ela. Então, foi mais por causa desse medo. Esse medo foi passando, os mais velhos foram contando essa história 'é perigoso, o juruá não tem essa educação de chegar, ver a gente assim e deixar’. Eles pegam mesmo. Aí, foi passando isso para as meninas, teve esse medo. Aí hoje já tem a lei que protege as mulheres e a mulher também tá conhecendo a lei. Então, hoje acontece isso, mas a função da mulher antes, ela que dominava tudo, ela plantava. O homem só fazia aquele serviço braçal que a mulher não fazia, roçar, limpar a terra, mas a plantação, a agricultura, era toda a mulher que fazia. Ela fazia plantação, fazia cestaria, fazia utensílio da casa, cerâmica, tudo para casa, tudo a mulher. O homem trabalhava com essa parte mais rústica, caçar, pescar, construir uma casa, limpar a terra. (Adão Antunes apud Rebelo, 2015: 65-66)

Esse relato aponta os motivos mais silenciados (de violência sexual jurua contra as mulheres indígenas), para se preservarem mais as mulheres no contato com os outros, no caso, os jurua, evitando principalmente o intercurso sexual com eles, o que, por sua vez, poderia vir a afetar todas relações de produção-proteção entre parentes humanosmbya, e acaba fazendo com que elas não se façam tão visíveis para fora, ou disponíveis para contato como, por exemplo, os homens e, talvez venha daí também a sua "invisibilidade" na literatura especializada). Como comentou comigo uma interlocutora: "é a gente mesmo que fica nessa posição de não aparecer muito, mas agora a mulherada acho que tá um pouco mais repensando essa coisa de ficar um pouco mais quieta, então estão começando a falar mais[para fora ] também” (Para Yxapy do Tekoa Koenju [RS], Local: São Paulo, 2016, alterações minhas). As mulheres, ainda que "mais quietas":

ao mesmo tempo são as que decidem mesmo, como vai ser [...] e dependendo do nome [nhe' $\tilde{e}]$ que ela tem também isso influencia muito assim na sociedade $[\ldots]$ na convivência [...] então acho que isso influencia um pouco nessas lutas [políticas pela terra e direitos], como se comporta né. (Idem, alterações minhas)

A questão de "calar" as mulheres foi uma "influência jurua”, segundo Karai Jekupe, pois os europeus acreditavam que "o homem que mandava em tudo e deixavam as mulheres mais fechadas, enclausuradas no âmbito doméstico, não permitindo que saíssem muito”, o que levou "os indígenas a se espelharem nisso”, e “antes [da invasão europeia] não era assim, tanto a mulher quanto o homem eram livres" (Karai Jekupe, Tekoa Kalipety 2015, alterações minhas). Mesmo pensando o machismo (ele mesmo assim definiu) como uma grande influência jurua, Karai reconhece sua existência em alguns casos nas comunidades guarani. No entanto, ele mesmo frisou que, ao menos o coletivo de lideranças, tenta "se livrar deste peso" ao máximo, em busca de um "viver mais livre”, para ambos os gêneros, pois devem "lutar hoje pela igualdade e não pela desigualdade", o que, ele também reconhece, não se mostra tarefa fácil tamanha a influência negativa de jurua reko. 
Entretanto, depois da entrada da "mulherada" para o Conselho da aldeia Tenonde, segundo minhas interlocutoras, elas quase não "param em casa”, nem aos finais de semana e feriados. Mas, ter que "cuidar dos afazeres domésticos e dos filhos, trabalhar fora e ainda participar da liderança” pode acabar desestimulando algumas a participarem com maior regularidade do movimento político interno, porque às vezes elas têm "reunião todos os dias, em qualquer horário, sem saber que horas irá acabar e quando irão poder voltar para casa", além de ser "muito cansativo" e, na maioria das vezes, "tenso", por conta dos desentendimentos que podem ocorrer dentro da comunidade, entre as famílias, e que o coletivo de lideranças deve procurar esclarecer até que todos ou a maioria dos presentes na reunião se sintam confortáveis e de acordo com a ação a ser tomada. Nestas reuniões, a "mulherada" toma cada vez mais a frente na hora de "falar" e "aconselhar", inclusive as mais jovens (especialmente quando formam parte de uma família "influente"), o que corresponde também à sua atuação inclusive no ambiente familiar, pois são elas que tomam a dianteira (com o apoio de seus companheiros) no comando e organização da distribuição dos afazeres domésticos e coletivos entre seus parentes, e que pode tomar uma escala maior, para além da família nuclear, quando assumem e desenvolvem uma posição de destaque e respeito para tanto, seja no interior do próprio núcleo de parentesco, ou mesmo quando seu prestígio o ultrapassa, nas alianças estabelecidas, e ocorre, geralmente, quando constituem família extensa ${ }^{356}$, ou seja, quando tornam-se avós.

Todavia, é importante frisar que a questão da criação dos filhos pequenos e a demanda de cuidado com a casa, algumas de suas atividades centrais, acaba dificultando bastante as mulheres se engajem mais nas atividades de liderança da comunidade, como me contaram algumas interlocutoras, já que muitas vezes os próprios companheiros não as ajudam nem dentro de casa, dividindo as tarefas domésticas que se acumulam, nem no cuidado com os filhos, dificultando sua jornada para fora dali e sobrecarregando elas de trabalho doméstico ${ }^{357}$. Elas também me relataram que tal "postura” dos homens está

\footnotetext{
356 Tradicionalmente, nas alianças formadas pelos casamentos entre parentelas, era sempre o homem quem se mudava para casa da sogra e do sogro, tido então como mais um membro da família. Era o então o genro que iria realizar o "serviço pesado" para os sogros, e também para a sua mulher e para os seus cunhados. Ainda que trabalhassem "todos juntos", seria o novo membro da família quem "iria trabalhar mais". No entanto, tal tradição também acabou sofrendo "influência jurua”, de acordo com meus interlocutores, sendo agora o casal quem decidiria onde irá morar. Mas, o que geralmente acaba sendo levado em conta nessa decisão é o potencial de se "viver bem" entre parentes e os recursos que estes ou aqueles manejam, além de seu prestígio e poder dentro de uma comunidade. Na relação entre cunhados, de acordo com Prates (2013) teríamos um exercício de "familiarização" com o marido recém-chegado, que tem obrigação de ajudar nas atividades diárias, correspondendo às demandas de seus sogros e cunhados, que devem fazer ele "se acostumar" entre eles, dada a sua potencialidade inimiga enquanto tovaja ("cunhado").

${ }^{357}$ No entanto, para Kerexu, que é uma liderança mais velha, a dificuldade em "puxar” as mulheres para a participação na liderança da comunidade não se dá por elas terem que estar "cuidando da casa”, e que vir "participar das reuniões coletivas depende da própria boa vontade" e da "força das mulheres”, e que seus
} 
mudando e, "de novo voltando um pouco mais como já foi antes" (do contato sistemático e intensivo com jurua reko). Tradicionalmente, como elas contaram, todos os homens guarani (avakue) deveriam "saber fazer tudo" o que as mulheres fazem, porque quando elas menstruavam, deveriam "ficar quietinhas, daí quem vai lavar a roupa, quem vai cozinhar, cuidar dos filhos e da casa é o homem”, mas depois do "contato", com a "influência muito forte da cultura jurua", "o homem ficou muito nesta parte de não poder fazer tais coisas porque é da função da mulher e aí isso [essa tradição] ficou um pouco esquecido”. O que, por sua vez, na visão de alguns deles, "parece estar mudando", "porque se o homem está pedindo a opinião da mulher, pedindo para mulher se colocar, para a mulher pensar e solucionar as coisas então está colocando a mulher no mesmo campo de valor, de possibilidade de solução e traçar caminhos para situações diferentes, e como está no mesmo campo, ele pode então fazer as coisas que a mulher faz também".

Para Kerexu, a questão do "machismo", como ela mesma assim definiu, é uma "influência jurua", porque sua mãe sempre lembra que no tempo dos antepassados, quando as suas tias e avós estavam vivas, "não existia” e que só "depois de um certo tempo que veio aparecendo" (Kerexu, Tekoa Tenonde Porã 2015). Ela lembra que segundo conta sua mãe, “antes os Guarani eram mais juntos, não é igual hoje né, que um quer ser melhor que o outro, então isso veio de jurua mesmo, esse negócio de que o homem sabe mais do que a mulher, que a mulher não sabe, que ela não presta para não sei o que, que tem que ficar em casa, que tem que lavar louça, roupa e tudo mais, mas só que não é assim” (Idem, grifos meus). É, portanto, entendido pelos meus interlocutores que relegar só às mulheres o cuidado com a esfera doméstica foi uma influência da cultura jurua. No entanto, neste tekoa, existe de fato um número notável de mulheres reconhecidas como lideranças locais, e no mo(vi)mento atual há, inclusive, "mais mulheres" do que homens atuando na "linha de frente" do "movimento de lideranças", com disposição de ir "para a frente, pensar juntos, colocar a opinião e encaminhar" as decisões e ações coletivas. Isso faz com que ocorra um desejado "equilíbrio" entre eles, com os homens que já atuavam na liderança não se sentindo "intimidados" ou "ameaçados" pela atuação mais ativa das mulheres, por elas estarem ocupando espaços de ação e interlocução pública e mesmo externa, antes dedicados ou reservados a figuras masculinas (por que eram eles que circulavam mais entre aldeias e sabiam falar mais o idioma estrangeiro, além do motivo,

maridos não poderão "impedi-las", dizendo o que elas devem ou não fazer, pois "Nhanderu põe no caminho", e a pessoa deve se esforçar para seguir nele (Kerexu, Tekoa Tenonde Porã 2015). 
geralmente, silenciado da preocupação coletiva com a violência jurua contra as mulheres) e aos sábios anciões e anciãs (pelo prestígio xamânico).

Como viemos argumentando ao longo dessa Dissertação, o casal é a unidade de movimento, ação e cooperação política mbya. Talvez seja por isso também, que os líderes busquem estimular as kunhãgue a participar cada vez mais da liderança da comunidade e a ocupar a frente junto com eles. A maioria dessas mulheres seriam casadas, contando com o apoio de seus maridos que, geralmente, “também são militantes”, como me explicou uma interlocutora, o que acaba ajudando e fortalecendo sua inserção nesta esfera de ação coletiva, para além da família nuclear. Assim sendo, na Tenonde, segundo essa interlocutora, as mulheres se "destacam" a partir das "ações e das posturas" dos próprios líderes, "que ficam puxando as mulheres, dando espaço para elas falarem, perguntam sobre a opinião delas, ou mesmo quando o problema está relacionado com outra mulher ou com crianças, às vezes, os líderes passam direto para as mulheres pensarem sobre o problema e dar uma solução", pois entendem que elas irão "se entender melhor entre si", e se "compreender mais", são vistas também como "mais protetoras" e, nesse sentido, iriam saber avaliar melhor e "dar um encaminhamento positivo para a situação".

Apesar de reconhecerem também que a participação de algumas mulheres na liderança coletiva teria seus problemas, "já que como em toda sociedade, na maioria das vezes, quem começa a discriminação ou julgamento negativo para outra mulher é sempre a mulher"358, minhas interlocutoras observam que tal prática se "modificou bastante no interior do grupo" de lideranças. Por isso, a ideia de "colocar mais mulheres na liderança" é uma maneira delas "conversarem mais" entre si, e também "uma forma de juntar mais os núcleos", porque há sempre algumas "mais esquentadas" que outras, o que, por sua vez, "acaba dificultando o diálogo" entre elas, pois as vezes "começam a jogar uma contra a outra e aí o grupo intervém", sendo esta mais uma das dificuldades em "unir" as mulheres na liderança da comunidade. Também tem a questão de que o exercício do poder envolve o trato com muitos humores perigosos como a raiva e o ciúmes, que podem levar à competição por prestígio, segundo me foi relatado, pois assim como acontece com os homens que "quanto mais poderoso no cargo, mais quer assumir" (colocações em que as remunerações ou o prestígio sejam "maiores"), o que significa também "maior responsabilidade" para com o coletivo, "com a mulher não é diferente", pois quando alguma mulher começa

\footnotetext{
${ }^{558}$ A dimensão efetiva que o "falatório" (ayvuxe rę) - ou como é comum na descrição etnográfica, a "fofoca" - ocupa como um importante instrumento de instabilidade cosmopolítica na vida cotidiana, se levamos a sério o quanto a fala produz, podendo incitar más disposições, humores perigosos e retaliações devido a sua potência agressiva, deve ser mais etnografada. Para uma discussão mais detalhada sobre a dimensão política da "fofoca" e da feitiçaria no Xingu, ver Vanzolini (2015).
} 
a ser vista como uma liderança acaba querendo "se levantar" cada vez mais, e as outras "ficam com ciúmes", o que pode causar indisposições e conflitos entre elas, levando-as a também "competir". No entanto, na visão de um interlocutor, "o respeito entre eles [homens] é maior porque pensam que se ele conseguiu estar onde está foi por mérito dele”, mas com as mulheres "é diferente", porque elas "têm que provar o tempo todo que merecem estar ali, senão outra irá provar", devendo estar "sempre alerta”. Isso ocorre, como vimos em outros relatos, pela grande cobrança coletiva e uma certa culpabilizaçao maior em relação às posturas e atitudes das próprias mulheres, principalmente das mais jovens e solteiras ${ }^{359}$ e que algumas kunhãgue, hoje em dia, estão repensando e agindo diferente.

Quando acontece algum problema como, por exemplo, uma "acusação de violência”, as lideranças "conversam bastante” entre si para "avaliar bem o que ocorreu” mas, na maioria das vezes, como ocorria "no começo da formação do grupo”, “quem levava a culpa nos problemas familiares era sempre a mulher". Atualmente, "as conversas nas reuniões são diferentes", as mulheres teriam "um apoio maior das outras mulheres e também das lideranças". Nestas reuniões, as lideranças buscam sempre falar sobre "situações simples, mas que são fundamentais como a questão de todas as mulheres se pronunciarem dizendo que é covardia o homem agredir a mulher, verbalmente e principalmente fisicamente" e que "quando têm algum problema dentro do casamento, têm que resolver conversando, ou se não dá certo que separem de uma vez, para não chegar na situação de violência". Essa postura do "movimento de lideranças", que atuam enquanto apaziguadores e conciliadores dos humores e disposições coletivas, foi uma das coisas que, segundo uma interlocutora, "se destacou muito e acabou por fortalecer tanto o grupo das mulheres, como o das lideranças também”. Assim, “muitas mulheres agora confiam nas lideranças, as procuram”, principalmente as lideranças femininas, para relatar e denunciar situações de violência e abuso sexual, e mesmo que eles fiquem "completamente perdidos" do que se deve fazer em casos extremos e raros como esses, moralmente reprovados e repreensíveis pela filosofia xamânica mbya, o coletivo de lideranças se reune para pensar e aconselhar as vítimas e familiares sobre o que pode ser feito nessas situações delicadas.

Existem também, cada vez mais, principalmente nas condições atuais em que vivem, casos de "mulheres abandonadas" 360 pelos maridos, "com muitos filhos", com

\footnotetext{
359 Uma pessoa (seja ela mulher, mãe, homem, pai, avô ou avó) sem complemento está, digamos assim, mais “disponível” aos olhares de outros. Nesse sentido, estar solteir@, sem par, sem o seu complemento é estar mais abert@ aos chamados do(s) outro(s) mundo(s). Talvez venha daí o cuidado com as mulheres abandonadas e-ou solteiras, que podem correr mais risco de sofrer -jepota, e afetar a dinâmica de parentesco.

360 Segundo Ladeira: "Os desvios, os erros, a instabilidade masculina são tolerados, principalmente na juventude, ao passo que 'os erros' e a instabilidade feminina são passiveis de punição conforme seu grau. Uma mulher que está sozinha, por ter abandonado o marido ou por ser a causa de separação, é mais discriminada do que
} 
grande dificuldade de criá-los sozinhas, ainda mais quando não possuem trabalho remunerado dentro da aldeia. Estas mulheres acabam sofrendo com "autoestima baixa", achando que já não "servem para mais nada", apresentando, muitas vezes, casos de "depressão" que podem levar, em muitos casos, elas a começarem a "beber" deixando de cuidar não só dos próprios filhos, como de si mesma. As lideranças da comunidade, principalmente, mulheres, que são as distribuidoras de bens e serviços por excelência, tentam então "ajudá-las" ao máximo, aconselhando e tentando mostrar que elas "têm capacidades para fazer alguma coisa para elas mesmas", pelo "coletivo de mulheres", para se fortalecerem juntas. Eles as ajudam também doando alimentos, e se percebem que elas têm capacidade e o desejo de exercer algum trabalho - remunerado de alguma maneira ${ }^{361}-$ dentro da comunidade, buscam fazer o possível para integrá-las, para que se "sintam sempre valorizadas", pois compreendem a grande "dificuldade" que elas estão passando e que, necessitam de grande "atenção" nesses momentos difíceis (que podem chegar a afetar as suas relações corporais-espirituais de parentesco, principalmente os filhos).

As lideranças cuidam dessas mulheres em busca de fazê-las "desejar viver" novamente, em comunidade, e para que continuem cuidando de seu bem maior, que são as crianças, "presentes" dos deuses. Ao aprender a lidar com essas "dificuldades”, essas mulheres podem vir a "inspirar” outras pessoas que passam pela mesma situação (há também casos de homens abandonados pelas mulheres, com ou sem filhos, que também sofrem com a sua falta ou distância, ou mesmo com a falta de ajuda em sua criação, podendo conseguir apoio dentro do próprio núcleo familiar). Assim, tanto a questão da "violência" como do "abandono" ${ }^{62}$, motivaram a "mulherada a se unir" na liderança, segundo uma

o homem, e a sua recuperação no meio social exige maiores sacrifícios. Desse modo, no que diz respeito às transgressões das normas e tabus, observa-se um maior rigor com relação às mulheres" (Ladeira, 2007 [1992]: 130-1, grifos meus). As mulheres abandonadas pelos maridos sofrem mais, por geralmente ficarem sozinhas com os filhos e, na maioria dos casos, não receberem ajuda deles na criação dos filhos, tendo que recorrer à família que tem perto de si para conseguir algum auxílio, mesmo que financeiro. Além disso, seria mais complicado para elas encontrarem um novo marido, uma vez que há o entendimento geral de que elas devem se "preservar" mais, ainda mais quando possuem filhos pequenos, não podendo circular muito para fora do próprio núcleo familiar e nem viajar com frequência para outras aldeias ou para a cidade. Também há casos de mulheres que abandonam os maridos, deixando-os com os filhos para criar, ou levando alguns deles com elas, o que não quer dizer que elas também não sofram as consequências de suas ações e do "falatório" que tal atitude irá gerar nas conversas internas e entre aldeias. No caso dos homens, podem sofrer retaliações físicas em casos de traição e abandono, corte de cabelo (as mulheres também) e até mesmo a expulsão da aldeia - principalmente se não possuir família com grande poder de influência interna.

${ }^{361}$ Se investe cada vez mais em projetos que buscam trabalhar a autoestima de mulheres abandonadas pelos maridos ou que simplesmente abram espaço para sua participação (e envolvem a fabricação de artesanatos, corte e costura, troca de sementes, plantio, a circulação e intercâmbio de cantos-reza-danças e fumaças entre aldeias), além de proporcionar ocupações para elas dentro do quadro de empregos dentro da aldeia, estimulando assim uma maior integração entre as mulheres e coletivo.

362 Podemos relacionar também, esse comportamento tipicamente masculino, de abandonar as mulheres, geralmente com filhos, sem auxiliar em sua criação, nem com os encargos econômicos decorrentes, como tendo origem na atitude de Nhanderu, que abandonou Nhandexy com o filho no ventre aqui na plataforma 
interlocutora, e passa tanto pela atitude delas em "se valorizar mais", como pela tentativa de "fortalecer a [sua] autoestima". Há casos em que "o casal ainda se gosta e acaba voltando" e as lideranças não podem impedir, devem respeitar a decisão do casal, só mesmo "quando envolve a questão da violência que entram para conversar". Essa interlocutora também me contou que, quando ela era mais jovenzinha "era bem diferente de hoje, a comunidade era bem menor e mudou bastante", pois hoje algumas delas são "agredidas pelos maridos e antigamente não era assim”, por isso, enquanto liderança e mulher considera esta uma "atitude errada", pois "as mulheres quase não têm como se defender da agressividade dos homens". O coletivo de lideranças tem conversado muito sobre esse assunto com as kunhãgue nas Reuniões Gerais da comunidade, principalmente sobre a questão de muitas delas serem jovens e "ingênuas" a respeito desse tema e "não saber[em] se defender” como algumas lideranças “de outra época”, em que essas situações não ocorriam da mesma maneira ou intensidade como acontece hoje. Há aqui a visão de que as lideranças mais "antigas” saberiam "se defender mais”, porque "sabem conversar", não se "calam" diante de alguma violência como algumas mulheres de hoje, que são agredidas pelos maridos e "acabam deixando por isso mesmo".

Têm-se o entendimento entre as lideranças de que esta dura realidade que estão vivendo atualmente vem a partir de "muitas mudanças na cultura guarani”, a partir da relação de contato mais sistemático com jurua kuery, pelo avanço das cidades e de seus comportamentos-atitudes. Dessa maneira, os diversos problemas sociais internos que têm hoje, como por exemplo, o abuso de bebidas alcoólicas, vícios em drogas, violência física e atitudes agressivas do tipo, são associadas ao fato de viverem em território muito reduzido, gerando um acúmulo de pessoas e de relações em um espaço restrito e também, às muitas influências de "fora", que acabam gerando desequilíbrio, e levam a essas "doenças" espirituais. Essa percepção vem também acompanhada da avaliação de que quando se "tinha um território mais amplo, tudo era mais equilibrado" e, por isso, tinham "menos problemas", "as pessoas eram mais saudáveis, mentalmente e espiritualmente”. E, com o confinamento territorial e a grande dificuldade em retomar lugares com mais autonomia para desenvolverem suas atividades tradicionais e manter a devida distância dos jurua, os jovens de hoje acabam "saindo muito e tendo um contato descontrolado" com o pessoal de fora, "experimentando coisas novas", "como dizem os mais velhos". Com isso, no trabalho que o coletivo de lideranças vem realizando seria muito importante, a seu ver,

terrestre (yzyrupa), após ela desconfiar de sua palavra. Ela foi então responsabilizada inteiramente pelo seu abandono (assim como o de seu filho Kuaray) e pelas dificuldades e desvios de caminho nessa terra. 
promover continuamente "conversas sobre tais influências, tanto as boas como as ruins, de maneira a controlá-las" mais efetivamente, o que não se mostra uma tarefa simples.

Temos aí a dimensão da importância desse coletivo que atua na frente da comunidade e de seu engajamento no aconselhamento tanto dos mais jovens, como das mulheres e famílias que passam por dificuldades, assim como na filtragem de outros problemas que se dão com a proximidade, interferência e influência de jurua reko dentro da aldeia, principalmente em relação à alimentação, carregada de muito óleo, sal e açúcar, que provêm de doações e da merenda disponibilizada pela Escola Estadual (que, muitas vezes, não respeita sua cultura alimentar), que enfraquece os corpos-espíritos mbya e, consequentemente seus comportamentos, ações e disposições, gerando ainda mais dor e sofrimento (tekoaxy). As novas gerações já crescem em outro contexto, muito diferente de seus pais ${ }^{363}$ : sem plantação, sem mata, com educação escolar, alimentação jurua, influência da tecnologia, etc. O que se soma também à grande demanda que a interlocução com os jurua ocupa em seu cotidiano, seja no âmbito interno, onde há um certo controle do turismo jurua dentro das aldeias, a administração das doações que recebem, e diversas reuniões com instâncias governamentais ou não-governamentais, seja no âmbito externo, das apresentações culturais de coral infantil, da dança-luta xondaro e da venda de artesanato na cidade. Nem todas as lideranças se engajam nesse trânsito constante entre aldeia e cidade, ou têm disponibilidade e traquejo para tanto, principalmente as mulheres casadas e com filhos pequenos, restando a algumas poucas figuras femininas e outras lideranças masculinas, se disporem a assumir essa frente de atuação política.

Nessa situação crítica, e com a introdução de "vícios" externos dentro das aldeias, a demanda de problemas internos "aumentou muito", levando a casos extremos que, não seriam "permitidos na cultura guarani", como "homens cometerem o delito, o pecado de agredir uma criança, fisicamente ou sexualmente”. No Tekoa Tenonde Porã, me foi muito enfatizado que, da parte do coletivo de lideranças (mas não só dele) está claro que se é “contra todo tipo de violência, principalmente contra as mulheres e as crianças" e, por isso, quando acontece algo do tipo as lideranças são informadas e procuradas para resolver a situação da melhor maneira possível, internamente ${ }^{364}$. A resolução destes inúmeros

${ }^{363}$ É importante problematizar também, nessa situação de confinamento, o homem que não caça mais, não constrói casa, só gosta de jogar futebol, sem se preocupar diretamente com o sustento da família, levando a inúmeros problemas conjugais, e uma maior responsabilização financeira nas mãos das mulheres que, hoje em dia, chegam a ocupar mais cargos assalariados que os homens, muitas vezes sustentando toda uma família sozinhas, enquanto os homens, sejam eles seus maridos, filhos ou netos, tornam-se dependentes economicamente delas, e pode ter a ver com o movimento atual de maior empoderamento e protagonismo público de mulheres guarani. Tais aspectos e suas transformações precisam ser mais etnografados.

${ }^{364} \mathrm{O}$ que pode incluir castigos desempenhados pelo coletivo de xondaro da comunidade, que podem levar até mesmo à expulsão da aldeia, além do fato da notícia se espalhar e percorrer outras aldeias, complicando 
problemas internos demanda muita atenção e trabalho desse coletivo, no cuidado e controle das relações cotidianas que se constroem no tekoa, fazendo-as dialogarem e conviverem da melhor maneira possível, daí a importância da colaboração e a busca do equilíbrio entre os gêneros. A divisão de "trabalhos" entre as lideranças, como me foi explicado, e pelo que pude observar em campo, seria pautada então, nas palavras de Karai Jekupe, pela "igualdade nas condutas das lideranças".

A igualdade seria então o valor perseguido por aqueles em exercício nestas atividades - e tem como base a ética xamânica de moderação em qualquer relação -, pelo entendimento de que ambos os gêneros têm a "facilidade" em realizar "os mesmos trabalhos", "em equilíbrio", contribuindo um com o outro na promoção das boas disposições e benefícios coletivos. Isso não significa que tal ideal seja fácil de ser implementado ou que por vezes não entre em choque com as disposições mais "tradicionais" de atividades de gênero, ou da sua própria concepção entre os chamados “domínios” públicos ou privados (ainda que coletivos). Tais disposições, por sua vez, não implicam uma indiferenciação de capacidades-poderes, mas sua inevitável complementação. Mesmo assim, nessa atual divisão do trabalho, "as mulheres acabam não saindo tanto" das aldeias pois, como vimos, muitas dessas lideranças são mães com filhos pequenos ou mesmo avós com netos e a casa e o fogo familiar para cuidar, o que acaba as impedindo de sair tanto como as lideranças masculinas. Isso, por sua vez, pode refletir uma continuidade com a "tradição" de homens circularem mais entre as aldeias e as mulheres cuidarem mais do interior da família e-ou tekoa, desempenhando suas disposições "públicas" e "privadas" de maneira diferenciada e complementar, e não implica desvalorização ou dominação de um gênero sobre o outro, apenas a diferenciação de disposições cosmopolíticas masculinas e femininas que operam em necessária cooperação, produção e proteção mútua, e se refletem nos diferentes comportamentos de cada corpo-gênero em cada relação. Por isso, circular mais entre aldeias ou para a cidade e levar e trazer informações não é mais político ou diplomático ou mais importante que produzir e cuidar dos filhos, da opy, da casa em que se vive e das relações entre os parentes. Não se trata aqui de criar equivalências entre gêneros ou mesmo entre gerações, mas expressar algumas de suas diferenças e assimetrias, sem esgotá-las. Se técnicas de diplomacia cosmopolítica, de aproximação e afastamento na interação com a alteridade são, em certo sentido, comuns e em geral, algo que se aprende gradualmente, é também a partir da distribuição das disposições coletivas que

a situação de quem cometeu o delito e dificultando o encontro de algum outro local para viver, mas o maior “julgamento” será realizado, como me disseram os Mbya, pelos Nhanderu e Nhandexy kuery. 
se diferenciam os corpos-gêneros, fazendo aparecer como os Guarani mesmos entendem essas categorias dentro de um mesmo fundo de socialidade e ética xamânica.

Em uma conversa sobre alguma "boa influência" jurua nessa aldeia, um interlocutor comentou comigo que, alguns anos atrás, "existiam só homens nos cargos de trabalho dentro da aldeia", e certa vez, "uma mulher jurua falou de uma maneira bem séria" que os Guarani tinham que "pensar em colocar mais mulheres para trabalhar, porque ela só via homens trabalhando nos cargos remunerados", mas "nenhuma mulher exercendo algum cargo de trabalho ou mesmo político, e que isso deveria servir para a comunidade mesmo", questionando eles então se isso "era bom ou ruim”. Depois disso, "o pessoal [da aldeia] foi se animando e começou a colocar mulheres como lideranças ou em cargos de trabalho" remunerado, o que acabou "dando super certo", e daí em diante "todos, até mesmo as mulheres começaram a querer participar mais”. Pereira (2008) comenta também que, nas últimas décadas várias atribuições associadas a cada um dos sexos estão sendo realocadas, acompanhando a "tendência de perda de importância econômica e social de atividades como a caça, coleta e mesmo da agricultura”, o que se dá pelo fato de haver surgido novos espaços socioeconômicos como o trabalho assalariado, tanto dentro como fora das reservas que abrigam os Kaiowa e Guarani. Esses novos espaços passam a desempenhar grande importância na dinâmica dos fogos domésticos, além de resultar no aumento dos conflitos e separações de casais (Pereira, 2008: 9). Nesse contexto, instituições estatais como a Escola, passam também a assumir grande parte das responsabilidades com as crianças, através de diversos programas educativos ou assistenciais, gerando muitas insatisfações entre os mais velhos, como conta uma interlocutora: "é o que todos os mais velhos dizem hoje em dia, a escola foi tirando as crianças da vida deles, da vida normal das crianças e colocando todo mundo em uma sala de aula e fazendo uma lavagem cerebral né, transformando a cabeça” (Kerexu Yxapyry da T.I. Morro dos Cavalos [SC], Local: Tekoa Tenonde Porã 2015).

Seraguza aponta também que a inserção do trabalho assalariado entre os Guarani e Kaiowa do MS, tanto entre os homens como entre as mulheres, estabelece a criação de categorias distintas, como por exemplo, o surgimento de "mulheres solteiras" como trabalhadoras para além dos limites da casa, do pátio e da roça, e por vezes, da própria aldeia, que acabam por contribuir com também a sustentação econômica dos fogos domésticos (Seraguza, 2013: 42-43). Essas mulheres solteiras, geralmente, se inserem nos serviços relacionados à educação, enquanto aquelas que são casadas acabam exercendo funções profissionais como merendeiras e faxineiras das Escolas Indígenas, podendo atuar também em atividades relacionadas à área de Saúde Indígena, como enfermeiras, 
técnicas de enfermagem ou agentes de saúde (Ibidem: 43-44). Pereira, ao refletir sobre esta temática, anuncia o surgimento de um “um novo papel” feminino:

\begin{abstract}
Nas circunstâncias atuais, um novo papel surge para o caso das mulheres que trabalham fora em atividades remuneradas, principalmente como professoras, agente de saúde e empregadas domésticas. O salário é considerado uma boa remuneração para o padrão econômico do grupo, além de ser em caráter permanente, agregando uma série de vantagens sociais para estas mulheres. Isto reestrutura as relações de gênero no interior do fogo, se o homem não dispõe de um trabalho remunerado com certa constância, certamente passará a ocupar uma posição de dependência econômica. Em muitos casos, isto pode dar origem a conflitos entre os cônjuges. É comum a mulher assalariada contratar uma irmã ou prima para se encarregar das atividades domésticas de sua casa. Assim, ela pode dispor de mais tempo para se dedicar às atividades profissionais. Nesse caso, começa a surgir uma nova forma de diferenciação social entre mulheres, instituindo novas formas de hierarquia e dando origem a laços de dependência que podem ser a base para a constituição de grupos políticos composto e liderados por mulheres. A mulher remunerada parece fazer surgir uma nova categoria de líder feminina, remodelando a estrutura política e o formato dos fogos. (Pereira, 2008: 16, grifos meus)
\end{abstract}

Esse movimento traz à tona um novo momento na organização política mbya que precisa ser mais observadopel@s guaraniólog@s, para além da ideia de complementaridade inscrita na figura do casal. Muitas kunhãgue do Tekoa Tenonde Porã atuam hoje como professoras na Escola Estadual Indígena Guyra Pepo, estando atualmente, inclusive, em maior número nesta função, o que não ocorre em todas as outras aldeias mbya, onde a maioria dos educadores seriam homens, destacando, mais uma vez, o protagonismo deste tekoa em relação aos demais, principalmente no que diz respeito às suas reações pioneiras mesmo sob os efeitos do contato mais sistemático com os jurua e a proximidade das cidades, servindo por vezes, como um modelo de ação e inspiração para outras aldeias menores (menos populosas). O fato de possuírem mais mulheres atuando seja na liderança da comunidade, ou na Escola como professoras, segundo meus interlocutores, pode ter a ver com a questão desse tekoa se engajar fortemente na luta pela demarcação de terras, tomando muitas vezes, a frente em das articulações políticas na cidade e nas redes sociais. No entanto, como viemos mostrando, há também o entendimento entre eles, de que se não houvesse uma disposição das próprias kunhãgue e de seu nome-espírito-missão (nhêe), isso poderia não acontecer.

Mas, mesmo que possuam uma "equipe grande de professores", nem todos participam da frente de liderança da comunidade, pois "cada um sente se quer, não é obrigado a participar". A questão de "sentir no coração" algo que lhe satisfaz e alegra é fundamental para a continuidade da existência nesta terra, como aprendi convivendo com os Mbya. A atuação das mulheres nesses cargos assalariados acaba ampliando suas possibilidades de agenciamentos para além de seu núcleo familiar, e se reverte na possibilidade de um maior investimento no desenvolvimento de capacidades-poderes de criar e multiplicar 
relações, algumas delas atuando também como lideranças. Seriam também essas kunhãgue, professoras e-ou lideranças, que com ajuda de "parceiros" jurua, escrevem os "projetinhos" de fortalecimento cultural e socioambiental que angariam recursos públicos para as comunidades. Há aí o reconhecimento e a percepção coletiva de que as lideranças e os professores são pessoas capazes de articular situações complicadas entre famílias, auxiliando na construção do consenso e no controle das relações que se desenrolam dentro do tekoa, além de serem considerados mais aptos para se engajarem a frente dos projetos culturais, por saberem argumentar melhor e com maior fluência nessa esfera de relações com o mundo jurua, além de saber "pensar junto" aos parentes, atuar na resolução de problemas internos e na distribuição dos recursos. O que, por sua vez, não quer dizer que haja um contentamento geral a respeito de suas ações, principalmente, no que se refere à essa distribuição dos recursos e à resolução dos problemas entre famílias, especialmente, quando envolve alguém de seu próprio núcleo familiar (ver Capítulo II).

Diante desse quadro, uma importante reflexão que construimos em interação com nossos interlocutores em campo, é que, nos dias atuais temos uma nova estratégia política de investimento das lideranças e professores da comunidade na formação, preparação e treinamento de jovens guardiões-guerreiros (xondaro e xondaria kuery) para a luta política, para além da $o p y$, via a instituição estatal escolar, que visa a apropriação de conhecimentos jurua, mas não de seus modos de conhecer, isto é, de seus comportamentosações, de modo a utilizá-los para se engajar na luta pela demarcação de terras e alcançar o seu maior objetivo que é viver o próprio nhandereko, o próprio "sistema" em harmonia e entre si, sem grandes influências e interferências jurua.

Tal investimento, se dá principalmente por iniciativa das lideranças e professores mais experientes nessa luta-embate intenso com o mundo jurua, buscando formar os jovens mbya politicamente para a luta contra esse modo de ser-pensar-agir jurua, preparando e treinando as novas gerações a resistir corporalmente-espiritualmente em meio a todo o caos, corruptibilidade, dor e sofrimento (tekoaxy) instaurado em seu mundo, decorrente principalmente, das práticas, ações e comportamentos agressivos jurua. E, apesar de haver diferenciações entre as atuações dos professores e das lideranças, uma vez que as últimas possuem uma maior liberdade de movimentação nas ações coletivas, e os primeiros têm maiores limitações enquanto funcionários do Estado, ambos atuam juntos na formação das novas gerações de guardiões-guerreiros. Há que se considerar também a habilidade das lideranças, principalmente aquelas que atuam também como professoras, em se utilizar da estrutura formal e institucionalizada do Estado, como a Escola para "fortalecer" o nhandereko e a luta pela recuperação de sua própria territorialidade. Ainda 
assim, a "formação" das jovens lideranças passa pelo que meus interlocutores insistem em dizer, pela própria disposição da pessoa em se interessar pela atuação na promoção do bem-estar da comunidade, ou mesmo, aquilo que os Mbya traduzem como o caminhoiluminação que se "mostra” para cada pessoa, a tal "missão” de cada nhe'ẽ aqui na terra. O importante é entender o que se produz a partir daí e de outras relações-caminhos que aparecem ao longo da sua trajetória e experiência de vida.

Apesar de aparentemente (des)contínuos, a opy e a escola indígena funcionam então como espaços cosmopolíticos, de gestão e treinamento para relações com o exterior que refletem modos diferentes de conhecer, aprender e ensinar que, no entanto, são complementares. A opy, enquanto local no qual circulam os conselhos-palavras bonitas-verdadeiras-eficazes (porã) de seus anciãos e onde são promovidos os ritos diários de rezacanto-dança-cura, constantes na vida mbya, é o espaço central de manutenção e sustentação da vida nesta terra, sua "coluna vertebral”. A escola vem mais para ajudar a complementar sua apropriação crítica dos conhecimentos e saberes jurua, de maneira eficaz e controlada, para a promoção do próprio nhandereko, que fica mais evidente pelo contraste que percebem ao comparar e contrapor mais enfaticamente e de modo mais recorrente seu próprio sistema e o sistema jurua, o jurua reko. O que, por sua vez, acaba reforçando o intenso empenho coletivo em continuamente lembrar (-ma'endu'a) e criar sempre novas ideias e possibilidades para colocar em prática e não esquecer jamais - apesar de todas as dificuldades - dos modos propriamente guarani de conhecer e ensinar, da sua ética do caminhar (-guata) e se comportar neste mundo em relação aos outros serespoderes, que serve de guia para suas ações nesta terra tekoaxy. No entanto, temos aí a promoção de um difícil debate: a Escola, enquanto uma criação jurua estaria tomando a frente de um espaço de aprendizagem que antes era competência somente das xejaryi, dos xeramoĩ e dos parentes (-retarã kuery) mais próximos. Isso, por sua vez, promove um embate direto entre a estrutura escolar estatal jurua, e a "coluna vertebral" Mbya, a opy, e por vezes um certo dissenso entre as gerações mais jovens, os professores e as lideranças espirituais, mais velhas. Como uma jovem interlocutora mbya comentou comigo: "com a Escola tem muitos problemas, muito mesmo, porque ainda tem essa visão de que parece que a aldeia está dentro da Escola, não que a Escola está dentro da aldeia [...] é muito difícil de lidar, tudo o tempo todo tem que estar no papel (Para Yxapy do Tekoa Koenju [RS], Local: São Paulo, 2016, grifos meus). E, entre os Mbya, há uma certa diferença entre a sabedoria que vem da espiritualidade e o conhecimento que vem do papel: 
hoje tem essa frente política com o Estado, com os governantes, porque a gente adquiriu esse conhecimento também né, que é do papel, então são duas formas de ser o que a gente é hoje: a questão da espiritualidade que é o povo guarani, que é sabedoria, que é o saber, eu sei quem eu sou e o que eu faço eu sei também, e outra coisa é o conhecimento, que é essa coisa do papel. (Kerexu Yxapyry da T.I. Morro dos Cavalos [SC], Local: Tekoa Tenonde Porã 2015, grifos meus)

Quando questionei sobre essa diferença, Kerexu me explicou com um exemplo:

vamos supor o conhecimento, que eu te dê a receita de um bolo de cenoura $[\ldots .$.$] você sabe$ qual o processo de fazer o bolo, porque você nunca fez o bolo, aí você tem o conhecimento, a partir do momento que você pegou e praticou isso, fez um bolo, que você errou, que você tentou consertar várias vezes, vai aprimorando, daí vai chegar um dia que você faz assim, eu sei fazer bolo de cenoura, eu sei fazer, eu sei, isso é a sabedoria, você sabe todo o processo assim na sua cabeça, tá com você já isso, isso é a sabedoria, então a diferença do conhecimento é que você sabe dizer como é, mas você não sabe o processo todo, a partir do momento que você vai fazer, você vai errar, você vai acertar. (Idem)

A critica dos mais velhos à escola vai então no sentido de que ela acaba "roubando" um espaço que antes era da opy, fazendo circular alguns saberes que somente ali deveriam ser transmitidos e não transpostos para a instituição jurua. Eles consideram que na sala de aula escolar deveriam ser ensinados apenas conhecimentos jurua, deixando os saberes guarani fora dali, reservados à opy entrando, por vezes, em um embate direto com as ações dos professores e lideranças mais jovens. Há, no entanto, cada vez mais o entendimento entre eles, de que jamais se deve escolarizar a opy, como comenta Poty, que atua na área de educação há muito tempo, seja como professora ou vice-diretora:

tem ensinamentos que não devem ser dados na Escola, a Escola é importante, mas a gente não pode escolarizar tudo, a escola não pode roubar o local do tradicional, então coisas que se tem que aprender na $o p y$, você tem que aprender na opy $[\ldots]$ eu não posso trazer o xamoĩ pra sala de aula, pra ele ficar explicando [...] nem posso levar alunos pra opy com caderno e lápis, se for pra fazer atividades na $o p y$, tem que ser com o xamoĩ, na opy e sem caderno, sem lápis... tem que ir lá pra fazer, pra aprender na prática, vai dançar xondaro, vai cantar, vai ouvir xamoĩ contando história, depois você pode trabalhar em sala de aula a memória do que aconteceu né, mas jamais deve escolarizar a opy [...] não é dar aula [...] sobre menstruação, a gente não vai dar aula de biologia né, a gente vai falar sobre uma coisa tradicional, então não pode ser escolarizado, você não pode falar na escola, fazer lição e tal, um texto, depois perguntas sobre, porque isso é escolariza a tradição e a tradição não dá pra ser escolarizada, porque a partir do momento que você começa a escolarizar tudo, você tá caindo no mesmo erro que a sociedade do jurua [...] tem que ter cuidado, tem que olhar, tem que saber [...] o que pode ser ensinado em sala de aula e o que não pode. Uma coisa mais fácil de se pensar é pensar assim, conhecimento do jurua é na Escola e o conhecimento tradicional é fora, mas não é bem assim também, tem que ser conhecimento do jurua usando as coisas guarani, valorizando a cultura e o saber guarani [...] [não adianta] falar assim "agora é só [conhecimento] jurua na Escola", enquanto o tradicional tem que ficar fora, a gente tem que trazer um pouco do mundo tradicional, mas a gente tem que ter cuidado pra não escolarizar, e a gente tem que dar um pouco da nossa educação, do que realmente nos importa né, sem perder muito o foco com o mundo do jurua, com o mundo da educação, com o que tá acontecendo e tudo né, então é assim, tudo é uma questão de saber dosar as doses. (Poty Porã, Tekoa Tenonde Porã 2016, grifos e alterações minhas)

Por não desejarem “esquecer” jamais os saberes tradicionais, há o pensamento de

que a "escola nos moldes jurua não pode ser centro da vida", como falaram na última 
Assembleia Geral da CGY, pois o centro da vida guarani, sua "coluna vertebral" é a opy, ali corpos-espíritos belos e fortes são fabricados continuamente. Mas, mesmo que a educação escolar indígena seja diferenciada, ela pode vir a produzir uma igualdade indesejada e perigosa, que não dá muito espaço para a diferença, devido à proximidade e interferência excessiva dos jurua e seus conhecimentos, correndo-se o risco de adquirir seu modo de agir, sua atitude e seus comportamentos, o que pode se converter em uma lógica de predação dos próprios parentes, e transformar os corpos guarani em corpos outros (jepota), no caso, em corpos jurua (Testa, 2014: 226). Testa comenta que uma vez, enquanto estava numa das escolas guarani, uma liderança que até então participava da sua gestão lhe contou um sonho:

Ele explicou que neste sonho pôde observar a escola de cima, como se estivesse flutuando sobre ela. Nisso, ele viu todas as crianças e adultos da comunidade saindo da escola, vestindo ternos e gravatas e carregando maletas, como os homens de negócios. Quando ele acordou, começou a pensar: "Então, é isso que a escola diferenciada está fazendo com a gente. Se continuar assim, vamos ficar igual os jurua (pessoas não indígenas)”. Ele contou que por conta disso, resolveu sair da escola, porque tinha entendido que a tentativa de "levar os conhecimentos guarani pra dentro da escola" estava produzindo o contrário da diferença, tornando os Guarani iguais aos não indígenas. Ele completou: Eu pensei que levando os mais velhos pra escola, estava fortalecendo nossa cultura, mas nesse sonho eu vi até os mais velhos se tornando iguais os jurua. O que vem depois? Vamos começar a brigar entre nós, como os jurua, vamos começar a matar nós mesmos. E, aí sim, vamos perder a nossa cultura. (Ibidem: 225-26, grifos meus)

No entanto, a educação escolar dentro da aldeia, apesar de ser vista como um problema por afetar dinâmicas de ensino e aprendizagem guarani que, tradicionalmente, ocorrem no âmbito familiar e na $o p y$, com o aprendizado do português e das dinâmicas de aprendizado de conhecimentos - e muitas vezes, dos comportamentos - jurua, passa cada vez mais por um processo de guaranização, sendo tomada como instrumento de "formação de jovens lideranças" para continuidade da luta pela demarcação das terras guarani, salvaguarda de seus direitos constitucionais e fortalecimento do nhandereko. Essa "formação" é uma das coisas que, segundo Jera Poty, “está bem forte na aldeia”, pois estão tentando "articular os mais jovens e estimulá-los a participar e a se engajar no movimento político" 365 , aconselhando-os a se inspirar nas "lideranças mais experientes"

$365 \mathrm{O}$ "acesso à informação com a Internet se torna mais facilitado aos mais jovens", mas mesmo com seu lado negativo, "com a falta de consciência de usar", ele traz um "grande número de mulheres e meninas utilizando as redes sociais para expressarem suas opiniões" e mesmo para se "organizarem” e se articularem para a "luta pela demarcação de terras", como comentou uma interlocutora. É o caso da Comissão Mirim da CGY, eleita em assembleia, que é responsável pela comunicação da organização nas redes sociais. No entanto, há uma grande atenção das lideranças na relação dos jovens com a tecnologia jurua, pois há o entendimento de que se aprenderem a usar com moderação e para a luta, esta pode se tornar uma potência, mas o fato de alguns jovens, principalmente, mulheres "se expondo" de maneiras diversas nas redes sociais, como comentaram comigo diversas vezes algumas interlocutoras, acaba afetando todas as mulheres ou mesmo o povo como um todo. Nesse sentido, há um intenso trabalho de conscientização promovido pelas 
e aprender com elas, afinal "o futuro é deles" (Jera Poty, Tekoa Kalipety 2015). Os mais jovens constituem a maior parte da população da aldeia, daí a importância, de participarem do que está acontecendo dentro e fora dali. O coletivo de lideranças da comunidade, junto aos professores e anciões, investe então, cada vez mais na estratégia pedagógica de formação desses jovens tanto na Escola, quanto na opy, atuando juntos como os formadores das novas gerações de xondaria e xondaro kuery. A fabricação das jovens lideranças, isto é, das novas gerações, seria fruto principalmente, de acordo com meus interlocutores, do incentivo dos familiares ou mesmo de outras lideranças já atuantes na gestão política da aldeia. Essa formação se desenvolve, no entanto, no tempo específico de cada um e pela manifestação de seu próprio interesse e disposição em acompanhar as lideranças e participar das mais variadas reuniões coletivas e eventos dentro ou fora da aldeia, em que se discutem políticas públicas, empreendimentos, questões fundiárias, etc., que afetam direta ou indiretamente suas comunidades. Daí a importância e ênfase dada ao aprendizado do saber ouvir e também ao saber falar, "dar opinião”, “conseguir se expor”, tanto dentro da comunidade como "fora", mas de uma maneira "tranquila" (o que se "vai aprendendo com o tempo"), além de saber ler em português, conhecer um pouco mais dos direitos constitucionais dos povos indígenas, justamente para aprender a usá-los para defender seu povo. $\mathrm{O}$ acesso a essas atividades é aberto, todos os jovens têm direito de participar e emitirem suas opiniões, o que não quer dizer que não ocorram conflitos a partir da postura que se assume, em cada situação.

Segundo Para Poty, estudando na Escola Estadual da aldeia não aprendeu "nada sobre as leis dos jurua”, só "o que o Governo mandava e estava no Caderno do Aluno”, mas foi "ficando junto e participando com a equipe de lideranças" das reuniões coletivas que aprendeu muito do que sabe hoje (Para Poty, Tekoa Tenonde Porã 2015, grifos meus). Esse conhecimento do papel não possui a sabedoria dos mais velhos, como comenta outra interlocutora, também é professora e liderança:

hoje as leis não se cumprem no país, todas as coisas tá no papel, tá garantido o direito, tem tudo ali [...] garantido na lei, tudo, mas por que não se cumpre? Porque não tem sabedoria nesse papel, não existe sabedoria, existe um conhecimento, todo mundo conhece que a lei é isso, agora o saber, compreensão... então pra nós lideranças, a gente tem que levar tanto a sabedoria quanto o conhecimento (Kerexu Yxapyry da T.I. Morro dos Cavalos [SC], Local: Tekoa Tenonde Porã 2015, grifos meus)

lideranças para que os jovens aprendam a usar ou a lidar melhor com essas ferramentas, que podem também trazer coisas boas. Ainda assim, essas tecnologias podem acabar afastando os jovens dos "saberes" da opy, por isso, há uma série de tentativas das lideranças, através do uso mesmo dessas novas tecnologias, como por exemplo, o uso didático de filmes e vídeos de coletivos de realizadores indígenas, mbya ou de outros povos, para chamar a atenção dos jovens e das crianças para o opy reko. 
Nos dias atuais, o coletivo de lideranças da Tenonde sempre procura falar para a “equipe de professores da Escola” focar na "questão da demarcação”, sobre as leis e procedimentos para uma área ser demarcada, já que antes não tinham muito essa "preocupação" - pois "não entendiam muito" do assunto e do que deveriam fazer a respeito, contando com o apoio do CTI -, que a cada dia se torna "mais forte e séria", daí que muitos professores "estão agora focando mais nisto e querendo dar aula sobre isso" (Para Poty, Tekoa Tenonde Porã 2015). Atualmente também, os professores e lideranças, em diálogo direto com a comunidade, estão trabalhando na construção de um Projeto Político Pedagógico (PPP) próprio, para de fato implementarem uma educação indígena diferenciada que respeite e promova adequadamente sua cultura, mesmo estando dentro de uma estrutura formalizada estatal. Para tanto, contam com o apoio da Ação Saberes Indígenas na Escola, organizada pela Secretaria de Educação Continuada, Alfabetização, Diversidade e Inclusão (Secadi) e financiada pelo Ministério da Educação (MEC) do Governo Federal, que os auxiliam na produção de novas possibilidades de aprendizagem indígena a partir da estrutura escolar como, por exemplo, a produção de materiais didáticos em guarani, implementando a circulação dos saberes guarani não só ali dentro, mas também pela própria aldeia em respeito aos ensinamentos dos seus anciãos, investindo ainda na promoção do intercâmbio de saberes com outros parentes e encontros para discussão de educação escolar guarani entre aldeias, onde os Guarani dizem aprender muito.

O risco, sempre presente, de virar branco reside, portanto, no perigo de adquirir seu modo de agir, sua atitude e não o conteúdo de seu conhecimento em si. Os conhecimentos jurua, se utilizados para objetivos específicos que visem o bem-estar coletivo e, moderadamente (como tudo na vida), podem ser lidos como um saber-poder capaz também de gerar e multiplicar relações, benéficas para a comunidade. Nesse sentido, podemos entender a apropriação guarani de armas jurua justamente para não se contaminar com jurua reko, em vista de uma "maior autonomia" de movimentação política com a luta pela garantia e posse de parte de seu território, para atuarem em conformidade com seu próprio sistema de pensamento-ação (nhandereko), inspirado pelas orientações dos deuses que os seus sábios anciões (nhaneramoĩ e nhandejaryi kuery) fazem circular. Esse mundo burocrático e formalizado e formatado pela lógica jurua, mas que ensina as crianças e jovens a lerem e escrever, a entender a linguagem e o pensamento jurua, pode se tornar então um modo de fortalecimento crítico contra as desigualdades que a própria sociedade jurua infligiu durante séculos aos Guarani, como um meio de lutar por "mais respeito” e “dignidade", mesmo que para isso se utilizem de recursos financeiros do próprio Estado. 
Há, portanto, uma certa imbricação entre a institucionalização da educação indígena e um movimento político por melhorias, mas não entendemos que haja aí uma espécie de "cooptação" das lideranças ou professores pelo Estado, esse potente aparelho de captura externo, mas antes uma incorporação, controlada pelo coletivo, dessa sua potência para obtenção de prestígio e poder interno (e que passa pela demonstração, recorrente, da generosidade na distribuição dos recursos entre os parentes de tekoa). Pois, ainda que o Estado requeira que os Guarani reproduzam a sua estrutura através do uso da burocracia, principalmente quando assumem cargos assalariados controlados pelo Estado, há um modo específico, guarani, de se mover nessa estrutura, confrontando a filosofia jurua com a sua própria e, contando, muitas vezes, com o apoio de parceiros jurua nesse duro e intenso enfrentamento. Nesse sentido, mesmo que algumas lideranças ocupem cargos na esfera do Estado, como professores, educadores ou agentes de saúde, estas disposições são lidas e transformadas a partir de sua própria filosofia cosmopolítica, assim como ocorreu com a apropriação, a seu próprio modo, do cargo de capitão e cacique, instituído no século XX pelo órgão indigenista estatal (SPI/FUNAI).

A formação das novas gerações de xondaro e xondaria, auxiliares, guardiões e guerreir@s dosnhaneramoĩ, das nhandejaryi e d@tekoa ruvixa para a luta política, se dá também via instituições estatais que atuam dentro das aldeias, como a Escola Indígena, que ao ser subvertida para se adequar a maneiras propriamente guarani de ensino-aprendizagem, estimula a produção de jovens lideranças que podem atuar na linha de frente da comunidade, se engajando tanto na política interna, como na articulação política externa. Há, inclusive, o protagonismo de jovens mulheres que estão se colocando cada vez mais a frente nestas tarefas, bem como a sua maior participação na organização da circulação entre aldeias e intercâmbio de cantos e danças, curas e fumaças, seja enquanto lideranças do Conselho da comunidade, seja enquanto professoras, educadoras ou agentes de saúde, atuando também na reflexão, escrita, execução e promoção de projetos culturais e sociambientais que buscam promover o fortalecimento do nhandereko. Esse mundo dos projetos, por sua vez, acaba estimulando cada vez mais também a promoção de mais espaços a serem ocupados por essas mulheres, para além de sua ocupação dentro do quadro de empregos remunerados dentro da própria aldeia, estimulando assim uma maior integração entre as próprias kunhãgue e o coletivo. Certamente há uma pressão maior do feminismo e das ONGs e seus financiadores pela maior inclusão de mulheres indígenas nos projetos e cargos remunerados internos, que junto ao maior aprendizado do português via Escola e TV, e o uso cada vez maior da tecnologia e da Internet, acabam contribuindo fortemente para inserção das kunhãgue na liderança da comunidade. 
É para preservar o grande projeto de se fortalecer coletivamente com autonomia e liberdade suficiente para replicar as moviment(ações) divinas e alcançar maturidade e plenitude corporal-espiritual (-aguyje) que os "mais velhos" pressionam e questionam as ações das lideranças “mais jovens”, mas juntas essas gerações compõem um propósito único: garantir a terra e sua territorialidade própria para viver em conformidade ao nhandereko, o que passa pela obtenção de recursos para apoio ao fortalecimento cultural, interno, e pela demarcação tal como delimitada pelas leis jurua, para que com isso, possam justamente se distanciar de seus costumes (jurua reko). Nesse sentido, as novas gerações de lideranças, ainda que venham cada vez mais intensificando o contato com parceiros jurua, incorporando algumas de suas ideias e propostas, fazem isso para ajudar as gerações mais velhas a conseguir garantir e concretizar esse projeto, trabalhando juntos na fabricação corporal-espiritual dos mais jovens e do coletivo. O objetivo aí é garantir a sua resistência xamânica contra o Estado, seguir as pegadas deixadas pelos "antigos", imitando seu movimento, caminhando para o "bem" (-guata porã) e se transformando, em conformidade com o próprio sistema de pensamento-ação. Pois, enquanto continuarem se lembrando (-ma'endu'a) e confiando (-jerovia) nos parentes divinos, serão olhados-cuidados (-ma'ẽ) por eles, que seguirão enviando capacidades-poderes para seus filhos caçulas se fortalecerem aqui nessa terra, daí a grande importância do treinamento das novas gerações e a constante preocupação com os rumos de seu bem viver (teko porã), pois é a continuidade dessa sabedoria que está em jogo, se ela se perder, o mundo terreno (yvyrupa) também deixará de existir.

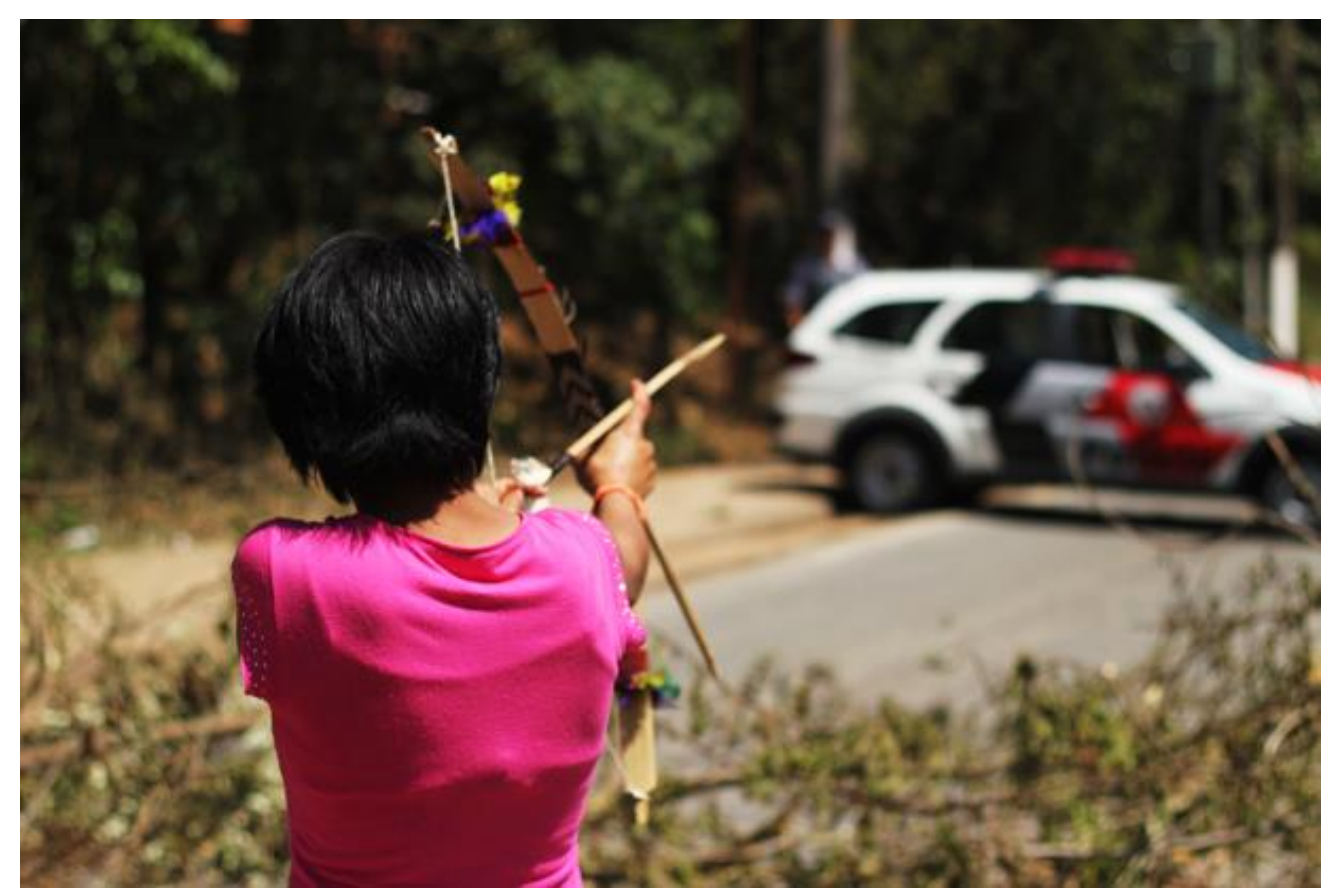

Xondaria na frente da luta pela demarcação. Arquivo CGY. São Paulo, 2013. 


\section{$\underline{\text { Algumas considerações finais }}$}

Meu canto esconde-se Como um bando de Yanomamis $\mathrm{Na}$ floresta

$\mathrm{Na}$ minha testa caem Vem colocar-se plumas

De um velho cocar... […] Eu não espero pelo dia Em que todos

Os homens concordem Apenas sei de diversas Harmonias bonitas Possíveis sem juízo final... [...] Alguma coisa Está fora da ordem Fora da nova ordem mundial (Fora da Ordem. Veloso, Caetano. 1991)

Caminhando contra o vento Sem lenço e sem documento No sol de quase dezembro Eu vou

[...] Nada no bolso ou nas mãos Eu quero seguir vivendo, amor Eu vou Por que não, por que não? (Alegria, Alegria. Veloso, Caetano. 1968)

Essa Dissertação versou sobre os modos de fazer(-se) polític@ entre os GuaraniMbya, sobre os modos como eles produzem diferença e causam ações e perpassam toda a sua filosofia cosmopolítica. Como dito na Introdução, não foi meu objetivo aqui fazer um mapeamento de todas as teorias sobre poder, chefia indígena ou sobre gênero, geração, parentesco e xamanismo, mas apenas ressaltar a importância das relações entre esses aspectos na sustentação da vida e promoção da alegria entre parentes Mbya nessa terra tekoaxy e apontar para algumas possibilidades, sem esgotar as questões. As oposições que muitas vezes a própria Antropologia coloca para tentar analisar@polític@dos outros não ajudam a entender os nativos, pois ali (como aqui), as coisas sempre acontecem ao mesmo tempo, paralelamente, não é isso ou aquilo, mas isso e aquilo. Devemos, portanto, buscar gerar simultaneidade nas análises e não separações. Essas mesmas oposições do pensamento ocidental devem ser continuamente rompidas para ambicionarmos compreender de fato, ainda que sempre parcialmente, o que as filosofias cosmopolíticas ameríndias falam, ouvem e veem e, principalmente, como agem, para podermos nos atentar de verdade para o que se pode aprender a partir desses modos outros de pensar e agir politicamente e nos inspirar. É por isso que, se queremos de fato "alargar" a nossa compreensão da política mbya que, como argumentamos aqui, vai muito além do domínio "oficial", 
oratório, "público" dos chefes e líderes masculinos, não faz sentido algum continuar separando momentos "rituais" daqueles ditos "cotidianos", visto que não há uma ruptura severa (tal como aparece em algumas etnografias) entre eles, no dia a dia de uma aldeia.

As distintas formas ameríndias de lidarcom@polític@ou com o poder podem ser capazes de revelar nossas próprias incapacidades cosmopolíticas. Uma pergunta se faz então presente: como os próprios modos indígenas de agir politicamente podem de fato influenciar os nossos, nos afetar? A resposta talvez passe pela tentativa em perceber e observar a própria indigenização da "modernidade"366, essa apropriação indígena de lógicas outras dentro da sua própria, subvertendo-as. Diante de algumas experiências radicais-canibais de re-nascimento ou re-invenção cultural, Sahlins (1997), Carneiro da Cunha (2009), Coelho de Souza (2010), mostram que ainda que os meios possam ser modernos, os fins são, decididamente, indígenas, revelando toda a originalidade de estratégias de resistência e criatividade indígenas, capazes de atualizar toda sua filosofia. $\mathrm{O}$ próprio desejo em continuar se diferenciando dos outros faz com que transformem a si mesmos com os elementos dos outros continuamente, ou seja, não é se transformem em outro(s), mas com os outros, através das relações que estabelecem com eles.

Nesse sentido, indigenizar ou guaranizar é pegar para si, se apropriar somente daquilo que consideram necessário para continuar resistindo enquanto Mbya, fazendo uso dessas coisas de fora a partir de modos próprios de ser-agir-pensar. Para tanto, eles não devem se deixar domesticar totalmente por nós, e para que possamos continuar nos inspirando neles, devemos lutar para garantir que essa sua resistência se fortaleça e continue. Tarefa difícil, mas não impossível! Há, por certo, grandes dificuldades em fazer o Estado e a sociedade civil compreenderem e apoiarem essas iniciativas indígenas sem criar maiores entraves que aqueles que já geram tantos desequilíbrios (físico-espiritual) internamente, principalmente em relação às coisas, posturas e modos de agir e viver jurua que enfraquecem o corpo e o nhe'ẽ mbya, deixando-os vulneráveis e sem vontade de viver, tais como: o uso financeiro do dinheiro, as doações de comida e roupas jurua, a Escola nos moldes burocráticos jurua, as novas tecnologias, além das inúmeras dificuldades que lhes são impostas na obtenção dos recursos e bens naturais (que estão sob intenso controle estatal) que os Guarani foram "enviados" pelos deuses para cuidar e proteger da ganância jurua, como guardiães-guerreiros (xondaro e xondaria kuery). A estratégia do

\footnotetext{
${ }^{366}$ Segundo Sahlins, essa “vida dupla” na qual as formas indígenas persistem apesar do contato interétnico, não significa uma volta a um suposto estado de natureza, ou a um estado de "cultura primordial", corresponde antes a uma "verdadeira esquizofrenia entre o indígena e o moderno" (Sahlins, 1997: 123-4, ver também, neste sentido, Latour, Wagner, Carneiro da Cunha, Carneiro de Souza, entre outros).
} 
Estado, no caso brasileiro, é tentar transformar os povos indígenas em trabalhadores nacionais, usurpando-lhes a terra da qual necessitam para subsistir dignamente, os forçando a entrar em um sistema capitalista de exploração e obtenção de recursos via políticas públicas e empregos assalariados, a partir do qual devem aprender a performar convincentemente o papel do "índio verdadeiro" para serem considerados aptos a receber financiamentos e, assim, sobreviver minimamente nas aldeias demarcadas. Há por trás dessa intenção, o pensamento de que eles enfim se darão por satisfeitos ou gratos apenas com os auxílios públicos jurua, e desistirão de lutar pela garantia de posse de suas terras.

Esse mesmo modelo ocidental que tem na propriedade fundiária seu fundamento, afeta e incide diretamente sobre esses povos em que o "fundiário" não é o principal valor, onde não é possível a apropriação "individual” da terra, que deve permanecer de uso coletivo pois é entendida como uma dádiva divina que deve ser cuidada dentro de determinados princípios e que tem na generosidade o motor mesmo de sua sobrevivência e prestígio, pela sua capacidade em promover alianças e trocas incessantes entre os coletivos. Primeiramente então, o Estado, essa tensão constante que coloca os direitos constitucionais indígenas sob recorrente ameaça, deve cumprir com seu papel e fazer valer de fato esses direitos que estão no papel, pois são eles que asseguram a liberdade para que os povos indígenas possam viver de acordo com seus costumes e filosofias próprias, o que inclui a salvaguarda da posse de suas terras tradicionais e dos recursos naturais que estão ali presentes, garantindo sua continuidade enquanto povo. Isso tem que ser feito logo, como insistem meus interlocutores guarani, pois que seus territórios sagrados estão acabando, sendo tomados pela cidade e por jurua reko.

Para os Guarani (mas não só para eles), a falta de terra e de espaço para plantação, coleta, caça, e pesca, está diretamente ligada a doenças de ordem corporal-espiritual. No entanto, ainda que a fabricação dos corpos-espíritos mbya sofra com a proximidade de jurua reko, se enfraquecendo, a busca pelo seu fortalecimento (-mbaraete), preparação e concentração (-japyxaka) para “aguentar” (-eropo’aka) o peso nocivo e perigoso dessa relação é constante e mesmo cotidiana, principalmente entre as lideranças da linha de frente. Assim, ainda que o mundo jurua atrapalhe em grande parte sua (r)evolução corporalespiritual, já não lhes parece interessante recusar como antes essa relação de contato, optando então por manter uma relação de mediação diplomática que continua evitando e mesmo temendo o conflito com os jurua, mas que procura realizar alianças e parcerias com eles. Temos assim uma certa estratégia mbya de resistência xamânica, que busca incorporar a "caça" ou captura-sedução dos jurua, que alternam, em um movimento pendular (in)constante, (dis)posições de inimigos, amigos ou parceiros, de acordo com cada 
contexto de troca ou relação, para que possam obter esses mesmos bens, conhecimentos e serviços jurua, para uso coletivo. Há aí a necessidade de união constante das diversas famílias que convivem em um mesmo espaço, compartilhando um território e formando assim uma "comunidade", diante das dificuldades que aparecem, sejam elas de (des)ordem financeira, espiritual ou social (ou todas juntas e misturadas), decorrentes principalmente do desequilíbrio causado por jurua reko, que ameaça duramente seu modo próprio de pensar e viver, seu sistema de pensamento-ação (nhandereko).

A opy enquanto lugar de formação e reunião dos corpos e espíritos guarani, atua diretamente no fortalecimento daqueles que vivem entre si, afinal viver e se relacionar é muito perigoso e necessita constante atenção-moviment(ação), já que tudo (literalmente) com o que nos relacionamos nos afeta corporalmente-espiritualmente, tanto positivamente, como uma afecção animal que visa o fortalecimento do corpo, quanto negativamente, quando um dono-espírito se vinga de alguém pois foi desrespeitado de alguma maneira, fazendo-a adoecer ou a conjurar um feitiço contra outra. Essa dinâmica entre enfraquecimento (vulnerabilidade) e fortalecimento (leveza-potência) dos corpos-espíritos passa então pela relação da pessoa com muitos outros seres-poderes que habitam este cosmos e que impõem respeito em cada um de seus domínios. Daí o constante investimento dos parentes na manutenção da perspectiva humana (no caso, Guarani), dada a instabilidade dos corpos e das relações, onde o pressuposto de sua condição transformacional orienta todos os (des)encontros. A construção da pessoa envolveria de tal modo, a criação e a transformação de relações que passam pelo corpo, confundindo-se com o processo mesmo de fabricação do parentesco, que constrói corpos humanos e os fortalece através do compartilhamento de substâncias, saberes-poderes e de carinho-cuidado entre parentes, tornando-os mais ou menos humanos, mais ou menos parentes (ver Coelho de Souza, 2004). Como sujeitos cosmopolíticos, é possível dizer então que as pessoas guarani são feitas ou fabricadas por outras que, por sua vez, produzem, protegem e cuidam de outras, participando e afetando diretamente a sua vida, cada qual com suas respectivas responsabilidades ou disposições-capacidades na atuação coletiva (reforçando assim a complementaridade entre homens e mulheres na construção e proteção de pessoas e coletivos). A chefia e liderança são feitas então nessa produção-proteção dos parentes (sejam eles consanguíneos ou não ${ }^{367}$ ). O xamanismo guarani aparece assim como um esforço coletivo para manter entre si a perspectiva humana, a boa saúde e alegria na convivência

${ }^{367}$ Em contextos de superpovoamento e confinamento territorial, a fabricação dos corpos dos xondaro e das xondaria acaba tornando-se ainda mais coletiva, para além do âmbito da família extensa, correspondendo mais propriamente a uma "comunidade" ou uma "aldeia". 
e na produção-proteção do parentesco e dos corpos-espíritos mbya, além de ser o meio por excelência de resistência cosmopolítica contra o Estado.

Como dizem alguns Mbya, seu mundo está em constante transformação e o xamanismo depende da capacidade que têm os rezadores de perceberem o movimento das coisas e dos sujeitos, como eles se deslocam e se transformam no espaço e no tempo: "A pessoa que faz essa cura, ela vê o movimento e a velocidade das coisas" (Vera Nhamandu Mirĩ apud Testa, 2014: 95-96). Isso também pode ser dito para as lideranças "políticas”, uma vez que ambas, sejam elas "políticas" e-ou "espirituais", devem saber manejar diferentes contextos de enunciação e experiências de comunicação e negociação com potências outras (humanos, deuses e não-humanos) garantindo a proteção do grupo, através de sua capacidade em traduzir saberes-poderes ${ }^{368}$ em ações eficazes para o coletivo, colocando sempre à prova a sua eficácia-validade. O saber levar a vida nessa terra envolve, portanto, aprender a utilizar os saberes da opy e os conhecimentos jurua, caminhando juntos pelas dificuldades e alegrias que aparecem, pois sabem que o caminho de Nhanderu e Nhandexy ete é repleto de provações.

Talvez seja por isso mesmo que as lideranças, principalmente as mais jovens, busquem se apropriar dos conteúdos dos conhecimentos dos brancos, mas não de suas fôrmas, o que pode se refletir em um maior "empoderamento 369 " interno, mesmo com a grande incidência do Estado dentro das aldeias, que é fonte de recursos financeiros (e alimentares) provenientes tanto de programas de geração de renda, aposentadorias, projetos e políticas públicas ou cargos públicos, e podem corresponder a certas diferenciações internas e levar à obtenção de maior prestígio. Muitas das parcerias estabelecidas com o mundo jurua podem decorrer do objetivo maior de magnificação que as lideranças perseguem - a multiplicação (idealmente controlada) de relações sociais benéficas e eficazes para a produção-proteção de um coletivo -, que as fazem potencialmente capazes de cuidar, controlar e administrar múltiplas relações político-cotidianas, fazendo crescer (-mbotuvixa) pessoas e grupos. Como dito anteriormente, o poder, a autoridade e o prestígio são socialmente construídos, controlados e atribuídos pelo coletivo, visando a não acumulação ou centralização deles em uma só pessoa (ou grupo fixo). Há modos próprios de desenvolver essas qualidades de liderança, a partir de maneiras apropriadas de falar,

\footnotetext{
${ }^{368}$ É impossível separar saber e poder dada as potencialidades dos primeiros traduzirem-se em ações eficazes, gerando prestígio e, por consequência, um certo controle sobre as ações dos outros.

369 Talvez seja por esse motivo que aprender a lidar com a burocracia jurua tenha algum valor para eles, diante da violência e humilhação que sofrem quando os não-indígenas questionam a capacidade deles, em transitar por esse mundo dos papéis. Há um constante desejo de capacitação para que possam desenvolver autonomia de fato, ainda que parcial, em relação ao mundo jurua, lutando por mais "respeito" e "dignidade", mesmo que para tanto se utilizem de recursos financeiros do próprio Estado.
} 
fazer política e se relacionar. As lideranças e as chefias de família buscam captar recursos de fora justamente para distribuir entre os seus, tornando-se aqueles que dão, os generosos, por excelência, adquirindo prestígio. Seu valor estando justamente nessa sua capacidade de enredar pessoas e manejar essas redes de relações. Essa sua potência para distribuição seria uma maneira propriamente ameríndia de fazer circular bens, serviços e objetos, gerando uma igualdade ideal de condições entre as pessoas, que parte de uma ética que rechaça a desigualdade entre parentes, mas não a sua diferenciação, e promove a aliança e a generosidade.

Essa apropriação dos conhecimentos jurua envolve também a necessidade de retomar o contato mais direto com a mata (ka'aguy), justamente, para não virar jurua ete (jurua “de verdade”), e continuar a ser Guarani ete (Guarani “de verdade”), ou achar um "meio termo", como comentaram em uma Assembleia recente da CGY, criando sempre maneiras renovadas de resistir politicamente, pois sem terra não há (como desenvolver plenamente) nhandereko. Como eles mesmos disseram, se "tá escrito na Constituição" que têm direitos, devem seguir caminhando e defendendo o "legado" dos seus "avós" (nhaneramoĩ e nhandejaryi), para garantir a terra e o futuro de suas crianças, seu bem mais precioso (presentes enviados por Nhanderu e Nhandexy kuery para fortalecer e alegrar a vida dos parentes nessa terra e ajudá-los a atingir aguyje). Outro ponto de destaque dessa Assembleia, além do tema principal da demarcação de terras, foi justamente a questão de estimular mais a participação e promover o fortalecimento das mulheres e dos jovens na liderança das comunidades, e também, para fora delas, sempre com moderação e cuidado nas relações com as potências exteriores, e foi ali também que, pela primeira vez, foram eleitas jovens mulheres para cargos de Coordenação regional dentro da CGY.

Os jovens, assim como as crianças (kyrĩgue), devem seguir os passos e caminhos dos seus sábios anciões, aprender observando e escutando o que eles dizem e fazem - não a partir de inúmeras e desconcertantes perguntas como os jurua-, acompanhando e imitando, (re)produzindo sua imagem para seguir caminhando belamente (-guata porã), junto e em direção a eles. Podemos dizer que esse é um comportamento geral entre os Mbya, pois desde a gestação, quando os bebês ainda estão no ventre das mães, se diz que eles começam a "imitar" seus parentes que devem então, junto aos pais ter muito cuidado em sua criação, especialmente quando eles são pequenos e estão se firmando aqui na terra, ou em outros momentos de "passagem". Os avós, como o modelo de pessoa ideal, que é imagem da própria divindade, devem então acompanhá-los até a puberdade, para que eles cresçam bem, saudáveis e fortalecidos e aprendam a “imitar” suas sábias ações e 
comportamentos, transformando-se nessa pessoa ideal, que é imagem da própria divindade. Para tanto, os jovens devem estar sempre alerta nessa guerra constante contra jurua reko, daí a necessidade expressa e posta cada vez mais em prática de formação das novas gerações de lideranças.

A formação d@s jovens guerreir@s se dá pelo cruzamento de diversos fatores, entre os quais: a (pre)disposição da pessoa em se tornar uma liderança; o lugar que constrói para si dentro da aldeia, desempenhando tarefas ou funções; características pessoais consideradas adequadas tais como "saber falar" e "conversar", "ser tranquilo", "ter equilíbrio" e "humildade", "conhecer" e "se dar bem" (na convivência) com as múltiplas parentelas que compõem a comunidade; aquisição de conhecimentos e saberes através de estudos, tanto das leis e política jurua, como de sua própria cultura e espiritualidade; acompanhar e participar das reuniões políticas e gerais da comunidade; reconhecimento coletivo de que suas capacidades e conhecimentos são válidos e importantes para a proteção-produção do grupo, principalmente em relação ao estabelecimento de alianças com outros grupos - famílias extensas, aldeias, jurua kuery. Para se formar como uma liderança, deve-se então acompanhar e imitar outras lideranças, pois como viemos mostrando, sempre tem alguém que inicia um movimento, provocando a movimentação coletiva. No entanto, o reconhecimento de uma liderança e a atribuição de autoridade-prestígio, segundo meus interlocutores, vai muito além de um "saber falar", uma vez que aqueles que vão à frente (tenondegua kuery) devem ser capazes de ir além da capacidade oratória e "fazer o que fala". A força e o poder que a fala tem entre eles, principalmente em "questionar", "enfrentar", como dizem os Mbya, tem grande potencial de gerar (-mbojera), criar e fazer, produzir eficácia, mas em escala menor ou menos potente que as palavras dos deuses, sendo os atos de falar então também entendidos como atos de fazer, daí a sua potência (para o "bem" e o "mal”), por isso, o cuidado e a moderação que se deve aprender a ter ao emitir as palavras, em não falar “à toa”. Nesse sentido, toda fala é potencialmente política, ela atua tanto na produção, como na dissolução de coletivos.

A palavra, quando eficaz, é a própria ação em si mesma. É a partir dessa agencialidade das palavras, que é possível entender a ênfase guarani (e talvez em toda parte) em sua importância, que parte também de uma ética que busca o "falar bem" ou "bonito" (ayou porã), essa fala que faz fazer, que é capaz de se traduzir em ações, ou mesmo inspirar movimento. Há a ideia de que as belas palavras, assim como o caminhar (para o) bem, a fumaça do petỹgua, o canto-reza, a dança, curam e protegem como remédios do mato (poã), daí o investimento constante em conversas que aconselham, nos cantos-rezas e danças na $o p y$, que produzem boas disposições entre os corpos-espíritos-parentes, auxiliam a 
desenvolver maturidade corporal-espiritual (-aguyje) e funcionam como instrumentoscaminhos de encontro às divindades e potencializam outras ações aqui na plataforma terrestre. E se como já dizia o ditado, quem canta [e dança] seus males espanta e, podemos acrescentar, caminha para o bem (guata porã). A alegria é a prova dos nove (Andrade, 1928) aí, ela equivale à beleza, ao bom, ao correto, verdadeiro: “aqui, também, a beleza é um critério, inclusive no sentido de que o belo e o alegre, por si, curam (e o que cura, por certo, é belo)" (Pimentel, 2012: 193, grifos meus). Nesse sentido, as danças e os cantos-reza guarani enquanto "disciplinas [de fabricação] do corpo" (Mauss 2003b [1935]), fazem seus corposespíritos alegres-saudáveis e, por isso mesmo, belos, e são como ferramentas ou uma espécie de antídoto para a tristeza, que combate doenças. Perrone-Moisés já dizia que no caso ameríndio: "coisas importantes e seríssimas são feitas - é essa a desconcertante (estonteante) lição dos índios - cantando e dançando, rindo, com transbordante alegria" (Perrone-Moisés, 2015: 103). Essas socialidades contra o Estado e para-a-guerra, são ao mesmo tempo e na mesma (des)medida, sociedades-para-a-festa, confirma a antropóloga.

Os Guarani, como todos os ameríndios, sabem que a vida nessa terra não é fácil. A esperança da vida sem sofrimento é típica do mundo burguês, com sua (falsa) imagem do Estado de bem-estar social, que acaba acirrando e promovendo a grande divisão entre dominantes e dominados, entre aqueles que mandam e aqueles que obedecem. Mas, ao contrário dos povos ameríndios, nós não temos grandes xamãs mais velhos e sábios para nos orientar pelos (des)caminhos, para nos ensinar diariamente que o sofrimento faz parte da vida e que podemos levá-la de uma maneira mais alegre, mais efetiva, afetando para o bem as pessoas que estão por perto. Esse deliberado cultivo da alegria e do bom humor, do investimento constante na produção de boas disposições entre os povos ameríndios pode ser apontado como uma das "tecnologias de sobrevivência ao fim do mundo" como comentava Viveiros de Castro na Conferência Curt Nimuendaju na USP em 2013, e seja essa talvez a "mais avançada das mais avançadas das tecnologias", como cantava belamente Caetano Veloso (Um Índio, 1977).

Enquanto isso, nesses novos tempos, especialmente, com o avanço das cidades e das tecnologias jurua, os modos de circulação, criação e gestão dos saberes guarani foram se transformando criativamente e produzindo novos valores, o que, por sua vez, gerou um certo gap geracional entre os mais jovens e os mais velhos. Entram em cena aí tanto as mobilizações políticas na cidade, como o uso do cinema indígena e das redes sociais como meios de adquirir visibilidade para a luta pela demarcação e garantia das terras tradicionais e fortalecimento cultural, que promove o debate constante entre eles sobre o (bom) uso dessas novas tecnologias e estratégias de resistência políticas-xamânicas 
contra o Estado. Consideramos importante nos atentar para os modos como os próprios Guarani lidam com a circulação desses saberes e conhecimentos, ou mesmo das informações, seja entre si, ou entre eles e os outros, pois é nessa tensão que se revela o que "pode" (geralmente, acordado coletivamente, sempre sob orientação dos mais velhos) ser mostrado da "cultura" para o público de fora (principalmente para os jurua e suas instituições) e o que é apenas de uso ou circulação privada e interna, numa dinâmica bastante ameríndia de abertura e distanciamento em relação ao outro.

O cinema guarani é uma dessas ferramentas de resistência que vem obtendo cada vez mais protagonismo dentro das aldeias e também para fora delas, uma vez que $f a z$ aparecer essa sua resistência em movimento, justamente, para não desaparecem aos olhares e ouvidos jurua, para que sua luta pela garantia de suas terras e pelo fortalecimento do nhandereko não seja esquecida pelo Estado ou pela sociedade envolvente. O vídeo, diferente das imagens fixadas em uma fotografia, capta e traduz imagens em perpétuo movimento, além de ser um meio de se fazer ouvir, para fora das aldeias, adquirindo também grande importância como um modo de fortalecer, circular e valorizar os saberes dos mais velhos entre as famílias, os jovens e as crianças de uma comunidade, e também no entre aldeias. Os cineastas guarani devem se especializar naquilo de mais bonito, forte e poético do nhandereko, traduzindo para os jurua apenas aquilo que consideram ser apropriado ou permitido ao amigo-inimigo (sempre potencial) escutar ou ver, os segredos mais valiosos ou aspectos muito sagrados (como, por exemplo, os modos de preparar remédios) da cultura não seriam feitos circular nessa escala e dessa maneira, jamais (às vezes, nem entre eles). Essas imagens em perpétuo movimento que os vídeos trazem, assim como as imagens imperfeitas dos corpos-espíritos celestes aqui na terra, não se fixam ou se aprisionam em algo acabado, se recusando ativamente em deixar-se sujeitar em algo fixo, estando mais bem em intensa e perpétua resistência contra o Um. O vídeo se aproximando mais de uma tecnologia diplomática guarani de resistência xamânica contra o Estado, esse Um que não se realiza plenamente porque é constantemente inibido pelo coletivo, em favor da multiplicidade do devir-deus(a).

E são os comportamentos dos ancestrais divinos em sua caminhada pela terra que servem como modelos de ação para os Guarani, que se inspiram neles para buscar proteção e iluminação contra as adversidades que se assolam sobre essa "terra má" (yvy vaı). Nas dificuldades, barreiras e provações que aparecem pelos caminhos, devem aprender a se esquivar e a seguir em frente com alegria-alegria, porque é Nhanderu e Nhandexy Tenonde que estão na frente e colocam esses testes para ver se seus filhos caçulas realmente 
prestam atenção e acreditam e confiam em seus ensinamentos, fortalecendo quem tem fé e coragem nessa sua "iluminação", que vem do sentir no coração e faz ver o vem além:

Tenonde rã quer dizer futuro (o que estará na frente) e Tenonde Porã é a vida boa, é a alegria do casal, dos parentes, das crianças. Ter Tenonde Porã é achar o caminho para andar junto com Nhanderu, lembrando de Nhanderu. Para levar a vida bem, para ter um bom futuro. [...] é um estar à espreita ("eles ficam prestando atenção", dizem dos karaioguerojapixaka). É Nhanderu que ilumina Tenondé Porã [...] aqueles que andam junto com Nhanderu é que têm Tenonde Porã. Então, para ter Tenonde Porã o mbya tem que encontrar tape porã para andar, o caminho bom, o caminho belo. [...] Dizem os karai e as kunha karai que a pessoa tem que colocar Nhanderu na sua frente, afirmar que Nhanderué Tenonde em sua vida, pois é indo na frente que Nhanderu ilumina o caminho. Só que Nhanderu nem sempre facilita as coisas. Então, quando ele deixa a pessoa encontrar o caminho bom, quando ele ilumina (ojapixaka) tape porã pra pessoa, ele quer saber se essa pessoa vai acreditar mesmo, confiar nele (jerovia). Para saber isto é que Nhanderu coloca armadilhas na vida da pessoa. Teko'a ã, a "barreira", é a armadilha de Nhanderu. [...] Vilmar diz que para a pessoa trabalhar bem vai ter sempre uma teko'a ã, pois a pessoa tem que passar por isso, para ficar forte sempre, para não cair na armadilha de Nhanderu. (Ramo, 2014: 161, grifos meus)

Muitas vezes os Guarani me disseram nas aldeias: o caminho (tape porã) de Nhanderu e Nhandexy é estreito, repleto de provas. O outro caminho, mais largo (tape tuvixa), pode até ser mais fácil, mas não é o caminho da sabedoria que as divindades colocaram para nós. Assim como no caminho do interior ao litoral que os irmãos Jaxy e Kuaray enfrentam diversas dificuldades até chegar a yryju porã, a morada de seu pai e mãe, é esse o modelo de ação para os Guarani aqui na terra. É se inspirando e confiando nas palavras dos deuses que levam seus saberes adiante. E se o significado do nome do Tekoa Tenonde Porã, segundo o xeramoĩ Valdelino é "luz e esperança" ou "aliança para o futuro", é caminhando juntos sob essa luz divina e fazendo boas alianças que os Guarani irão continuar resistindo e guardando essa terra. Como canta o rap de protesto lançado no contexto das mobilizações guarani para a demarcação de terras na capital: "mesmo sofrendo a gente sabe ser feliz, medo de prova, o dia a dia é nosso teste, a todo povo de luta: Aguyjevete!”. 


\section{$\underline{\text { Referências Bibliográficas }}$}

Albert, Bruce. 2000. O ouro canibal e a queda do céu: Uma crítica xamânica da economia política da natureza (Yanomami). In: Albert, Bruce e Ramos, Alcida Rita (Orgs.). Pacificando o branco: Cosmologias do contato no Norte-Amazônico. São Paulo: Editora Unesp, p. 239276.

Andrade, Oswald de. 1928. Manifesto Antropófago. Revista de Antropofagia, Ano 1, No. 1, São Paulo.

Antunha Barbosa, Carla Gonçalves e Antonio Barbosa, Marco. 1987. Uma parte da história desta publicação. In: Nimuendaju, Curt Unkel. 1987 [1914]. As lendas da criação e destruição do mundo como fundamentos da religião dos Apapocúva-Guarani. São Paulo: Hucitec/Edusp.

Aranha, Aline e Freire, Gabriela. 2016. Verbete do conceito Sociedade contra o Estado de Pierre Clastres. Enciclopédia de Antropologia, FFLCH-USP, São Paulo. Disponível em: (http://ea.fflch.usp.br/lista-de-verbetes?q=node/70). Acesso em 20 out 2017.

Barbosa, Gustavo. B. 2004. A Socialidade contra o Estado: A antropologia política de Pierre Clastres. São Paulo: Revista de Antropologia, v. 37, n.2)

Belaunde, Luisa E. 2006. A força dos pensamentos, o fedor do sangue. Hematologia e gênero na Amazônia. São Paulo: Revista de Antropologia (USP), v. 49, n. 1, p. 205-243.

Cadogan, León.

1948. Los índios Jeguaká Tenondé (Mbyá) del Guairá, Paraguay. América Indígena, n. 2, vol. VIII, México.

1959. Ayvu Rapyta: Textos míticos de los Mbyá-Guaraní del Guairá. São Paulo: FFLCHUSP.

1962. Aporte a la etnografía de los Guaraní del Amambái, Alto Tpané. RA, (10, 1-2): 43-91.

1965. En torno al Bai-Ete-Ri-Va Guayaki y el concepto Guarani de Nombre. Revista del Ateneo Paraguayo, Separata del Suplemento Antropológico, vol. 1, no 1: 3-13. Asunción.

1992. Diccionario Mbya-Guarani. Asunción: Fundación León Cadogan, CEADUC, CEPAG.

Cadogan, León e Meliá, Bartomeu. 1971. Che Retambipe (Datos para el estudio de la función de la mujer en la organización social de los Guaraní). In: Cadogan, León. Yroyra Ñe'ery: fluye del árbol la palabra. Sugestiones para el estudio de la cultura Guaraní. Asunción, Paraguai: CEADUC, p. 113-122.

Calixto, Benedito. 1905 [1903]. Primitivos aldeamentos e os índios mansos de Itanhaém. Revista do IHGSP, v. X. São Paulo.

Campanha Guarani. 2014. Resistência Guarani SP. Disponível em: (http://campanhaguaranisp.yvyrupa.org.br/?page_id=460). Acesso em 20 out 2017.

Carneiro da Cunha, Manuela. 2009. Cultura com aspas. São Paulo: Cosac Naify.

Cebolla Badie, Marilyn. 2014. 'Iñengue'. Transformarse en mujer en la sociedad mbya-guaraní. In: Modernidad Indígena, 'Indigeneidad' e Innovación Social desde la Perspectiva del Género. Celigueta, G., Orobitg, G. e Pitarch, Pedro (Coords.). Barcelona: Publicacions i Edicions de la Universitat de Barcelona. 
Centro de Trabalho Indigenista (CTI).

2013. Comissão Guarani Yryrupa realiza sua $6{ }^{a}$ Assembleia Geral. Disponível em: (https://trabalhoindigenista.org.br/comissao-guarani-yvyrupa-realiza-sua-6a-assembleia-geral).

Acesso em 20 out 2017.

2015a. Atlas das Terras Guarani no Sul e Sudeste do Brasil. In: Salles, Camila; Pierri, Daniel; Castilla, Eliza e Ladeira, Maria Inês. (Orgs.). Disponível em: (http://bd.trabalhoindigenista.org.br/node/4931). Acesso em 20 out 2017.

2015b. Lançamento: Atlas das Terras Guarani no Sul e Sudeste do Brasil. Disponível em: (http://trabalhoindigenista.org.br/lancamento-atlas-das-terras-guarani-no-sul-e-sudestedo-brasil-2015). Acesso em 20 out 2017.

2016a. Tenondé Porã: os muitos anos de luta por reconhecimento. Disponível em: (http://trabalhoindigenista.org.br/tenonde-pora-os-muitos-anos-de-luta-por-reconhecimento). Acesso em 20 out 2017.

2016b. VII Assembleia da CGY reafirma luta por reconhecimento territorial do povo Guarani. Disponível em: (http:// trabalhoindigenista.org.br/vii-assembleia-da-cgy-reafirma-luta-por-reconhecimento-territorial-do-povo-guarani). Acesso em 20 out 2017.

2016c. Ka'aguy re jaiko. Vivemos na Mata. Programa Aldeias (Org.). São Paulo: Centro de Trabalho Indigenista.

2017a. Programa Guarani. Disponível em: (http://trabalhoindigenista.org.br/programa/programaguarani). Acesso em 20 out 2017.

2017b. Mapa do território Guarani será lançado em São Paulo. Disponível em: (https://trabalhoindigenista.org.br/mapa-territorio-guarani-sera-lancado-em-sao-paulo). Acesso em 20 out 2017.

2017c. Repúdio à anulação da Portaria Declaratória da Terra Indígena Jaraguá. Disponivel em: (https:// trabalhoindigenista.org.br/repudio-anulacao-da-portaria-declaratoria-da-terra-indigena-jaragua/). Acesso em 20 out 2017.

Chamorro, Graciela. 2009. Decir el cuerpo: Historia y etnografía del cuerpo en los pueblos Guaraní. Asunción: Tiempo de Historia, Fondec. 408 p. Tomo I Diccionario etnográfico histórico del Guaraní.

Chaumeil, Jean-Pierre.

1998 [1983]. Ver, saber, poder: el chamanismo de los yagua de la Amazonía peruana. Argentina: Centro Argentino de Etnologia Americana.

2015 [2003]. Xamanismos de geometria variável na Amazônia. Revista Campos, v. 16, n. 1, p. 148-159.

Ciccarone, Celeste.

2001. Drama e Sensibilidade: Migração, Xamanismo e Mulheres Mbya Guarani. São Paulo: Tese de doutorado em Ciências Sociais pela PUC-SP.

2004. Drama e Sensibilidade: Migração, Xamanismo e Mulheres mbya. Revista de Indias, Madrid, v. LXIV, n. 230, p. 81-96.

Clastres, Hélène. 1978 [1975]. Terra sem Mal. O profetismo tupi-guarani. São Paulo: Brasiliense.

Clastres, Pierre.

1980. La tierra imperfecta. In: Literatura Guaraní del Paraguay, Rubén Bareiro Saguier (Org.). Caracas: Biblioteca Ayacucho.

1990 [1974]. A fala sagrada: cantos sagrados dos indios Guarani. Campinas: Papirus.

2003 [1974]. A Sociedade contra o Estado: pesquisas de antropologia política. São Paulo: Cosac Naify.

2011 [1980]. Arqueologia da violência: pesquisas de antropologia política. São Paulo: Cosac Naify. 
Clifford, James. 1998 [1994]. A experiência etnográfica: antropologia e literatura no século XX. Rio de Janeiro: Editora UFRJ.

Coelho de Souza, Marcela S.

2004. Parentes de sangue: incesto, substância e relação no pensamento Timbira. Rio de Janeiro: Mana, v. 10, n. 1, p. 25-60.

2010. A vida material das coisas intangiveis. In: Conhecimento e Cultura: práticas de transformação no mundo indígena. Coelho de Souza, M. S. e Cofacci de Lima, E. (Orgs.). Brasília: Athalaia Gráfica e Editora.

Colpron, Anne-Marie. 2005. Monopólio Masculino do Xamanismo Amazônico: O contra-exemplo das mulheres xamã Shipibo-Conibo. Mana, vol. 11, n. 1, p. 95-128.

Comissão Guarani Yvyrupa (CGY).

2013a. Mensagem à bancada ruralista. Disponível em: (https://www.youtube.com/watch?v=zFMKpzSU9Yk). Acesso em 20 out 2017.

2013b. Manifesto: Por que fechamos a Bandeirantes? Disponível em: (http://www.youtube.com/watch?v=eV7WMdvGirM\&feature=youtu.be). Acesso em 20 out 2017.

2013c. Rodovia rojoko. O dia em que fechamos a Bandeirantes. Disponível em: (http:/ /www.youtube.com/watch?v=JCBOU4wQmR8). Acesso em 20 out 2017.

2014a. Resistência Guarani SP: Assina logo, Cardozo! Disponível em: (https://www.youtube.com/watch?v=btfb2eY7tSo). Acesso em 20 out 2017.

2014b. Resistência Guarani SP: Por que ocupamos o Pátio do Colégio? Disponível em: (https://www.youtube.com/watch?v=ShzMhVgna-g). Acesso em 20 out 2017.

2014c. Manifesto Antirruralista da Comissão Guarani Yryrupa. Disponível em: (http://campanhaguaranisp.yvyrupa.org.br/?p=394). Acesso em 20 out 2017.

2014d. Demarcação Já: nosso protesto na abertura da Copa. Disponível em: (http://campanhaguaranisp.yvyrupa.org.br/?p=403). Acesso em 20 out 2017.

2015a. Lançamento da Campanha Resistência Guarani SP. Disponível em: (http://www.yvyrupa.org.br/blog/2015/04/07/lancamento-da-campanha-resistenciaguarani-sp/). Acesso em 20 out 2017.

2015b. Jaraguá é Guarani. Agora é Tenondé: contra reintegração de posse no Itakupe e pela Portaria Declaratória do Tenondé Porã. Disponível em: (https://www.facebook.com/events/810811482300770). Acesso em 20 out 2017.

2015c. A todo povo de luta - Rap Guarani Mbya. Disponível em: (https://www.youtube.com/watch?v=uUvS8Gnbkwk). Acesso em 20 out 2017.

2016a. Campanha Benfeitoria: Assembleia 2016. Disponível em: (https://www.youtube.com/watch?v=FC2tJRCJ9_o). Acesso em 20 out 2017.

2016b. Manifesto da $7^{a}$ Assembleia da Comissão Guarani Yryrupa. Disponível em: (http://www.yvyrupa.org.br/blog/2016/09/16/manifesto7assembleiacgy). Acesso em 20 out 2017.

2017a. Sobre a CGY. Disponível em: (http://www.yvyrupa.org.br/sobre-a-cgy). Acesso em 20 out 2017.

2017b. Contato. Disponível em: (http://www.yvyrupa.org.br/contato). Acesso em 20 out 2017.

2017c. O Jaraguá é Guarani! Contra o Marco Temporal e a revogação de demarcações! Disponível em: (https://www.facebook.com/events/772364599638869). Acesso em 20 out 2017.

2017d. O Jaraguá é Guarani: por que ocupamos a casa temer: Disponível em: (https://www.youtube.com/watch?v=uXtF6L7XaDY). Acesso em 20 out 2017.

Corrêa, Mariza. 2003. Antropólogas e antropologia. Belo Horizonte: Editora da UFMG. 
Da Silva, Renato. 2011. Comissão Yryrupa: articulação guarani em defesa de seu território. In: Ricardo, Beto e Ricardo, Fany (Orgs.). Povos Indígenas no Brasil (PIB) 2006/2010. São Paulo: Instituto Socioambiental (ISA).

Deleuze, Gilles e Guattari, Félix.

1997 [1980]. 1227 - Tratado de Nomadologia: A Máquina de Guerra. In: Mil platôs: capitalismo e esquizofrenia, vol. 5. São Paulo: Editora 34.

2010 [1972]. O Anti-Édipo: Capitalismo e Esquizofrenia I. São Paulo: Ed. 34.

Donzelot, Jacques. 1976. Uma anti-sociologia. In: Carrilho, M. M. (Org.). Capitalismo e Esquizofrenia. Dossier anti-Édipo. Lisboa: Assírio e Alvim, p. 152-84.

Dooley, Robert A. 2006. Léxico guarani, dialeto mbyá. Brasília: Sociedade Internacional de Linguística.

Douglas, Mary. 2012 [1966]. Pureza e Perigo. São Paulo: Editora Perspectiva.

Eckart, Jan-Arthur Bruno. 2014. Tenonde Porã: uma aldeia e seus núcleos - um estudo sobre política Mbya (Guarani). Dissertação de Mestrado, PPGAS-UFSCar.

Fausto, Carlos.

2001. Inimigos Fiéis: História, Guerra e Xamanismo na Amazônia. São Paulo: EDUSP. 2005. Se Deus fosse Jaguar: Canibalismo e Cristianismo entre os Guarani (séculos XVI-XX). Mana, Rio de Janeiro, v. 11, n. 2, p. 385-418.

2008. Donos demais: Maestria e Domínio na Amazônia. Mana, Rio de Janeiro, v. 14, n. 2, p. 329-366.

Favret-Saada, Jeanne. 2005 [1990]. Ser afetado. Revista Cadernos de Campo, n. 13, p. 155161.

Fernandes, Doralice (Kunhã Tatá). 2011. Nhanderu acha que o mundo já está muito velho e quer limpar a terra. In: Ricardo, Beto e Ricardo, Fany (Orgs.) Povos Indígenas no Brasil (PIB) 2006/2010. São Paulo: Instituto Socioambiental (ISA).

Franchetto, Bruna. 1996. Mulheres Entre Os Kuikúro. Rio de Janeito: Revista Estudos Feministas, v. 4, n. 1, p. 35-54.

Fundação Nacional do Índio (Funai). 2017. Terras Indígenas no Brasil. Disponível em: (http://www.funai.gov.br/index.php/indios-no-brasil/terras-indigenas). Acesso em 20 out 2017.

Gallois, Dominique Tilkin.

1988. Movimento na cosmologia waiapi: criação, expansão e transformação do universo. Tese de Doutorado em Antropologia Social. São Paulo: Universidade de São Paulo.

1996. Xamanismo Waiãpi: nos caminhos invisíveis, a relação i-paie. In: Langdon, E. Jean Matteson (Org.). Xamanismo no Brasil: Novas Perspectivas. Florianópolis: Editora UFSC, p. 39-74.

2000. Nossas falas duras: discurso político e auto-representação Waiãpi. In: Albert, Bruce; Ramos, Alcida Rita (Orgs.). Pacificando o branco: Cosmologias do contato no Norte-Amazônico. São Paulo: Editora Unesp, p. 205-238.

2001. Essa incansável tradução. In: Sexta Feira - Antropologia, Artes e Humanidades, no 6. São Paulo: Editora 34, p. 103-122.

2004. Terras ocupadas? Territórios? Territorialidades? In: Ricardo, Fany (Org.). Terras Indígenas \& Unidades de Conservação da Natureza: o desafio das sobreposições. São Paulo: Instituto Socioambiental, p. 37-41. 
Garlet, Ivori José. 1997. Mobilidade mbyá: história e significação. Dissertação de Mestrado, Porto Alegre: PUC-RS.

Goldman, Marcio.

1999. O que Fazer com Selvagens, Bárbaros e Civilizados? In: Alguma Antropologia. Rio de Janeiro: Relume-Dumará, cap. V.

2008. Os Tambores do Antropólogo: Antropologia Pós-Social e Etnografia. Ponto Urbe (NAUUSP), n. 3.

2011a. O Fim da Antropologia. Novos Estudos, CEBRAP, v. 89: 195-211.

2011 b. Pierre Clastres ou uma Antropologia contra o Estado. São Paulo: Revista de Antropologia, USP, v. $54, \mathrm{n}^{\circ} 2$.

Gonçalves, Maurício. 2011. Comissão Yryrupa: articulação guarani em defesa de seu território. In: Ricardo, Beto e Ricardo, Fany (Orgs.). Povos Indígenas no Brasil (PIB) 2006/2010. São Paulo Instituto Socioambiental (ISA).

Guata Porã - Belo Caminhar. 2015. Pesquisadores Guarani de Aldeias de Santa Catarina e Paraná e Ramo y Affonso, Ana M. (Org.). São Paulo: Centro de Trabalho Indigenista.

Horta Barbosa, Luiz. 1928a. Relatório Da Inspetoria do Estado de São Paulo (MF 341 Ft. 947986).

Instituto Sociambiental (ISA).

1996. Povos Indígenas no Brasil $\llbracket \mathrm{PIB}\rceil$ 1991/1995. São Paulo: Instituto Socioambiental. 2011. Povos Indígenas no Brasil [PIB] 2006/2010. São Paulo: Instituto Socioambiental. 2013a. Manifestação reúne 1,3 mil em defesa de direitos de indígenas e quilombolas em Brasília. Disponível em: (https://www.socioambiental.org/pt-br/noticias-socioambientais/manifestacao-reune-13-mil-em-defesa-de-direitos-de-indigenas-e-quilombolas-em-brasilia). Acesso em 20 out 2017.

2013b. Ato em defesa dos direitos indígenas e quilombolas acontece nesta quarta (2/10) em São Paulo. Disponível em: (https://www.socioambiental.org/pt-br/noticias-socioambientais/ato-publico-em-defesa-dos-direitos-indigenas-acontece-nesta-quarta-2 10-em-saopaulo). Acesso em 20 out 2017.

2014. Guarani realizam ato contra reintegração de posse em São Paulo. Disponível em: (https://www.socioambiental.org/pt-br/noticias-socioambientais/guarani-realizam-atocontra-reintegracao-de-posse-em-sao-paulo). Acesso 20 out 2017.

2015a. Terra Indígena Jaraguá, em São Paulo (SP), é declarada pelo Ministério da Justiça. Disponível em: (https://www.socioambiental.org/pt-br/noticias-socioambientais/terra-indigena-jaragua-em-sao-paulo-sp-e-declarada-pelo-ministerio-da-justica). Acesso em 20 out 2017.

2015b. Povos indígenas fazem ato público na Av. Paulista (SP) contra ameaças a seus direitos. Disponível em: (https://www.socioambiental.org/pt-br/blog/blog-do-monitoramento/povos-indigenas-fazem-ato-publico-na-av-paulista-sp-contra-ameacas-a-seus-direitos).

Acesso em 20 out 2017.

2016a. AVISO DE PAUTA: O dia D de Demarcação da Terra Indígena Tenondé Porã. Disponível em: (https://www.socioambiental.org/sites/blog.socioambiental.org/files/nsa/arquivos/releasetenonde.pdf). Acesso em 20 out 2017.

2016b. Marinho apoia demarcação indígena em São Bernardo. Disponível em: (https://pib.socioambiental.org/pt/noticias? id=164172\&id_pov=80). Acesso em 20 out 2017.

2016c. Em ato, Guarani exigem que governo demarque Terra Indígena na cidade de São Paulo. Disponível em: (https://www.socioambiental.org/pt-br/noticias-socioambientais/em-atoguarani-exigem-que-governo-demarque-terra-indigena-na-cidade-de-sao-paulo). Acesso em 20 out 2017. 
2016d. Terra Indígena Tenondé Porã é oficialmente dos Guarani. Disponível em: (https://www.socioambiental.org/pt-br/blog/blog-do-monitoramento/terra-indigena-tenonde-pora-e-oficialmente-dos-guarani). Acesso 20 em out 2017.

2017a. Guarani prometem resistência contra anulação da Terra Indígena Jaraguá. Disponível em: (https://www.socioambiental.org/pt-br/noticias-socioambientais/guarani-prometem-resistencia-contra-anulacao-da-terra-indigena-jaragua). Acesso em 20 out 2017.

2017b. Após 24h de cantos e danças, termina ocupação guarani na Presidência. Disponível em: (https://www.socioambiental.org/pt-br/noticias-socioambientais/apos-24h-de-cantos-edancas-termina-ocupacao-guarani-na-presidencia). Acesso em 20 out 2017.

2017c. Guarani ocupam Parque Estadual do Jaraguá em defesa de seu direito à terra. Disponível em: (https://www.socioambiental.org/pt-br/noticias-socioambientais/guarani-ocupamparque-estadual-do-jaragua-em-defesa-de-seu-direito-a-terra). Acesso em 20 out 2017.

Keese dos Santos, Lucas. 2017. A esquiva do xondaro: movimento e ação política entre os Guarani Mbya. Dissertação de Mestrado, PPGAS-USP.

Kulick, D. 1993. Speaking as a woman: structure and gender in domestic arguments in a New Guinea village. Cult. Anthropol. Vol. 8, n. 4, p. 510-41.

Ladeira, Maria Inês.

1984. Aldeias Livres do Litoral de São Paulo e da periferia da capital. In: Comissão Pró índio (Org.). Índios no Estado de São Paulo. São Paulo: Yankatu, p. 123-144.

1996. Os Guarani na Mata Atlântica. In: Ricardo, Beto (Org.). Povos Indígenas no Brasil (PIB) 1991/95, Instituto Socioambiental (ISA), p. 773-780.

2000. Comunidades Guarani da Barragem e do Krukutu e a Linha de Transmissão de $750 \mathrm{Kv}$ Itaberá - Tijuco Preto III. Relatório de Interferências. São Paulo, Furnas/SA.

2001. As Demarcações Guarani, a Caminho da Terra Sem Mal. In: Ricardo, Beto (Org.). Povos Indígenas no Brasil (PIB) 1996/2000, Instituto Socioambiental (ISA), p. 782-785.

2006. São Paulo na Terra dos Índios. In: Ricardo, Beto e Ricardo, Fany (Orgs.). Povos Indígenas no Brasil (PIB) 2001/2005, Instituto Socioambiental (ISA), p. 831-832.

2007 [1992]. O caminhar sob a luz. O território mbya à beira do oceano. São Paulo: Editora Unesp.

2008 [2001]. Espaço Geográfico Guarani-Mbya: Significado, Constituição e Uso. Eduem, Edusp. 2011. Reconhecimento dos Direitos Territoriais no Sul e Sudeste do Brasil. In: Ricardo, Beto e Ricardo, Fany (Orgs.). Povos indígenas no Brasil (PIB) 2006/2010. São Paulo: Instituto Socioambiental, v. 1, p. 717-722.

Ladeira, Maria Inês e Azanha, Gilberto. 1988. Os Índios da Serra do Mar. A presença MbyaGuarani em São Paulo. São Paulo: Centro de Trabalho Indigenista, Nova Stella.

Ladeira, Maria Inês e Pierri, Daniel. 2015. Apresentação. In: Atlas das Terras Guarani no Sul e Sudeste do Brasil, Centro de Trabalho Indigenista (Org.).

Ladeira, Maria Inês e Vera, Manoel da Silva. 1993. Observações sobre o projeto "Obras de Aproveitamento do Rio Capivari para o Abastecimento de Água da Região Metropolitana de São Paulo" e os impactos no meio ambiente, segundo os princípios éticos e de subsistência Guarani Mbya. São Paulo: Arquivo CTI.

Langdon, E. Jean Matteson. 1996. Introdução: Xamanismo - velhas e novas perspectivas. In: Langdon, E. Jean Matteson (Org.). Xamanismo no Brasil: Novas Perspectivas. Florianópolis: Editora UFSC, p. 9-37.

Lasmar, Cristiane. 1999. Mulheres indígenas: representações. "Dossiê Mulheres Indígenas". Revista Estudos feministas, v. 7, n. 1 e 2, p. 143-156. 
Latour, Bruno. 1994 [1991]. Jamais fomos modernos. São Paulo: Editora 34.

Lévi-Strauss, Claude.

1986 [1985]. A oleira ciumenta. São Paulo: Brasiliense.

1989 [1962]. O pensamento selvagem. Campinas, SP: Papirus.

1993 [1991]. Historia de Lince. São Paulo: Companhia das Letras.

2006 [1968]. A origem dos modos à mesa. Mitológicas, v. 3. São Paulo: Cosac Naify.

2013 [1973]. Antropologia estrutural dois. São Paulo: Cosac Naify.

Lima, Tânia Stolze. 2002. O que é um corpo? Religião e Sociedade, 22 (1).

Lima, Tânia Stolze e Goldman, Marcio. 2003. Prefácio. In: A Sociedade contra o Estado: pesquisas de antropologia política. São Paulo: Cosac Naify, p. 7-20.

Locatelli, Piero. 2014. Indígena estende faixa por demarcação na abertura da Copa. In: Carta Capital. Disponível em: (https://www.cartacapital.com.br/sociedade/indio-estende-faixapor-demarcacao-na-abertura-da-copa-1454.html). Acesso em 20 out 2017.

Macedo, Valéria.

2010. Nexos da diferença. Cultura e afecção em uma aldeia guarani na Serra do mar. São Paulo, Tese de Doutorado em Antropologia Social. São Paulo: PPGAS/USP.

2012a. Vetores porã $e$ vai na cosmopolítica guarani. Tellus (UCDB), n. 21.

2012b. Dos cantos para o mundo. Invisibilidade, figurações da cultura e o se fazer ouvir nos corais guarani. Revista de Antropologia (USP. Impresso), v. 51, p. 357-400.

2012c. Guarani cosmopolitcs and the world of projects. In: 54th International Congress of Americanists 'Building dialogues in the Americas'. Vienna: Universität Wien, v. 1.

2013. De encontros nos corpos guarani. Ilha, Revista de Antropologia, v. 15, p. 181-210.

Macedo, Valéria e Sztutman, Renato. 2014. A parte de que se é parte. Notas sobre individuação e divinização (a partir dos Guarani). Cadernos de Campo (USP), São Paulo, n. 23, p. 287-302.

Mapa Guarani Digital. 2017. Disponível em: (http://guarani.map.as). Acesso em 20 out 2017.

Mauss, Marcel.

2003a [1925]. Ensaio sobre a dádiva - Forma e razão da troca nas sociedades arcaicas. In: Sociologia e Antropologia. São Paulo: Cosac Naify.

2003b [1935]. As técnicas do corpo. In: Sociologia e Antropologia. São Paulo: Cosac Naify.

McCallum, Cecilia A.

2001. Gender and Sociability in Amazonia. How Real People are Made. Oxford: Berg.

2013. Nota sobre as categorias "gênero" e "sexualidade" e os povos indígenas. Cadernos Pagu

(UNICAMP), v. 41, p. 53-61.

Meliá, Bartomeu. 1989. A experiência religiosa Guarani. In: O rosto índio de Deus. São Paulo: Ed. Vozes.

Mello, Flávia C. 2006. Aetchá Nhanderukuery Karai Retarã. Entre deuses e animais: Xamanismo, Parentesco e Transformação entre os Chiripá e Mbyá Guarani. Tese de Doutorado em Antropologia Social. Florianópolis: Universidade Federal de Santa Catarina.

Métraux. Alfred. 1931. Les Hommes-Dieux chez les Chiriguano et dans l'Amérique du Sud. Revista del Instituto de Etnología de la Universidad Nacional de Tucuman, v. 2, n. 1. Tucuman: Universidad Nacional de Tucuman. 
Montardo, Deise Lucy. 2002. Através do Mbaraka: Música e Xamanismo Guarani. Tese de Doutorado em Antropologia Social. São Paulo: Universidade de São Paulo.

Monteiro, John. M. 2004. Dos campos de Piratininga ao Morro da Saudade: a presença indígena na história de São Paulo. In: História da Cidade de São Paulo: A Cidade Colonial. Porta, Paula (Org.). São Paulo: Paz e Terra, v. 1, p. 21-67.

Mura, Fábio. 2006. À Procura do Bom Viver: Território, tradição de conhecimento e ecologia doméstica entre os Kaiowa. Tese de Doutorado, PPGAS/MN-UFRJ.

Nimuendaju, Curt Unkel. 1987 [1914]. As lendas da criação e destruição do mundo como fundamentos da religião dos Apapocúva-Guarani. São Paulo: Hucitec/Edusp.

Nogueira da Silva, Fábio de O.

2008. Elementos de etnografia mbyá: lideranças e grupos familiares na aldeia Tekoá Pyaú (Jaraguá - São Paulo, SP). São Paulo: Dissertação de mestrado em Antropologia Social pelo PPGAS-USP.

2015. Do Tekoa Pyau à nova aldeia: sujeitos em movimento na produção do espaço local. São Paulo: Tese de doutorado em Antropologia Social pelo PPGAS-USP.

Overing, Joanna. 1986. Men Control Women? The 'Catch 22' in the analysis of gender. International Journal of Moral and Social Studies, v. 1, n. 2, p. 135-156.

Passes, Alan. 2004. The place of politics: powerful speech and women speakers in everyday pa'ikwené (Palikur) life. The Journal of the Royal Anthropological Institute, Vol. 10, n. 1, p. 118.

Pierri, Daniel Calazans.

2013a. O perecível e o imperecível: lógica do sensivel e corporalidade no pensamento Guarani-Mbya. Dissertação de Mestrado em Antropologia Social. São Paulo: PPGAS/USP.

2013b. Como acabará essa terra? Reflexões sobre a cataclismologia Guarani-Mbya, à luz da obra de Nimuendajú. Revista Tellus, ano 13, n. 24, p. 159-188, Campo Grande, MS.

2014. O dono da figueira e a origem de Jesus: uma crítica xamânica ao cristianismo. Revista de Antropologia (USP), São Paulo, v. 57, n. 1.

Pimentel, Spensy K. 2012. Elementos para uma teoria política kaiowá e guarani. São Paulo: Tese de doutorado em Antropologia Social pelo PPGAS-USP.

Pereira, Levi Marques. 2008: A criança kaiowa, o fogo doméstico e o mundo dos parentes: espaços de sociabilidade infantil. In: $32^{\circ}$ Encontro Anual da Anpocs, Caxambu.

Perrone-Moisés, Beatriz.

2011. Bons chefes, maus chefes, chefões: excertos de filosofia política ameríndia. Revista de Antropologia (USP), São Paulo, 54/2.

2015. Festa e guerra. São Paulo: Tese de Livre-Docência em Etnologia Indígena pelo Departamento de Antropologia, FFLCH-USP.

Pissolato, Elizabeth.

2007. A duração da pessoa: mobilidade, parentesco e xamanismo mbyá (guarani). Tese de Doutorado em Antropologia Social. Rio de Janeiro: Museu Nacional/UFRJ.

2012. Gênero, casamento e trocas com brancos. In: Gênero e Povos Indígenas. Sacchi, Ângela e Gramkow, Márcia Maria (Orgs.). Rio de Janeiro, Brasília: Museu do Índio/GIZ, p. 98-109. 
Plínio dos Santos, Carlos Alexandre B. 2004. Os Mbyá no Distrito de Parelheiros (SP), In: Ricardo, Fany (Org.). Terras Indígenas \& Unidades de Conservação da natureza: o desafio das sobreposições. São Paulo: Instituto Socioambiental, p. 282-286.

Poty, Jera. 2016. Conexões mulheres indígenas. Instituto Socioambiental: (https://conexoes.socioambiental.org/retomadas.html). Acesso em 20 out 2017.

Prates, Maria P. 2013. Da instabilidade e dos afetos: pacificando relações, amansando Outros. Cosmopolítica-mbyá (Lago Guaíba/RS-Brasil). Tese de Doutorado em Antropologia Social. Porto Alegre: Universidade Federal do Rio Grande do Sul.

Ramo, Ana Maria. 2014. De pessoas e palavras entre os Guarani-Mbya. Tese de Doutorado, PPGA, Universidade Federal Fluminense: Niteroi.

Rebelo, Francine Pereira. 2015. Kunhangue Mba'e Kua: As trajetórias das mulheres-cacicas Guarani Mbya de Santa Catarina. Dissertação de Mestrado em Antropologia Social, Universidade Federal de Santa Catarina.

Rede Brasil Atual. 2017. Ameaçados de despejo, indígenas ocupam Pico do Jaraguá e exigem falar com Alckmin. Disponível em: (http://www.redebrasilatual.com.br/cidadania/2017/09/indigenas-com-territorio-ameacado-ocupam-antenas-no-jaragua-e-exigem-presenca-de-alckmin). Acesso em 20 out 2017.

Relatório Circunstanciado de Identificação e Delimitação da Terra Indígena Tenonde Porã (RCID T.I. Tenonde Porã). 2010. Pimentel, Spensy K.; Pierri, Daniel C.; Bellenzani, Maria Lúcia R. (Orgs.). Brasília: CGID/DPT/FUNAI.

Rosaldo, Michelle e Lamphere, Louise. 1974. Introduction. In: Rosaldo, M. e Lamphere, L. (Eds.). Woman, Culture and Society. Stanford: Stanford University Press.

Sahlins, Marshall. 1997. O 'pessimismo sentimental' e a experiência etnográfica: por que a cultura não é um 'objeto' em via de extinção (Parte I e Parte II). Mana, vol. 3, nº 1 e 2.

Schaden, Egon. 1974. Aspectos fundamentais da cultura guarani. São Paulo: Epu-Edusp

Seeger, Anthony. 1980. Corporação e corporalidade: ideologia de concepção e descendência. In: "Os índios e nós". Seeger e Viveiros de Castro (Orgs). Ed. Campus, p.127-132.

Seeger, Anthony., Da Matta, Roberto. e Viveiros de Castro, Eduardo B. 1979. A construção da pessoa nas sociedades indígenas brasileiras. Boletim do Museu Nacional, Série Antropologia, n. 32, p. 2-19.

Seraguza, Lauriene. 2013. Cosmos, Corpos e Mulheres Kaiowa e Guarani: de Aña à Kuña. Dissertação de Mestrado, PPGA, Universidade Federal da Grande Dourados.

Strathern, Marilyn.

2006 [1988]. O gênero da dádiva: problemas com as mulheres e problemas com a sociedade na Melanésia. Campinas, SP: Editora da Unicamp.

2014a [1984]. Sujeito ou Objeto? As mulheres e a circulação de bens de valor nas terras altas da Nova Guiné. In: O efeito etnográfico e outros ensaios (2014), Capítulo 3: 109-132, Trad. Iracema Dulley. São Paulo: Cosac Naify.

2014b [1987]. Os limites da autoantropologia. In: O efeito etnográfico e outros ensaios (2014). Capítulo 4: 133-157, Trad. Iracema Dulley. São Paulo: Cosac Naify: 
Sztutman, Renato.

2005. O Profeta e o Principal: a ação política ameríndia e seus personagens. São Paulo: Tese de Doutorado, PPGAS/FFLCH/USP.

2009a. Religião nômade ou germe do Estado? Pierre Clastres e Hélène Clastres e a vertigem tupi. Novos Estudos Cebrap, São Paulo, vol. 83, p.129-157.

2009b. De caraíbas e morubixabas: A ação política ameríndia e seus personagens. Revista de Antropologia Social dos Alunos do PPGAS - UFSCar, vol. 1, p. 16-45.

2012a. O profeta e o principal: a ação política ameríndia e seus personagens. 1. ed. São Paulo: Edusp.

2012b. O contra-Estado e as políticas ameríndias. In: PET Ciências Sociais - UFMG. (Org.). O poder em perspectiva. 1ed. Belo Horizonte: Sografe, v. 1, p. 126-158.

2009c. Ética e profética nas Mitológicas de Lévi-Strauss. Horizontes Antropológicos, Porto Alegre, ano 15, n. 31, p. 293-319.

2013. Metamorfoses do Contra-Estado: Pierre Clastres e as Políticas Ameríndias. São Paulo: Ponto Urbe, v. 13.

2015. Diplomacias cosmopolíticas nas terras baixas sul-americanas - Exercícios de comparação etnográfica. São Paulo: Projeto de Auxílio à Pesquisa FAPESP.

Testa, Adriana. 2014. Caminhos de saberes Guarani Mbya: modos de criar, crescer e comunicar. São Paulo: Tese de doutorado em Antropologia Social pelo PPGAS-USP.

Taylor, Anne-Christine. 2012 [1996]. O corpo da alma e seus estados: uma perspectiva amazônica sobre a natureza de ser-se humano. São Paulo: Cadernos de Campo (USP), n. 21, p. 213-228.

Tupã, Marcos.

2013a. Índios fecham rodovia por arquivamento de PEC e novas demarcações em São Paulo. In: Breda, Tadeu. Rede Brasil Atual. Disponível em: (http://www.redebrasilatual.com.br/cidadania/2013/09/indios-fecham-rodovia-dos-bandeirantes-para-exigir-arquivamento-depec-e-novas-demarcacoes-em-sp-4238.html). Acesso em 20 out. 2017.

2013b. Monumento à resistência do povo guarani. Disponível em: (http://www.revistaforum.com.br/2013/10/05/monumento-as-bandeiras-homenageia-genocidas-que-dizimaram-nosso-povo-diz-lideranca-indigena). Acesso em 20 out 2017.

Vanzolini, Marina.

2011. Eleições na aldeia ou, o Alto Xingu contra o Estado? Anuário Antropológico, v. 1, p. 31 54.

2015. A flecha do ciúme: o parentesco e seu avesso segundo os Aweti do Alto Xingu. São Paulo: Terceiro Nome.

Vera, Estela. 2016. Se não tiver mais reza o mundo vai acabar. Disponível em: (https://pib.socioambiental.org/pt/c/no-brasil-atual/narrativas-indigenas/se-nao-tiver-reza-o-mundovai-acabar). Acesso em 20 out 2017.

Vera Popygua, Timoteo.

2006. Em vez de desenvolvimento, envolvimento. Povos Indígenas no Brasil (PIB) 2001/2005, ISA - Palavras indígenas)

2011. Comissão Yryrupa: articulação guarani em defesa de seu território. In: Ricardo, Beto e Ricardo, Fany (Orgs.). Povos Indígenas no Brasil (PIB) 2006/2010. São Paulo: Instituto Socioambiental (ISA).

2017. Yryrupa. A terra Uma Só. São Paulo: Editora Hedra.

Vilaça, Aparecida. 2005. Chronically unstable bodies: Reflections on amazonian corporalities. Journal of the Royal Anthropological Institute (N.S.), v. 11, n. 3, p. 445-464. 
Viveiros de Castro, Eduardo.

1979. A fabricação do corpo na sociedade xinguana. In: Boletim do Museu Nacional, Série Antropologia, n. 32, p. 40-49.

1986. Araweté: os deuses canibais. Rio de Janeiro: Zahar/Anpocs.

1987. Nimuendaju e os Guarani. In: Nimuendaju, Curt. Unkel. As lendas da criação e destruição do mundo como fundamentos da religião dos Apapocúva-Guarani. São Paulo: Hucitec/Edusp, xvii-xxxviii.

1996. Os pronomes cosmológicos e o perspectivismo ameríndio. Mana, vol. 2, n. 2.

2002a. Perspectivismo e multinaturalismo na América indígena. In: A inconstância da alma selvagem e outros ensaios de antropologia. São Paulo: Cosac \& Naify, p. 345-399.

2002b. O nativo relativo. Mana: Estudos de Antropologia Social 8: 1, p. 113-40.

2004. Perspectival anthropology and the method of controlled equivocation. Tipití, 2(1): 3-22.

2007. Filiação intensiva e aliança demoníaca. Novos estudos, CEBRAP, v.77: 91-126.

2011a. Posfácio: O intempestivo, ainda. In: Clastres, P. Arqueologia da Violência: investigações de antropologia política. São Paulo: Cosac Naify, p 295-361.

201 1b. O medo dos outros. São Paulo: Revista de Antropologia (USP), v. 54, n. 2.

2011 c. Do mito grego ao mito ameríndio: uma entrevista sobre Lévi-Strauss com Eduardo Viveiros de Castro. Por Lagrou, E. e Belaunde, Luisa Elvira. Revista de Sociologia e Antropologia, vol. 1, n. 2, p. 9-33.

2015 [2009]. Metafisicas Canibais: Elementos para uma antropologia pós-estrutural. São Paulo: Cosac Naify e N-1 Edições.

Wagner, Roy.

2011 [1991]. A pessoa fractal. São Paulo: Ponto Urbe, v. 8.

2010a [1974]. Existem grupos sociais nas terras altas da Nova Guiné? Cadernos de Campo, São Paulo, n. 19, p. 1-384.

$2010 b$ [1975]. A invenção da cultura. São Paulo, Cosac Naify. 